\title{
16. RADIOLARIA: LEG 14, DEEP SEA DRILLING PROJECT
}

\author{
M. G. Petrushevskaya, Zoological Institute of the Academy of Sciences of the USSR, Leningrad, USSR \\ and \\ G. E. Kozlova, All-Union Oil Institute (VNIGRI), Leningrad, USSR
}

\section{CONTENTS}

$\begin{array}{lccr} & \text { Page } & & \text { Page } \\ \text { Introduction } & 495 & \text { Cyrtida } & 534 \\ \text { Cretaceous occurrences } & 495 & \text { Family Lampromitridae } & 534 \\ \text { Cenozoic zonation } & 497 & \text { Family Lophophaenidae } & 534 \\ \text { Cenozoic radiolarians at each site } & 501 & \text { Family Sethoperidae } & 535 \\ \text { Systematics } & 515 & \text { Family Carpocanidae } & 535 \\ \text { Spumellaria } & 515 & \text { Family Artostrobiidae } & 536 \\ \text { Family Collosphaeridae } & 515 & \text { Family Neosciadiocapsidae } & 540 \\ \text { Family Actinommidae } & 515 & \text { Family group N } & 541 \\ \text { Family Coccodiscidae } & 522 & \text { Family Williriedellidae } & 541 \\ \text { Family Porodiscidae } & 524 & \text { Family Pterocoryidae } & 543 \\ \text { Family Pseudoaulophacidae } & 527 & \text { Family Amphipyndacidae } & 545 \\ \text { Family Spongodiscidae } & 528 & \text { Family Eucyrtidiidae } & 545 \\ \text { Family Litheliidae } & 529 & \text { Family Plectopyramididae } & 550 \\ \text { Nassellaria } & 529 & \text { Family Lychnocaniidae } & 552 \\ \text { Spyrida } & 529 & \text { Family Cannobotryidae } & 554 \\ \quad \text { Family Triospyrididae } & 529 & \text { References } & 554 \\ \text { Family Acanthedesmiidae } & 532 & \text { Explanation of the Plates } & 557\end{array}$

\section{INTRODUCTION}

DSDP material was sent by D. E. Hayes and by A. C. Pimm (Co-chief Scientists of the Leg 14 team) for investigation of the radiolarians. They were in the form of prepared slides, made by Lillian F. Musich (Scripps Institution of Oceanography).

In these materials, radiolarians were used for the determination of ages of Cenomanian, Early Campanian, Maestrichtian, Lower(?) Eocene, Middle and Upper Eocene, Oligocene, Lower and Middle Miocene and Pliocene deposits.

Neogene occurrences were studied by M. G. Petrushevskaya. Oligocene and Latest Eocene occurrences were studied jointly by both authors. Eocene and Cretaceous occurrences were studied by G. E. Kozlova.

As it was indicated by Riedel and Sanfilippo (1970), stratigraphic correlation by means of radiolarians is not as routine a matter as it is with foraminifera and calcareous nannoplankton. Therefore it is impossible to provide simple lists of well-known species to substantiate agedeterminations. Even for the best known radiolarian species, used in previous DSDP volumes as zone-indicators (Calocycletta virginis, Theocyrtis tuberosa, etc.), generic and specific identifications are doubtful. That is why M. G. Petrushevskaya wrote most of the Systematics Sectionsome parts of it (concerning discoids) were prepared by G. E. Kozlova.

\section{CRETACEOUS OCCURRENCES}

Cretaceous rocks with radiolarian remains have been recovered by drilling at Sites 136, 137, 138, 140 and 144 . As a rule, these remains are poorly preserved, especially in the lower part of the Cretaceous section: they are corroded, filled with consolidated sediment, recrystallized, or impregnated with iron oxides. However, in a series of instances, specimens did preserve a sufficient number of the species characteristics essential for their identification.

Cretaceous radiolarians have not yet been thoroughly studied, neither in the Atlantic nor on the continents. As yet there is no zonation for this group of fauna. The Leg 14 material is also insufficient for this type of study; therefore, in this work we will limit ourselves to the age definition only when the material permits.

Of interest for stratigraphic correlation, in our opinion, are three complexes, each of which is found at various points and each having a sufficient composition of species.

\section{Cenomanian Complex}

Deposits containing the Cenomanian complex were discovered near the western coast of Africa from Site 136 ( 271 to 280 meters below the sea floor), and Site 137 (256 to 265 meters) and Site 138 (425 to 431 meters). The containing rocks are: coccolith marl, calcareous clays, marly clays and siliceous argillites. The most complete composition of the complex is: Cryptamphorella sp., 
Holocryptocanium barbui Dumitrica, Holocryptocapsa sp. aff. hindei (Tan Sin Hok), Squinabollum sp. aff., S. fossilis (Squinabol), *Dictyomitra pseudomacrocephala Squinabol, ${ }^{*} D$. costata (Squinabol), ${ }^{*} D$. veneta (Squinabol), D. tiara (Holmes), ${ }^{*} D$. multicostata Zittel group, D. crassispina (Squinabol), *Stichocapsa sp. aff. *S. ferosia (Kh. Aliev), $S$. disparlita (Kh. Aliev), S. sp. aff., *Lithostrobus elegans Squinabol, *Eusyringium sp. aff. *Theocampe subtilis Squinabol, *Conosphaera sphaeroconus Rüst, Conosphaera? fossilis Squinabol, ?Hexapyramis sp., Pseudoaulophacus superbus (Squinabol), *Pseudoaulophacidae gen. et sp. indet. (The most numerous specimens are marked with an asterisk.)

Its great similarity to the Cenomanian complex of the northeastern Caucasus speaks for the Cenomanian age of this complex (besides the data on the foraminifera and nannoplankton analysis): many of the above-mentioned species were found by Aliev (Kh. Aliev, 1965; at this point a group of them was assigned new synonymous names); Holocryptocanium barbui and Holocryptocapsa cf. hindei (Dumitrica, 1970) were described from the Cenomanian deposits of the Carpathian Mountains. However, it should be noted that almost all the species in the above list (with the exception of Cryptamphorella sp., Holocryptocapsa hindei and Holocryptocanium barbui) have a broader vertical distribution in the Atlantic region as well as on the European mainland; they were found in Caucasian Albian rocks (Kh. Aliev, 1965), in the Upper Cretaceous rocks of Italy (Squinabol 1903, 1904, 1914), in the Upper Cretaceous (Lower Turonian) rocks of the Rumanian Platform (P. Dumitrica collection); some species were encountered by Pessagno in the Lower Albian of the Atlantic (Pessagno 1970, Leg 1, Hole 5A, Core 3). Apparently the above-mentioned species in general are characteristic for both the Lower Cretaceous and lower horizons of the Upper Cretaceous of the Alpine Zone and the Atlantic region.

Radiolarian skeletons from the Cenomanian rocks are almost without exception poorly preserved; they usually occur as light transparent nuclei. In order to reveal the still-preserved sculpture we had to remove the skeletons from the balsam medium, into the vinegar-formaldehyde medium commonly used by diatomists.

\section{The Early Campanian Complex}

Deposits of this age were also discovered near the African coast from Site 137, Cores 6 and 5 (209 to 225 meters below sea floor level) and from Site 138, Core 5 (332 to 341 meters). The containing rocks are brown zeolitic clays. The most complete composition of the complex is: Dictyomitra duodecimcostata Squinabol, $D$. regina (Campbell and Clark), D. sp. aff. Stichocapsa tecta Rüst, D. multicostata Zittel group, Cryptamphorella sp. aff., C. conara (Foreman), Cryptamphorella sphaerica (White), Myllocercion sp. aff., M. minima Dumitrica, *Pseudoaulophacus superbus (Squinabol), P. sp. aff. $P$. parqueroensis Pessagno, *Patellula planoconvexa (Pessagno), *P. verteroensis (Pessagno), P. sp., Dactyliosphaera sp. aff., Lithocyclia justa Rüst, Histiastrum? valanginica $\mathrm{Kh}$. Aliev, ?Hexapyramis sp., *Porodiscus cretaceus Campbell and Clark, *Lithelidae gen. B, Lithelidae gen. A.
The specific character of this complex is determined by the predominance of large Discoidea, the majority of which have a pseudoaulophacid structure. A very similar fauna, almost identical in its species composition, was found by Pessagno (1963) in the Cariblanco Formation and in the limestones of the Parguera, Puerto Rico (Lower Campanian). On the basis of this similarity it is possible to stipulate the Early Campanian age of the complex with pseudoaulophacidae.

\section{Maestrichtian Complex}

Found in the equatorial part of the western and eastern Atlantic, Site 137, Core 4 (165 to 173 meters below sea floor level), Site 140, Core 8 (645 to 651 meters), Hole 144 , Core 3 (162 to 166 meters) and Hole 144A, Core 4 (171 to 180 meters). The containing rocks are nannofossilforaminiferal marls, and oozy zeolitic clays with interlayers of quartzy sandstones.

Incomplete list of the species: Dictyomitra multicostata Zittel group, $D$. ornata Kh. Aliev, $D$. sp. aff., $D$. regina (Campbell and Clark), D. tiara (Holmes), D. striata Lipman, Amphipyndax enessefi Foreman, A. stocki (Campbell and Clark), A. plousious Foreman, Stichocapsa asymbatos (Foreman), S. cingulata (Squinabol), S. sp. aff. producta (Kh. aliev), Gongylothorax sp. aff., G. verbeeki (Tan Sin Hok), Theocapsomma sp. aff. T. comys Foreman, Theocampe? bassillis Foreman, Theocampe ? daseia Foreman, Rhopalosyringium sp. aff. $R$. magnificum Campbell and Clark, $R$. colpodes Foreman, Theocampe sp. P. myllocercion sp. C. Diacanthocapsa ovoidea Dumitrica, Bathropyramis sanjoaquinensis Campbell and Clark, Petassiforma speciosa (Squinabol), Tripodiscium? sp. aff. Lithomelissa hoplites Foreman, Porodiscus cretaceus Campbell and Clark, $P$. delicatulus (Lipman), Spongotrochus polygonatus (Campbell and Clark), Spongotripus morenoensis Campbell and Clark, Pseudoaulophacus gallowayi (White), $P$. superbus (Squinabol), Cenosphaera sp. aff. C. euganea Squinabol, Spongosaturnalis (M) sp. aff. S. latuformis Campbell and Clark, Cenosphaera sphaeroconus Rüst, Stylatractus (?) sp., Spongoprunum (?) sp. aff. Cyphantus probus Rüst, Lithelidae gen. A and others.

The majority of these species, according to the data of Foreman (1968, Table 1) are distributed from the Late Campanian to the Late Maestrichtian. However, on the whole, the given association, in its species composition, appears to be closest to the Late Maestrichtian complex of California described and depicted in the above-mentioned work. Only in the Maestrichtian were found small Tricyrtida: Rhopalosyringium colpodes, Theocampe bassilis, Theocapsomma comys. Complexes from Sample 24A-11 (Atlantic, Leg 4; Riedel and Sanfilippo, 1970) and Sample 59-2-5-CC (Pacific, Leg 6; Kling, 1970) seem somewhat older due to the absence of this particular group of species; species of the genus Amphibrachium also tend to give it an ancient aspect.

\section{Site $136\left(34^{\circ} 10.13^{\prime} \mathrm{N}, 16^{\circ} 18.19^{\prime} \mathrm{W}\right.$; water depth 4169 meters)}

At a depth of 269 ? to 271 meters below the sea floor, in Sample 6-1, and also in Samples 6-CC, very poorly preserved radiolarians were found, mainly nuclei. The 
presence of Lithelidae gen.A can attest to the postTuronian (Senonian) age of the containing rocks. At a depth of approximately 280 meters in Core 7 , only unidentifiable nuclei were encountered. In Core 8 , at a depth of 288 ? to 289 meters (Sections $8-1,5-7 \mathrm{~cm}$ and $8-1$, $80-82 \mathrm{~cm}$ ) a small number of very poorly preserved radiolarians was found; among them several species could successfully be identified; these pointed to a possible Cenomanian age of Core 8. In Sections 8-6 and 8-CC only fragments of Pseudoaulophacidae were found. See Table 1.

Site $137\left(25^{\circ} 55.53^{\prime} \mathrm{N}, 27^{\circ} 03.64^{\prime} \mathrm{W}\right.$; water depth 5361 meters)

Cores 1, 2 and 3 contain no radiolarians. At a depth of 165 to 173 meters in Core 4 (Sections 4-1, 4-2 and 4-CC) there are numerous radiolarians of moderately poor preservation; the composition of the complex indicates the possibility of a Maestrichtian age.

At a depth of 219 ? to 225 meters, in Core 6 (Section 6-1) and also in Sections 5-CC and 6-CC, species of the Early Campanian complex were found. In the interval from 256 to 265 meters (Cores 7 and 8) are a great number of poorly preserved skeletons, presumably of Cenomanian age. See Table 2.

Site $138\left(25^{\circ} 55.37^{\prime} \mathrm{N}, 25^{\circ} 33.79^{\prime} \mathrm{W}\right.$; water depth 5288 meters)

At a depth of 332 to 341 meters (Section 5-CC) below sea floor, a small number of Early Campanian radiolarians were encountered; their state of preservation was satisfactory. A small number of species of the Cenomanian complex were found in samples taken at a depth of 425 to 431 meters (Core 6, Sections 6-2, 6-3 and 6-CC). The remains are very poorly preserved: these are predominantly nuclei, filled with transparent silica. See Table 3.

Site $140\left(21^{\circ} 44.97^{\prime} \mathrm{N}, 21^{\circ} 47.52^{\prime} \mathrm{W}\right.$; water depth 4483 meters)

At a depth of 645 to 641 meters (Core 8, Sections 1, 2 and $\mathrm{CC}$ ) below the sea floor were found a great number of poorly preserved radiolarians, partially dissolved, impregnated with iron oxides, sometimes pyritized. The age of the complex is probably Maestrichtian. See Table 4.

Site $144\left(09^{\circ} 27.23^{\prime} \mathrm{N}, 54^{\circ} 20.52^{\prime} \mathrm{W}\right.$; water depth 2939 meters)

At a depth of 162 to 166 meters below the sea floor (Core 3, Sections 3-1 and 3-2), species of the Maestrichtian complex were found; this is the richest of all Cretaceous finds of Leg 14 in terms of species and specimen numbers; the preservation of the remains is relatively poor. Exactly the same complex was discovered in Sections 144-3-CC and 144A-4-CC. See Table 5.

\section{CENOZOIC ZONATION}

The age assignments were made on the basis of the Cenozoic zonation proposed by Riedel and Sanfilippo (1970, 1971), and modified by J. Hays and others (1969) and by T. Moore (in press); see Table 6.

In Leg 14 the samples with radiolarians apparently belong to the following zones.
TABLE 1

Site 136

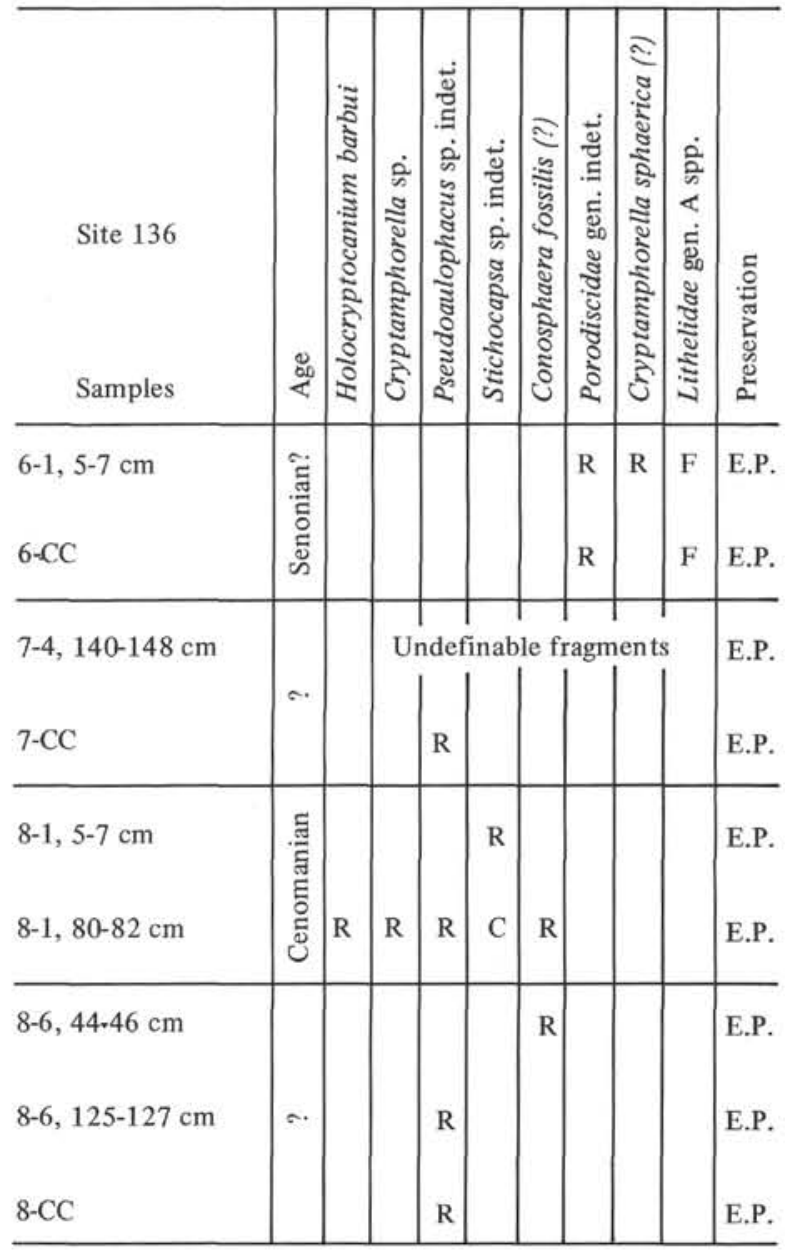

Lampterium chalara (= Podocyrtis chalara) Zone. Some samples from Site 144 (Table 2) seem to belong in this zone because the main species-indicators of this zone, defined by Riedel and Sanfilippo (1970,1971), were observed in them. Lithochytris sp. O, Lithochytris sp. T, Lithochytris sp. aff. L. ventricosa, Anthocyrtella spatiosa group and Stylatractus coronatus are also characteristic for the assemblage.

Lampterium goetheana (= Podocyrtis goetheana) Zone. Samples from Site 140 and Site 144 seem to belong in this zone (see Tables 10 and 12). The assemblage is the same as defined by T. Moore (in press): nearly the same species as in the Lampterium chalara Zone, but the appearance of Lampterium goetheana and Lampterium sp. aff. $L$. goetheana and also of Lophocyrtis jacchia are the distinguishing features.

Thyrsocyrtis bromia Zone (apparently the uppermost part). Some samples from Site 140 seem to belong in this zone (Table 10). For the uppermost part of the Thyrsocyrtis bromia Zone, as defined by Riedel and Sanfilippo (1970, 1971) and Moore (in press), the following peculiarities of the assemblage are characteristic: 1) the earliest appearance of Calocycletta tuberosa and Cyrtophormis gracilis, 2) the absence (as a rule) of Thyrsocyrtis bromia, 3) occurrence of Lithochytris sp. aff. L. tripodium (babylonis), Lophocyrtis jacchia, Cycladophora? turris. The 
Site 137

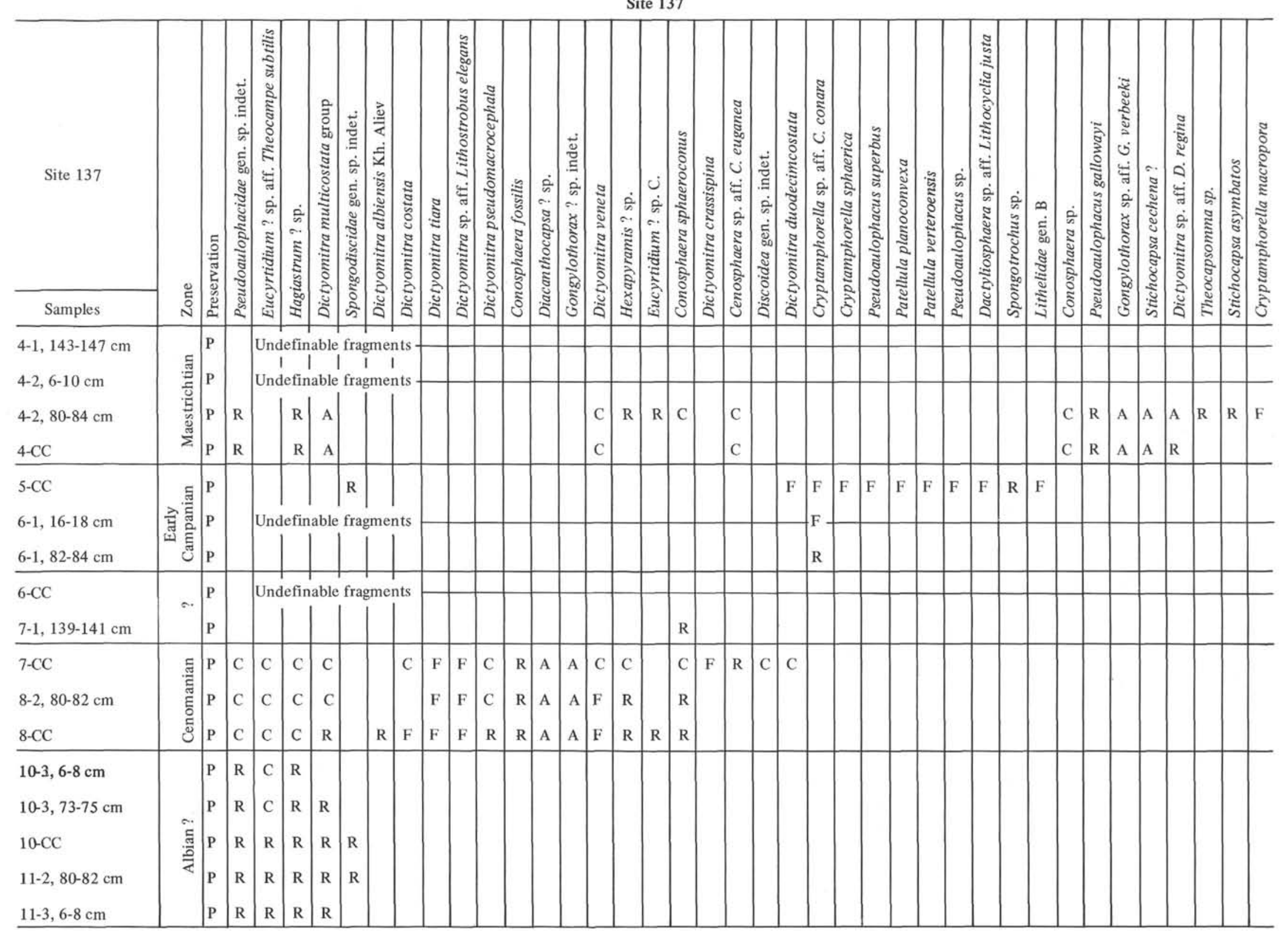




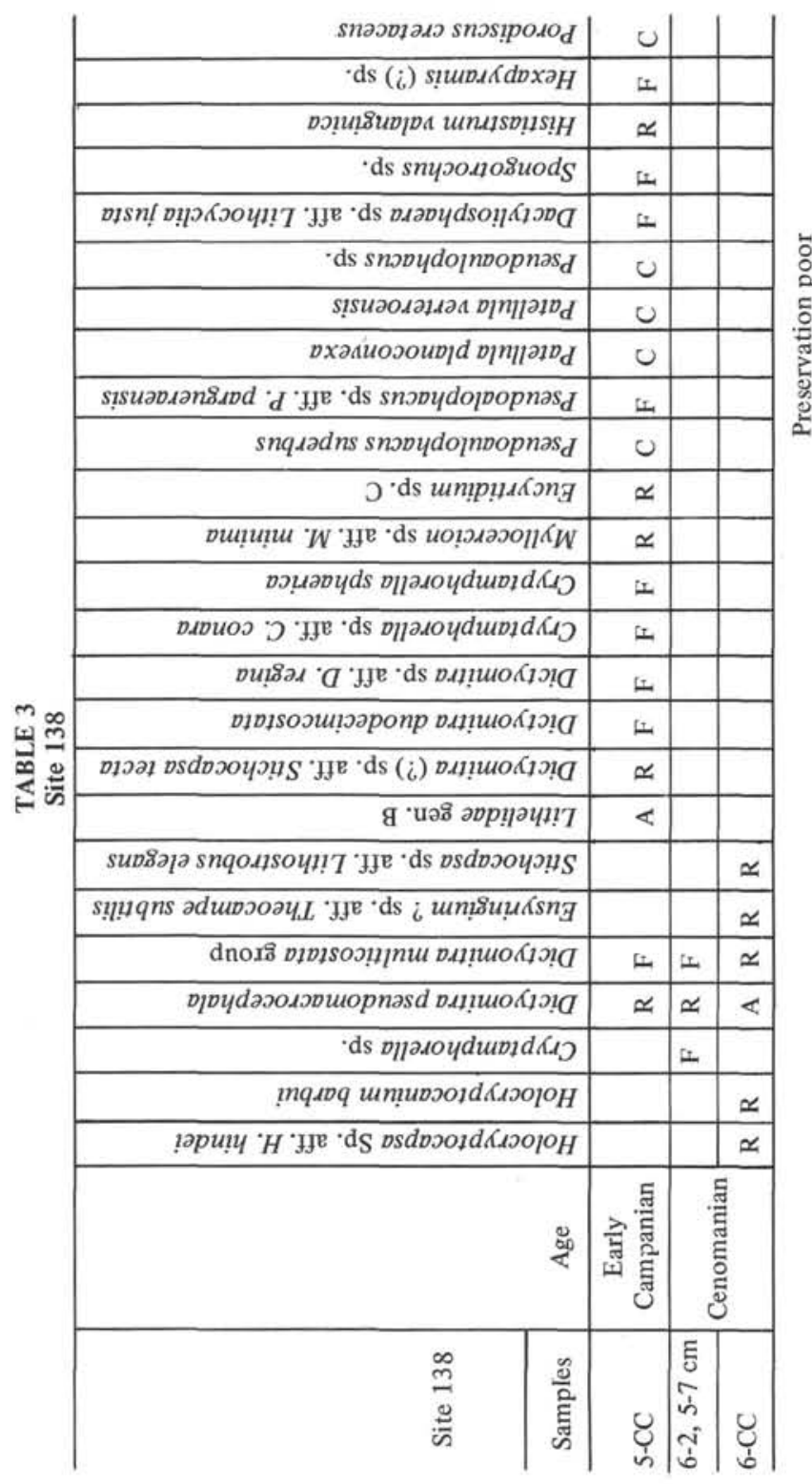

present authors can indicate abundant Calocycletta virginis typ., abundant Coccodiscinae and Phacodiscinae, common Theocapsomma sp. aff., T. ornata and Lithamphora sacculifera quadrata typ.

Calocycletta tuberosa (=Theocyrtis tuberosa) Zone. Samples from Sites 138, 140 and 144 (Tables 8, 10, 12, 13) seem to belong in this zone. The assemblage is abundant in Cyrtophormis gracilis and Calocyclas asperum; Trigonactinium? angustum is frequent; Calocycletta tuberosa is represented by three forms (subspecies ?); Periphaena? dupla, Cyclampterium milowi, Desmospyris sp. aff. D. anthocyrtoides and Liriospyris sp. B are also characteristic for the assemblage of this zone.

Upper and lower parts of the Calocycletta tuberosa Zone are likely to be distinguished. In the lower part Eucyrtidium sp. aff. E. montiparum, Lithamphora sacculifera quadrata typ., Petalospyris sp. E, and Calocycletta tuberosa forms A occur. They are absent or rare in the upper part of the zone. Calocycletta acanthcephala is abundant, and
TABLE 4

Site 140

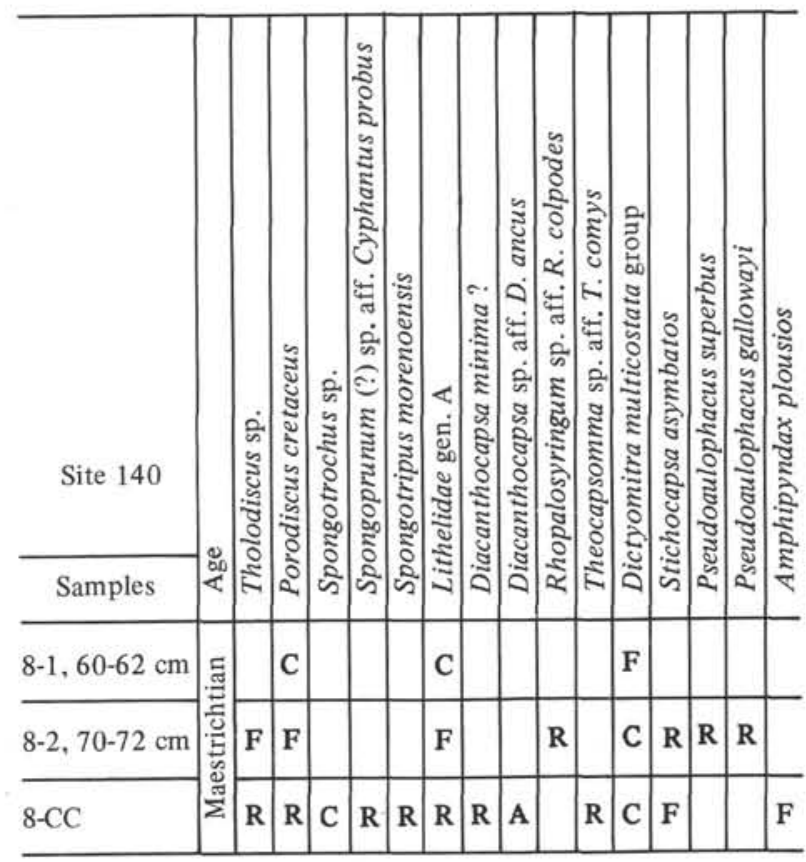

Dorcadospyris ? ateuchus, Astractinium sp. C, Lithocampe subligata, Eucyrtidiidae gen. sp. "rocket", Botryocella multicellaris gr., Orosphaeridae genn. and Lamprocyclas rhinoceras become more frequent in the upper part than they are in the lower part.

Calocycletta veneris $(=$ Calocycletta virginis $)$ Zone. Samples from Sites 138, 139, 140 and 142 seem to belong in this zone. Though some species indicated by Riedel and Sanfilippo $(1970,1971)$ do not occur in the samples, the definition of the zone is the same as given by Riedel and Sanfilippo.

The presence of Calocycletta veneris, Cannartus violina, Lithocampe (Cyrtocapsella) tetrapera and Stichocorys wolfii and the absence of Calocycletta costata are characteristic for the assemblage of the zone.

The upper and lower parts of the Calocycletta veneris Zone are likely to be distinguished. Only two samples (138-1-CC and 139-7-CC) seem to belong in the lower part of the Calocycletta veneris Zone. In this assemblage Lychnocanium bipes and Calocycletta annosa are frequent, and many species characteristic for the upper part of the zone are absent (see Tables 8,9 ). The samples which apparently belong in the upper part of the zone are more numerous (Tables 9, 10, 11). The assemblage from the upper part of the zone may be characterized 1) by the absence of Lychnocanium bipes, Calocycletta annosa and some other species going from the Oligocere, and 2) by the presence of a number of species (absent in the lower part), some of these species (Dorcadospyris dentata, Cyrtophormis armata and Trissocyclus stauropora) have been indicated by Riedel and Sanfilippo as characteristic for the upper part of the zone.

Calocycletta costata Zone. Some samples from Sites 139, 140 and 142 (Tables 9, 10, 11) seem to belong in this zone. It is the appearance of Calocycletta costata (indicated by Riedel and Sanfilippo, 1970, as defining the base of the zone) that permits the identification of the zone in the 


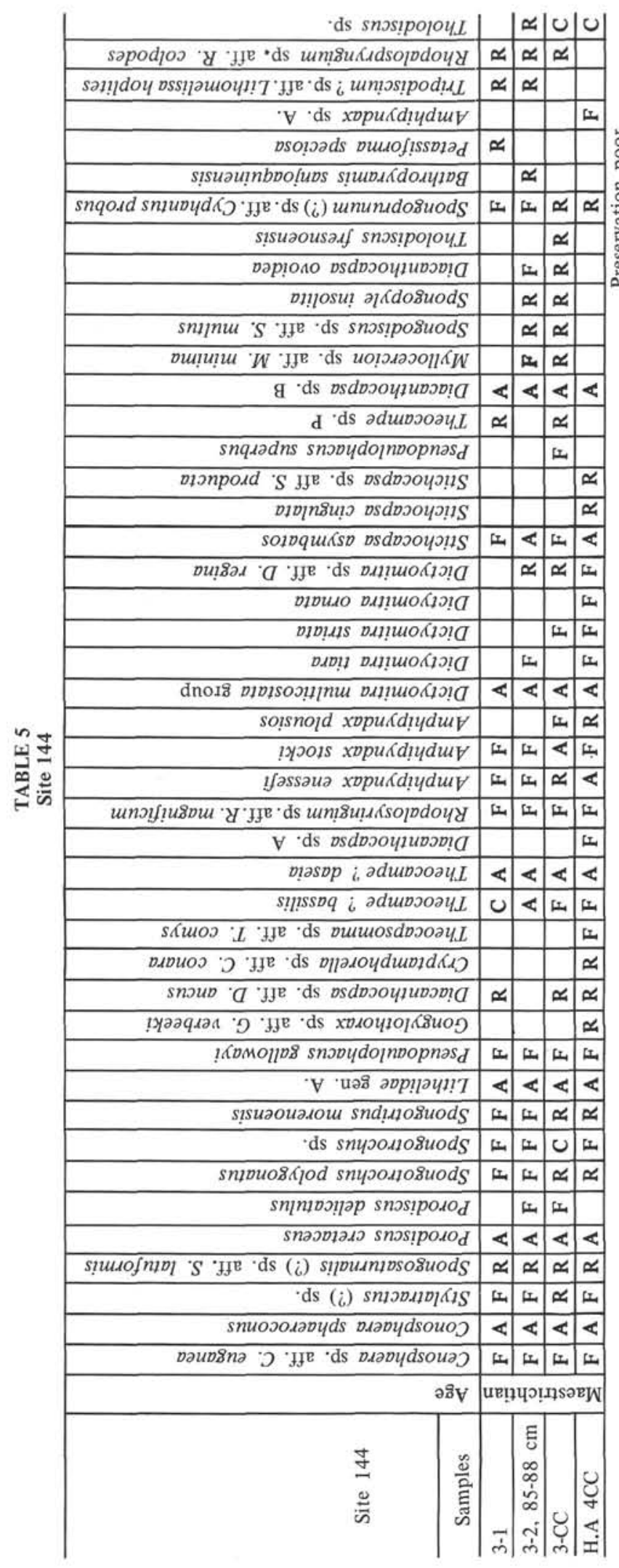

mentioned sites. The assemblage occurring in these samples is not quite the same as defined in the previous volumes. Cannartus mammiferus, for example, appears not at the base of the Calocycletta costata Zone, but low in the Calocycletta veneris Zone. Cannartus violina does not become extinct in the lower part of the Calocycletta costata Zone, but became even more numerous in this zone than in the upper part of the Calocycletta veneris Zone.

Dorcadospyris alata Zone. Only some samples from Site 140 (Table 10) seem likely to belong in this zone. The assemblage of this zone is characterized (as was indicated by Riedel and Sanfilippo, 1970, 1971) by the presence of Dorcadospyris alata, Dorcadospyris dentata, Lithocampe (Cyrtocapsella) cornuta, Cannartus mammiferus, Calocycletta veneris and Stichocorys delmontensis.

Pterocanium prismatium Zone. Samples from Site 139 (Table 9) might belong in this zone.

This zone, established for tropical sediments, is characterized (by Riedel and Sanfilippo, 1970) by the extinction of Spongaster pentas and the presence of Pterocanium prismatium. Though Site 139 is situated in the tropics, there are neither Spongaster pentas nor Pterocanium prismatium in the samples determined, on the base of foraminiferal and some other data, as middle Pliocene. Some other species widely-distributed in tropical warm water (according to data of Nigrini, 1967, and Petrushevskaya, 1969b), (such as Pterocorys campanula hertwigii, Centrobotrys thermophila, Callimitra spp., Rhizosphaera arcadoporum) are also absent here, though they occur in the tropics in the Pterocanium prismatium Zone (Petrushevskaya, 1970, 1971b). This might be explained by the near-shore position of Site 139. It seems significant that some species described by Nigrini (1968) for East Pacific tropical sediments [Lithostrobus hexagonalis Hck., Pterocorys minithorax (Nigrini), Conarchidium? sp. A Nigrini, Carpocanium sp. A Nigrini] are present in these East Atlantic near-shore sediments. Moreover, many species typical for transitional regions of the North and South Atlantic (Hays, 1965; Petrushevskaya, 1967, 1969a), occur in the samples in question [Botryostrobus tumidulus (Bailey), Spongodiscus resurgens osculosa, Archipilium sp. aff. A. macropus (Hck.), Lamprocyclas aegles (Ehr.), Hexacontium arachnoidale group, Haliometta miocenica group, Stylatractus neptunus, Tricolocapsa papillosa, Dictyophimus hirundo group, Lamprotripus mawsoni, Diplocyclas bicorona group, Pseudodictyophimus gracilipes, Lipmanella xiphephorum group, Lipmanella dogieli group, etc.]

Of the species present, those useful for age-assignment are: (1) tropical Anthocyrtidium ophirense Hck. and Ommatartus sp. aff. O. ceratospyris (= O. tetrathalamus), Pliocene to Recent; (2) Antaractic transitional Lamprocyclas heteroporus Hays, known to extend no higher than Pliocene zones $\Upsilon$ or $\Phi$, (Hays 1965, see plate 6); (3) transitional tropical Cromyechinus tetrapyla (Hays), which occur up to the $\chi$ zone. Thus the set of species age indicators in these samples, as well as the whole assemblage is mixed: both high and low latitude species are present. The species typical for Miocene and Low Pliocene zones (Prunopyle titan, Astromma hughesi, Stichocorys peregrinus and Ommatartus penultimus) are absent in these sediments. Their absence and the presence of the four species mentioned as age-indicators, indicate the radiolarian assemblage to be of Middle Pliocene age. It may be referred to the Pterocanium prismatium Zone as well as zone $\Phi$ of 
TABLE 6

Cenozoic Radiolarian Zonation

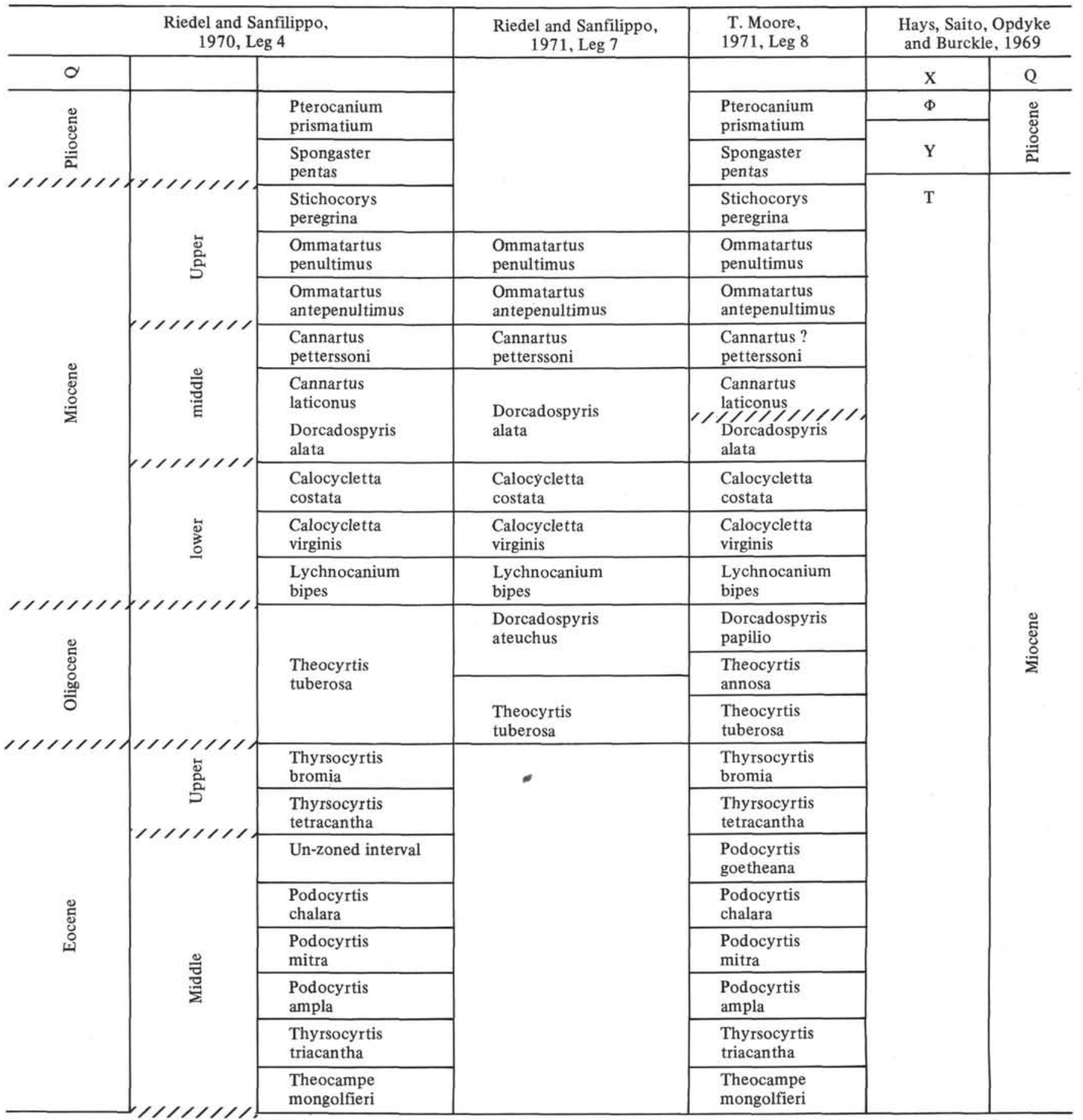

Hays, and yet the assemblage is atypical for both highlatitude sediments of that age and for tropical sediments of that age.

Table 7 gives the ranges of the species taken into account for the age-assignment of the Leg 14 samples. It is based on the samples mentioned above. It is incomplete, because there were no complete Cenozoic sequences, but single samples, and there were no radiolarians from the Low Eocene, Upper Oligocene and Upper Miocene.

\section{CENOZOIC RADIOLARIANS AT EACH SITE}

Tables 8 through 13 show the occurrences of radiolarians in Cenozoic samples from Leg 14. The list of the species taken into account for these tables may be seen in Table 7. If a species was searched for, but not found, that species is not named in Tables 8-13. The letters "a", "c", " $\mathrm{f}$ " and " $\mathrm{r}$ " indicate that a species is abundant, common, few or rare in relation to the total number of the 
TABLE 7

Radiolarian Ranges and Zones for Leg 14

\begin{tabular}{|c|c|c|c|c|c|c|c|c|c|c|}
\hline \multirow[t]{2}{*}{ Paleocene $\}\}$} & $\left\{\begin{array}{l}\text { low } / \text { mid. } \\
\text { Eocene }\end{array}\right.$ & \multicolumn{2}{|c|}{ Middle Eocene } & \multirow{2}{*}{$\begin{array}{l}\$\left\{\begin{array}{c}\text { Upper } \\
\text { Eocene }\end{array}\right. \\
\text { Thyrsocyrtis } \\
\text { bromia } \\
\text { (upper part) }\end{array}$} & \multirow{2}{*}{$\begin{array}{c}\text { Oligocene } \\
\begin{array}{c}\text { Calocycletta } \\
\text { tuberosa }\end{array}\end{array}$} & \multicolumn{2}{|c|}{ Lower Miocene } & \multirow{2}{*}{$\begin{array}{c}\text { Middle } \\
\text { Miocene } \\
\begin{array}{c}\text { Dorcadospyris } \\
\text { alata }\end{array}\end{array}$} & \multirow{2}{*}{$\frac{\text { Pliocene }}{\begin{array}{c}\text { Pterocanium } \\
\text { prismatium }\end{array}}$} & \multirow[b]{2}{*}{$\stackrel{N}{\circ} \quad$ Age } \\
\hline & $\begin{array}{l}\text { Unzoned } \\
\text { interval }\end{array}$ & $\begin{array}{l}\text { Lampterium } \\
\text { chalara }\end{array}$ & $\begin{array}{c}\text { Lampterium } \\
\text { goetheana }\end{array}$ & & & $\begin{array}{l}\text { Calocycletta } \\
\text { veneris }\end{array}$ & $\begin{array}{c}\text { Calocycletta } \\
\text { costata }\end{array}$ & & & \\
\hline & & & & & & & & & $\begin{array}{l}1 \\
1 \\
1 \\
1\end{array}$ & $\begin{array}{l}\text { Lithocampium } \text { sp. A } \\
\text { Lithochytris } \text { sp. A } \\
\text { Desmospyris } \text { sp. aff. D. lata } \\
\text { Pterocanium } \text { ? satelles } \\
\text { Plectodiscus circularis } \\
\end{array}$ \\
\hline & & & & & & & & & $\begin{array}{l}1 \\
1\end{array}$ & $\begin{array}{l}\text { Eusyringium striata } \\
\text { Becoma bidarfensis } \\
\text { Thyrsocyrtis argulus } \\
\text { Podocyrtis mitra group } \\
\text { Theocotyle venezuelensis }\end{array}$ \\
\hline & & & & & $--\cdots$ & & & & 1 & $\begin{array}{l}\text { Lithochytris sp. aff. L tripodium } \\
\text { Podocyrtis papalis } \\
\text { Theocampe mongolfieri } \\
\text { Spongosphaera pachystyla } \\
\text { Ratagospyris pentas group } \\
\end{array}$ \\
\hline & & & & ? & $\begin{array}{r}\cdot \\
\cdot\end{array}$ & & & & 1 & $\begin{array}{l}\text { Periphaena decora } \\
\text { Dendrospyris didiceros group } \\
\text { Eusyringium fistuligerum group } \\
\text { Calocycloma ampulla } \\
\text { Lampterium chalara } \\
\end{array}$ \\
\hline | & & & & $\begin{array}{l}? \\
?\end{array}$ & & & & & 1 & $\begin{array}{l}\text { Lychnocanium bellum } \\
\text { Anthocyrtella spatiosa } \\
\text { Stylatractus coronatus } \\
\text { Heliodiscus hexasteriscus } \\
\text { Heliodiscus pentasteriscus } \\
\end{array}$ \\
\hline । & & & & ? & $\begin{array}{l}? \\
\cdot \quad \cdot\end{array}$ & & & & $\begin{array}{l}1 \\
1 \\
1\end{array}$ & $\begin{array}{l}\text { Porodiscus concentricus } \\
\text { Lithochytris } \mathrm{sp} . \mathrm{O} \\
\text { Lithochytris } \mathrm{sp} . \mathrm{T} \\
\text { Lithochytris } \mathrm{sp} . \text { aff. L. ventricosa } \\
\text { Astractinium aristotelis }\end{array}$ \\
\hline 1 & & P & $\cdot$ & $?$ & 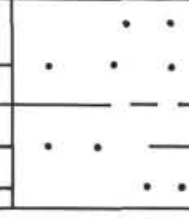 & & & & 1 & $\begin{array}{l}\text { Trigonactinium pithagore } \\
\text { Tholodiscus splendens } \\
\text { Thyrsocyrtis triacantha } \\
\text { Lophophaena capito group } \\
\text { Lithocyclia ocellus sens. str. }\end{array}$ \\
\hline
\end{tabular}




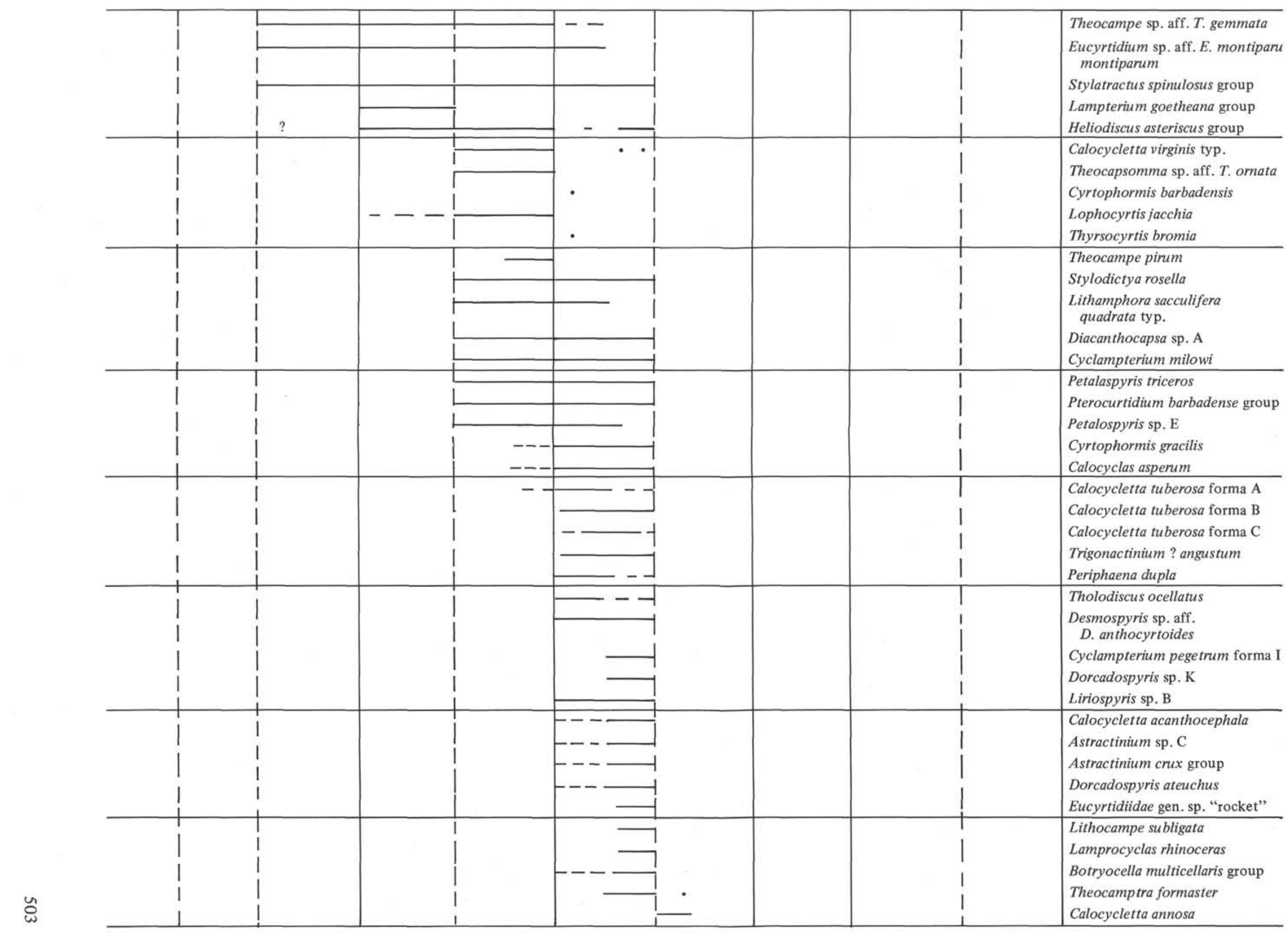


TABLE 7 - Continued

\begin{tabular}{|c|c|c|c|c|c|c|c|c|c|c|}
\hline \multirow[t]{2}{*}{ Paleocene } & \multirow{2}{*}{ 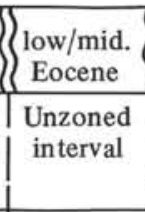 } & \multicolumn{2}{|c|}{ Middle Eocene } & \multicolumn{2}{|c|}{$\begin{array}{c}\text { Upper } \\
\text { Eocene }\end{array}$ 言 Oligocene } & \multicolumn{2}{|c|}{ Lower Miocene } & \multirow{2}{*}{$\begin{array}{c}\text { Middle } \\
\text { Miocene } \\
\begin{array}{c}\text { Dorcadospyris } \\
\text { alata }\end{array}\end{array}$} & \multirow{2}{*}{ 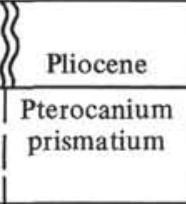 } & \multirow[b]{2}{*}{$\stackrel{N}{\circ} \quad$ Age } \\
\hline & & $\begin{array}{c}\text { Lampterium } \\
\text { chalara }\end{array}$ & $\begin{array}{c}\text { Lampterium } \\
\text { goetheana }\end{array}$ & $\begin{array}{l}\text { Thyrsocyrtis } \\
\text { bromia } \\
\text { (upper part) }\end{array}$ & $\begin{array}{c}\text { Calocycletta } \\
\text { tuberosa }\end{array}$ & $\begin{array}{l}\text { Calocycletta } \\
\text { veneris }\end{array}$ & $\begin{array}{c}\text { Calocycletta } \\
\text { costata }\end{array}$ & & & \\
\hline & & & & & & - & $?$ & . & $=$ & $\begin{array}{l}\text { Cannartus prismaticus } \\
\text { Myllocercion sp. C } \\
\text { Lychnocanium bipes } \\
\text { Theocamptra collaris } \\
\text { Stichopodium martellii conicum }\end{array}$ \\
\hline & & & & & & $1-$ & 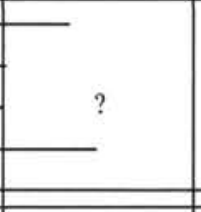 & & & $\begin{array}{l}\text { Acrobotrys sp. aff. A. disolenia } \\
\text { Cannartus tubarius } \\
\text { Stichopodium martellii typ. } \\
\text { Stichopodium cienkowskii } \\
\text { Botryocyrtis quinaria group }\end{array}$ \\
\hline & $\begin{array}{l}1 \\
1 \\
1\end{array}$ & & & & & ---- & ---- & ---1 & & $\begin{array}{l}\text { Stichocorys delmontensis group } \\
\text { Lithocampium sp. B } \\
\text { Rhodospyris De I group } \\
\text { Calocycletta veneris sensu str. } \\
\text { Carpocanopsis favosum group } \\
\end{array}$ \\
\hline & & & & $\mid$ & & 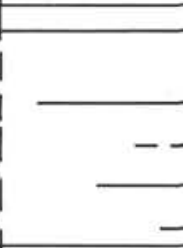 & & - & & $\begin{array}{l}\text { Lithocampe (Cyrtocapsella) } \\
\text { tetrapera } \\
\text { Spongasteriscus } \mathrm{sp} . \\
\text { Cyrtophormis armata } \\
\text { Eucyrtidiidae gen. sp. W } \\
\text { Theocamptra marylandica group } \\
\end{array}$ \\
\hline & & & & & & & & & & $\begin{array}{l}\text { Stichocorys wolffii } \\
\text { Cannartus violina } \\
\text { Theocamptra corona } \\
\text { Calocycletta costata } \\
\text { Desmospyris sp. A }\end{array}$ \\
\hline & & & & & & & & - & & $\begin{array}{l}\text { Lithocampe (Cyrtocapsella) } \\
\text { cornuta } \\
\text { Cannartus mammiferus } \\
\text { Dendrospyris pododendros group } \\
\text { Rhodospyris sp. aff. } R \text {. tricornis } \\
\text { Cyrtophormis sp. }\end{array}$ \\
\hline & $\begin{array}{l}1 \\
1 \\
1 \\
1\end{array}$ & & & & & - & & $\begin{array}{l}- \\
- \\
-\end{array}$ & & $\begin{array}{l}\text { Lithotympanium tuberosum } \\
\text { Lipmanella sp. O } \\
\text { Tympanomma binoctonum } \\
\text { Dicolocapsa microcephala }\end{array}$ \\
\hline
\end{tabular}




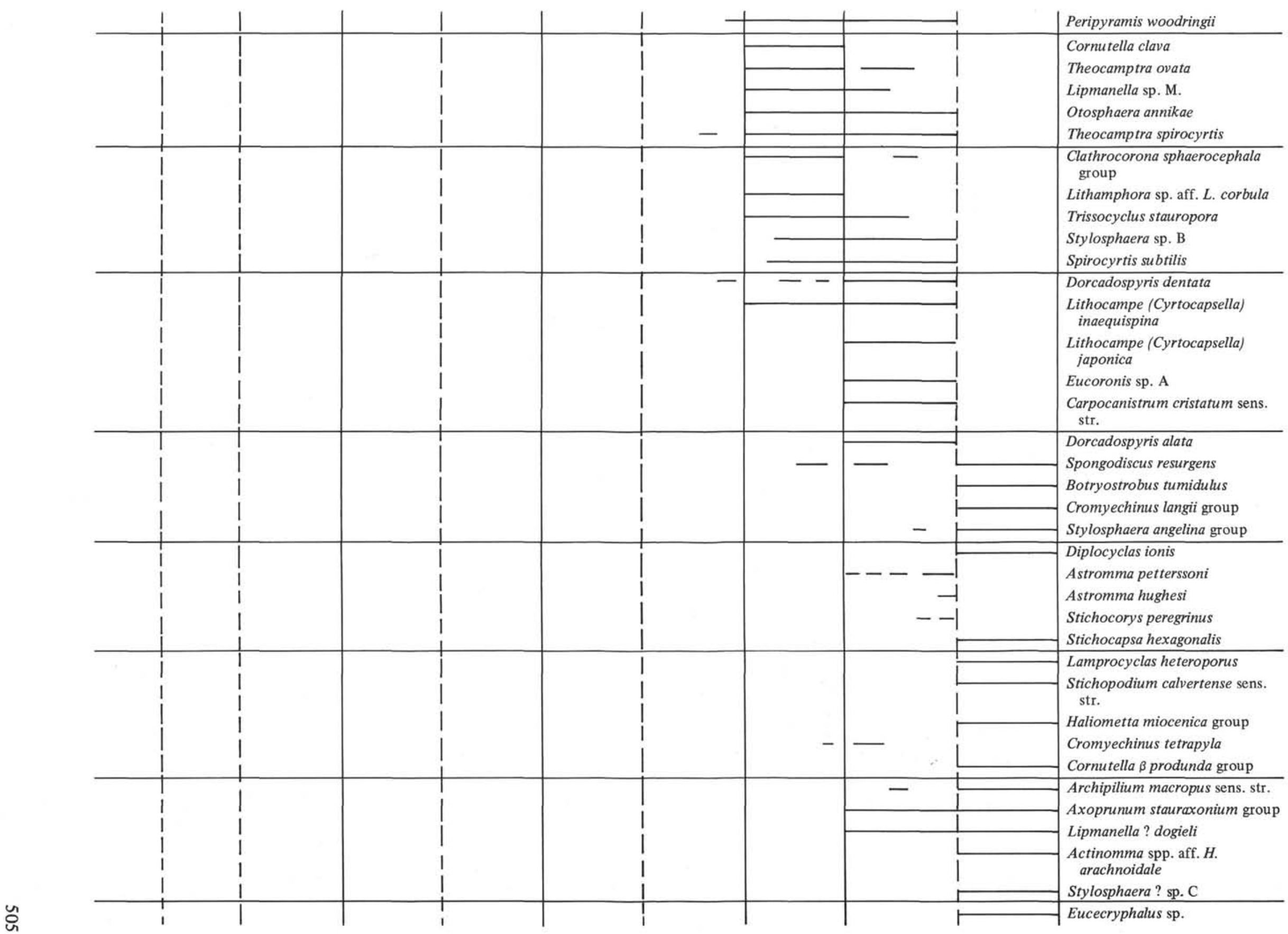




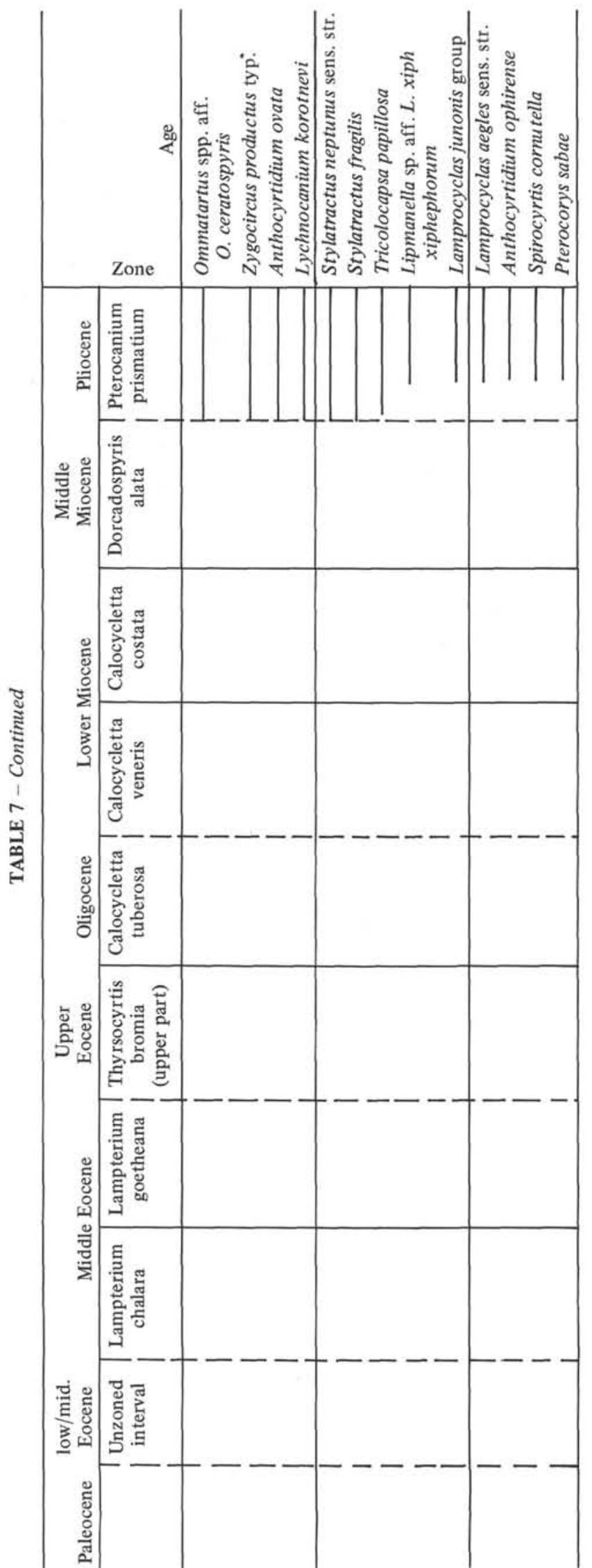

radiolarian assemblage in a sample. For the characterization of the total assemblage, the same letters " $a$ ", "c", "f $f$ " and " $r$ " are applied. The preservation of the skeletons is classified as "good - g" (all specimens are preserved), "moderate - m" (some specimens are destroyed, in fragments, nassellarians without heads) and "poor - p" (nearly all specimens are destroyed or dissolved).

\section{Site $138\left(25^{\circ} 55.37^{\prime} \mathrm{N}, 25^{\circ} 33.70^{\prime} \mathrm{W}\right.$; water depth 5288} meters)

Rare radiolarians occur at about 52 to 61 meters below the sea floor (1-CC); they apparently belong in the Calocycletta veneris Zone. Frequent radiolarians of moderate preservation occur from 110 to 113 meters below the sea floor (Core 2). Radiolarians from the upper part of this core seem to belong in the upper part of the Calocycletta tuberosa Zone. The lower part of Core 2 seems to belong in the lower part of the Calocycletta tuberosa Zone. Paleocene? radiolarians from Core 4 were not studied. Lower than 332 meters below the sea floor, Cretaceous radiolarians of poor preservation occur (see "Cretaceous Occurrences").

Site $139\left(23^{\circ} 31.14^{\prime} \mathrm{N}, 18^{\circ} 42.26^{\prime} \mathrm{W}\right.$; water depth 3047 meters)

Radiolarians, if present, were of good preservation, and the assemblages are rich in species and in individuals.

Radiolarians are common and even abundant from 114 to 123 meters below the sea floor (Core 1). These samples seem to belong no lower than the Pterocanium prismatium Zone.

Radiolarians are frequent and even common from 345 to 576 meters below the sea floor (Core 3). Sample 3-CC contains a Middle Miocene assemblage. It is difficult to determine the zone it belongs in, but it may be in the lowest Cannartus petterssoni Zone. Samples 4-CC, 5-CC and 139-SW1 seem to belong in the Calocycletta costata Zone. Core 7 (576 to 665 meters below the sea floor) is poor in radiolarians; it apparently belongs in the Calocycletta veneris Zone. Sample 7-CC is abundant in radiolarians; it belongs in the lowest part of the Calocycletta veneris Zone.

Site $140\left(21^{\circ} 44.97^{\prime} \mathrm{N}, 21^{\circ} 47.52^{\prime} \mathrm{W}\right.$; water depth 4483 meters)

\section{Hole 140}

Well-preserved radiolarians are common from about 201 meters below the sea floor (Core 2). The samples from the upper part of this core seem to belong in the lower part of the Dorcadospyris alata Zone. The middle part of this core (Section 2 and 4) appear to belong in the Calocycletta costata Zone. The lower part of Core 2 and Sample 2-CC apparently belong in the Calocycletta veneris Zone, but the slide marked as 2-CC contains an abundance of wellpreserved Late Eocene radiolarians. It apparently belongs in the upper part of the Thyrsocyrtis bromia Zone.

Well-preserved (but many fragmented) radiolarians are common in Core 3 ( 311 to 318 meters below the sea floor). These samples seem to belong in the Lampterium goetheana Zone.

Poorly preserved skeletons (infilled with silt) are abundant in Core 4 (368 to 374 meters below the sea floor). Apparently it belongs in the Low Eocene (similar to the samples described by C. Nigrini, 1970). 
TABLE 8

Radiolarians in Site 138

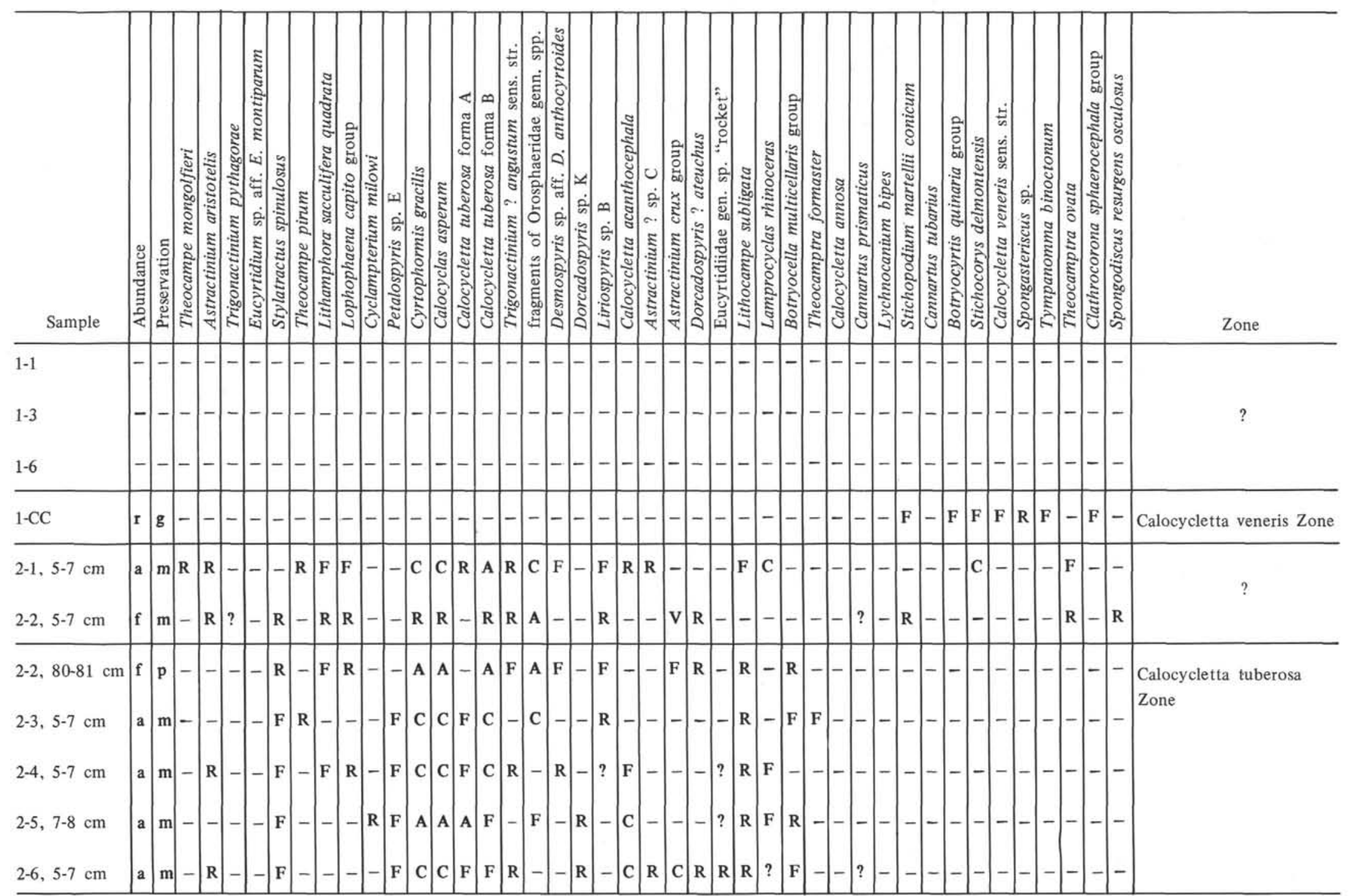


TABLE 9

Radiolarians in Site 139

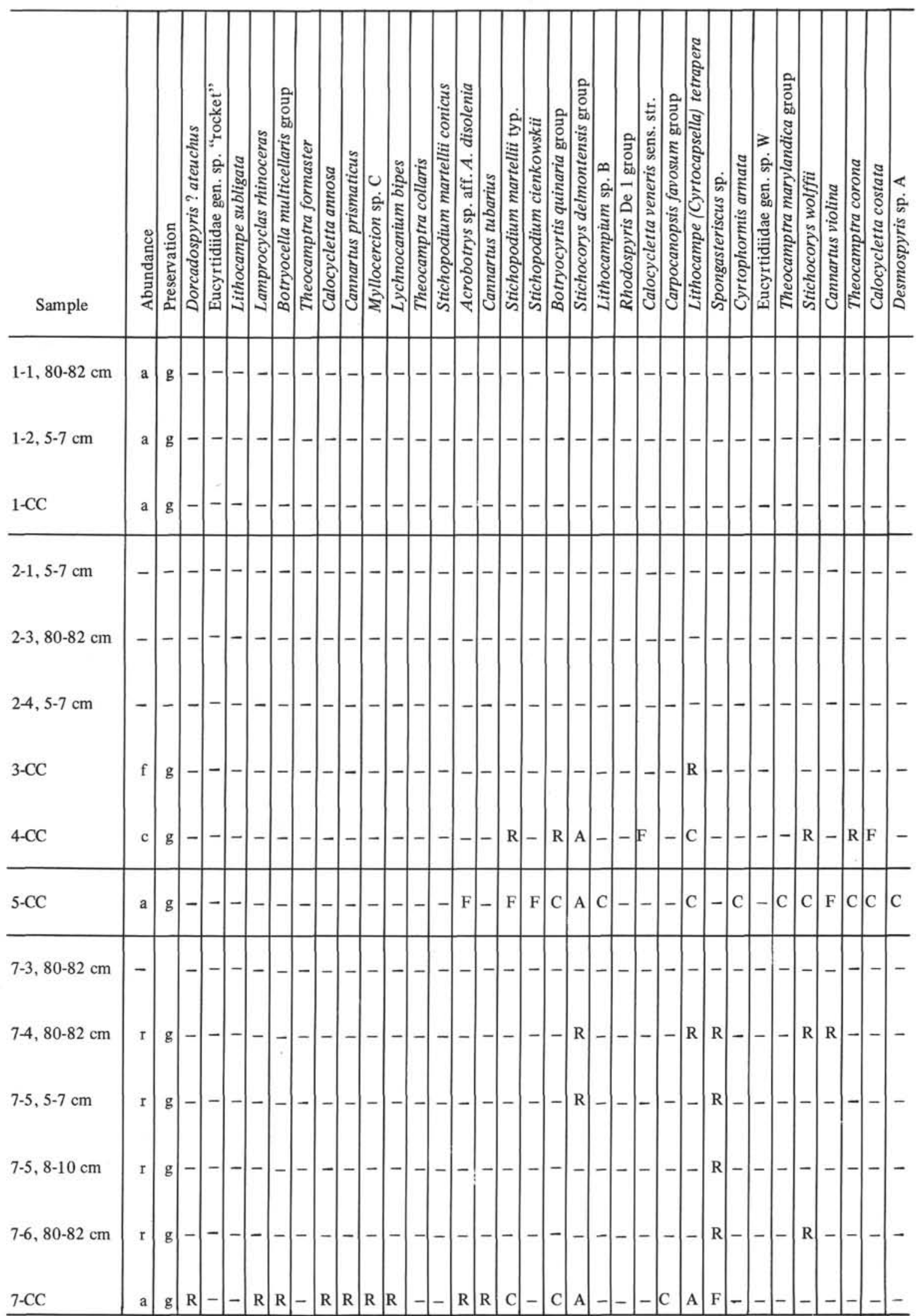


TABLE 9 - Continued

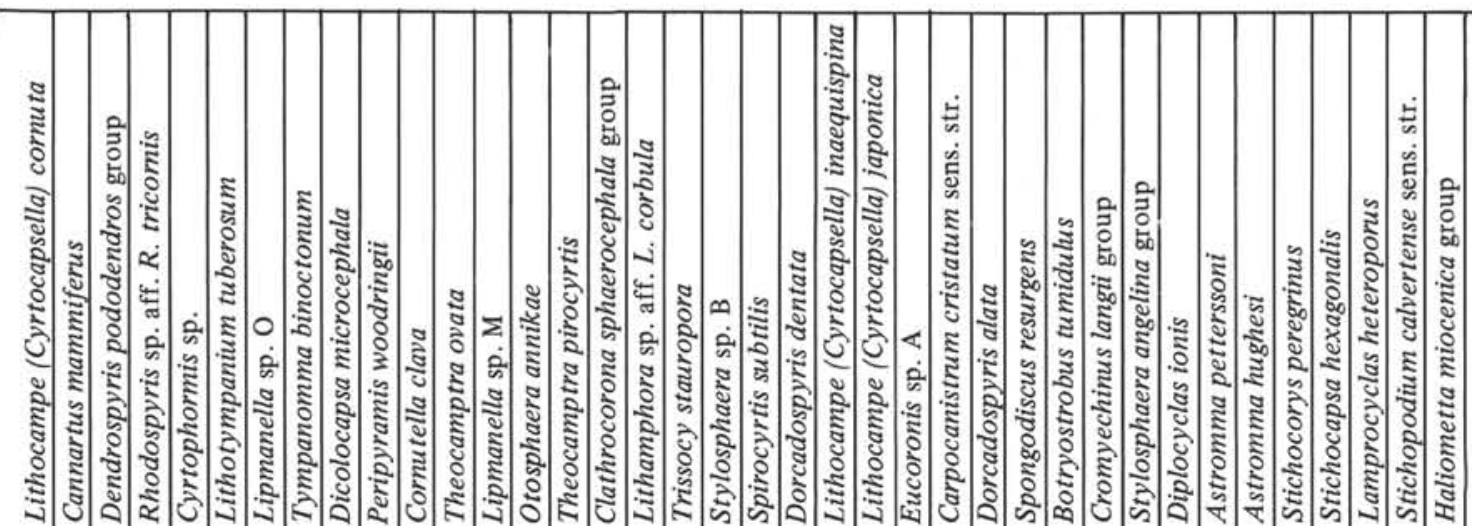

Zone
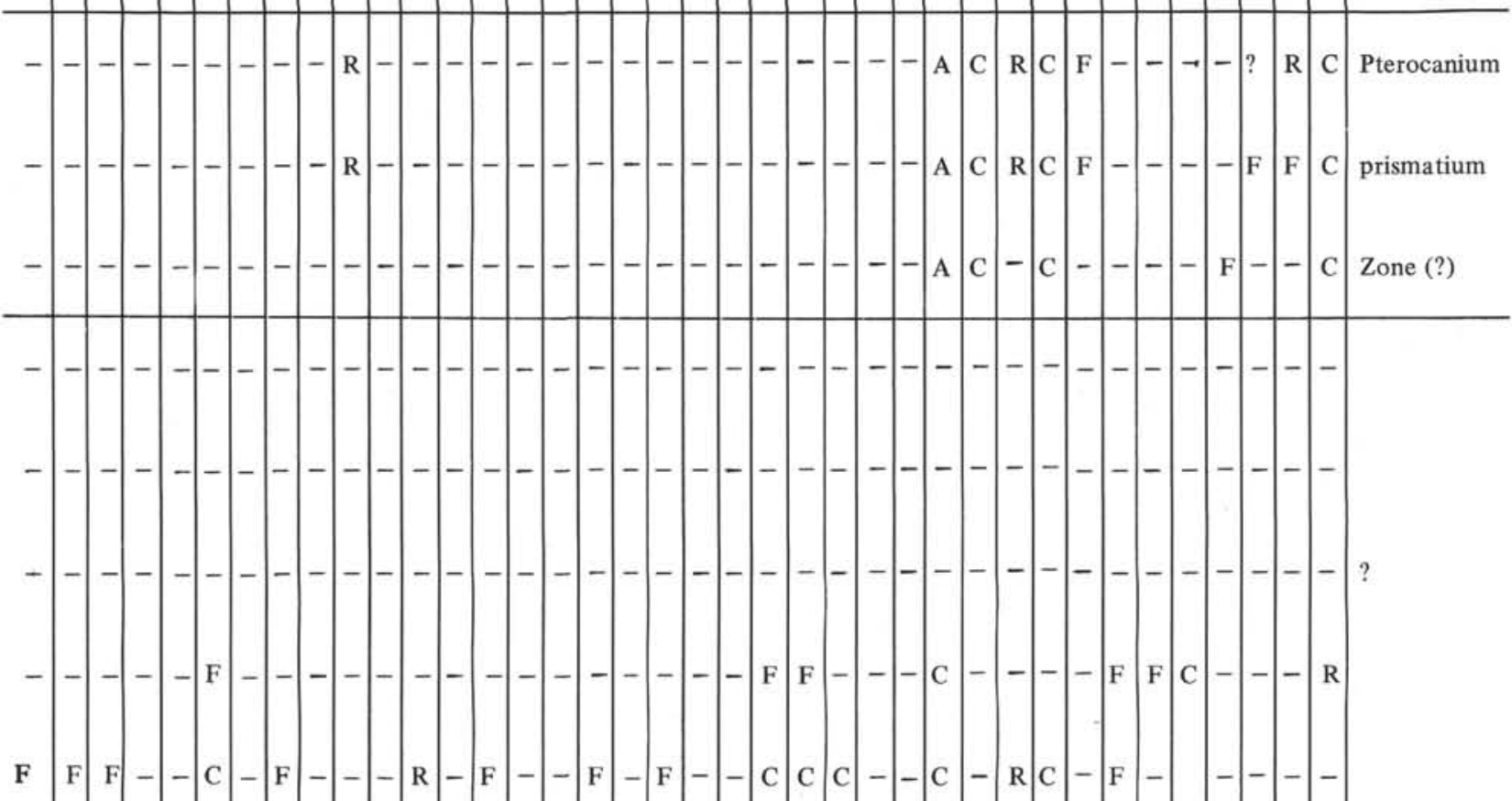

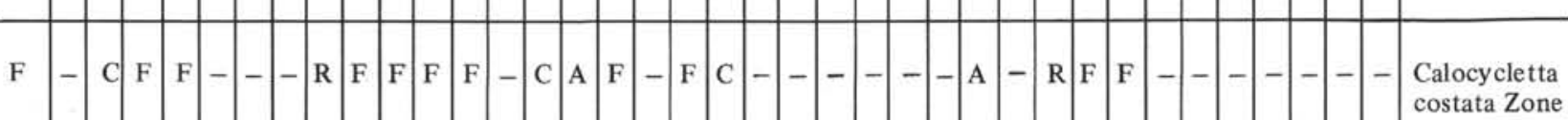

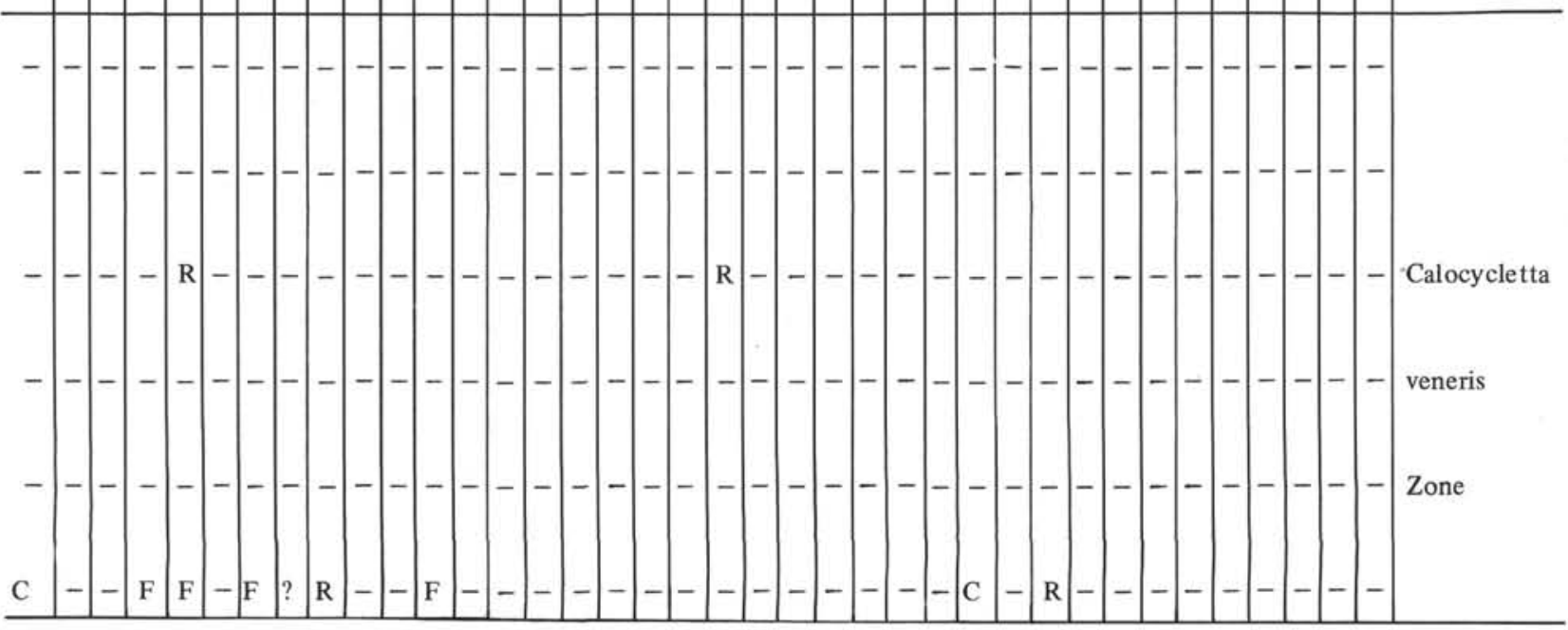


TABLE 9 - Continued

\begin{tabular}{|c|c|c|c|c|c|c|c|c|c|c|c|c|c|c|c|c|c|c|c|c|c|c|c|c|}
\hline Sample & 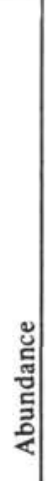 & 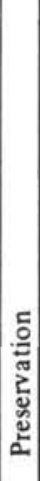 & 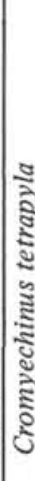 & 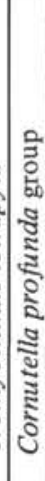 & 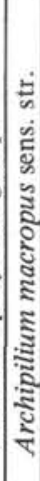 & 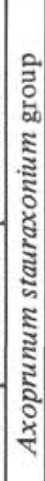 & 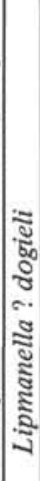 & 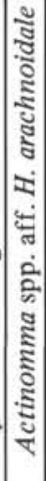 & 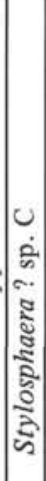 & 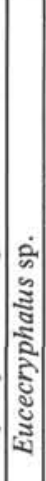 & 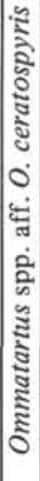 & $\mid$ & 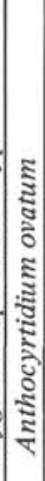 & 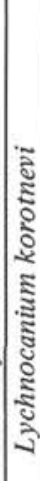 & 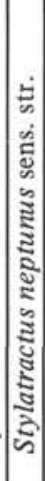 & 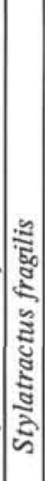 & 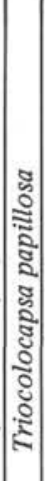 & 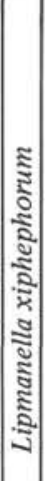 & 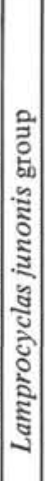 & 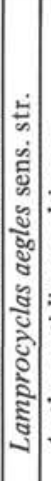 & 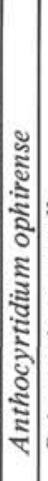 & 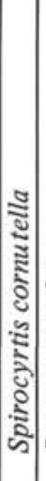 & 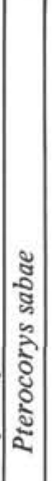 & Zone \\
\hline $1-1,80-82 \mathrm{~cm}$ & a & $\mathrm{g}$ & - & C & - & A & C & A & C & - & F & F & $\mathrm{C}$ & $\mathrm{F}$ & C & $\mathrm{F}$ & C & $\mathrm{F}$ & $\mathrm{C}$ & A 1 & $\mathrm{R}$ & $\mathrm{F}$ & $\mathrm{R}$ & Pterocanium \\
\hline $1-2,5-7 \mathrm{~cm}$ & a & $\mathrm{g}$ & - & C & - & C & C & C & C & $\mathrm{F}$ & F & F & $\mathrm{C}$ & C & C & C & $\mathrm{F}$ & F & C & A & $\mathrm{F}$ & $\mathrm{R}$ & F & prismatium \\
\hline $1-\mathrm{CC}$ & $\mathrm{a}$ & 8 & - & - & - & C & F & C & $\mathrm{F}$ & $\mathrm{F}$ & F & $\mathrm{R}$ & $\mathrm{F}$ & $\mathrm{F}$ & $\mathrm{C}$ & $\mathrm{F}$ & C & - & - & - & - & - & - & Zone (?) \\
\hline $2-1,5-7 \mathrm{~cm}$ & - & - & - & - & - & - & - & - & - & - & - & - & - & - & - & - & - & - & - & - & - & - & - & \\
\hline $2-3,80-82 \mathrm{~cm}$ & - & - & - & - & - & - & - & - & - & - & - & - & - & - & - & - & - & - & - & - & - & - & - & \\
\hline $2-4,5-7 \mathrm{~cm}$ & - & - & - & - & - & - & - & - & - & - & - & - & - & - & - & - & - & - & - & - & - & - & - & $?$ \\
\hline $3-\mathrm{CC}$ & $\mathrm{f}$ & $\mathrm{g}$ & - & - & - & F & F & $\mathrm{F}$ & - & - & - & - & - & - & - & - & $\mathrm{R}$ & - & - & - & - & - & - & \\
\hline $4-\mathrm{CC}$ & c & $\mathrm{g}$ & - & - & C & F & F & - & - & - & - & - & - & - & - & - & - & - & - & - & - & - & - & \\
\hline $5-\mathrm{CC}$ & $\mathrm{a}$ & $g$ & - & - & - & - & - & - & - & - & - & - & - & - & - & - & - & - & - & - & - & - & - & $\begin{array}{l}\text { Calocycletta } \\
\text { costata Zone }\end{array}$ \\
\hline $7-3,80-82 \mathrm{~cm}$ & - & & - & - & - & - & - & - & - & - & - & - & - & - & - & - & - & - & - & - & - & - & - & \\
\hline $7-4,80-82 \mathrm{~cm}$ & $\mathrm{r}$ & $\mathrm{g}$ & - & - & - & - & - & - & - & - & - & - & - & - & - & - & - & - & - & - & - & - & - & Calocycletta \\
\hline $7-5,5-7 \mathrm{~cm}$ & r & $\mathrm{g}$ & - & - & - & - & - & - & - & - & - & - & - & - & - & - & - & - & - & - & - & - & - & veneris \\
\hline $7-5,8-10 \mathrm{~cm}$ & r & g & - & - & - & - & - & - & - & - & - & - & - & - & - & - & - & - & - & - & - & - & - & Zone \\
\hline $7-6,80-82 \mathrm{~cm}$ & $\mathrm{r}$ & $\mathrm{g}$ & - & - & - & - & - & - & - & - & - & - & - & - & - & - & - & - & - & - & - & - & - & \\
\hline $7-\mathrm{CC}$ & $\mathrm{a}$ & $\mathrm{g}$ & - & - & - & - & - & - & - & - & - & - & - & - & - & - & - & - & - & - & - & - & - & \\
\hline
\end{tabular}


TABLE 10A

Radiolarians in Site 140 (Neogene)

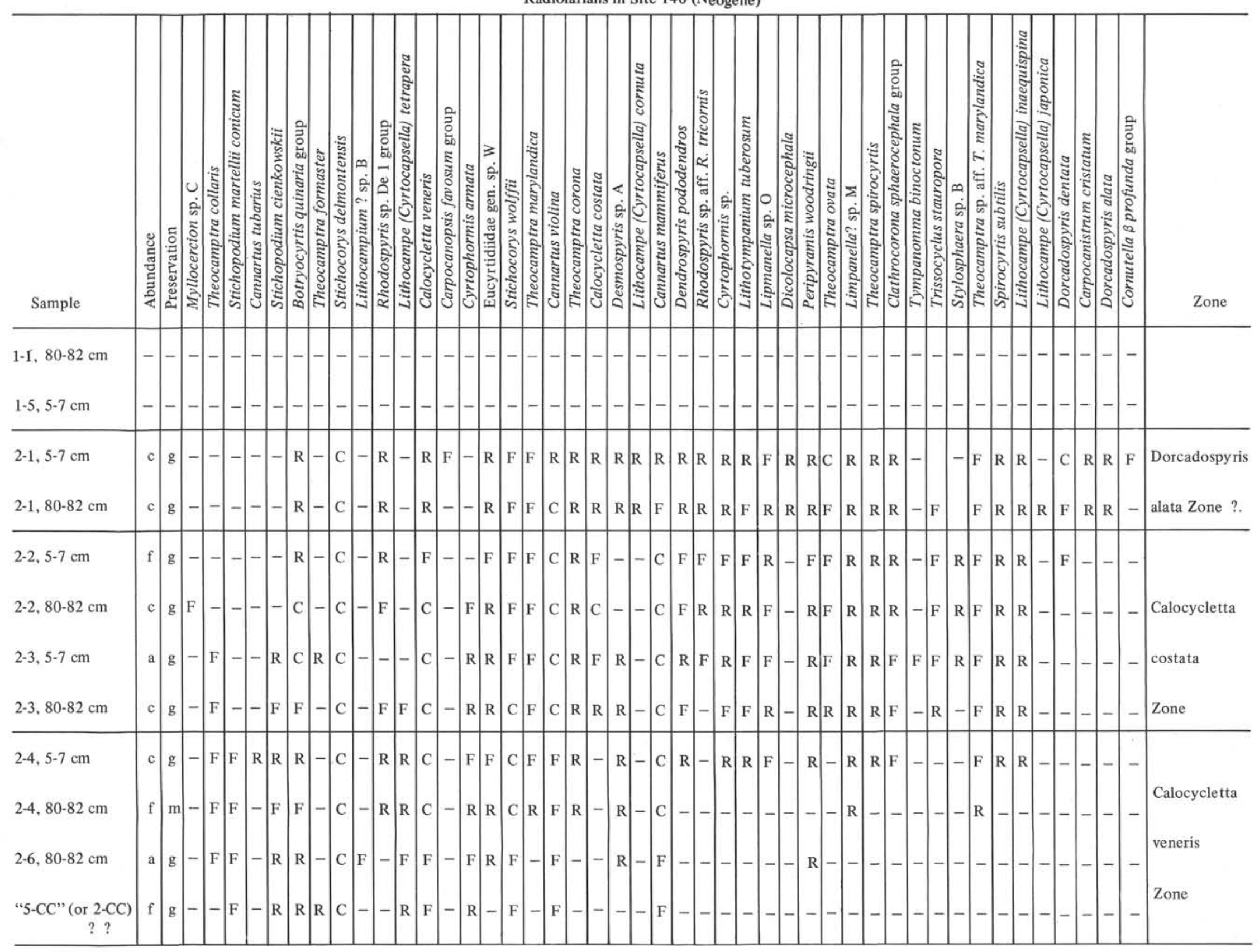


TABLE 10B

(Paleogene) Radiolarians in Site 140 Holes 140 and 140A

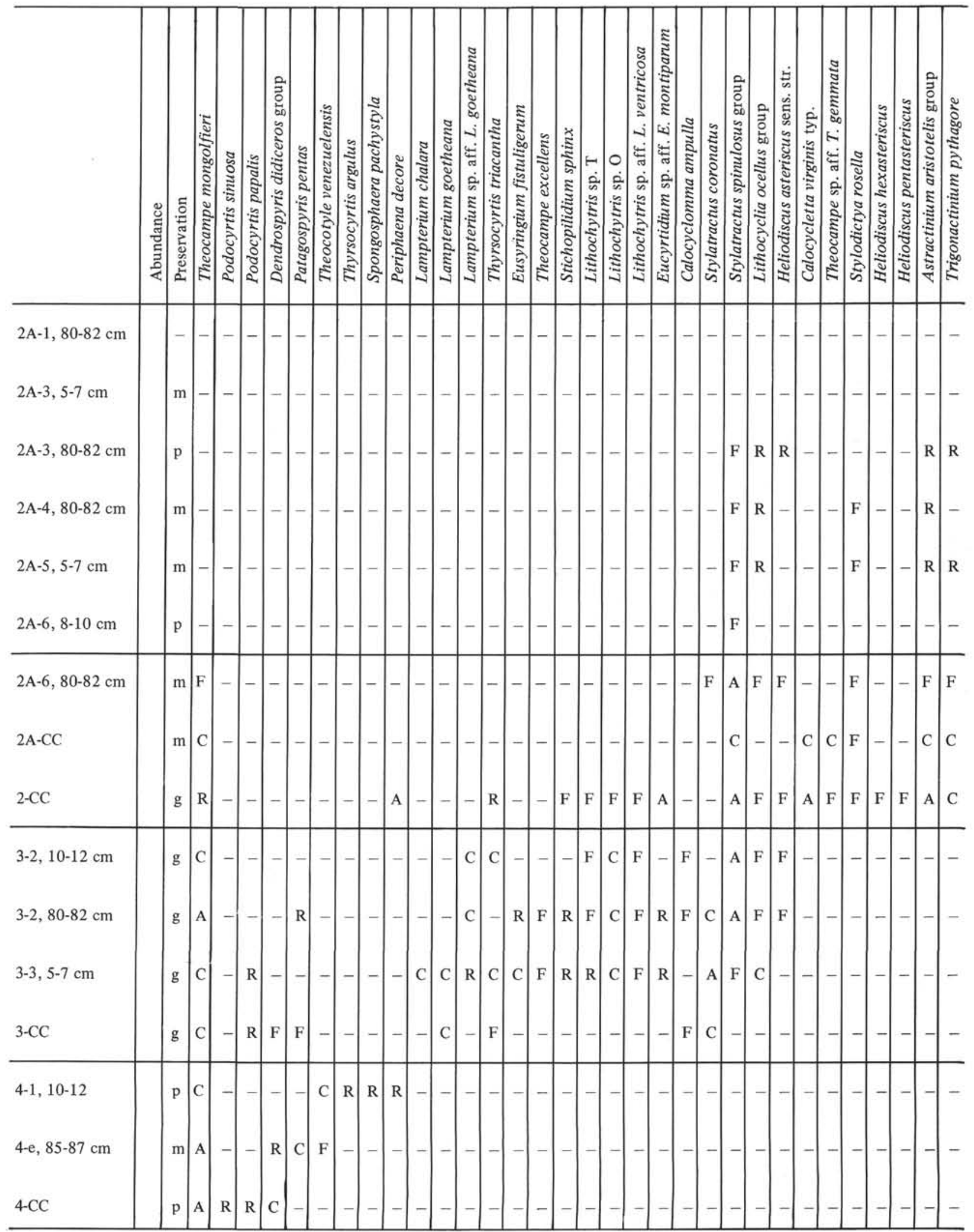


TABLE 10B - Continued

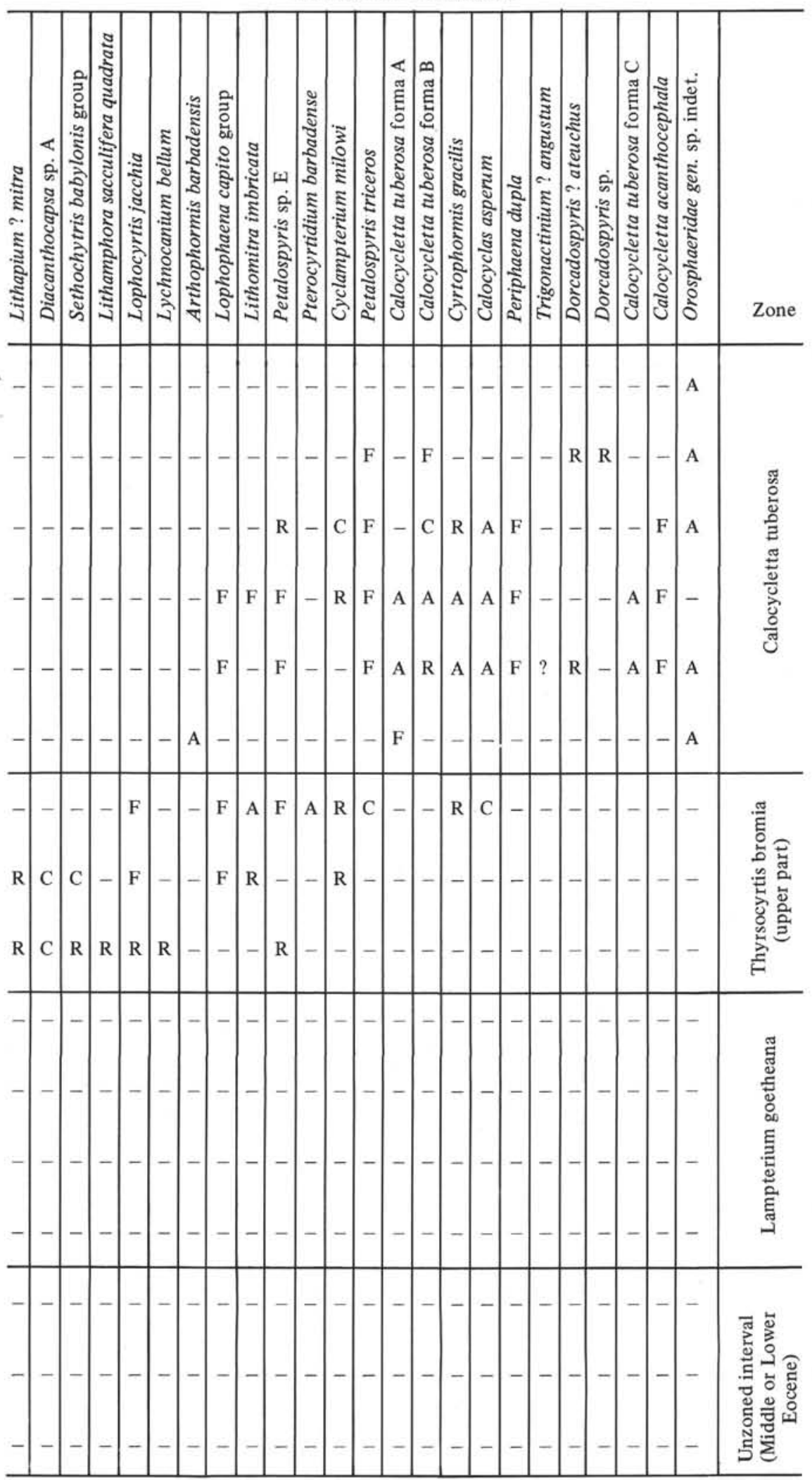


TABLE 11

Radiolarians in Site 142

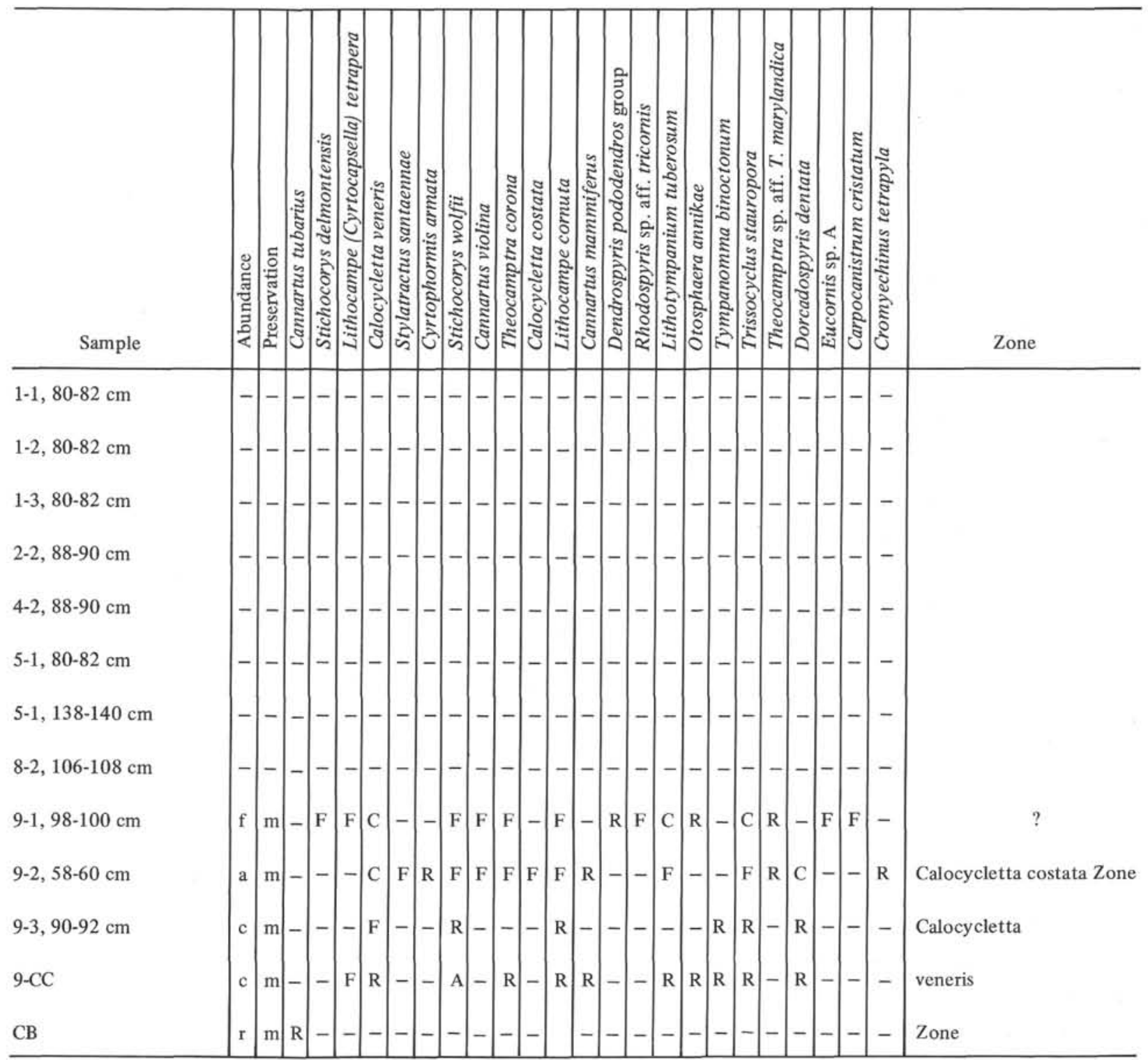

From 641 to 645 meters below the sea floor (Core 8), poorly preserved (dissolved, pyritized and so on) skeletons of Cretaceous radiolarians occur.

\section{Hole 140A}

From 235 to 244 meters below the sea floor (Core 2, Sections $3,4,5$ and $6,8-10 \mathrm{~cm}$ ) rare fragments of radiolarians which seem to belong in the Calocycletta tuberosa Zone, occur. The lower part of Core 2 (samples 6, $80-82 \mathrm{~cm}$ and 140Al2-CC) contains nearly the same assemblage as on the slide marked as 140-2-CC; it seems to belong in the upper part of the Thyrsocyrtis bromia Zone. This part of that zone was observed by T. Moore (1970, see Leg 8, Site 69, Sections 9-1, 9-3).

Site $141\left(19^{\circ} 25.16^{\prime} \mathrm{N}, 23^{\circ} 59.91^{\prime} \mathrm{W}\right.$; water depth 4148 meters)

Only in Sample 2-CC occur well preserved, rare Miocene radiolarians.
Site $142\left(03^{\circ} 22.11^{\prime} \mathrm{N}, 42^{\circ} 23.51^{\prime} \mathrm{W}\right.$; water depth 4350 meters

Radiolarians are common only from 575 to 581 meters below the sea floor (Core 9).The skeletons are moderately preserved: many specimens are destroyed; nasellarians without heads were found. The assemblage is poor in species. The lower part of Core 9 appears to belong in the Calocycletta veneris Zone, and the upper part in the Calocycletta costata Zone.

Site $144\left(09^{\circ} 27.23^{\prime} \mathrm{N}, 54^{\circ} 20.52^{\prime} \mathrm{W}\right.$; water depth 2939 meters

\section{Hole 144}

Radiolarians of good preservation are very abundant from 57 to 61 meters (Core 1). They seem to belong in the Lampterium goetheana Zone. The samples from 61 to 63 meters below the sea floor (samples from 1-6, 1-CC) are also abundant in radiolarians. The skeletons are of good 
preservation. They seem to belong in the Lampterium chalara Zone.

The samples from Core 2 (about 104 to 112 meters below the sea floor) are abundant in radiolarian skeletons. The skeletons are of various preservation: some are of good preservation, others are either destroyed, or dissolved, or infilled with silt, some representing only "ghosts" of the skeletons. As to the stratigraphic position of these samples, they are placed in the Paleocene because of the foraminifera and other data. Radiolarian assemblages were not homogeneous in this core. Sample 2-1-Top seems to belong in the Calocycletta tuberosa Zone (it contains an assemblage similar to that of the samples from 144A-2). The next sample, 2-1, contains an assemblage abundant in species; Eusyringium striata, Lithocampium sp. A, Bekoma bidarfensis, Pterocanium satelles, and Desmosphris sp. aff. D. lata being common in the assemblage. There are also rare specimens of Eocene and Oligocene species of the same assemblage as that listed for the Calocycletta tuberosa Zone (see Tables 10, 12). Sample 2-2-Top seems to be in the Calocycletta tuberosa Zone. Samples 2-2-Bottom and 2-3-Top contain nearly the same assemblage as 2-1. Sample 2-CC is abundant in moderately and poorly preserved radiolarian skeletons. The assemblage is very much the same as in Samples 2-1, 2-2-Bottom and 2-3-Top, but there are no Eocene or Oligocene species mentioned. An assemblage similar to that in the sample in question (144-2-CC) was described by Riedel and Sanfilippo (in press, 1971) from Site 67 (1-2-CC) as Upper Paleocene.

\section{Hole 144A}

Radiolarians of good preservation (though many in fragments) are abundant from 20 to 29 meters below the sea floor (Core 1). These samples seem to belong in the upper part of the Calocycletta tuberosa Zone. The samples from Core 2 (from 38 to 47 meters below the sea floor) seem to belong in the lower part of the Calocycletta tuberosa Zone.

\section{Hole 144B}

Radiolarians of good preservation (though many in fragments) are abundant in Core 2 (from 10 to 19 meters below the sea floor). These samples apparently belong in the Calocycletta tuberosa Zone. The samples from Core 3 (3-3, 3-4 and 3-5) contain rare, poorly preserved radiolarians; only fragments of orosphaerids are numerous. It is difficult to judge the age of these samples without special investigation of the Orosphaeridae.

\section{SYSTEMATICS}

The taxonomy applied here is a new one, combined from the "polycystine systematics" proposed by W. R. Riedel (Riedel, 1967a, b; Riedel and Sanfilippo, 1970, 1971) and the polycystine classification discussed by M. G. Petrushevskaya (1969c, 1971a, $1971 \mathrm{~b})$. In the future, some of the genera mentioned here might be united. But before this can be done, these old genera of Haeckel and Ehrenberg must be investigated and discussed. Unfortunately, the system of polycystine radiolarians still remains far from complete. In the Leg 14 material a number of species, important for stratigraphy, were found which could not be studied exhaustively. They are included in the present "Systematic Section", but their taxonomic position remains doubtful.

Genera within families, and species within genera, are disposed not in alphabetical order, but with a hint of their phylogeny.
Type specimens and other figured specimens are deposited in the Zoological Institute of the Academy of Sciences of the USSR, and VNIGRI Institution (Leningrad, USSR).

\section{SPUMELLARIA \\ Family COLLOSPHAERIDAE Muller \\ Genus OTOSPHAERA Haeckel emend. Nigrini}

Otosphaera Haeckel, 1887, p. 116; Campbell, 1954, p. 52; Nigrini, 1967 , p. 27. Type species Otosphaera polymorpha Haeckel, 1887 , pl. 7, fig. 6 .

Otosphaera annikae sp. nov. (Plate 9, Figure 1)

Solenosphaera sp. Riedel and Sanfilippo, in press, pl. 1A, fig. 21, part.

Description based on 24 specimens from 139-3-CC, 139-4-CC, $140-2-2,142-9-1,88-100 \mathrm{~cm}$.

The smooth wall is perforated by rounded pores. The diameter of the pores is equal to or less than the interval between them. The rounded shell (about $120-140 \mu$ in diameter) is very much the same as in the type species of the genus. It differs from $O$. polymorpha by having two (instead of three) tubes. The tubes are disposed (as in $O$. auriculata, described by C. Nigrini, 1967, pl. 1, fig. 7) on the opposite poles of the shell. The wall of the tube is perforated on the proximal end and stretched into a long needle on the distal end. In O. auriculata (Plate 9, Figure 2) there are no such needles on the ends of the tubes.

O. annikae is characteristic of the early Dorcadospyris alata Zone. The species is named for Annika Sanfilippo, who, together with W. R. Riedel, first illustrated this species.

\section{Family ACTINOMMIDAE Haeckel}

Actinommidae Haeckel, 1862, emend. Riedel, 1967b. Sphaeroidea Haeckel, sensu Hollande and Enjumet, 1960.

Subfamily ACTINOMMINAE Haeckel, emend.

Actinommatidae Haeckel, 1862 , p. $440 ; 1887$, p. 251; Riedel, 1967 b, p. 294, part.

Thecosphaeridae Haeckel, 1881, p. 449, 1887, p. 78; emend. Hollande and Enjumet, 1960, p. 110.

Actinommidae with the axoplast situated in the center of the nucleus and axopodial threads going through the nucleus. Sometimes there is a bunch of axopodial threads and thus the central capsule becomes bipolar. The innermost (first) skeletal shell, called since Haeckel the "medullary" shell, is latticed. It is about $15-35 \mu$ in diameter-of "microsphaera-type". The second and the third shells have porous walls.

\section{Genus ACTINOMMA Haeckel}

Actinomma Haeckel, 1862 , p. $440 ; 1881$, p. $453 ; 1887$, p. 251 ; Campbell, 1954, p. 64; Hollande and Enjumet, 1960, p. 110; not Nigrini, 1967 , p. 26 . Actinommetta Haeckel, 1887 , p. 253 Campbell, 1954, p. 64. Type-species Haliomma trinacrium Haeckel, 1860 (Haeckel, 1862, pl. 24, figs. 6-8).

The test consists of three shells. The innermost (first) shell is about $20 \mu$ in diameter. The third shell is spherical, with a small number of large irregular pores. Radial spines three-edged; they run through the second and third shells and form external spines. There are numerous small additional spines on the surface of the third shell.

\section{Actinomma sp. group aff. Hexaconthium arachnoidale Hollande and Enjumet} (Plate 9, Figures 4-7)

?Hexaconthium arachnoidale Hollande and Enjumet, 1960, p. 110. pl. 53, fig. 1.

Echinommaa leptodermum Jörgensen in Hays, 1965 , p. 169 , p. 1 fig. 2 (non Jörgensen, 1905, p. 116, fig. 33).

About 7 pores on the half equator of the third shell. About 5 to 11 main radial spines.

The species differs from Actinomma trinacrium in the shape and number of the pores. The species differs from Hexaconthium arachnoidale in having a variable number of main spines, not always 
TABLE 12

Radiolarians at Holes 144 and 144A

\begin{tabular}{|c|c|c|c|c|c|c|c|c|c|c|c|c|c|c|c|c|c|c|c|c|c|c|c|c|c|c|c|}
\hline Sample & 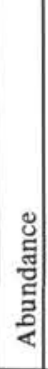 & 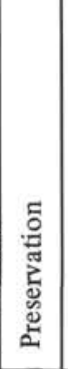 & 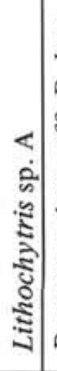 & 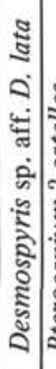 & 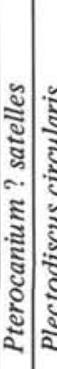 & 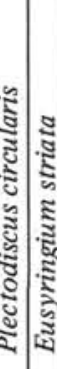 & 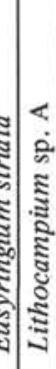 & 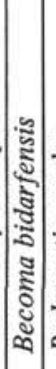 & 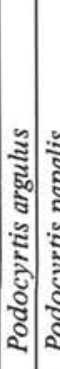 & 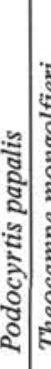 & 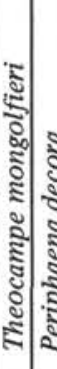 & 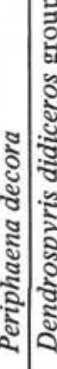 & 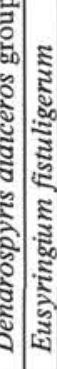 & 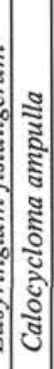 & 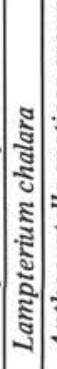 & 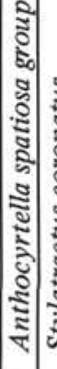 & 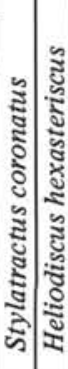 & 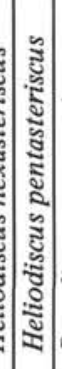 & 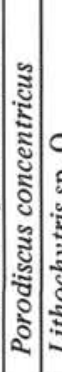 & 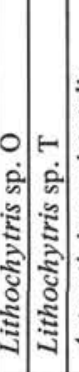 & 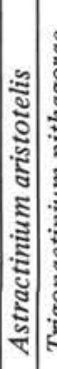 & 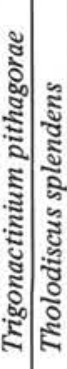 & 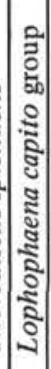 & 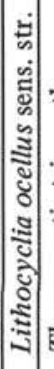 & 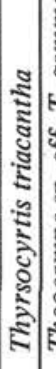 & 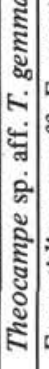 & 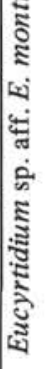 \\
\hline $1 \mathrm{~A}-2,12-14 \mathrm{~cm}$ & - & g & - & - & -- & -- & - & - & $-1-$ & -- & -- & -- & -- & - & - & - & $-1-$ & - & $-1-$ & $-R$ & $\mathbf{R}$ - & $-C$ & $F$ & $\mathrm{~F}$. & - & - & - \\
\hline $1 \mathrm{~A}-2,78-80 \mathrm{~cm}$ & - & $\mathrm{m}$ & - & - & -- & -- & - & - & $-1-$ & $-F$ & $\mathrm{R}-$ & -- & $F$ & - & - & - & -- & - & $-1-$ & -- & - & $\mathrm{R}-$ & $F$ & -1 & $\mathbf{R}$ - & - & - \\
\hline $1 \mathrm{~A}-3,5-7 \mathrm{~cm}$ & - & $\mathrm{m}$ & - & - & -- & -- & -1 & - & $-1-$ & -- & -- & -1 & -- & - & - & -1. & -- & - & $-1-$ & -- & $-1-$ & $-1-$ & $R$ & - & - & - & - \\
\hline $1 \mathrm{~A}-3,76-78 \mathrm{~cm}$ & - & $\mathrm{m}$ & - & - & -- & $-1-$ & - & - & $-1-$ & $-\mathrm{F}$ & $\mathrm{R}-$ & -- & -- & - & - & -1. & $-1-$ & - & $-1-$ & -- & $\mathrm{F}$. & -- & $\mathrm{r}$ & - & - & - & - \\
\hline $1 \mathrm{~A}-4,5-7 \mathrm{~cm}$ & - & $\mathrm{m}$ & - & - & $-1-$ & -- & -- & - & $-1-$ & $-\mathrm{F}$ & $\mathrm{R}-$ & -- & $-R$ & - & - & - & $-1-$ & - & $-1-$ & -- & -1. & -- & $\mathrm{r}$ & -1 & $\mathrm{R}$. & - & - \\
\hline $1 \mathrm{~A}-4,80-82 \mathrm{~cm}$ & - & $\mathrm{p}$ & - & - & $-1-$ & -- & - & - & $-R$ & $\mathbf{R}$ - & -1 & -- & -- & - & - & - & -- & -1 & $-1-$ & -1. & - & -- & $\mathrm{R}$ & - & - & - & - \\
\hline $1 \mathrm{~A}-5,5$ & - & $\mathrm{m}$ & - & - & -- & -- & - & - & $-1-$ & - & -- & -- & -- & - & - & - & -- & - & $-1-$ & -1 & - & -- & - & - & - & - & - \\
\hline $1 \mathrm{~A}-\mathrm{CC}$ & - & $\mathrm{m}$ & - & - & -- & -- & - & - & $-1-$ & - & $-F$ & $\mathrm{~F}-$ & -- & - & - & - & $-1-$ & - & $-1-$ & -1 & - & -- & - & - & - & - & - \\
\hline $2 \mathrm{~A}-4,5-7 \mathrm{~cm}$ & - & $\mathrm{m}$ & - & - & -- & -- & - & - & $-R$ & \begin{tabular}{l|l}
$\mathrm{R}$ & $\mathrm{F}$
\end{tabular} & \begin{tabular}{l|l}
$F$ & $F$
\end{tabular} & $\mathrm{~F}-$ & $-R$ & $\mathrm{R}$ & - & - & $-1-$ & - & $-1-$ & -1 & $\mathrm{~F}$. & $-R$ & $R$ & - & C. & - & - \\
\hline $2 A-5,5-7 \mathrm{~cm}$ & - & $\mathrm{m}$ & - & - & -- & -- & -- & - & $-R$ & \begin{tabular}{l|l}
$\mathrm{R}$ & $\mathrm{F}$
\end{tabular} & $\mathrm{F} / \mathrm{R}$ & $\mathrm{R}-$ & -- & - & - & - & -- & -1 & $-1-$ & -1 & - & -- & - & $\mathrm{R}$ & $\mathrm{R}$ & -1 & R \\
\hline $2 \mathrm{~A}-5,80-82 \mathrm{~cm}$ & - & $\mathrm{m}$ & - & - & -- & -- & -- & - & $-R$ & $\mathrm{R}-$ & $-R$ & $\mathrm{R}-$ & -- & - & - & - & $-1-$ & -- & $-1-$ & -1 & - & -- & - & $\mathrm{R}$ & $\mathrm{R}$ & $\mathrm{R}$ & $\mathrm{R}$ \\
\hline $2 \mathrm{~A}-6,2$ & - & $\mathrm{m}$ & - & - & -- & -- & - & - & $-R$ & \begin{tabular}{l|l}
$\mathrm{R}$ & $\mathrm{F}$
\end{tabular} & $\mathrm{F}$ R & $\mathrm{R}-$ & $-R$ & $\mathrm{R}$ & - & - & $-1-$ & - & $-1-$ & -- & $\mathrm{R}$ & \begin{tabular}{l|l}
$\mathrm{R}$ & $\mathrm{R}$
\end{tabular} & $R$ & R & R 1 & $\mathrm{R}$ & $\mathrm{R}$ \\
\hline 1-2, MID & - & $\mathrm{g}$ & - & - & -- & -- & -- & - & $-c$ & C $A$ & $\mathrm{~A} C \mathrm{C}$ & C $\quad$ C & $\mathrm{C}$ & $\mathrm{F}$ & $\mathrm{A}$ & C 1 & $\mathrm{~F}-$ & - & R $\mathrm{C}$ & $\mathrm{C}$ C & - & $-C$ & $R$ & C & C 1 & $\mathrm{~F}$ & C \\
\hline $1-3,80-85 \mathrm{~cm}$ & - & $g$ & - & - & - & -- & - & - & $-c$ & C $A$ & $\mathrm{~A} C \mathrm{C}$ & $\mathrm{C}$ C & $\mathrm{C}$ & F & A C & C $\mathrm{I}$ & $\mathrm{F}-$ & - & $\mathrm{R} C \mathrm{C}$ & $\mathrm{C}$ C & - & $-C$ & $R$ & C & C 1 & $\mathrm{~F}$ & C \\
\hline $1-4$ & - & g & - & - & - & -- & -- & - & $-c$ & $\mathrm{C} A$ & A $C$ & $C \mathrm{C}$ & $\mathrm{C}$ & $\mathrm{F}$ & A C & $\mathrm{C} \mathrm{H}$ & $\mathrm{F}-$ & - & R $\mathrm{C}$ & $\begin{array}{lll}C & C\end{array}$ & - & $-\mathrm{C}$ & $R$ & C & C 1 & $\mathrm{~F}$ & C \\
\hline $1-5,80-85 \mathrm{~cm}$ & - & g & - & - & -- & -- & - & - & $-c$ & C $A$ & $\mathrm{~A} C$ & $\mathrm{C} C \mathrm{C}$ & $C$ & $\mathrm{~F}$ & A C & $\mathrm{CH}$ & $\mathrm{F}-$ & - & \begin{tabular}{l|l}
$\mathrm{R}$ & $\mathrm{C}$
\end{tabular} & $\begin{array}{lll}\mathrm{C} & \mathrm{C} .\end{array}$ & -- & $-\mathrm{C}$ & $R$ & C & C 1 & $\mathrm{~F}$ & C \\
\hline $1-6,80-85 \mathrm{~cm}$ & - & $\mathrm{g}$ & - & - & -- & -- & - & - & $-c$ & $\mathrm{C} A$ & A C & C- & $-A$ & $\mathrm{~F}$ & $\mathrm{~A}$ & C $\mathrm{r}$ & $\mathrm{F}-$ & - & \begin{tabular}{l|l}
$\mathrm{R}$ & $\mathrm{C}$ \\
\end{tabular} & \begin{tabular}{l|l|l}
$\mathrm{C}$ & $\mathrm{C}$ \\
\end{tabular} & - & $-\mathrm{C}$ & $R$ & c & C & C & A \\
\hline $1-\mathrm{CC}$ & - & g & - & - & -- & -- & - & - & -- & $-c$ & C $A$ & $\mathrm{~A}-$ & $F$ & C & A & A 1 & F $\mathrm{C}$ & C & \begin{tabular}{l|l}
$\mathrm{R}$ & $\mathrm{C}$
\end{tabular} & \begin{tabular}{l|l}
$C$ & $C$
\end{tabular} & $\mathrm{~A}$ & $-C$ & - & $\mathrm{A}$. & A. & - & A \\
\hline $2-1$, TOP & - & $\mathrm{p} / \mathrm{g}$ & - & - & - & -- & -- & - & -- & $-\mathrm{F}$ & \begin{tabular}{l|l}
$\mathrm{R}$ & $\mathrm{R}$
\end{tabular} & $\mathrm{R} / \mathrm{R}$ & $\mathrm{R}$ & F & $\mathrm{R}$. & - & $-1-$ & - & -- & -- & $\mathrm{R}$ - & $-1-$ & $R$ & - & - & - & - \\
\hline $2-1$ & - & $\mathrm{m} / \mathrm{g}$ & $\mathrm{R}$ & R $\mathrm{F}$ & $\mathrm{F}$ & $\mathrm{C}$ C & $C$ & $\mathrm{R}$ & $\mathrm{R} / \mathrm{R}$ & $\mathrm{R} / \mathrm{F}$ & \begin{tabular}{l|l}
$\mathrm{R}$ & $\mathrm{R}$
\end{tabular} & \begin{tabular}{l|l}
$\mathrm{R}$ & $\mathrm{R}$
\end{tabular} & $\mathrm{R}$ & $\mathrm{F}$ & - & - & -- & - & -- & -- & $\mathrm{R}$ & $\mathrm{A}-$ & $r$ & $\mathrm{R}$ & $\mathrm{F}$. & - & - \\
\hline $2-2$, TOP & - & $\mathrm{p} / \mathrm{m}$ & - & - & -- & -- & - & - & -- & $-\mathrm{F}$ & $\mathbf{R}-$ & -1 & $-R$ & - & $?$ & -1 & $\mathrm{~F}-$ & - & -- & -1 & - & $-\mathrm{R}$ & $R$ & - & $\mathrm{R}$ & -1 & $\mathrm{~F}$ \\
\hline $2-3$ & - & $\mathrm{p} / \mathrm{g}$ & $\mathrm{R}$ & R & F & $\mathrm{A}$ C & $\mathrm{C}$ & $\mathrm{F}$ & $-?$ & ? $\mathrm{F}$ & \begin{tabular}{l|l}
$R$ & $F$
\end{tabular} & $\mathrm{R}-$ & $-\mathrm{R}$ & $\mathrm{F}$ & - & - & -- & -- & $-\mathrm{R}$ & \begin{tabular}{l|l|}
$\mathrm{R}$ & $\mathrm{R}$ \\
\end{tabular} & - & $-F$ & $\mathrm{r}$ & - & $\mathrm{F}$ & - & - \\
\hline $2-\mathrm{CC}$ & 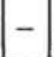 & $\mathrm{p} / \mathrm{m}$ & - & - & $-F$ & $\mathrm{~F} / \mathrm{F}$ & $=\mathrm{C}$ & F & -1 & - & -1 & -1 & -- & - & - & - & -- & -- & -- & --1 & - & -- & & 1 & & - & 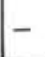 \\
\hline
\end{tabular}

six. It differs from Echinomma leptodermum in shape and number of the pores, in the number of spines, and in the dimensions of the third shell.

From the Cannartus petterssoni Zone till Recent. Earlier forms of that very type existed, but they differ from the species in question by having a thicker, heavier third shell with smaller pores.

\section{Genus HALIOMETTA Haeckel, emend.}

Haliometta Haeckel, 1887 , p. 233; Campbell, 1954, p. 62. Type species Haliomma circumtextum (Haeckel, 1887, pl. 28, fig. 7). The test consists of three (rarely four) shells. The first is irregular, about $20 \mu$ in diameter. The first and second (so-called 


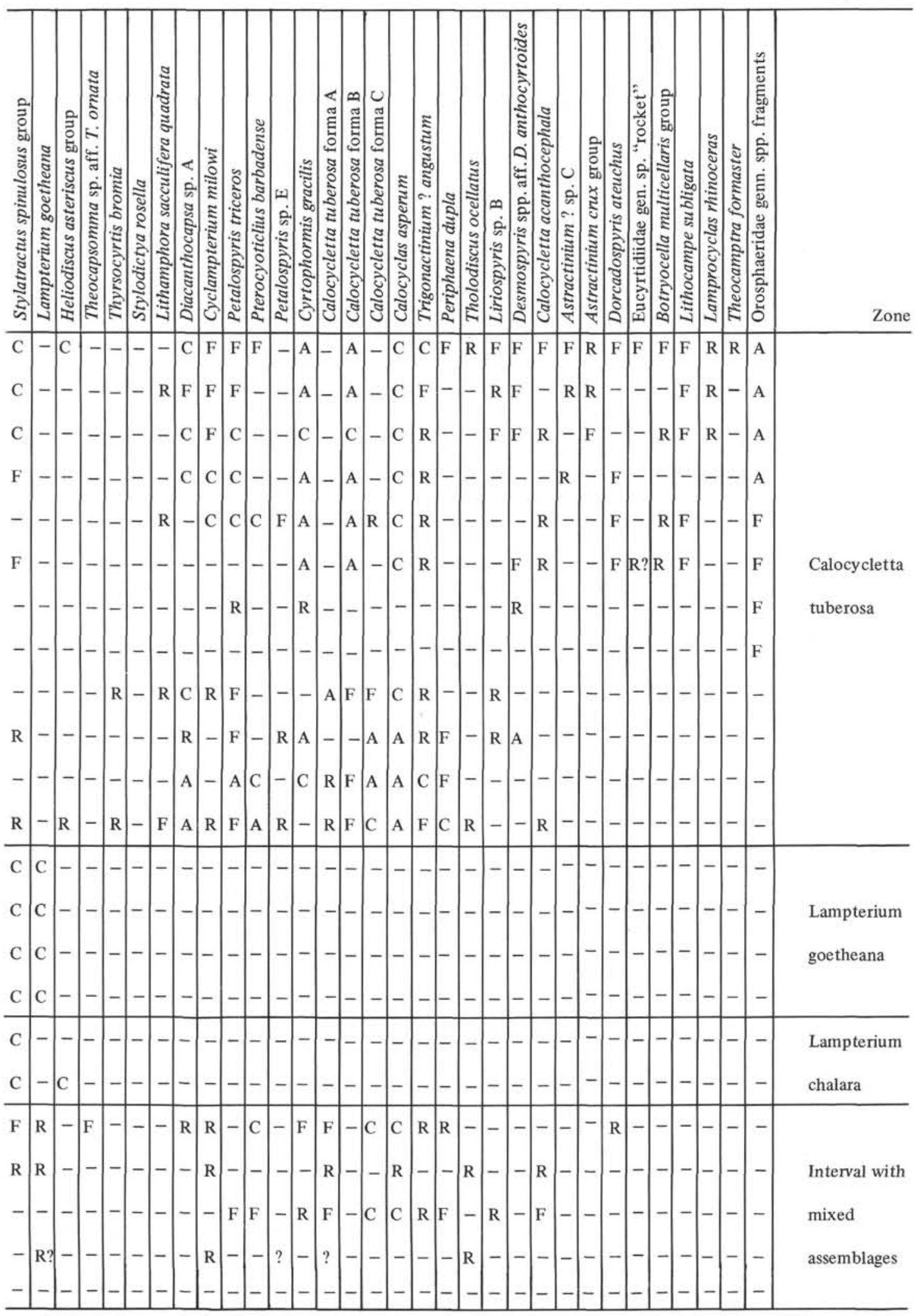

"medullary") shells are very of ten destroyed. The pores on the third shell are of equal size.

The radial spines do not run through the third shell, but there are rods uniting the second and third shells, which do not extend outside. At the points where these rods touch the third shell, there are little funnels, and the third shell does not represent by itself the regular sphere, but has convex and concave sections. The main external radial spines are not connected with the mentioned inner rods, as is usual. As a rule they arise on the convex parts of the third sphere. Small additional spines are present on the third shell (may be broken off).

Haliommetta miocenica (Campbell and Clark) group (Plate 9, Figures 8, 9)

Heliosphaera miocenica Campbell and Clark, 1944A, p. 16, pl.2, figs. 10-14. 


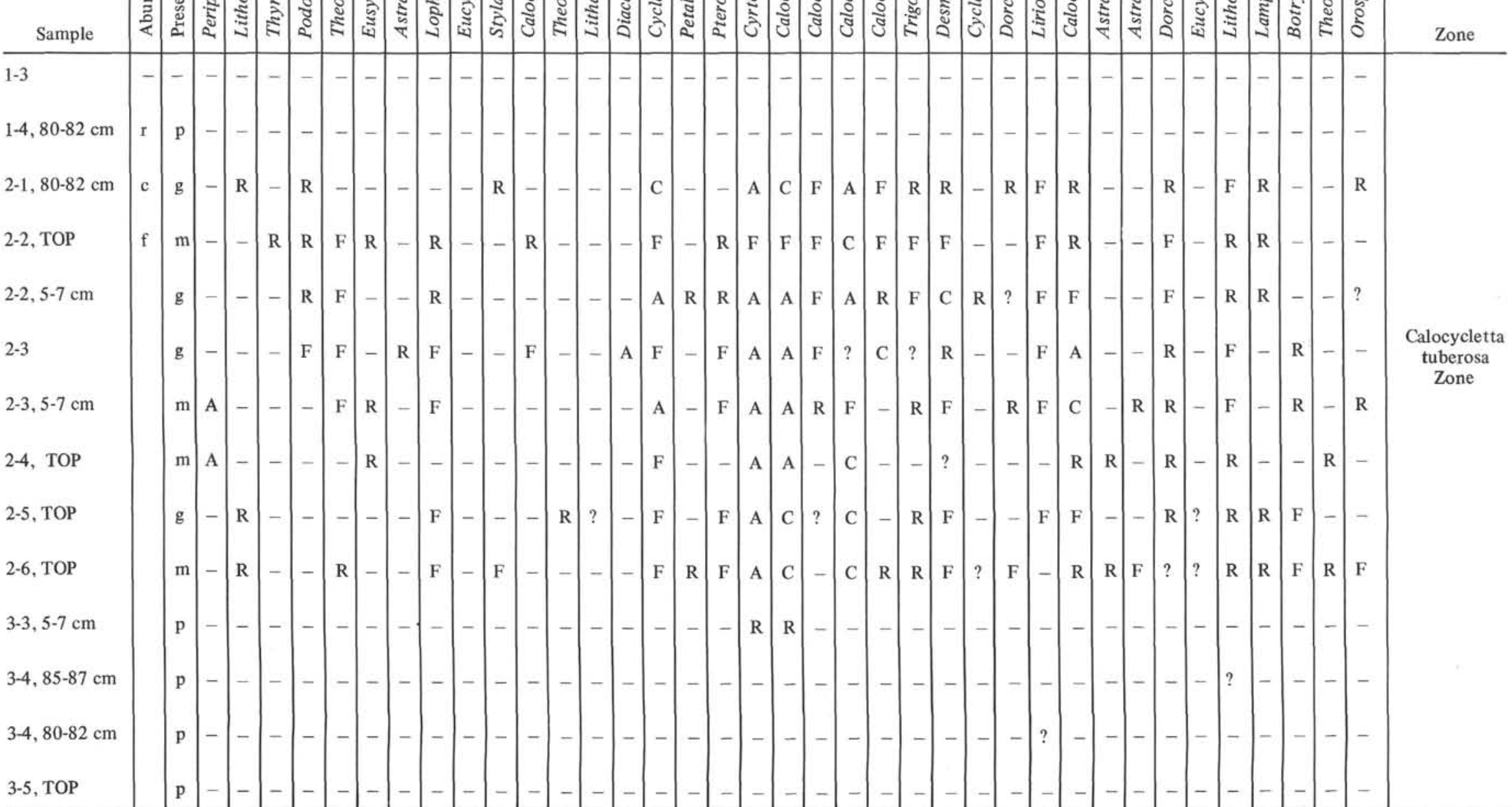


Acanthosphaera sp. Hays, 1965 , p. 169 , p. 2 , fig. 8

Echinomma popofskii Petrushevskaya, 1967, p. 23, pl. 12, figs. 1-3. Echinomma quadrisphaera Dogiel in Petrushevskaya, 1969b, p. 138, fig. 1(4).

Diameter of the third shell $90-130 \mu$. Main external radial spines three-edged.

Very likely there are two main forms (subspecies?) of this species. One of them-typical H. miocenica and recent cold water Haliometta, described as Echinomma popofskii-is characterized by a smaller number of pores (about 12) on the half equator of the third shell. The other group-Acanthosphaera sp. Hays and Haliometta described as Echinomma quadrispina-has more pores (about 18) on the half equator of the third shell.

The Eocene species of this group (Plate 9, Figure 10) is characterized by greater dimensions. Some of its external radial spines are connected with the second shell.

All these forms are similar to Haliomma circumtextum in the characters of the third shell.

These species differ sharply from Heliosphaera echinoides Haeckel, 1862, pl. 9, fig. 4 (the type species of Heliosphaera) in the construction of the nucleo-axopodial complex, and they cannot be in the genus Heliosphaera.

\section{Genus THECOSPHAERA Haeckel}

Thecosphaera Haeckel, 1881 , p. 452; 1887, p. 78; Campbell, 1954 , p. 50; emend. by Hollande and Enjumet, 1960, p. 111. Type species Thecosphaera tripodictyon Haeckel, 1887, unfigured.

Thecosphaerella Haeckel, 1887 , p. 80; Campbell, 1954, p. 50. Type species Haliomma inerme Haeckel, 1860 (Haeckel, 1862, pl. 24, fig. 5).

Very much the same as Haliometta, but as a rule without external main radial spines.

\section{Thecosphaera sp. A \\ (Plate 9, Figure 17)}

?Haliomma aequorea Ehrenberg, 1844a, p. 83; 1854, pl. 22, fig. 35. ?Carposphaera melitomma Haeckel, 1887, p. 73, pl. 20, fig. 4.

?Haliomma lirianthus Haeckel, 1887, p. 232, pl. 28, fig. 1.

Dimensions. Diameter of the second shell $60 \mu$, of the third $150 \mu$.

Eocene. The Recent species Thecosphaera radians Hollande and Enjumet is very similar to the form in question, but has more pores on the third shell.

\section{Thecosphaara? sp. B}

(Plate 9, Figure 18)

This species is distinguished from Thecosphaera sp. A by the greater number of pores (about 11, instead of 8 in Thecosphaera sp. A) on the half equator of the third shell, and by the presence of thin external radial spines. The dimensions of the test and the festooned outline of the pores on the third shell are the same in both species.

Eocene to Early Oligocene?

\section{Thecosphaera ? sp. C \\ (Plate 9, Figure 19)}

Has strong radial spines.

Eocene.

\section{Genus ACTINOMMURA Haeckel}

Actinommura Haeckel, 1887 , p. 255 ; Campbell, 1954, p. 66. Type species Actinomma capillaceum Haeckel, 1887, pl. 29, fig. 6.

The test consists of three shells, the first about $18 \mu$ in diameter, the second about $60 \mu$, the third $150-200 \mu$. They relate as $1: 3: 9$. Numerous rounded, nearly equal pores on the spherical third shell. Numerous radial spines are usually present, going from the second shell, through the third shell, to the outside.

\section{Actinommura sp. A}

(Plate 9, Figure 13)

?Haliomma medusa Ehrenberg, 1844a, p. 83; 1854, pl. 22, fig. 33.

?Acanthosphaera setosa Ehrenberg, 1872a, p. 301; 1872b, pl. 9 , fig. 11.

Eocene.

\section{Actinommura sp. B}

(Plate 9, Figure 14)

Differs from Actinommura sp. A in greater size of the third shell, and in greater diameter of the pores on the third shell.

Eocene.

Actinommura ? sp. aff. californica

(Plate 9, Figure 15)

?Thecosphaera californica Clark and Campbell, 1945, p. 22, pl. 4, fig. 7 .

?Thecosphaera scabra Kozlova in Kozlova and Gorbovetz, 1966, p. 52 , pl. 7 , figs. 5,6 .

The radial spines were not observed. Besides, the number of pores on the half equator of the third shell is more-about 20 -instead of 15 in Actinommura sp. B. The dimensions of the test are similar for both species.

Eocene-Oligocene.

\section{Genus CROMYECHINUS Haeckel}

Cromyechinus Haeckel, 1881, p. 454; 1887, p. 263; Campbell, 1954 , p. 66. Type species Cromyechinus icosacanthus Haeckel, 1887 , pl. 30 , fig. 1 .

Chromyechinus Jörgensen, 1905, p. 117.

Sphaeropyle Dreyer, 1899 , p. 89 ; Campbell, 1954, p. 66. Type species Sphaeropyle langii Dreyer, 1899, fig. 54.

The first shell about $15-20 \mu$ in diameter, the second about $30-50 \mu$. The diameter, as well as the shape and the number of the pores of the third shell, is variable. It is always spherical. Radial spines numerous; they go from the second shell through the third. The difference from Actinomma lies mainly in the nearly obligate presence of a delicate fourth shell in Cromyechinus. Very often the fourth shell has a pylome at one pole.

\section{Cromyechinus langii (Dreyer) group (Plate 9, Figure 12)}

Sphaeropyle langii Dreyer, 1899 , p. 89, fig. 54; Hülsemann, 1963, p. 17 , fig. 9.

Cromyechinus borealis (Cleve, 1899) Jörgensen, 1905, p. 117, pl. 9, fig. 35-37; Petrushevskaya, 1967 , p. 25-30, pl. 13, figs. 5-9; Petrushevskaya, 1969a, p. 124, pl. 1, fig. 1.

Cromyechinus antaractica (Dryer) Petrushevskaya 1967, pl. 14, figs. $4,5,7$, part.

Cromyechinus sp. Petrushevskaya 1969b, pl. 10, figs. 1, 5-8.

The fourth shell is more removed from the third than in $C$. antarctica.

Miocene-Recent.

\section{Cromyechinus tetrapyla (Hays) (Plate 9, Figure 11)}

Prunopyle tetrapyla Hays, 1965 , p. 172 , pl. 2, fig. 5 . Miocene-Quaternary. Antarctic, transitional and tropical regions.

\section{Genus STYLATRACTUS Haeckel}

Stylatractus Haeckel, 1887, p. 328; Campbell, 1954, p. 73. Stylatractura Haeckel, 1887, p. 328. Type species Amphistylus neptunus Haeckel, 1878, Atlas, pl. 17, fig. 6.

The first shell about $35 \mu$ in diameter, the second ellipsoidal or pear-shaped, major axis about $40-70 \mu$. The second and third shells are joined by numerous rods going in various directions. Some of them form external radial spines. Two of these spines, situated on opposite poles of the test, are much stouter than the others. The third shell is usually very thick-walled, ellipsoidal. It has 8 to 10 pores on the half equator. The pores of the third shell may be overgrown by the delicate rods of the fourth shell.

\section{Stylatractus spinulosus (Ehrenberg) group (Plate 11, Figures 2-4)}

Stylosphaera spinulosa Ehrenberg, 1873, p. 259; 1875, pl. 15, fig. 8. ?Xiphatractus trochilus Haeckel, 1887, p. 129, pl. 13, fig. 10.

Besides two polar spines, there are 5 to 8 stout additional radial spines of various length.

Eocene-Oligocene. 


\section{Stylatractus ostracion (Haeckel)}

(Plate 11, Figure 1)

Druppatractus ostracion Haeckel, 1887, p. 326, pl. 16, figs. 8,9 .

The length of the major axis of the third shell is about $160 \mu$, of the minor axis about $120 \mu$. Only two external spines. About seven pores on the half equator of the third shell.

Eocene-Oligocene.

\section{Stylatractus radiosus (Ehrenberg)}

Stylosphaera radiosa Ehrenberg, 1854, p. 256; 1875, pl. 24, fig. 5 . Two polar spines only. Dimensions of the third shell variable. About nine pores on the half equator of the third shell.

Eocene.

\section{Stylatractus neptunus Haeckel}

(Plate 11, Figure 11)

Stylatractus neptunus Haeckel, 1887 , p. 328 , pl. 17, fig. 6; Riedel, 1958 , p. 266, pl. 1, fig. 9.

Xiphatractus radiosus (Ehrenberg) Haecker, 1908, p. 442, pl. 84, fig. 588 , text-fig. 81 .

Stylatractus sp. Petrushevskaya, 1967, p. 30, pl. 15, fig. 3, part.

The length of the major axis of the second shell is about $75 \mu$, of the third about $140 \mu$; of the minor axis of the second shell $60 \mu$, of the third about $110 \mu$. Eight or nine pores on the half of the equator of the third shell; they are usually overgrown by the rods of the fourth shell. Two three-edged polar spines.

Quaternary.

\section{Stylatractus santaennae (Campbell and Clark)} (Plate 11, Figure 10)

Lithatractus santaennae Campbell and Clark, 1949a, p. 19, pl. 2, figs. 20-22.

Differs from $S$. neptunus by the thicker-walled third shell. Middle and Late Miocene.

\section{Stylatractus fragilis (Haeckel) \\ (Plate 11, Figure 12)}

Lithatractus fragilis Haeckel, 1887, p. 319, pl. 16, fig. 3.

?Amphisphaera cronos Haeckel, 1887, p. 117, pl. 17, fig. 5 .

Thin-walled third shell. Two weak cylindrical polar spines.

Quaternary. In the Miocene thicker-walled forms of that type existed, somewhat similar to $S$. santaennae.

\section{Stylatractus sp. aff. Stylosphaera sulcata Ehrenberg}

(Plate 11, Figures 13,14)

?Stylosphaera sulcata Ehrenberg, 1873, p. $259 ; 1875$, pl. 24 , fig. 6 . About ten festooned pores on the half diameter of the third shell.

Eocene.

\section{Stylatractus coronatus (Ehrenberg)}

(Plate 11, Figure 9)

Stylosphaera coronata Ehrenberg, 1873, p. $258 ; 1875$, pl. 25 , fig. 4. Xiphostylus plasianus Haeckel, 1887, pl. 127, pl. 13, fig. 9.

Differs from $S$. sulcata by the characteristic shape of one of the polar spines.

Eocene.

\section{Genus STYLOSPHAERA Ehrenberg}

Stylosphaera Ehrenberg, 1847 b, p. 54 ; Haeckel, 1881, p. $451 ; 1887$, p. 133; Campbell, 1954 , p. 53. Stylosphaerella Haeckel, 1887, p. 135; Campbell, 1954 , p. 53. Type species Stylosphaera hispida

Ehrenberg, 1854, pl. 36, fig. 26.

The construction of the inner part of the skeleton of the type species is as yet unknown. Very probably there are two "medullary" shells of the same type as characteristic for Actinomminae. The second shell is very likely joined to the third shell by numerous radial spines. Two of the latter, disposed on opposite poles of the skeleton, are much stouter than the other. The third shell of irregular shape has 18 to 20 small pores on the half equator.

\section{Stylosphaera minor Clark and Campbell typ.} (Plate 10, Figure 9)

Stylosphaera minor Clark and Campbell, 1942, pl. 16, pl. 1, figs. 13,14 .
Major axis of the third shell about $100-150 \mu$, shorter axis about $90-140 \mu$. About 15 pores on the half equator of the third shell. Two long polar spines.

Eocene-Oligocene.

\section{Stylosphaera sp. A}

(Plate 10, Figure 8)

?Amphisphaera spinosa Carnevale, 1908, p. 14, pl. 2, fig. 6 .

?Doryconthidium maximum Carnevale, 1908, p. 11, pl. 2, fig. 1.

Stylosphaera angelina Campbell and Clark, 1944a, p. 12, pl. 1, figs. 17,18 , part.

Third shell thick-walled, about $120 \mu$ in diameter. About 20 pores on the half equator of the third shell. Two long polar spines and some small additional spines, going in various directions.

Lower Miocene.

\section{Stylosphaera sp. B}

(Plate 10, Figure 7)

Skeleton of the same construction as in Stylosphaera sp. A, but one polar spine is much shorter than the other. The third shell is only about $100 \mu$ in diameter.

Middle Miocene.

\section{Stylosphaera angelina Campbell and Clark group (Plate 11, Figures 15-19)}

Stylosphaera angelina Campbell and Clark, 1944a, p. 12, pl. 1, figs. 15 and 20 , (part).

Stylatractus universus Hays in Kling, in press, pl. 1, fig. 1.

Because of the convex-concave shape of the third shell it looks, in optical section, as if festooned-very much the same as in Haliometta miocenica (Plate 9, Figures 8, 9; Plate 11, Figures 15, 18). This feature distinguishes this species from the Stylosphaera species mentioned above. The surface of the third shell with irregularly disposed pores (about eighteen on the half of the equator) and with small additional spines. Sometimes the surface of the third shell is spongy (Plate 11, Figure 17).

This species differs from the Antaractic species Stylatractus sp. Hays $(1965$, pl. 1, fig. 6$)$ by having thinner polar spines.

Calocycletta costata Zone to Quaternary.

\section{Stylosphaera ? sp. C}

(Plate 11, Figures 5-7)

Resembles Stylosphaera angelina in having the third shell of the same festooned shape, with very similar small numerous pores, and having two polar spines of the same type. But it differs from $S$. angelina in the dimensions: the first shell about $10 \mu$, the second $25-35 \mu$, the third, major axis $60-80 \mu$, minor axis $50-65 \mu$. A distinguishing character of the species is also the pear-shaped second shell (as in Stylatractus neptunus). Sometimes a delicate fourth shell is developed (Plate 11, Figure 7).

Calocycletta virginis Zone to Quaternary.

Stylosphaera ? laevis Ehrenberg

(Plate 11, Figure 8)

Stylosphaera laevis Ehrenberg, 1873, p. 259; 1875, pl. 25, fig. 6.

Having the "cortical" (third?) shell of nearly the same size as in Stylosphaera ? sp. C, it differs from that species in the shape (rosette) of the pores on the "cortical" shell and in the number of these pores. The disposition of the trabeculae joining the "cortical" and the "medullary" shells is also different. In the species in question they are disposed in the equatorial plane as in Axoprunum species, while in the species described here as Stylosphaera such rods go in various directions.

Eocene.

\section{Genus AXOPRUNUM Haeckel}

Axoprunum Haeckel, 1887 , p. 298 ; Campbell, 1954, p. 68 ; Hays, 1965 , p. 170 . Type species Axoprunum stauraxonium Haeckel, 1887 , pl. 48 , fig. 4.

The first shell about $10 \mu$ in diameter, the second about $30-40 \mu$ and slightly ellipsoidal, the third shell nearly ellipsoidal abut with equatorial intake. The second and third shells are joined by rods (about 6) disposed in the equatorial plane, and by two rods going to the opposite poles of the shell. These two rods go through the third shell and form two strong polar spines. The other rods never 
protrude outside the third shell, but at the points where they touch the third shell little pits exist.

\section{Axoprunum stauraxonium Haeckel}

(Plate 10, Figure 10)

Axoprunum stauraxonium Haeckel, 1887, p. 298, pl. 48, fig. 4; Hays, 1965 , p. 170 , pl. 1, fig. 3 .

The major axis of the third shell about $150 \mu$, the minor axis about $120 \mu$. Polar spines cylindrical.

Upper Miocene to Recent.

\section{Axoprunum polycentrum (Clark and Campbell)}

(Plate 10, Figures 11, 12)

Druppatractus polycentrus Clark and Campbell, 1942, p. 35 , pl. 5 , fig. 19.

The major axis of the third shell is about $120-130 \mu$, the minor axis about $110-120 \mu$. As in $A$. stauraxonium there are about nine large pores on the half equator of the third shell. The polar spines are three-edged. "Equatorial" rods uniting the second and third shells are disposed irregularly: some of them somewhat higher than the equatorial plane, others somewhat lower.

Remark: The species (Plate 10, Figure 9) figured by Riedel and Sanfilippo (in press, pl. 2C, fig. 14) as Cannartus sp. aff. Cannartus prismaticus has the same construction and dimensions. The difference between it and $A$. polycentrum is only in the number of pores: it has about twelve pores on the half equator of the third shell. It cannot be placed into Cannartus because it has inner rods connected with polar spines.

Eocene-Oligocene.

\section{Axoprunum liostylum (Ehrenberg) group} (Plate 10, Figure 3)

Stylosphaera liostylus Ehrenberg, 1873, p. $259 ; 1875$, pl. 25 , fig. 2 . The major axis of the third shell about $150-170 \mu$, the minor axis about $140 \mu$. About twelve pores on the half equator of the third shell. The polar spines cylindrical, very long.

Upper-Eocene?-Oligocene.

Remark: In the Miocene and Pliocene, forms with very similar third shells exist but they have short, of ten curved polar spines.

\section{Axoprunum carduum (Ehrenberg)} (Plate 10, Figure 1)

Stylosphaera carduus Ehrenberg, 1873, p. $258 ; 1875$, pl. 25 , fig. 7. The major axis of the third shell about $200 \mu$, the minor axis about $160 \mu$.

Eocene.

\section{Genus SPONGOSPHAERA Ehrenberg}

Spongosphaera Ehrenberg, 1847b, p. 54; Campbell, 1954, p. 74 (non Spongosphaera Haeckel, 1887, p. 282). Spongatractus Haeckel, 1887, p. 282. Type species Spongosphaera pachystyla Ehrenberg.

\section{Spongosphaera pachystyla Ehrenberg} (Plate 10, Figure 5)

Spongosphaera pachystyla Ehrenberg, 1873, p. 256; 1875, pl. 26 , fig. 3 .

Spongotractus pachystylus Ehr., Riedel and Sanfilippo, 1970, pl. 4, fig. 1.

The inner construction is very likely the same as in Axoprunum species, but the surface of the third shell is spongy.

Eocene.

\section{Cretaceous Actinommidae ${ }^{1}$}

More or less regular spheres, some of them even flattened to become lenticular. All of them have double cortical shells. The external shell has larger pores, the internal one smaller pores. The pores of the internal shall may be seen through large pores of the external shell. The latter are not rounded, but festooned, and look like rosettes. Specimens similar to the discussed actinommids were described by Kh., Aliev, 1965, pl. 2, figs. 5, 6. The internal

\footnotetext{
${ }^{1}$ This group was studied only by G. E. Kozlova.
}

construction is unknown, and thus only conventional generic identification is possible.

\section{Conosphaera fossilis Parona} (Plate 1, Figure 8)

Conosphaera fossilis Parona, 1890, p. 148, pl. 1, fig. 9. Cenomanian.

\section{Conosphaera sphaeroconus Rüst} (Plate 4, Figure 2)

Conosphaera sphaeroconus Rüst, 1898, p. 13, pl. 4, fig. 8. Albian-Maestrichtian.

Cenosphaera? sp. aff. Cenosphaera euganea Squinabol (Plate 1, Figure 10; Plate 4, Figure 1)

?Cenosphaera euganea Squinabol, 1904, p. 109, pl. 8, fig. 1 .

It has smaller dimensions of the test and of the pores, than Squinabol's species.

Cenomanian-Maestrichtian.

\section{Subfamily SATURNALINAE Deflandre}

Saturnalidae Deflandre, 1953, p. 419; Riedel and Sanfilippo, 1970, p. 504.

The subfamily was treated only in Cretaceous occurrences, though in the late Tertiary and Early Quaternary fragments of saturnalin rings were frequent.

\section{Spongosaturnalis? sp. aff. Spongosaturnalis latuformis Campbell and Clark (Plate 4, Figure 5)}

?Spongosaturnalis latuformis Campbell and Clark, 1944b, p. 8, pl. 3, figs. 2, 4, 7, 8, 11, 12 .

Cretaceous (Maestrichtian).

\section{Subfamily ARTISCINAE Haeckel}

Haeckel, 1881, p. 462; Riedel, 1967b, p. 294.

Actinommidae which very likely have the same nucleo-axoplast complex as Actinomminae.

The innermost (first) skeletal shell latticed, about $15 \mu$ in diameter. The second shell is flattened along the main axis of the skeleton: its dimension along that axis is no more than $40 \mu$, while the diameter of the second shell measured in the equatorial plane is as a rule about $50 \mu$. The second shell is joined with the third by means of numerous rods situated exactly in the equatorial plane or near it. Unlike Axoprunum, there are no inner polar rods. The third shell is elongated along the main axis of the skeleton, constricted in the equatorial plane. It may be surrounded on all sides, or only on the poles, by irregular chambered shells or by spongy meshwork. The most ancient representative of the subfamily seems to be like the specimen illustrated on Plate 12, Figure 1.

\section{Genus CANNARTUS Haeckel}

Cannartus Haeckel, 1881, p. 462; 1887, p. 358; Campbell, 1954, p. 74; Riedel and Sanfilippo, 1970, p. 520.

Artiscinae with spongy polar columns, without distinct polar caps. The diameter of the columns is less than the equatorial diameter of the third shell.

\section{Cannartus prismaticus Haeckel}

See Riedel and Sanfilippo, 1970, p. 520, pl. 15, fig. 1.

\section{Cannartus tubarius (Haeckel)}

Pipettaria tubaria Haeckel, 1887, p. 339, pl. 39, fig. 15; Riedel, 1959 b, p. 289 , pl. 1, fig. 2.

Cannartus tubarius (Haeckel), Riedel and Sanfilippo, 1970, p. 520 , pl. 15, fig. 2; Kling (1971), pl. 3, fig. 3; Riedel and Sanfilippo, in press, pl. 2C, figs. 8-10.

Miocene.

\section{Cannartus mammiferus (Haeckel)}

(Plate 12, Figure 3)

Cannartidium mammiferum Haeckel, 1887, p. 375, pl. 39, fig. 16. Cannartus mammiferus (Haeckel), Riedel, 1959a, p. 291, pl. 1, fig. 4; Riedel and Sanfilippo, 1970, p. 520, pl. 14, fig. 1; Riedel and 
Sanfilippo, in press, pl. 2C, figs. 1-3; Kling, 1971, pl. 3E; Moore, in press, pl. 12, fig. 5 .

Miocene.

\section{Cannartus violina Haeckel \\ (Plate 12, Figure 9, 10)}

Cannartus violina Haeckel, 1887, p. 358, pl. 39, fig. 10; Riedel, 1959a, p. 290, pl. 1, fig. 3; Kling, 1971, pl. 3, fig. D; Riedel and Sanfilippo, in press, pl. 2C, figs. 4-7; Moore, in press, pl. 12, fig. 4.

Pores on the third shell $5-12 \mu$ in diameter.

Miocene.

Cannartus sp. A.

(Plate 12, Figures 11-14)

?Cannartus haeckelianus Vinassa, 1900, p. 547, pl. 1, fig. 44.

Cannartus sp. Riedel and Sanfilippo, in press, pl. 2B, fig. 10, only.

Differs from $C$. violina by more delicate wall of the third shell, without mammiferous papillae. The number of pores on the half circumference of the third shell is about fourteen, the diameter of the pores $3-7 \mu$. The third shell more elongate than in $C$. violina, and it is inclined-to malformations (Plate 12, Figures 13,14). One or two irregular envelopes, extending from the equator to the polar tubes, may surround the third shell.

Having delicate, irregular (nearly spongy) surface of the main shell, and being inclined to malformations, the species in question is somewhat similar to the form of Trigonactinium angustum (Plate 17, Figure 3). Maybe they are both terminal stages (species, or forms) of a genus. Rare, mainly in 139-5-CC.

Miocene.

\section{Genus ASTROMMA Ehrenberg}

Astromma Ehrenberg, 1847 b, p. 54 ; Campbell, 1954 , p. 74 . Type species Astromma enthomocora Ehrenberg, 1847 (Ehrenberg, 1854 , pl. 22, fig. 32).

Cypassis Haeckel, 1887 , p. 366; Campbell, 1954, p. 74 . = Didymocyrtis Haeckel, 1881, p. 445; Campbell, 1954, p. 74. Type species Cypassis palliata Haeckel (1887, pl. 40, fig. 5).

Artiscinae (Plate 12, Figure 6) with the polar caps pressed closely to the third shell. The distance between the polar cap and the pole of the third shell is less than one-quarter of the third shell's long axis.

The polar columns are initially of the same breadth of even broader than the third shell.

\section{Astromma petterssoni (Riedel)}

(Plate 12, Figure 5)

Cannartus (?) petterssoni in Riedel and Sanfilippo, 1970, p. 520, pl. 14 , fig. 3 ; Moore, in press, pl. 12, fig. 7.

The walls of the third shell have mammiferous papillae. Polar columns are spongy; only one cap may be distinguished in them. Miocene.

\section{Astromma hughesi (Campbell and Clark)} (Plate 12, Figure 4)

Ommatocampe hughesi Campbell and Clark, 1944a, p. 23, pl. 3, fig. 12.

Ommatartus hughesi (Campbell and Clark), Riedel and Sanfilippo, 1970 , p. 520; Moore, in press, pl. 12, fig. 8. non? Ommatocampe hughesi Bandy, Casey and Wright, 1971, pl. 1, fig. 3.

Differs from $A$. petterssoni by more elongate shape of the third

shell and by chambered (not spongy) polar columns. Miocene.

\section{Genus OMMATARTUS Haeckel}

Ommatartus Haeckel, 1881 , p. $463 ; 1887$, p. 395 ; Campbell, 1954 , p. 76; Riedel and Sanfilippo, 1970, p. 521. Type species Ommatartus amphicanna Haeckel, 1887, aff. pl. 40, fig. 12.

?Artiscus Haeckel, 1881 , p. 462; 1887, p. 355 ; Campbell, 1954, p. 74. $=$ Artiscium Haeckel, 1887 , p. 355 ; Campbell, 1954, p. 74 . Type species Artiscus paniscus Haeckel, 1887, like pl. 40, fig. 1.

Panaronium Haeckel, 1887 , p. 389 ; Campbell, 1954, p. 76 . Type species Panarium tubularium Haeckel, 1887, pl. 40, fig. 9.
The third shell delicate, without any mammiferous papillae or other thickenings. There are distinct polar caps. The distance between a cap and a pole of the third shell is more than a quarter of the third shell's major axis. Therefore the caps are elongated further from the third shell than in Astromma. Spongy columns, if present, are as narrow as in Cannartus.

\section{Ommatartus spp. aff. O. ceratospyris (Haeckel)} (Plate 12, Figure 15-17)

?Haliomma didymocyrtis Haeckel, 1860, p. 816. = Didymocyrtis ceratospyris Haeckel, 1862 , p. 445 , pl. 22 , figs. 14-16. $=$ Cyphonium ceratospyris Haeckel, 1887, p. 366.

Panartus tetrathalamus Haeckel in Nigrini, 1967, pl. 2, fig. 4b, part.

Ommatartus tetrathalamus (Haeckel), Moore, in press, pl. 12, fig. 12.

The third shell rather short, long axis about $100-150 \mu$, minor axis (not in the equatorial plane) $80-100 \mu$. The shape of the third shell is variable, 6-8 pores on the half circumference (not at the equator) of the third shell.

Pleistocene-Recent.

\section{Family COCCODISCIDAE Haeckel ${ }^{2}$}

Haeckel, 1862, p. 485; Riedel, 1967b, p. 294.

The so-called "medullary" shell is double. The first shell is about $18-30 \mu$ in diameter, and the second shell about $30-50 \mu$ in diameter. The construction is very much the same as in Artiscinae, with the exception that the second shell is joined with the third shell by means of numerous rods situated in the equatorial plane of the skeleton, but along the main axis of the skeleton. The third shell is flattened along the main skeletal axis, and has the shape of a lens.

\section{Subfamily PHACODISCINAE Haeckel}

Phacodiscidae Haeckel, 1881, p. 456; Riedel, 1967b, p. 294.

The lens of the third shell is about $130-260 \mu$ in diameter. The third shell may be armed with spines, but not with chambered or spongy arms or rings.

\section{Genus SETHOSTYLUS Haeckel}

Sethostylus Haeckel, 1881, p. 457; 1887, p. 420; Campbell, 1954 , p. 81. Type species Sethostylus distyliscus Haeckel, 1887, pl. 31, fig. 9.

Phacostylus Haeckel, 1881, p. 457; Haeckel, 1887, p. 430; Campbell, 1954, p. 80. Type species Phacostylus amphistylus Haeckel (1887, pl. 31, fig. 12).

Phacodiscinae with two main spines in the equatorial plane, going from the second shell through the third shell.

\section{Sethostylus sp. aff. Phacostylus amphistylus Haeckel} (Plate 13, Figure 1)

?Phacostylus amphistylus Haeckel, 1887, p. 430, pl. 31, fig. 12. Eocene.

\section{Genus HELIOSESTILLA Haeckel}

Heliosestilla Haeckel, 1887 , p. 440; Campbell, 1954, p. 78. Type species Heliosestrum octonum Haeckel, 1887, pl. 34, fig. 3.

Phacodiscinae with eight main spines on the margin of the lenticular third shell. The spines are situated in the equatorial plane.

\section{Heliosestilla spicata (Haeckel)}

(Plate 13, Figure 10)

?Sethostylus spicatus Haeckel, 1887, p. 430.

Marginal spines of variable length. This species differs from the type species of the genus by possessing unequal spines, two of them being longer than the others. The number, size and shape of pores are similar in both species.

Eocene-Oligocene.

\section{Genus TRIACTIS Haeckel}

Triactis Haeckel, 1881 , p. 457 ; non Campbell, 1954 , p. 81 ; Riedel and Sanfilippo, 1970, p. 521. Triactiscus Haeckel, 1887, p. 432; non Campbell, 1954, p. 81; but Strelkov, Chabakov and Lipman,

\footnotetext{
${ }^{2}$ This group was studied mainly by G. E. Kozlova.
} 
1959, p. 433. Type species Triactiscus tripyramis Haeckel (1887. pl. 33 , fig. 6).

Phacotriactis Sutton 1896a, p. 61; Riedel and Sanfilippo, 1970, p. 521. Type species Phacotriactis triangula Sutton (1896a, pl. 61, fig. 3).

Phacodiscinae with three main spines.

\section{Triactis triactis (Ehrenberg) (Plate 13, Figure 2)}

Haliomma triactis Ehrenberg, 1873, p. $236 ; 1875$, pl. 28 , fig. 4 . Differs from $T$. tripyramis tripyramis, described by Riedel and Sanfilippo, (1970, pl. 4, fig. 8) and by Moore (in press, pl. 1, fig. 8) by the smaller number of pores on the third shell.

Eocene.

\section{Genus HELIODISCUS HaeckeI}

Heliodiscus Haeckel, 1862 , p. 436; 1887, p. 444; non Campbell, 1954 , p. 82 , but Nigrini, 1967, p. 32. Type species Heliodiscus asteriscus Haeckel (1887, pl. 33, fig. 8).

Phacodiscinae with undetermined number of spines (5-20 and more) on the margin of the third shell.

\section{Heliodiscus asteriscus Haeckel group} (Plate 13, Figure 3)

?Heliodiscus asteriscus Haeckel, 1887, p. 445, pl. 33, fig. 8; Hays 1965 , p. 171, pl. 3, fig. 7; Nigrini, 1967, p. 32, pl. 3, fig. 1. Eocene?-Recent.

\section{Heliodiscus hexasteriscus Clark and Campbell} (Plate 13, Figure 4)

Heliodiscus hexasteriscus Clark and Campbell, 1942, p. 40, pl. 3, figs. 14,15 .

Having the pores of the same character as in H. asteriscus, but differing in the size of the third shell. Eocene.

\section{Heliodiscus sp.}

(Plate 13, Figure 9)

Similar to Asteriscus echiniscus Haeckel (1887, p. 448, pl. 34 , fig. 5) in the structure of the surface, and differs in a larger dimension (to $500 \mu$ ) of outermost shell.

Eocene-Oligocene.

\section{Heliodiscus saturnalis Clark and Campbell (Plate 13, Figure 8)}

Heliodiscus saturnalis Clark and Campbell, 1942, p. 41, pl. 3, figs. 9 , 9a.

Similar to Periphaena decora in the character of the pores on the third shell. Differs in the size of the third shell and the absence of a hyaline girdle.

Eocene.

\section{Heliodiscus pentasteriscus Clark and Campbell} (Plate 13, Figure 6, 7)

Heliodiscus pentasteriscus Clark and Campbell, 1942, p. 39, pl. 3 . fig. 8.

Eocene.

\section{Genus PERIPHAENA Ehrenberg}

Periphaena Ehrenberg, 1873, p. 246; Haeckel, 1887, p. 426; Campbell, 1954, p. 78. Type species Periphaena decora Ehrenberg (1875, pl. 28, fig. 6).

Perizona Haeckel, 1881 , p. $457 ; 1887$, p. 427 ; Campbell, 1954, p. 78. Type species Perizona scutella Haeckel, 1887, pl. 32, fig. 7.

Heliodiscomma Haeckel, 1887, p. 448; Campbell, 1954, p. 82. Type species Heliodiscus cingulatum Haeckel (1887, pl. 37, fig. 7).

The margin of the lens has a girdle. The latter may be festooned, but there are no real needles.

\section{Periphaena decora Ehrenberg}

(Plate 14, Figures 1, 2)

Periphaena decora Ehrenberg, 1873, p. 246; 1875, pl. 28, fig. 6 . Eocene-Oligocene.
Periphaena? dupla (Kozlova)

(Plate 14, Figure 3)

?Astrophacus duplus Koslova, in Kozlova and Gorbovetz, 1966, p. 74 , pl. 12 , figs. 2,3 .

Differs from $P$. decora in the character of the pores on the third shell; they are less in number, less regular, and of greater size. Oligocene.

\section{Periphaena sp.}

(Plate 14, Figures 4, 5)

Similar to $P$. decora in the structure of the third shell, but has 6 to 10 spines of different size. The diameter of the third shell is less than in $P$. decora.

Eocene-Oligocene.

\section{Subfamily COCCODISCINAE Haecke}

Coccodiscidae Haeckel, 1862, p. 485; Riedel, 1967b, p. 294.

Coccodiscidae with the lens of the third shell surrounded by chambered or spongy rings, arms or spines, situated in the equatorial plane of the skeleton.

Genus LITHOCYCLIA Ehrenberg sens. str.

Lithocyclia Ehrenberg, 1847a, p. 385; Haeckel, 1887, p. 459; Campbell, 1954, p. 82; Riedel and Sanfilippo, 1970, p. 522, part. Type species Lithocyclia ocellus Ehrenberg, 1854, pl. 36, fig. 30. Coccodiscinae with rings, but without arms or spines.

Lithocyclia ocellus Ehrenberg sens. str. (Plate 15, Figures 1, 2)

Lithocyclia ocellus Ehrenberg, 1854, pl. 36, fig. 30; 1873, p. 240; 1875 , pl. 29, fig. 3; Riedel and Sanfilippo, in press, pl. 3A, fig. 6 ; Moore, in press, pl. 4 , fig. 1.

Most of the specimens have a thick spongy equatorial zone surrounding the third shell (as in L. stella Ehrenberg, 1875, pl. 29, fig. 2). But in some specimens the outer zone consists of distinct concentric (or spiral) chambered rings (as in L. ocellus Ehrenberg, 1875 , pl. 29, fig. 3). These two forms may be considered as variations of a single species: very often one can see intermediate specimens possessing a spongy ring, concentrically zoned.

Diameter of the first shell $15-18 \mu$, of the second $40-45 \mu$, of the third $90-100 \mu$. Diameter of the pores on the third shell about $3-4 \mu$. Eocene-Oligocene.

\section{Lithocyclia sp. aff. L. lenticula Haeckel}

(Plate 15, Figure 3)

?Lithocyclia lenticula Haeckel, 1887, p. 459, pl. 36, fig. 3.

This form differs from $L$. lenticula in the character of the pores on the third shell; they are more numerous (18 to 20 on the diameter) and of smaller size. The outer zone consists of only two porous rings. It is more delicate in structure and less regular than the third shell. The margin has a number of small spines. Diameter of the first shell $15-18 \mu$, of the second shell $45-50 \mu$, of the third shell $135-140 \mu$; diameter of the shell with rings $210-220 \mu$. Diameter of the cortical pores $5-6 \mu$.

Eocene.

\section{Genus STYLOCYCLIA Ehrenberg}

Stylocyclia Ehrenberg, 1847, p. 54; Haeckel, 1887, p. 462; Campbell, 1954, p. 82. Type species Stylodictya dimidiata Ehrenberg.

Coccodiscinae with two spines.

\section{Stylocyclia dimidiata Ehrenberg (Plate 15, Figure 4)}

Stylocyclia dimidiata Ehrenberg, 1873, p. 256; 1875, pl. 29, fig. 4. Diameter of the second shell $50-60 \mu$, of the third shell $110-120 \mu$; diameter of the test with the outer zone $230-250 \mu$. Length of the spines $180-250 \mu$.

Eocene.

\section{Genus TRIGONOCYCLIA Haecke}

Trigonocyclia Haeckel, 1881, p. 458; 1887, p. 464; Campbell, 1954 , p. 82. Type species Trigonocyclia triangularis Haeckel (1887, pl. 37 , fig. 5).

Coccodiscinae with three spines. 
Trigonocyclia prima Kozlova sp. $\mathrm{n}$. (Plate 15, Figure 6)

Medullary shell double. Phacoid cortical shell without a secondary spongy layer, with circular to subcircular pores, 14 to 18 on the diameter. Cortical shell surrounded by a single wide porous ring, the porous structure of which is less regular than that of the cortical shell. The spines three-bladed, short, acute, originating within the cortical shell, do not form a regular triangle. Diameter of the inner medullary shell $15-18 \mu$, of the second shell $40-50 \mu$, of the thirc (cortical) shell $120-130 \mu$, of the shell with porous ring $190-200 \mu$.

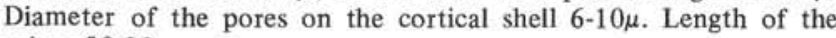
spines $50-80 \mu$.

Eocene.

\section{Trigonocyclia (?) sp. A}

(Plate 15, Figure 5)

The first and second shells constitute a so-called double medullary shell. The phacoid cortical shell (the third) has distinct circular to subcircular pores, 8 to 9 pores on the diameter. The outer zone consists of four concentric porous rings, the outermost being covered by secondary spongy layers. The spines are short, three-edged. They form a regular triangle. Diameter of the second shell about $50 \mu$, of the third shell about $90 \mu$; diameter of the skeleton with the outer zone about $220 \mu$. Diameter of the cortical pores $5-9 \mu$. Length of the spines up to $50 \mu$.

Remarks: This species differs from typical Coccodiscinae in the ratio of the diameters of the second and third shells. As a rule the diameter of the third shell is three times greater than the diameter of the second shell. But in Trigonocyclia (?) sp.A this ratio is less, the diameter of the third shell being only twice that of the second shell. A species with this ratio was described by S. Tochilina (1970) as a new genus Hexacyclia. A more detailed study may result in the assignment of Trigonocyclia(?) sp.A to Hexacyclia.

Eocene.

\section{Genus TRIGONACTINIUM Haeckel}

Trigonactinium Haeckel, 1887, p. 472; Campbell, 1954, p. 84. Type species Trigonactura triacantha Haeckel $(1887, \mathrm{pl}$. 38, figs. 6, 7). Coccodiscinae with three chambered or spongy arms extending from the third shell.

\section{Trigonactinium pythagorae (Ehrenberg)}

(Plate 17, Figure 1)

Astromma pythagorae Ehrenberg, 1873, p. $217 ; 1875$, pl. 30, fig. 2. Hymeniastrum pythagorae Ehrenberg, 1854 , pl. 36 , fig. $31 ; 1873$, pl. $237 ; 1875$, pl. 30 , fig. 5 .

Lithocyclia aristotelis group Riedel and Sanfilippo, 1970, p. 522. part.; Riedel and Sanfilippo, in press, pl. 3A, fig. 5, part.; Moore, in press, pl. 4, fig. 4, part.

Eocene-Oligocene.

\section{Trigonactinium (?) angustum (Riedel) sens. str.} (Plate 17, Figure 3)

Trigonactura angusta Riedel, 1959a, p. 292, pl. 1, fig. 6 .

Lithocyclia angustum (Riedel) Riedel and Sanfilippo, 1970, p. 522. pl. 13, figs. 1, 2? Riedel and Sanfilippo, in press, pl. 3A, fig. 5 , part.

Differs from the typical Trigonactinium in having very narrow arms. The irregular pores and even spongy surface of the third shell are also characteristic.

Oligocene.

\section{Genus ASTRACTINIUM Haeckel}

Astractinium Haeckel, 1887 , p. 476 ; Campbell, 1954, p. 83 . Type species Astromma aristotelis Ehrenberg

Coccodiscinae with four chambered or spongy arms, arising from the third shell.

\section{Astractinium aristotelis group}

(Plate 16, Figures 1-5)

Astromma aristotelis Ehrenberg, 1847b, p. 55, fig. 10; 1873, p. 217; 1875 , pl. 30 , figs. 3,4 .

Astromma pentactis Ehrenberg, 1873, p. 217; 1875, pl. 30, fig. 1 .
Lithocyclia aristotelis group Riedel and Sanfilippo, in press, pl. 3A, figs. 2, 4, part; Moore, in press, pl. 4, fig. 5, part.

The diameter of the third shell about $110 \mu$, pores on it about 4-5 $\mu$. There are various forms (subspecies or even species?) in this group.

Eocene-Oligocene.

\section{Astractinium spp. aff. Lithocy clia crux Moore}

(Plate 16, Figures 8,9)

Lithocyclia crus Moore, in press, pl. 6, fig. 4. Oligocene.

\section{Astractinium (?) sp. C \\ (Plate 16, Figure 10)}

This form is similar to Trigohactinium(?) angustum in having very narrow arms and irregular (nearly spongy) surface of the third shell. It differs from $T$. (?) angustum in the rounded outline of the main shell, and in possessing four (instead of three) arms.

Oligocene.

\section{Genus ASTROCYCLIA Haeckel}

Astrocyclia Haeckel, 1881 , p. 458 ; 1887 , p. 466 ; Campbell, 1954 , p. 82. Type species Astrocyclia solaster Haeckel (1887, p. 36 , fig. 7).

Coccodiscinae with numerous radial spines.

Astrocyclia sp.

(Plate 15, Figure 7)

Lithocyclia ocellus group Riedel and Sanfilippo, 1970, p. 522, pl. 5, fig. 2, part.

The cortical shell (the third) rounded-polygonal, with circular to subcircular pores, occasionally very small, about 16 to 20 on the diameter of the shell. There are 6 to 8 outer spines. The outer zone consists of concentric porous rings, all of them covered by a thick spongy layer.

The spines three-edged, acute, originating within the cortical shell. Diameter of the second shell $40-50 \mu$, of the third shell $100-110 \mu$, of the skeleton with the outer zone $210-230 \mu$. Diameter of the cortical pores $3-6 \mu$. The spines are about $100 \mu$ in length.

Eocene.

\section{Family PORODISCIDAE Haeckel emend. Kozlova}

Haeckel, 1887, p. 481; Riedel, 1967b, p. 296; Kozlova, 1967a, p. 1171.

For some time, this group has been studied by one author, G. E. Kozlova. She believes some porodiscids belong to a new genera. Though M. G. Petrushevskaya had studied some species and genera, and had discussed these data and drawn some conclusions, she is not the author of these genera, therefore, the genera are signed by one name.

Emended diagnosis: The central shell is latticed, spherical or ellipsoidal, about $12-20 \mu$ in diameter. It is surrounded by a system of three bands-frontal, sagittal and equatorial, very much the same as in Larcoidea (see Jörgensen, 1905, pl. 10, fig. 42). Each band consists of two curved porous plates or wings, which may even form cupolas. The wings of the three bands surrounding the central shell come into contact and form the first chambered system. It is about $30-50 \mu$ in diameter.

The first system of porous bands is surrounded by the second system, the third, etc. The flattening of the skeleton results because in the second and following systems the frontal and the sagittal bands are constricted along the main axis (Plate 19, Figures 5, 6, 11). They do not enclose the whole preceding system, but the growth of each following system begins from the margin of the preceding system. The difference from Larcoidea is that in Larcoidea the subsequent systems enclose one another entirely.

In Porodiscidae there are no gates, of the type characteristic for Larcoidea.

In Porodiscidae, incomplete frontal and sagittal bands of the following systems are on the surface, and form the outside walls of the flattened skeleton. The equatorial bands are complete. They are usually seen as rings, spirals or more complicated figures characteristic for Porodiscidae. 
There are four main radial spines, lying in the equatorial plane of the disk, going from the central shell in two perpendicular directions. There are some additional spines, lying in the same plane, going from second and subsequent systems. There are also secondary spines inclined to the equatorial plane. They are joined from inside with the outside walls of the skeleton, and they are rarely seen.

\section{Genus Porodiscus Haeckel, 1881, emend. Kozlova}

Flustrella Ehrenberg, 1838, p. 122; Porodiscus Haeckel, 1887, p. 491 (part.); Flustrella Campbell, 1954, p. 89, (part); Stylodictya Campbell, 1954, p. 92 (part.) Type species Porodiscus concentrica (Ehrenberg) 1838, p. 132.

The skeleton is flat or slightly concave in its center, has a rounded outline and is composed of annular equatorial rings (the rest is not developed); first system is of the Archidistcus type (central chamber and one ring), $\mathrm{d} \approx 30 \mu$, very rarely submerged in the skeleton; distance between the annular rings is less than or equal to the diameter of the initial chamber. Main spines are indistinct and as a rule cannot be distinguished from the secondary spines, the number of which in the latter systems exceeds fifty. The rim of the skeleton is either smooth or covered by numerous spines.

Remarks: Rings in Porodiscus sometimes merge into a spiral.

Differs from the genus Stylodictya by the absence of cupolashaped chambers in the first system and by the more or less constant width of the rings.

Early Cretaceous-Recent.

\section{Porodiscus cretaceus Campbell and Clark} (Plate 5, Figure 6, 7)

Porodiscus cretaceus Campbell and Clark, 1944, p. 15, pl. VI, fig. 7. $2-5 \mu$.

Disc diameter $90-210 \mu$, width of ring $10-13 \mu$; diameter of pores

Campanian-Maestrichtian.

\section{Porodiscus delicatulus Lipman \\ (Plate 5, Figures 8, 9)}

Stylodictya delicatula Lipman, 1954, p. 33, pl. 1, figs. 19-20.

Specimens from the Atlantic have a smaller number of rings; its central part is covered by spongy tissue; in some specimens rings are joined in a spiral (Figure 9).

Diameter of disc $110-170 \mu$, width of rings $10-13 \mu$.

Campanian-Maestrichtian.

\section{Porodiscus concentricus (Ehrenberg) (Plate 18, Figure 11)}

Flustrella concentrica Ehrenberg, 1838, p. 132; 1854, pl. 19, fig. 61; 1875 , p. 72 , pl. 22 , fig. 13.

Trematodiscus concentricus (Ehrenberg) Haeckel, 1862, p. 493; Trematodiscus concentricus (Ehrenberg) Stöhr, 1880, p. 108; Porodiscus concentricus (Ehrenberg) Haeckel, 1887, p. 492. Eocene-Oligocene.

\section{Genus THOLODISCUS Kozlova, new genus}

Stylodictya Ehrenberg, 1838 (part.); Porodiscus Haeckel, 1881, p. 491 (part.), Staurodictya Haeckel, 1881, p. 506 (part.). Type species Stylodictya ocellata Ehrenberg $(1875$, p. 84 , pl. 23, fig. 7).

Skeleton is flat or slightly concave, rounded-multiangular or rounded-quadrangular in outline. Consists of equatorial and sagittal rings (frontal ring is not developed); wings of the rings are displaced at $45^{\circ}$ in relation to the main axis, and have a cupola-like structure, quite clearly expressed in the first systems and less distinct in the subsequent ones, where the wings are elongated in the direction of the periphery of the disc. At the point of their merging, the wings become overlapped by each other and form four zig-zag lines in the direction of the main axes.

First system of the Tholostaurus type (in sensu Haeckel), diameter $\approx 40-50 \mu$, is not submerged into the skeleton; the distance between systems (width of cupolas) is larger than or equal to the diameter of the central chamber, four main radial spines going from the central shell; four additional-from the tops of the cupolas of the first system; both often are transformed into the outside spines.
Tholodiscus differs from the related genus Stylodictya by the type of wings-cupola connection, which forms four zig-zag radial lines, and also by the multiangular outline of its disc.

The name is derived from Greek "Tholos" (dome) and "Discos" (disk), masculine.

\section{Tholodiscus fresnoensis (Foreman)}

(Plate 5, Figure 1)

Staurodictya(?) sp. Koslova and Gorbovets, 1967, pl. 4, fig. 2. Staurodictya(?) fresnoensis Foreman, 1968, p. 14, pl. 11, fig. 2. Campanian-Maestrichtian.

\section{Tholodiscus sp. \\ (Plate 5, Figure 5)}

Nine to ten concentric systems of the same width; shell is thin-walled, with two pores on a ring; rim is devoid of spines, the middle is overgrown by spongy tissue.

Disc diameter $200-240 \mu$ width of a ring $12-13 \mu$, diameter of pores $2-3 \mu$.

Campanian-Maestrichtian.

\section{Tholodiscus ocellatus (Ehrenberg)}

(Plate 18, Figures 1,2)

Stylodictya ocellata Ehrenberg, 1875, p. 84, pl. 23, fig. 7.

Staurodictya ocellata (Ehrenberg), Haeckel, 1887, p. 508.

Skeleton is irregularly quadrangular, consisting of 3-4 systems; width of the cupolas is relatively large, especially in the last systems; zig-zag radial lines are clearly expressed, pores are round. On the first system pores are half the size of most on the others; there are $3-4$ pores on the width of a cupola. Four rather thick and long, three-bladed spines are arranged at right angles.

Disc diameter $140-170 \mu$, width of cupolas $12 \mu$ (first system), $40 \mu$ (fourth system); pore diameter $7-8 \mu$, in the first system $3 \mu$; length of spines exceeds $100 \mu$.

Oligocene.

\section{Tholodiscus splendens (Ehrenberg)}

(Plate 18, Figures 3-5)

Stylodictya splendens Ehrenberg, 1875, p. 84, pl. 23, fig. 9. Stylodictya clavata Ehrenberg, 1875, p. 84, pl. 23, fig. 2.

Staurodictya splendens (Ehrenberg) Haeckel, 1887, p. 508. Stylodictya clavata Ehrenberg, Haeckel, 1881, p. 513.

Skeleton is rounded-quadrangular, consisting of 6-10 systems of almost the same width; porous shell has two, or seldom three, round pores on a ring; radial spines are thick, their number varies from 4 to 8; small, numerous inner radial spines lend a "chamber-like" appearance to the rings.

Disc diameter $200-270 \mu$, width of rings $15 \mu$, diameter of pores 4-5 $\mu$, length of external spines $60-170 \mu$.

Eocene-Oligocene.

Genus STYLODICTYA Ehrenberg 1847, emend. Kozlova

Stylodictya Ehrenberg, 1847, p. 54, (part.); Porodiscus Haeckel, 1881 , p. 491 (part.); Staurodictya Haeckel 1881, p. 506 (part.); Stylodictya Haeckel, 1881, p. 509 (part.) Type species Stylodictya gracilis Ehrenberg, 1854, p. 246.

Skeleton is flat or slightly concave with round outline; consists of equatorial and sagittal girdles (frontal girdle is not developed), wings of the rings are displaced at $45^{\circ}$ in relation to the main axes; at their merging point they do not envelope each other and thus form girdles of regular round or scalloped form, especially distinctive in the first systems. The first system is close to Tholostaurus (cupolas do not overlap each other), diameter $\approx 30-40 \mu$, not submerged into the skeleton; the distance between systems is greater than or equal to the diameter of the central chamber.

The main and additional spines are well developed and often extend as external spines. Rim of the disc is smooth with 4,8 , or more spines.

Differs from Tholodiscus new gen. by the annular character of the wing connection, by the absence of the zig-zag radial lines in the plane of the disc, and by its more regular round outline.

Eocene-Recent. 
Stylodictya inaequalispina Clark and Campbell (Plate 18, Figure 8)

Stylodictya inaequalispina Clark and Campbell, 1942 , p. 45 , pl. 3 , fig. 5 .

Disc diameter $150-190 \mu$; width of rings $12 \mu$, pore diameter $4-6 \mu$ (in center $2 \mu$ ), length of spines up to $50 \mu$. Eocene-Oligocene.

\section{Stylodictya rosella, Kozlova sp. n. (Plate 18, Figure 9)}

Stylodictya sp. Clark and Campbell, 1945, p. 24, pl. 3, fig. 19. Central chamber is surrounded by 9-11 slightly curved (scalloped) annular systems, each system doubling in size beginning in the center to the edge of the disc; pores are found, 2 or 3 on each ring, approximately of the same size; there are up to twenty-four inner spines of uniform thickness; at the rim of the disc they appear either as thin spicules or as massive flat teeth.

Disc is very thin in its central part and becomes very thick at the rim (the last 5 to 6 rings).

Disc diameter $250-270 \mu$, width of rings $7-16 \mu$, pore diameter $3-4 \mu$; diameter of the first system $24 \mu$.

It differs from $S$. targaeformis (see below) by larger dimensions, the thickness along its rim, and by a greater number of spines.

Eocene-Oligocene.

\section{Stylodictya targaeformis (Clark and Campbell)} (Plate 18, Figure 10)

Staurodictya targaeformis Clark and Campbell, 1942, p. 43, pl. 3 , fig. 6 .

Specimens from Atlantic have eight external spines.

Disc diameter $170-200 \mu$; width of rings $5-10 \mu$; pore diameter

$2-5 \mu$, length of spines $40 \mu$; diameter of the first system $30 \mu$.

Eocene-Oligocene.

\section{Stylodictya orbiculata (Haeckel) \\ (Plate 18, Figure 7)}

Trematodiscus orbiculatus Haeckel, 1862, pl. 28, fig. 2.

Porodiscus orbiculatus Haeckel, 1887, p. 492.

Disc diameter $125-140 \mu$, width of rings $7-15 \mu$; pore diameter $5 \mu$. Eocene-Oligocene.

\section{Stylodictya aculeata (Jörgensen)}

(Plate 18, Figure 6)

Stylodictya aculeata Jörgensen, 1905, p. 119, pl. 10, fig. 41 Petrushevskaya, 1967, p. 35, pl. 11, figs. 1-3.

Quaternary.

\section{CIRCODISCUS Kozlova, new genus}

Porodiscus Haeckel, 1881, p. 491, (part.); Ommatodiscus Stöhr, 1880 , p. 115 (part.); Flustrella Campbell, 1954, p. 89 (part.)

Type species Trematodiscus microporus Stöhr, 1880, p. 108, pl.

4 , fig. 17.

Slightly convex skeleton with round or oval outline. Consists of frontal, sagittal and equatorial girdles, their wings connected to form regular round or oval rings.

First system is of the Trizonium type (in sensu Haeckel), its dimension $\approx 30-40 \mu$, with fully developed girdles; in the rest of them, only the equatorial girdle is fully developed; saggital and frontal girdles terminate at the point of the junction with the ring of the previous system; distance between (width of rings) is considerably larger than the diameter of the central chamber. Spines (four main and four secondary) pass inside of the skeleton. Rim is smooth.

It differs from Plectodiscus gen. nov., by the character of the connection of its wings and accordingly by the structure of the first system.

The name is derived from Greek "Circos" (circle) and "Discos" (disk), masculine.

Eocene-Recent.

\section{Circodiscus microporus (Stöhr)}

(Plate 19, Figure 1-7)

Trematodiscus microporus Stöhr, 1880, p. 108, pl. 4, fig. 17.

Porodiscus microporus Stöhr, Haeckel, 1887, p. 493.
Skeleton is oval, flat, consisting of 3 or 4 comparatively wide, oval, annular girdles; pores are even, circular, 5 or 6 on each ring. Inner spines (8?) do not extend outside; rim of the disc seldom has a smooth, clearly outlined tapered edge; more often it is "torn" and disconnected.

Disc diameter with four systems $180-200 \mu$ width of rings 25-35 $\mu$, pore diameter $5-8 \mu$.

Miocene-Quaternary.

Circodiscus sp.

(Plate 19, Figure 8)

From $C$. microporus it differs by having wider rings and smaller pores.

Disc diameter (with three systems) $160 \mu$, width of rings $30-40 \mu$, pore diameter $3-4 \mu$.

Miocene.

\section{Genus PLECTODISCUS Kozlova, new genus}

Discospira Haeckel, 1862 (part.); Porodiscus Haeckel, 1882, p. 492 (part.); Flustrella Campbell 1954, p. 89 (part.). Type species Porodiscus circularis Clark and Campbell, 1945, p. 42, pl. 11, figs. $2,6,10$.

Thin, biconvex skeleton, with oval, less frequently circular outline, consisting of frontal, equatorial and sagittal girdles. The closed-spiral structure of girdles is of the Spironium type: wings of the same type of girdle form a one-half turn of the spiral, and at the point of their juncture overlap each other. First system has fully developed girdles, its dimensions are $40 \times 50 \mu$; in the rest of the girdles, only the equatorial girdle is fully developed, both saggital and frontal girdles terminating at the point of their junction with the previous system. Distance between rings is greater than is the diameter of the central chamber. Inner spines are indistinct; rim of the disc is smooth or is covered by numerous short spines.

Depending on the degree of inclination of the plane of the girdles in relation to the main axes of the skeleton, the equatorial girdles appear from the surface (rest of girdles in corresponding cross-section) in the form of rings, as a single or double spiral, or in the form of rings connected by zigzag radial lines.

The name is derived from Greek "plecta" (interlacing) and "Discos" (disk), masculine.

Paleocene-Oligocene.

\section{Plectodiscus circularis (Clark and Campbell)}

(Plate 19, Figures 9-12)

Porodiscus circularis Clark and Campbell, 1942, p. 42, pl. 11, figs. 2, 6,10 .

Porodiscus uralicus Lipman, 1960, p. 86, pl. XI, figs. 9-11; Porodiscus durus Moksyakova, p. 146, pl. 2, fig. 8 .

Skeleton is oval, less frequently circular in outline, consisting of 4 to 6 systems, the width of which increases slightly from the center toward the rim of the disc; all possible varieties of the outer forms of the girdle are represented here: the enclosed-spiral (Plate-Figure 12), annular (Plate-Figures 9,10) and spiral; pores are round and of uniform size, four or five on the width of each system; disc rim is tapered; main and secondary radial spines are of uniform thickness and appear at the rim of the disc in the form of (16?) tiny spicules.

Disc diameter $120-250 \mu$, distance between systems $20-35 \mu$, pore diameter 6-9

Paleocene?-Eocene. Paleocene forms have a coarser and larger skeleton.

\section{Plectodiscus bergontianus (Carnevale)}

(Plate 19, Figure 13)

Porodiscus bergontianus Carnevale, 1908, p. 23, pl. 4, fig. 2.

Porodiscus squinaboli Carnevale, 1908, p. 23, pl. 4, fig. 3 . $-7 \mu$.

Disc diameter $230-240 \mu$, width of rings $15-20 \mu$, pore diameter

This form differs from $P$. circularis by the greater number of systems and their smaller width.

Eocene.

\section{Genus OMMATOCAMPE Ehrenberg}

Ommatocampe Ehrenberg, 1860 , p. 852 ; Haeckel, 1887 , p. 392 ; Campbell, 1954 p. 76. Type species Ommatocampe polyarthra Ehrenberg, 1872 b, pl. 6, fig. 9 . 
Amphymenium Haeckel, 1881 , p. $460 ; 1887$, p. 519 ; Campbell, 1954 , p. 86 . Type species Amphymenium zygartus Haeckel, 1887 , pl. 44 , fig. 7.

Ommathymenium Haeckel, 1887 , p. 520; Campbell, 1954, p. 88 . Type species Amphymenium amphistylium Haeckel, 1887, pl 44 , fig. 9.

Porodiscidae with two chambered arms. Very often with patagium.

Ommatocampe spp. aff. Amphymenium amphistylium Hck. (Plate 20, Figures 1,2)

?Amphymenium amphistylium Haeckel, 1887, p. 520, pl. 44, fig. 9 . Central chamber about $18 \mu$ in diameter.

Paleogene.

\section{Genus TRIGONASTRUM Haeckel}

Trigonastrum Haeckel, 1887, p. 538; Campbell, 1954, p. 88. Type species Trigonastrum regulare Haeckel, 1887, pl. 43, fig. 16.

?Chitonastrum Haeckel, 1881 , p. 460; 1887, p. 536; Campbell, 1954 , p. 86. Type species Chitonastrum triglochin Haeckel, 1887 , unfigured.

Porodiscidae with three chambered arms, rarely with patagium.

Trigonastrum sp. aff. Chitonastrum lyra Haeckel (Plate 20, Figure 3)

?Chitonastrum lyra Haeckel, 1887 , p. 538, pl. 43, fig. 15.

Differs from C. lyra by shorter and unforked arms. Although it has the same outline as Euchitonia elegans (see Nigrini, 1967, pl. 4, fig. 2), Trigonastrum sp. differs from it in having chambered, not spongy, arms.

Pliocene-Quaternary,

Trigonastrum sp. aff. Euchitonia muelleri Haeckel (Plate 20, Figure 4)

In Euchitonia muelleri ( $=E$. furcata, type species of genus Euchitonia, described by C. Nigrini, 1967, p. 37) the arms are spongy. In the species in question they are chambered. The other characters are nearly the same in both species.

Pliocene-Quaternary.

\section{Genus STEPHANASTRUM Ehrenberg}

Stephanastrum Ehrenberg, 1847, p. 54; Haeckel, 1887, p. 548; Campbell, 1954, p. 88. Stephanastromma Haeckel, 1887, p. 549; Campbell, 1954, p. 88. Type species Stephanastrum rhombus Ehrenberg, 1854, pl. 25, fig. 1.

Four-armed Porodiscidae with the central disc having 2 or 3 systems of chambered elongated rings.

\section{Stephanastrum sp. aff. S. rhopaloporum Haeckel} (Plate 20, Figures 10, 11)

?Stauralastrum rhopaloporum Haeckel, 1887, p. 541, pl. 45, fig. 1. ?Histiastrum boseanum Haeckel, 1887, p. 546, pl. 45, fig. 1.

The ends of the arms are widened (often broken). Rare five-armed malformations exist.

The species differs from $S$. rhombus only in the absence of the rhombic patagium.

Eocene-Oligocene.

\section{Family PSEUDOAULOPHACIDAE Riedel ${ }^{3}$}

Pseudoaulophacidae Riedel, 1967a, p. 148.

Genus PSEUDOAULOPHACUS Pessagno

Pseudoaulophacus Pessagno, 1963, p. 200. Type species Pseudoaulophacus florensis Pessagno, 1963, pl. 2, figs. 2, 5.

Biconvex lens, circular, irregular or nearly triangular from above.

Spines on the equatorial margin of the test.

\section{Pseudoaulophacus superbus (Squinabol)}

(Plate 3, Figures 1-3)

Theodiscus superbus Squinabol, 1914, p. 271, pl. 10, fig. 4. Cretaceous (Albian-Maestrichtian).

\footnotetext{
${ }^{3}$ This group was studied by G. E. Kozlova.
}

\section{Pseudoaulophacus gallowayi (White)}

(Plate 6, Figure 1)

Baculogypsina? gallowayi White, 1928, p. 305 , pl. 41, figs. 9-10.

Pseudoaulophacus gallowayi (White) Pessagno, 1963, p. 202, pl. 2, figs. $1,3,6 ;$ pl. 4 , figs. $2,5,7 ;$ pl. 7 , figs. 2,4 .

Differs from P. superbus in 1) the greater dimensions of the disc,

2) the more delicate pseudoaulophacid meshwork, the triangular frames being larger, and 3 ) its longer spines.

Cretaceous (Cenomanian-Maestrichtian).

\section{Pseudoaulophacus sp. aff. P. pargueraensis Pessagno}

(Plate 3, Figures 10-12)

?Pseudoaulophacus pargueraensis Pessagno, 1963, p. 204, pl. 2, figs. 4,7 .

Differs from $P$, pargueraensis by the absence of spines on the equatorial margin, but this may be because of unsatisfactory preservation.

Cretaceous (Early Campanian).

PATELLULA Kozlova, new genus

Type species Stylospongia planoconvexa Pessagno, 1963, pl. 3, figs. 4-6.

Includes a discoids with skeletons, planoconvex in cross section and subcircular in outline, consisting throughout of pseudoaulophacid meshwork. There are spines on the equatorial margin. On the plane surface a pit or a funnel may be present.

Remarks: This genus differs from Pseudoaulophacus in the shape of the skeleton. It differs from Stylospongia Haeckel, 1860 (type species Stylospongia hexleyi Haeckel, 1862, pl. 28, fig. 7) in the type of meshwork: this genus is characterized by pseudoaulophacid structure, and Stylospongia by spongy structure

Species belonging to this genus were described by Squinabol from Euganean Cretaceous deposits: Stylotrochus helios Squinabol, 1903, pl. 10, fig. 23; Dactylodiscus cayeuxi Squinabol, 1903, pl. 9, fig. 18 and discoid gen. sp. indet. Squinabol, 1903, pl. 9, fig. 21.

The name is derived from Greek, "Patella" (saucer), feminine.

Campanian.

\section{Patellula planoconvexa (Pessagno)} (Plate 3, Figure 13)

Stylospongia planoconvexa Pessagno, 1963, p. 199, pl. 3, figs. 4-6; pl. 6 , fig. 1 .

Cretaceous (Early Campanian).

Patellula verteroensis (Pessagno)

(Plate 3, Figures 8, 9)

Stylospongia verteroensis Pessagno, 1963, p. 199, pl. 3, figs. 1-3; pl. 6 , figs. 2,3 ; pl. 7 , figs. $3-6$.

Cretaceous (Early Campanian).

Genus HAGIASTRUM Haeckel, emend.

Hagiastrum Haeckel, 1881 , p. 460; 1887, p. 542 ; Campbell, 1954, p. 94. Type species Hagiastrum plenum Rüst, 1885, pl. 23, fig. 10. $X$-astrum Neviani, 1900 , p. 657.

Skeleton very much the same as in Spongasteriscus and in Stephanastrum. It consists of a central solid disc or sphere provided with four arms (often armed by spines), the arms being of the same solid structure as the central part. The difference is that in Hagiastrum this structure is pseudoaulophacoid, while in Spongasteriscus it is spongy and in Stephanastrum porodiscoid.

\section{Hagiastrum sp. aff. Stauralastrum euganea Squinabo}

(Plate 6, Figures 4, 5)

Stauralastrum euganea Squinabol, 1903, p. 123, pl. 9, fig. 19.

Pseudoaulophacid gen. sp. Riedel and Sanfilippo, 1970, pl. 2, fig. 7. Specimens in our material have the arms shorter than those in Squinabol's material.

Albian-Maestrichtian.

Subfamily DACTYLIOSPHAERIDAE Squinabol Genus DACTYLIOSPHAERA Squinabol, emend. Kozlova

Dactyliosphaera Squinabol, 1904, p. 196; Campbell, 1954, p. 68. Type species Dactyliosphaera silvae Squinabol, 1904, pl. 9, fig. 21. 
Emended diagnosis. Skeleton is a biconvex lens. Central part represents by itself a sphere (hollow??). Sphere is surrounded in its equatorial plane by a thick ring composed of a dense pseudoaulophacoid meshwork.

\section{Dactyliosphaera sp. aff. Lithocyclia jüsta}

(Plate 3, Figure 16)

?Lithocyclia jüsta Rüst, 1888, p. 197, pl. 24, fig. 6 .

Diameter of the whole skeleton about $150 \mu$, of the central sphere $65-70 \mu$. This species differs from typical $L$. jüsta Rüst by the ratio of the dimensions of the sphere and ring.

Cretaceous (Early Campanian).

\section{Family SPONGODISCIDAE Haeckel}

Spongodiscidae Haeckel, 1862, p. 452; Riedel, 1967b, p. 295.

The skeleton, flattened along the main axis, consists of so-called spongy substance. It represents by itself small chambers. They are disposed irregularly or in a dense spiral, or in closely disposed spheres. The central chamber is usually not visible.

\section{Genus SPONGODISCUS Ehrenberg}

Spongodiscus Ehrenberg, 1854, p. 237; Haeckel, 1881, p. 461; 1887, p. 567; Campbell, 1954, p. 93. Spongodisculus Haeckel, 1887, p. 576; Campbell, 1954, p. 93. Type species Spongodiscus resurgens Ehrenberg.

Spongodiscidae with discoid (lenticular) skeleton without arms or any other subdivisions. On the surface, a plate with small pores ("gown") may be present. Very often there is a pylome. No strong outside radial spines.

\section{Spongodiscus resurgens Ehrenberg typ.} (Plate 21, Figure 5)

Spongodiscus resurgens Ehrenberg, 1854, pl. 35B, F, Fig. 16.

Delicate spongy disc without gown, about $100 \mu$ in diameter.

Pylome tube is indistinct.

Pliocene-Quaternary.

\section{Spongodiscus resurgens Ehrenberg osculosa (Dreyer)}

$$
\text { (Plate 21, Figure 4) }
$$

Spongopyle osculosa Dreyer, 1899, p. 42, figs. 99, 100; Riedel, 1958, p. 226, pl. 1 , fig. 12.

Disc of the same delicate spongy structure as in S. resurgens typ., $190-270 \mu$ in diameter, very often with "gown". Pylome tube distinct.

Middle Miocene-Recent (in Antaractic).

In the Paleogene, Spongodiscus species existed with rougher, spongy, even lithelid, structure (Plate 21, Figures 1, 3).

\section{Genus SPONGOTROCHUS Haeckel}

Spongotrochus Haeckel, 1860 , p. $844 ; 1887$, p. 585; Campbell, 1954 , p. $94 .=$ Spongotrochiscus Haeckel, 1862, p. $463 ; 1887$, p. 585; Campbell, 1954, p. 94. Type species Spongotrochus brevispinus Haeckel, 1862, pl. 27, figs. 4-5.

Spongodiscidae with the flattened skeletal lens provided with numerous spines.

Spongotrochus? spp.

(Plate 3, Figure 4; Plate 5, Figures 11, 12)

Cretaceous (Maestrichtian).

Spongotrochus? polygonatus Clark and Campbell

(Plate 4, Figures 9, 10)

Spongotrochus polygonatus Clark and Campbell, 1944b, p. 19, pl. 5 , figs. $2,10,11$

Cretaceous (Campanian-Maestrichtian).

\section{Spongotrochus longispinus Haeckel} (Plate 21, Figure 15)

Spongotrochus longispinus Haeckel, 1887, p. 463, pl. 27, figs. 2, 3. Diameter of the disc about $200 \mu$.

Miocene-Quaternary.

\section{Genus SPONGOTRIPUS Haeckel}

Spongotripus Haeckel, 1881, p. 461; 1887, p. 580; Campbell, 1954 , p. 94. Type species Spongotripus regularis Haeckel, 1887, unfigured.
Spongodiscidae with discoidal skeleton provided with three main spines.

Cretaceous-Paleogene.

\section{Spongotripus morenoensis Campbell and Clark}

(Plate 6, Figures 2, 3)

Spongotripus morenoensis Campbell and Clark, 1944b, p. 19, pl. 5 , fig. 1.

Our specimens have somewhat greater dimensions than do specimens from Campbell and Clark's material.

Cretaceous (Maestrichtian).

\section{Spongotripus sp. \\ (Plate 21, Figure 2)}

This species is somewhat similar to Tripodictya triacantha Haeckel (1887, pl. 42, fig. 7), but it has a spongy skeleton, while in $T$. triacantha chambered rings are distinct.

Eocene-Oligocene.

\section{Genus SPONGASTER Ehrenberg}

Spongaster Ehrenberg, 1860 , p. 833 ; Haeckel, 1881 , p. $462 ; 1887$, p. 596; Campbell, 1954, p. 94; Riedel and Sanfilippo, 1970, p. 522. Spongastrella Haeckel, 1887, p. 597; Campbell, 1954, p. 94. Type species Spongaster tetras Ehrenberg.

Schizodiscus Dogiel and Reshetnjak, 1952, p. 8. Type species Schizodiscus disymmetricus Dogiel (see pl. 21, fig. 14.).

Spongodiscidae with discoidal skeleton without arms or spines. The spongy disc may be subdivided into one central and 4-6 peripheral thick masses separated by thinner (more transparent) spongy bands (a kind of patagium?).

Spongaster sp.

(Plate 21, Figure 13)

Elongated, nearly ellipsoidal Spongaster, somewhat similar to Spongurus sp. in Kruglikova, 1969, pl. 4, Fig. 33

Miocene.

\section{Genus OMMATOGRAMMA Ehrenberg}

Ommatogramma Ehrenberg, 1860; Haeckel, 1887, p. 519; Campbell, 1954, p. 88. Type species Ommatogramma naviculare Ehrenberg, 1872 b, pl. 6, fig 7 .

Spongurus Haeckel, 1862 , p. $465 ; 1881$, p. $461 ; 1887$, p. 343 Campbell, 1954, p. 74. Type species Spongurus cylindricus Haeckel, 1862, pl. 27, fig. 1.

Spongocore Haeckel, 1887 , p. 345 ; Campbell, 1954, p. 74. = Spongocorina Haeckel, 1887 , p. 345 ; Campbell, 1954, p. 74. Type species Spongocore velata Haeckel, 1887, not illustrated. Spongocorisca Haeckel, 1887 , p. 345 ; Campbell, 1954 , p. 74 . Type species Spongocore puella Haeckel, 1887, pl. 48, fig. 6.

Spongodiscidae with nearly cylindrical (constricted) skeleton, often surrounded by a patagium.

\section{Ommatogramma sp. aff. Amphibrachium robustum Vinassa} (Plate 21, Figure 10)

?Amphibrachium robustum Vinassa, 1900, p. 577, pl. 2 , fig. 11. Differs from $O$. puella (Hck.) in greater dimensions, and stronger spines extending from the middle part of the skeleton. Miocene-Quaternary.

\section{Genus RHOPALASTRUM Ehrenberg}

Rhopalastrum Ehrenberg, 1847 b, p. 54 ; Haeckel, 1887 , p. 526 ; Campbell, 1954 , p. $88 .=$ Rhopalastrella Haeckel, 1887 , p. 526 Campbell, p. 88. Type species Rhopalastrum lagenosum Ehrenberg, 1847 , in 1854 , pl. 22 , fig. 22.

Rhopalodictyum Ehrenberg 1860, p. 830; Haeckel, 1887, p. 589; Campbell, 1954, p. 94. Type species Rhopalodictyum abyssorum Ehrenberg, 1872b, pl. 8, fig. 17.

Dictyocoryne Ehrenberg, 1860 , p. 830 ; Haeckel, 1887 , p. 592 ; Campbell, 1954, p. 94. Type species Dictyocoryne profunda Ehrenberg, 1872 b, pl. 7 , fig. 23.

Dictyastrum Ehrenberg 1860, p. 830; Haeckel, 1887, p. 524; Campbell, 1954 , p. $86 .=$ Dictyastrella Haeckel, 1887 , p. $524 ;$ Campbell, 1954 , p. 86. Type species Dictyastrum angulatum Ehrenberg, $1872 \mathrm{~b}$, pl. 8, fig. 18. 
Euchitonia Ehrenberg, 1860, p. 831; Haeckel, 1887, p. 532; Campbell, 1954, p. 86. = Stylactis Ehrenberg, 1872, p. 320; Campbell, 1954, p. 86. Type species Euchitonia furcata Ehrenberg, 1872 b, pl. 8, fig. 6 .

Pteractis Ehrenberg, 1872, p. 320; Campbell, 1954, p. 86. Type species Pteractis elegans Ehrenberg, 1872b, pl. 8, fig. 3 .

Spongodiscidae with thin spongy central disc (where chambered rings may be sometimes seen), with three spongy arms and patagium between them.

\section{Rhopalastrum sp. aff. Dictyocoryne pentagona Stöhr}

(Plate 21, Figure 12)

?Dictyocoryne pentagona Stöhr, 1880, p. 118, pl. 7, fig. 2 .

Having the same central disc, our form differs from typical pentagona by smaller dimensions. The species is closely related to Spongaster pentas Riedel and Sanfilippo, 1970: they both have indistinct arms and patagium. The difference between the two species is in the structure of the central disc.

Early Miocene.

\section{Rhopalastrum profunda (Ehrenberg) group \\ (Plate 17, Figure 4-6; Plate 20, Figure 8)}

?Rhopalastrum lagenosum Ehrenberg, 1854, pl. 22, fig. 22.

Dictyocoryne profunda Ehrenberg, 1861a, p. 767; 1872a, p. 307;

1872 b, pl. 7, fig. 23; Ling and Anikouchine, 1967, p. 1489, pls.

191, 192, fig. 6 .

The arms and the patagium consist of different spongy meshwork. As in Rhopalastrum sp. aff. pentagona, the chambered rings are about $7-10 \mu$ high. The difference from $R$. mülleri (Hck.) (=Euchitonia furcata Ehr.) described by C. Nigrini (1967, p. 37) is in the outline of the arms: in the $R$. profunda group they are broader toward the end, while in $R$. furcata they are of nearly the same breadth from the base to the end.

Early Miocene-Recent.

\section{Rhopalastrum angulatum (Ehrenberg) group}

(Plate 17, Figures 7, 8)

Dictyastrum angulatum Ehrenberg, 1872a, p. 289; 1872b, pl. 8, fig. 18 ; Haeckel, 1887 , p. 524.

The arms and the patagium consist of different spongy substance. In Recent forms the chambers are about $4-5 \mu$ high, while Tertiary forms have larger meshes-about $7-10 \mu$ (the same as in the $R$. profunda group). The species is distinguished by the angular (not rounded) outline of the arms.

Early Miocene-Recent.

\section{Genus SPONGASTERISCUS Haeckel}

Spongasteriscus Haeckel, 1862, p. 474; 1887, p. 594; Campbell, 1954 , p. $94 .=$ Spongasteriscinum Haeckel, 1887, p. $594 ;$ Campbell, 1954, p. 94. Type species Spongasteriscus ovatus Haeckel, 1887, unfigured.

Spongodiscidae with central spongy sphere provided with four spongy cylindical arms.

\section{Spongasteriscus spp.}

(Plate 20, Figure 12; Plate 21, Figures, 6, 7)

?Histiastrum martinianum Carnevale 1908, pl. 26, pl. 4, fig. 11.

?Spongasteriscus marylandicus Martin, 1904, p. 435, pl. 130 , fig. 10.

Middle Miocene.

In the Oligocene, forms of Spongasteriscus with inflated ends of the arms existed.

\section{Cretaceous Spongodiscid}

(Plate 5, Figure 13)

The central part of the skeleton is spiral, the distal part spongy. It resembles Spongocyclia Haeckel, 1862, p. 469 (type species Spongocyclia cycloides Haeckel, 1862, pl. 28, fig. 1). It is very likely that some specimens described in Haeckel's monograph of 1862 are of great age.

Maestrichtian.

\section{Spongoprunum sp. aff. Cyphantus probus Rüst}

(Plate 4, Figures 6,7)

?Cyphinus probus Rüst, 1888, p. 196, pl. 24, fig. 4 .

Spongodiscid gen. sp. Riedel and Sanfilippo, 1970, pl. 1, fig. 8 .

This species differs from Rüst's species in the longer spongy part of the skeleton. The central construction of the skeleton in this form is less distinct than in typical $S$. probus.

Cretaceous (Maestrichtian).

\section{Family LITHELIDAE}

While numerous in Tertiary and Quaternary deposits, this family was examined by G. E. Kozlova only for the Cretaceous, because of the stratigraphic importance of some Cretaceous species.

\section{Cretaceous Lithelid Genus A}

Includes species with a spiral skeleton (spiral is double?). They are somewhat elogated along one main axis. They cannot be included in any known genus.

\section{Cretaceous Lithelid Genus A sp. indet.} (Plate 5, Figures 14, 15)

Cromyodruppa sp. Lipman, 1954, pl. 24, figs. 15, 16.

Cretaceous (Campanian-Maestrichtian).

\section{Cretaceous Lithelid Genus B}

Includes species very much the same as those referred to "Cretaceous genus $A$ ". This genus is distinguished by its pseudoaulophacoid surface, while "Cretaceous lithelid genus $A$ " is characterized by a porous surface of the skeleton.

Cretaceous Lithelid Genus B sp. indet. (Plate 3, Figure 17)

Cretaceous (Campanian)

\section{NASSELLARIA ${ }^{4}$}

\section{SPYRIDA Ehrenberg emend. Petrushevskaya}

Spyridina Ehrenberg, 1847b, p. 53; Petroshevskaya 1971a, p. 990; 1971 b, p. 240

Acanthodesmiidae Haeckel, 1862 sens. Riedel, 1967b, p. 296.

Nassellarians possessing a sagittal ring, or nassellarians arising from such species.

We do not give here any account of the evolution of the group, and we do not propose here any new classification of the Spyrida. Here illustrated are the species (found in Leg 14 material) closely related to the type species of some of Haeckel's genera.

\section{Family TRIOSPYRIDAE Haeckel emend. Petrushevskaya}

Haeckel, 1881, p. 441; 1887, p. 1025; Petrushevskaya, 1971a, p. $990 ; 1971$ b, p. 243.

Zygocyrtida Haeckel, 1862, p. 291, part.

Spyroidea Haeckel, 1887 , p. 1015 , part.

Spyrida with the cephalis very much the same as in many cyrtoids, especially in dicyrtids. The internal rods $L r$ and $L l$ are strong and produce the basal or lateral feet of the skeleton. The internal spines $A$ and Vert (the greater part of the sagittal ring) are often situated in the test. In such cases the sagittal ring is joined with the walls of the cephalis by means of some internal additional rods. The ring may be seen through some pores of the test (the pores named by Goll, 1968, as "vertical", "sternal" and "frontal" pores). The other pores are small, numerous and they are disposed without any symmetry about the sagittal plane. In the other cases, if the sagittal ring is included in the wall of the test, the number of the pores is less and they are disposed symmetrically about the sagittal plane.

\section{Genus HEXASPYRIS Haeckel}

Hexaspyris Haeckel, 1887, p. 1046; Riedel, 1959, p. 15 (not Campbell, 1954, p. 113). = Hexaspyridium Haeckel, 1887, p.

\footnotetext{
${ }^{4}$ Species identification of Cretaceous nassellarians was made by G. E. Kozlova.
} 
TABLE 14

Subdivisions of the Nassellaria Proposed and Used by W. R. Riedel and Subdivisions Proposed and Used by M. G. Petrushevskaya

\begin{tabular}{|c|c|c|c|c|c|c|}
\hline Riedel, $1967 \mathrm{~b}$ & \multicolumn{4}{|c|}{ Petrushevskaya, 1971} & & Nassellarian taxonomy applied here \\
\hline \multirow{2}{*}{ Acanthodesmiidae } & \multirow{2}{*}{ 莺 } & \multicolumn{3}{|c|}{ Triospyrididae } & & Family Triospyrididae \\
\hline & & \multicolumn{3}{|c|}{ Acanthodesmiidae } & & Family Acanthodesmiidae \\
\hline \multirow{4}{*}{ Plagoniidae } & \multirow{17}{*}{ 莺 } & \multicolumn{3}{|c|}{ Sethophormididae } & \multirow{4}{*}{ 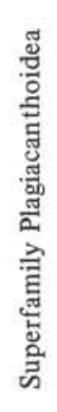 } & Family Sethophormididae \\
\hline & & \multirow{3}{*}{ 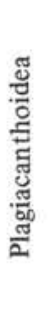 } & \multirow{3}{*}{ 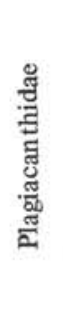 } & Lophophaeninae & & $\begin{array}{l}\text { Family Lampromitridae } \\
\text { Family Lophophaenidae }\end{array}$ \\
\hline & & & & Sethoperinae & & Family Sethoperidae \\
\hline & & & & Plagiacanthinae & & Family Plagiacanthidae \\
\hline Carpocaniidae & & \multirow{13}{*}{ 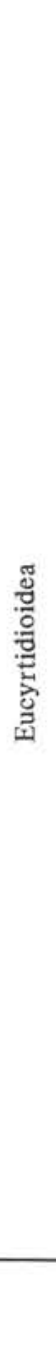 } & & pocaniidae & & $\begin{array}{c}\text { Family Carpocaniidae sub fam. Carpocaniinae } \\
\text { subfam. group C }\end{array}$ \\
\hline Artostrobiidae & & & \multirow{11}{*}{ 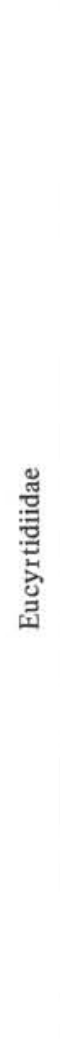 } & Artostrobiinae & & $\begin{array}{l}\text { Family Artostrobiidae subfam. group A } \\
\qquad \text { subfam. Artostrobiinae }\end{array}$ \\
\hline \multirow{5}{*}{ Theoperidae } & & & & & & Family Neosciadiocapsidae \\
\hline & & & & & $\frac{\mathbb{E}}{0}$ & Cryptocephalic dicyrtid group \\
\hline & & & & Eucyr tidiinae & 永 & Family Williriedelidae \\
\hline & & & & & 育 & Family group $\mathrm{N}$ \\
\hline & & & & & ڤ્ळ & ? subfam. group E \\
\hline Pterocoryidae & & & & Pterocoryinae & & Family Pterocoryidae \\
\hline Amphipyndacidae & & & & Amphipyndacinae & & Family Amphipyndacidae \\
\hline \multirow{3}{*}{ Theoperidae } & & & & Eucyrtidiinae & & Family Eucyrtidiidae \\
\hline & & & & Plectopyramidinae & & Family Plectopyramididae \\
\hline & & & & Eucyrtidiinae & & Family Lychnocaniidae \\
\hline Cannobotryidae & & & \multicolumn{2}{|c|}{ Cannobotryoidea } & & Superfamily Cannobotryoidea \\
\hline
\end{tabular}


1047. Type species Ceratospyris setigera Ehrenberg, 1873; 1875, pl. 20 , fig. 11 .

Thick-walled cephalis with numerous, irregularly disposed pores. Sagittal ring is enclosed in the cephalis. No thorax. Mouth of the cephalis constricted. About 6 feet. The feet are cylindrical, weak, They go from the margin of the cephalis downwards. Horns, if present, are weak (see Plate 39, Figure 13).

Genus LIRIOSPYRIS Haeckel sens. str.

Liriospyris Haeckel, 1881 , p. 443 ; 1887, p. 1049; Campbell, 1954 , p. 114; Goll, 1968 , p. 1423 , part. Type species Liriospyris hexapoda Haeckel, 1887, pl. 86, Fig. 7.

Thin-walled cephalis with definite number of large pores. The saggital ring is included in the walls. The mouth of the shell is constricted, and there is no thorax. Undetermined number of cylindrical feet. As a rule the feet are short and weak. Horns, if present, weak.

\section{Liriospyris sp. aff. L. clathrata}

(Plate 39, Figure 15)

On the frontal side of the cephalis, three pairs of large pores beside the sagittal ring are seen without turning the shell. On the lateral sides of the cephalis the wall is very thin (often damaged), pores irregular. No sagittal construction. Feet as little horns. The species is somewhat similar to Dictyospyris clathrata Ehrenberg (Plate 39, Figure 14).

Eocene.

Liriospyris sp. B. group

(Plate 39, Figures 17-20)

Two pairs of large pores may be seen beside the sagittal ring. The upper (alongside the arch of the sagittal ring) pores, scarcely visible, are the largest. The lateral sides of the test are well developed. The sagittal constriction is distinct. Feet as small horns from the margin of the mouth.

Oligocene.

\section{Genus THAMNOSPYRIS Haeckel}

Thamnospyris Haeckel, 1881, p. 443; 1887, p. 1071; Campbell, 1954, p. 114; Petrushevskaya 1971b, p. 248.

Type species Gorgospyris shizopodia Haeckel, 1887, pl. 87, fig. 4 .

?Archiphatha Haeckel, 1881, p. 422; Campbell, 1954, p. 119. = Coronophatna Haeckel, 1881, p. 429. = Archiphaena Haeckel, 1887 , p. $1177 .=$ Coronophaena Haeckel, 1887 , p. 1178 . Type species Archiphaena gorgospyris Haeckel, 1887, p. 1178, pl. 98. fig. 10 .

Thick-walled cephalis with small irregularly disposed pores. Pores are few. The sagittal ring is enclosed in the cephalis. Walls of cephalis are prolonged into a peristome-a kind of thorax, but pore-less. The margin of the peristome has a crown of flat chisel-shaped springs. They cannot be named "feet", as they are not connected with the internal spines $D, L, I$. No horns (apical, vertical, etc.).

\section{Thamnospyris sp. aff. T. schizopodia} (Plate 38, Figure 3)

?Gorgospyris schizopodia Haeckel, 1887, p. 1071, pl. 87, fig. A. Differs from typical $T$. schizopodia in the greater length of the peristomial teeth, and in the outline of the test.

Early Miocene.

\section{Genus RHODOSPYRIS Haeckel}

Rhodospyris Haeckel, 1881, p. $443 ; 1887$, p. 1088; Campbell, 1954; Petrushevskaya, 1971b, p. 248. Type species Rhodospyris tricornis Haeckel, 1887, pl. 83, fig. 13.

Thick-walled test consists of two segments: cephalis and thorax, the cephalis being broader than the thorax. The sagittal ring may be enclosed in the cephalis and connected with the wall from the inside. Pores on the cephalis are small, irregularly disposed. There are no real feet going from the margin of the cephalis. The margin of the thorax may be armed with flat teeth or sprigs. As a rule, apical and some additional horns are present on the cephalis.
Remarks: Two trends in the change of the morphology may be indicated. The first is the overgrowing of the thorax (from Rhodospyris sp. aff. $R$. tricornis to Rhodospyris sp. De 1). The second is diminution of the thorax (from Rhodospyris sp. A to Rhodospyris sp. aff. $R$. Anthocyrtis). Maybe they indicate the existence of two subgenera.

\section{Rhodospyris sp. aff. R. tricornis}

(Plate 38, Figures 7-10)

?Rhodospyris tricornis Haeckel, 1887, p. 1089, pl. 83, fig. 13.

Differs from the typical $R$. tricornis in the smaller number of pores on the cephalis, and their more regular disposition. In $R$. tricornis typ. The thorax is longer and armed with terminal teeth, which is not the case in the species in question.

Miocene.

Rhodospyris sp. A

(Plate 38, Figure 11)

The species is distinguished by having a short closed thorax with irregular pores.

Early Miocene.

\section{Rhodospyris? spp. De 1 group \\ (Plate 38, Figures 15,16)}

Dendrospyris sp. 1 Goll, 1968 , p. 1417 , text-fig. 8.

Cephalis is very much the same as in Rhodospyris sp. aff. tricornis - the same wall, the same pores-only the dimensions are a little less. The thorax, on the contrary, is different from that of $R$. tricornis. It is twice as broad as the cephalis. The pores on it are very small and numerous: about 20 longitudinal rows of pores on the half equator of the thorax.

Oligocene?-Early Miocene.

\section{Rhodospyris sp. aff R. anthocyrtis (Plate 38, Figure 14)}

Patagospyris anthocyrtis Haeckel, 1887, p. 1088, pl. 95, fig. 19.

Multipored cephalis, the sagittal ring included in the wall of the cephalis. The thorax is of the same breadth as the cephalis. Cephalis and thorax are separated by a distinct constriction of the test. The mouth of the thorax has some teeth.

Middle Miocene. In the Oligocene a very similar species existed (Plate 38, Figures 18, 19). They are distinguished by the arrangement of the pores.

\section{Genus DESMOSPYRIS Haeckel}

Desmospyris Haeckel, 1881, p. 443; 1887, p. 1089; Campbell, 1954 , p. 116; Petrushevskaya, 1971 b, p. 248 . Type species Desmospyris mammilata Haeckel, 1887, pl. 83, fig. 14.

Diagnosis. The test consists of two segments, the thorax being narrower than the cephalis. The sagittal ring is 1) enclosed in the cephalis or 2) included in the cephalic wall. In the first case the wall has numerous irregular pores and may even be spongy. In the second case the wall of the cephalis has rather large pores, symmetrically disposed on the sides of the sagittal ring. No real feet, only teeth on the thoracic margin. As a rule no horns.

Desmospyris sp. A

(Plate 38, Figures 12,13)

?Dictyocephalus obtusus Bütschli, 1882, p. 535, fig. 20.

Differs from D. obtusus and from D. mamillata (Plate 38, Figure

6) by its larger pores.

Middle Miocene.

\section{Desmospyris spp. aff. D. anthocyrtoides (Bütschli)}

\author{
(Plate 40, Figure 3)
}

?Petalospyris anthocyrtoides Bütschli, 1881, Fig. 19.

Dendrospyris anthocyrtoides (Bütschli), Goll, 1968, p. 1469, pl. 175, figs. 9, 11-14, part.; Riedel and Sanfilippo, in press, pl. 5, fig. 5 , part.

The sagittal ring is entirely within the test. This species differs from the species described by Bütschli in the greater number of the pores, and by the sagittal ring being "deeper" in the test. Thorax very short, with practically no teeth.

Oligocene. 
Desmospyris sp. aff. D. lata (Plate 38, Figure 1)

?Dendrospyris acutis Goll 1968, p. 1419, pl. 173, figs. 7-9, 12. Giraffospyris lata Goll, 1969, p. 334, pl. 58. figs. 22, 24-26.

In our specimens the number of pores was the same as in D. lata, but the entire outline of the test was more similar to that of $D$. acutis (though in some specimens the outline of the shell was intermediate between $D$. lata and D. acutis). Maybe this Paleocene species was ancestral to the two Eocene species described by Goll. Paleocene.

Genus DENDROSPYRIS Haeckel, sens. str.

Dendrospyris Haeckel, 1881 , p. $441 ; 1887$, p. 1038; Campbell, 1954 , p. 112 ; Goll, 1968 , p. 1417 , part. Type species Ceratospyris stylophora Ehrenberg, 1873 (1875, pl. 20, fig. 10).

Giraffospyris Haeckel, 1881, p. 442; 1887, p. 1056; Campbell, 1954 , p. 114; Goll, 1969, p. 329, part. Type species Ceratospyris heptaceros Ehrenberg, $1873 ; 1875$, pl. 20, fig. 2 .

Aegospyris Haeckel, 1881, p. 442; 1887, p. 1053; non Campbell, 1954 , p. 112 ; Riedel, 1959 b, p. 6 . Type species Aegospyrys aegoceras Haeckel, 1887, pl. 95, fig. 10.

Triospyrium Haeckel, 1887, p. 1030; Campbell, p. 112. Type species Ceratospyris furcata Ehrenberg, 1873; 1875, pl. 20, fig. 8.

Diagnosis. Test consists of one segment, a thick-walled cephalis. Large pores situated symmetrically on both sides of the sagittal ring. (Plate 39, Figure 22). The latter is connected with or included in the cephalic wall. The mouth constricted. Six feet are directed downwards, two of them being stronger than the others. Several horns on the cephalis.

\section{Dendrospyris didiceros group}

(Plate 40, Figure 12)

Ceratospyris didiceros Ehrenberg, 1873, p. 228; 1875, pl. 21, fig. 6.

Ceratospyris longibarba Ehrenberg, 1873, p. 219; 1875, pl. 21, fig. 2 .

Ceratospyris heptaceros Ehrenberg, 1873, p. 219; 1875, pl. 20, fig. 2.

Giraffospyris didiceros (Ehrenberg) Goll, 1969, p. 332, pl. 60, figs. 5-7, 9, part; Riedel and Sanfilippo, 1970, pl. 5, fig. 5, part. Eocene-Oligocene?

\section{Dendrospyris pododendros (Carnevale) group} (Plate 39, Figures 26-28)

Tessarospyris pododendros Carnevale, 1908, p. 28, pl. 3, fig. 18 .

Dendrospyris pododendros (Camevale) Goll, 1968, p. 1422, pl. 174, figs. $1-4$.

Early and Middle Miocene.

\section{Genus PETALOSPYRIS Ehrenberg}

Petalospyris Ehrenberg, 1847, p. 54; Haeckel, 1881, p. 443; 1887, p. 1059; Bütschli, 1882 , p. 510; Campbell, 1954 , p. 114 ; Petrushevskaya, 1971b, p. 249. Type species Petalospyris foveolata Ehrenberg, 1854, pl. 36, fig. 14 .

This genus is very closely related to Dendrospyris. The difference lies in the wide-open mouth of the test, the legs going first laterally, and only then they may be curved and directed downwards. The legs, about six in number, are more or less strong, cylindrical.

\section{Petalospyris triceros (Ehrenberg) group (Plate 40, Figure 9)}

Ceratospyris triceros Ehrenberg, 1873 , p. $220 ; 1875$, pl. 21 , fig. 5. Tristylospyris triceros Ehrenberg) Riedel, 1959a, p. 292, pl. 1, figs. 7, 8; Riedel and Sanfilippo, in press, pl. 3A, figs. 11, 12; Moore, in press, pl. 6, figs. 1-3.

Six divergent feet, three of them being stronger than the others. Eocene-Oligocene.

\section{Petalospyris sp. E}

(Plate 40, figure 1)

All of the feet are weak.

Oligocene.

Dorcadospyris(?) or Petalospyris(?) ateuchus (Ehrenberg)

Ceratospyris ateuchus Ehrenberg, 1873, p. 218.
Cantharospyris ateuchus (Ehrenberg) Riedel, 1959, p. 294, pl. 22, fig. 3,4 .

Dorcadospyris ateuchus (Ehrenberg) Riedel and Sanfilippo, 1970, p. 253 , pl. 15 , fig. 4 ; Moore, in press, pl. 8, figs. 1, 2.

Two of the feet are stronger than the others as in Dorcadospyris, but all feet are divergent as in Petalospyris, and they are not inclined to form any ring.

Oligocene.

\section{Genus DORCADOSPYRIS Haeckel}

Dorcadospyris Haeckel, 1881 , p. 441; 1887, p. 1040; Campbell, 1954 , p. 112; Goll, 1969, p. 335, part. Type species Dorcadospyris dentata Haeckel, 1887 , pl. 85, fig. 6 .

Gamospyris Haeckel, 1881, p. 441; 1887, p. 1042; Campbell, 1954, p. 112. Type species Gamospyris circularis Haeckel, 1887, pl. 83, fig. 19.

Stephanospyris Haeckel, 1881, p. 441; 1887, p. 1042; Campbell, 1954 , p. 112. Type species Stephanospyris cordata Haeckel, 1887 , pl. 85 , fig. 10 .

?Brachiospyris Haeckel, 1881 , p. $441 ; 1887$, p. 1037; Campbell, 1954, p. 112. Type species Ceratospyris ocellata Ehrenberg, $1873 ; 1875$, pl. 20 , fig. 5 .

This genus is closely related to Petalospyris. The only difference lies in the development of the feet. In Dorcadospyris two of the feet are stronger than the other four, and these two legs are inclined to be joined to form a ring.

\section{Dorcadospyris sp. $\mathbf{K}$}

(Plate 40, Figure 5)

Two feet form a complete ring. The four other feet are rather strong and long. It is very much the same as in $D$. spinosa Moore (in press, pl. 7, figs. 2-5), but the feet are smooth, without horns.

Oligocene.

\section{Dorcadospyris simplex (Riedel)}

(Plate 40, Figure 11)

See Riedel and Sanfilippo, 1970, p. 523, pl. 15, fig. 6. Miocene.

\section{Dorcadospyris dentata Haeckel}

See Goll, 1969, p. 338, pl. 60, figs. 8, 10-13. Miocene.

\section{Dorcadospyris alata (Riedel)}

See Riedel and Sanfilippo, 1970, p. 523, pl. 14, fig. 5. Miocene.

\section{Genus PATAGOSPYRIS Haeckel}

Patagospyris Haeckel, 1881, p. 443; 1887, p. 1087; Campbell, 1954 , P. 116; Petrushevskaya, 1971b, p. 248. = Petalospyrella Haeckel, 1887 , p. 1060; Campbell, 1954, p. 114. Type species, Petalospyris confluens Ehrenberg, 1873;1875, pl. 22, fig. 5 .

All features are nearly the same as in Petalospyris, but the feet are more numerous and flat (not cylindrical).

\section{Patagospyris argisca (Ehrenberg) \\ (Plate 40, Figure 8)}

Petalospyris argiscus Ehrenberg, 1873, p. 246; 1875, pl. 22, fig. 1. Dorcadospyris argisca (Ehrenberg) Goll, 1969, p. 336, part.

The specimen illustrated by Goll has no sagittal constriction, while the sagittal constriction is distinct in the specimens from Ehrenberg's and from our material.

Eocene.

\section{Patagospyris pentas (Ehrenberg)} (Plate 39, Figures 32, 33)

Petalospyris pentas Ehrenberg, 1873, p. 247; 1875, pl. 22, fig. 11. Eocene.

\section{Family ACANTHODESMIIDAE Haeckel}

Haeckel, 1862 , p. 265 ; Hertwig, 1879 , p. 68 ; Bütschli, 1882 , p. 495 ; Riedel 1967b, p. 296, part; Petrushevskaya, 1971a, p. 990; 1971 b, p. 260.

Stephoidea Haeckel, 1887, p. 931. 
Spyrida without cephalis similar to that of cyrtoids, the sagittal ring and some arches connected with it being the basic elements of the skeleton.

\section{Genus TRICOLOSPYRIS Haeckel}

Tricolospyris Haeckel, 1881 , p. $44 ; 1887$, p. 1078 ; Campbell, 1954 , p. 114; Petrushevskaya, 1971b, p. 246. Type species Tricolospyris kantiana Haeckel, 1887 , pl. 88 , fig. 10.

Tholospyris Haeckel, in Goll, 1969, p. 322, part.

Thick-walled cephalis with a sagittal ring in its walls, and a small number of large pores. The pores are disposed symmetrically with respect to the sagittal plane. A galea and thorax are also present-they have a delicate wall with numerous small pores. Sometimes the cephalis is surrounded by a delicate envelope not only above (galea) and below (thorax) but all around.

\section{Tricolospyris leibnitziana group (Plate 38, Figures 26, 29)}

Tricolospyris leibnitziana Haeckel, 1887, p. 1098, pl. 88, fig. 9. valls.

Differs from T. kantiana Haeckel in the thickness of the cephalic Miocene.

\section{Genus TYMPANOMMA Haeckel}

Tympanomma Haeckel, 1887, p. 100; Campbell, 1954, p. 109 Petrushevskaya, $1971 \mathrm{~b}$, p. 260. Type species Tympanidium binoctonum Haeckel, 1887 , pl. 94, fig. 18 .

Six pairs of main rods arise from the sagittal ring. The test consists of a thick-walled cephalis having a small number of large pores.

\section{Tympanomma binoctonum (Haeckel)}

(Plate 39, Figures 23, 24)

Tympanidium binoctonum Haeckel, 1887 , p. 100 , pl. 94 , fig. 18 Riedel, 1957, p. 78, pl. 1, fig. 2.

Miocene.

\section{Genus TRISSOCYCLUS Haeckel}

Trissocyclus Haeckel, 1881, p. 446; 1887, p. 986; Campbell 1954 , p. 108 , Petrushevskaya, 1971 b, p. $260 .=$ Tricyclarium Haeckel, 1887, p. 987; Campbell, 1954, p. 108. Type species Trissocyclus stauropora Haeckel, 1887 , pl. 83, fig. 5 .

Trissocircus Haeckel, 1881, p. 446; 1887, p. 985; Campbell, 1954, p. $108 .=$ Tricircarium Haeckel, 1887 , p. 985 ; Campbell 1954 , p.108. Type species Trissocircus lentellipsis Haeckel, 1887, pl. 93, fig. 10 .

Zygostephanium Haeckel, 1887, p. 972; Campbell, 1954, p. 108. Type species Zygostephanium dizonium Haeckel, 1887, pl. 93, fig. 3 .

Liriospyris Haeckel in sens. Gol. 1, 1968, p. 1423, part.

The skeleton consists of the frontal and sagittal rings, the frontal ring being porous.

\section{Trissocyclus stauropora Haeckel}

(Plate 39, Figures 29-31)

Trissocyclus stauropora Haeckel, 1887, p. 987, pl. 83, fig. 5 .

Zygostephanus dissocircus Haeckel, 1887, p. 971, pl. 93, fig. 1.

Zygostephanium dizonium Haeckel, 1887, p. 973 , pl. 93 , fig. 3 .

Liriospyris stauropora (Haeckel) Goll, 1968, p. 1431, pl. 175, figs. $1-3,7$.

Miocene.

\section{Trissocyclus elevata (Goll)}

(Plate 39, Figure 25)

Liriospyris elevata Goll, 1968, p. 1426, pl. 175, figs. 4, 5, 8, 9. Early Miocene.

\section{Genus LITHOTYMPANIUM Haeckel emend. Petrushevskaya}

Lithotympanium Haeckel, 1887, p. 447; 1887, p. 1006; Campbell, 1954, p. 109. Type species Lithotympanium tuberosum Haeckel, 1887, pl. 83, fig. 1.

Eight pairs of thick rods originate from the sagittal ring. The lateral walls are as two large plates.

\section{Lithotympanium tuberosum Haeckel}

(Plate 38, Figures 22-24)

Lithotympanium tuberosum Haeckel, 1887, p. 1006, pl. 83, fig. 1; Petrushevskaya, 1971b, pl. 131, figs. 18, 19.

Liriospyris sp. 2, Goll, 1968, text-fig. 9. Miocene.

\section{Genus EUCORONIS Haeckel}

Eucoronis Haeckel, 1881, p. 445; 1887, p. 976; Campbell, 1954, p. 108; Petrushevskaya, 1971 b, p. 267 . = Acrocoronis Haeckel, 1881 , p. $445 ; 1887$, p. 977 ; Campbell, 1954 , p. 108 . Type species Eucoronis perspecillum Haeckel, 1887, pl. 82, fig. 6 .

Acrocubus Haeckel, 1887, p. 447; 1887, p. 992; Campbell, 1954, p. 108. = Apocubus Haeckel, 1887, p. 992; Campbell, 1954, p. 108. Type species Acrocubus octopylus Haeckel, 1887, pl. 82, fig. 9.

Coronidium Haeckel, 1887, p. 973; Campbell, 1954, p. 108. Type species Coronidium dyostephanus Haeckel, 1887, pl. 82, fig. 6. Four pairs of rods, arising from the sagittal ring, form two arches of the frontal ring. (Plate 41, Figures 13,14).

\section{Eucoronis sp. A}

(Plate 41, Figures 1, 2)

The arches of the frontal ring are without horns.

Miocene.

\section{Eucoronis hertwigii group}

(Plate 41, Figures 15-17)

Acanthodesmia hertwigii Bütschli, 1882, pl. 32, fig. 9; Petrushevskaya, 1971b, p. 967, pl. 141, figs. 1-3,

The arches of the frontal ring have an irregular outline and they are thorny. Eocene-Oligocene.

\section{Genus PODOCORONIS Haeckel}

Podocoronis Haeckel, 1881 , p. $445 ; 1887$, p. 980; non Campbell, 1954 , p. 108 ; Riedel, 1959 b, p. $19 .=$ Dipocoronis Haeckel, 1881 , p. $445 ; 1887$, p. 980 ; non Campbell, 1954 , p. 108 ; Riedel, 1959 b, p. 19. Type species Podocoronis toxarium Haeckel, 1887 , pl. 83 , fig. 7 .

Dipocubus Haeckel, 1887, p. 993; Campbell, 1954, p. 108. Type species Acrocubus arcuatus Haeckel, 1887, pl. 93, fig. 15.

Tripocubus Haeckel, 1887, p. 994; Campbell, 1954, p. 108. Type species Acrocubus cortina Haeckel, 1887, pl. 93, fig. 16.

Tetracubus Haeckel, 1887, p. 994; non Campbell 1954, p. 108; Riedel, 1959 b, p. 25. Type species Acrocubus amphithectus Haeckel, 1887, pl. 93, fig. 17.

Toxidium Haeckel, 1887, p. 996; Campbell, 1954, p. 109. Type species Toxarium cordatum Haeckel, 1887, pl. 93, fig. 19.

Giraffospyris Haeckel, sens. Goll, 1969, p. 329, part.

Four pairs of rods, arising from the sagittal ring, form the frontal ring as in Eucoronis. The difference is in the presence 1) of the apical horn with two galear arches and 2) of two basal feet.

\section{Podocoronis toxarium Haeckel (Plate 41, Figure 3)}

Podocoronis toxarium Haeckel, 1887, p. 980, pl. 83, fig. 7.

Acrocubus arcuatus Haeckel, 1887, p. 993, pl. 93, fig. 5 .

Giraffospyris toxaria (Haeckel) Goll, 1969, p. 335, pl. 56, figs. 1, 2, 4,7 . Miocene

Genus ZYGOCIRCUS Bütschli, emend. Petrushevskaya

Zygocircus Bütschli, 1882, p. 496; Haeckel, 1887, p. 945; Campbell, 1954 , p. 108; Petrushevskaya, 1971b, p. 279. Type species Lithocircus productus Hertwig, 1879, pl. 7, fig. 4.

Sagittal ring with basal spines $D, L_{r}$ and $l_{l}$.

\section{Zygocircus productus (Hertwig) (Plate 41, Figure 4)}

Lithocircus productus Hertwig, 1879, p. 69, pl. 7, fig. 4.

Zygocircus productus (Hertwig) Bütschli, 1882, p. 496; Haeckel, 1887, p. 946; Petrushevskaya, 1971b, p. 281, pl. 145, figs. 10,11 .

The feet are very weak.

Quaternary. 
Zygocircus bütschlii Haeckel (Plate 41, Figure 4)

Zygocircus bütschlii Haeckel, 1887, p. 948.

The feet are distinct. The horns on the ring are numerous. The sagittal ring is three-edged as in $Z$. productus.

Oligocene.

Zygocircus sp.

(Plate 41, Figures 8-11)

?Semantis triangularis Clark and Campbell, 1945 , p. 29 , pl. 5 , fig. 7 .

The edges on the rings are not so distinct as in $Z$. butschlii. number of horns on the arch of the sagittal ring is less than in $Z$. butschlii and than in typical $Z$. triangulatis (Campbell and Clark).

Eocene.

\section{Zygocircus cimelium sp. nov. Petrushevskaya} (Plate 41, Figures 5, 6)

The skeleton is very much the same as in $Z$. productus, but the length of the ring is three to four times greater. The arch of the sagittal ring is without horns and without edges.

The name of the species derived from a Greek noun (neuter), meaning "treasure." Description based on 5 specimens from $140-5-3,5-7 \mathrm{~cm}$.

Eocene.

\section{CYRTIDA}

Cyrtida Haeckel, 1862, p. 280, part.; Petrushevskaya, 1971a, p. 984; 1971 b, p. 56

Cyrtiden Hertwig, 1879, p. 74, part.

Cyrtellaria Haeckel, 1887, p. 1015, part.

Nassellarians without sagittal ring, but with arches $a j$ and $a p$ in the cephalis.

\section{Superfamily PLAGIACANTHOIDEA Hertwig, emend,} Petrushevskaya

Plagiacanthiden Hertwig, 1879, p. 72; Petrushevskaya, 1971a, p. $989 ; 1971$ b, p. 57.

Plagoniidae Haeckel. Riedel, 1967b, p. 295.

Crytida with large cephalis, compared with the whole skeleton. Thorax may or may not be developed.

Family LAMPROMITRIDAE Haeckel, emend. Petrushevskaya

Lampromitrida Haeckel, 1881, p. 431

Lophophaeninae group II, Petrushevskaya, 1971a, p. 989.

The thorax is well developed. It may be even larger than the cephalis. The cephalis has a low eucephalic part, nearly hidden in the skeleton.

Genus TRIPODISCIUM Haeckel, emend. Petrushevskaya

Tripodiscium Haeckel, 1881 , p. 428; 1887, p. 1143; Campbell, 1954, p. 117 ; Petrushevskaya, 1971 b, p. $70 .=$ Tripodiscinus

Haeckel, 1887, p. 1143; Campbell, 1954, p. 117. Type species Tripodiscium tristylospyris Haeckel, 1887, unfigured.

The spine $A$ goes as a columella in the cephalis, and forms a stout apical horn. The spine Vert forms an occipital horn or tube. The spines $D, L r$ and $L I$ form stout lateral feet, all three being disposed nearly in the horizontal plane. The cephalis has a large antecephalic lobe ("dorsal" lobe in the report of Foreman, 1968). The cephalis is widely open towards the thorax. The thorax may be more or less long (Plate 37, Figures 16, 17).

Cretaceous-Eocene.

Remark: This genus is not typical for the Lampromitridae.

Tripodiscium? sp. aff. Lithomelissa hoplites

(Plate 7, Figure 2)

?Lithomelissa (?) hoplites Foreman, 1968, p. 26, pl. 3, fig. 2.

The thorax is very long, and the test resembles the skeleton of three-segmented nassellarians.

The species is not typical for Tripodiscium, but it cannot be placed in the genus Lithomelissa. For Lithomelissa, species like $L$. microptera Ehr. and L. macroptera Ehrenberg, 1873, 1875, (with collar constriction) seem to be typical.

Cretaceous (Maestrichtian).
Tripodiscium sp. A

(Plate 37, Figure 17)

Lithomelissa sp. Clark and Campbell, 1945, p. 38, pl. 6, fig. 1. Typical Tripodiscium with short thorax. Eocene.

\section{Genus CERATOCYRTIS Bütschli}

Ceratocyrtis Bütschli, 1882 , p. 536; non Haeckel, 1887 , p. 1290 non Campbell 1954, p. 128; but Petrushevskaya, 1971b, p. 98. Type species Cornutella cucullaris Ehrenberg, 1873, 1875, pl. 2, fig. 7.

Helotholus Jörgensen, 1905, p. 137; Campbell, 1954, p. 128. Type species Helotholus histricosa Jörgensen, 1905, pl. 16, figs. 86-88.

Bathrocalpis Clark and Campbell, 1942, p. 64; Campbell, 1954, p. 118. Type species Bathrocalpis campanula Clark and Campbell, 1942, pl. 9, fig. 27.

Very much like Tripodiscium, but without large feet or horns.

\section{Ceratocyrtis sp. aff. C. Cucullaris (Ehrenberg)} (Plate 37, Figure 12)

Cornutella cucullaris Ehrenberg, 1873, p. 221; 1875, pl. 2, fig. 7.

Ceratocyrtis cucullaris (Ehrenberg) Bütschli, 1882, p. 536, fig. 36; Petrushevskaya, 1971b, pl. 52, fig. 1. Paleogene.

Genus LAMPROTRIPUS Haeckel emend Petrushevskaya

Lamprotripus Haeckel, 1881 , p. $432 ; 1887$, p. 1199; non Campbell, 1954 , p. 122; but Petrushevskaya, 1971b, p. 95 . Type species Lamprotripus squarrosus Haeckel, 1881 (1887, pl. 60, fig. 1). Somewhat like Ceratocyrtis, but with long feet, included proximally in the thoracic wall. The feet are terminal, not lateral as in Tripodiscium

\section{Lamprotripus mawsoni (Riedel)}

Dictyophimus mawsoni Riedel, 1958 , p. 234 , pl. 3, figs. 6, 7; Petrushevskaya, 1967 , p. 76, fig. 430 .

Quaternary.

\section{Genus PSEUDODICTYOPHIMUS Petrushevskaya}

Pseudodictyophimus Petrushevskaya, 1971b, p. 91.

Dictyophimus Ehrenberg, Petrushevskaya, 1967a, p. 67-74. Type species Dictyophimus gracilipes Bailey (1856, fig. 8$)$.

Very much the same as Tripodiscium, but the antecephalic lobe of the cephalis is small and is confused with the thorax (compare Figures 17 and 18 on Plate 37).

\section{Pseudodictyophimus gracilipes (Bailey) group}

(Plate 37, Figure 21)

Dictyophimus gracilipes Bailey 1856, see Petrushevskaya, 1967a, p. 67 , figs. 38,39 .

Quaternary.

Pseudodictyophimus sp. A

(Plate 37, Figures 19, 20)

Miocene.

Family LOPHOPHAENIDAE Haeckel, emend, Petrushevskaya

Lophophaenida Haeckel, 1881, p. 430; Campbell, 1954, p. 123 Petrushevskaya, 1971a, p. 989, group III, part; 1971b, p. 86 , part.

The cephalis is large, egg-shaped, with distinct collar constriction. The spine $A$ is inclined so as to be included in the cephalic wall.

Genera: Lithomelissa Ehr., 1847b (type species L. microptera Ehr., 1856); Lophophaena Ehr., 1847b (Loph. galea orci Ehr., 1854) and Lophophaenoma Hck., 1887 (Lophophaena radians Ehr., 1875).

Genus LOPHOPHAENA Ehrenberg, emend. Petrushevskaya

Lophophaena Ehrenberg, 1847b, p. 54; Haeckel, 1887, p. 1303 Campbell, 1954, p. 128; Petrushevskaya, 1971b, p. $105 .=$ Lophophaenula Haeckel, 1887, p. 1303; Campbell, 1954, p. 128. Type species Lophophaena galea orci Ehrenberg, 1854. $=L$. apicata Ehrenberg, 1873 (1875, pl. 8, fig. 11). 


\section{Lophophaena? capito Ehrenberg group}

(Plate 33, Figures 20-23)

?Lophophaena capito Ehrenberg, 1873, p. $242 ; 1875$, pl. 8, fig. 6 . Lophophaenoma sp. G. Petrushevskaya, 1971b, pl. 56, figs. 16, 17. Our species differs from the typical $L$. capito by its greater dimensions. From typical Lophophaena species (L. apicata Ehr.), this species group differs in its ball-shaped cephalis and narrow "neck".

Eocene-Oligocene.

Family SETHOPERIDAE Haeckel, emend. Petrushevskaya

Sethoperida Haeckel, 1881 , p. 433; 1887, p. 1232; Haecker, 1908. p. 448 ; Petrushevskaya, 1971 a, p. $989 ; 1971$ b, p. 76.

The cephalis is surrounded by latticed plates. Spine $A$ forms a columella; its branches $a$ extend in the cavity of the cephalis. The spine Vert is weak

\section{Genus CLATHROCORONA Haeckel}

Clathrocorona Haeckel, 1881 , p. 431; 1887, p. 1212; Campbell, 1954 , p. 122. Type species Clathrocanium (Clathrocorona) diodema Haeckel (1887, pl. 64, fig. 2).

The latticed plates surrounding the cephalis are practically undeveloped. The lower three plates form the walls of a distinct thorax; the lateral three plates are represented only by 1) the edges on the apical horn and 2) the edges of the feet, included in the thoracic wall.

\section{Clathrocorona sphaerocephala (Haeckel) group} (Plate 37, Figures 27-30)

?Clathrocanium sphaerocephalum Haeckel, 1887 , p. 1211 , pl. 64 , fig. 1; Petrushevskaya, 1971b, pl. 39, figs. 5-7.

Thorax has three gates, sometimes overgrown with very thin threads. The pores on the thorax are small and numerous. Miocene.

\section{Superfamily EUCYRTIDIOIDEA Ehrenberg}

Eucyrtidina Ehrenberg, 1847, p. 53; Petrushevskaya, 1971a, p. 985 ; 1971 b, p. 166.

Cyrtoidea Haeckel, 1887, p. 1126, part.

As a rule the cephalis is small compared with the whole skeleton. It is separated from the thorax by some distinct arches. After the thorax comes the abdomen, and as a rule some other segments.

\section{Family CARPOCANIIDAE Haeckel}

Carpocanida Haeckel, 1881, p. 427; Riedel, 1967 b, p. 296 Petrushevskaya, 1971a, p. 988; 1971b, p. 238.

Eucyrtidioidea with the small eucephalic chamber merged within the thorax. Thorax with round pores. Abdomen may be in the form of a peristome.

\section{Subfamily CARPOCANIINAE Haeckel}

Carpocanida Haeckel, 1881, p. 427; Riedel, 1967b, p. 296 Petrushevskaya, 1971a, p. 988.

Carpocaniidae with ovate or nearly cylindrical thorax, the pores being disposed in longitudinal rows on it. Abdomen very often without pores (in the form of a peristome) or with pores, smaller than those of the thorax.

\section{Genus MYLLOCERCION Foreman}

Myllocercion Foreman, 1968, p. 37. Type species Myllocercion acineton Foreman, 1968, pl. 5, fig. 11.

The wall of the thorax is very thick. Thorax is separated from abdomen by internal wall (ring or shelf) with a small opening. Abdomen with pores much smaller than the thoracic pores.

Myllocercion sp. aff. M. minima (Dumitrica)

(Plate 2, Figures 19, 20; Plate 7, Figure 3)

?Diacanthocapsa minima Dumitrica, 1970 , p. 62 , pl. 15 , figs. 92 , 93, 95 .

The species in question differs from typical $M$. minima by its longer thorax.

Specimens from the Campanian (Plate 2, Figures 19,20) are somewhat distinguished from the Maestrichtian specimens (Plate 7, Figure 3 ) by the outline of the test.

Early Campanian-Maestrichtian.
Myllocercion sp. C

(Plate 22, Figures 13, 14)

?Carpocanopsis cingulatum Riedel and Sanfilippo, in press, pl. 2G, figs. 17-19, part.

This species differs from the type species of Myllocercion ( $M$. acineton) only in its narrower thorax.

Early ard middle Miocene.

Genus THEOCAPSOMMA Haeckel, emend. Foreman

Theocapsomma Haeckel, Foreman, 1968, p. 29, part.

The species, indicated by Campbell $(1954$, p. 136) as type species for the genus Theocapsomma Haeckel, 1887, p. 1429 , (Theocapsa linneai Haeckel, 1887, pl. 66, fig. 13) has a different cephalis with distinct apical horn and a different disposition of pores, than in Carpocaninae. A species, typical for Theocapsomma in our definition, is Theocapsomma comys Foreman, 1968, pl. 4, fig. 2 .

The pores on the thorax are the same as on the abdomen. They are situated in longitudinal furrows. The abdomen is rather long.

\section{Theocapsomma sp. aff. T. comys Foreman}

(Plate 7, Figure 6)

?Theocapsomma comys Foreman, 1968, p. 29, pl. 4, fig. 2c. part; Not only longitudinal, but also horizontal rows of pores are distinct.

Cretaceous (Maestrichtian)

Theocapsomma sp. F group

(Plate 22, Figure 3)

?Theocapsomma comys Foreman, 1968, p. 29, pl. 4, fig. 2a, part.

The abdomen is very long, of ten destroyed. This group of species differs from typical $T$. comys by the greater number of longitudinal rows of pores.

Eocene.

Theocapsomma ornata (Ehrenberg) (Plate 22, Figure 1)

Cryptoprora ornata Ehrenberg, 1873, p. 222; 1875, pl. 5, fig. 8; Riedel and Sanfilippo, in press, pl. 30, fig. 10, part.

Differs from $T$. comys by its higher cephalis. The number of pores in a longitudinal row of the thorax is smaller than in Theocapsomma sp. F. Typical $T$. ornata was rare in Leg 14 material. Common was Theocapsomma sp. aff. T. ornata (Plate 22, Figure 2), first figured by Riedel and Sanfilippo (pl. 3D, fig. 10).

Paleocene-Eocene.

\section{Genus CARPOCANOPSIS Riedel and Sanfilippo}

Carpocanopsis Riedel and Sanfilippo, in press. Type species Carpocanopsis cingulatum Riedel and Sanfilippo, in press, pl. 8, fig. 8 .

\section{Carpocanopsis favosum (Haeckel) group}

(Plate 22, Figure 24)

Cycladophora favosa Haeckel, 1887 , p. 1380 , pl. 62, figs. 5, 6; Riedel, 1954, p. 172, pl. 1, fig. 2, part.

Carpocanopsis favosum (Haeckel) Riedel and Sanfilippo, in press, pl. $2 \mathrm{G}$, figs. 15,16 , pl. 8 , figs. 9-11.

There are various forms of this group, differing in the width of the thoracic mouth, in the size of the thorax and in the size of the pores on the thorax. Characteristic for all of them is the outline of the cephalo-thorax, and little irregularity of the longitudinal rows of pores on the thorax. Abdomen as a peristome.

Miocene.

\section{Genus CARPOCANISTRUM Haeckel}

Carpocanistrum Haeckel, 1887, p. 1170; Riedel and Sanfilippo, in press (not Campbell, 1954, p. 119). Type species Carpocanistrum evacuatum Haeckel 1887, pl. 52, fig. 11.

Cystophormis Haeckel, 1887, p. 1165; Campbell, 1954, p. 118 Type species Cystophormis pyla Haeckel, 1887, pl. 52, fig. 1 .

Sethamphorus Burma, 1959, p. 327. Type species Sethamphora favosa Haeckel, 1887, pl. 57, fig. 4.

Thorax is thick-walled. 
Carpocanistrum sp. 0

(Plate 22, Figures 28, 30)

Carpocanistrum sp. Riedel and Sanfilippo, in press, pl. 2F, figs. 5-7, part.

Test about $70-90 \mu$ long and $65-75 \mu$ broad. About eight to nine longitudinal rows or pores on the half equator of the thorax. About seven or eight pores in one row. Mouth as a short tube.

Oligocene-Miocene.

\section{Carpocanistrum sp. aff. C. pulchrum}

(Plate 22, Figures 19, 20)

Carpocanistrum sp. Riedel and Sanfilippo, in press, pl. 3D, figs, 3, 5, part.

?Carpocanium pulchrum Carnevale, 1908, p. 30, pl. 4, fig. 15 .

Test about $70-100 \mu$ long and $70-90 \mu$ broad. About six to eight longitudinal rows of pores on the half equator of the thorax. About six pores in one row. Rows are separated by longitudinal ridges. Mouth as a short tube.

Upper Oligocene-Miocene.

\section{Carpocanistrum cristatum Carnevale}

Sethocorys cristata Carnevale, 1908, p. 31, pl. 4, fig. 18.

Carpocanopsis cristotum (Carnevale) Riedel and Sanfilippo, in press, pl. $1 \mathrm{G}$, fig. 16 , pl. $2 \mathrm{G}$, figs. 1, 2, part.

The description as in Riedel and Sanfilippo. But only about nine or ten pores on the half equator of the thorax. Cephalis plus thorax are about $75-80 \mu$ long.

Miocene.

Genus CARPOCANIUM Ehrenberg sens. str.

Carpocanium Ehrenberg, 1847 b, p. 54; Haeckel 1887, 1279; Campbell, 1954, pl. 127; Petrushevskaya, 1971b, p. 239, part. = Carpocanidium Haeckel, 1887, p. 1280; Campbell, 1954, p. 127. Type species Lithocampe solitaria Ehrenberg 1844 (1854, pl. 22. fig. 28).

Cyrtocalpis Haeckel, 1860, p. 835; 1887, p. 1185; Campbell, 1954 , p. 121. Type species Cyrtocalpis amphora Haeckel $(1862$, pl. 5 , fig. 2).

Very much the same as Carpocanistrum, but the thoracic wall is thinner. The thorax is ovate, nearly cylindrical.

\section{Carpocanium sp. aff. C. coronatum Ehrenberg} (Plate 22, Figures 25, 26)

?Carpocanium coronatum Ehrenberg, 1858 , p. $30 ; 1875$, pl. 5 , fig. 7.

?Carpocanistrum sp. Riedel and Sanfilippo, in press, pl. 3D, fig. 8 , part.

Test about $70-80 \mu$ long and $60-70 \mu$ broad. About eleven longitudinal rows of the pores on the half equator of the thorax. About nine to ten pores in a row. Mouth as a short tube.

Oligocene.

\section{Genus CARPOCANOBIUM Haeckel}

Carpocanobium Haeckel, 1887, p. 1282; Campbell, 1854, p. 127. Type species Carpocanium trepanium Haeckel, 1887, pl. 52, fig. 18.

Asecta Popofsky, 1903, p. 373; Campbell, 1954, p. 128. Type species Asecta prunoides Popofsky, 1913, text-fig. 89.

The thoracic wall is thin. The thorax is broader in its distal part than near the cephalis.

\section{Carpocanobium sp. aff. C. setosa (Ehrenberg)}

(Plate 22, Figures 27, 28)

?Halicalyptra setosa Ehrenberg, 1875, pl. 2, fig. 12.

Carpocanium hexagonale Haeckel, 1887, p. 1282, pl. 52, fig. 15.

Carpocanistrum sp Riedel and Sanfilippo, in press, pl. 3D, figs. 7, 9.

Test about $80-100 \mu$ long and up to $70-85 \mu$ broad. Longitudinal rows or pores are uncertain. There are about twelve pores on the half equator of the thorax, and about eight or nine pores on the length of the thorax. Mouth as a broad tube (very short).

Oligocene.

\section{Subfamily Group C}

Includes Carpocaniidae with pores arranged irregularly or in checker-board order. Abdomen is rather large. Pores on the abdomen are similar to those on the thorax.

This group was described by P. Dumitrica $(1970$, p. 53-54) as "Cryprocephalic tricyrtid group". But here this group is accepted in a narrower sense than was suggested by P. Dumitrica. The species which are distinguished by longitudinal arrangement of pores (Diacanthocapsa comys, Diacanthocapsa sp. Dumitrica 1970, pl. 20, figs. 129-130) are included in the present paper as real Carpocaniidae. As can be seen on Figure 43, Plate 7 in Dumitrica's report, the species mentioned above not only have a spherical eucephalic part (chamber) of the cephalis, but also the surrounding parts (lobes) of the cephalis. One of these parts, the lateral lobe, is even figured by P. Dumitrica on Figure 43. It is the same lobe as figured by M. Petrushevskaya (1968d, fig. 9). All these Carpocaniids are not included in the cryptocephalic group in question. By the way, the eucephalic chamber in this latter group is not so deeply hidden in the skeleton as is typical for real Carpocaniinae, and the subfamily group in question is very similar to many Eucyrtidiidae (Lithocampe, Theocotyle).

\section{Genus DIACANTHOCAPSA Squinabol}

Diacanthocapsa Squinabol, 1903, p. 133; Campbell, 1954, p. 129; Dumitrica, 1970, p. 61. Type species Diacanthocapsa euganea Squinabol (1903, pl. 8, fig. 26).

Diacanthocapsa sp. A group

(Plate 7, Figure 11; Plate 22, Figures 4,6)

?Theocapsa (Theocapsomma) amphora Campbell and Clark, 1944b, p. 35 , pl. 7 , figs. 30,31 .

?Theocapsomma amphora (Campbell and Clark) Foreman, 1968, p. 31 , pl. 4 , figs. 9 a-c.

Our Cretaceous specimens (Plate 7, Figure 11) differ from the Tertiary specimens in the outline of the abdomen (Plate 22, Figures $4,6)$.

Cretaceous-Tertiary.

\section{Diacanthocapsa sp. B \\ (Plate 7, Figures 4, 5)}

Theocapsomma sp. Riedel and Sanfilippo, 1970, pl. 3, fig. 1.

Differs from Diacanthocapsa sp. A group by its more pronounced cephalis.

Cretaceous (Maestrichtian).

\section{Family ARTOSTROBIIDAE Riedel}

Artostrobiidae Riedel, 1967 a, p. $149 ; 1967$ b, p. 296; Petrushevskaya, 1971a, p. $985 ; 1971$ b, p. 235.

Cephalis originally widely open to the thorax. It consists of a eucephalic lobe and antecephalic lobe. The latter has only a "dorsal" (sens. H. Foreman, 1968) part, without the apical-dorsal. As a rule, there is a distinct tube connected with the spine Vert-see Petrushevskaya, 1968 b, fig. 6 .

\section{Subfamily Group A}

Includes three-segmented genera having the pores disposed irregularly or in distinct longitudinal rows.

\section{Genus RHOPALOSYRINGIUM Campbell and Clark,} emend. Foremen

Rhopalosyringium Campbell and Clark, 1944b, p. 30; Campbell, 1954 , p. 130 ; Foreman, 1968, p. 54. Type species Rhopalosyringium magnificum Campbell and Clark (1944b, pl. 7, figs. 16, 17).

\section{Rhopalosyringium sp. aff. R. magnificum} (Plate 7, Figures 14-17)

?Rhopalosyringium magnificum Campbell and Clark, 1944 b, p. 30 , pl. 7, figs. 16,17 ; Foreman, 1968 , p. 55 , pl. 6, figs. 7, a, b.

?Theoperid gen. sp. indet. Riedel and Sanfilippo, 1970, pl. 3, fig. 4. Cretaceous (Campanian-Maestrichtian). 
Rhopalosyringium sp. aff. R. colpodes Foreman

(Plate 7, Figure 12)

Rhopalosyringium colpodes Foreman, 1968, p. 57, pl. 6, fig. 6.

This species is distinguished not only by the outline of the test,

but also by the regular disposition of pores-longitudinal as well as horizontal rows may be seen.

Cretaceous (Campanian-Maestrichtian).

\section{Genus PHORMOCYRTIS Haeckel}

Phormocyrtis Haeckel, 1887, p. 1368; Campbell, 1954, p. 134. Type species Theocorys longicornis Haeckel, 1887, pl. 69. fig. 15.

Cephalic lobes are indistinct. The pores are disposed in longitudinal rows.

\section{Phormocyrtis sp. E}

?Phormocyrtis proxima Clark and Campbell, 1942a, p. 82, pl. 7 , figs. 24,25 .

Differs from the typical $P$. proxima in the shape of its thorax (more bulbiform) and in the shape of its abdomen (more cylindrical). These features are very similar to those of Rhopalosyringium species.

Paleocene.

\section{Phormocyrtis embolum (Ehrenberg) group}

(Plate 22, Figures 8,9)

Eucyrtidium embolum Ehrenberg, 1873, p. 228; 1875, pl. 10, fig. 5 . Our specimens somewhat differ from the typical $P$. embolum in the shape of the abdomen.

Eocene.

\section{Phormocyrtis sp. A}

(Plate 22, Figure 7)

This form is distinguished from Phormocyrtis [=Theocorys] longicornis (Hck.) in the outline of the abdomen. It differs from Phormocyrtis proxima Clark and Campbell in the dimensions of its abdomen (broader than the thorax) and in the shape of the thorax (more slender).

Oligocene, rare.

\section{Genus TRICOLOCAPSA Haeckel}

Tricolocapsa Haeckel, 1881, p. 436; 1887, p. 1431; Campbell, 1954 p. 136. = Tricolocapsula Haeckel, 1887, p. 1432; Campbell, 1954, p. 136.; Petrushevskaya, 1971b, p. 198. Type species Tricolosapsa theophrasti Haeckel, 1887, pl. 66, fig. 1.

Carpocanarium Haeckel, 1887, p. 1279; Campbell, 1954, p. 127; Riedel and Sanfilippo, in press. Type species Carpocanium calocyclothes Stöhr, 1880, pl. 3, fig. 8 .

Abdomen is more or less reduced.

\section{Tricolocapsa papillosa (Ehrenberg) group}

(Plate 22, Figure 31)

Eucyrtidium papillosum Ehrenberg, 1872a, p. 310; 1872b, pl. 7 , fig. 10.

Dictyocephalus papillosus (Ehrenberg) Haeckel, 1887, p. 1307; Riedel, 1958, p. 236, pl. 3, fig. 10; Petrushevskaya, 1967, p. 114 , fig. $66 ; 1969$ c, pl. 8 , figs. $7-13$.

Dictyocryphalus papillosus (Ehrenberg) Nigrini, 1967, p. 63, pl. 6 , fig. 6.

Carpocanium calocyclothes Stöhr, 1880 , p. 96 , pl. 3 , fig. 8 .

Dictyocephalus bergontianus Carnevale, 1908, p. 32, pl. 4, fig. 20.

Carpocanarium sp. Riedel and Sanfilippo, in press, pl. 11, figs. $17-20,21-25$ (not 21 ), pl. 2 J, figs. 8, 9 .

Tube may be distinct or not.

Miocene-Recent.

\section{Tricolocapsa (?) sp.}

(Plate 22, Figures 33, 34)

Description is based on twelve specimens from 140A-2-6, 80-82 $\mathrm{cm}$, and from 140-2-CC (? 5-CC).

The thorax is flattened laterally. The pores are rare, and disposed irregularly or in checker-board order. The length of the test is about $80-90 \mu$, the breadth up to $75 \mu$.

Eocene.
Remarks: The species is similar to Dicolocapsa microcephala (Plate 22 , Figure 32) in the construction of its thorax (and this feature distinguishes it from all Tricolocapsa species), but the cephalic structures in our species and in Dicolocapsa are different.

\section{Genus THEOCAMPE Haeckel}

Theocampe Haeckel, 1887, p. 1422; Campbell, 1954, p. 134; Riedel, 1958, p. 26; Burma, 1959, p. 325; Foreman, 1968, p. 48. $=$ Theocampana Haeckel, 1887, p. $1422 .=$ Theocampula Campbell, 1954, p. 134. Type species Dictyomitra ehrenbergii Zittel, 1876, pl. 2, fig. 5 .

Tricolocampe Haeckel, 1881 , p. 434, 1887, p. 1411; non Campbell, 1954, p. 134; Petrushevskaya, 1971b, p. 198. = Tricolocampium Haeckel, 1887 , p. 1412 . Type species Tricolocampe cylindrica Haeckel (1887, pl. 66, fig. 21).

The genus may be subdivided into subgenera.

\section{Subgenus I (or even genus)}

Proposed by H. Foreman (1968, p. 48) for Theocampe daseia Foreman and $T$. bassilis Foreman (not for $T$. lispa Foreman). This group is distinguished by the well developed shelf between thorax and abdomen. This shelf is also characteristic for Myllocercion, Rhopalosyringium, Eribotrys and other Cretaceous tricyrtids and stichocyrtids.

This group differs from typical Theocampe by the abdomen being, in its upper part, as a rule, narrower than the thorax. The abdomen is slender, nearly cylindrical. Mouth indefinite.

\section{Theocampe? sp. aff. T. daseia Foreman}

(Plate 7, Figures 8-10)

Theocampe daseia Foreman, 1968, p. 48, pl. 6, figs. 9, as, b.

Abdomen becomes narrower distally. Not only horizontal, but also longitudinal rows of the pores are distinct on the abdomen.

Cretaceous (Maestrichtian).

This species seems to be closely related to some Rhopalosyringium species.

\section{Theocampe? bassilis Foreman} (Plate 7, Figure 7)

Theocampe bassilis Foreman, 1968, p. 50, pl. 6, fig. 10.

The abdomen is cylindrical or even becomes broader in its middle part. The pores on the abdomen are situated in transverse rows.

Cretaceous (Maestrichtian).

Subgenus THEOCAMPE Haeckel sens. str.

Theocampe Haeckel, 1887, p. 1422; Campbell, 1954, p. 134, part. Type species Dictyomitra ehrenbergii Zittel, 1876, pl. 2, fig. 5 .

The shelf between thorax and abdomen is more or less pronounced. Abdomen in its lower (or middle) part is much broader than the thorax. The mouth is constricted and forms a short tube. The pores on the abdomen are disposed in longitudinal rows, but sometimes horizontal rows are very distinct. Abdomen is flattened laterally (oval in cross section).

\section{Theocampe sp. P \\ (Plate 7, Figure 1)}

This species differs from $T$. vanderhofi Campbell and Clark (see Foreman, 1968, pl. 6, fig. 12) in the outline of the abdomen, in the more constricted mouth and in the disposition of the pores.

Cretaceous (Maestrichtian).

\section{Theocampe pirum (Ehrenberg)}

(Plate 23, Figure 11)

Eucyrtidium pirum Ehrenberg, 1873, p. $232 ; 1875$, pl. 10 , fig. 14 . Theocampe pirum (Ehrenberg) Haeckel, 1887, p. 1423; Riedel and Sanfilippo, in press, pl. 3E, figs. $10,11$.

?Dictyocephalus pulcherrimus curtis Clark and Campbell, 1942, p. 97 , pl. 8, figs. $3,6,7$.

Very much the same as Theocampe sp. P, but differing somewhat in the ratio between thorax and abdomen.

Eocene. 
Theocampe mongolfieri (Ehrenberg) group

(Plate 23, Figures 3-5)

Eucyrtidium mongolfieri Ehrenberg, 1854, pl. 36, fig. 18B; 1873, p. $230 ; 1875$, pl. 10 , fig. 3 .

Theocampe mongolfieri (Ehrenberg), Burma 1959, p. 239; Riedel and Sanfilippo, p. 536; Riedel and Sanfilippo, in press, pl. 3E, fig. 13.

?Sethamphora costata Haeckel, 1887 , p. 1251 , pl. 62 , fig. 3.

?Dictyocephalus pulcherrimus typ. Clark and Campbell, 1942, p. 78 , pl. 8 , fig. 2 .

Eocene.

\section{Theocampe excellens (Ehrenberg)}

(Plate 23, Figure 7)

Eucyrtidium exellens Ehrenberg, 1873, p. 228; 1875, pl. 10, fig. 12. Differs from $T$. mongolfieri by its smaller pores on the abdomen.

These pores are not disposed in distinct longitudinal rows. Oligocene.

\section{Subgenus TRICOLOCAMPE Haeckel}

Tricolocampe Haeckel, 1881 , p. $434 ; 1887$, p. 1411 ; non Campbell, 1954 , p. 134 ; Petrushevskaya, 1971 b, p. $198 .=$ Tricolocampium Haeckel, p. 1412. Type species Tricolocampe cylindrica Haeckel (1887, pl. 66, fig. 21).

The shelf between thorax and abdomen may be more or less pronounced. Abdomen is slender, ovate. It is somewhat broader than the thorax in its upper part. In fully developed specimens the mouth is constricted and even elongated into a short tube, but very often the skeleton is incomplete. Abdomen is flattened laterally. The pores on the abdomen are disposed in horizontal (transverse) rows-as in typical artostrobiids.

Cretaceous-Recent.

The species $T$. vanderhoofi Campbell and Clark, Theocampe lispa Foreman, T. altamonensis (Campbell and Clark) and $T$. dactylica Foreman (described by H. Foreman (1968) seem to belong in this group.

This group is more closely related to Theocampe subgenus I than to typical Theocampe.

\section{Theocampe sp. aff. T. gemmata (Ehrenberg)}

(Plate 23 Figure 10)

?Eucyrtidium gemmatum Ehrenberg, 1873, p. 229; 1875, pl. 10, fig. 6 .

This species differs from $T$. gemmata by the outline of the test. It is somewhat similar to the species described as Theocorys ovata Haeckel, 1887 , pl. 69 , fig. 16 , but differs from it by the smaller number of the pores in a horizontal row and by the deeper constriction between thorax and abdomen.

Eocene.

\section{Theocampe callimorphos (Clark and Campbell)} (Plate 23, Figure 8)

Dictyocephalis callimorphos Clark and Campbell, 1945, p. 42, pl. 6 , fig. 7.

Lithomitra sp. aff. Lithomitra lineata (Ehr.) Riedel and Sanfilippo, in press, pl. $3 \mathrm{E}$, figs. 17,18 , part.

This form has longitudinal furrows between the pores of a horizontal row.

Eocene.

\section{Theocampe eos (Clark and Campbell)}

$$
\text { (Plate 23, Figure 9) }
$$

Dictyocephalus eos Clark and Campbell, 1945, p. 42, pl. 6, fig. 8. Very much the same as $T$. callimorphos, but without longitudinal furrows.

Eocene.

\section{Subfamily ARTOSTROBIINAE Riedel}

Artostrobiidae Riedel, 1967a, p. 149; 1967b, p. 296; Petrushevskaya, 1971a, p. $985 ; 1971$ b, p. 235

Four- or multi-segmented Artostrobiidae. Pores are disposed on the abdomen in distinct transverse (horizontal) rows.
Genus THEOCAMPTRA Haeckel, emend, Petrushevskaya

Theocamptra Haeckel, 1887, p. 1424; Campbell, 1954, p. 134. Type species Theocampe collaris Haeckel, 1887, pl. 66, fig. 18.

After the cephalis, which is united with thorax, the third segment (distinctly separated from the other part of the skeleton) is distinguished. The third segment is rather short, nearly of the same length as the thorax. The lower part of the test is very much like the abdomen of Theocampe species, and the third segment seems to be inserted between thorax and abdomen. This is the only difference between Theocamptra and Theocampe (Tricolocampe).

Paleogene-Neogene.

\section{Theocamptra marylandica (Martin)}

(Plate 23, Figures 20, 21)

Lithocampe marylandica Martin, 1904, p. 450, pl. 130, fig. 4.

Three transverse rows of pores on the third segment. The fourth segment up to $90-100 \mu$ broad.

Miocene.

\section{Theocamptra sp. aff. T. marylandica}

(Plate 23, Figures 22, 23)

?Lithocampe marylandica Martin, 1904, p. 450.

Artostrobium sp. aff. A. doliolum Riedel and Sanfilippo, in press, pl. 21 , fig. 4 .

Differs from the typical $T$. marylandica by its smaller dimensions; the fourth segment up to $60-70 \mu$ broad.

Miocene.

Remark: Both species are very similar to Theocampe callimorphos (Clark and Campbell) (Pl. 23, fig. 8). The difference lies in the segmentation of the test.

Theocamptra ovata (Haeckel)

(Plate 23, Figures 17-19)

Lithocampe ovata Haeckel, 1887, p. 1504, p. 77, fig. 1.

Two transverse rows of pores on the third segment. No furrows near the pores on the fourth segment.

Miocene.

Theocamptra sp. aff. Theocamptra ovata (Haeckel)

(Plate 23, Figures 15, 16; Plate 24, Figure 6)

Very much the same as typical $T$. ovata, but has longitudinal furrows between the pores. This feature makes this species similar to Theocamptra aff. marylandica and to Theocampe callimorphus.

Oligocene.

\section{Theocamptra collaris (Haeckel)}

Theocampe collaris Haeckel, 1887, p. 1425, pl. 66, fig. 18.

Artostrobium sp. aff. A. doliolum Riedel and Sanfilippo, in press, pl. 21, figs. 1, 3, 5, part.

One transverse row of pores on the third segment. The fourth segment is 1.5 times broader than the third (the same as in $T$. marylandica group and in $T$. ovata group).

Miocene.

\section{Theocamptra corona (Haeckel) group}

(Plate 23, Figures 24, 25)

Cyrtophormis corona Haeckel, 1887, p. 1462, pl. 77, fig. 15.

Phormostichoartus corona (Haeckel) Riedel and Sanfilippo, in press, pl. 2J, figs. 1-5.

Four transverse rows of pores on the third segment. It is distinguished from $T$. collaris, $T$. marylandica and $T$. ovata also by the comparative breadth of the fourth segment. In $T$. corona the fourth segment is 2 to 2.5 times broader than the third segment.

Miocene.

Theocamptra spirocyrtis Petrushevskaya sp. nov. (Plate 23, Figures 28-30)

The description is based on 21 specimens from 139-5-CC; $140-2-1,5-7 \mathrm{~cm}$ and $80-82 \mathrm{~cm} ; 140-2-3,80-84 \mathrm{~cm}$ and $140-2-4,5-7$ $\mathrm{cm}$ and $80-82 \mathrm{~cm}$.

Seven to nine transverse rows of pores on the third segment, which is about $60 \mu$ long. It is broader in its lower part (about $60-80 \mu$ ) than in its upper part. The fourth segment 2 to 2.5 times as broad as the third. Very often the large and thin-walled fourth segment is damaged.

Miocene. 
Remark:, Some specimens have irregular strictures in the middle part of the third segment. They resemble representatives of the genus Spyrocyrtis.

\section{Theocamptra formaster Petrushevskaya sp. nov.} (Plate 23, Figures 26, 27)

Phormostichoartus sp. aff. P. corona (Haeckel) Riedel and Sanfilippo, in press, pl. $2 \mathrm{~J}$, fig. 7 , pl. $3 \mathrm{~F}$, figs. 4,5 , part.

The third segment is small, even narrower than the thorax. There are 2 to 3 transverse rows of pores on the third segment. The fourth segment is large, nearly three times broader than the third segment. The pores on the fourth segment are larger in size and more numerous than in all Theocamptra species mentioned above. Not only horizontal rows of the pores, but also longitudinal rows may be seen on the fourth segment. This character is similar to Theocampe species. There is a fifth segment. This feature is uncommon for Theocamptra species.

"Formaster"-latin nominative, meaning "imitator".

Oligocene.

The description is based on eighteen specimens from 144B-2-5, Top, 144B-2-6, Top and $138-2-3,5-7 \mathrm{~cm}$.

Genus LITHAMPHORA Popofsky, emend. Petrushevskaya

Lithamphora Popofsky, 1908, p. 294; Campbell, 1954, p. 140; Petrushevskaya, 1971b, p. 198. Type species Lithamphora furcaspiculata Popofsky, 1908, pl. 36, figs. 6-8.

There is no shelf between thorax and abdomen, as in Theocampe species, and the mouth of the test is not constricted as in those species. There is no distinct division into third and fourth segments, as in characteristic for Theocamptra species.

The most ancient known representative of the genus seems to be Artostrobiid gen. sp. Riedel and Sanfilippo, 1970, pl. 3, fig. 13 (see also Plate 30 , Figure 1).

Lithamphora sacculifera (Clark and Campbell) quadrata subsp. nov. (Plate 30, Figures 4-6)

?Lithomitra sacculifera Clark and Campbell, 1945, p. 50, pl. 7, fig. 18.

Differs from $L$. sacculifera typ. (Plate 30, Figure 3) by greater dimensions. Test is up to $200 \mu$ long and up to $80-100 \mu$ broad. The pores are nearly quadrangular and hence the name "quadrata".

The description is based on fourteen specimens from the slide marked in our Leg 14 material as 140-2-CC.

Eocene.

\section{Lithamphora sp.}

(Plate 30, Figure 2)

This form is very much like $L$. sacculifera quadrata but only about $120 \mu$ long and up to $65-70 \mu$ broad. Only six or seven pores in a half of a transverse row of the abdomen, instead of ten pores as in L. sacculifera quadrata.

Eocene-Oligocene.

\section{Lithamphora sp. aff. Lithocampe corbula Harting} (Plate 30, Figure 7)

?Lithocampe corbula Harting, 1863, p. 12, pl. 1, fig. 21

?Tricolocampe polyzona Haeckel, 1887, p. 1412, pl. 66, fig. 19. Tricolocampe amphizona Haeckel, 1887, p. 1412, pl. 66, fig. 20 Siphocampe corbula (Harting) Nigrini, 1967, p. 85, pl. 8, fig. 5.

$S$. sp. aff. S. corbula (Harting) Riedel and Sanfilippo, in press, pl. 2I, figs. 11,12 .

Miocene.

\section{Genus LITHOMITRA Bütschli}

Lithomitra Bütschli, 1882 , p. 528; Haeckel, 1887, p. 1483 Campbell, 1954 , p. $141 .=$ Lithomitrella Haeckel, 1887 , p. 1483 Campbell, 1954, p. 141. Type species Eucyrtidium pachyderma Ehrenberg, 1873; 1875, pl. 11, fig. 21 .

The post-thoracic part of the skeleton is subdivided into numerous segments. Each of these segments has one row (rarely two rows) of pores. The surface "striate", very much as in some Theocampe (Tricolocampe) species (Plate 24, Figure 1).

Lithomitra imbricata group (Plate 24, Figure 2-5)

Eucyrtidium imbricatus Ehrenberg, 1873, p. 229; 1875, pl. 11, fig. 22.
Lithomitra lineata (Ehrenberg) Riedel and Sanfilippo, in press, pl. 2I, fig. 16, part.

The test spindle-shaped. The broadest segment is the sixth or the seventh (cephalis being the first). The pores numerous, rather small. Eocene-Oligocene.

Lithomitra nodosaria group

(Plate 24, Figures 29, 30)

Lithomitra nodosaria Haeckel, 1887 , p. 1484, pl. 79, fig. 1; Petrushevskaya, 1967, pl. 83, figs. 8, 9; Kruglikova, 1969, pl. 4, fig. 3 .

?Lithomitra altamiraensis Campbell and Clark, 1944a, p. 53, pl. 7, fig. 9 .

The test robust, nearly cylindrical. The broadest segment is the fourth or the fifth (cephalis being the first). Pores are greater in size and less numerous than in $L$. imbricata.

Oligocene-Quaternary.

Remark: The Oligocene specimens have more segments (and longer test) than Quaternary ones.

\section{Lithomitra eruca Haeckel \\ (Plate 24, Figures 32, 33)}

Lithomitra eruca Haeckel, 1887, p. 1485, pl. 79, fig. 3; Petrushevskaya, $1971 \mathrm{~b}$, pl. 122 , fig. 6 .

The distance between segments is less than in L. nodosaria and in

$L$. imbricata, and the number of pores in a row is greater.

Neogene.

\section{Genus BOTRYOSTROBUS Haeckel}

Botryostrobus Haeckel, 1887, p. 1475; Campbell, 1954, p. 141. Type species Lithostrobus botryocyrtis Haeckel, 1887, pl. 79, fig. 18.

Artostrobium Haeckel, 1887, p. 1482; Campbell, 1954, p. 140; Petrushevskaya, $1971 \mathrm{~b}$, p. 171. Type species Lithocampe aurita Ehrenberg, 1844; 1854, pl. 22, fig. 25.

Fully developed test consists of about 10 segments. Each segment has 2 to 8 horizontal rows of pores. Segments (except cephalis and thorax) are separated by distinct constrictions of test wall. The most ancient Botryostrobus seems to be Botryostrobus sp. P (Plate 24, Figures 8-11).

\section{Botryostrobus miralestensis (Campbell and Clark)} (Plate 24, Figure 31)

?Dictyomitra costata Stöhr, 1880, p. 101, pl. 3, fig. 23 .

Dictyocephalus miralestensis Campbell and Clark, 1944, p. 45, pl. 6, figs. 12-14.

Artostrobium miralestense (Campbell and Clark) Riedel and Sanfilippo, in press, pl. $1 \mathrm{H}$, figs. $14-17$, pl. 2I, figs. 9, 10, pl. 3E, fig. 12 , part.

Differs from Botryostrobus (=Eucyrtidium) tumidulus (Bailey, 1856) 1) by greater dimensions of the test, 2) by smaller number of pores: only one or two rows on a segment (instead of 3 to 6 in $B$. tumidulus, see Plate 24, Figures 20,21)

Oligocene-Miocene.

\section{Botryostrobus auritus (Ehrenberg) group} (Plate 24, Figures 15-18)

Lithocampe aurita Ehrenberg, 1844a, p. 84.

Eucyrtidium auritum (Ehr.) Ehrenberg, 1854, pl. 22, fig. 25.

Lithostrobus seriatus Haeckel, 1887, p. 1474, pl. 79, fig. 17; Petrusherskaya, 1967 , p. 145 , pl. 82 , figs. 1-4, 1971b, pl. 124, figs. 6-8.

Artostrobium auritum (Ehrenberg) group, Riedel and Sanfilippo, in press, pl. $1 \mathrm{H}$, fig. 7 , part.

The broadest segment is the fifth or the sixth. Pliocene-Quaternary.

Remark: Differs from closely related Botryostrobus (=Lithostrobys) lithobotrys (Haeckel, 1887), see Plate 24, Figure 19, by more narrow (up to $60 \mu$, instead of $80 \mu$ in $B$. lithobotrys), more slender, elongated skeleton.

\section{Botryostrobus australis (Ehrenberg) group}

(Plate 24, Figures 12-14)

Lithocampe australe Ehrenberg, 1844b, p. 187.

Eucyrtidium austral (Ehrenberg) Ehrenberg, 1854, pl. 35a, 21, fig. 18. 
?Eucyrtidium euporum Ehrenberg, 1872a, p. 291; 1872b, pl. 4, fig. 20; Petrushevskaya, 1967 , p. 141 , pl. 80, figs. 1-4.

Dictyomitra drigalskii Popofsky, 1908, p. 293, pl. 36, fig. 4.

?Lithomitra bramlettei Clark and Campbell, 1944, p. 53, pl. 7, fig. 11 , part.

Artostrobium auritum (Ehrenberg) group, Riedel and Sanfilippo, in press, pl. $1 \mathrm{H}$, fig. 8 , part.

The broadest segment is the fourth (cephalis being the first). The greatest breadth of the fourth segment is up to $60-70 \mu$.

Differs from the closely related Botryostrobus (=Lithostrobus)

botryocyrtis (Haeckel, 1887), see Riedel and Sanfilippo, in press, pl. $1 \mathrm{H}$, fig. 6 , by more slender, elongated skeleton.

Miocene-Recent.

\section{Genus SPIROCYRTIS Haeckel}

Spirocyrtis Haeckel, 1887, p. 1508; Campbell, 1954, p. 142, Petrushevskaya, 1971 b, p. 236 . = Spirocyrtidium Haeckel, 1887 , p. 1509. Type species Spirocyrtis scalaris Haeckel (1887, pl. 76, fig. 14).

Very much the same as Botryostrobus. Differs by the difference in the thickness of the thoracic wall and that of the post-thoracic segments, pores being smaller on them than on the thorax. The length of the post-thoracic segments is not so definite as it is in Botryostrobus species.

Neogene-Recent.

\section{Spirocyrtis subtilis Petrushevskaya sp. nov.}

(Plate 24, Figures 22-24)

Spirocyrtis sp. aff. S. scalaris, Riedel and Sanfilippo, in press, pl. 1G, fig. 24 ; pl. $2 \mathrm{H}$, figs. $15,17,18$, pl. $3 \mathrm{E}$, fig. 2 , part.

Artostrobium sp. B, Petrushevskaya, 1971b, pl. 124, figs. 4-5.

The narrowest post-thoracic segment-the third-is about $45 \mu$ broad. The broadest segment-the seventh or the eighth-about $70-80 \mu$ broad. The outline of the test is variable. The length of a post-thoracic segment is variable also. Very often there is a tube, connected with the spine $A$.

Description is based on thirteen specimens from 139-5-CC, $140-2-1,5-7 \mathrm{~cm}$ and $140-2-4,80-82 \mathrm{~cm}$.

"Subtilis' - Latin adjective meaning "slender".

Miocene.

\section{Spirocyrtis sp.}

(Plate 24, Figures 27, 28)

The species is distinguished from $S$. scalaris by its rounded, not angular segments-the outline of the test is festooned, not step-like as it is in $S$. scalaris.

This species differs from the Botryostrobus species referred to by Riedel and Sanfilippo as Spirocyrtis sp. aff. $S$. scalaris (in press, pl. 1G, figs. $19,20,22$ ) by the skeleton being broader distally, and having more segments.

Quaternary.

\section{Spirocyrtis cornutella Haeckel (Plate 24, Figure 26)}

Spirocyrtis cornutella Haeckel, 1887, p. 1509, pl. 76, fig. 13; Petrushevskaya, 1971c.

Spirocyrtis scalaris Hck., Riedel and Sanfilippo, in press, pl. 1G, fig. 26, part.

This species is distinguished from $S$. scalaris by the irregular outline and narrower skeleton. It is similar in these features to $S$. subtilis but in $S$. cornutella the skeleton is shorter, and there is no tube connected with the spine $A$.

Pliocene?-Quaternary.

\section{Family NEOSCIADIOCAPSIDAE Pessagno}

Neosciadiocapsidae Pessagno, 1969, p. 392.

Spines $A, D$, Vert, Axial, two $L$ and two $l$ are going from $M B$ in the same way as in all typical Eucyrtidioidea. Cephalis hemispherical to conical, imperforate or perforate, with or without horns. The eucephalic part of the cephalis is confused with the other parts, and there exists one cavity of the cephalis unseparated into lobes. Arches $a p$ go in the upper part of the cephalic wall (the same as in Eribotrys described by Foreman. 1968)-see Petrushevskaya (1968a, fig. 5 IV-IX). Tube ("cephalopyle", Pessagno, 1969) may be present, connected with the spine Vert. Poorly developed or pronounced collar stricture. Thorax conical to cylindrical in shape proximally, flaring to form a narrow to broad thoracic shirt (a velum) distally. Thoracic pores variable in size are situated in transverse (concentric) rows. Mouth may be closed by planiform to conical plate.

Cretaceous-Recent.

\section{Genus PETASSIFORMA Pessagno}

Petassiforma Pessagno, 1969, p. 411. Type species Petassiforma foremanae Pessagno, 1969, pl. 23, figs. 6-10, pl. 24, fig. 2.

Petassiforma speciosa (Squinabol)

(Plate 7, Figure 21)

Sethoconus speciosus Squinabol, 1904, p. 131, pl. 8, fig. 16.

The dimensions of the skeleton are nearly the same as in $P$. formanae Pessagno.

Cretaceous (Maestrichtian).

\section{Genus EUCECRYPHALUS Haeckel}

Eucecryphalus Haeckel, 1860 , p. 836 ; 1881, p. 431; 1887, p. 1220 ; Campbell, 1954, p. 122; Petrushevskaya, 1972b, p. 222, part. = Eucecryphalium Haeckel, 1887, p. 1221; Campbell, 1954, p. 122. Type species Eucecryphalus gegenbauri Haeckel, 1862, pl. 5 , figs. $12-15$.

Eucecryphalus sp.

(Plate 33, Figures 6, 7, 8)

Two divergent horns on the cephalis. The upper part (about $20-30 \mu$ long) of the thorax has small pores. Then, after a constriction, comes the middle part-conical, with larger pores. It is about $70 \mu$ long and up to $100-110 \mu$ broad. The thoracic velum has 3 to 4 rows of pores. The latter are smaller than the pores on the middle part of the thorax. This species is very similar tc Cassideus yoloensis Pessagno 1969, pl. 26, figs. 1-3, in the outline of the shell. It differs from $C$. yoloensis by its smaller pores on the thorax and by its smaller velum.

Quaternary.

\section{Genus CLATHROCYCLAS Haeckel}

Clathrocyclas Haeckel, 1888 , p. 434 ; 1887 , p. 1385; Campbell, 1954 , p. 132; Foreman, 1968, p. 46. Type species Clathrocyclas principessa Haeckel, 1887 , pl. 74, fig. 7.

Characteristic for this genus is the roomy, bulbous thorax, nearly cylindrical in its lower part. In Petassiforma and in Eucecryphalus it is slender, high-conical. In Clathrocyclas, pores on the thorax are rather large, not numerous. The cephalis is up to $28-38 \mu$ broad. Vertical spines form tube or horn (Petrushevskaya, 1971b, pl. 115, fig. 2).

Cretaceous-Recent.

\section{Clathrocyclas bicornis (Popofsky)}

(Plate 33, Figures 11, 12)

Pterocorys bicornis Popofsky, 1908, p. 228, pl. 34, figs. 7, 8.

Theocalyptra bicornis (Popofsky) Riedel, 1958, p. 240, pl. 4, fig. 4; Petrushevskaya, 1967 , p. 126 , pl. 71 , figs. 2 , 7 , part. non Clathrocyclas bicornis Hays, 1965.

The latter species must have another name, "bicornis" being preoccupied in this genus. If J. Hays has nothing against it, as a name for his species "antebicornis" may be suggested.

Pliocene-Recent- $C$. bicornis.

Miocene-Pliocene- $C$, antebicornis.

\section{Genus DIPLOCYCLAS Haeckel}

Diplocyclas Haeckel, 1881, p. 434; 1887, p. 1392; Campbell, 1954, p. 132. Type species Diplocyclas bicorona Haeckel, 1887, pl. 59, fig. 8 .

Thorax high, conical, nearly cylindrical, often irregular in outline. As a rule, the test is smaller than in Clathrocyclas. Pores on the thorax rather large, not numerous. The species Theocalyptra davisiana (Ehrenberg). described by Riedel, 1958, p. 239, pl. 4, figs. 2,3 and by Petrushevskaya, 1967, p. 122, pl. 69, figs. 1-7, seems to belong in this genus.

\section{Diplocyclas sp. aff. D. bicorona Haeckel}

(Plate 33, Figures 17, 18)

?Diplocyclas bicorona Haeckel, 1887, pl. 59, fig. 8 . 
The upper corona of apophyses is not so distinct as illustrated by E. Haeckel.

Pliocene-Quaternary.

Diplocyclas ionis (Haeckel) group (Plate 33, Figure 19)

Clathrocyclas ionis Haeckel, 1887, p. 1389 , pl. 59, fig. 9 .

Differs from the $D$. bicorona group by the shell being broader distally.

Pliocene-Quaternary.

Diplocyclas sp. A group

(Plate 33, Figures 14-16)

Stout apical horn. Nearly cylindrical upper part of the thorax.

Lower part of the thorax with very large, irregular pores.

Oligocene.

\section{Genus ANTHOCYRTELLA Haeckel}

Anthocyrtis Ehrenberg, 1847 , p. 54; Haeckel, 1887, p. 1269 Loeblich and Tappan, 1961, p. 228 (the name is preoccupied). Anthocyrtella Haeckel, 1887, p. 1269; non Campbell, 1954; Loeblich and Tappan, 1961, p. 228. Type species Anthocyrtis mespilis Ehrenberg, 1854, pl. 36, fig. 13.

Differs from Diplocyclas by the regular outline of the thorax. There is a distinct shelf separating the velum. The thorax in Anthocyrtella is very much like that in Clathrocyclas but the dimensions in Anthocyrtella are less, and the number of pores is greater. The pores themselves are smaller than in Clathrocyclas. The distinguishing character of Anthocyrtella is the large and very regular velum with longitudinal rods, more pronounced than the transverse rods. In this characteristic, species of Anthocyrtella are similar to Sciadiocapsa (?) petasus Foreman, 1968, pl. 7, figs. 1, a, b.

\section{Anthocyrtella spatiosa (Ehrenberg) group}

(Plate 33, Figures 1-3)

Cycladophora spatiosa Ehrenberg, 1873, p. 222; 1875, pl. 18, figs. 5,6 .

?Clathrocyclas universa grandis Clark and Campbell, 1942, p. 88, pl. 7 , fig. 18.

There are two subspecies (or species) described by Ehrenberg under that name: 1) with porous velum (Plate 33, Figures 1,2), and 2) with checkerboard meshwork instead of velum (Plate 33, Figure 3).

Eocene.

\section{Cryptocephalic dicyrtid group}

Described by Dumitrica $(1970$, p. 52). This group is characterized by "simple" or "theoperid" cephalis-a thick-walled sphere not divided into lobes.

\section{Genus GONGYLOTHORAX Foreman}

Gongylothorax Foreman, 1968, p. 19; Dumitrica, 1970, p. 56. Type species Dicolocapsa verbeeki Tan Sin Hok (1927, pI. 8, figs. $40,41)$.

\section{Gongylothorax sp. aff. G. verbeeki (Tan Sin Hok)}

(Plate 7, Figures 18, 19)

Dicolocapsa verbeeki, Tan Sin Hok, 1927, p. 44, pl. 8, figs. 40, 41 . Gongylothorax verbeeki (Tan Sin Hok) Foreman, 1968, p. 20, pl. 2, figs. 8, a-c; Dumitrica, 1970 , p. 57, pl. 1, fig. 6, pl. 2, figs. 7-10. Because of poor preservation, no sutural pore was seen. Cretaceous (Maestrichtian).

\section{Family WILLIRIEDELLIDAE Dumitrica}

Cryptothoracic nassellaria with simple cephalis, described by $\mathrm{P}$. Dumitrica $(1970$, p. 68).

\section{Genus CRYPTAMPHORELLA Dumitrica}

Cryptamphorella Dumitrica, 1970 , p. 80 . Type species Hemicryptocapsa conara Foreman (1968, pl. 4, figs. 11a-b). Cretaceous.

\section{Cryptamphorella sp. aff. C. conara (Foreman)}

(Plate 2, Figure 17)

?Hemicryptocapsa conara Foreman, 1968, p. 35, pl. 4, figs. 11 a-b.
?Cryptamphorella conara (Foreman) Dumitrica, 1970, p. 80, pl. 11, figs. 66 a-c.

The wall of the test is thicker than in the specimens figured by H. Foreman and by P. Dumitirca. The sutural pores and modes on the surface are not seen because of poor preservation.

Cretaceous (E. Campanian).

$$
\begin{gathered}
\text { Cryptamphorella sphaerica (White) } \\
\text { (Plate 2, Figures 15, 16) }
\end{gathered}
$$

?Baculogyspina sphaerica White, 1928, p. 306, pl. 41, figs. 12-13.

Holocryptocapsa (?) sphaerica (White) Pessagno, 1963, p. 206, pl. 1, fig. 3 , pl. 5 , figs. $1-2$, text-fig. 4 .

Cryptamphorella sphaerica (White) Dumitrica, 1970, p. 82, pl. 12, figs. 73-77, pl. 20, figs. 133 a-b.

Cretaceous (E. Campanian).

\section{Genus HOLOCRYPTOCAPSA Tan Sin Hok}

Holocryptocapsa Tan Sin Hok, 1927, p. 51; Campbell, 1954, p. 136; Dumitrica', 1970, p. 74. Type species Holocryptocapsa fallax Tan Sin Hok $(1927$, pl. 10, figs. 73, 74).

\section{Holocryptocapsa sp. aff. H. hindei Tan Sin Hok}

(Plate 1, Figure 1)

?Holocryptocapsa hindei Tan Sin Hok, 1927, p. 53, pl. 10, fig.75; Dumitrica 1970 , p. 74 , pl. 15, figs. 100 a-d.

Our specimens are somewhat larger than the specimens in Dumitrica's material.

Cretaceous (Albian?-Cenomanian)

\section{Family Group N}

To include di- or tri-segmented Nassellaria Eucyrtidioidea with large terminal segment, this segment with or without aperture. If present, the aperture as a tube is small. Cephalis seems to be divided into two chambers by a transverse annular shelf. The shelf is formed by arches $a p$ (see Petrushevskaya, 1968a, figs. 5, 10-12). Part of these arches were described by P. Dumitirca as arches $m p$. The spine referred to as the spine $V$ (Dumitrica 1970, text-fig. 4) is the normal spine $A$, going from a very short $M B$ and forming the apical horn. Vertical spine in Squinabollum is absent. Thus this kind of cephalis cannot be regarded as an aberrant type. This type of cephalis is very much the same as in Pterocoryidae and in Amphipyndacinae. These two families and the family in question cannot be united into one family, not because of the difference in their cephalic structure, but because of the different segmentation of their tests.

Cretaceous-Tertiary.

\section{Genus SQUINABOLLUM Dumitrica}

Squinabollum Dumitrica, 1970 , p. 83. Type species Clistophaena fossilis Squinabol (1903, pl. 10, fig. 11).

Clistophaena armche (Plate 28, Figure 19). Type species of Clistophaena is quite different from this genus.

Cretaceous.

\section{Squinabollum sp. aff. S. fossilis (Squinabol)}

$$
\text { (Plate 1, Figure 4) }
$$

?Squinabollum fossilis (Squinabol) Dumitrica, 1970, p. 83, pl. 19, figs. 118-122.

The outline of the test, the strong spines on the lower half of the abdomen and the characteristics of the porous wall are the same as in typical Squinabollum. The preservation is too poor to identify the species.

Cretaceous (Cenomanian).

\section{Genus DICOLOCAPSA Haeckel}

Dicolocapsa Haeckel, 1881, p. 433; 1887, p. 1312; non Campbell, 1954 , p. 129 ; Riedel, 1959 b, p. 11 . Type species, as indicated by Riedel, Dicolocapsa microcephala Haeckel (1887, pl, 57, fig. 1). Tertiary.

\section{Dicolocapsa microcephala Haeckel}

$$
\text { (Plate 22, Figure 32) }
$$

Dicolocapsa microcephala Haeckel, 1887, p. 1312, pl. 57, fig. 1; Sanfilippo and Riedel, 1970, pl. 1, fig. F.

Miocene. 
Genus LIPMANELLA Loeblich and Tappan, emend. Petruskevskaya

Lipmanella Loeblich and Tappan, 1961, p. 119. = Dictyoceras Haeckel, 1860 , p. $333 ; 1887$, p. 1324; Campbell, 1954, p. 130; Petrushevskaya, 1971b, pp. 198, 220. Type species Lithornithium dictyoceras Haeckel (Haeckel, 1862, pl. 8, figs. 1-5).

The cephalis thick-walled, divided (as a rule) into upper and lower parts by means of the arches $a p$, as in Squinabollum and in Dicolocapsa. The thorax is larger than the cephalis. The abdomen may be separated distinctly from the thorax or it may be united with the thorax in a single segment. The spines $D, L 1$ and $L r$ form external feet, which are rather weak. They go laterally from the thorax. In the upper walls of the thorax are three ribs formed by these spines. The spine $A$ forms the apical horn. The mouth of the shell is very often open.

Cretaceous?-Quaternary.

Remark: The taxonomical position of the genus is doubtful-maybe it is really pterocoryid.

\section{Lipmanella (?) sp. aff. Lithomelissa? amazon Foreman} (Plate 37, Figure 1)

?Lithomelissa amazon Foreman, 1968, p. 26, pl. 4, fig. 1.

The division of the cephalis into lower and upper parts is not developed. In typical Lithomelissa amazon, the cephalis is smoother. Paleogene.

\section{Lipmanella (?) sp. M}

(Plate 37, Figure 2)

The thorax, the spines and the pores are very much the same as in Lipmanella (?) sp. aff. Lithomelissa amazon. The difference is in the smaller dimensions and in the cephalis being constricted at its base, with pronounced subdivision into upper and lower parts.

Miocene.

Lipmanella sp. 0

(Plate 37, Figures 4, 5)

Differs from Lipmanella (?) sp. M by the distinct subdivision of the skeleton into thorax and abdomen.

This species is somewhat similar to Dictyoceras insectum Haeckel (1887, pl. 71, fig. 6), and there is no doubt in the generic identification of this species (Dictyoceras $=$ Lipmanella). It is also somewhat similar to Pterocorys columbo Haeckel (1887, pl. 71, fig. 2 ), but differs in the construction of the cephalis. Some specimens are similar to Pterocyrtidius barbadense (Ehrenberg) (see Plate 27, Figure 18,19$)$ in the proportions of the test.

Miocene.

Lipmanella (?) dogieli (Petrushevskaya)

(Plate 37, Figure 10)

Sethoconus (?) dogieli Petrushevskaya, 1967, p. 95, pl. 53, figs. 1, 2; 1971 b, pl. 110 , fig. 2 .

The number of pores is less than in Lipmanella sp. C-only about 7 pores on a half equator. Pores are irregular and of different sizes. There is no subdivision into thorax and abdomen.

Pliocene-Quaternary.

Remark: This species is very similar also to the Miocene species described as Lithomelissa campanulaeformis by Campbell and Clark (1945, p. 44, pl. 6, fig. 1), see Plate 37, Figure 11 in the present report. Lipmanella (?) dogieli differs from $L$. campanulaeformis by smaller dimensions. Perhaps it represents by itself only Quaternary subgenus of the Miocene species $L$. campanulaeformis.

\section{Subfamily Group E}

To include genera without a wide velum (characteristic for Neosciadiocapsidae). In place of the velum there is a long, nearly cylindrical abdomen. Abdominal pores are much larger than thoracic pores, and therefore the thorax and abdomen seem to be built of different kinds of skeletal meshwork. Cephalis of the same kind as in Neosciadiocapsidae, with the arches $a p$ going in the upper walls. Cephalis conical, wide at the base. The apex gradually turns into a conical apical horn. Lampterium is the most typical genus of the group. Whether this group should be placed among Pterocoryidae or among Neosciadiocapsidae is questionable.

\section{Genus THYRSOCYRTIS Ehrenberg}

Thyrsocyrtis Ehrenberg, 1847b, p. 54; Haeckel, 1887, p. 1350; Campbell, 1954, p. 130; Riedel and Sanfilippo, 1970, p. 525. Type species Thyrsocyrtis rhizodon Ehrenberg, 1873 (1875, pl. 12, fig. 1).

Podocyrtarium Haeckel, 1887, p. 1337; Campbell, 1954, p. 130. Type species Podocyrtis tripodiscus Haeckel, (1887, pl. 72, fig. 4).

Podocyrtonium Haeckel, 1887, p. 1347, Campbell, 1954, p. 130. Podocyrtis pedicellaria Haeckel (1887, pl. 72, fig. 8).

Differs from Lampterium by distinct longitudinal rows of pores not only on the thorax, but also on the abdomen. Differs from Podocyrtis 1) by the abdomen being larger than the thorax, and 2 ) by the difference in the size between thoracic and abdominal pores.

Tertiary.

\section{Thyrsocyrtis rhizodon Ehrenberg}

Thyrsocyrtis rhizodon Ehrenberg, 1873, p. $262 ; 1875$, pl. 12, fig. 1; Riedel and Sanfilippo, in press, pl. 3C, fig. 6.

Eocene.

\section{Thyrsocyrtis tetracantha (Ehrenberg)}

Podocyrtis tetracantha Ehrenberg, 1873, p. 254; 1875, pl. 13, fig. 2. Thyrsocyrtis tetracantha (Ehrenberg) Riedel and Sanfilippo, 1970, p. 527.

Eocene.

Thyrsocyrtis triacantha (Ehrenberg)

(Plate 32, Figure 9; Plate 34, Figure 6)

Podocyrtis triacantha Ehrenberg, 1873, p. 254; 1875, pl. 13, fig. 4. Thyrsocyrtis triacantha (Ehrenberg) Riedel and Sanfilippo, 1970, p. 526 , pl. 8, figs. 2, 3; Moore, pl. 4, fig. 2.

Eocene-Oligocene?

\section{Thyrsocyrtis argulus (Ehrenberg)} (Plate 32, Figure 8)

Podocyrtis argulus Ehrenberg, 1873, p. 248; 1875, pl. 16, fig. 2.

Thyrsocyrtis hirsuta hirsuta (Krasheninnikov) Riedel and Sanfilippo, 1970 , p. 7 , figs. 8,9 .

Eocene.

\section{Thyrsocyrtis sp. E}

(Plate 32, Figure 11)

?Podocyrtis pedicellaria Haeckel, 1887, p. 1347, pl. 72, fig. 8 .

?Podocyrtis sinuosa (?) in Riedel and Sanfilippo, 1970, p. 534, pl. 11 , figs. 3,4 .

Eocene.

Podocyrtis (?) or Thyrsocyrtis (?) mitra (Ehrenberg)

Podocyrtis mitra Ehrenberg, 1854 , pl. 36, fig. B 20; 1873, p. 251; non Ehrenberg, 1875, pl. 15, fig. 4.

Podocyrtis (Lampterium) mitra (Ehrenberg) Riedel and Sanfilippo, 1970, p. 534, pl. 11, figs. 5, 6; Moore, in press, pl. 3, fig. 4. Eocene.

\section{Thyrsocyrtis ? bromia Ehrenberg}

Thyrsocyrtis bromia Ehrenberg, 1873, p. 260; 1875, pl. 12, fig. 2; Riedel and Sanfilippo, 1970, p. 526; Riedel and Sanfilippo, in press, pl. 8 , fig. 6 , Moore, in press, pl. 5, figs. 1-3.

Cephalis and thorax very similar to Cyclampterium species, but abdomen is smaller.

Eocene.

\section{Genus LOPHOCYRTIS Haeckel}

Lophocyrtis Haeckel, 1887, p. 1410; Campbell, 1954, p. 134; Riedel and Sanfilippo, 1970, p. 529. Type species Eucyrtidium stephanophorum Ehrenberg (1873, p. 223; 1875, pl. 8, fig. 14). Differs from Thyrsocyrtis mainly by the abdomen being narrower.

\section{Lophocyrtis? jacchia (Ehrenberg) group}

(Plate 28, Figure 21)

Thyrsocyrtis jacchia Ehrenberg, 1873, p. 261; 1875, pl. 12, fig. 7 . Thyrsocyrtis dionisia Ehrenberg, 1873, p. 260; 1875, pl. 12, fig. 5 . 
Lophocyrtis? jacchia (Ehrenberg) Riedel and Sanfilippo, 1970, p. 530; Riedel and Sanfilippo, in press, pl. 3C, fig. 4 (non fig. 5); Moore, in press, pl. 5, figs. 4,7 .

Eocene.

\section{Genus THEOCOTYLE Riedel and Sanfilippo}

Theocotyle Riedel and Sanfilippo, 1970, p. 524. Type species Theocotyle venezuelensis Riedel and Sanfilippo (1970, pl. 6, fig. 10).

The two upper segments, cephalis and thorax, very similar to these segments of Stichocorys and Cyrtophormis (in Theocotyle they are only larger).The abdomen and the proportions of the whole test are nearly the same as in Thyrsocyrtis. The difference between Theocotyle cryptocephala and Thyrsocyrtis argulus lies mainly in the length of the peristomial teeth. Theocotyle venezuelensis (type species of Theocotyle) differs from Thyrsocyrtis more obviously, but the existence of species like Theocotyle cryptocephala indicates a relationship between the two genera.

Eocene.

Theocotyle venezuelensis Riedel and Sanfilippo

Theocotyle venezuelensis Riedel and Sanfilippo, 1970, p. 525, pl. 6, figs. 9-10, pl. 7, figs. 1-2.

Eocene.

\section{Genus LAMPTERIUM Haeckel emend}

Lampterium Haeckel, 1881, p. 434; 1887, p. 1376; Campbell, 1954 , p. 132; Riedel and Sanfilippo, 1970, p. 534, partim. Type species Cycladophora goetheana Haeckel (1887, pl. 65, fig. 5).

Tetralocorys Haeckel, 1881 , p. 436; 1887 , p. 1370; Campbell, 1954 , p. 132; Riedel and Sanfilippo, 1970, p. 534. Type species Alacorys litheri Haeckel (1887, pl. 65, fig. 4).

Lamptidium Haeckel, 1887, p. 1377; Campbell, 1954, p. 132; Riedel and Sanfilippo, 1970. Type species Cycladophora hexapleura Haeckel, (1887, = Lanterna chinensis Bury (pl. 13, fig. 7).

The difference between Lampterium goetheana and species of Anthocyrtella, especially A. spatiosa forma 2 (Plate 33, Figure 3), is less than the difference between $L$. goetheanum and Podocyrtis papalis (type species of Podocyrtis). That is the reason for Lampterium to be not a subgenus of Podocyrtis, but an independent genus. The cephalis in Lampterium has not the pronounced lateral lobes characteristic for Pterocoryidae. The arches ap are situated in the Lampterium cephalis as high as they are in the species of Ectonocorys Foreman. The cephalis itself is wide towards the thorax. The thorax in Lampterium is very much the same as in Anthocyrtella species, but the longitudinal disposition of the pores is more pronounced. The abdomen is not so wide as the velum of Neosciadiocapsidae. Abdominal wall has less pores (they are enormous) and less rods, even than in Anthocyretella spatiosa forma 2 . Very likely this genus must be placed among Pterocoryidae, as has been done by Riedel and Sanfilippo (1970), but there are some uncertainties about its evolution from Podocyrtis species. It may as well have evolved from Thyrsocyrtis species (see Plate 32, Figure $11)$.

\section{Lampterium chalara (Riedel and Sanfilippo)}

(Plate 32, Figure 12)

?Podocyrtis (?) sp. Bury, 1862, pl. 12, fig. 2.

Podocyrtis chalara Riedel and Sanfilippo, 1970, p. 535, pl. 12, figs. 2,3 ; Moore, in press, pl. 3 , fig. 5 .

Eocene.

\section{Lampterium goetheanum (Haeckel)}

Cycladophora goetheana Haeckel, 1887, p. 1376; pl. 65, fig. 5 .

Podocyrtis goetheana (Haeckel) Riedel and Sanfilippo, 1970, pl. 535; Riedel and Sanfilippo, in press, pl. 8, fig. 13; Moore, in press, pl. 3 , figs. 7,8 .

There do exist varieties of $L$. goetheanum (Plate 32, Figures 13, 14) differing from the typical $L$. goetheanum in the disposition of pores on the abdomen.

Eocene.

\section{Genus CALOCYCLOMA Haeckel}

Calocycloma Haeckel, 1887, p. 1384; Campbell, 1954, p. 132 ; Riedel and Sanfilippo, 1970, p. 524. Type species Calocyclas casta Haeckel (1887, pl. 73, fig. 10).

Eocene.

\section{Calocycloma ampulla Ehrenberg}

(Plate 34, Figure 4)

Eucyrtidium ampulla Ehrenberg, 1854, pl. 36, fig. 15; 1875, pl. 10, figs. 11,12 .

Sethamphora ampulla (Ehrenberg) Haeckel, 1887, p. 1251.

Calocycloma ampulla (Ehrenberg) Riedel and Sanfilippo, 1970, p. 524 , pl. 6, fig. 1; Riedel and Sanfilippo, in press, pl. 3B, fig. 4 . Eocene.

\section{Family PTEROCORYIDAE Haeckel, emend, Riedel}

Pterocorida Haeckel, 1881, p. 435.

Lamptrocycladidae Haecker, 1908, p. 452.

Pterocoryidae Haeckel, Riedel, 1967b, p. 296; Petrushevskaya, 1971a, p. 986; 1971b, p. 230.

Eucyrtidioidea with cephalis and thorax, and usually also with abdomen. Cephalis consists of eucephalic lobe and two lateral lobes. The lateral lobes are separated from above by the arches ap and from below by the archs $l p$. The cephalis is constricted up to its lower margin. It is a high cone or nearly a cylinder in outline. Apical horn stout. The feet corresponding to the spines $D$ and $L$ are weak. The pores on the thorax and abdomen are disposed in checkerboard order, or they form longitudinal rows.

\section{Genus PODOCYRTIS Ehrenberg}

Podocyrtis Ehrenberg, 1847, p. 54; Haeckel, 1881, p. 436; 1887, p. 1337; Campbell, 1954, p. 130; Riedel and Sanfilippo, 1970, p. 533, part. $=$ Podocyrtidium Haeckel, 1887, p. 1344; Campbell, 1954, p. 130. Type species Podocyrtis papalis Ehrenberg (1854, pl. 36, fig. 23).

Atypically for Pterocoryidae, the cephalis is often wider towards its lower margin. Abdomen funnel-shaped, conical, narrower than the thorax, and as a rule it is shorter than the thorax. The mouth of the shell is festooned. Festoons are poreless.

Paleogene.

\section{Podocyrtis papalis Ehrenberg} (Plate 35, Figure 1)

Podocyrtis papalis Ehrenberg, 1847b, fig. $2 ; 1854$, pl. 36 , fig. 23 ; 1873, p. 251; Riedel and Sanfilippo, 1970, p. 533, pl. 11, fig. 1; Riedel and Sanfilippo, in press, pl. 3E, fig. 1.

Podocyrtis mitrella Ehrenberg, 1873, p. 351; 1875, pl. 15, fig. 3 .

?Podocyrtis fasciata Clark and Campbell, 1942, p. 80, pl. 7, figs. 29,33 .

Thorax up to $100-80 \mu$ long and about $120 \mu$ broad.

Eocene.

Podocyrtis coronatus (Ehrenberg) (Plate 35, Figure 3)

Eucyrtidium coronatum Ehrenberg, 1873, p. 227; 1875, pl. 10, fig. 9.

Cephalis nearly cylindrical, of ten curved. Thorax up to $65-75 \mu$ long and up to $70-80 \mu$ broad. Eocene.

\section{Genus CALOCYCLETTA Haeckel}

Calocycletta Haeckel, 1887, p. 1381; Campbell, 1954, p. 132 ; Riedel and Sanfilippo, 1970, p. 535. Type species Calocyclas veneris Haeckel (1887, pl. 74, fig. 5).

?Anthocyrtonium Haeckel, 1887, p. 1274; Campbell, 1954, p. 125. Type species Anthocyrtium campanula Haeckel (1887, pl. 62, fig. 17).

Cephalis is typical for Pterocoryidae, thick-walled. Abdomen cylindrical, of the same breadth as the thorax or somewhat narrower. The mouth of the shell is as a rule armed with long flat teeth.

Tertiary. 
Calocycletta acanthocephala (Ehrenberg)

(Plate 35, Figures 5-7)

Eucyrtidium acanthocephalum Ehrenberg, 1873, p. 225, 1875, pl. 9 , fig. 8 .

Cephalic horns, very similar to those in $C$. tuberosa forma $\mathrm{A}$, are present. About 9 to 11 pores on half of the thoracic equator. Oligocene.

\section{Calocycletta virginis Haeckel sens. str.} (Plate 35, Figures 8-10)

Calocycletta virginis Haeckel, 1887, p. 1381, pl. 74, fig. 4; Riedel and Sanfilippo, 1970, p. 535, part. (non fig. 14, pl. 10) Riedel and Sanfilippo, in press, pl. $2 \mathrm{H}$, figs. 8-11 (non figs. 5-9), part."

?Theocyrtis tuberosa (Riedel) Moore, in press, pl. 5, fig. 5, part.

About 12 to 15 pores on half of the thoracic equator. The external constriction between thorax and abdomen is distinct. The teeth of the abdomen may be undeveloped.

Eocene, not Miocene.

\section{Calocycletta veneris Haeckel sens. str.} (Plate 5, Figure 16)

Calocycletta veneris Haeckel, 1887, p. 1381, pl. 74, fig. 5 .

Calocycletta virginis Haeckel, Riedel and Sanfilippo, 1970, p. 535 , pl. 14, fig. 10; Riedel and Sanfilippo, in press, pl. 2H, figs. 5-7, part; Moore, in press, pl. 10, fig. 7 .

About 10 pores on half of the thoracic equator. No external constriction between thorax and abdomen, only an inner shelf. Abdominal teeth are distinct (if not broken). Riedel and Sanfilippo indicate the evolution of this species from forms similar to $C$. virginis (Riedel and Sanfilippo, in press, pl. 2H, figs. 8-11).

Miocene. Characteristic for the zone called the "Calocycletta virginis Zone"; therefore (because typical $C$. virginis is absent in this zone) this zone must be named the "Calocycletta veneris Zone".

\section{Calocycletta costata (Riedel)}

(Plate 35, Figure 17)

Calocyclas costata Riedel, 1959 , p. 296, pl. 2, fig. 9.

Calocycletta costata (Riedel) Riedel and Sanfilippo, 1970, p. 535 , pl. 14 , fig. 12 ; Moore, in press, pl. 10 , fig. 8

?Anthocyrtium flosculus Haeckel, 1887, p. 1277, pl. 62, fig. 19.

About 11 to 13 longitudinal rows of pores on half of the thoracic equator; they are separated by ridges. Teeth of the abdomen are very well developed.

Miocene.

\section{Calocycletta tuberosa (Riedel)}

(Plate 35, Figures 11-14)

Theocyrtis tuberosa Riedel 1959a, p. 298, pl. 2, figs. 10,11; Riedel and Sanfilippo, 1970, p. 535, pl. 13, figs. 8-10; Moore, in press, pl. 5 , fig. 6 , part.

About 15 to 18 pores on half of the thoracic equator. The surface of the thorax has small tuberculae. The teeth of the mouth are not developed.

There are several forms (subspecies?) of this species.

Calocycletta tuberosa forma A (Plate 35, Figures 11, 12), see Riedel and Sanfilippo (1970, pl. 13, fig. 9), has less pores on the thorax. The cephalis has the same horns that are characteristic for $C$. acanthocephala.C. tuberosa forma A and $C$. acanthocephala seem to be closely related and originate from one and the same ancestor. $C$. tuberosa forma A is restricted to Early Oligocene.

Calocycletta tuberosa forma B (Plate 35, Figures 13, 14). Typical $C$. tuberosa. It is distinguished from $C$. tuberosa forma A, 1) by a greater number of pores, 2 ) by more pronounced tuberculae, and 3) by the narrower cephalis without the additional horns.

Restricted to Oligocene.

Remark: The generic identification is emended for the following reasons. C. tuberosa resembles Eucyrticium barbadense Ehrenberg (1875, pl. 9, fig. 7, the type species of Theocyrtis, which is somewhat similar in the upper two segments of the skeleton to Calocycletta costata) no more than it resembles Calocycletta veneris (the type species of Calocycletta). Taking into account the relation between $C$. veneris and $C$. virginis on the one hand, and the relation between $C$. virginis and $C$. tuberosa on the other, it seems likely that there existed two lines from one and the same ancestor. Both lines may be included in one and the same genus Calocycletta.
Calocycletta tuberosa forma C was figured by Riedel and Sanfilippo (in press, pl. 3D, figs. 16 and 18) as Theocyrtis sp. aff. T. tuberosa. It has tuberculae only on the upper part of the thorax. On the lower part of the thorax there are longitudinal ribs, as characteristic for $C$. annosa. Calocycletta tuberosa forma $\mathrm{C}$ is very similar to $C$. virginis in the shape and size of the test, and also in the number and disposition of the pores.

Late Eocene-Early Oligocene.

\section{Calocycletta annosa (Riedel)}

Phormocyrtis annosa Riedel, 1959a, p. 295, pl. 2 , fig. 7 .

Theocyrtis annosa Riedel and Sanfilippo, 1970, p. 535, pl. 15, fig. 9; Moore, in press, pl. 7, fig. 7.

Seems to originate from Calocycletta tuberosa forma C. Oligocene-Miocene.

\section{Genus LAMPROCYCLAS Haeckel}

Lamprocyclas Haeckel, 1881, p. 434; 1887, p. 1390; Campbell, 1954 , p. 132. = Lamprocyclia Haeckel, 1887, p. 1390; Campbell, 1954 , p. 132 ; Nigrini, 1967 , p. 74 ; Petrushevskaya, 1971b, p. 232. Type species Lamprocyclas nuptialis Haeckel (1887, pl. 74, fig. 15).

Theocorbis Haeckel, 1887 , p. 1401; Campbell 1954, p. 134. Type species Theoconus jovis Haeckel (1887, pl. 69, fig. 4).

Craterocyclas Haecker, 1908, p. 454; Campbell, 1954, p. 127. Type species Craterocyclas robustissima Haecker (1908, p. 85, fig. 596).

Hexalodus Haecker, 1908, p. 456; Campbell, 1954, p. 134. Type species Hexalodus dendroporus Haecker (1908, p. 85, fig. 593). Cephalis is as a rule nearly cylindrical, but sometimes conical (wide at its base). Abdomen as a rule is longer and broader than thorax [In Theocorythium (Plate 36, Figure 15) it is smaller]. The mouth of the abdomen is somewhat constricted. As a rule, margin is poreless. It may be elongated into a peristome. Peristome may have festoons or teeth. The walls of the abdomen very often have horns (teeth?). The peristomial and abdominal teeth may constitute a "double corona".

Paleogene-Recent.

\section{Lamprocyclas rhinoceros (Haeckel)}

(Plate 36, Figure 1-3)

Lophoconus rhinoceros Haeckel, 1887, p. 1405, pl. 69, fig. 2.

Cephalis has a tube, which is more or less developed in various specimens.

Oligocene.

\section{Lamprocyclas sp. A}

(Plate 36, Figure 4)

?Calocyclas parthenia Haeckel, 1887, p. 1385, pl. 74, fig. 1.

?Calocyclas hannai Campbell and Clark, 1944a, p. 48, pl. 6, figs. $21,22$.

Abdomen (without peristome) $100-120 \mu$ long and $130-150 \mu$ broad. About 12 longitudinal rows or pores on the half equator of the abdomen.

Miocene.

\section{Lamprocyclas aegles (Ehrenberg) group}

(Plate 36, Figure 13)

Podocyrtis aegles Ehrenberg, 1854, pl. 35, B IV, fig. 18; Petrushevskaya, 1971b, pl. 116, fig. 1.

?Phormocampe lamprocyclas Haeckel, 1887, p. 1457, pl. 77, fig. 16 . ?Lamprocyclas maritalis antiqua Riedel, 1953, p. 811, pl. 85, fig. 8 . Abdomen $50-70 \mu$ broad. About 11 or 12 longitudinal rows of pores on the half equator of the abdomen. Miocene-Quaternary.

\section{Lamprocyclas maritalis Haeckel \\ (Plate 36, Figure 14)}

Lamprocyclas maritalis Haeckel, 1887, p. 1390 , pl. 74 , figs. 13,14 ; Nigrini, 1967, p. 74, pl. 7, fig. 5 .

Differs from Lamprocyclas sp. A by the length of the abdomen-it is about $70-80 \mu$ long (without peristome). About 14 or 15 longitudinal rows of pores on the half equator of the abdomen. Pliocene-Quaternary. 


\section{Lamprocy clas heteroporus Hays}

(Plate 36, Figures 6, 7)

Lamprocyclas heteroporus Hays, 1965, p. 179, pl. 3, fig. 1; Petrushevskaya, $1971 \mathrm{~b}$, pl. 117, figs. 4,5 .

Somewhat similar to Androcyclas gamphonychos Jörgensen (1905, pl. 18, figs. 92-97) on the one hand, and it is somewhat similar to Thyrsocyrtis bromia (see Riedel and Sanfilippo, in press, pl. 8, fig. 6).

Pliocene.

\section{Lamprocyclas junonis (Haeckel) group} (Plate 36, Figure 8)

Theoconus junonis Haeckel, 1887, p. 1401, pl. 69, fig. 7; Kruglikova, 1969, pl. 4, fig. 38.

Cephalis may be open from above. Abdomen $60-75 \mu$ long, $75-90 \mu$ broad. About 6-8 longitudinal rows of pores on the half equator of the abdomen.

Pliocene-Quaternary.

\section{Genus PTEROCORYS Haeckel}

Pterocorys Haeckel, 1881, p. 435; 1887, p. 1316; non Campbell, 1954 , p. 130; Petrushevskaya, 1971 b, p. 232. Type species Pterocorys campanula Haeckel, 1887, pl. 71, fig. 3.

Theoconus Haeckel, 1887, p. 1399; Campbell, p. 134. Type species Eucyrtidium zancleum Müller (1858, pl. 6, figs. 1-3).

Lithopilium Popofsky, 1913, p. 377; Campbell, 1954, p. 130. Type species Lithopilium macroceras Popofsky (1913, pl. 38, fig. 2, text-fig. 95).

Cephalis cylindrical or conical. Abdomen longer and broader than thorax (if fully developed). The margin of the abdomen without any teeth, or horns. No peristome. The mouth of the shell may be closed as a sack.

Tertiary-Recent.

\section{Pterocorys sabae (Ehrenberg) \\ (Plate 36, Figure 19)}

Pterocanium sabae Ehrenberg, 1872, pl. 7, fig. 17.

Cephalis cylindrical. About thirteen pores on the half equator of the abdomen.

Pliocene-Quaternary.

\section{Pterocorys clausus group (Popofsky)}

(Plate 36, Figures 16-18)

Lithornithium clausum Popofsky, 1913, p. 393, text-fig. 116.

Cephalis more conical than in $P$. campanula. All dimensions are

less: thorax $60-70 \mu$ broad, $30-40 \mu$ long; abdomen $60-75 \mu$ broad, up to $80 \mu$ long. About 12 to 14 longitudinal rows of pores on a half equator of the abdomen.

Pliocene-Quaternary

\section{Genus ANTHOCYRTIDIUM Haeckel emend. Petrushevskaya}

Anthocyrtidium Haeckel, 1881, p. 431; 1887, p. 1278; Campbell, 1954 , p. 125 ; Nigrini, 1967 , p. 56 . Type species Anthocyrtidium cineraria Haeckel (1887, pl. 62, fig. 16)

?Conarachnium Haeckel, 1881 , p. $430 ; 1887$, p. 1290; Campbell, 1954 , p. 128. Type species Eucyrtidium trochus Ehrenberg (1872b, pl. 7, fig. 17)

Anthocyrtissa Haeckel, 1887, p. 1270; Campbell, 1954, p. 126. Type species Anthocyrtis ophirensis Ehrenberg (1872b, pl. 9, fig. 13).

Sethoconus Haeckel, 1887 , p. 1290; Campbell, 1954, p. 128. Type species Eucyrtidium trochus Ehrenberg (1872b, pl. 7, fig. 17).

Sethocyrtis Haeckel, 1887, p. 1298; Campbell 1954, p. 128. Type species Sethochytris oxycephalus Haeckel (1887, pl. 62, fig. 9).

?Phormocampe Haeckel, 1887, p. 1456; Campbell 1954, p. 139. Type species Phormocampe campanula Haeckel (1887, pl. 77 , fig. 13).

Pterocoryidae without abdomen. Cephalis nearly cylindrical. Pliocene-Quaternary.

\section{Anthocyrtidium ophirense (Ehrenberg)}

(Plate 36, Figure 11)

Anthocyrtis ophirensis Ehrenberg 1872a, p. 301; 1872b, pl. 9, fig. 13
Anthocyrtidium cineraria Haeckel, 1887, p. 1278, pl. 62, fig. 16.

Anthocyrtidium ophirense (Ehrenberg), Nigrini, 1969, p. 56, pl. 6, fig. 3 .

Pliocene-Quaternary.

\section{Anthocyrtidium ovata (Haeckel) \\ (Plate 36, Figure 10)}

Anthocyrtis ovata Haeckel, 1887, p. 1272, pl. 62, fig. 13.

?Anthocyrtidium zanguebaricum (Ehrenberg). Nigrini, 1969, p. 58, pl. 6, fig. 4 .

Pliocene-Quaternary.

\section{Family AMPHIPYNDACIDAE Riede}

Amphipyndacidae Riedel, 1967a, p. 149; 1967b, p. 296; Petrushevskaya, 1971 a, p. 985.

The shell consists of numerous segments, and is high-conical in shape. Round pores are disposed on all segments (except cephalis) in checkerboard order. Cephalis thick-walled, consisting of eucephalic lobe, subdivided into upper and lower parts by means of low-disposed arches $a j$ (=VB of Foreman, 1966).

\section{Genus AMPHIPYNDAX Foreman}

Amphipyndax Foreman, 1966, p. 355. Type species Amphipyndax enessefi Foreman (1966, text-figs. 10,11).

\section{Amphipyndax enessefi Foreman \\ (Plate 8, Figure 15)}

Amphipyndax enessefi Foreman, 1966, p. 356, text-figs. 10, 11 a, b. Cretaceous (Campanian-Maestrichtian).

\section{Amphipyndax stocki (Campbell and Clark) \\ (Plate 8, Figures 16, 17)}

Stichocapsa stocki Campbell and Clark, 1944b, p. 44, pl. 8 , figs. 31-33.

Stichocapsa megalocephala Campbell and Clark, 1944b, p. 44, pl. 8 , figs. 26, 34 .

?Dictyomitra uralica Gorbovetz in Kozlova and Gorbovetz, p. 116, pl. 6, figs. 6, 7; Petrushevskaya, 1971b, pl. 88, figs. 2-3.

Amphipyndax stocki (Campbell and Clark), Foreman, 1968, p. 78, pl. 8 , fig. 12

Cretaceous (Santonian-Maestrichtian).

\section{Amphipyndax sp. A}

(Plate 8, Figure 18)

Similar to $A$. enessefi in the number of pores on a segment, but there are no nodes. The walls are thicker on the boundaries between segments. It is similar to the species described as Lithostrobus punctulatus Pessagno (1963, pl. 5, fig. 5) in the pores on the segments.

Cretaceous (Maestrichtian).

Family EUCYRTIDIIDAE Ehrenberg, emend. Petrushevskaya

Eucyrtidina Ehrenberg, 1847, p. 53.

Eucyrtidiidae Ehrenberg, Petrushevskaya, 1971a, p. 985; 1971b, p. 215 .

Theoperidae Haeckel, Riedel 1967b, p. 296, part.

Cephalis is small, of ten spherical. Post-thoracic segments may be numerous, but may be reduced, or be represented by the abdomen only. The pores are disposed in checkerboard order.

\section{Genus STICHOCAPSA Haecke}

Stichocapsa Haeckel, 1881 , p. $439 ; 1887$, p. 1515; Campbell, 1954, p. 143. Type species Stichocapsa jaspidea Rüst (1885, pl. 41, fig. 6).

The segments are numerous, and the distalmost ones may be narrower than the middle ones. The segments are separated by distinct external constrictions of the test. H. Foreman (1968) named this genus Stichomitra, but Stichomitra, as was indicated by Campbell, is a synonym of Dictyomitra.

Cretaceous-Tertiary.

\section{Stichocapsa sp. aff. S. ferosia (Kh. Aliev)}

(Plate 2, Figure 6)

?Dictyomitra ferosia Kh. Aliev, 1961, p. 55, pl. 1, figs. 5, 6 .

This form differs from Kh. Aliev's specimens by the smaller longitudinal dimension of a segment. Cretaceous (Albian-Cenomanian) 
Stichocapsa asymbatos (Foreman) (Plate 8, Figures 1-3)

Stichomitra asymbatos Foreman, 1968, p. 73, pl. 8, fig. 10.

?Stichocapsa oblongula Rüst, 1885 , pl. 41, fig. 9 . Cretaceous (Campanian-Maestrichtian).

\section{Stichocapsa sp. aff. S. producta (Kh. Aliev)}

(Plate 8, Figures 4-5)

?Dictyomitra producta Kh. Aliev, 1961, p. 58, pl. 11, fig. 1; 1965 , p. 44 , pl. 7 , fig. 7 .

Typical specimens are larger than this species.

Cretaceous (Albian-Maestrichtian).

\section{Stichocapsa cingulata (Squinabol)} (Plate 8, Figure 19)

Stichomitra cingulata Squinabol, 1914, p. 281, pl. 20, fig. 11. Cretaceous (Maestrichtian).

Stichocapsa sp. aff. L. elegans Squinabol (Plate 2, Figure 7)

?Lithostrobus elegans Squinabol, 1903, p. 138, pl. 9, fig. 22.

Dictyomitra clivosa Kh. Aliev, 1961, p. 54, pl. 1, figs. 1, 2; 1965, p. 38 , pl. 6 , figs. 7,8 .

There are numerous papillae or beads of the same type as described for Lithostrobus pseudoconulus Pessagno (1963, p. 210, pl. 1 , fig. 8 , pl. 5 , figs. 6,8$)$.

Cretaceous (Cenomanian).

\section{Stichocapsa hexagonalis (Haeckel)} (Plate 25, Figure 1)

Lithostrobus hexagonalis Haeckel, 1887, p. 1475, pl. 79, fig. 20; Nigrini, 1968 , p. 58 , pl. 1 , fig. 10.

The walls are thinner than in Cretaceous species, and there is no inner shelf separating the segments.

Pliocene-Quaternary.

\section{Genus LITHOSTROBUS Bütschli}

Lithostrobus Bütschli, 1882, p. 529; Haeckel, 1887, p. 1469; Campbell, 1954, p. 141; =Cyrtostrobus Haeckel, 1887, p. 1471. Type species Eucyrtidium argus Ehrenberg (1875, pl. 9, fig. 1). As in Stichocapsa, the segments are numerous. They are separated from one another by distinct external constrictions. The distinguishing characteristic is the increasing breadth of the subsequent segments, the thorax and abdomen being very narrow (Plate 25, Figure 2). The genus is closely related to Cyrtopera laguncula (Haeckel, 1887, pl. 75, fig. 10) and some other species on this plate.

Cretaceous-Quaternary.

\section{Genus LITHOCAMPE Ehrenberg}

Lithocampe Ehrenberg, 1838, p. 128; Haeckel, 1887, p. 1501; Campbell, 1954 , p. $140 .=$ Lithocampula Haeckel, 1887, p. 1502; Campbell, 1954, p. 140. Type species Lithocampe radicula Ehrenberg, 1838 (1854, pl. 22, fig. 23a).

Eusyringoma Haeckel, 1887, p. 1498; Frizzell and Middour, 1951, p. 35 ; Campbell, 1954 , p. 140 . Type species Eucyrtidium lagenoides Stöhr (1880, pl. 4, fig. 8).

Cyrtocapsella Haeckel, 1887, p. 1512; Campbell, 1954, p. 143; Sanfilippo and Riedel, 1970 , p. 451; Riedel and Sanfilippo, 1970, p. 530. Type species Cyrtocapsa tetrapera Haeckel (1887, pl. 78, fig. 5).

Syringium Principi 1909, p. 19; Riedel and Sanfilippo, 1970, p. 530. Type species Syringium vinassai Principi (1909, pl. 1, fig. 60).

Diabolocampe Burma 1959, p. 329. Type species Theocampe stenostoma Haeckel (1887, pl. 66, fig. 23).

The number of segments is 3 to 8 . The terminal segment is funnel- or sack-shaped, closed or nearly closed. Its walls are thinner than the walls of the other segments. Thorax, abdomen and the other segments are separated by external constrictions of the shell and by internal rings or shelves. The diameter of the openings, especially that of the preterminal segment, may be comparatively very small. A. Sanfilippo and W. Riedel (1970) believe the 3-4 segmented species belongs in the separate genus Cyrtocapsella. Their specimens have three or four segments plus a terminal segment. The latter is more or less developed (or broken), but it must be counted.
A. Sanfilippo and W. Riedel indicate the important tendency in the Lithocampids to "throw off" the distal segments, resulting in the genus Cyrtocapsella. Nevertheless it is difficult to find the boundary between the specimens on Figures 8 and 14 of Plate 25, and to place them into different genera. I believe Cyrtocapsella to be no more than a subgenus of the genus Lithocampe.

The character of Lithocampe species is that their thorax is $35-60 \mu$ long and $50-95 \mu$ broad. This genus is most closely related to Stichocorys.

Tertiary.

\section{Lithocampe subligata Stöhr group}

(Plate 25, Figures 7-10)

Lithocampe subligata Stöhr, 1880, p. 102, pl. 4, fig. 1 .

Lithocampe sp. cf. L. radicula Ehrenberg, in Petrushevskaya, 1971b, pl. 90 , fig. 5 .

Oligocene-Miocene.

Lithocampe tetrapera (Haeckel)

(Plate 25, Figure 14)

Cryptocapsa tetrapera Haeckel, 1887, p. 1512 , pl. 78 , fig. 5 .

Cryptocapsella tetrapera (Haeckel) Riedel and Sanfilippo, 1970, p. 530 , pl. 14 , fig. 7 .

Miocene.

\section{Lithocampe cornuta (Haeckel)}

(Plate 25, Figures 15, 16)

Cyrtocapsa cornuta Haeckel, 1887 , p. 1513 , pl. 78 , fig. 9.

Cyrtocapsella cornuta (Haeckel) Riedel and Sanfilippo, 1970, p. 531 , pl. 14 , fig. 8 .

Miocene.

\section{Lithocampe compacta (Haeckel)}

(Plate 25, Figure 17)

Cyrtocapsa compacta Haeckel, 1887 , p. 1512 , pl. 77 , fig. 8 .

Cyrtocapsella tetrapera (Haeckel), Riedel and Sanfilippo, in press, pl. $2 \mathrm{E}$, fig. 6 , part.

Miocene.

Lithocampe inaequispina (Principi)

Cyrtocapsa inaequispina Principi, 1909, p. 19, pl. 1, fig. 62.

?Cyrtocapsa subconica Nakaseko, 1963, p. 120, pl. 4, fig. 9 . Miocene.

Lithocampe japonica (Nakaseko) (Plate 25, Figure 18)

Eusyringium japonicum Nakaseko, 1963, p. 193, pl. 4, figs. 1-3, text-figs. 20, 21.

Cyrtocapsella japonica (Nakaseko), Riedel and Sanfilippo, 1970, p. 532 , pl. 14, fig. 9)

Miocene.

\section{Genus STICHOCORYS Haeckel}

Stichocorys Haeckel, 1881, p. 438; 1887, p. 1479; Campbell, 1954, p. 140; Sanfilippo and Riedel, 1970 , p. 530; Riedel and Sanfilippo, 1970, p. 530. Type species Stichocorys wolfii Haeckel (1887, pl. 80, fig. 10).

?Cyrtocapsa Haeckel, 1881, p. 439; 1887, p. 1512; non Campbell, 1954 , p. 143 ; Riedel, 1959 b, p. 11 . Type species to be not Cyrtocapsa ovalis Rüst, 1885 , but Cyrtocapsa chrysalidium Haeckel (1887, pl. 76, fig. 9).

Very much the same as Lithocampe, but the thorax is a little smaller $(25-40 \mu$ long and $50-60 \mu$ broad). The fourth segment is narrower than the third or of the same breadth. The fifth segment is narrower than the fourth.

Miocene-Pliocene.

\section{Stichocorys delmontensis (Campbell and Clark)}

(Plate 25, Figures 11, 12)

See Riedel and Sanfilippo, 1970, p. 530.

Miocene.

\section{Stichocorys wolffii Haeckel}

(Plate 25, Figure 22)

Stichocorys wolffii Haeckel, 1887, p. 1479, pl. 80, fig. 10, Riedel, 1957a, p. 92, pl. 4, figs. 6, 7; Riedel and Sanfilippo, 1970, p. 530; Riedel and Sanfilippo, in press, pl. 2E, figs. 8, 9. 
Stichocorys baerii Haeckel, 1887, p. 1479, pl. 80, fig. 8 .

?Stichocorys huschkei Haeckel, 1887, p. 1480, pl. 80, fig. 3 . Miocene.

Stichocorys coronata (Carnevale)

(Plate 25, Figures 23, 24)

Calocyclas coronata Carnevale, 1908, p. 33, pl. 4, fig. 24 .

Abdomen is joined to the thorax only by sparse and thin meshwork. The thorax is somewhat larger than in St. wolffii.

Miocene.

\section{Stichocorys peregrina (Riedel)}

(Plate 25, Figure 25)

Eucyrtidium elongatum peregrinum Riedel, 1953, p. 812, pl. 85, fig. 2, Riedel, 1957 a, p. 94.

Stichocorys peregrina (Riedel), Riedel and Sanfilippo, 1970, p. 530.

?Cyrtocapsa chrysalidium Haeckel, 1887, p. 1515, pl. 76, fig. 9.

??Stichocorys okenii Haeckel, 1887, p. 1480, pl. 80, fig. 5 .

Miocene-Pliocene.

\section{Genus CYRTOPHORMIS Haeckel}

Cyrtophormis Haeckel, 1887, p. 1459; Campbell 1954, p. 139 (non Cyrtophormis Haeckel, 1887, p. 1165). = Cyrtophormiscus Haeckel, 1887, p. 1460; Campbell, 1954, p. 139. Type species Cyrtophormis armata (Haeckel, 1887, pl. 78, fig. 17).

Cyrtophormidium Haeckel, 1887, p. 1460; Campbell, 1954, p. 139. Type species Cyrtophormis cingulata Haeckel $(1887$, pl. 78 , fig. 18).

Cyrtophormis is distinguished from Stichocorys as a rule by larger thorax $(30-60 \mu$ long and $50-95 \mu$ broad) and by the fourth segment being terminal. This genus differs from Lithocampe by the larger abdomen (about $60-90 \mu$ long). The distinguishing character is the cephalis which is often not thick-walled and ball-shaped, but possesses postcephalic lobe and tube, with additional horns.

Eocene-Miocene.

\section{Cyrtophormis sp. Ch \\ (Plate 26, Figure 1)}

The fourth segment with small regular pores. Abdomen about 110-120 $\mu$ broad, $75-85 \mu$ long.

Eocene-Oligocene.

\section{Cyrtophormis dominasinensis (Ehrenberg)}

$$
\text { (Plate 28, Figure 11) }
$$

Podocyrtis dominasinensis Ehrenberg, 1873, p. 250; 1875, pl. 14, fig. 4 .

Artophormis dominasinensis (Ehrenberg) Riedel and Sanfilippo, 1970 , p. 532; Riedel and Sanfilippo, in press, pl. 6, fig. 6 .

The fourth segment is constricted; its pores are irregular, but nearly of the same size. It differs from Cyrtophormis sp. Ch only by somewhat smaller dimensions (abdomen about $95 \mu$ broad and about $70 \mu$ long) and in the number of pores on the abdomen (about 13 pores on half of the thoracic equator, instead of about 15 as in Cyrtophormis sp. Ch).

Oligocene.

\section{Cyrtophormis barbadensis (Ehrenberg)}

(Plate 28, Figure 12)

Calocyclas barbadensis Ehrenberg, 1873, p. 217,1875 , pl. 18 , fig. 8 . Artophormis barbadensis (Ehrenberg), Riedel and Sanfilippo, 1970, p. 532 , pl. 13 , fig. 5 ; Moore, in press, pl. 5 , fig. 9 .

Our specimens have the fourth segment widely open, and its pores are of various sizes. Longitudinal rods or ribs are pronounced on the fourth segment; its walls are thinner than the walls of the whole test. The abdomen is shorter than in $C$. dominasinensis, and has a larger number of smaller pores. These specimens differ from the specimens described by Riedel and Sanfilippo.

Oligocene.

\section{Cyrtophormis gracilis (Riedel)}

(Plate 28, Figures 13-15)

Artophormis gracilis Riedel, 1959c, p. 300, pl. 2, figs. 12,13; Riedel and Sanfilippo, 1970 , p. 532, pl. 13, figs. 6, 7; Riedel and Sanfilippo, in press, pl. 3B, figs. 5-7.
Artophormis barbadensis (Ehrenberg), Riedel and Sanfilippo, in press, pl. 3B, fig. 8 , part; Moore, in press, pl. 5, figs. 10,11 .

The fourth segment is cylindrical with large irregular meshes. Abdomen rather short (about 50-70 $\mu$ ) barrel-shaped. The ring separating abdomen and the fourth segment is pronounced. About ten longitudinal rows of pores on a half equator of the abdomen.

Eocene-Oligocene.

\section{Cyrtophormis armata Haeckel}

\section{(Plate 25, Figures 19, 20)}

Cyrtophormis armata Haeckel, 1887, p. 1460, pl. 78, fig. 17. Lithocampe compressa Stöhr, 1880 , p. 103, pl. 4, fig. 5 .

Stichocorys armata (Haeckel), Sanfilippo and Riedel, 1970, pl. 1 , figs. 30,31 , part; Riedel and Sanfilippo, in press, pl. 2E, figs. 13 and 15 only.

Oligocene?-Miocene.

\section{Cyrtophormis sp \\ (Plate 25, Figure 21)}

?Cyrtophormis cingulata Haeckel, 1887, p. 1460, pl. 78, fig. 18 . Eusyringium cf. vicentense Campbell and Clark, Nakaseko, 1955, p. 113 , pl. 10 , fig. 7 .

Stichocorys diploconus (Haeckel), Sanfilippo and Riedel, 1970, pl. 1 , fig. 32, only; Riedel and Sanfilippo, in press, pl. 2E, fig. 16.

Stichocorys armata (Haeckel), Riedel and Sanfilippo, in press, pl. $2 \mathrm{E}$, fig. 14 , only.

Miocene.

\section{EUCYRTIDIIDAE Genus}

To include species with confused post-thoracic segments. Cephalis and thorax are very much the same as in Stichocorys, and nearly of the same dimensions. Thorax is separated from the post-thoracic part by a distinct constriction and an inner ring. The abdomen is cylindrical or conical. It is not separated from the fourth segment, but rather they are united in the last segment of the skeleton. As a rule it is widely open to the mouth. The wall of the post-thoracic part of the skeleton is thinner than the wall of the thorax.

Oligocene-Miocene.

\section{EUCYRTIDIIDAE gen. sp. "rocket"}

(Plate 28, Figures 2, 3)

The post-thoracic part is proximally cylindrical, then it becomes nearly discoidal, and distally again nearly cylindrical. It is more than $100 \mu$ long. In the cylindrical part it is about $50 \mu$ broad, in its broader part it is about $75-100 \mu$ broad. About 9 to 11 longitudinal rows of pores on the cylindrical post-thoracic part of the skeleton.

Oligocene.

\section{EUCYRTIDIDAE Gen. sp. W} (Plate 28, Figures 6, 7)

?Artophormis gracilis Riedel, Riedel and Sanfilippo, in press, pl. 6, fig. 7, part.

Thorax is somewhat bigger than in Eucyrtidiidae gen. sp. "rocket", and the pores on the post-thoracic part are of greater size (the number of longitudinal rows being the same). It is distinguished from the specimen illustrated by Riedel and Sanfilippo by the regular disposition of pores on the post-thoracic part of the skeleton.

Miocene.

\section{Genus CALOCYCLAS Ehrenberg}

Calocyclas Ehrenberg, 1847b, p. 54; Haeckel, 1887, p. 1381 Campbell, 1954, p. 132. Type species Calocyclas turris Ehrenberg (1875, pl. 18 , fig. 2 ).

The test consists of cephalis, thorax and abdomen. Abdomen is smaller than thorax. They are separated by a distinct constriction and by a well-developed ring. Thorax $70-110 \mu$ broad and of the same length; it is nearly spherical in outline. Pores on abdomen are of the same size as the thoracic pores.

Paleogene. 
Calocyclas asperum (Ehrenberg) (Plate 28, Figures 16-18)

Eucyrtidium asperum Ehrenberg, 1873, p. 226; 1875, pl. 8, fig. 15 . About 10 to 13 longitudinal rows of pores on a half of the thoracic equator.

Eocene-Oligocene.

\section{Genus CYCLAMPTERIUM Haeckel}

Cyclampterium Haeckel, 1887, p. 1379; Campbell, 1954, p. 132. Type species Cycladophora pantheon Haeckel (1887, pl. 68, fig. 3).

The test consists of cephalis, thorax and abdomen. Abdomen is larger than thorax. They are separated by an inner ring. Thorax $100-180 \mu$ long and about $200 \mu$ broad. Pores on the abdomen are much larger than thoracic pores. Cyclampterium is similar to Lampterium in the construction of the shell. They differ by the characters of their cephalises. In Cyclampterium it is ball-like, "theoperid", simple. In Lampterium it is conical with a pyramidal horn, of "Ectonocorys-type".

Tertiary.

\section{Cyclampterium milowi Riedel and Sanfilippo}

Cyclampterium milowi Riedel and Sanfilippo, in press, pl. 3B, fig. 3, pl. 7, fig. 8, 9 .

Abdomen long, subcylindrical or expanding distally, often destroyed. Pores large, irregular. Thorax hemispherical, constricted at the boundary between thorax and abdomen.

Oligocene.

\section{Cyclampterium pegetrum Sanfilippo and Riedel} (Plate 34, Figures 7, 8)

Cyclampterium? pegetrum Sanfilippo and Riedel, 1970, p. 456, pl. 2, figs. 8-10.

There are several forms (subspecies?) of this species. One (Riedel and Sanfilippo, in press, pl. 2D, figs. 12 and 14 , only) is characterized by a high (about $140-150 \mu$ ) thorax, having about 14 longitudinal rows of pores on a half of its equator. Thorax is sack-shaped with irregularly disposed pores. See Plate 34, Figure 8. This form is here named "f.II".

Low Miocene.

C. pegetrum f.I (Plate 34, Figure 7) is characterized by a flat thorax (about $100 \mu$ long). It has about 11 longitudinal rows of pores on a half of its equator. Thorax conical or cylindrical. Its pores are of nearly equal size, and are disposed regularly. It is illustrated by Riedel and Sanfilippo, in press (pl. 3B, fig. 1, 2).

Restricted to " $D$. ateuchus Zone", Oligocene.

\section{Genus EUCYRTIDIUM Ehrenberg}

Eucyrtidium Ehrenberg, 1847 a, p. 54; Haeckel, 1887, p. 1487; Campbell, 1954 , p. 140; Petrushevskaya, $1971 \mathrm{~b}$, p. 215 , part. $=$ Eucyrtis Haeckel, 1881 , p. $438 ; 1887$, p. 1488 . Type species Lithocampe acuminata Ehrenberg, 1844 (1854, pl. 22, fig. 27).

Very similar to Lithocampe. It has multisegmented skeleton, constricted distally. It is distinguished by less pronounced external constrictions between the segments. In many species the pores are disposed not in checkerboard order but in distinct longitudinal rows. Cephalis and thorax are united to form a compound cephalo-thorax. The upper part of the skeleton is conical, because of that union and because of the conical apical horn. The horn, as a rule is broad at its base. In Lithocampe the apical horn is thin, often broken.

\section{Eucyrtidium? sp. C}

(Plate 2, Figure 13)

The pores are disposed in checkerboard order. It is somewhat similar to Stichomitra cechena Foreman (1968, p. 8, fig. 1), but the cephalis has not apical horn and it is submerged into thorax, and the wall of the skeleton is much thicker than in Foreman's species.

Cretaceous (E. Campanian).

\section{Eucyrtidium? cubense Riedel and Sanfilippo}

Eucyrtidium cubense Riedel and Sanfilippo, in press, pl. 7, figs. 10,11 .
Thick-walled test. Post-abdominal part not separated into segments. Pores on this part irregular. Somewhat similar to Eusyringium and Lithocampium species, but post-abdominal part of the skeleton is not constricted.

Eocene.

Eucyrtidium sp. aff. E. montiparum Ehrenberg (Plate 26, Figures 2-4)

?Eucyrtidium montiparum Ehrenberg, 1873, p. 230; 1875, pl. 9, fig. 11.

Similar to E. montiparum in the proportions of the test and in the number and disposition of pores. But for $E$. montiparum more distinct constrictions between segments are typical. The species in question differs from $E$.? cubense by the presence of distinct inner rings separating the segments of the post-abdominal part.

Eocene.

\section{Eucyrtidium acuminatum (Ehrenberg) group} (Plate 26, Figure 17)

Lithocampe acuminata Ehrenberg, 1844, p. 84.

Eucyrtidium acuminatum (Ehrenberg) Ehrenberg, 1854, pl. 22, fig. 27 , Stöhr, 1880 , p. 104 , pl. 4 , fig. 6 , non Bandy, Casey and Wright, 1971, pl. 2, fig. 5 .

Miocene-Quaternary.

\section{Genus STICHOPODIUM Haeckel}

Stichopodium Haeckel, 1881, p. 439; 1887, p. 1447; Campbell, 1954 , p. 136. Type species Stichopodium dictyopodium Haeckel, (1887, pl. 75, fig. 6).

In all features very similar to Eucyrtidium. Nevertheless it is distinguished by deep outer constriction and by pronounced inner shelf separating cephalo-thorax from post-thoracic part of the skeleton. Abdomen and other segments are united into one unit. The walls of the latter may be thinner than the walls of the cephalo-thorax. The post-thoracic segments are separated from one another only by rings in the wall. These rings may have a variable position and even form a spiral. As a rule there are not more than four post-thoracic segments in the "unit".

\section{Stichopodium ? microporum (Ehrenberg)}

(Plate 25, Figures 4-6)

Eucyrtidium microporum Ehrenberg, 1873, p. 230; 1875, pl. 9, fig. 20.

Lithostrobus cornutus Haeckel, 1887, p. 1474, pl. 77, fig. 6. Eocene-Oligocene.

\section{Stichopodium cienkowskii (Haeckel)}

(Plate 26, Figures 18, 19)

Eucyrtidium cienkowskii Haeckel, 1887, p. 1493 , pl. 80 , fig. 9.

?Eusyringium cannostoma Haeckel, 1887, p. 1499, pl. 80, fig. 13.

The first post-thoracic segment (abdomen?) is about $30-40 \mu$ long. The broadest part of the test is not in this segment, but in the second or in the third post-thoracic segment. On the post-thoracic segments there are about 17 to 19 longitudinal rows of pores on the half equator.

Miocene.

\section{Stichopodium martellii (Principi)}

(Plate 26, Figures 9, 10)

Stichocorys martellii Principi, 1909, p. 16, pl. 1, fig. 52.

The first post-thoracic segment (abdomen?) is about $60 \mu$ long. The broadest part of the test is in the lower part of this segment. About 13 longitudinal rows of pores on the half equator of the post-thoracic part.

Low Miocene.

Stichopodium martellii conicum Petrushevskaya subsp. nov.

The description is based on 28 specimens from Site 140, Core 2 . Differs from typical St. martellii by shorter first post-thoracic segment (about $40-50 \mu$ ). This segment has somewhat different outline.

Miocene. 


\section{Stichopodium calvertense (Martin)}

(Plate 28, Figure 13)

Eucytidium calvertense Martin, 1904, p. 450, pl. 130, fig. 5; Kling, in press, pl. 1, fig. C. (Non Eucyrtidium calvertense Martin, Hays 1965, non E. calvertense in Bandy, Casey and Wright, 1971, pl. 9 , fig. 1.

?Spirocyrtis elegans Nakaseko, 1963, p. 196, pl. 3, fig. 12, part.

Very similar to $S$. cienkowskii, but differs by narrower shell (the broadest place being about $80 \mu$ instead of $90-100 \mu$ ), by a smaller number of segemnts, and by a smaller number of longitudinal rows of pores (about 11 instead of 17 on the half equator of the second post-thoracic segment).

Miocene-Pliocene.

Remark: This species differs from Antaractic Miocene-Pliocene specimens by the thinner wall of post-thoracic part, by a narrower shell (about $80 \mu$ instead of about $90-110 \mu$ ), and by a smaller number of pores (about 11 longitudinal rows on half of the second post-thoracic segment, instead of 15).

\section{Stichopodium ? sp. aff. Eucyrtidium matuyamai Hays}

(Plate 26, Figures 5, 6, 15, 16)

Eucyrtidium matuyamai Hays, Kling, 1971, pl. 1, fig. D.

?Eucyrtidium lagena Haeckel, 1862, pl. 4, fig. 11.

The broadest part of the shell is about $70-90 \mu$. There are about 10 to 12 longitudinal rows of pores on the second post-thoracic segment. The pores are large and somewhat irregularly disposed. The post-thoracic part is very long, nearly cylindrical. The first post-thoracic segment is about $70 \mu$ long.

Pliocene.

Stichopodium ? spp.

(Plate 26, Figures 21, 22)

They differ from Stichopodium? sp. aff. E. matuyamai by the ovate outline of the shell, and by greater number of pores (about 12 to 14 longitudinal rows on the second post-thoracic segment). It is very much the same as $S$. martellii coincum but the first post-thoracic segment is longer or it may be of variable length.

\section{Stichopodium sp. T}

(Plate 26, Figure 14)

Similar to Eucyrtidium teuscheri, Haeckel, 1887 (see Petrushevskaya, 1967 , p. 121 , pl. 68 , figs. 1,2), but differing from typical $E$. teuscheri by broader shell and greater number of pores.

Quaternary.

\section{Genus ARTOCYRTIS Haecke}

Artocyrtis Haeckel, 1887, pl. 1490; Campbell, 1954, p. 140. Type species Eucyrtidium profundissimum Ehrenberg $(1872 \mathrm{~b}, \mathrm{pl} .7$, fig. 12).

Very similar to Eucyrtidium in compact outline of the shell. Differs by larger thorax (about $50-70 \mu$ long and $70-100 \mu$ broad), and by irregular or sometimes transverse disposition of pores on abdomen and post-abdominal segments (see Plate 26, Figure 11).

\section{Genus EUSYRINGIUM Haeckel}

Eusyringium Haeckel, 1881, p. 437; 1887, p. 1496; Frizzell and Middour, 1951, p. 35; Campbell, 1954, p. 140; Riedel and Sanfilippo, 1970 , p. $527 .=$ Eusyringartus Haeckel, 1887 , p. 1496; Campbell, 1954, p. 140. Type species Eusyringium conosiphon Haeckel (1887, pl. 78, fig. 10).

Very similar to Stichopodium in the construction and dimensions of cephalis and thorax. Differs from Stichopodium by its post-thoracic part not being subdivided into any segments (very much as in Eucyrtidiidae genus, described above). Differs from mentioned Eucyrtidiidae genus by the funnel-shaped outline of that part. The pores on it are situated in longitudinal rows. These pores are of the same type as those on the thorax. The thorax is smaller than in Thyrsocyrtis and Lampterium. In other features Eusyringium is similar to these two genera. The taxonomic position of this genus is doubtful. The existence of such species as $E$. striata and Lithocampium? sp. B, very similar to Thyrsocyrtis sp. E (Plate 32, Figure 11) in all features except the size of abdominal pores, indicates the possibility of Eusyringium and Thyrsocyrtis being closely related; Thyrsocyrtis a descendant of Eusyringium. This possibility is no more questionable than the possibility (indicated by Riedel and Sanfilippo, 1970) that Podocyrtis and the species referred to here as Thyrsocyrtis are closely related. What is more, the construction of the cephalis in Eusyringium species and in the representatives of Thyrsocyrtis is practically the same.

Cretaceous-Tertiary.

Eusyringium striata (Brandt)

(Plate 32, Figures 1, 2)

Phormocyrtis striata Brandt, 1935 in Wetzel, 1935, p. 55, pl. 9, fig. 12; Riedel and Sanfilippo, 1970,p. 532, pl. 10, fig. 7; Riedel and Sanfilippo, in press, pl. 8 , fig. 4 .

Early Tertiary.

\section{Eusyringium? sp. aff. Theocampe subtilis (Squinabol)} (Plate 1, Figure 1)

?Theocampe subtilis Squinabol, 1904, p. 135, pl. 8, fig. 43.

Differs from $E$. striata in the proportions of the test.

The preservation of the specimens is too poor to permit any certain conclusions about species identification. The indication of the similarity with Theocampe species is appropriate for the Cretaceous forms of Eusyringium.

Cretaceous (Albian-Cenomanian).

\section{Eusyringium fistuligerum (Ehrenberg)} (Plate 32, Figure 3)

Eucyrtidium fistuligerum Ehrenberg, 1873,p. 229; 1875, pl.9, fig. 3 . Eucyrtidium sipho Ehrenberg, 1873, p. 233; 1875, pl. 9, fig. 2 .

Eusyringium fistuligerum (Ehrenberg) Haeckel, 1887, p. 1497; Riedel and Sanfilippo, 1970, p. 527, part.; Riedel and Sanfilippo, in press, pl. 3B, fig. 14; Moore, in press, pl. 4, fig. 10, part.

Abdomen (without siphon) more than $120 \mu$ long and no less than $120 \mu$ broad.

Eocene.

\section{Eusyringium tubulus (Ehrenberg)} (Plate 32, Figures 4, 5)

Eucyrtidium tubulus Ehrenberg, 1854, pl. 36, fig. 19; 1873, p. 233; 1875 , pl. 9 , fig. 6 .

Eusyringium fistuligerum (Ehrenberg) Moore, in press, pl. 4, fig. 11, part.

Abdomen up to $100 \mu$ long (without siphon) and up to $90 \mu$ broad.

Eocene.

In the Early Oligocene a small, aberrant form of this species existed (Plate 32, Figure 5).

\section{Genus LITHOCAMPIUM Haeckel}

Lithocampium Haeckel, 1881 , p. 437; 1887, p. 1504; non Campbell, 1954 , p. 141 , but Riedel, 1959b, p. 16. Type species Lithocampe diploconus Haeckel (1887, pl. 77, fig. 3).

The type species of this genus (Plate 26, Figure 12) is similar to the genus Artocyrtis Haeckel (Plate 26, Figure 11) in the proportions of the test. But Artocyrtis has no longitudinal ribs on the surface that separate the rows of pores. In the other species (Lithocampium sp. A) the thorax is smaller. These species are similar to Eusyringium striata. The difference between Lithocampium and Eusyringium lies in the segmentation of the post-thoracic part of the test.

\section{Lithocampium sp. A}

Lithocampium sp. A, Riedel and Sanfilippo, in press, pl. 7, fig. 12. Paleocene.

\section{Lithocampium (?) sp. B}

(Plate 32, Figures 6, 7)

This species is similar to Eusyringium striata in the ratio of the segments, and in the size and disposition of the pores. The difference is in the presence of an internal ring (or shelf) dividing the abdomen into two parts (or separating the abdomen from a short fourth segment). This segment is very much like the siphon of typical Eusyringium. This species differs from Lithocampium sp. A by the greater number of pores and by the distinct longitudinal disposition of the pores.

Miocene. 
Lithocampium diploconus (Haeckel) group (Plate 26, Figure 12)

Lithocampe diploconus Haeckel, 1887, p. 1505, pl. 77, fig. 3 . About 13 to 15 longitudinal rows of pores on the thorax, sometimes continuing on the surface of the first post-thoracic segment and even on the second post-thoracic segment. The first post-thoracic segment is about $40-50 \mu$ long. It may be a little broader than the thorax, convex, as a very short, flattened waterbarrel, or it may be nearly cylindrical and even narrower than the thorax.

Oligocene-Low Miocene.

\section{Genus DICTYOMITRA Zittel}

Dictyomitra Zittel, 1876, p. 80; Haeckel, 1887, p. 1476; Campbell, 1954 , p. 140 ; Foreman, 1968 , p. $63 .=$ Dictyomitroma Haeckel, 1887 , p. 1478 ; Campbell, 1954 , p. 140 . Type species Dictyomitra multicostata Zittel (1876, pl. 11, figs. 2-4).

Stichomitra Cayeux 1897, p. 204; Campbell, 1954, p. 140. Type species Stichomitra costata Cayeux (1897, pl. 8, fig. 68).

Diplostrobus Squinabol, 1904, p. 140; Campbell 1954, p. 140. Type species Diplostrobus crassispina Squinabol (1904, pl. 8, fig. 37). Longitudinal ribs on the shell surface.

Cretaceous.

Dictyomitra crassispina (Squinabol)

(Plate 2, Figure 4)

Diplostrobus crassispina Squinabol, 1904 , p. 140 , pl. 8, fig. 37. Cretaceous (Albian ?-Cenomanian).

\section{Dictyomitra costata (Squinabol)}

(Plate 2, Figure 3)

Stichophormis costata Squinabol, 1904, p. 136, pl. 8, fig. 41 . Cretaceous (Albian?-Cenomanian).

\section{Dictyomitra (?) disparlita Kh. Aliev}

Dictyomitra ? disparlita Kh. Aliev, 1961, p. 59, pl. 2, fig. 2;1963, p. 46 , pl. 8 , fig. 2 , pl. 14 , fig. 8 .

Cretaceous (Albian-Cenomanian).

\section{Dictyomitra veneta (Squinabol)}

(Plate 2, Figure 2)

Phormocyrtis veneta Squinabol, 1904, p. 134, pl. 9, fig. 30. Cretaceous (Albian?-Maestrichtian).

\section{Dictyomitra pseudomacrocephala Squinabol} (Plate 2, Figure 5)

Dictyomitra pseudomacrocephala Squinabol, 1904, p. 139, pl. 10, fig. 2 .

Dictyomitra sagitafera Kh. Aliev, 1961, p. 25, pl. 1, figs. 1-3; 1965 , p. 55 , pl. 10, figs. $2-4$.

Cretaceous (Albian?-E. Campanian).

\section{Dictyomitra sp. A \\ (Plate 2, Figure 12)}

Similar to Dictyomitra duodecimcostatas Squinabol, but differs by the broader shell. The fourth, or the fifth, or the sixth segment may be inflated.

Cretaceous (Maestrichtian).

\section{Dictyomitra duodecimcostata Squinabol group} (Plate 2, Figures 10, 11)

Lithostrobus duodecimcostatus Squinabol, 1904, p. 138, pl. 10, fig. 21.

Cretaceous (Lower Campanian).

\section{Dictyomitra striata Lipman}

(Plate 8, Figures 12,13)

Dictyomitra striata Lipman, 1953, p. 41, pl. 3, figs. 12-14; Kh. Aliev, 1965, pl. 10, fig. 6; Kozlova and Gorbovetz, 1966, p. 116, pl. 6 , figs. $2-5$.

?Dictyomitra lamellicostata Foreman, 1968, p. 65, pl. 7, figs. 8, a, b.

The absence of apertural teeth and proximal costal lamellae in $D$. striata seem to be the result of poor preservation of the specimens described as $D$. lamellicostata.

Cretaceous (Campanian-Maestrichtian).

\section{Dictyomitra multicostata Zittel}

(Plate 8, Figures 9, 10)

Dictyomitra multicostata Zittel, 1876, p. 81, pl. 2, figs. 2-4; Campbell and Clark, 1944b, p. 39, pl. 8, fig. 42, part.; Foreman, 1968 , p. 63, pl. 7, figs. 9 , a, b.

Cretaceous (Albian-Maestrichtian).

\section{Dictyomitra ornata Kh. Aliev}

(Plate 8, Figure 8)

Dictyomitra ornata Kh. Aliev, 1961, p. 29, pl. 1, figs. 6, 7, 1965, p. 53 , pl. 9, figs. 9, 10 .

There are several pores (instead of one as in D. multicostata) in a longitudinal furrow on a segment.

Cretaceous (Albian-Maestrichtian).

\section{Dictyomitra ? sp. aff. D. regina (Campbell and Clark)} (Plate 8, Figure 11)

?Lithomitra regina Campbell and Clark, 1944 b, p. 41 , pl. 8 , figs. 30 , 38,40 .

?Dictyomitra regina (Campbell and Clark), Foreman, 1968, p. 68, pl. 8 , figs. 5 a-c.

?Dictyomitra crebrisulcata Squinabol, 1904, p. 231, pl. 10, fig. 11. There are several pores on a segment in a longitudinal row, as in D. ornata. What is more, there are no distinct external constrictions separating the segments, and the outline of the test is very much as in Eucyrtidium species.

Cretaceous (Campanian-Maestrichtian).

\section{Dictyomitra? sp. aff. Stichocapsa tecta Rüst} (Plate 2, Figure 14)

?Stichocapsa tecta Rüst, 1885 , p. 318, pl. 41, fig. 11.

The difference from typical Dictyomitra is the same as is mentioned for Dictyomitra sp. aff. D. regina. It differs from Stichocapsa species by the disposition of pores and the outline of the test. It differs from Rüst's specimens by the number of segments and the smaller pores.

Cretaceous (E. Campanian).

\section{Dictyomitra tiara Holmes (Plate 2, Figure 8)}

Dictyomitra tiara Holmes 1900, p. 702, pl. 38, fig. 4 .

Dictyomitra ordinaria Kh. Aliev, 1965, p. 51, pl. 9, fig. 4.

Dictyomitra carpatica Lozynyak, 1969, p. 38, pl. 2, figs. 11-13. This species is distinguished by the ribs, which do not extend from segment to segment, but are interrupted. Cretaceous (Albian-Cenomanian).

Family PLECTOPYRAMIDIDAE Haecker, emend. Petrushevskaya

Plectopyramidae Haecker, 1908, p. 457; Petrushevskaya, 1971a, p. $986 ; 1971$ b, p. 225.

Small dome-shaped cephalis and a vast thorax. Pores are disposed on the thorax in distinct longitudinal rows. Internal spines nearly reduced.

Remark: It is very likely that such species as Lithapium (?) mitra (?) Riedel and Sanfilippo, 1970, pl. 4, figs. 6, 7 belong in the Plectopyramidinae.

\section{Genus CORNUTELLA Ehrenberg, emend. Petrushevskaya}

Cornutella Ehrenberg, 1838, p. 128; Haeckel, 1881, p. 427; 1887, p. 1180 (non Campbell, 1954, p. 121); Petrushevskaya, 1971b, p. 212. = Cornutissa Haeckel, 1881 , p. $427 ; 1887$, p. 1181 ; Campbell, 1954 , p. 121. Type species Cornutella clathrata Ehrenberg, 1838; 1854 , pl. 22, fig. 39.

Cornutanna Haeckel, 1881 , p. 427 ; 1887, p. 1183; Campbell, 1954, p. 121. Type species Cornutanna ortoconus Haeckel (1887, unfigured).

Cornutosa Haeckel, 1881, p. 427; Campbell, 1954, p. 121. Type species Cornutura spiralis Haeckel, 1881, unfigured.

Cornutellium Haeckel, 1881, p. 430; 1887, p. 1293; Campbell, 1954 , p. $121 .=$ Ceratarachnium Haeckel 1887 , p. 1293. Type species Cornutella trochus Ehrenberg (1872b, pl.9, fig. 14).

Cornutellium Haeckel, 1887, p. 1180 (non Campbell 1954, p. 121, but Riedel, $1959 \mathrm{~b}$, p. 10. Type species Cornutella hexagona Haeckel, 1887 , pl. 54, fig. 9. 
Ortocornutana Clark and Campbell, 1945; Campbell, 1954, p. 121. Type species Cornutanna orthoconus Haeckel, 1887, unfigured. Cretaceous-Recent.

Cornutella sp. aff. C. californica Campbell and Clark (Plate 30, Figure 10)

?Cornutella californica Campbell and Clark, 1944b, p. 22, pl. 7, figs. $33,34,42$, 43; Foreman, 1968, p. 21, pl. 3, fig. 1b, part.

Long, narrow skeleton somewhat irregular in outline (up to $300 \mu$ long and up to $70 \mu$ broad without a horn). Up to six pores on the half equator of the shell.

Eocene-Oligocene.

Cornutella clava Petrushevskaya, sp. nov.

(Plate 30, Figures 11, 16)

Somewhat similar to Cornutella sp. aff. $C$. californica, but broader (up to $100 \mu$ broad). It is distinguished 1) by the strange shape of its apical horn, resembling a mace, and 2) by a ridge (may be a foot produced by spine $D$ ) on the surface of the shell.

The description is based on five specimens from 139-5-CC and $140 \mathrm{~A}, 2-6 \mathrm{~cm}, 80-82 \mathrm{~cm}$.

"Clava" is a Latin noun, feminine, meaning "a mace".

Oligocene.

\section{Cornutella stiligera Ehrenberg group}

(Plate 30, Figures 14, 15)

Cornutella stiligera Ehrenberg, 1854, pl. 36, fig. 1; 1875, pl. 3, fig. 3 .

It is distinguished by its straight outline. Up to $220 \mu$ long (without a horn), and up to $70 \mu$ broad.

Oligocene.

\section{Cornutella bimarginata (Haeckel) group} (Plate 30, Figures 13)

Sethoconus bimarginatus Haeckel, 1887 , p. 1295, pl. 57, fig. 12; Petrushevskaya, 1967, p. 106, pl. 59, fig. 4.

Sethoconus subtilis Carnevale, 1908, pl. 4, fig. 16.

Sethoconus woodfordi Campbell and Clark, 1944, p. 44, pl. 6, fig. 8; Nakaseko, 1963 , p. 174 , text-fig. 7, pl. 7, fig. 8 .

Miocene-Recent.

\section{Cornutella clathrata Ehrenberg}

(Plate 30, Figures 16, 17)

Cornutella clathrata Ehrenberg, 1844a, p. 77, 1854, pl. 22, fig. 39, part.

Pores are disposed somewhat irregularly, and the outline of the shell is irregular. The test may be curved. Up to $200 \mu$ long (without a horn), and up to $60-70 \mu$ broad.

Oligocene.

\section{Cornutella profunda Ehrenberg}

(Plate 30, Figures 18, 19)

Cornutella clathrata $\beta$ profunda Ehrenberg, 1854, pl. 35B, IV, fig. 24 .

Cornutella verrucosa Ehrenberg, 1872a, p. $287 ; 1872$ b, pl. 9, fig. 16; Petrushevskaya, 1967 , p. 109 , pl. 61 , figs. $1-4$

It is distinguished by having the smallest dimensions, by the weak apical horn, and by the number and disposition of pores. Miocene-Recent.

\section{Cornutella longisetta Ehrenberg (Plate 30, Figure 8)}

Cornutella longisetta Ehrenberg, 1872a, p. 287; 1872b, pl. 9, fig. 15 ; Petrushevskaya, 1967 , p. 110 , pl. 62 , figs. 1,2 .

Distinguished by its large cephalis.

Oligocene?-Recent.

\section{Genus PERIPYRAMIS Haeckel}

Peripyramis Haeckel, 1881, p. 428; 1887, p. 1162; Campbell, 1954, p. 119; Riedel, 1958 , p. 231. Type species Peripyramis circumtexta Haeckel, 1887 , pl. 54, fig. 5 .

??Spongopyramis Haeckel, 1887, p. 1260; Campbell, 1954, p. 128. Type species Plectopyramis spongiosa Haeckel, 1881 (1887, pl. 56 , fig. 10 ).
Quadrangular pores are disposed in longitudinal, but not in transverse, rows.

\section{Peripyramis magnifica (Clark and Campbell)} (Plate 31, Figure 3)

Sethopyramis magnifica Clark and Campbell, 1942, p. 72, pl. 8, figs. $1,5,9$.

Somewhat similar to Bathropyramis quadrata Haeckel, and at the same time to Lithapium (?) mitra (?) Riedel and Sanfilippo, 1970 (Plate 34, Figure 3). The difference lies in the disposition and outline of the pores.

Eocene.

\section{Peripyramis woodringi (Campbell and Clark)} (Plate 31, Figure 10)

Bathropyramis woodringii Campbell and Clark, 1944a, p. 39, pl. 5, figs. 21,22 ; Riedel, 1953 , p. 810 , pl. 85 , fig. 6 .

?Cinclopyramis infundibulum Haeckel, 1887, p. 1161, pl. 54, fig. 7. The ribs of the thorax are divergent for up to $200 \mu$ of their length.

Miocene.

\section{Peripyramis circumtexta Haeckel (Plate 31, Figure 4)}

Peripyramis circumtexta Haeckel, 1887, p. 1162, pl. 54, fig. 5; Riedel, 1958 , p. 231, pl. 2, figs. 8, 9; Petrushevskaya, 1967, p. 113 , pl. 64 , figs. 1,2 .

?Bathropyramis ramosa Haeckel, 1887, p. 1161, pl. 54, fig. 4.

?Bathropyramis reticulata Vinassa, 1900, p. 579, pl. 2, fig. 22

The ribs of the thorax are divergent for only up to $100-150 \mu$ of their length, they then become parallel and even convergent. Miocene-Quaternary.

\section{Genus BATHROPYRAMIS Haeckel}

Bathropyramis Haeckel, 1881, p. 428; 1887, p. 1159; Campbell, 1954 , p. $118 .=$ Acropyramis Haeckel, 1887 , p. 1159 ; Campbell, 1954, Type species not Bathropyramis acephala Haeckel, 1887, unfigured, but Bathropyramis quadrata Haeckel, 1887, pl. 54, fig. 1 .

Cephalopyramis Haeckel, 1881, p. 432; 1887, 1253; Campbell, 1954 , p. 127 . Type species Cephalopyramis enneactis Haeckel, 1881 (1887, pl. 56, fig. 7).

Sethopyramis Haeckel, 1887, p. 1253; Campbell, 1954, p. 127. Type species Cornutella scalaris Ehrenberg, 1873 (1875, pl. 2, fig. 1).

Not only longitudinal, but also transverse rows or pores are distinct. The inner rings separating the transverse rows of pores are somewhat like the "shelves" in Dictyomitra species. Cretaceous-Recent.

?Bathropyramis sanjoaquinensis Campbell and Clark (Plate 7, Figure 20)

?Bathropyramis sanjoaquinensis Campbell and Clark, 1942, p. 22, pl. 7 , fig. 2 .

Cretaceous (Campanian-Maestrichtian).

\section{Bathropyramis sp. aff. B. spongiosa (Haeckel)} (Plate 31, Figure 8)

?Plectopyramis spongiosa Haeckel, 1881; Prodromus, 1887, p. 1261 , pl. 56 , fig. 10 .

If this form is really Plectopyramis spongiosa-type species of the genus Spongopyramis-the latter must be regarded as a synonym of Bathropyramis, not of Peripyramis. "Spongy" envelope is characteristic for both Peripyramis and Bathropyramis species. Oligocene.

\section{Bathropyramis scalaris (Ehrenberg)} (Plate 31, Figure 6)

Cornutella scalaris Ehrenberg, 1873, p. 221; 1875, pl. 2, fig. 1 .

?Sethopyramis pulcherrima Clark and Campbell, 1945, p. 39, pl. 6, fig. 3 .

Eocene. 
Bathropyramis aeshna Petrushevskaya sp. nov. (Plate 31, Figures 1, 2)

Description is based on four specimens from $138-2-2,80-81 \mathrm{~cm}$ and $2-4 \mathrm{~cm}, 5-7 \mathrm{~cm}$.

Similar to $B$. sclaris in nearly all features except for the armature of the cephalis: it is not "spongy", but there are two long horns, directed as two wings. That is why the species name means "beam". Oligocene.

Family LYNCHNOCANIIDAE Haeckel, emend. Petrushevskaya

Lychnocanida Haeckel, 1881, p. 432; Petrushevskaya, 1971b, p. 227.

Eucyrtidioidea with usually three-segmented shell. As a rule the apical horn is stout. Three feet or legs, produced by the inner spines $D, L 1$ and $L r$. This group seems very likely to have evolved from Eucyrtidiidae, but is probably polyphyletic.

\section{Genus STICHOPILIDIUM Haeckel}

Stichopilidium Haeckel, 1887, p. 1438; Campbell, 1954, p. 136; Foreman, 1968, p. 70. Type species Stichopilium macropterum Haeckel, 1887. = ?Rhopalocanium sp. Bury, 1862, pl. 17, fig. 7 .

Four- or multi-segmented skeleton, similar to that of Stichocapsa, Lithocampe or Stichocorys. The difference lies in the presence of three feet going from abdomen or from the second post-thoracic segment.

Cretaceous-Paleocene.

\section{Stichopilidium sphinx (Ehrenberg)} (Plate 27, Figure 1)

Pterocanium ? sphinx Ehrenberg, 1873, p. 255; 1875, pl. 17, fig. 5 . Eocene.

\section{Genus LITHOCHYTRIS Ehrenberg}

Lithochytris Ehrenberg, 1847 b, p. 54; Haeckel, 1887, p. 1362; Campbell, 1954, p. 132. =' Lithocytridium Haeckel, 1887, p. 1363; Campbell, 1954, p.132. Type species Lithochytris vespertilio Ehrenberg (1875, pl. 4, fig. 10).

As a rule two segments only, the second being enormously large.

\section{Subgenus LITHOCHYTRODES Haeckel}

Lithochytrodes Haeckel, 1887, p. 1362; Campbell, 1954, p. 132. Type species Lithochytris pyriformis Haeckel (1887, pl. 61, fig. 11).

?Sethochytris Haeckel, 1881, p. 433; 1887, p. 1239; Campbell, 1954, p. 124. Type species Sethochytris triconiscus Haeckel (1887, pl. 57, fig. 13).

In contrast to the nominative subgenus, in the subgenus Lithochytrodes the feet are solid spines, more or less pronounced, sometimes absent. The thorax is pear-shaped. It seems to be composed of thorax plus abdomen.

Paleogene.

\section{Lithochytris (Lithochytrodes) sp. A (Plate 27, Figure 2)}

The second segment has a rather wide opening. A delicate third segment, short and cylindrical in shape, may be developed.

Paleogene.

\section{Lithochytris (Lithochytrodes) sp. T} (Plate 27, Figure 6)

Theoperid gen. sp. indet. Riedel and Sanfilippo, 1970, pl. 8, fig. 10 . Similar to Lithochytris sp. A, but the opening of the second segment is less. About fifteen pores on a half equator of the second segment.

Eocene.

Lithochytris (Lithochytrodes) turgidulum (Ehrenberg) (Plate 27, Figures 8,9)

Lychnocanium turgidulum Ehrenberg, 1873 , p. $245 ; 1875$, pl. 7, fig. 6 .

?Lychnocanium pyriforme Haeckel, 1887, p. 1225, pl. 61, fig. 11 . Similar to Lithochytris sp. T, but the number of pores is less and the feet are shorter.

Eocene.
Lithochy tris (Lithochytrodes) sp. aff. L. ventricosa (Ehrenberg) (Plate 27, Figures 3, 4)

?Anthocyrtis ventricosa Ehrenberg, 1873, p. $217 ; 1875$, pl. 8, fig. 1 . Similar to Lithochytris sp. T, but the feet are reduced. About 17 pores on the half equator of the second segment. Eocene-Oligocene.

Lithochytris (Lithochytrodes) sp. 0

(Plate 27, Figure 7)

Very much the same as Lithochytris sp. aff. L. ventricosa, but there is no opening, the second segment being closed.

Eocene.

Lithochytris (Lithochytrodes) sp. aff. L. tripodium Ehrenberg (Plate 27, Figure 5)

?Lithochytris tripodium Ehrenberg, 1873, p. 239; 1875, pl. 4, fig. 11.

?Dictyophimus babylonis Clark and Campbell, 1942, p. 67, pl. 9, figs. 32,36 .

Sethochytris babylonis (Clark and Campbell) group, Riedel and Sanfilippo, 1970 , p. 528 , pl. 9, figs. 1-3,; Moore, in press, pl. 3, figs. 9,10 .

Eocene-Oligocene.

\section{Genus PTEROCYRTIDIUM Bütschli}

Pterocyrtidium Bütschli, 1882 , p. 531 ; non Haeckel, 1887 , p. 1316 ; non Campbell, 1954, p. 136. Type species Pterocanium barbadense Ehrenberg (1875, pl. 17, fig. 6).

Small cephalis, and nearly spherical thorax separated from abdomen. Abdomen cylindrical, of equal breadth or narrower than thorax. Feet originate from the lower part of the thorax. Paleogene.

\section{Pterocyrtidium barbadense (Ehrenberg) group} (Plate 27, Figures 18, 19)

Pterocanium barbadense Ehrenberg, 1873, p. 254; 1875 , pl. 17, fig. 6 .

Eocene-Oligocene.

\section{Genus RHOPALOCANIUM Ehrenberg}

Rhopalocanium Ehrenberg, 1847b, p. 54; Haeckel, 1887, p. 1359; Campbell, 1954, p. 132. Type species Rhopalocanium ornatum Ehrenberg (1854, pl. 34, fig. 9).

Similar to Pterocyrtidium, but the feet originate from the abdomen.

Paleogene,

\section{Rhopalocanium ornatum Ehrenberg}

(Plate 27, Figures 13, 14)

Rhopalocanium ornatum Ehrenberg, 1854, pl. 36, fig. 9; 1875, pl. 17 , fig. 8.

Eocene.

\section{Genus PTEROCANIUM Ehrenberg}

Pterocanium Ehrenberg, 1847 b, p. 54 ; Haeckel 1881, p. 436; 1887 , p. 1328; Campbell, 1954, p. 130; Petrushevskaya, 1971b, p. 228. = Pterocanarium Haeckel, 1887, p. 1329; Campbell, 1954, p. 130. Type species Pterocanium proserpinae Ehrenberg (1872b, pl. 11 , fig. 220.

Similar to Pterocyrtidium and Rhopalocanium in the proportions of the shell. The feet originate from the lower part of the thorax, but they are included in the abdominal walls. The difference from Pterocyrtidium and Rhopalocanium lies in the character of the walls of the thorax and abdomen. The thorax in Pterocanium has thick walls with rather large pores. The abdomen has thin walls with irregular pores of various sizes. The abdomen may be nearly reduced; sometimes it is broken.

Neogene-Recent.

$$
\text { Pterocanium (?) satelles (Kozlova) }
$$

?Pterocanium pyramis Haeckel, 1887, p. 1330 , pl. 68 , fig. 7 .

?Theopodium satelles Kozlova in Kozlova and Gorbovetz, 1966, p. 105 , pl. 16 , fig. 8 . 
Differs from the type species of Theopodium Haeckel $1881(T$. tricostatum Haeckel, 1887, pl. 97, fig. 14, indicated by Campbell 1954 , fig. 67-5) by smaller pores on the abdomen. Siberian specimens have fewer and larger pores than Leg 14 specimens.

Paleocene-Eocene.

\section{Pterocanium (?) sp. aff. prismatium}

(Plate 27, Figures 10,11)

Having a similar outline and nearly the same size as Pterocanium prismatium Riedel, this species seems to be an ancestor of that well-known species. Abdomen undeveloped.

Oligocene-Miocene, rare.

\section{Genus DICTYOPHIMUS Ehrenber}

Dictyophimus Ehrenberg, 1847 b, p. 53; Haeckel, 1881, p. 432; 1887 , p. 1195 ; non Campbell, 1954, p. 122; but Nigrini, 1967 , p. 66. = Dictyophimium Haeckel, 1887, p. 1195. Type species

Dictyophimus crisae Ehrenberg, =D. arabicus Ehrenberg (1872b, pl. 10, fig. 3).

Differs from Pterocyrtidium and Rhopalocanium by the conical shape of the test (instead of cylindrical or ellipsoidal). Differs from Pterocanium by the smaller number of pores on the thorax. Thorax may not be distinctly separated from abdomen (without inner shelf or ring).

Eocene-Recent.

\section{Dictyophimus pocillum Ehrenberg} (Plate 29, Figure 5)

Dictyophimus pocillum Ehrenberg, 1873, p. $223 ; 1875$, pl. 5, fig. 6 . Eocene-Oligocene.

\section{Dictyophimus sp. aff. D. hirundo Haeckel}

(Plate 27, Figures 16,17)

?Pterocorys hirundo Haeckel, 1887, p. 1318, pl. 71, fig. 4; Riedel, 1958, p. 238, pl. 3, fig. 11: pl. 4, fig. 1; Petrushevskaya, 1967, p. 115 , pl. 67 , figs. $1-5 ; 1971 \mathrm{~b}$, pl. 111 , figs. $4-5$.

?Dictyophimus triserratus Haeckel 1887, p. 1200, pl. 61, fig. 17; Petrushevskaya, $1971 \mathrm{~b}$, pl. 111, figs. 2-3.

Differs from the Antarctic specimens by the weak apical horn.

Pliocene-Quaternary.

\section{Genus ARCHIPILIUM Haeckel}

Archipilium Haeckel, 1881 , p. 427 ; 1887, p. 1139; Campbell, 1954, p. 117. Type species Archipilium orthopterum Haeckel, 1887, pl. 98 , fig. 7 .

Similar to Dictyophimus in all characteristics, but there is no apical horn.

Tertiary.

\section{Archipilium sp. aff. A. macropus (Haeckel)}

(Plate 29, Figure 14)

?Sethopilium macropus Haeckel, 1887, p. 1203, pl. 97 , fig. 9.

Pliocene.

Remark: Specimens similar to this species occur in the Oligocene (Plate 29, Figure 13).

\section{Genus PTEROPILIUM Haeckel}

Pteropilium Haeckel, 1881, p. 435; 1887, p. 1326; Campbell, 1954 , p. 130. Type species Pteropilium stratiotes Haeckel, 1887, pl. 70 , fig. 9 .

Being multi-segmented, this genus is similar to Stichopilidium. It differs from Stichopilidium in the dimensions of the shell, primarily in the dimensions of the thorax and abdomen (up to 70-100 $\mu$ broad, instead of about $120 \mu$ ). The distinguishing characteristic is the construction of the feet. They arise from the thorax, and may be solid or hollow. There may be framework plates between the apical horn and feet-very much the same as in Sethoperidae. The feet are directed laterally.

Tertiary.

Pteropilium sp. B

(Plate 29, Figure 12)

Somewhat similar to Lychnocanium tridentatum Ehrenberg, (1875, pl. 7, fig. 4), but the feet are hollow at their base. The "sethoperid" plates are distinct.

Miocene.
Pteropilium (?) sp. group aff. Pterocanium continguum Ehrenberg (Plate 29, Figures 8-10)

?Pterocanium continguum Ehrenberg, 1873, p. 255; 1875, pl. 17, fig. 7.

The specimens are similar to $P$. continguum (Plate 29, Figure 11) in the two upper segments (they are somewhat smaller and have fewer pores). They are distinguished by the abdominal and post-thoracic part of the test, which is very much the same as in Eucyrtidiidae gen. sp. "rocket" (Plate 28, Figures 2, 3).

Oligocene.

\section{Genus LYCHNOCANIUM Ehrenberg}

Lychnocanium Ehrenberg, 1847b, p. 54; Haeckel, 1881, p. 432; 1887 , p. 1224; Campbell, 1954 , p. 124; Riedel and Sanfilippo, 1970 , p. 529 , part. = Lychnocanissa Haeckel, 1887, p. 1226 ; Campbell, 1954 , p. 124. Type species Lychnocanium falciferum Ehrenberg (1854, pl. 36, fig. 7).

Fenestracantha Bertolini, 1935; Campbell, 1954, p. 124. Type species

Three segments, thorax being separated from abdomen by an external constriction and an inner ring. The thorax and the abdomen have different walls, as in Pterocanium. The difference from Pterocanium is in the position of the feet. As in Pteropilium, they originate from the thorax and are not included into the walls of the abdomen.

Eocene-Quaternary.

\section{Lychnocanium bellum Clark and Campbell} (Plate 29, Figure 1)

Lychnocanium bellum Clark and Campbell, 1942, p. 72, pl. 9, figs. 35, 39; Riedel and Sanfilippo, 1970, p. 529.

Eocene.

\section{Lychnocanium tripodium Ehrenberg}

(Plate 29, Figure 2)

Lychnocanium tripodium Ehrenberg, 1873, p. 245; 1875, pl. 7, fig. 2.

Eocene.

\section{Lychnocanium hirundo Ehrenberg}

(Plate 29, Figure 3)

Lychnocanium hirundo Ehrenberg, 1856, pl. 36, fig. 6; 1875, pl. 7, fig. 8.

Thorax about $70-80 \mu$ long and $90-100 \mu$ broad. About 7 to 9 pores on the thorax between two feet. Feet three-edged, very long, curved.

Eocene-Oligocene.

\section{Lychnocanium sp.}

(Plate 29, Figure 7)

Very much the same as $L$. hirundo, but smaller in all dimensions. Eocene-Early Oligocene.

\section{Lychnocanium bipes Riedel}

Lychnocanium bipes Riedel, 1959, p. 294, pl. 2, figs. 5, 6; Riedel and Sanfilippo, 1970, p. 529, pl. 15, fig. 8.

Oligocene.

\section{Lychnocanium grande Campbell and Clark}

(Plate 29, Figure 6)

Lychnocanium grande Campbell and Clark, 1944a, p. 42, pl. 6 , figs. 3-6.

Cephalic wall without pores. About 8 to 9 pores on the thorax between feet. Feet three-edged, nearly straight. Oligocene-Miocene.

\section{Lychnocanium korotnevi (Dogiel)}

(Plate 29, Figure 16)

Pterocorys korotnevi Dogiel in Dogiel and Reshetnyak, 1952, p. 17, fig. 11 ; Petrushevskaya, 1962 , p. 338 , fig. $8 ; 1971$ b, pl. 111 , fig. 1 .

Thorax $40-55 \mu$ long and about $80 \mu$ broad. Cephalis poreless. Pliocene-Quaternary. 


\section{Genus BEKOMA Riedel and Sanfilippo}

Bekoma Riedel and Sanfilippo, in press. Type species Bekoma bidarfensis Riedel and Sanfilippo, in press, pl. 7, figs. 1-7. Similar in many features to Lychnocanium, but the construction of the collar region is somewhat different. Paleogene.

Bekoma bidarfensis Riedel and Sanfilippo

Bekoma bidarfensis Riedel and Sanfilippo, in press, pl. 7, figs. 1-7. Paleocene.

\section{Superfamily CANNOBOTRYOIDEA Haeckel}

Cannobotryidae Haeckel, 1881; Riedel, 1967b, p. 296; Petrushevskaya, 1971a, p. $988 ; 1971$ b, p. 154.

Polycyrtida Haeckel, 1862 , p. 341.

Botrida Haeckel, 1881, p. 439.

Botryodea Haeckel, 1887, p. 1105; Strelkov, Khabakov and Lipman, 1959, p. 444; Petrushevskaya, 1965, p. 79.

Cyrtida with the skeleton consisting of cephalis and thorax; other segments are very rare. Cephalis rather large comparted with the whole skeleton (up to one half its size). Cephalis consists of eucephalic and many additional lobes. Lobes are separated by internal walls. The arches $a p$ and $a l$ are included into these walls. Ante-cephalic lobe has two parts, named by H. Foreman (1968) "apical-dorsal" and "dorsal". The cephalis is separated from the thorax by a basal plate.

\section{Genus BOTRYOCELLA Haeckel}

Botryocella Haeckel, 1881, p. $440 ; 1887$, p. 1116 : Campbell, 1954 , p. 144: non Petrushevskaya, 1965 , p. 110; but Petrushevskaya, $1971 b$, p. 161.Type species Lithobotrys nucula Ehrenberg (1875, pl. 3, fig. 16).

Eucephalic lobe is nearly hidden, submerged into the antecephalic lobe. Post-cephalic part is smaller than ante-cephalic. Tubes of ante-cephalic lobe and of post-cephalic lobe, if present, are situated on the level of the basal plate.

Differs from Centrobotrys by the thickness of the test, by the pronounced separation into thorax and cephalis, and by the tubes near the basal plate. Centrobotrys seems very likely to originate from Botryocella.

Paleogene.

\section{Botryocella multicellaris Haeckel group}

(Plate 39, Figures 8, 10)

Botryocella multicellaris Haeckel, 1887, p. 1117, pl. 96, fig. 12. Botryocella sp. O, Petrushevskaya, 1971b, pl. 82, figs. 4-6.

Botryopyle dictyocephalus group Riedel and Sanfilippo, in press, $\mathrm{pl}$. 2J, fig. 18 ; pl. $3 \mathrm{~F}$, fig. 12 , part.

Botryopyle sp. A, Riedel and Sanfilippo, in press, pl. 2J, figs. 20, 21 , pl. 3F, fig. 13 .

Centrobotrys? sp. A, Riedel and Sanfilippo, in press, pl. 3F, figs. 15,16 .

The walls are thick, and the pores rather large. The apex of ante-cephalic lobe ovate in outline. Abdomen narrow, cylindrical. Oligocene.

Botryocella spp. aff. B. cribrosa (Ehrenberg) group (Plate 39, Figures 4-6)

?Lithobotrys cribrosa Ehrenberg, 1873, p. 237; 1875, pl. 3, fig. 20. Botryopyle dictyocephalus group Riedel and Sanfilippo, in press, pl. $2 \mathrm{~J}$, fig. 17 ; pl. $3 \mathrm{~F}$, fig. 10 , part.

The pores as a rule are smaller than in the B. multicellularis group. The apex of the ante-cephalic lobe is conical, even with a small tube. Abdomen in its upper part is nearly of the same breadth as the cephalis.

Oligocene-Early Miocene.

\section{Genus ACROBOTRYS Haeckel}

Acrobotrys Haeckel, 1881 , p. $440 ; 1887$, p. 1114 ; non Campbell, 1954 , p. 106; Petrushevskaya, 1965, p. 106. Type species Acrobotrys disolenia Haeckel (1887, pl. 96, fig. 10).

The upper part of the eucephalic lobe is on the surface of the skeleton. It is of nearly the same size as the ante-and post-cephalic lobes. Ante- and post-cephalic lobes have tubes situated higher than in Botryocella, that is, higher than the basal plate.

Oligocene-Pliocene.

Acrobotrys sp. aff. A. disolenia Haeckel

(Plate 39, Figures 3, 9)

?Acrobotrys disolenia Haeckel, 1887, p. 1114, pl. 96, fig. 10. Late Oligocene-Early Miocene.

\section{Acrobotrys sp. aff. A sphaerothorax Haeckel}

(Plate 39, Figures 1, 2)

?Lithobotrys sphaerothorax Haeckel, 1887, p. 1119, pl.96, fig. 15. Distinguished by two symmetrical pairs of tubes, on antecephalic and post-cephalic lobes.

Early Miocene.

\section{Genus BOTRYOCYRTIS Ehrenberg}

Botryocyrtis Ehrenberg, 1860, p. 829; Haeckel, 1881, p. 440; 1887 , p. 1120; Campbell, 1954; Petrushevskaya, 1965, p. 101. Type species Botryocyrtis caputserpentis Ehrenberg (1872b, pl. 10, fig. 21).

Acanthobotrys Popofsky, 1913, p. 314; Campbell, 1954, p. 143. Type species Acanthobotrys multispina Popofsky (1913, pl. 29, figs. 10,11 ; pl. 30 , fig. 5 ).

Monotubus Popofsky, 1913, p. 322; Campbell, 1954, p. 144; Petrushevskaya, 1965, p. 99. Type species Monotubus microporus Popofsky (1913, text-fig. 20).

Eucephalic, ante-cephalic and post-cephalic lobes of nearly the same size and shape. Thorax (and sometimes abdomen) are comparatively large. The surface of the skeleton is spongy.

Neogene-Quaternary.

\section{Botryocyrtis quinaria Ehrenberg group}

(Plate 39, Figure 7)

Botryocyrtis quinaria Ehrenberg, 1872a, p. 287; 1872b, pl. 10, fig. 16; Petrushevskaya, 1965 , p. 104, figs. 14,15 .

Botryocyrtis spp. Riedel and Sanfilippo, in press, pl. 1J, fig. 8, 11; pl. $2 \mathrm{~J}$, figs. 10,$11 ; \mathrm{pl} 3 \mathrm{~F}$, fig. 7 .

There is no separation into thorax and abdomen. The skeleton somwhat larger than in B. microporus (Popofsky). Miocene.

\section{REFERENCES}

Aliev, Kh. Sh., 1961. Novye vidy semeistva Porodiscidae iz otlozhenii valanzhina severo-vostochnogo Azerbaidzhana. Dokl. AN Azerb. SSSR. t. 17, No. 7. 1965. Radiolarii nizhnemelovykh otlozhenii severovostochnogo Azerbaidzhana i ikh stratigraficheskoe znachenie. Izd. AN Azerb. SSSR, Baku.

Bailey, J. W., 1856. Notice of microscopic forms found in the soundings of the sea of Kamtschatka. Am. J. Sci. Arts. ser. 2, XXII.

Bandy, O. L., Casey, R. E. and Wright, R. C., 1971. Late Neogene planktonic zonation, magnetic reversals and radiometric dates, Antarctic to the Tropics. Antarctic Research Series. (Biology, Antarctic Seas, IV), 15, Washington, pp. 1-26.

Burma, B. H., 1959. On the status of Theocampe Haeckel, and certain similar genera. Micropaleontology. 5 (3).

Bury, M., 1862. Polycystins, figures of remarkable forms in the Barbados chalk deposits. Atlas. London.

Bütschli, O., 1882. Beitrage zur Kenntnis der Radiolarienskelette, insbesondere der der Cyrtida. Zeitschr. Wiss. Zool. 36, pp. 485-540, pls. 31-33.

Campbell, A. S., 1954. Radiolaria. In: Treatise on Invertebrate Paleontology R. C. Moore. (Ed.) (Univ. Kansas Press and Geol. Soc Am.) Pt. D, Protista 3, pp. 11-163.

and Clark, B. L., 1944a. Miocene radiolarian faunas from Southern California. Geol. Soc. Am. Spec. Paper. (51), pp. i-vii and 1-76, pls. 1-7. 
1944b. Radiolaria from Upper Cretaceous of Middle California. Geol. Soc. Am. Spec. Paper. (57), pp. i-viii and 1-61, pls. 1-8.

Carnevale, P., 1908. Radiolarie e Silicoflagellati di Bergonzano (Reggio Emilia). Mem. R. 1st. Veneto Sci. Lett. Arti. 28 (3), pp. 1-46, pls. 1-4.

Clark, B. L. and Campbell, A. S., 1942. Eocene radiolarian faunas from the Mt. Diablo area, California. Geol. Soc. Am. Spec. Paper. (39).

1945. Radiolaria from the Kreyenhagen Formation near Los Banos, California. Mem. Geol. Soc. Am. 10, pp. i-vii and 1-66, pls. 1-7.

Deflandre, G., 1953. Radiolaires fossiles. In Traité de Zoologie. P.-P. Grassé (Ed.). Paris (Masson), 1, pt. 2, pp. 389-436.

Dogel, V. A. and Reshetnyak, V. V., 1952. Materialy po radiolariyam severo-zapadnoi chasti Tikhogo okeana. Issled. dalnevostochnykh morei SSSR. t. III.

Dreyer, F., 1889. Morphologische Radiolarienstudien. 1. Die Pylombildungen in vergleichend-anatomischer und entwicklungsgeschichtlịcher Beziehung bei Radiolarien und bei Protisten uberhaupt, nebst System und Beschreibung neuer und der bis jetzt bekannten pylomatischen Spumellarien. Jena. Zeitschr. Naturw. 23, new ser. vol. 16, pp. 1-138, pls. 1-6.

Dumitrica, P., 1970. Cryptocephalic and cryptothoracic Nassellaria in some Mesozoic deposits of Romania. Rev. Roum. Geol., Geophys et Geogr. Ser. Geol. 14 (1).

Ehrenberg, C. G., 1838. Über die Bildung der Kreidefelsen und des Kreidemergels durch unsichtbare Organismen. Abhandl. Preuss. Akad. Wiss. Jahrg. 1838.

1844a. Über 2 neue Lager von Gebirgsmassen aus Infusorien als Meeres-Absatz in Nord-Amerika und eine Vergleichung derselben mit den organischen KreideGebilden in Europa und Afrika. Monatsber, Kgl. Preuss. A kad. Wiss. Berlin. Jahrg. 1844, pp. 57-97.

1844b. Einige vorlaufige Resultate seiner Untersuchungen der ihm von der Südpolreise des Capitain Ross, so wie von den Herren Schayer und Darwin zugekommenen Materialien über das Verhalten des kleinsten Lebens in den Oceanen und den grössten bisher zugänglichen Tiefen des Weltmeeres. Monatsber. $\mathrm{Kgl}$. Preuss. Akad. Wiss. Berlin. Jahrg. 1844, pp. 182-207.

Ehrenberg, C. G., 1847a. Über eine halibiolithische, von Herrn R. Schomburgk entdeckte, vorherrschend aus mikroskopischen Polycystinen gebildete, Gebirgsmasse von Barbados. Monatsber. Kgl. Preuss. Akad. Wiss. Berlin. Jahrg. 1846 , pp. 382-385.

$1847 \mathrm{~b}$. Über die mikroskopischen kieselschaligen Polycystinen als mächtige Gebirgsmasse von Barbados und über das Verhältnis der aus mehr als 300 neuen Arten bestehenden ganz eigenthümlichen Formengruppe jener Felsmasse $\mathrm{zu}$ den lebenden Thieren und zur Kreidebildung. Eine neue Anregung zur Erforschung des Erdlebens. Monatsber. Kgl. Preuss. Akad. Wiss. Berlin. Jahrg. 1847 , pp. 40-60, 1 pl.

(1856).

1854. Mikrogeologie. Leipzig (Fortsetzung,

1858. Kurze Characteristik der 9 neuen Genera und der 105 neuen Species des ägäischen Meeres und des Tiefgrundes des Mittelmeeres. Monatsber. Kgl. Preuss. Akad. Wiss. Berlin. Jahrg. 1858.

$1860 \mathrm{a}$. Über die organischen und unorganischen Mischungsverhaltnisse des Meeresgrundes in 19,800 Fuss Tiefe nach Lieut. Brookes Messung. Monatsber. $\mathrm{Kgl}$. Preuss. Akad. Wiss. Berlin. Jahrg. 1860. 1860b. Über den Tiefgrund des stillen Ozeans zwischen Californien und den Sandwich-Inseln aus bis 15,600 Fuss Tiefe nach Lieut. Brookes. Monatsber. Kgl. Preuss. Akad. Wiss. Berlin. Jahrg. 1860, pp. 819-833.

1872a. Mikrogeologischen Studien als Zusammenfassung seiner Beobachtungen des kleinsten Lebens der Meeres-Tiefgründe aller Zonen und dessen geologischen Einfluss. Monatsber. Kgl. Preuss. Akad. Wiss. Berlin. Jahrg. 1872, pp. 265-322.

$1872 \mathrm{~b}$. Mikrogeologischen Studien über das kleinste Leben der Meeres-Tiefgrunde aller Zonen und dessen geologischen Einfluss. Abhandl. Kgl. Akad. Wiss. Berlin. Jahrg. 1872, pp. 131-399, pls. 1-12, 1 chart.

1973. Grössere Felsproben des PolycystinenMergens von Barbados mit weiteren Erlauterungen. Monatsber. Kgl. Preuss. Akad. Wiss. Berlin. Jahrg. 1873, pp. 213-263.

1875. Fortsetzund der mikrogeologischen Studien als Gesammt-übersicht der mikroskopischen Paläontologie gleichartig analysirter Gebirgsarten der Erde, mit specieller Rücksicht auf den Polycystinen-Mergel von Barbados. Abhandl. Kgl. Preuss. A kad. Wiss. Berlin. Jahrg. 1875, pp. 1-226, pls. 1-30.

Foreman, H. P., 1966. Two Cretaceous radiolarian genera, Micropaleontology. 12 (3), pp. 355-359.

1968. Upper Maestrichtian Radiolaria of California. Spec. Pap. Palaeontol. (Palaeontol. Ass., London), no. 3, 82 pp., 8 pls.

Frizzel, D. L. and Middour, E. S., 1951. Paleocene Radiolaria from Southeastern Missouri. Bull, Univ. Missouri School Mines Metall. Tech. ser. no. 77, pp. $1-41$, pls. $1-3$.

Goll, R. M., 1968. Classification and phylogeny of Cenozoic Trissocyclidae (Radiolaria) in the Pacific and Caribbean basins. Pt. I. J. Paleontol. 42 (6), pp. 1409-1432, pls. 173-176, 9 text-figs.

1969. Classification and phylogeny of Cenozoic Trissocyclidae (Radiolaria) in the Pacific and Caribbean basins. Pt. II. J. Paleontol. 43 (2), pp. 322-339, 6 pls. 2 text-figs.

Haeckel, E., 1860. Abbildungen und Diagnosen neuer Gattungen und Arten von lebenden Radiolarien des Mittelmeeres. Monatsber. Kgl. Preuss. Akad. Wiss. Berlin. Jahrg. 1860, pp. 835-845.

1862. Die Radiolarien (Rhizopoda Radiaria). Eine Monographie. Berlin (Reimer), xiv +572 pp., 35 pls.

1881. Prodromus Systematic Radiolarium. Entwurf eines Radiolarien-Systems auf Grund von Studien der Challenger-Radiolarien. Jena. Zeitschr. Naturw. 15 (new ser., vol. 8), no. 3, pp. 418-472.

1887. Report on the Radiolaria collected by H.M.S. Challenger during the years 1873-1876. Rep. Sci. Res. Voy. Challenger. 1873-1876, Edinburgh, Zool., t. XVIII, Pt. I, II.

Haecker, V., 1908. Tiefsee-Radiolarien. Wiss. Ergebn. $d$. Deutschen Tiefsee-Exped. Valdivia. 14, pp. 477-706, pls. $86-87,2$ charts.

Harting, P., 1863. Bijdrage tot de kennis der mikroskopische faune en flora van de Banda-Zee. Verh. Konkinkl. Akad. Wetensch. Amsterdam 10, pp. 1-34, pls. 1-3.

Hays, J., 1965. Radiolaria and Late Tertiary and Quaternary history of Antaractic seas. Antarctic Research Series. (Biol. Antarc. Seas, vol. 2) (A. Geophys. Union), 5, pp. 125-184. 
Saito, T., Opdyke, N. D. and L. H. Burckle, 1969. Pliocene- Pleistocene sediments of the equatorial Pacific: their paleomagnetic biostratigraphic and climatic record. Bull. Geol. Soc. A. 80 (8), pp. 1481-1514.

Hertwig, R., 1879. Der Organismus der Radiolarien. Jena G. Fischer, iv + 149 pp., 10 pls.

Hollande, A. and Enjumet, M., 1960. Cytologie, évolution et systematique des Sphaeroüés (Radiolaires). Arch. Mus. Natn. Hist. Nat. Paris.Ser. 7, 7, pp. 1-134, pls. 1-64.

Holmes, W. M., 1900. On Radiolaria from the Upper Chalk at Coulsdon (Surrey). Quart. J. Geol. Soc., London. 56.

Hülsemann, K., 1963. Radiolaria in plankton from the Arctic Drifting Station T-3, including the description of three new species. Arctic Inst. N. Am.., Tech. Pap. Arct. No. 13 , pp. 1-52.

Jörgensen, E., 1905. The protist plankton and the diatoms in bottom samples. Bergens Mus. Skr. pp. 49-151, $195-225$, pls. 6-18.

Kling, S. A., 1970. Radiolaria. In Initial Reports of the Deep Sea Drilling Project, Volume VI. Washington D. C., U. S. Government Printing Office, pp. 1069-1092.

Kozlova, G. E., 1967a. Tipy stroeniya radiolarii iz sem. Porodiscidae. Zool. Zhurn.t. 46, vyp. 8.

1967b. O filogeneticheskoi svyazi podotryadov Discoidea i Larcoidea (Radiolaria, Spumellaria). Zool Zhurn.t. 46, vyp. 9.

i Gorbovets, A. N. 1966. Radiolarii verkhnemelovykh i verkhne-eozenovykh otlozhenii ZapadnoSibirskoi nizmennosti, nedra. Vses. Neft. Nauchno-issled. Geol.-Razu Inst. No. 248, pp. 159, pls. 17.

Kruglikova, S. B., 1969. Radiolarii v kolonke St. 4066 (severnaya chast Tikhogo okeana). V sb. Osnovnye problemy mikropaleonotologii i organo-gennogo osadkonakopleniya v okeanakh i moryarch. M., Nauka Moscow. pp. 48-72.

Ling, H. Y. and Anikouchine, W. A., 1967. Some Spumellarian Radiolaria from the Java, Philippine and Mariana Trenches. J. Paleontol. 41 (6), pp. 1481-1491, pls. 189-192, 5 text-figs.

Lipman, R. Kh. 1952. Materialy k monograficheskomu izucheniyu radiolyarii verkhnemelovykh otlozhenii Russkoi platformy. Tr. VSEGEI, Paleontologiya i stratigrafiya.pp. 24-51, 3 pls.

1953. Novye dannye o radiolyariyakh Dalnego Vostoka. Tr. VSEGEI, Paleontologiya i stratigrafiya. pp. 126-146, 1 pl.

Loeblich, A. R. Jr. and Tappan, H., 1961. Remarks on the systematics of the Sarkodina (Protozoa), renamed homonyms and new and validated genera. Proc. Biol. Soc. Washington. 74, pp. 213-214.

Lozynyak, P. Yu., 1969. Radiolyarii nizhnemelovykh otlozhenii Ukrainskikh Karpat. V kn. Iskopaemye i sovremennye radiolarii. Ukrainian NIGRI Lvov. pp. 29-40, pls. 2.

Martin, G. C., 1904. Radiolaria. Maryland Geol. Surv. Gen. Ser., Baltimore. pp. 447-459.

Moore, T. G., 1971. Radiolaria. In Initial Reports of the Deep Sea Drilling Project Volume VIII.Washington D.C. (U.S. Government Printing Office) pp. 391-411.

Müller, J., 1858. Über die Thalassicollen, Polycystinen und Acanthometren des Mittelmeeres. Abhandl. Kgl. Preuss. Acad. Wiss. Berlin. Jahrg. 1858, pp. 1-62, pls. 1-11.

Nakaseko, K., 1955. Miocene radiolarian fossil assemblage from the Southern Toyama Prefecture in Japan. Sci. Repts., Osaka Univ. No. 4, pp. 65-127, pls. 1-11.
1963. Neogene Cyrtoidea (Radiolaria) from the Isozaki Formation in Ibaraki Prefecture, Japan. Sci Repts., Osaka Univ., 12 (2), pp. 165-198, pls. 1-4.

Nigrini, C., 1967. Radiolaria in pelagic sediments from the Indian and Atlantic Oceans. Bull. Scripps Inst. Oceanog. 11

1968. Radiolaria from eastern tropical Pacific sediments. Micropaleontology. 14 (1), pp. 51-63, pl. 1. 1970. Biostratigraphy. In Inital Reports of the Deep Sea Drilling Project, Volume II. Washington, D. C. (U. S. Government Printing Office) pp. 391-411.

Parona, C. F., 1890. Radiolarie nei noduli selciosi del calcare giurese di Cittiglio presso Laveno. Boll. Soc. Geol. Ital. 9, pt. 1, pp. 1-46, pls. 1-6.

Pessagno, E. A., 1963. Upper Cretaceous Radiolaria from Puerto Rico. Micropaleontology. 9 (2), pp. 197-214, pls. 1-7.

1969a. The Neosciadiocapsidae, a new family of upper Cretaceous Radiolaria. Bull. Am. Paleontol. 56 (253).

1969b. Mesozoic planktonic foraminifera and Radiolaria. In Initial Reports of the Deep Sea Drilling Project, Volume I. Washington, D. C. (U. S. Government Printing Office).

Petrushevskaya, M. G., 1962. Znachenie rosta skeleta radiolyarii dlya ikh sistematiki. Zool. Zhurn. t. XII, vyp. 3, pp. 331-341.

1965. Osobennosti konstruktsii skeleta radiolarii Botryoidae (otryad Nassellaria). Tr. Zool. In-ta $A N$ SSSR, t. XXXV.

1967. Radiolarii otryadov Spumellaria i Nassellaria Antarkticheskoi oblasti (po materialam Sovetskoi Antarkticheskoi ekspeditsii). Issled. fauny morei, t. IV (XII). Resultaty biol. issled. Sovetskoi Antarkticheskoi Ekspeditsii (1950-1958). vyp. 3, pp. 5-186.

1968a. Gomologii v skeletakh radiolarii Nassellaria. 1. Osnovnye dugi $\mathrm{v}$ semeistve Cyrtoidae. Zool. Zhurn. t. 47, vyp. 9.

1968 b. Gomologii v skeletakh radiolarii Nassellaria. 2. Osnovnye dugi slozhnoustroennykh tsefalisov Cyrtoidae i Botryoidae. Zool. Zhurn. t. 47, vyp. 12. 1969a. Raspredelenie skeletov radiolarii $v$ osadkakh severnoi Atlantiki. Sb. "Drevnie i sovremennye radiolarii". Izd. Lvovsk. Gos un-ta, Lvov.

1969 b. Spumelline and Nasselline Radiolarians in Bottom Sediments as Water-masses Indicators. In Micropaleontology and Organogenous sedimentation in the oceans. Nauka, Moscow. pp. 127-150.

1970. Prodolzhitelnost zhizni vidov radiolarii. Otchetnaya nauchnaya sessiya. Zool. Inst. AN SSSR, Leningrad. Str. 6-7.

1971a. On the nautral system of Polycystine Radiolaria. Proc. II Planktonic Conference, Rome.

1971b. Radiolarii Nassellaria v planktone Mirovogo Okeana. Issled. fauny morey, Leningrad,

Popofsky, A., 1908. Die Radiolarien der Antarktis. Deutsche Südpolar Expedition 1901-1903, Berlin. 10, (Zool. vol. 2), no. 3, pp. 183-305, 1 table, pls. 20-36.

1913. Die Nassellarien des Warmwassergebietes. Deutsche Südpolar Expedition 1901-1903, Berlin. 14, Zool., vol. VI, no. 11.

Principi, P., 1909. Contributo allo studio dei Radiolari Miocenici Italiani. Boll. Soc. Geol. Ital. 28, pp. 1-22, pl. 1

Riedel, W. R., 1957. Radiolaria: a preliminary stratigraphy. Rep. Swed. Deep-Sea Exped. 6 (3), pp. 59-96, pls. $1-4$. 
1958. Radiolaria in Antarctic sediments. Rep. B.A.N.Z. Antarct. Res. Exped. Ser. B, 6, pt. 10, pp. 217-255.

1959a. Oligocene and Lower Miocene Radiolaria in tropical Pacific sediments. Micropaleontology. 5 (3), pp. 285-302.

Riedel, W. R. 1959b. Preliminary draft of a petition to be submitted to the International Commission on Zoological Nomenclature. Scripps Institution of Oceanog. La Jolla, California.

1967a. Some new families of Radiolaria. Proc. Geol. Soc. London. No. 1640.

1967b. Class Actinopoda. In The Fossil Record. London (Geol. Soc. London).

and Sanfilippo, A., 1970. Radiolaria. In Initial Reports of the Deep Sea Drilling Project, Volume IV. Washington, D. C. (U. S. Government Printing Office) pp. $503-575,15 \mathrm{pl}$.

and Sanfilippo, 1971. Radiolaria. In Initial

Reports of the Deep Sea Drilling Project, Volume VII. Washington, D. C. (U. S. Government Printing Office) pp. $1529-1672,8$ pls.

Rüst, D., 1898. Neue Beiträge zur Kenntniss der fossilen Radiolarien aus Gesteinen des Jura und der Kreide. Palaeontographica. 45, pp. 1-67, pls. 1-19.

Sanfilippo, A. and Riedel, W. R., 1970. Post-Eocene "closed theoperid" radiolarians. Micropaleontology. 16 (4), pp. 446-462, 2 pls.

Seguenza, G., 1880. Le formazioni terziarie nella provincia di Reggio (Calabria) Formazione Pliocenica. Atti $R$. Accad. Lincei, 1879-1880. Ser. 3, Mem. cl. sci. fis. mat. nat., vol. 6 , pp. 1-446, pls. 1-17.

Squinabol, S., 1903. Le Radiolarie dei Noduli selciosi nella Scaglia degli Euganei. Riv. Ital. Paleont. 9, pp. 105-150, pls. 8-10.

1904. Radiolarie cretacee degli Euganei. Atti Memorie R. Accad. Sci. Lett. Arti Padova. New ser., vol. 20, pp. 171-244, pls. 1-10.

1914. Contributo alla conoscenza dei Radiolarii fossili del Veneto. Mem. 1st. R. Univ. Padova. 2, pp. 249-306, pls. 20-24.

Stöhr, E., 1880. Die Radiolarienfauna der Tripoli von Grotte, Provinz Girgenti in Sicilien. Palaeontographica. 26, (ser. 3, vol. 2), pp. 69-124, pls. 17-23 (1-7).

Strelkov, A. A., Khabakov, A. V., Lipman, R. Kh., 1959. Radiolarii. V kn. "Osnovy paleontologii", t. 1, Izd. AN SSSR, $M$.
Sutton, H. J., 1896. Radiolaria; a new genus from Barbados. Am. Month. Micros. J. 17, pp. 61-62.

Tan Sin Hok, 1927. Over de samenstelling en het onstaan van krijt-en mergelgesteenten van de Molukken. Jaarb. Mijnw. Ned.-Vost-Indië, jaarg. 1926, Verhand. Pt. 3, pp. 5-165, pls. 1-16.

Tochilina, S. V., 1970. Hexacyclia - novyi rod Spumellaria iz otlozhenii verkhnego eotsena Voronezhskoi anteklizy. $\mathrm{Tr}$. Voronezh. Universiteta.

Vinassa de Regny, P. E., 1900. Radiolari Miocenici Italiani. Mem. R. Accad. Sci. 1st Bologna. Ser. 5, 8, pp. 565-595, pls. 1-3.

Wetzel, O., 1935. Die Micropaleontologie des Heiligenhafener Kieseltones (Ober-Eozän). Niedersaechs. Geol. Verhandl., Jahresber. 27.

White, M. P., 1928. Some index foraminifer of the Tampico Embayment area of Mexico. Pt. II. J. Paleontol. 2 (4).

Zittel, K., 1876. Über fossile Radiolarien der oberen Kreide. Zeitschr. Deutsch. Geol. Gesellsch. 28.

\section{EXPLANATION OF PLATES}

The numbers following the identification of each figure indicate the locality of the illustrated specimen: number of the site, core, section ${ }^{5}$ and sometimes the interval within a section in centimeters. In most cases, the authors have included the text-page of the systematic section, where the references and the description may be found.

On the following plates, figures are at a magnification of 200X. Whether these photographs are of good or of poor quality, this magnification is not sufficient for most nassellarians, especially Neogene ones. Therefore, the representatives of different species and even genera may look alike to the investigator unacquainted with these species, if the specimens are examined under that magnification.

On the first eight plates are the assemblages of Cretaceous radiolarians. On the other plates (Plates 9 through 41) are Cenozoic radiolarians, more or less in systematic order.

\footnotetext{
${ }^{5}$ The sample $140-2-\mathrm{CC}$ is marked by $*$ because this section is Miocene, but the slide marked as "2-CC" contains Eocene radiolarians.
} 
Plate 1

Magnification 200X

Figure 1

Holocryptocapsa hindei

p. 541 $138-6-2,5-7 \mathrm{~cm}$.

Figure 2

Cryptamphorella sp. $138-6-3,77-79 \mathrm{~cm}$.

Figure 3

Holocryptocanium barbui $138-6-2,5-7 \mathrm{~cm}$.

Figure 4

Squinabollum sp. aff. fossilis

p. 541

Figure 5

Diacanthocapsa? sp. 137-7-CC.

Figure $6 \quad$ Gongylothorax (?) sp. indet. 137-7-CC.

p. 541

Figure 7 Sphaeroidea gen. sp. indet. 137-7-CC.

Figure 8

Conosphaera fossilis

p. 521

Figure 9 Pseudoaulophacidae gen, et sp. indet. 137-7-CC.

Figure 10

Cenosphaera sp. aff. C. euganea 137-7-CC.

p. 521

Figure 11-13 Discoidea gen. et sp. indet. 137-7-CC. 

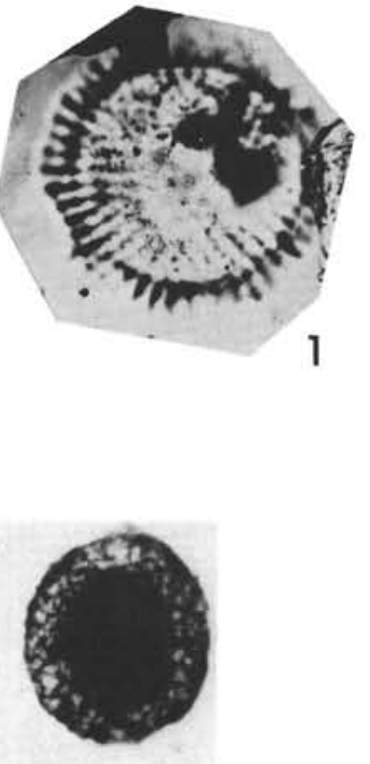

5

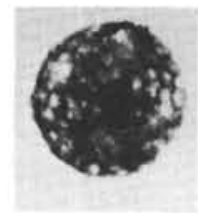

6

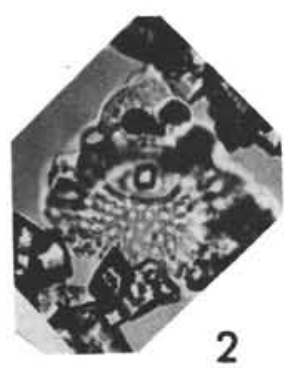

2

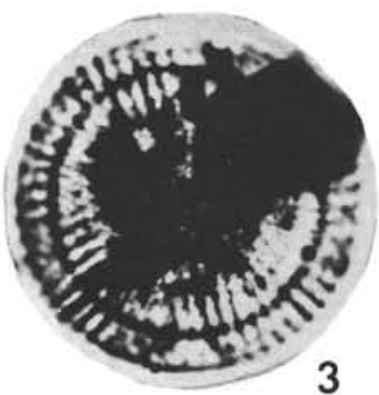

3

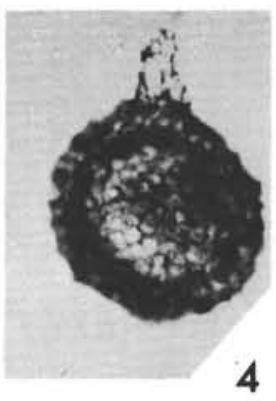

4
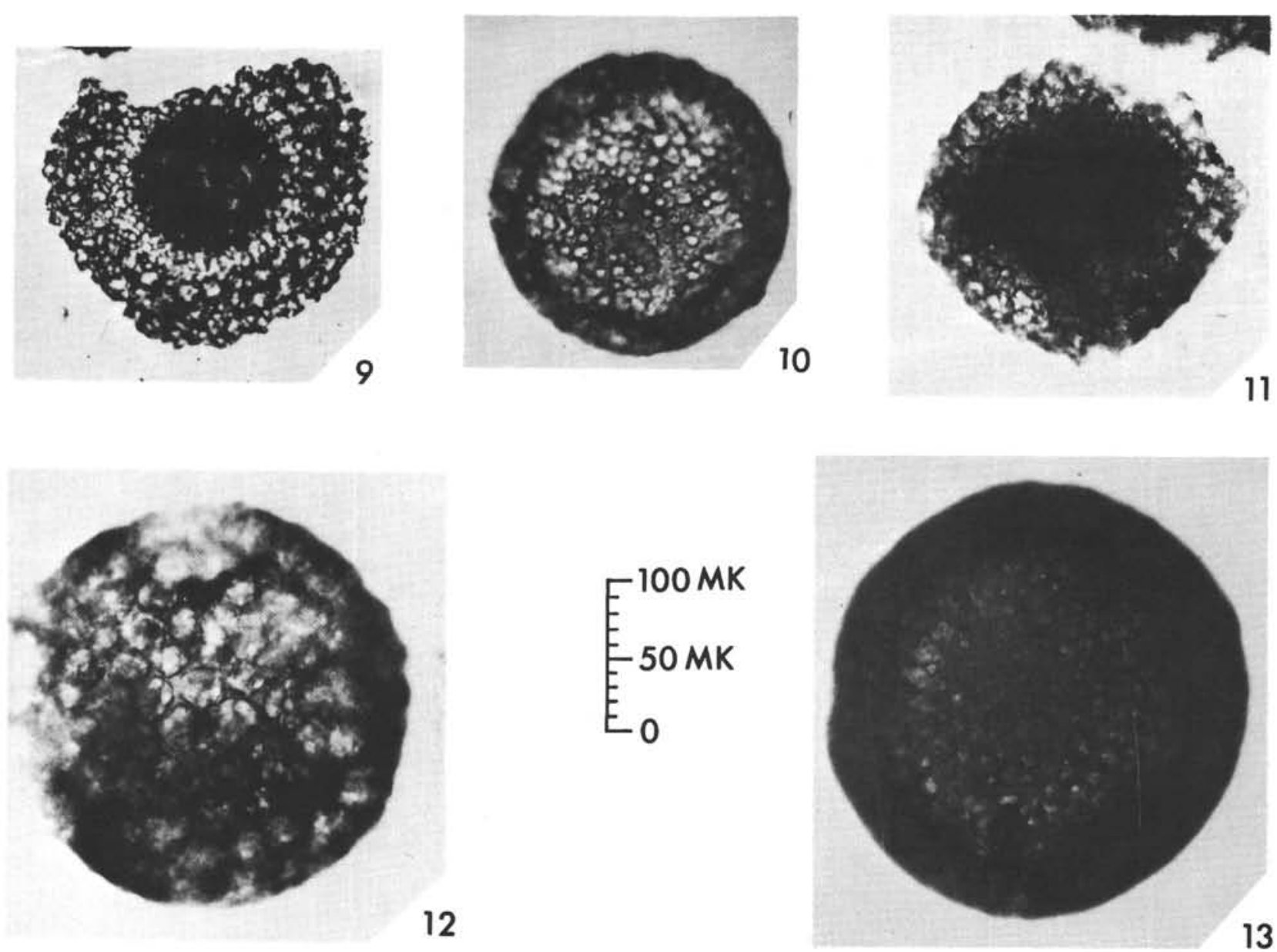
Plate 2

Magnification 200X

Figure 1

Figure 2

Figure 3

Figure 4

Figure 5

Figure 6

Figure 7

Figure 8

Figure 9

Figure 10, 11

Dictyomitra duodecimcostata group 138-5-CC.

Figure 12

$$
\text { Dictyomitra sp. A }
$$
$144-3-2,85-88 \mathrm{~cm}$

Figure 13

Figure 14

Figures 15, 16

$$
\begin{aligned}
& \text { Eucyrtidium ? sp. C } \\
& \text { 138-5-CC. }
\end{aligned}
$$

Dictyomitra? sp. aff. Stichocapsa tecta 138-5-CC.

Cryptamphorella sphaerica 138-5-CC.

Figure 17

Cryptamphorella sp. aff. conara 138-5-CC.

Figure 18

$$
\begin{aligned}
& \text { Gongylothorax ? sp. } \\
& \text { 138-5-CC. }
\end{aligned}
$$

Figures 19, 20 138-5-CC. 
PLATE 2
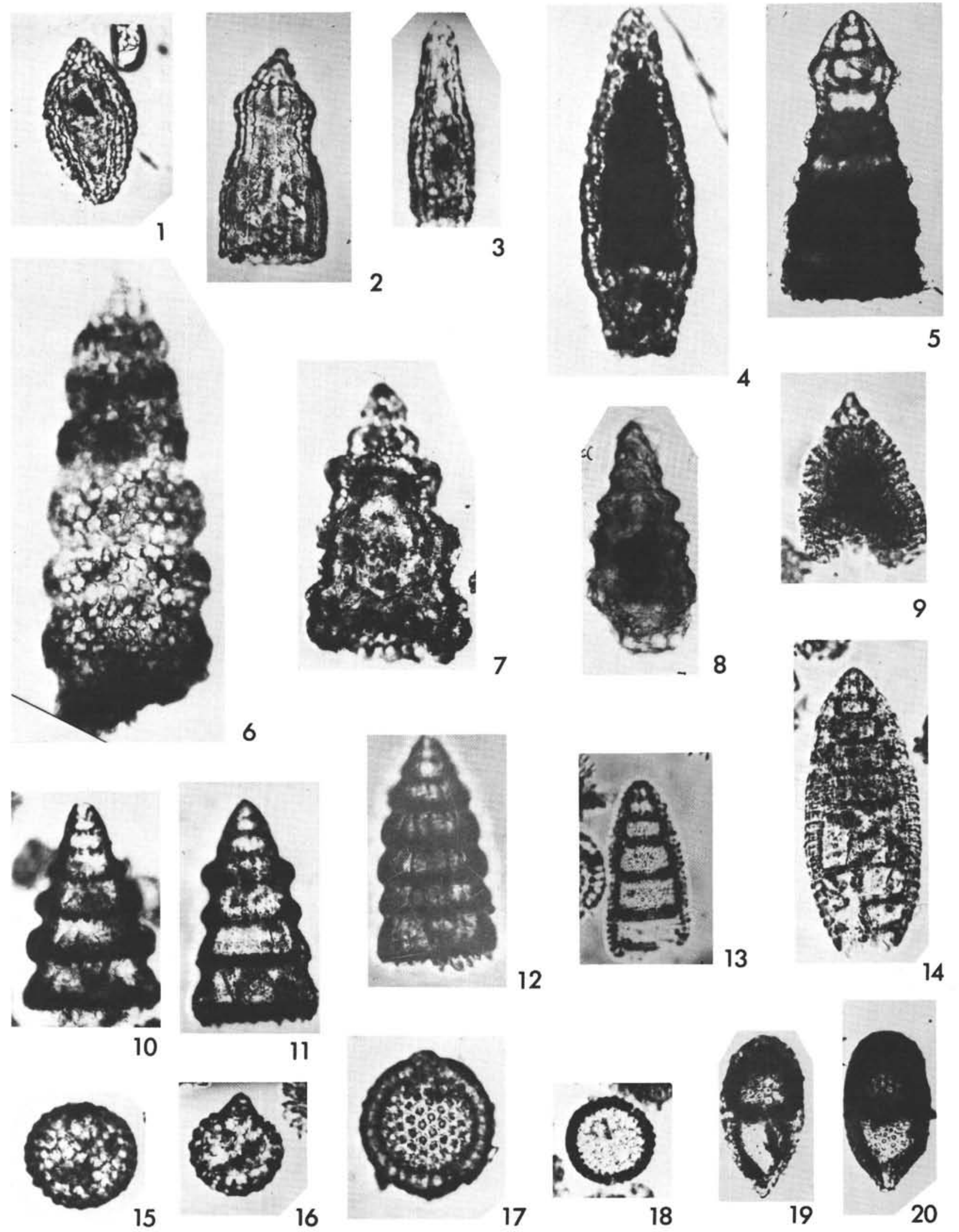
Plate 3

Magnification 200X

Figure 1.3 Pseudoaulophacus superbus

138-5-CC.

3: Transverse section.

Figure 4 Spongotrochus sp. 138-5-C.

Figures 5-7 Pseudoaulophacus sp. 138-5-CC.

Figures 8,9 Patellula verteroensis p. 527 138-5-CC.

Figures 10-12 Pseudoaulophacus sp. aff. P. pargueranensis 138-5-CC.

Figure 13

Patellula planoconvexa

p. 527 138-5-CC.

Figures 14, 15 Spongodiscidae gen. sp. indet. 138-5-CC.

Figure 16

Dactyliosphaera sp. aff. Lithocyclia justa 138-5-CC.

p. 528

Figure 17

Lithelidae gen. B sp.

p. 529 138-5-CC.

Figure 18, $19 \quad$ Lithelidae gen. sp. 138-5-CC. 
PLATE 3
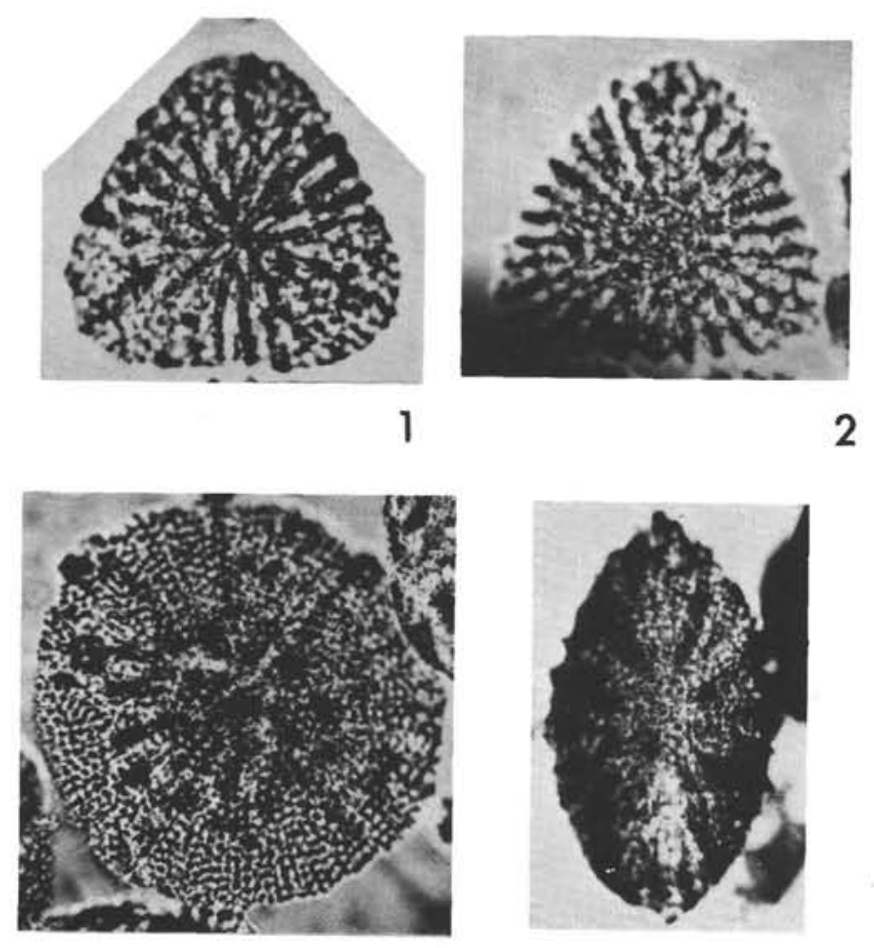

5
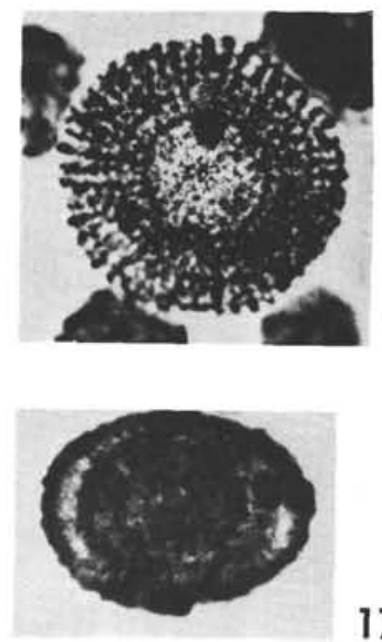

16

17

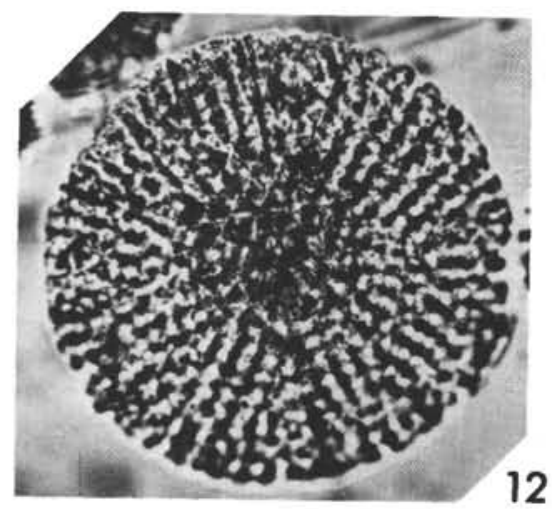

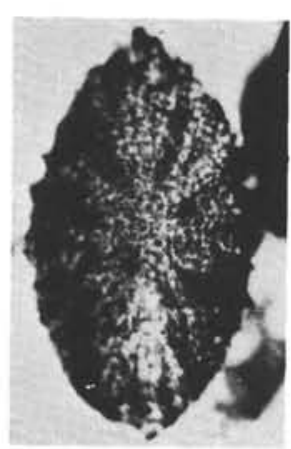

6
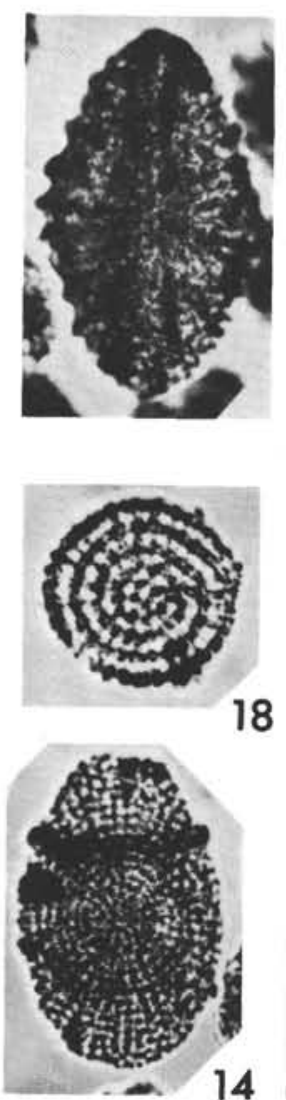

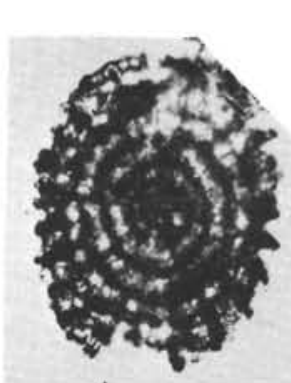

3

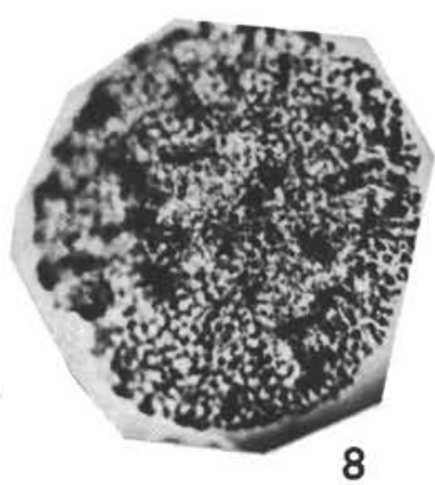

8

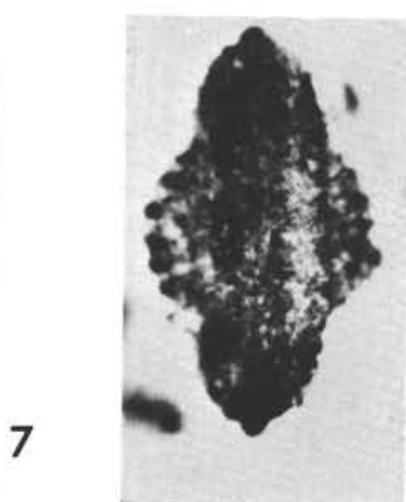

10
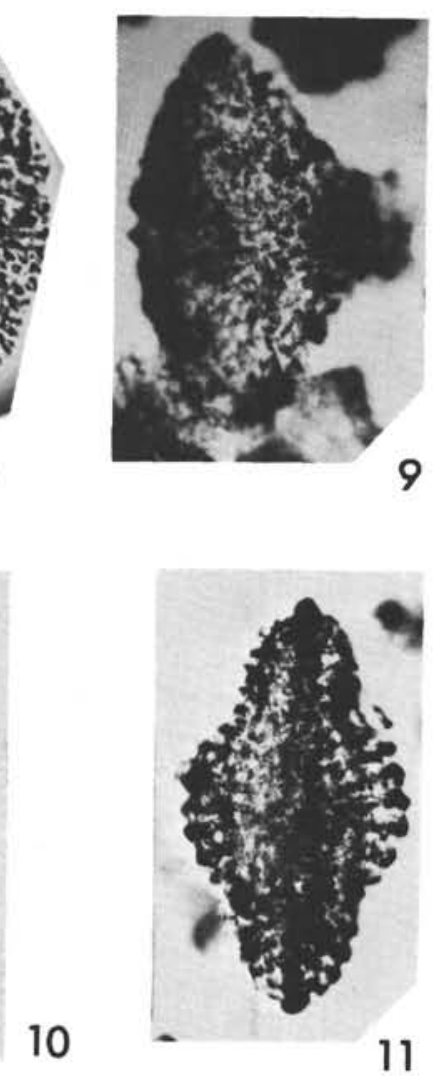

8 19

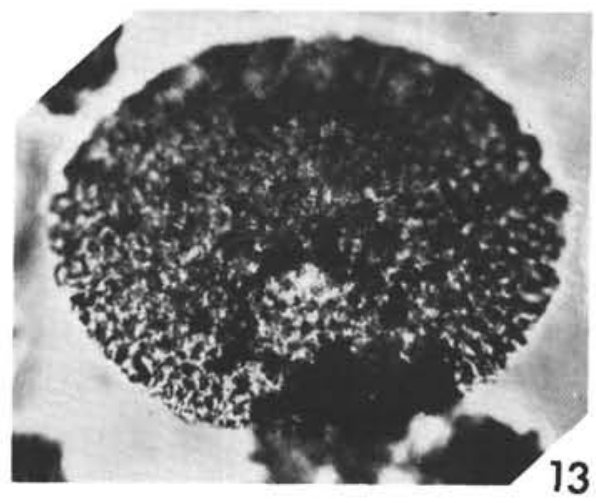


Plate 4

Magnification 200X

Figure $1 \quad$ Cenosphaera sp. aff. C. euganea

p. 521 $137-4-2,80-84 \mathrm{~cm}$.

Figure 2 Conosphaera? sphaeroconus

p. 521 $137-4-2,80-84 \mathrm{~cm}$.

Figures 3, $4 \quad$ Stylatractus (?) sp.

3: $144-4-\mathrm{CC}$

4: 144-3-CC.

Figure 5

Spongosaturnalis (?) sp. aff. S. latuformis 144-3-CC.

Figure 6,7 Spongoprunum (?) sp. aff. Cyphantus probus

p. 529 6: $144-3-2,85-88 \mathrm{~cm}$.

7: 144-3-CC.

Figure $8 \quad$ Spongodiscidae ? gen. et sp. indet. $144-3-2,85-88 \mathrm{~cm}$.

Figures 9, 10 Spongotrochus? polygonatus

9: 144-3-CC.

10: $144-3-2,85-88 \mathrm{~cm}$. 
PLATE 4
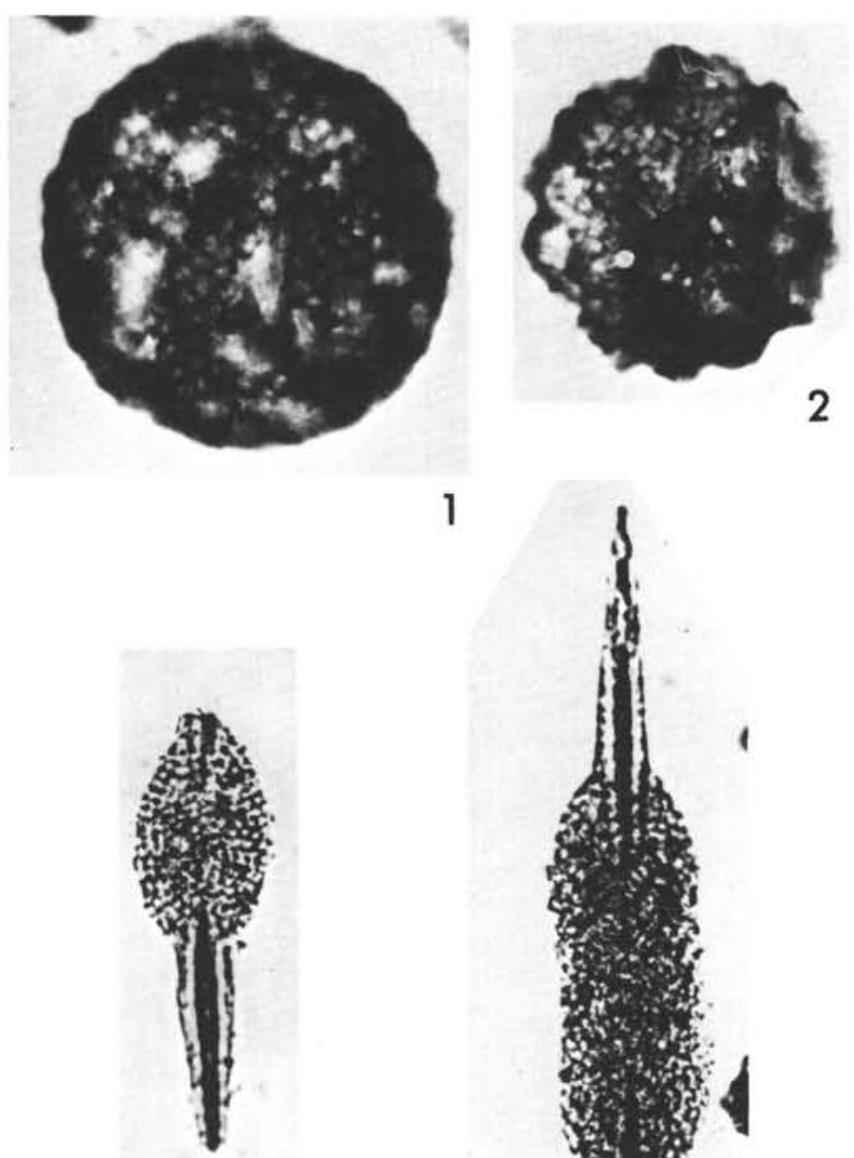

6

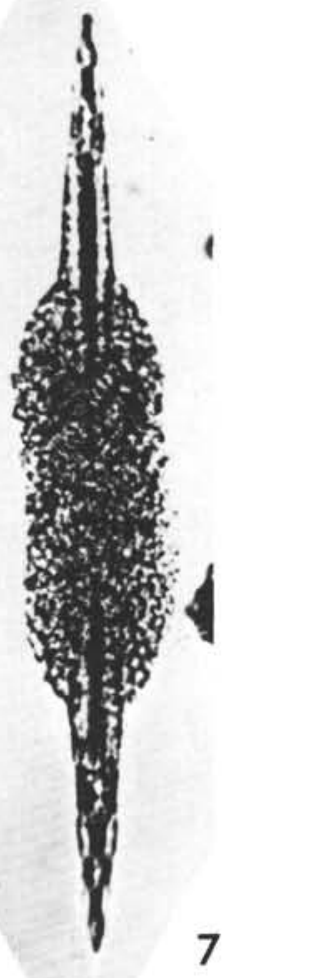

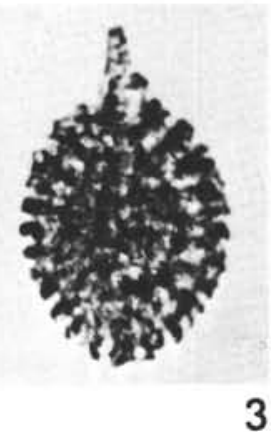

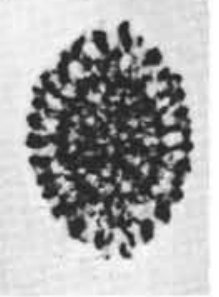

3
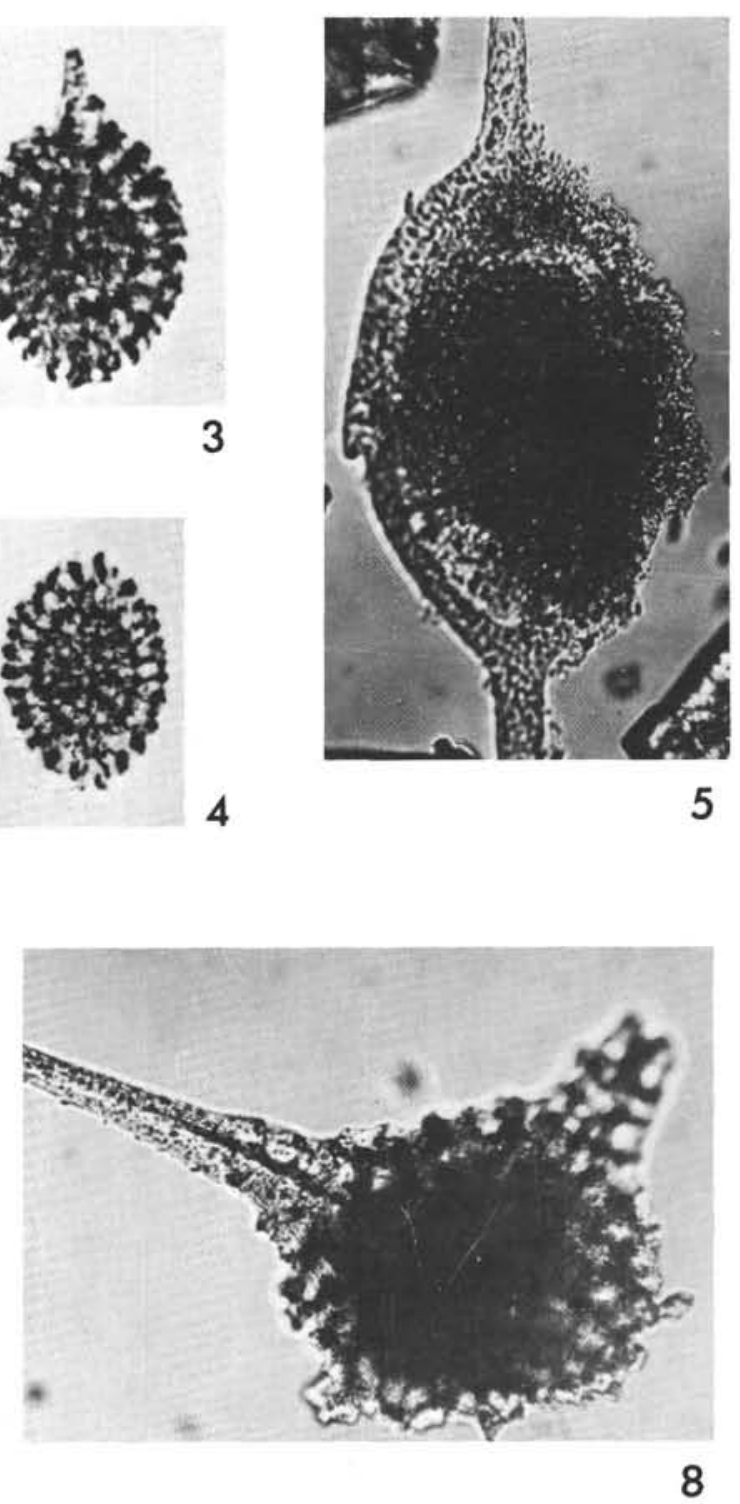

8

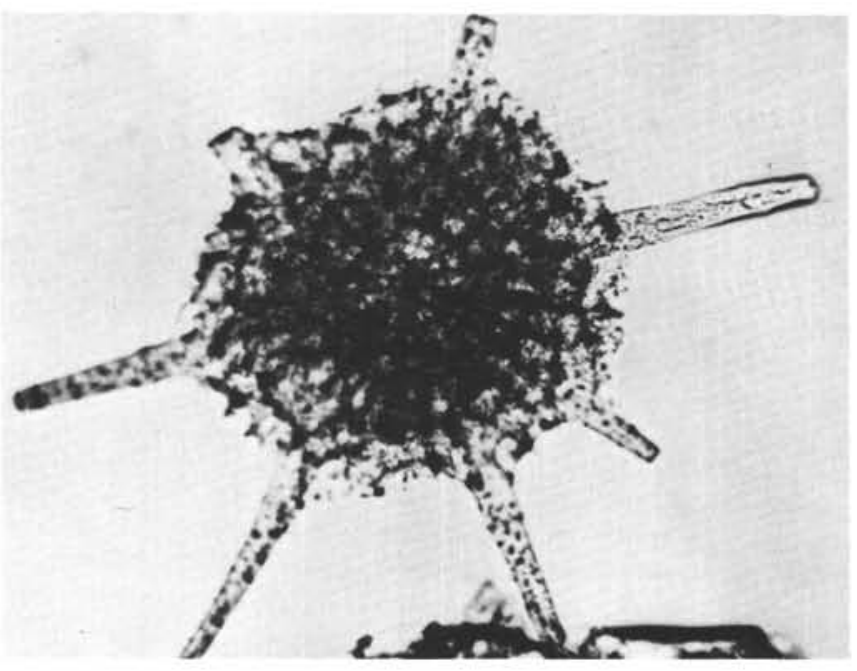

9

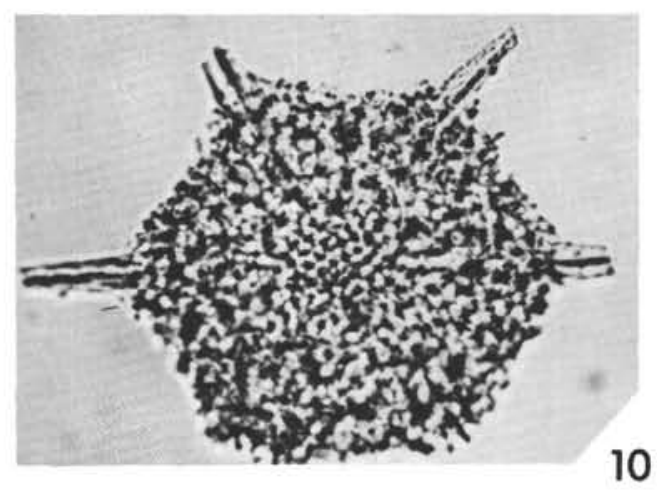


Plate 5

Magnification 200X

Figure 1

Tholodiscus fresnoensis 144-3-CC.

p. 525

Figure 2-4 Porodiscidae genn. et spp. indet.

p. 525

2, 3: 144-3-CC.

4: 144-3-1.

Figure $5 \quad$ Tholodiscus sp.

p. 525

144-3-CC.

Figures 6,7 Porodiscus cretaceus

p. 525

Figures 8,9 Porodiscus delicatulus

p. 525 144-3-CC.

Figure $10 \quad$ Spongopyle insolita 144-3-CC.

Figure 11, 12 Spongotrochus (?) sp.

p. 528 144-3-CC.

Figure 13 Spongodiscidae ? gen. et sp. indet.

p. 529 144-3-CC.

Figures 14,15 Lithelidae gen. A sp. aff. Cromyodruppa sp. Lipman

p. 529 144-3-CC. 
PLATE 5

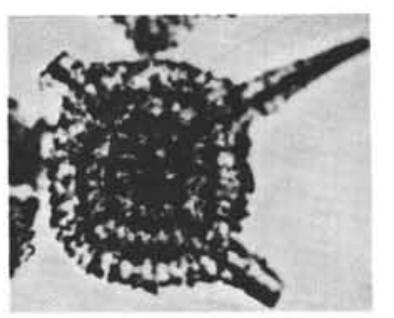

1
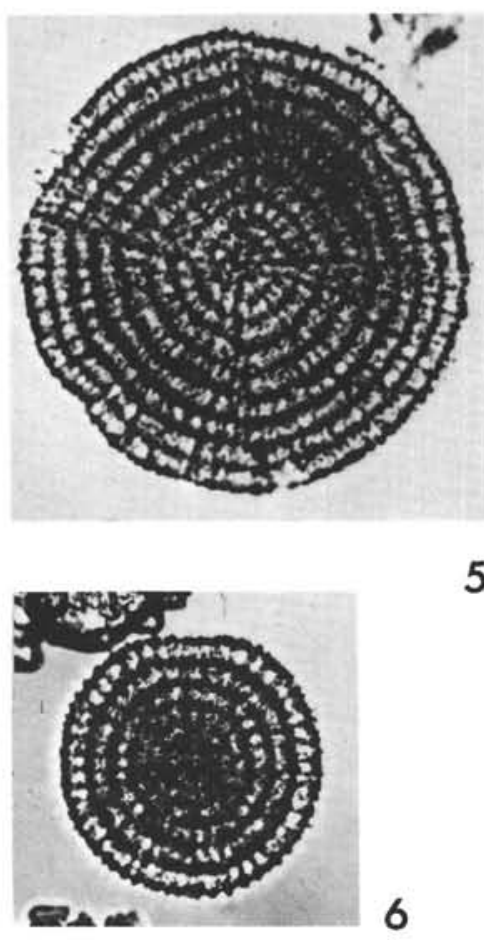

5

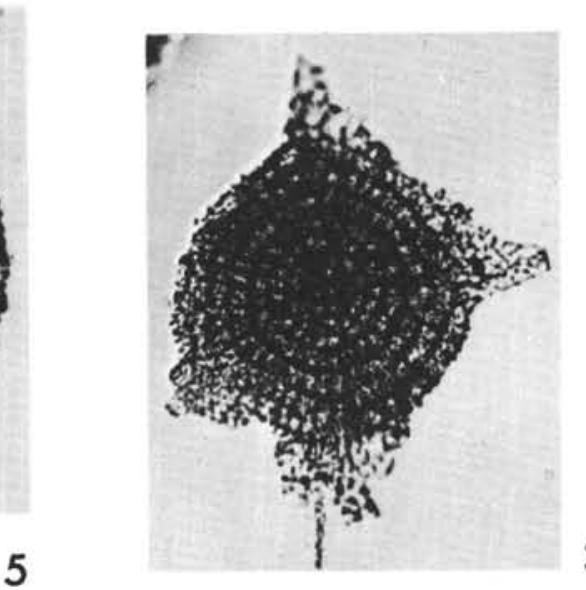

3
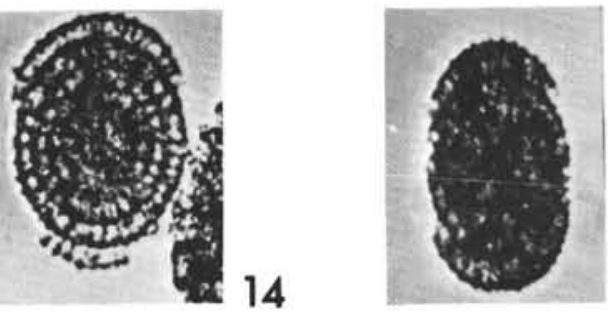

15

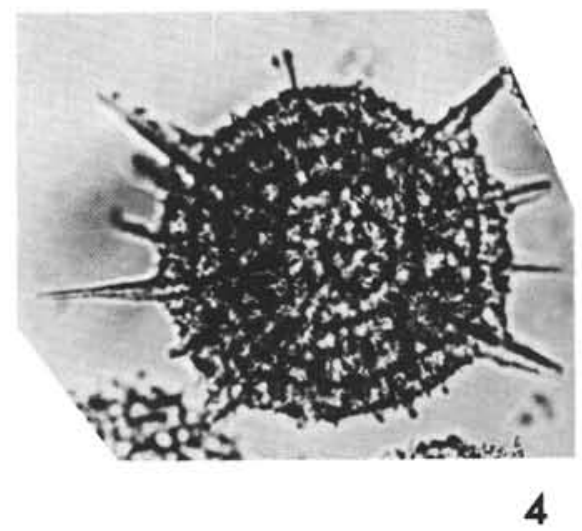

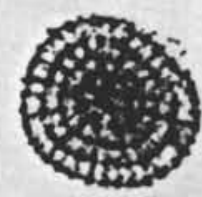
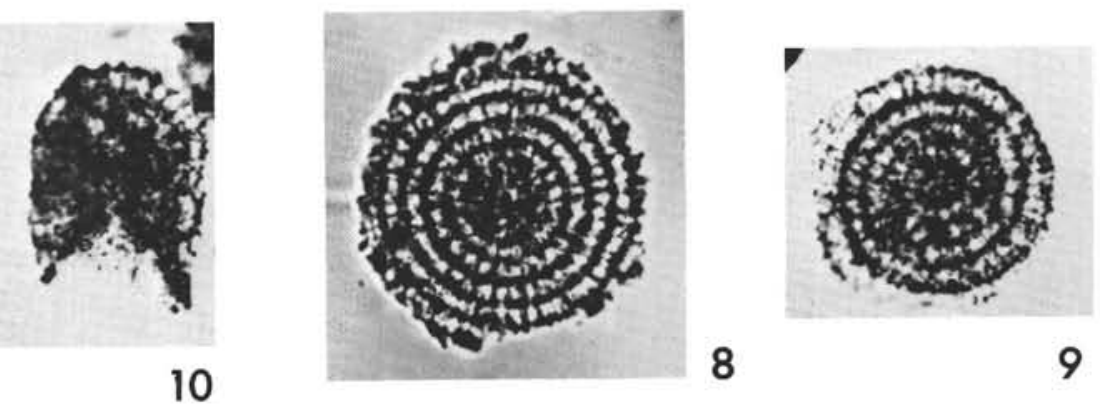

7
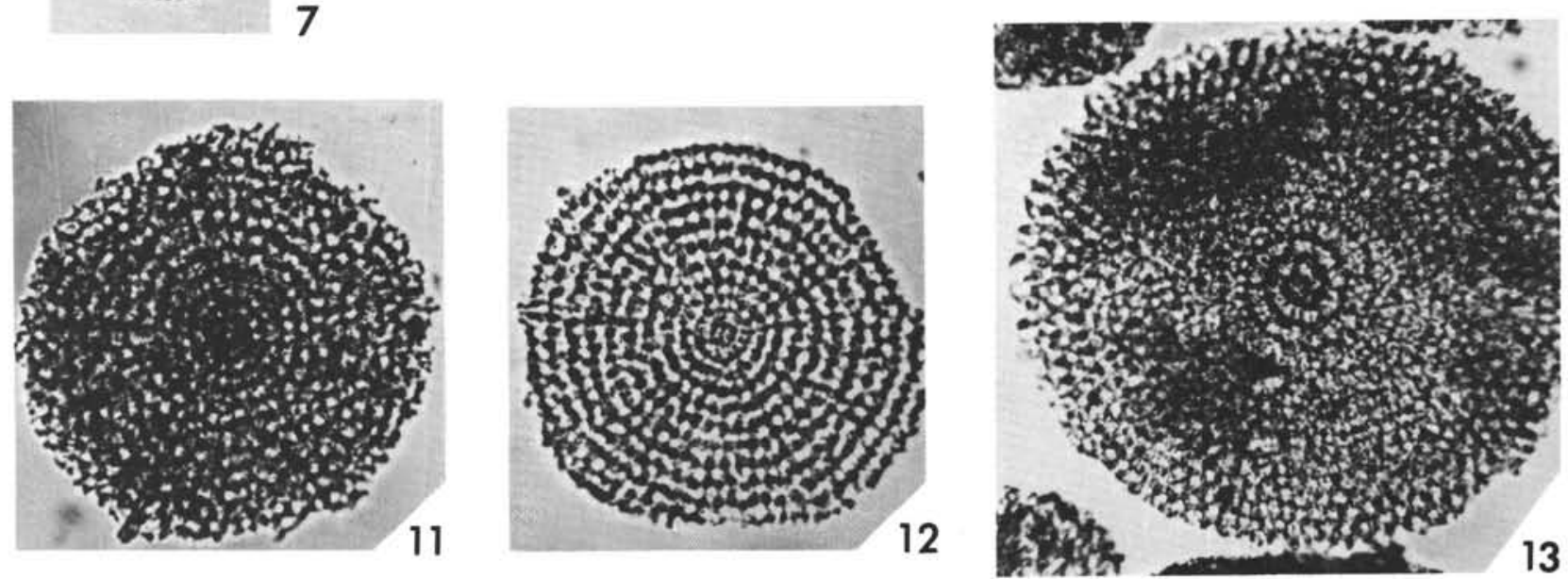
Plate 6

Magnification 200X

Figure $1 \quad$ Pseudoaulophacus gallowayi (?) 144-3-1.

Figures 2, 3 Spongotripus morenoensis

p. 528

2: $144-3-2,85-88 \mathrm{~cm}$.

3: 144-3-1.

Figures 4-7 Pseudoaulophacidae

4: Hagiastrum sp. aff. Stauralastrum euganea p. 527 144-3-2, $85-88 \mathrm{~cm}$.

5: Hagiastrum sp. aff. Stauralastrum euganea 144-3-CC.

6, 7: Genn. et spp. indet.

p. 527 144-3-2, $85-88 \mathrm{~cm}$. 
PLATE 6
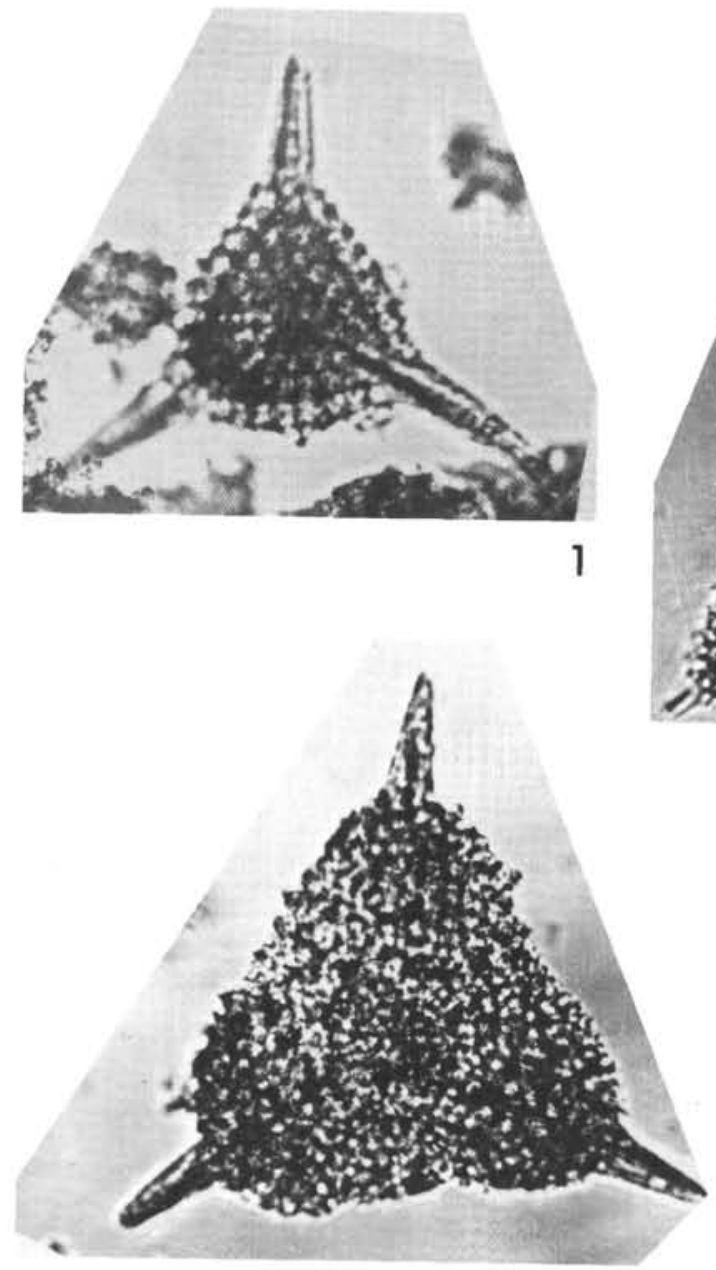

2

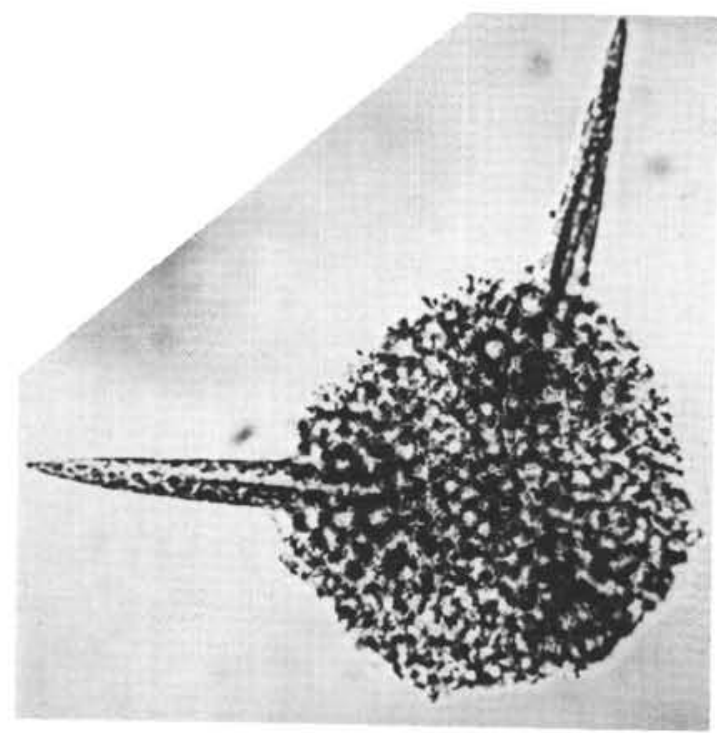

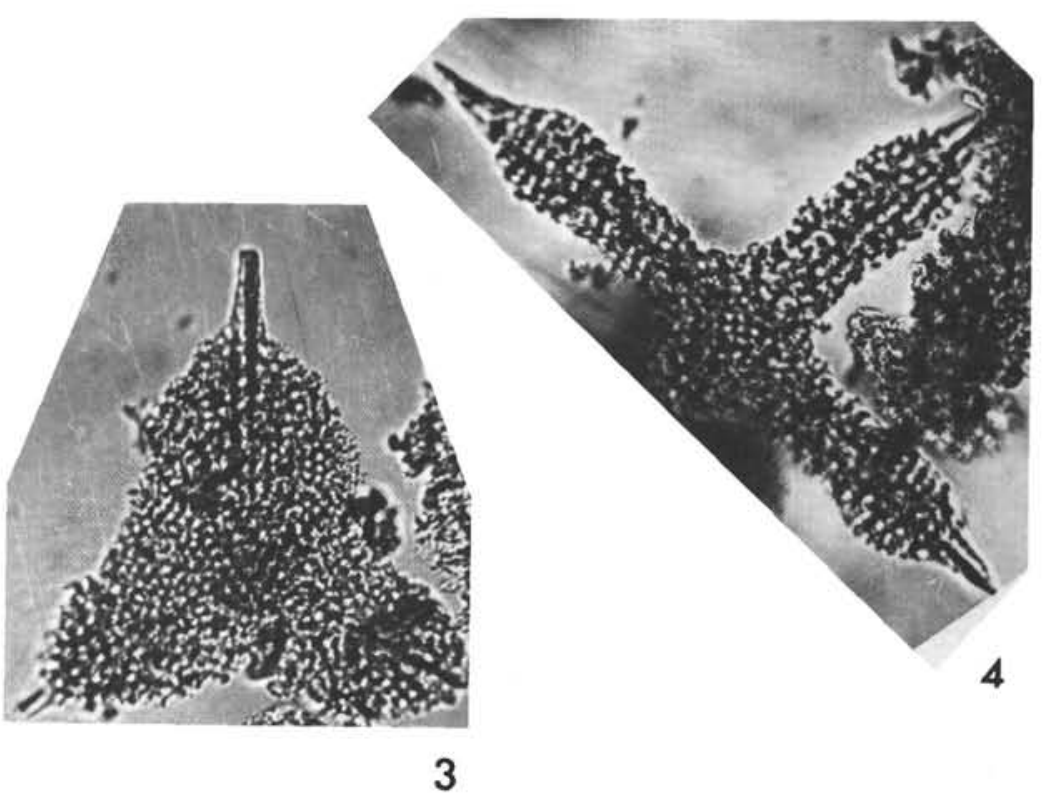

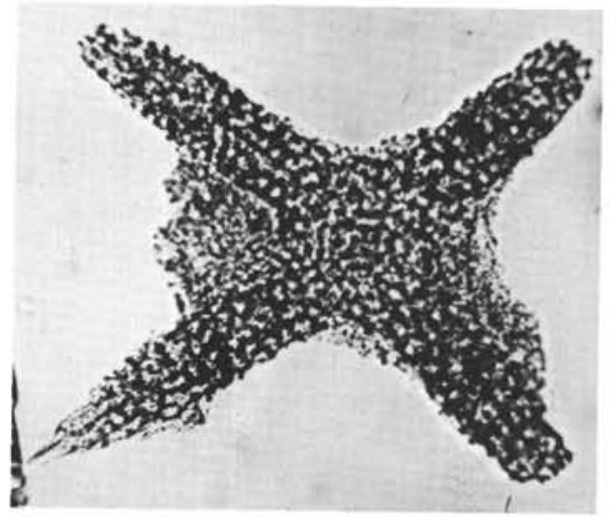

5

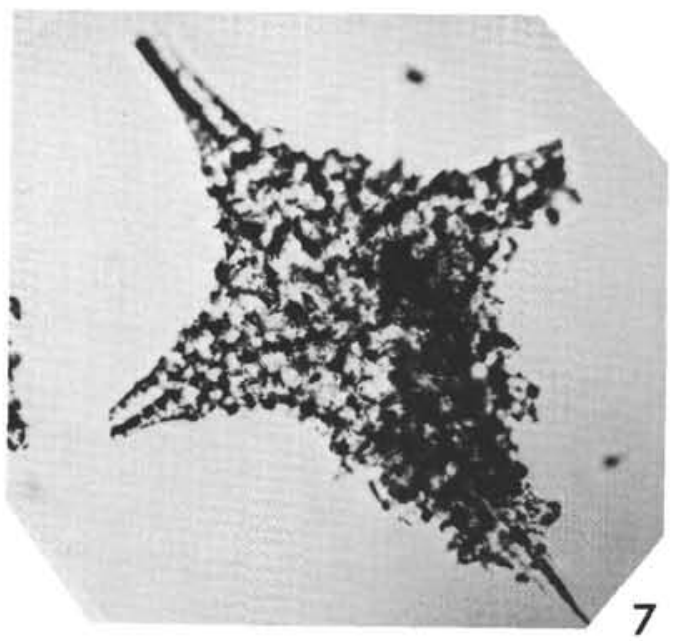


Plate 7

Magnification 200X

Figure 1

Figure 2

Figure 3

Figures 4, 5

Figure 6

Figure 7

Figures 8-10

Figure 11

Figure 12

Figures 14-17

Figures 18, 19$$
\text { Gor }
$$

Gongylothorax sp. aff. G. verbeeki 144A-4-CC.

Figure 20

?Bathropyramis sanjoaquinensis 144-3-2, $85-88 \mathrm{~cm}$.

$$
\text { 144-3-2, } 85-88 \mathrm{~cm} \text {. }
$$$$
\text { Tripodiscium ? sp. aff. Lithomelissa hoplites }
$$

Myllocercion sp., aff. M. minima $144-3-2,85-88 \mathrm{~cm}$.

$$
\begin{aligned}
& \text { Diacanthocapsa sp. B } \\
& \text { 4: } 144-3-2,85-88 \mathrm{~cm} . \\
& \text { 5: } 144 \text { A-4-CC. }
\end{aligned}
$$

Theocapsomma sp. aff. T. comys 144-3-CC.

Theocampe? bassilis 144-3-CC.

p. 535

p. 536

Theocampe? sp. aff. $T$. daseia 8, 9: $144-3-2,85-88 \mathrm{~cm}$.

10: 144-3-CC.

Diacanthocapsa sp. A 144-3-CC.

Rhopalosyringium sp. aff. $R$. colpodes 144-3-CC.

Rhopalosyringium sp. aff. $R$. magnificum $144-3-2,85-88 \mathrm{~cm}$.

Figure 21

Petassiforma speciosa p. 536

p. 537

p. 537

p. 541

p. 535

p. 537

p. 537

p. 551

p. 540 144-3-1. 


\section{PLATE 7}
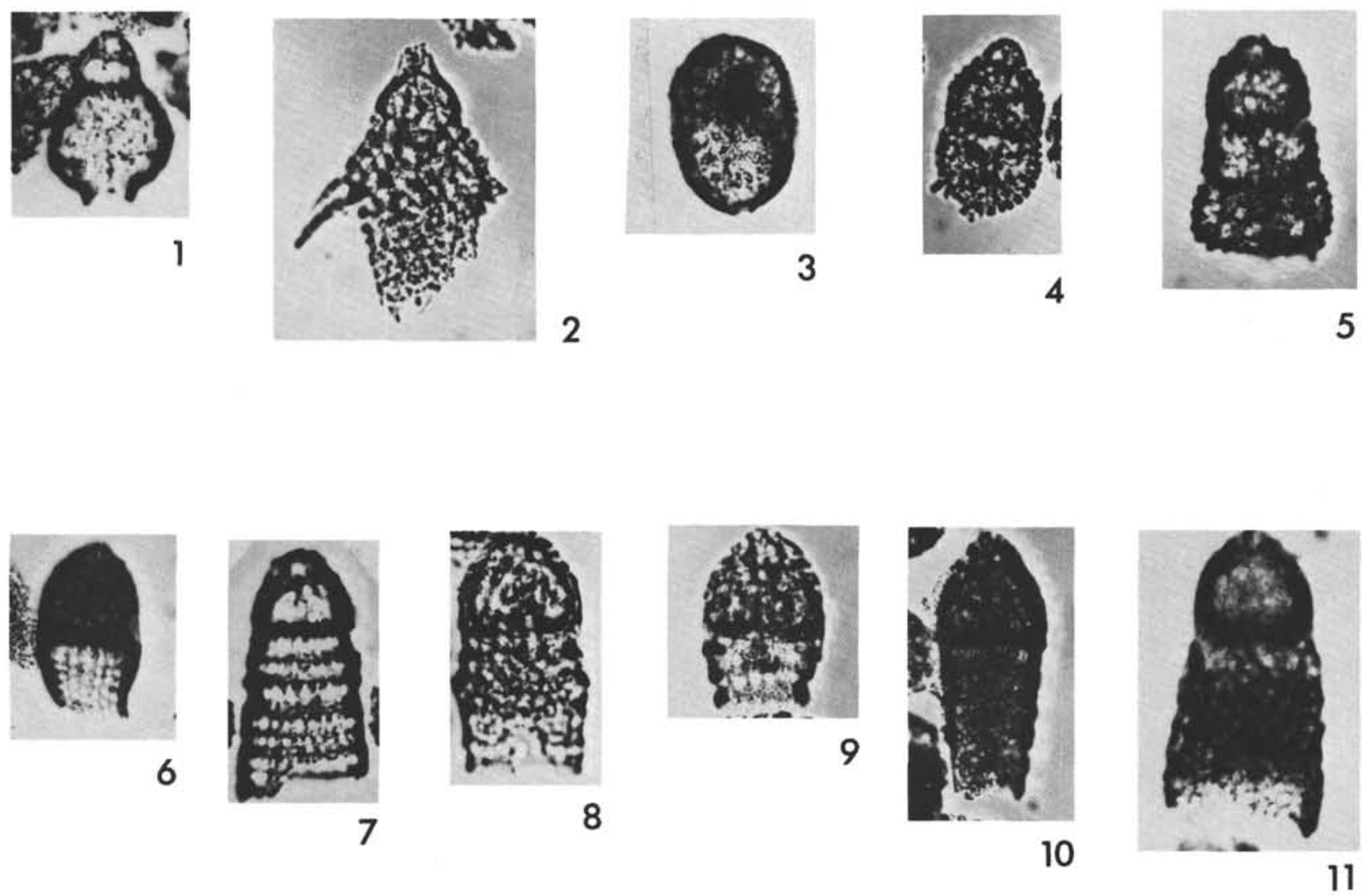

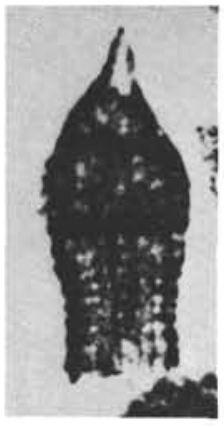

12

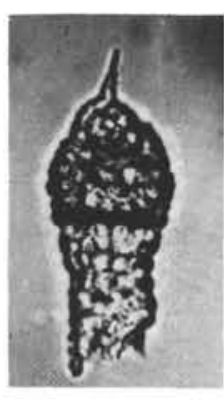

13
14
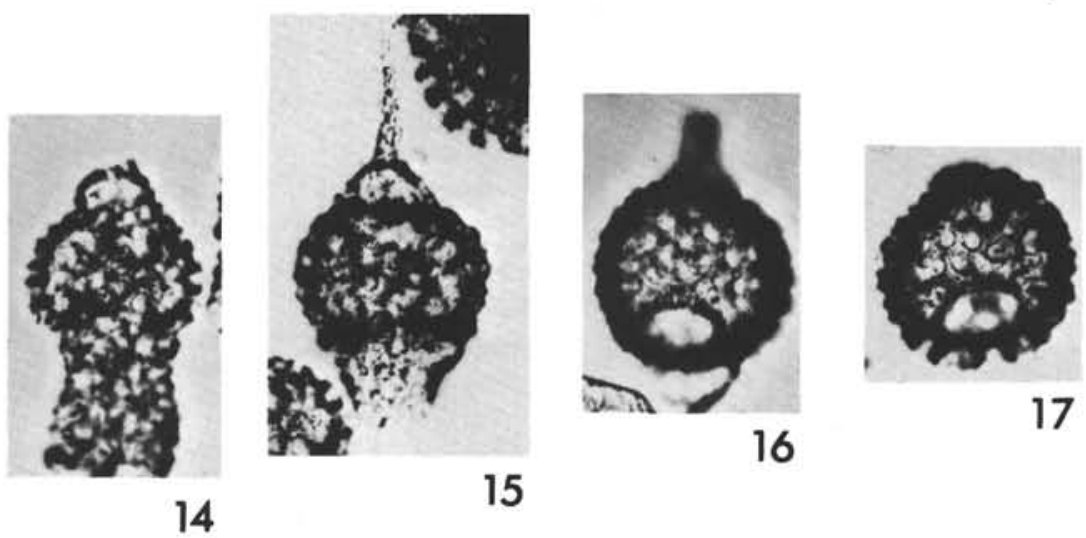

17

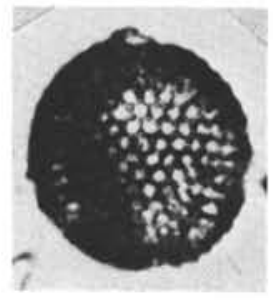

18

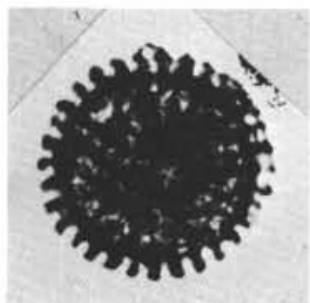

19

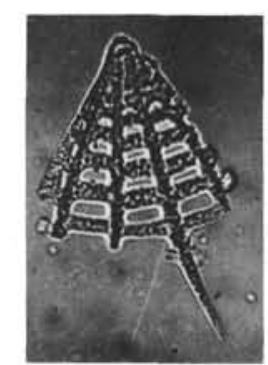

20

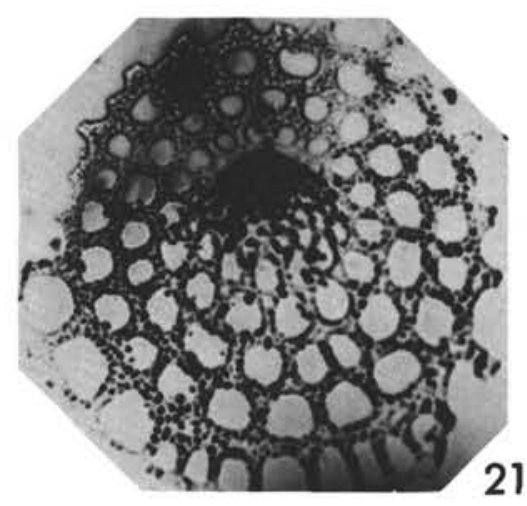


Plate 8

Magnification 200X

Figure 1-3 Stichocapsa asymbatos

p. 546

1, $2: 144-3-2,85-88 \mathrm{~cm}$.

3: $144 \mathrm{~A}-4-\mathrm{CC}$.

Figures 4, $5 \quad$ Stichocapsa sp. aff. S. producta

p. 546

4: 144A-4-CC.

5: $137-4-2,80-84 \mathrm{~cm}$.

Figures 6, 7 Stichocapsa sp.

144-3-2, $85-88 \mathrm{~cm}$.

Figure 8 Dictyomitra ornata

p. 550

144A-4-CC.

Figures 9, 10 Dictyomitra multicostata

p. 550

9: $144-3-2,85-88 \mathrm{~cm}$.

10: 144-3-CC.

Figure 11 Dictyomitra aff. regina

p. 550 144A-4-CC.

Figures 12, 13 Dictyomitra striata

p. 550

12: 144A-4-CC.

13: 144-3-CC

Figure 14 Amphipyndax sp. aff. A. enessefi $144-3-2,85-88 \mathrm{~cm}$.

Figure 15

Amphipyndax enessefi 144-3-CC.

p. 545

Figures 16, 17 Amphipyndax stocki

16: 144-3-CC.

17: $144-3-2,85-88 \mathrm{~cm}$.

Figure 18 Amphipyndax sp.

p. 545 144-3-CC.

Figure 19

Stichocapsa cingulata

p. 546 144-3-CC. 
PLATE 8
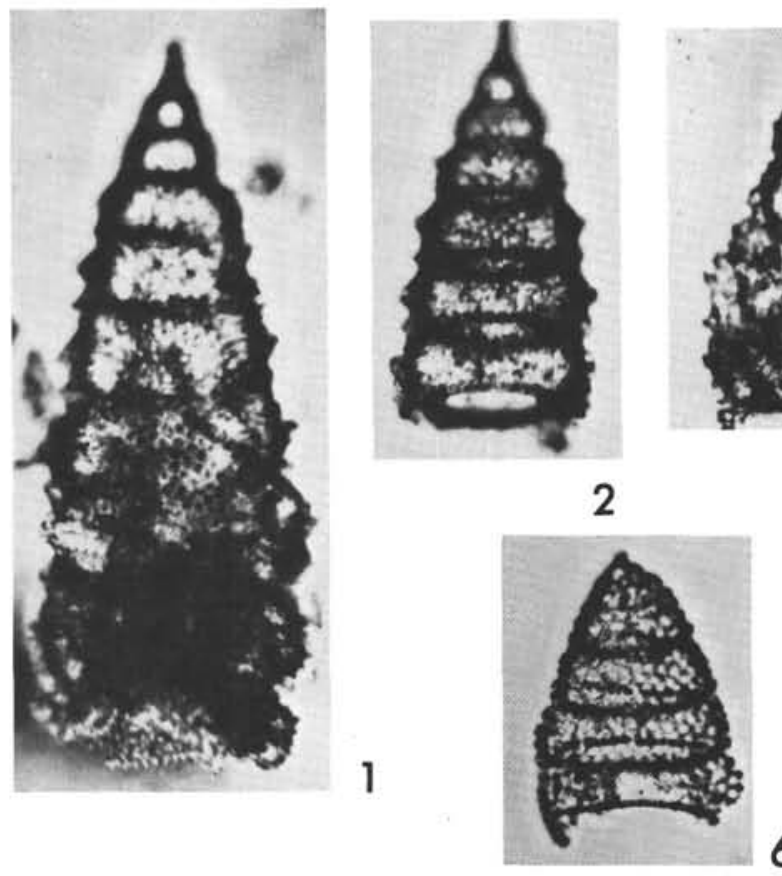

6
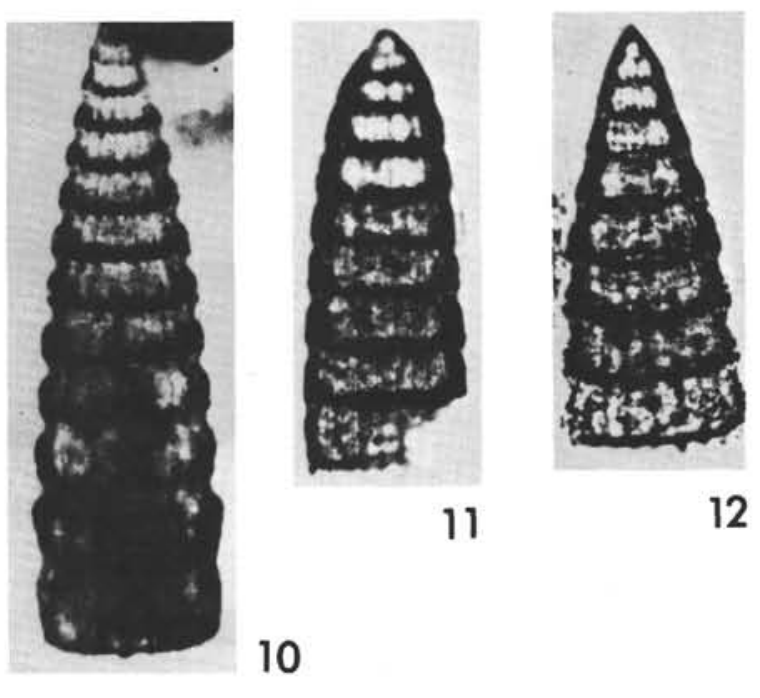

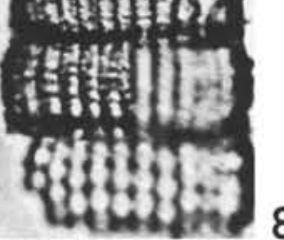
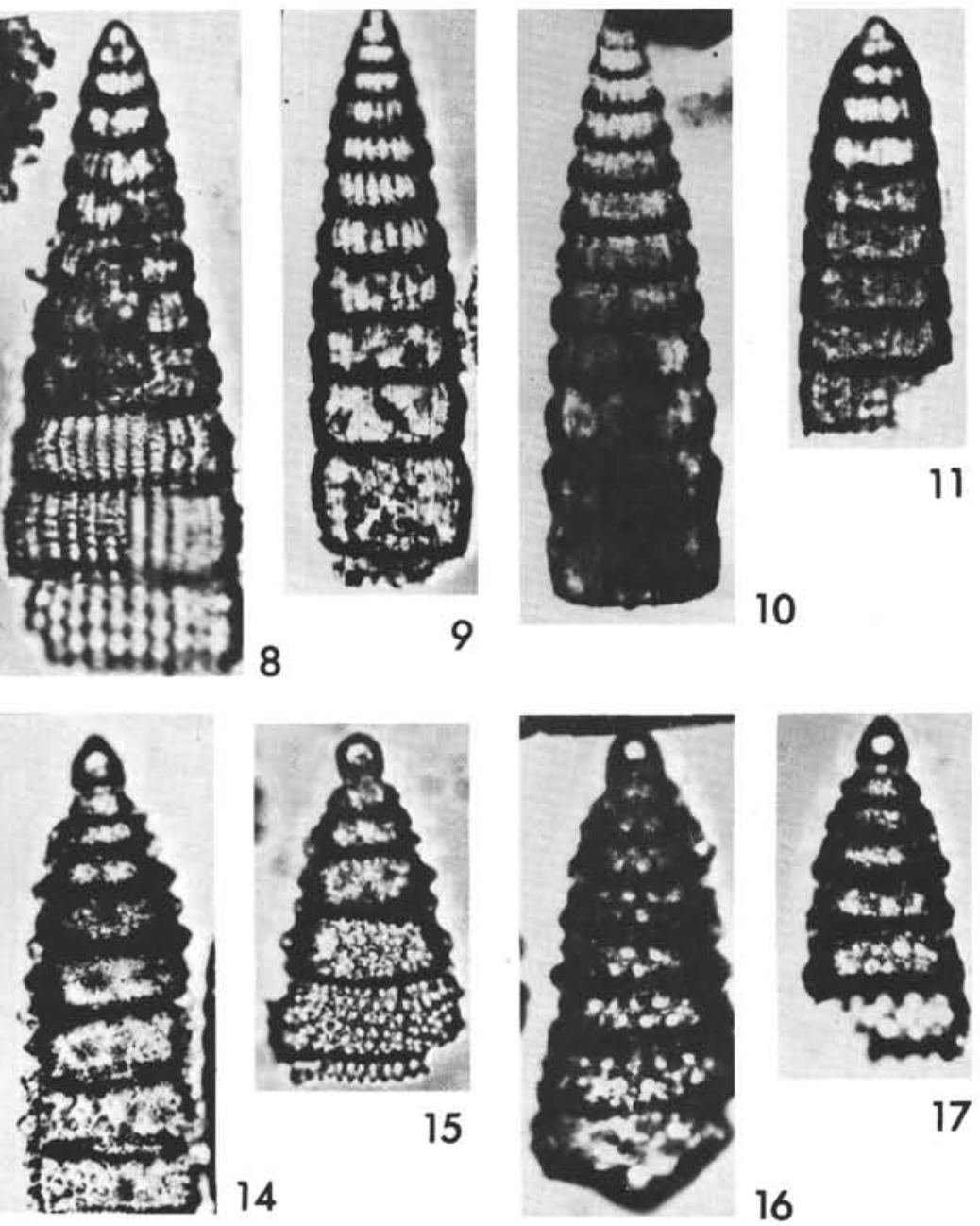
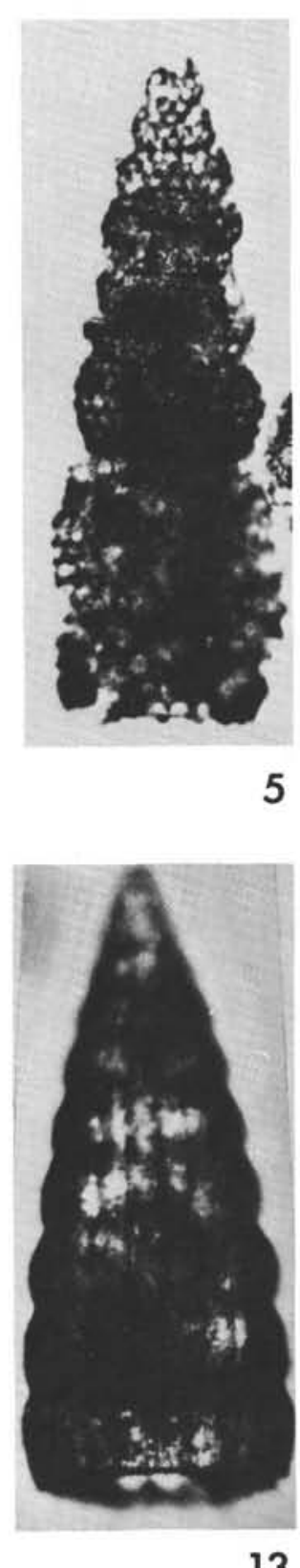

13

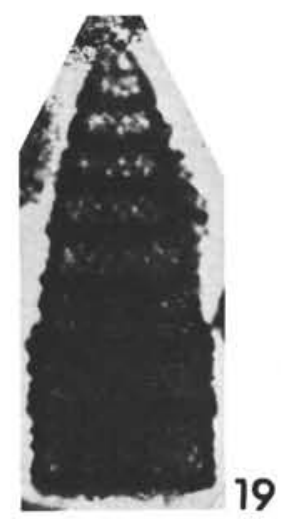


Plate 9

Magnification 200X

Figure $1 \quad$ Otosphaera annikae holotype 139-3-CC.

Figure 2 Otosphaera auriculata 139-4-CC.

Figure 3 Collosphaeridae gen. et sp. indet. 139-1-1.

Figures 4-7 Actinomma sp. aff. Hexacontium arachnoidale $139-1-1,80-82 \mathrm{~cm}$.

Figures 8,9 Haliometta miocenica $139-1-1,80-82 \mathrm{~cm}$.

Figure 10 Haliometta sp. 140A-2-4, $80-82 \mathrm{~cm}$.

Figure 11 Cromyechinus tetrapila $142-9-2,58-60 \mathrm{~cm}$.

Figure 12 Cromyechineu langii 139-7-4, 80-82 cm.

Figure 13 Actinommura sp. A 140A-2-5, 5-7 cm.

Figure 14 Actinommura sp. B, the rods connecting medul- p. 519 lary and cortical shells are boken. $140 \mathrm{~A}-2-6,80-82 \mathrm{~cm}$.

Figure 15 Actinommura sp. C $140-2-\mathrm{CC} *$

Figure 16 Acanthosphaera ? haliformis 140A-2-5, $5-7 \mathrm{~cm}$.

Figure 17 Thecosphaera sp. A 140-2-CC *.

Figure 18 Thecosphaera (?) sp. B p. 519 140-2-CC *.

Figure 19 Thecosphaera? sp. C p. 519 144-1-CC. 
PLATE 9
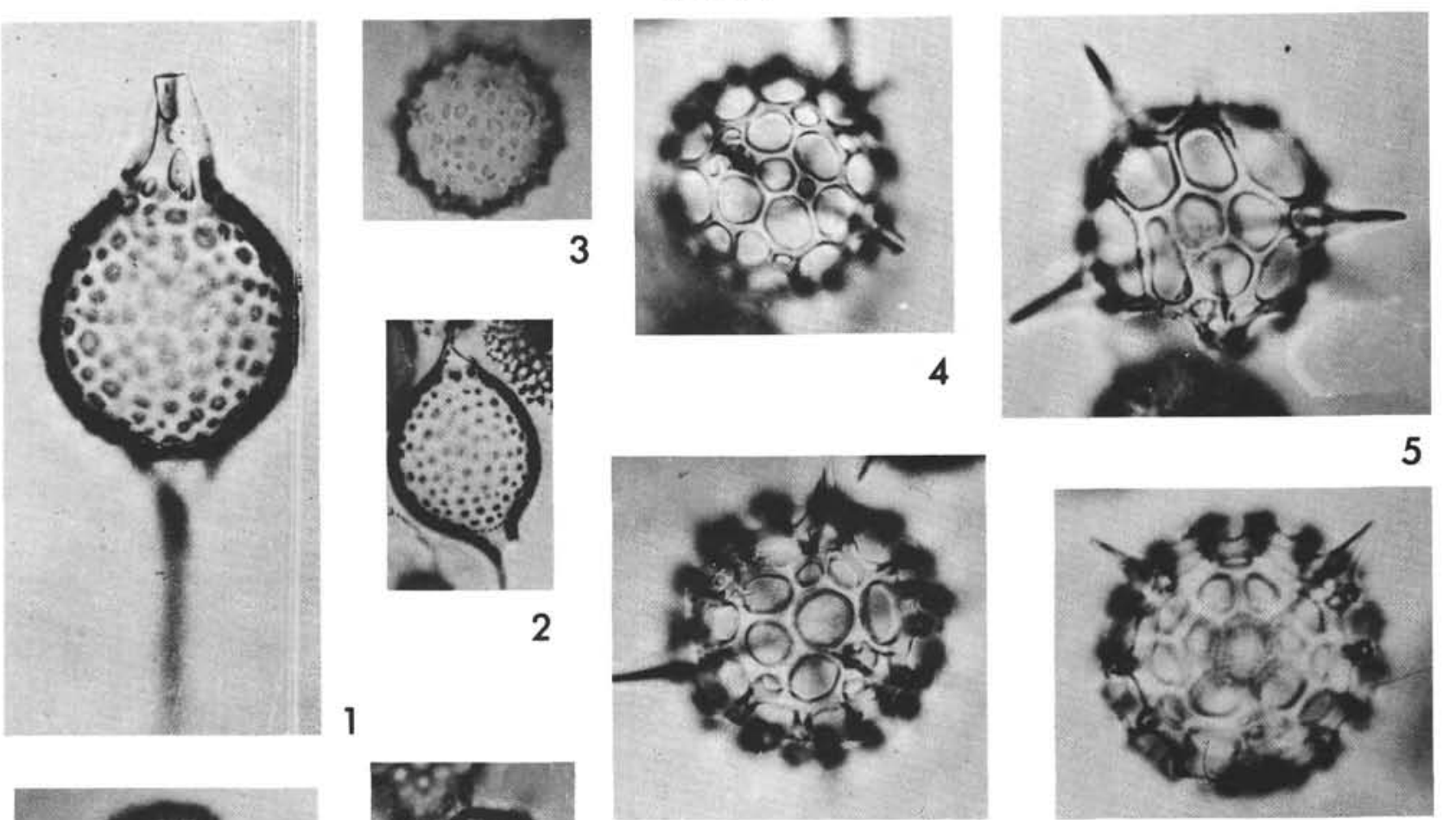

4

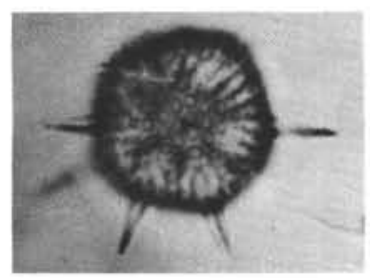

8

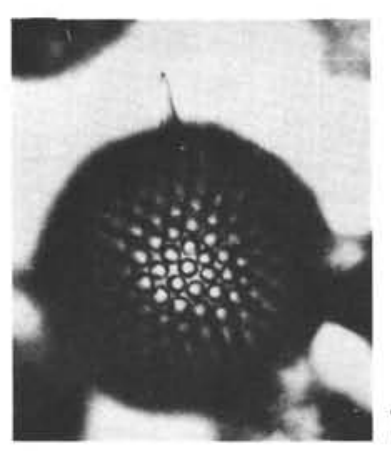

13

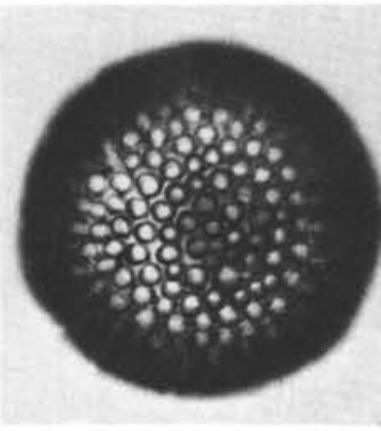

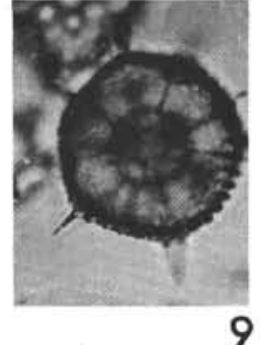

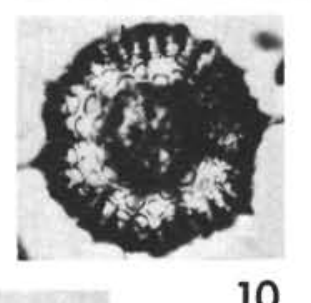

10
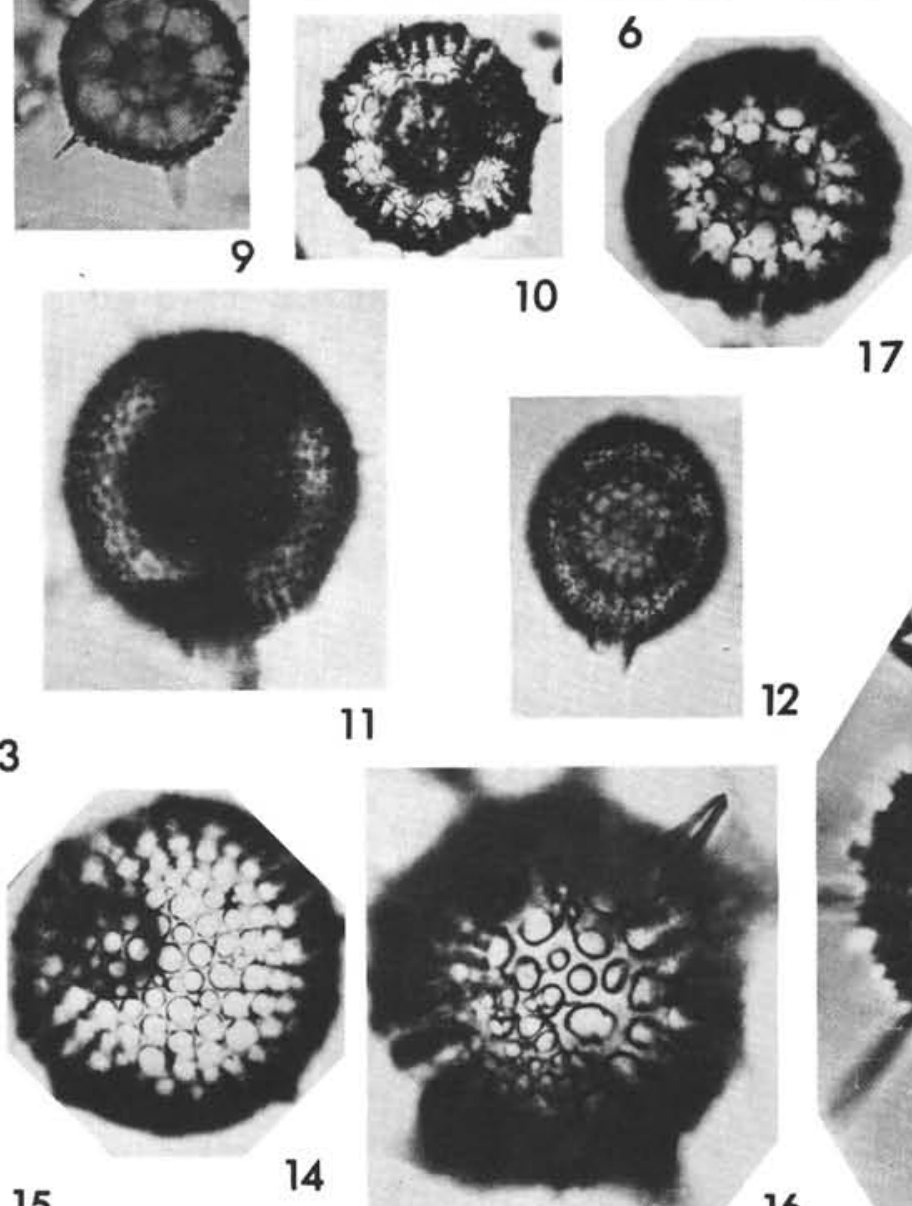

15
11
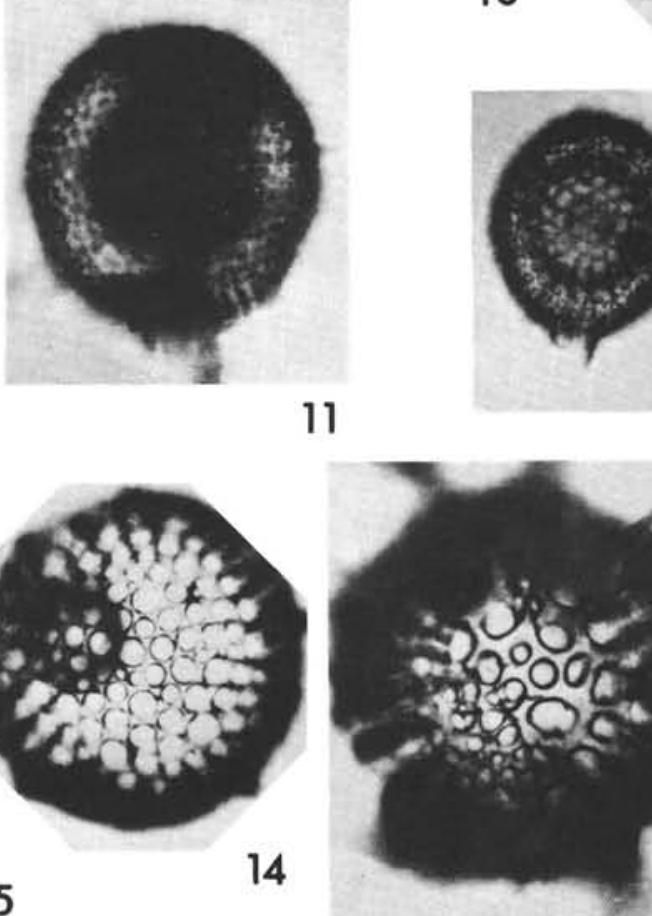

17

5

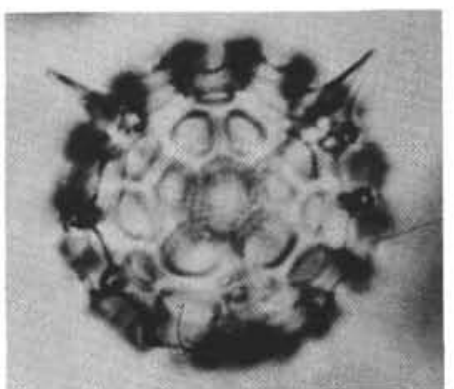

7

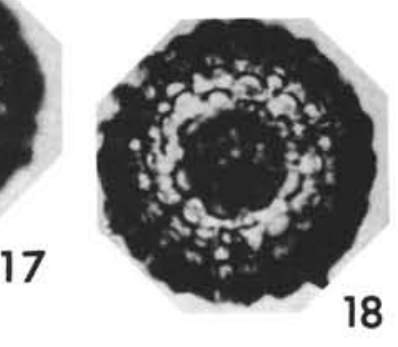

12

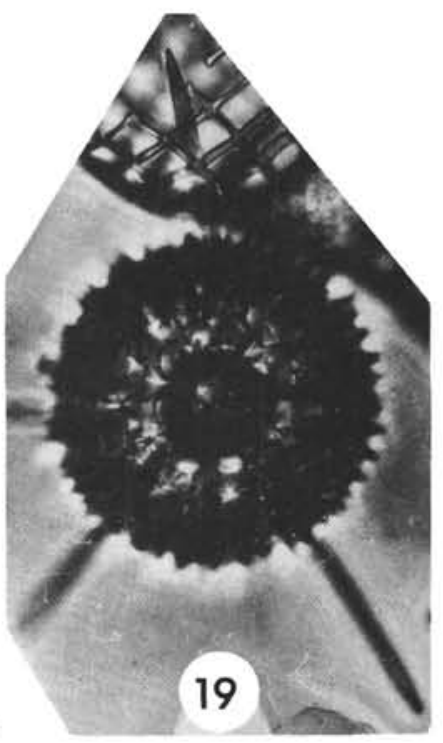


Plate 10

Magnification 200X

Figure 1

Axoprunum carduum

p. 521

140A-2-3, $80-82 \mathrm{~cm}$.

Figure 2 Axophrunum sp. 140-2-CC *

Figure 3 Axoprunum liostylum

p. 521

Figure 4

Stylosphaera minor

p. 520

Figure 5

Spongosphaera pachystyla

Figure 6

Saturnalinae gen. indet. 144-2-3.

p. 521

Figure 7

Stylosphaera sp. B

p. 520 139-5-CC.

Figure 8

Stylosphaera sp. A 139-7-CC.

p. 520

Figure 9

Cannartus sp. aff. C. prismaticus

p. 521 140-2-CC *.

Figure 10 Axoprunum stauraxonium

p. 521 $139-1-2,5-7 \mathrm{~cm}$.

Figures 11, 12 Axoprunum polycentrum

p. 521

11: $140 \mathrm{~A}-2-6,80-82 \mathrm{~cm}$.

12: $138-2$. 

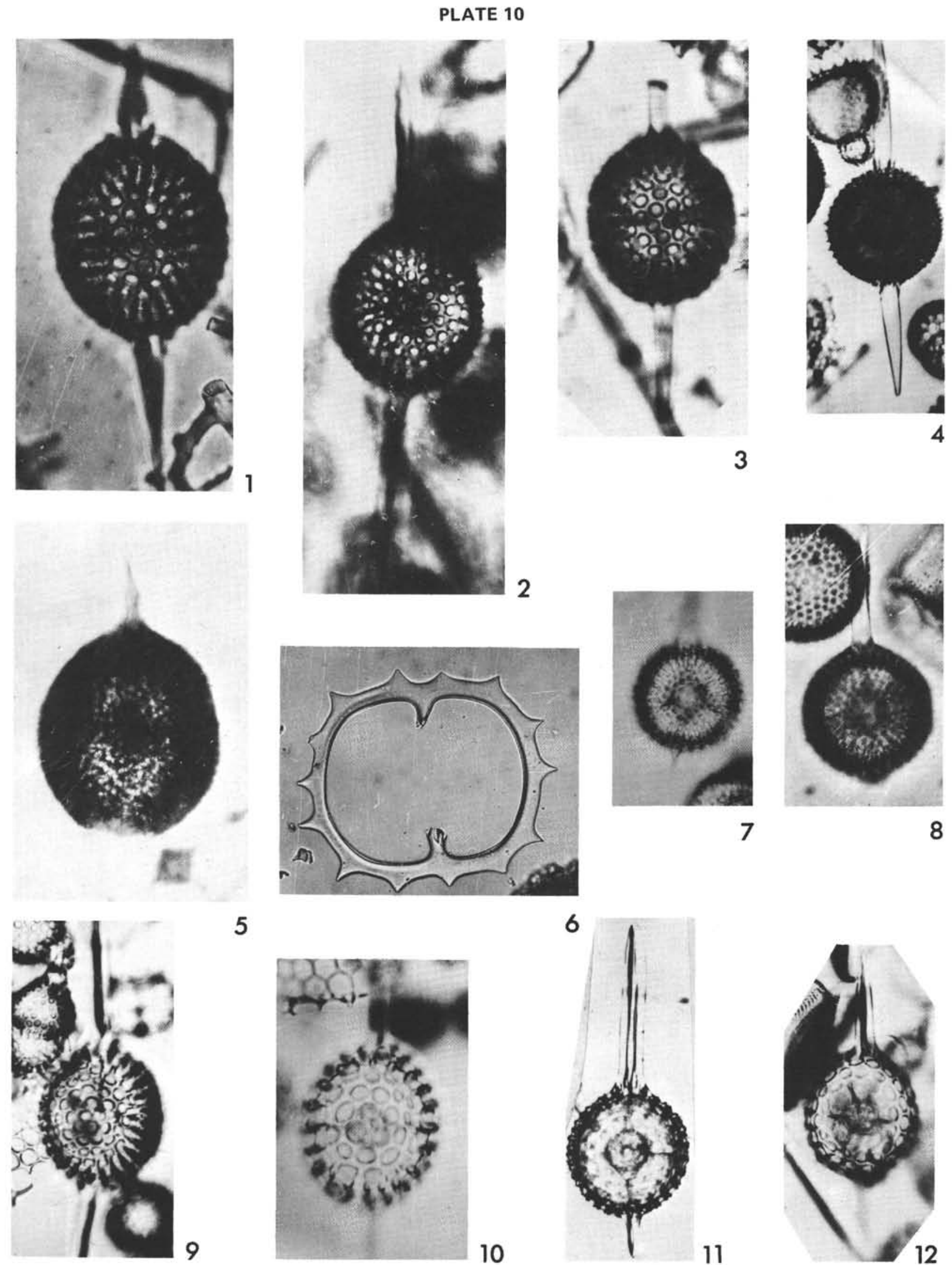

5
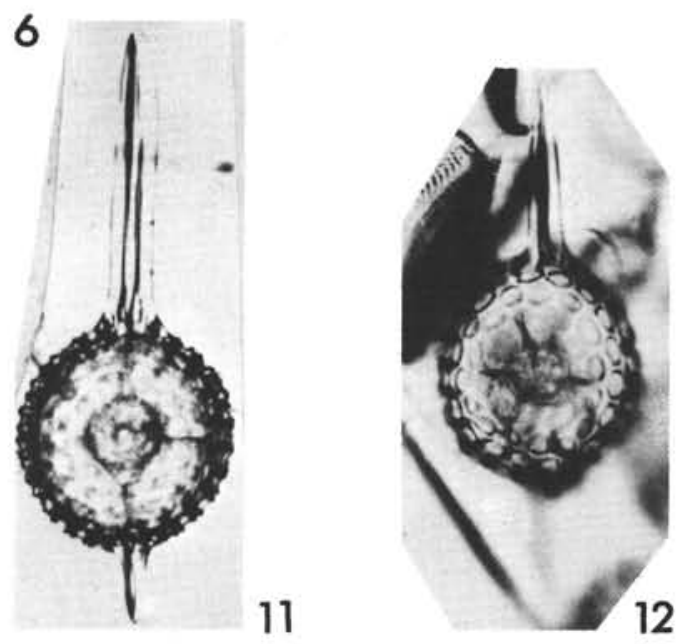
Plate 11

Magnification 200X

Figure 1

Figures 2-4

Figure 8

Figure 9

Figure 10

Figure 11

Figure 12

Figures 13, 14

Figures 15-19
Stylatractus ostacion 140 A-2-5, 5-7 cm.

p. 520

Stylatractus spinulosus group

p. 519

2: $140 \mathrm{~A}-2-6,80-82 \mathrm{~cm}$.

3: $140-2-C C^{*}$.

4: $138-2-3,5-7 \mathrm{~cm}$.

Stylosphaera sp. C

5: 139-1-1, 80-82 cm.

6: 139-1-CC.

7: $139-1-2,5-7 \mathrm{~cm}$.

Stylosphaera (?) laevis 144-1-4, 80-85 cm.

Stylatractus coronatus 144-1-4, 80-85 cm.

p. 520

p. 520

Stylatractus santaennae 139-4-CC.

p. 520

Stylatractus neptunus 138-1-1.

p. 520

Stylatractus fragilis 139-1-1, 80-82 cm.

p. 520

Stylosphaera sp. aff. sulcata

p. 520 144-1-5, 80-85 cm.

p. 520

Stylosphaera angelina group 15: California.

16, 18, 19: 139-1-2, $5-7 \mathrm{~cm}$.

17: 139-1-CC. 
PLAte 11

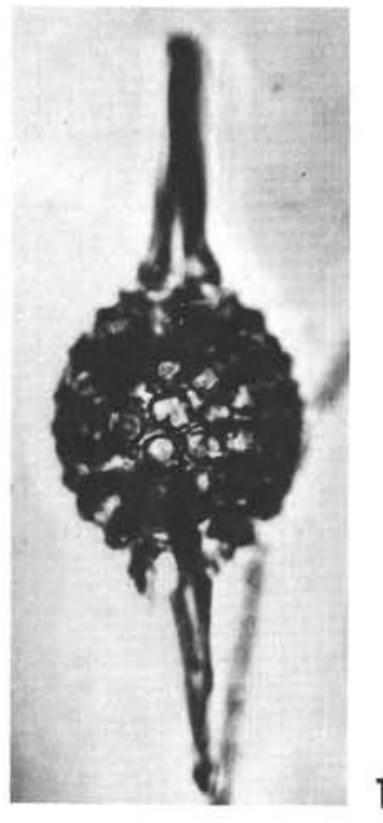

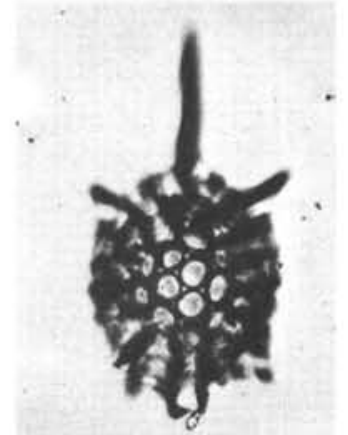
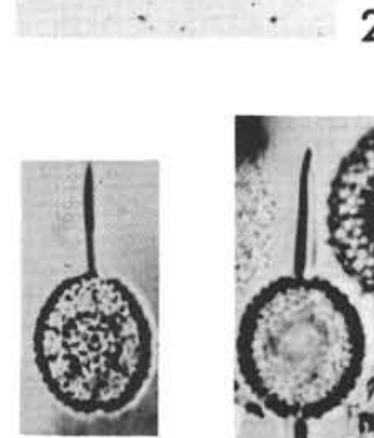

5
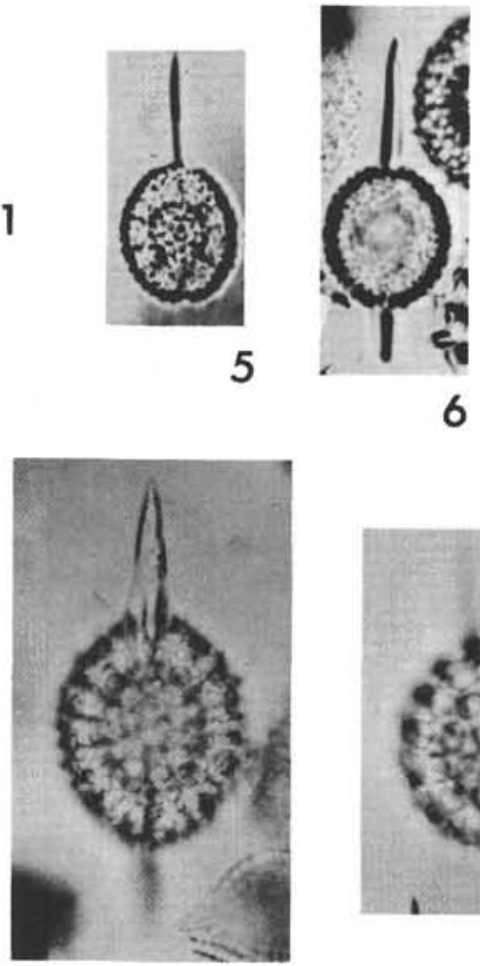

11

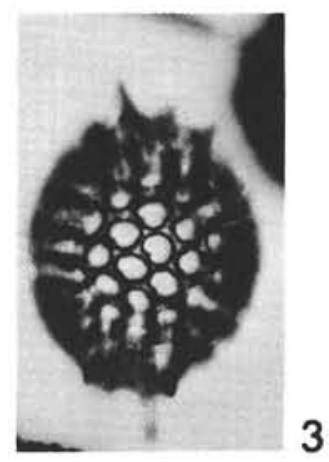

2
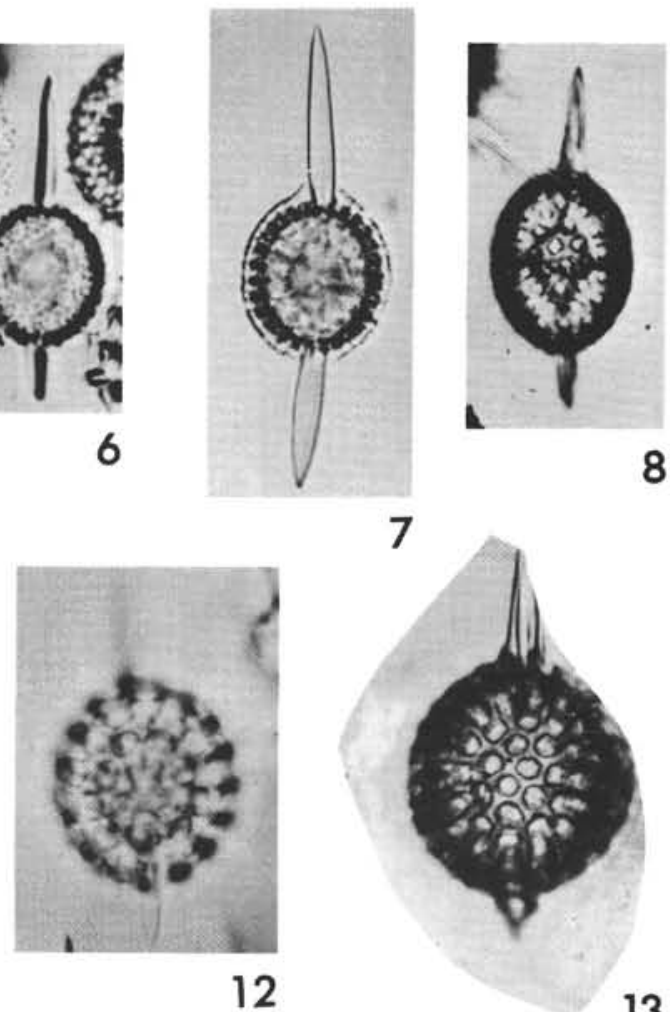

12
13
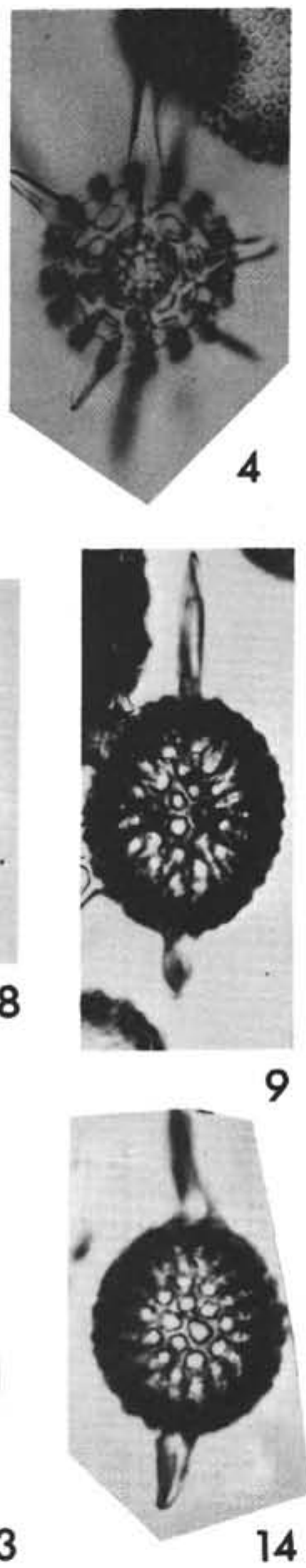

14
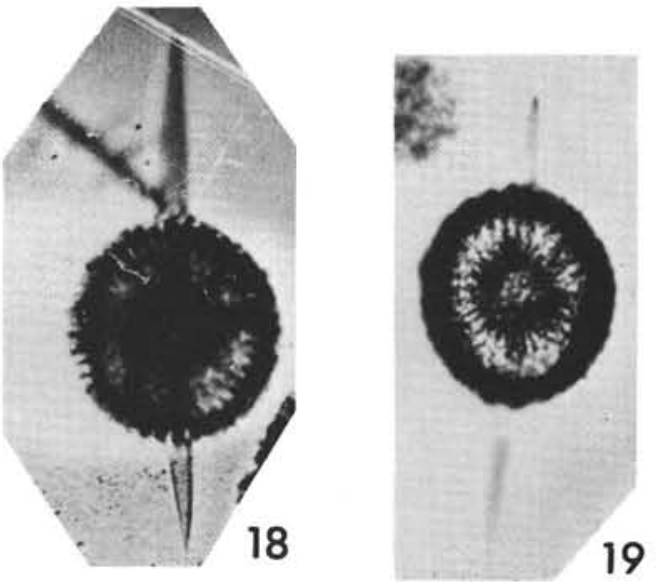
Plate 12

Magnification 200X

Figure 1

Figure 2

Figure 3

Figure 4

Figure 5

Figure 6

Figures 7,8

Figures 9, 10
Artiscinae gen. sp. with hollow polar columns. $140-4-1,10-12 \mathrm{~cm}$.

Cannartus sp. $138-2-2,5-7 \mathrm{~cm}$.

Cannartus mammiferus 140-2-Bumper

Astromma hughesi 139-3-CC.

Astromma petterssoni 139-3-CC.

Astromma enthomocora 139-3-CC.

Astromma? supp.

7: $139-4-C C$

8: $142-9-1,98-100 \mathrm{~cm}$

Cannartus violina

9: $140-2-1,80-82 \mathrm{~cm}$

10: $140-2-1,5-7 \mathrm{~cm}$

Figures 11-14 Cannartus sp. A

11: $139-5-\mathrm{CC}$

12: $140-2-3,5-7 \mathrm{~cm}$

13, 14: 139-5-CC

Figures 15-17 Ommatartus spp. aff. O. ceratosphyris 15, 17: 139-1-CC

16: $139-1-1,80-82 \mathrm{~cm}$ p. 522

p. 521

p. 521

p. 522

p. 522

p. 522

p. 522

p. 522

p. 522

p. 522 
PLATE 12
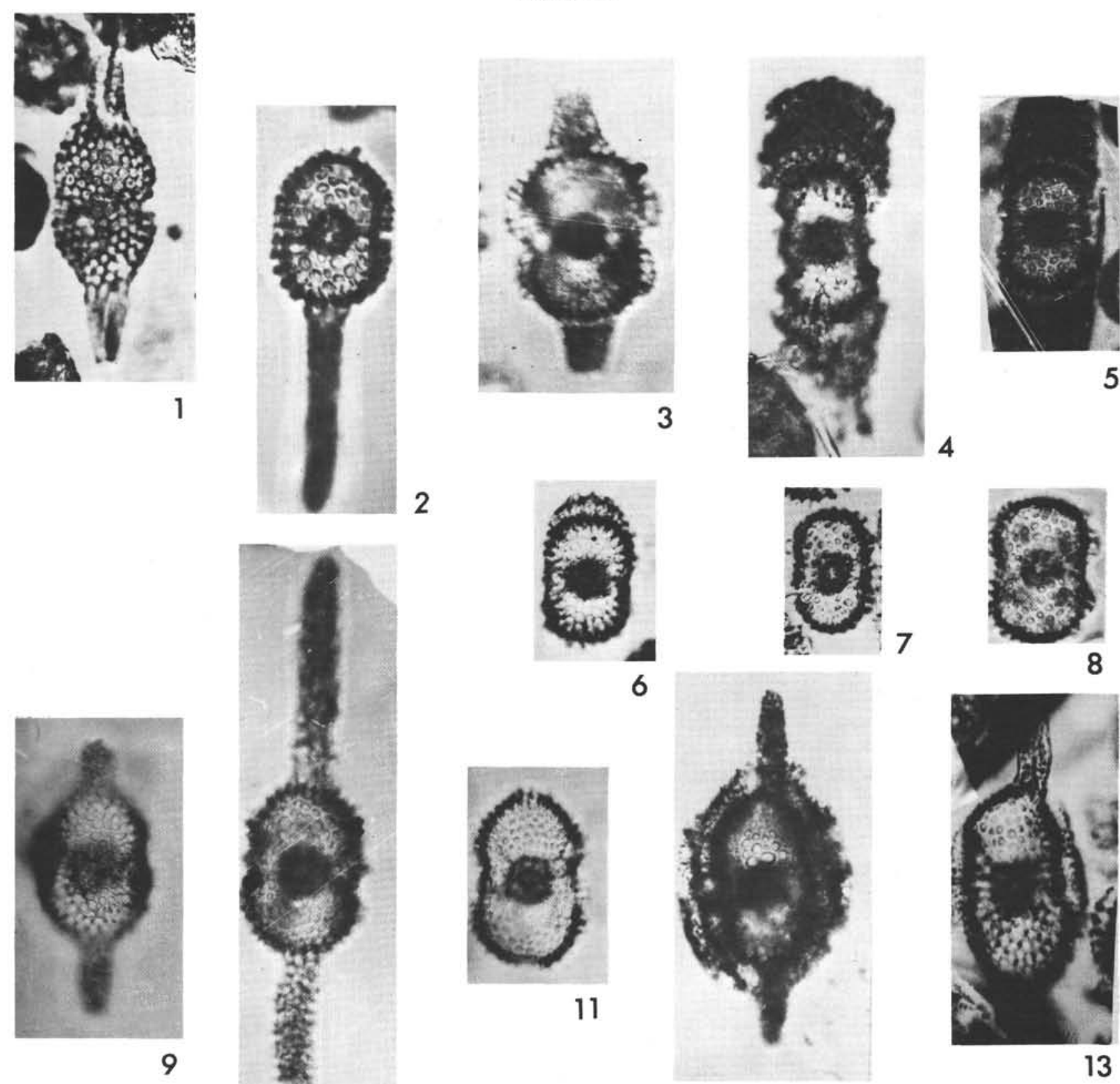

7

4
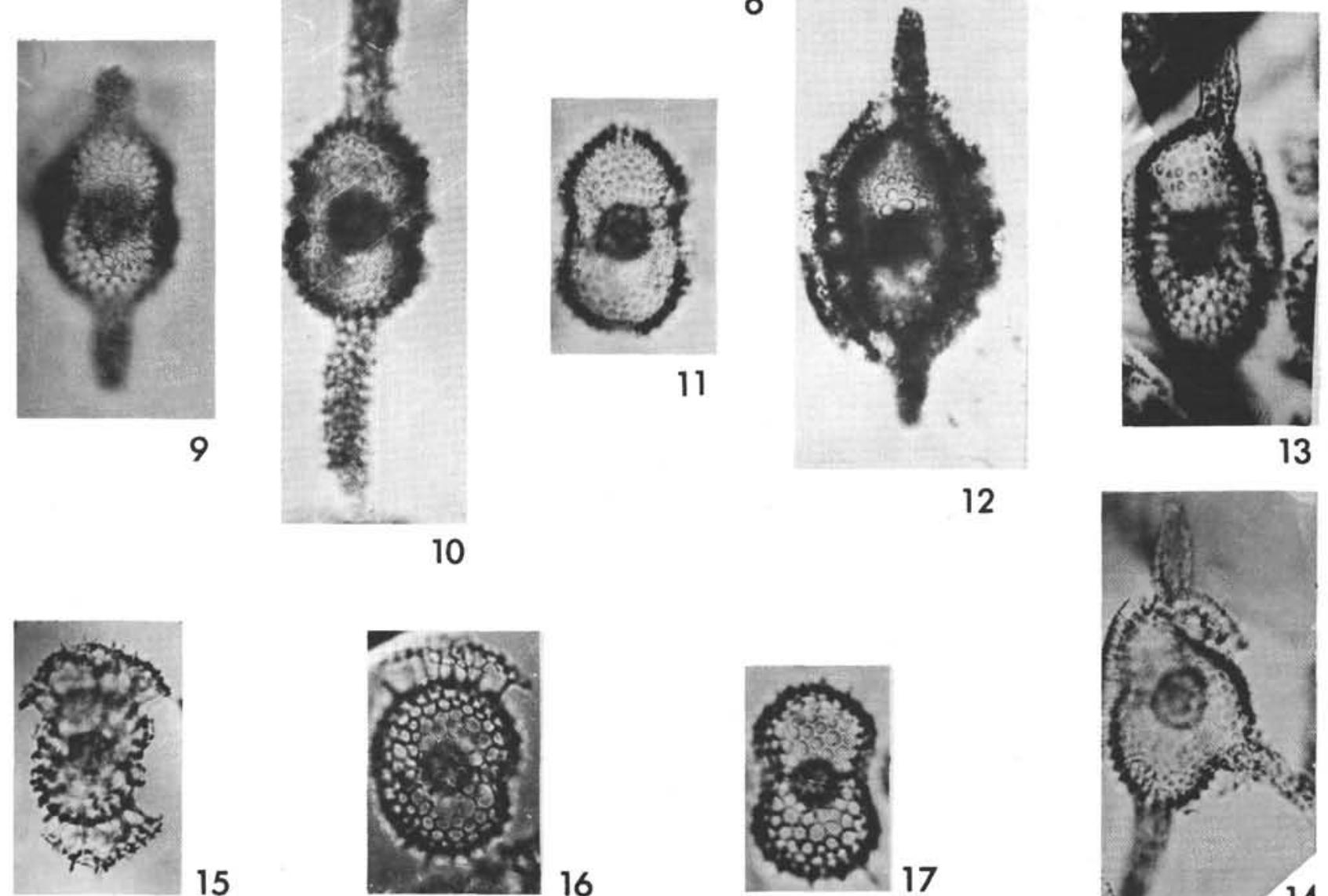

15
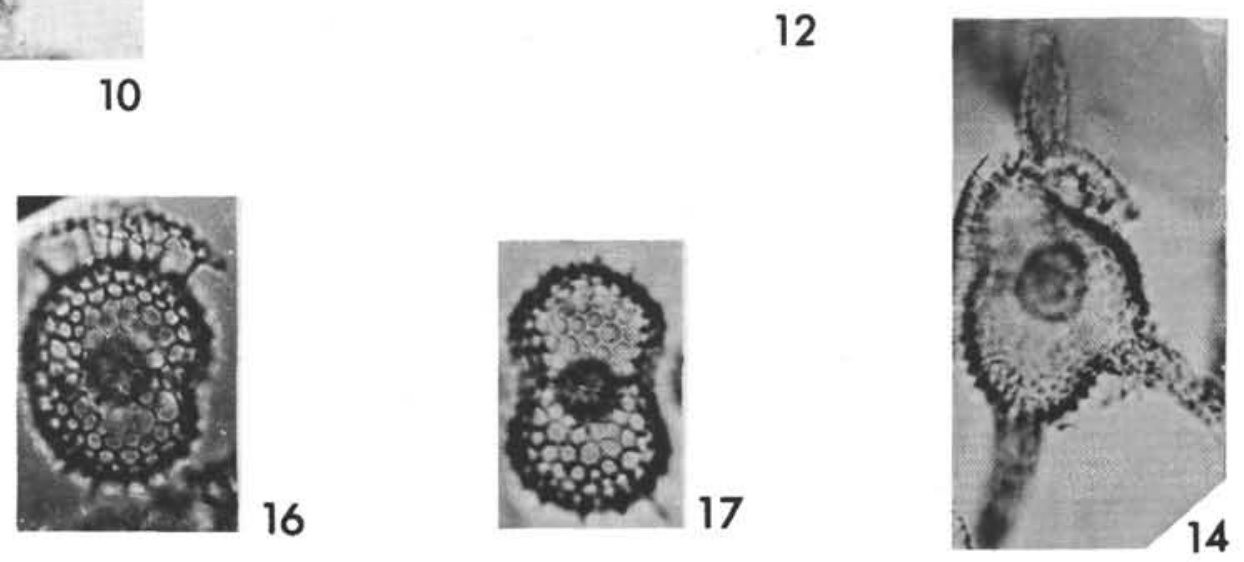
Plate 13

Magnification 200X

Figure 1

Figure 2

Figure 3

Figure 4

Figure 5

Figure 6, 7

Figure 8

Figure 9

Figure 10
Sethostylus sp. aff. Phacostylus amphistylus 140-2-CC*.

\section{Triactis triactis} 140-2-CC*.

Heliodiscus asteriscus grp. $144-1-3,80-85 \mathrm{~cm}$.

Heliodiscus hexasteriscus 144-1-CC.

Heliodiscus sp. aff. $H$. saturnalis 144-1-6, 80-85 cm.

Heliodiscus pentasteriscus 144-1-5, 80-85 cm.

Heliodiscus saturnalis 144-1-CC.

Heliodiscus sp. aff. $H$. echiniscus $144 \mathrm{~A}-2-6,2-4 \mathrm{~cm}$.

Heliosestilla spicata $140 \mathrm{~A}-2-5,5-7 \mathrm{~cm}$. p. 522

p. 523

p. 523

p. 523

p. 523

p. 523

p. 523

p. 523

p. 522 
Plate 13
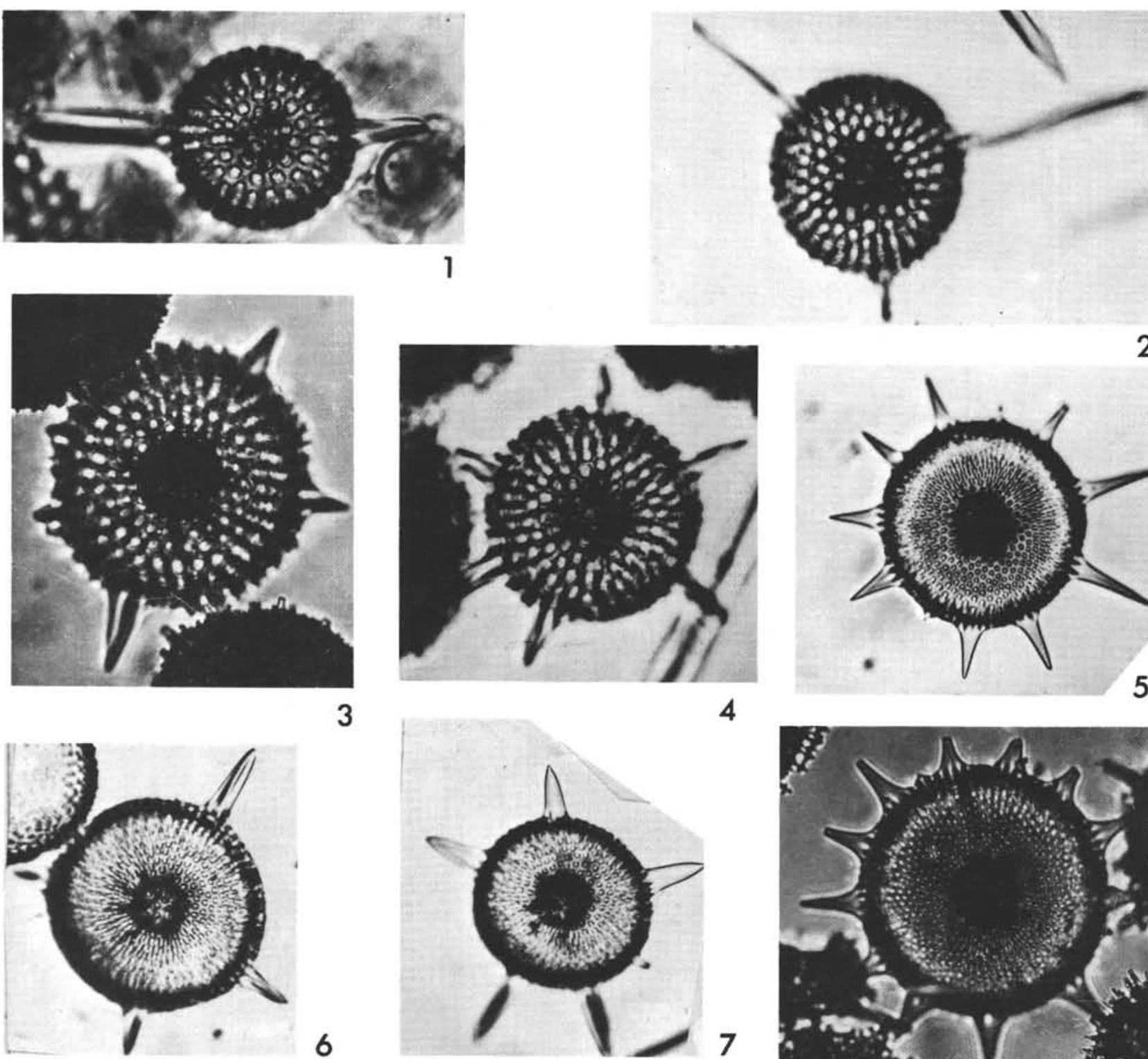

3
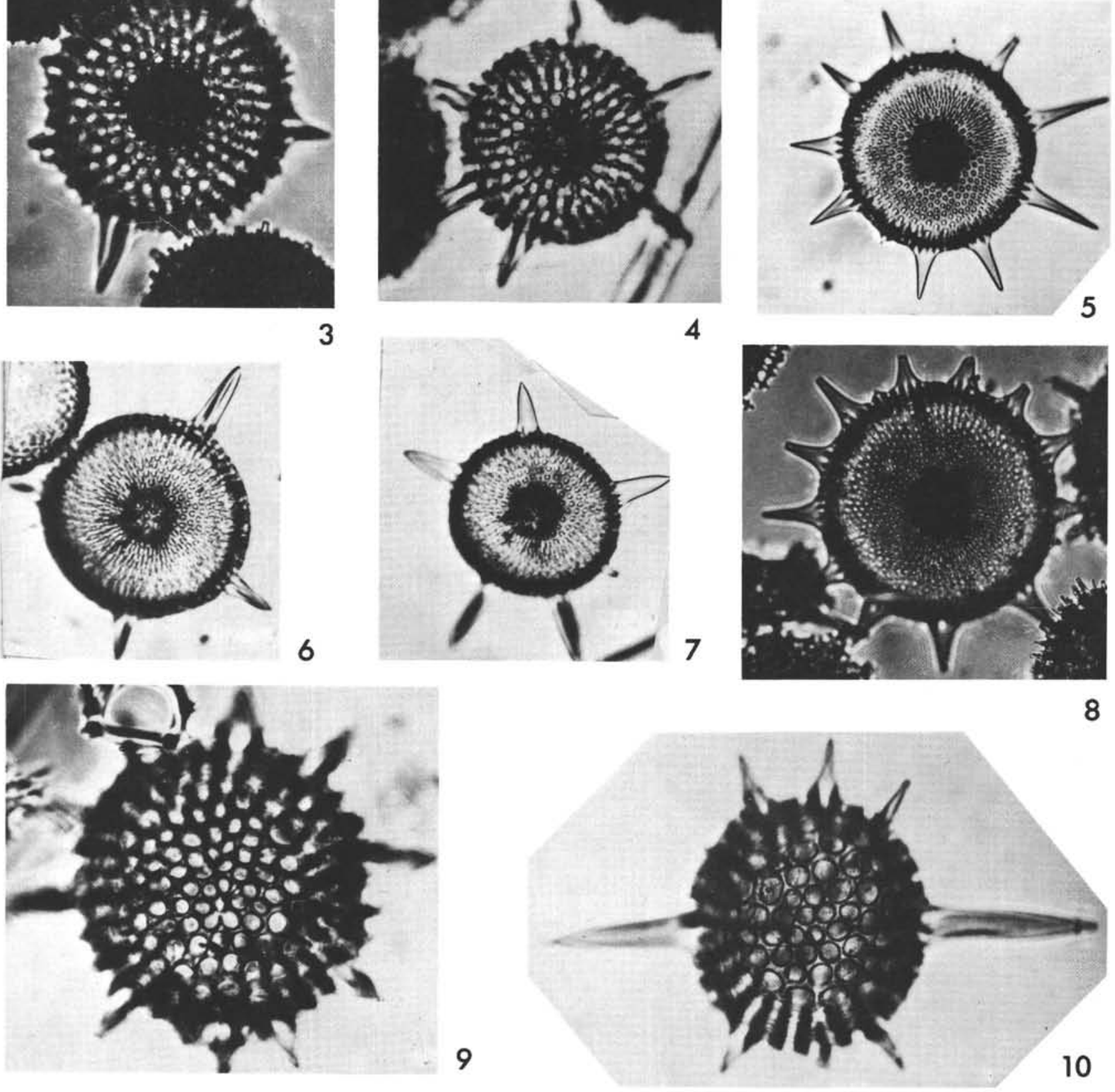
Plate 14

Magnification 200X

\begin{tabular}{|c|c|c|}
\hline Figure 1,2 & $\begin{array}{l}\text { Periphaena decora } \\
\text { 1: } 140-2-C{ }^{*} . \\
\text { 2: } 144-1-5,80-85 \mathrm{~cm} .\end{array}$ & p. 523 \\
\hline Figure 3 & $\begin{array}{l}\text { Periphaena dupla } \\
\quad \text { 144A-2-6, } 2-4 \mathrm{~cm} .\end{array}$ & p. 523 \\
\hline Figures 4,5 & $\begin{array}{c}\text { Periphaena sp. } \\
\text { 144-1-CC. }\end{array}$ & p. 523 \\
\hline Figure 6 & $\begin{array}{l}\text { Stylocyclia ? sp. } \\
\text { 144-1-CC. }\end{array}$ & p. 523 \\
\hline Figure 7 & Lithocyclia? sp. & p. 523 \\
\hline
\end{tabular}
144-1-CC. 
PLATE 14
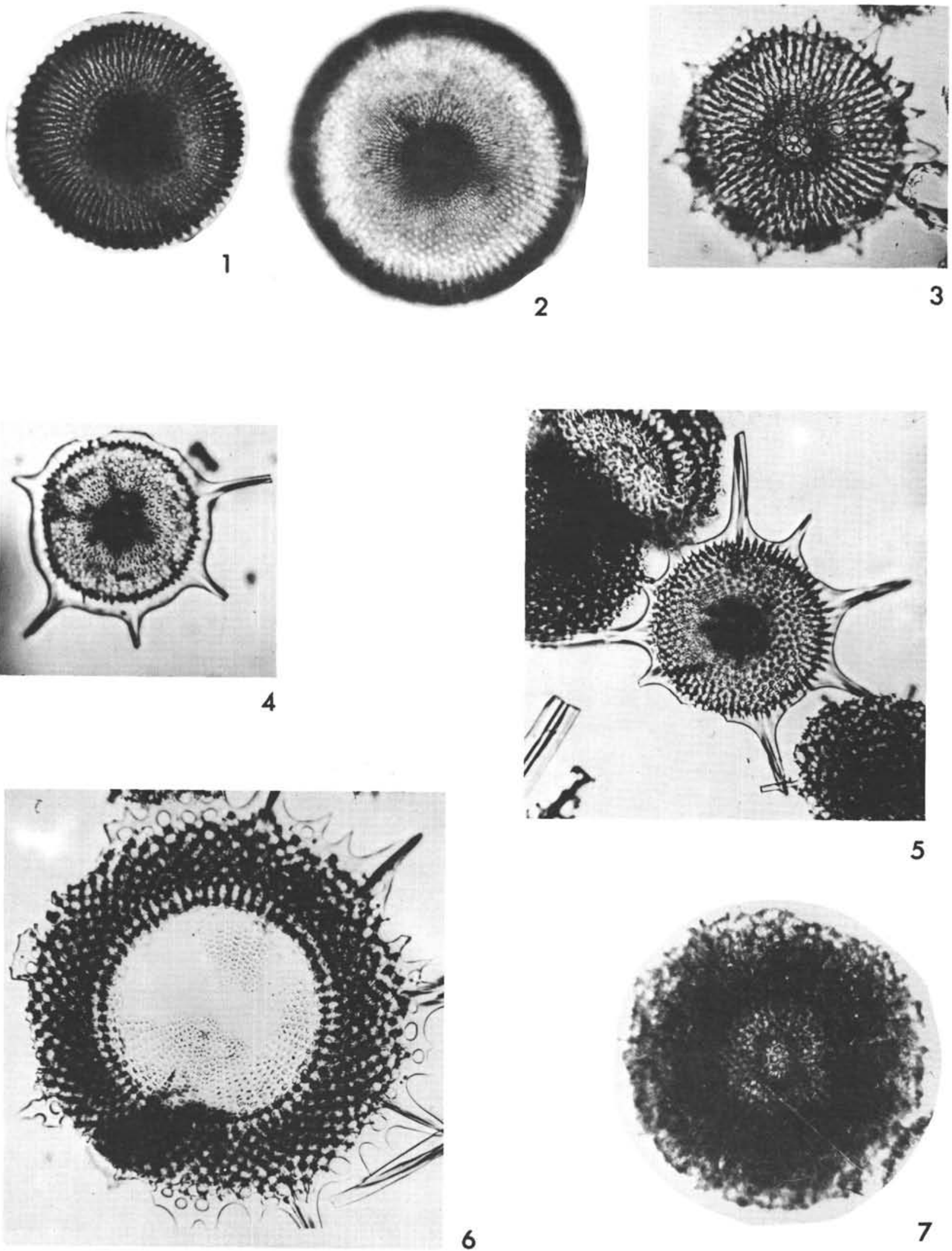
Plate 15

Magnification 200X

\begin{tabular}{|c|c|c|}
\hline Figures 1,2 & $\begin{array}{l}\text { Lithocyclia ocellus } \\
\text { 144-1-CC. }\end{array}$ & p. 523 \\
\hline Figure 3 & $\begin{array}{l}\text { Lithocyclia sp. aff. L. Lenticula } \\
\text { 144-1-CC. }\end{array}$ & p. 523 \\
\hline Figure 4 & $\begin{array}{l}\text { Stylocyclia dimidiata } \\
144-1-6,80-85 \mathrm{~cm} .\end{array}$ & p. 523 \\
\hline Figure 5 & $\begin{array}{l}\text { Trigonocyclia sp. A } \\
144-1-5,80-85 \mathrm{~cm} .\end{array}$ & p. 524 \\
\hline Figure 6 & $\begin{array}{l}\text { Trigonocyclia prima holotype } \\
\text { 144-1-CC. }\end{array}$ & p. 524 \\
\hline Figure 7 & $\begin{array}{c}\text { Astrocyclia sp. } \\
\text { 144-1-CC. }\end{array}$ & p. 524 \\
\hline
\end{tabular}


PLATE 15

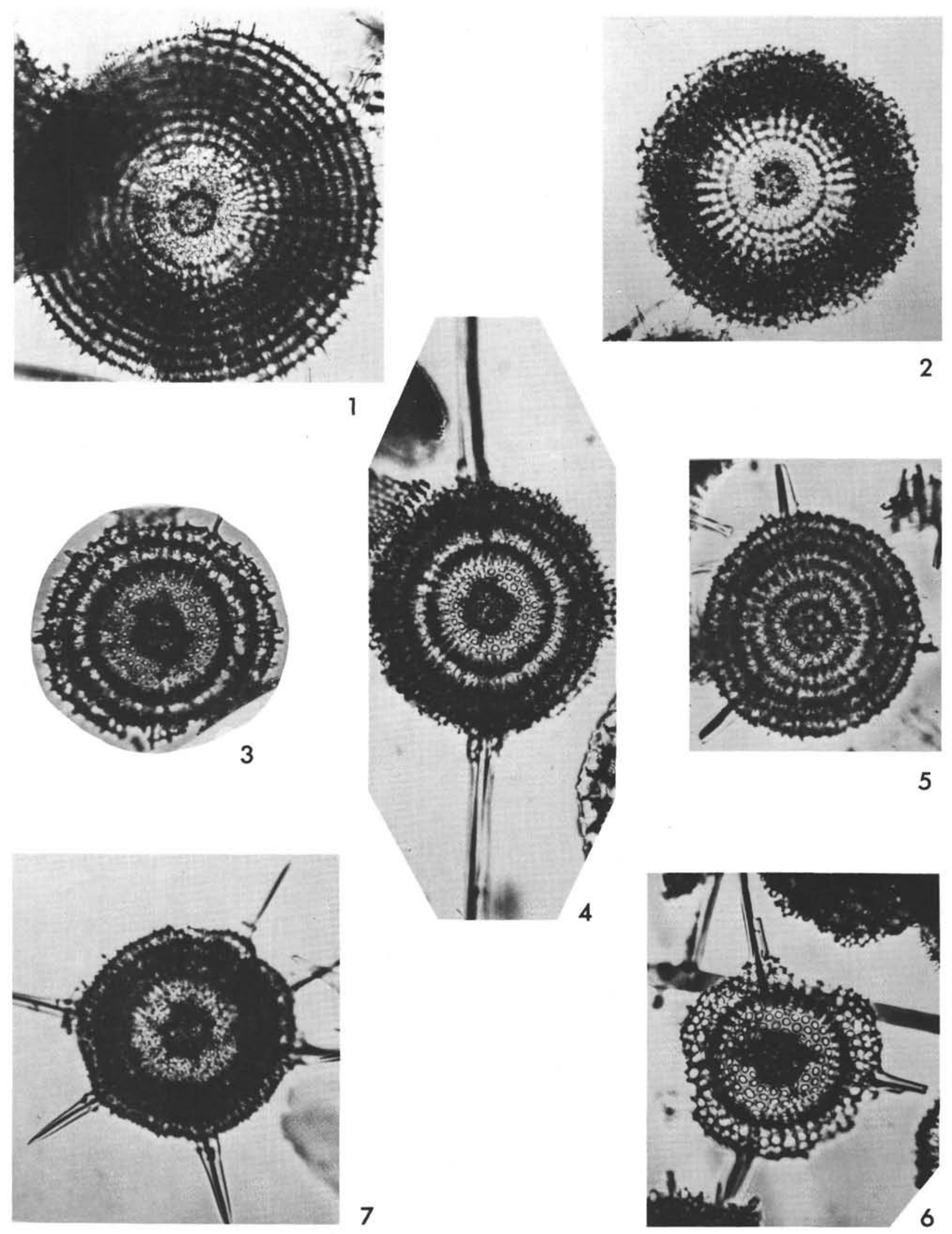


Plate 16

Magnification 200X

\begin{tabular}{|c|c|c|}
\hline Figures 1-5 & $\begin{array}{l}\text { Astractinium aristotelis group } \\
\text { 140-2-CC*. }\end{array}$ & p. 524 \\
\hline Figure 6 & $\begin{array}{l}\text { Astractinium sp. A } \\
140-2-C^{*} \text {. }\end{array}$ & \\
\hline Figure 7 & $\begin{array}{c}\text { Astractinium sp. B } \\
\text { 140-2-CC* }\end{array}$ & \\
\hline Figures 8,9 & $\begin{array}{l}\text { Astractinium spp. aff. Lithocyclia crux } \\
\text { 8: } 144 \mathrm{~B}-2-6 \text {, Top. } \\
\text { 9: } 138-2-6,5-7 \mathrm{~cm} .\end{array}$ & p. 524 \\
\hline Figure 10 & $\begin{array}{l}\text { Astractinium sp. C } \\
\text { 144B-2-5, Top. }\end{array}$ & p. 524 \\
\hline
\end{tabular}


PLATE 16
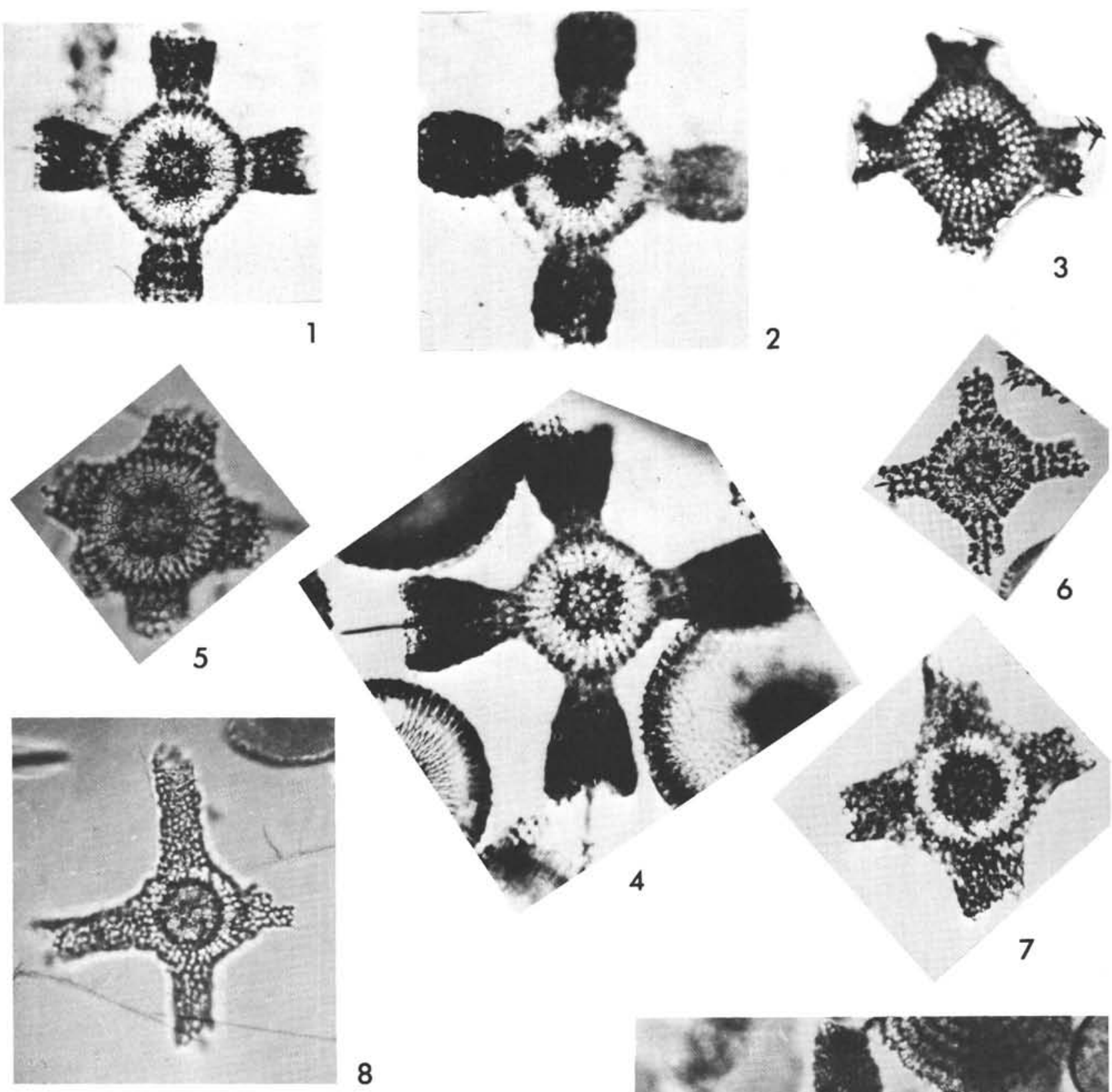

8
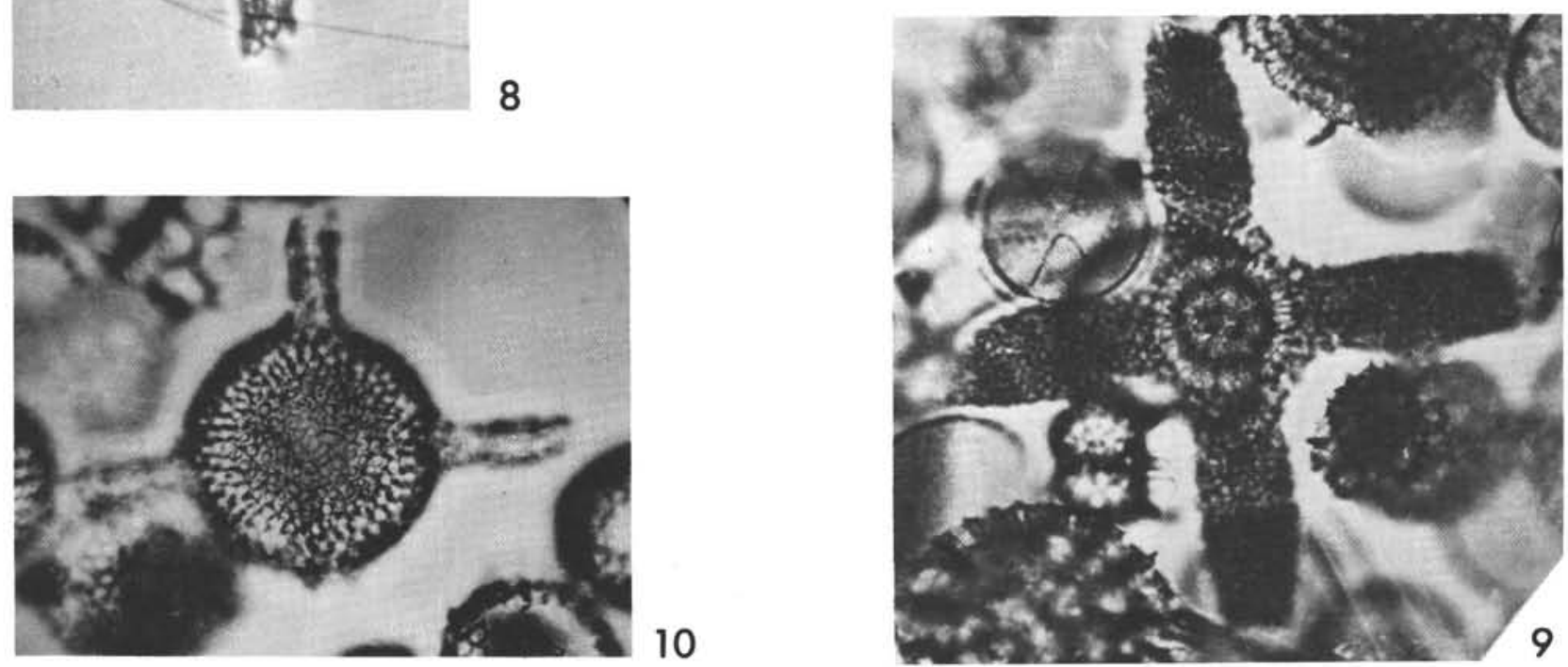
Plate 17

Magnification 200X

Figure 1

Figure 2

Figure 3

Figures 4-6

Figures 7, 8
Trigonactinium pithagore 140-2-CC*

Trigonactinium $\mathrm{sp}$. $140 \mathrm{~A}-2-5,5-7 \mathrm{~cm}$.

Trigonactinium ? angustum $138-2-6,5-7 \mathrm{~cm}$.

Rhopalastrum profundum group

4: $140-2-6,80-85 \mathrm{~cm}$.

5: $139-1-2,5-7 \mathrm{~cm}$.

6: $140-2-1,5-7 \mathrm{~cm}$.

Rhopalastrum angulatum group

7: $139-1-2,5-7 \mathrm{~cm}$.

8: 139-5-CC. p. 524

p. 524

p. 524

p. 529

p. 529 
PLATE 17
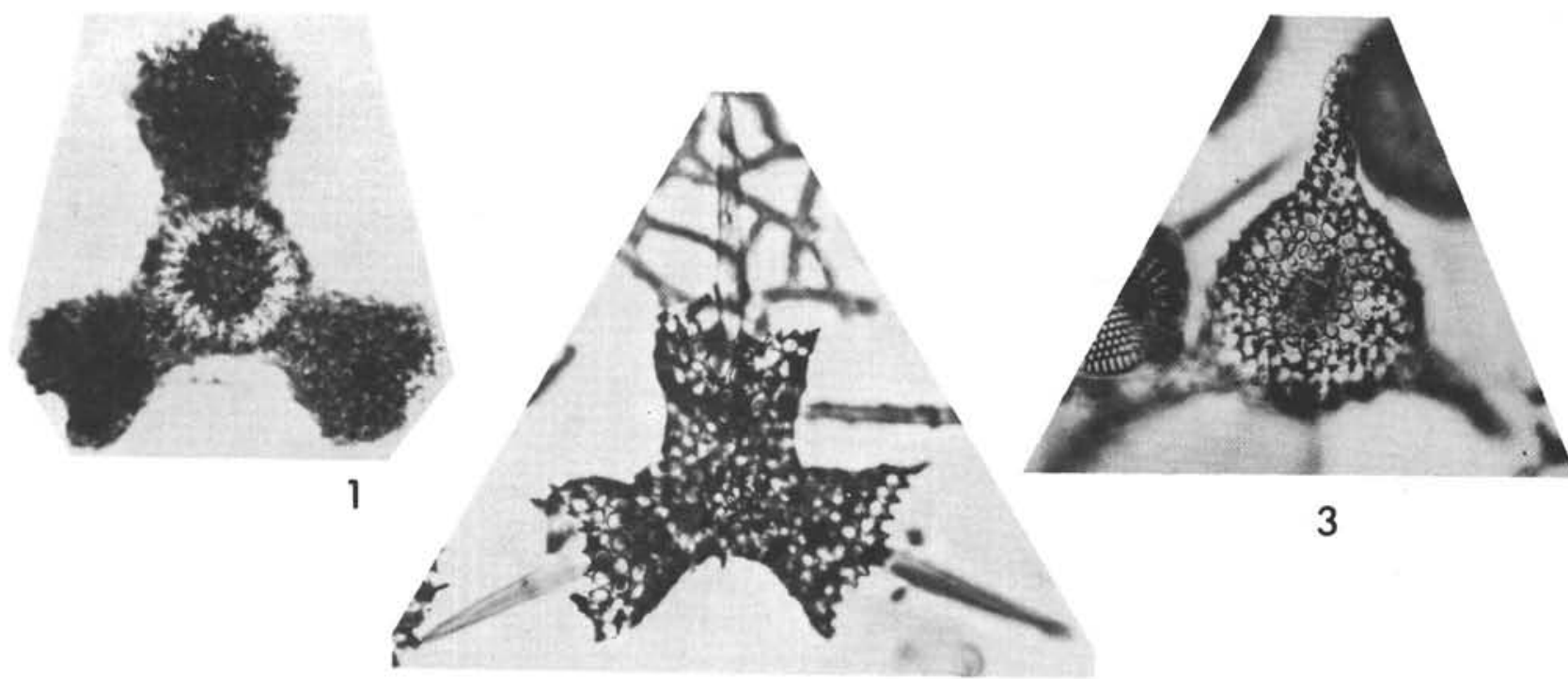

3
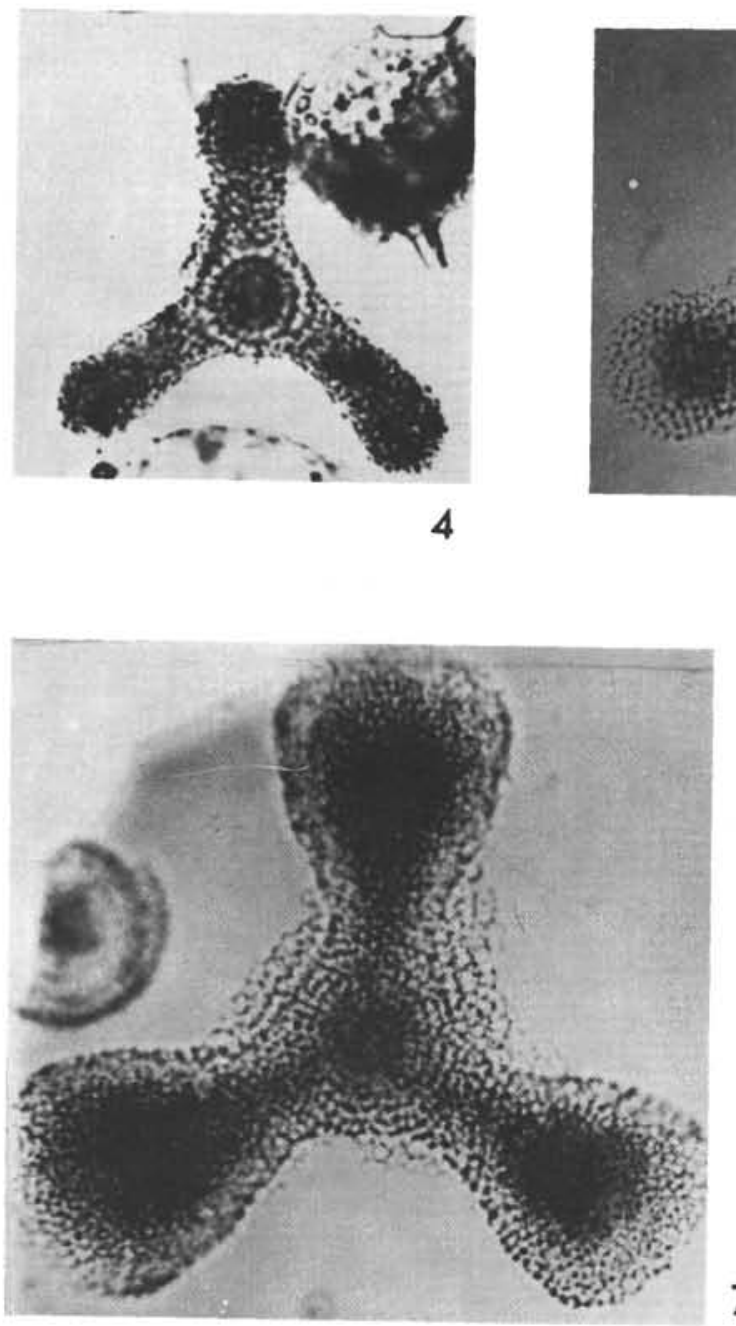
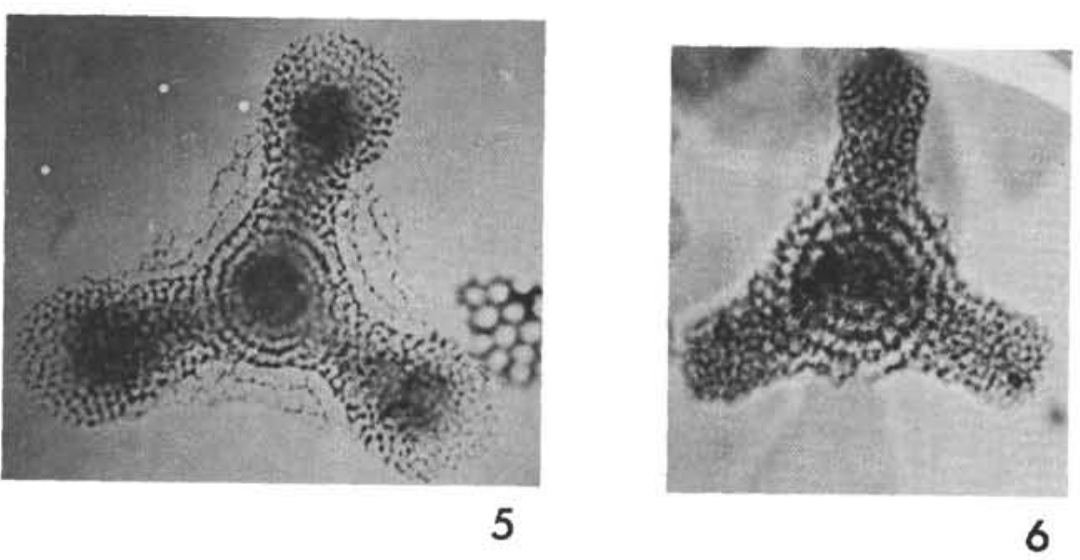

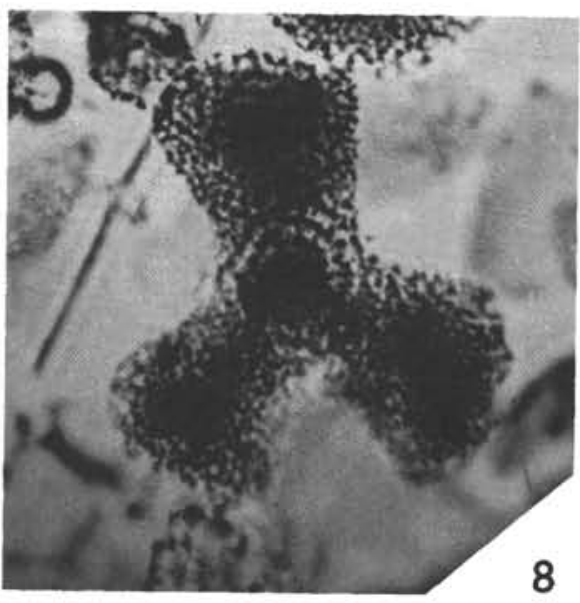


Plate 18

Magnification 200X

Figures 1,2 Tholodiscus ocellatus

p. 525

1: $144-1-4,80-85 \mathrm{~cm}$

2: $144 \mathrm{~A}-2-6,2-4 \mathrm{~cm}$.

Figures 3-5 Tholodiscus splendens

p. 525

3: $144-1-5,80-85 \mathrm{~cm}$. 4, 5: $140-2-C^{*}$.

Figure 6

Stylodictya aculeata $139-1-2,5-7 \mathrm{~cm}$.

p. 526

Figure 7

Stylodictya orbiculata

p. 526 $144 \mathrm{~A}-2-6,2-4 \mathrm{~cm}$.

Figure $8 \quad$ Stylodictya inaequalispina

p. 526 $144-1-6,80-85 \mathrm{~cm}$.

Figure 9

Stylodictya rosella holotype

p. 526 140-2-CC*.

Figure 10

Stylodictya targaeformis 144-1-CC*.

p. 526

Figure 11

Porodiscus concentricus

p. 525 144-1-6, 80-85 cm. 
PLATE 18
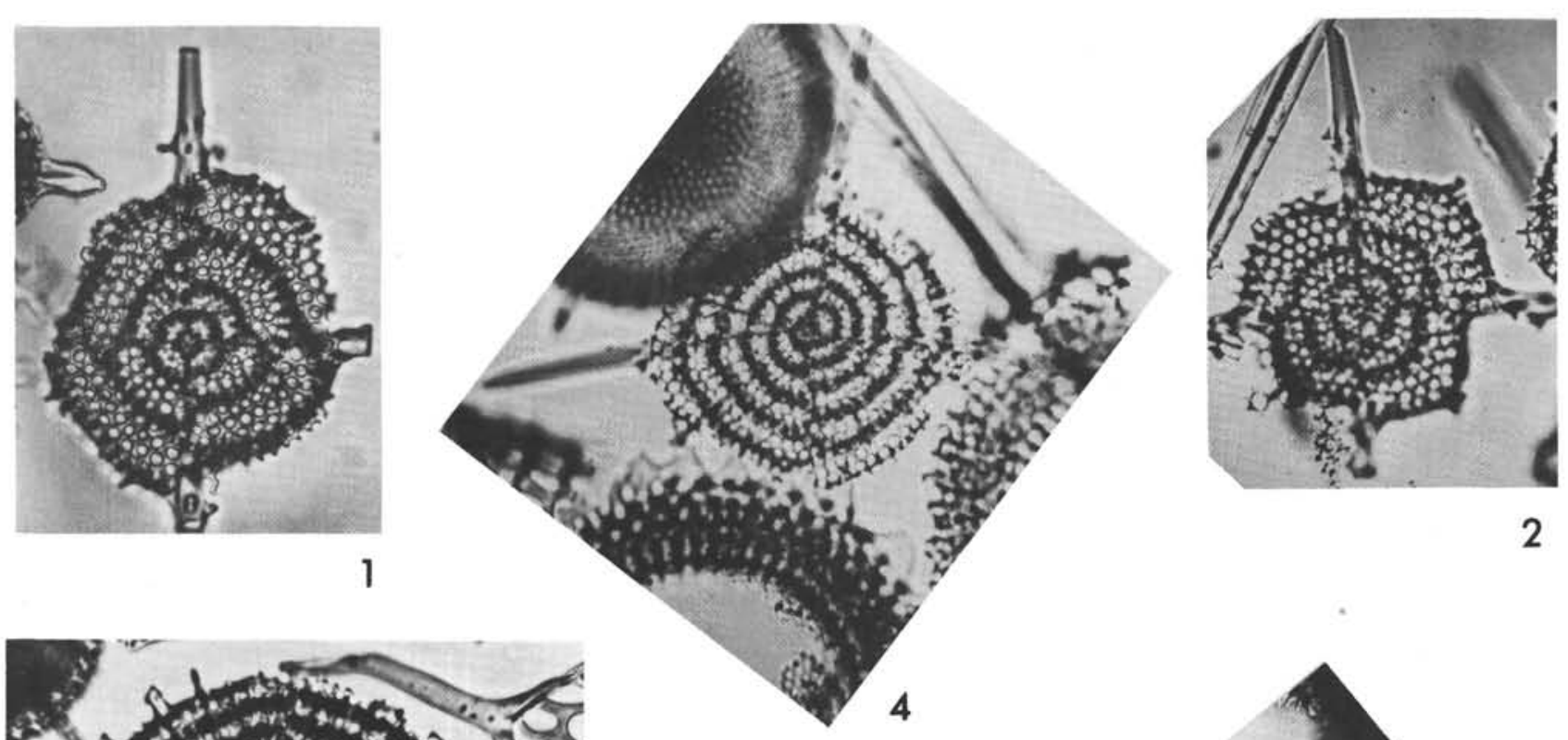

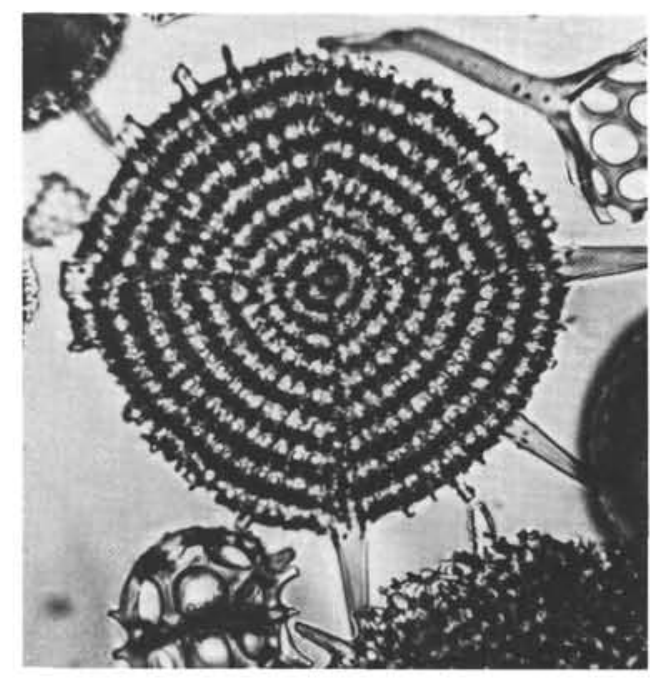

3

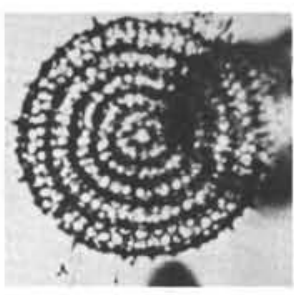

7

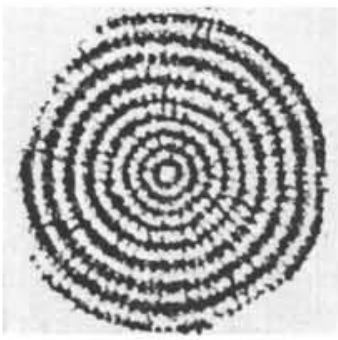

11
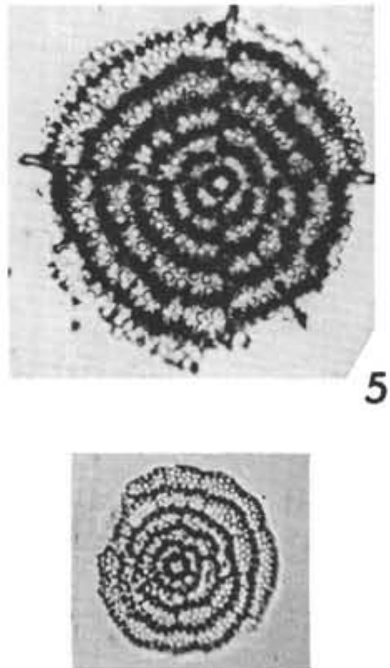

6
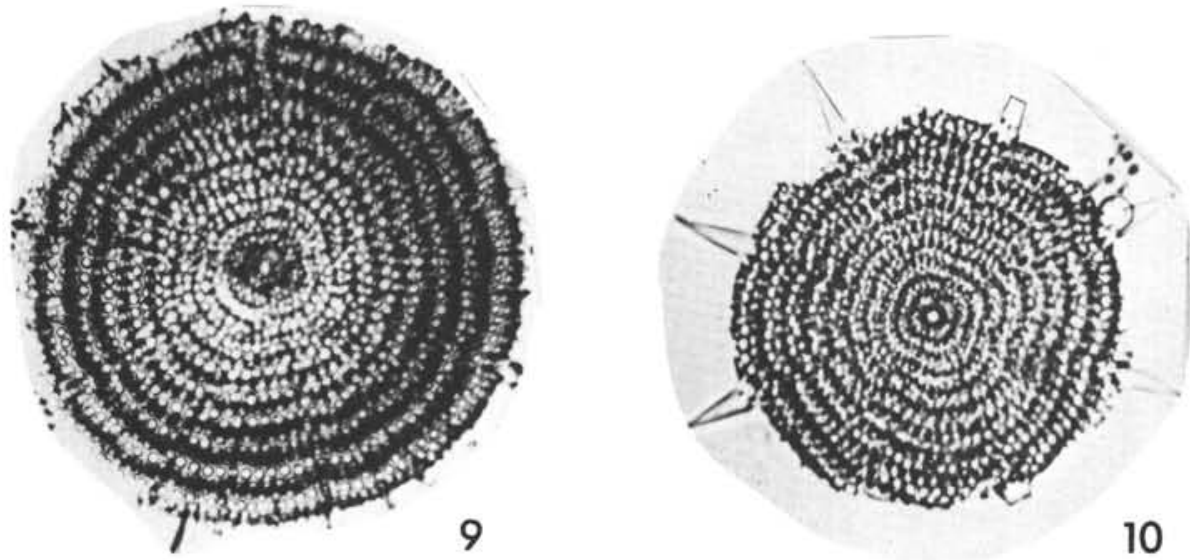

10 
Plate 19

Magnification 200X

(except Figure 6)

Figures 1-6

Figure 7

Figure 8

Figures 9.12

Figure 13

Figure 14

Figure 15
Circodiscus microporus

Indian Ocean, St. 4550 "VITYAZ"

4: Equatorial section.

5: Sagittal section.

6: Frontal section - $400 \mathrm{X}$.

Circodiscus microporus

p. 526

139-1-CC.

Circodiscus sp.

139-3-CC.

p. 526

Plectodiscus circularis

p. 526

9-11: California, Kellogg Shale

(11 - sagittal section).

12: $144-2-3$

Plectodiscus bergontianus 144-1-CC.

p. 526

Plectodiscus sp.

148A-2-6, 80-82 cm.

Phacodiscidae? gen indet. $140-2-6,80-82 \mathrm{~cm}$. 
PLATE 19
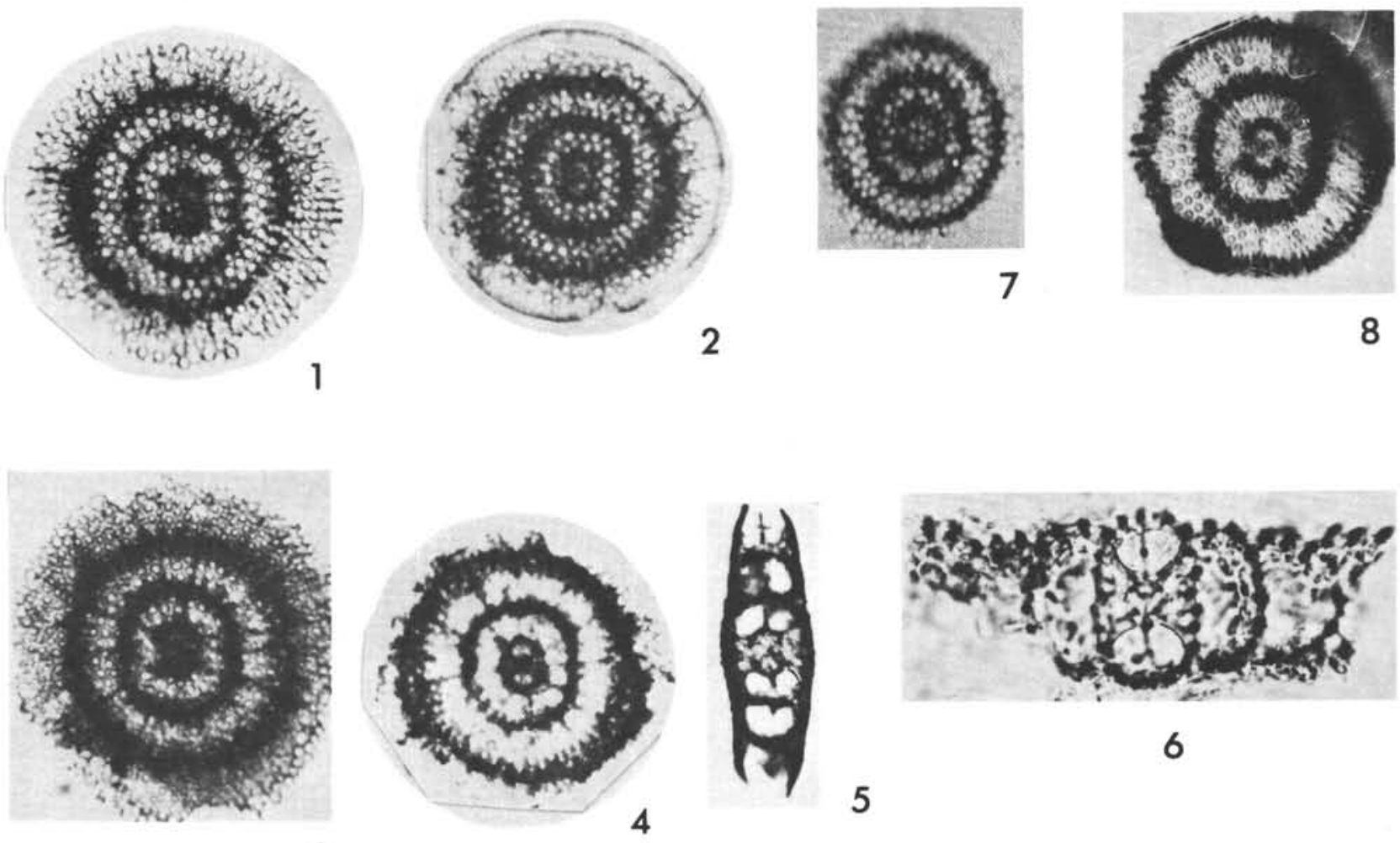

3
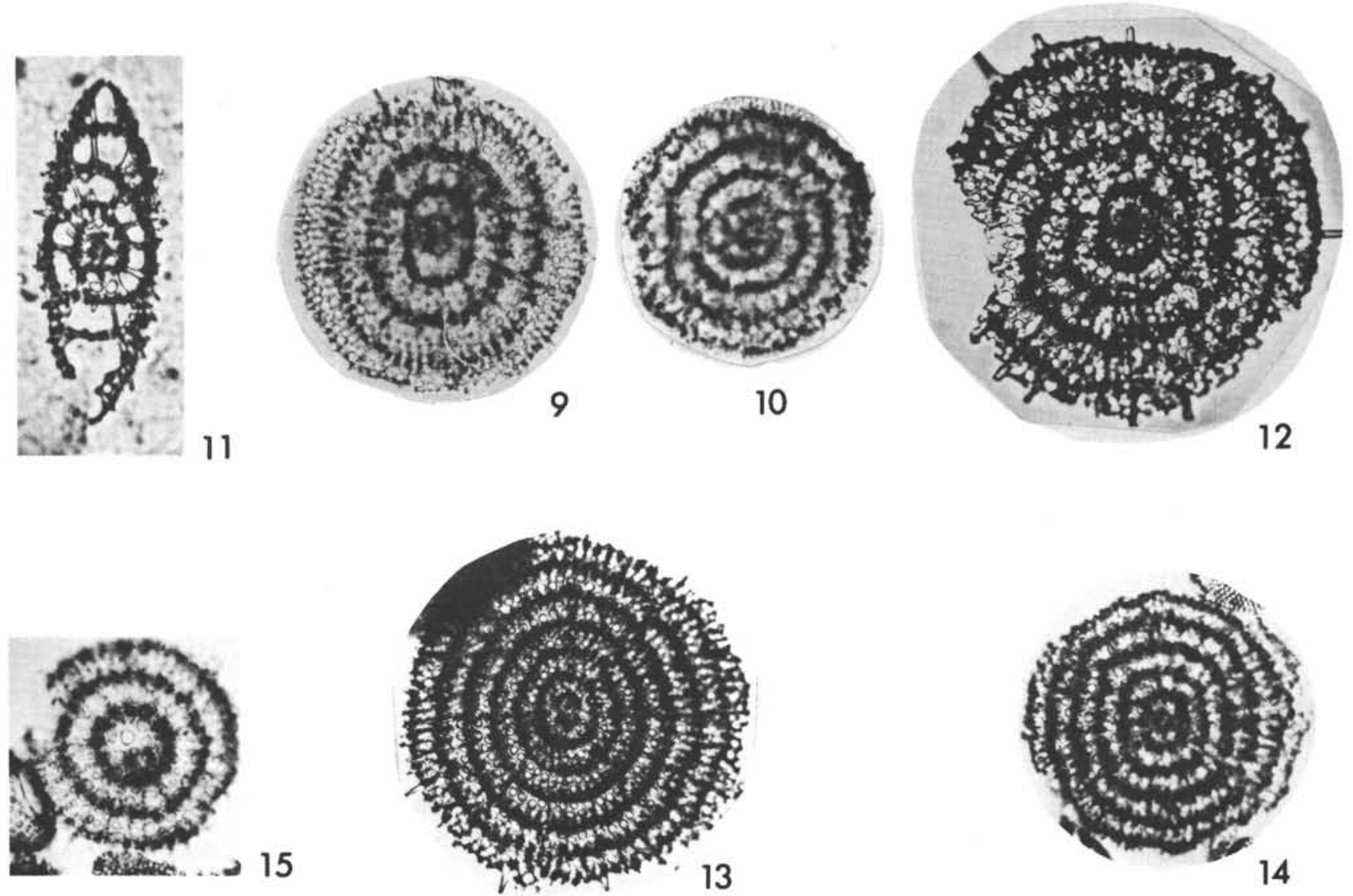
Plate 20

Magnification 200X

Figures 1-2 Ommatocampe spp. aff. O. amphistylium

p. 527

1: 144-1-CC.

2: 139-7-CC.

Figures $3 \quad$ Trigonastrum sp. aff. Chitonastrum lyra

p. 527 $139-1-1,80-82 \mathrm{~cm}$.

Figure 4

Trigonastrum sp. aff. Euchitonia mulleri

p. 527 $139-1-1,80-82 \mathrm{~cm}$.

Figure $5 \quad$ Trigonastrum sp.

$139-1-1,80-82 \mathrm{~cm}$.

p. 527

Figure 6

Spongodiscidae ? gen indet. (=Porodiscus fortii) 144-1-CC.

Figure $7 \quad$ Porodiscidae gen. indet. (=Porodiscus ellipticus?)

$\begin{array}{lll}\text { Figure } 8 & \text { Rhopalastrum profunda group } & \text { p. } 529\end{array}$ 140-2-CC*.

Figures 9-11 Stephanastrum sp. aff.S. rhopaloporum

p. 527

9: $140 \mathrm{~A}-2-6,80-82 \mathrm{~cm}$.

10: $140-2-C^{*}$.

11: 144B-2-5, Top.

Five-armed malformation.

Figure $12 \quad$ Spongasteriscus sp.

p. 529 139-7-CC. 
PLATE 20
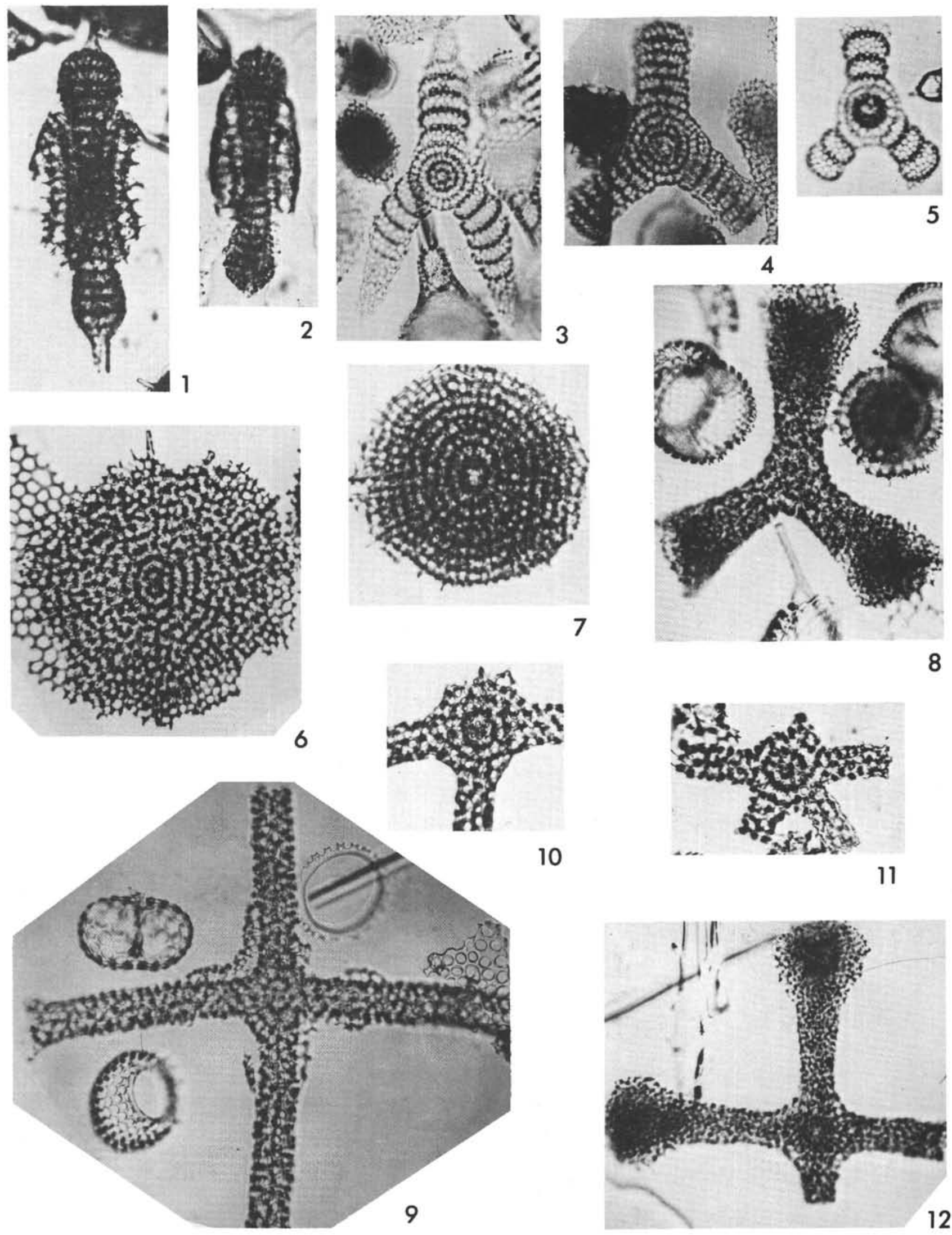

10
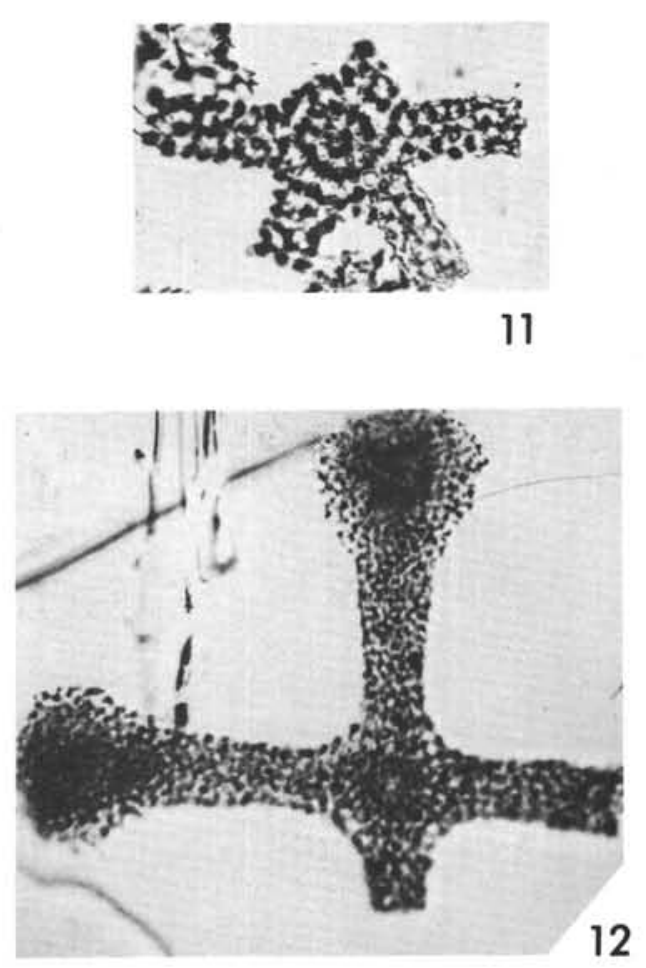
Plate 21

Magnification 200X

(except Figure 14)

Figure 1 Spongodiscus? sp.

p. 528

$140-2-1,5-7 \mathrm{~cm}$.

Figure 2 Spongotripus sp.

p. 528 140-2-CC*.

Figure 3 Spongodiscus? sp.

p. 528

Malaga Mudstone, California.

Figure 4 Spongodiscus resurgens osculosa

p. 528 $139-1-1,80-82 \mathrm{~cm}$.

Figure 5 Spongodiscus resurgens resurgens

p. 528 $139-1-1,80-82 \mathrm{~cm}$.

Figures 6-7 Spongasteriscus spp.

p. 529

6: $140-2-1,5-7 \mathrm{~cm}$.

7: $140-2-3,5-7 \mathrm{~cm}$.

Figure $8 \quad$ Ommatogramma sp. A $140-2-1,5-7 \mathrm{~cm}$.

Figure 9 Ommatogramma sp. B 139-5-CC.

Figure 10 Ommatogramma sp. aff. Amphibrachium robustum

p. 528 $139-1-2,5-7 \mathrm{~cm}$.

Figure 11 Ommatogramma sp. 140-2-CC*.

Figure 12 Rhopalastrum sp. aff. Dictyocoryna pentagona 139-5-CC.

Figure 13 Spongaster sp.

p. 528 $140-2-1,5-7 \mathrm{~cm}$.

Figure 14 Spongaster disimmetricus

Northwestern Pacific.

Dogiel's collection, S1. 124; 100X.

Figure 15 Spongotrochus longispinus

p. 528

$140-2-1,5-7 \mathrm{~cm}$. 
PLATE 21
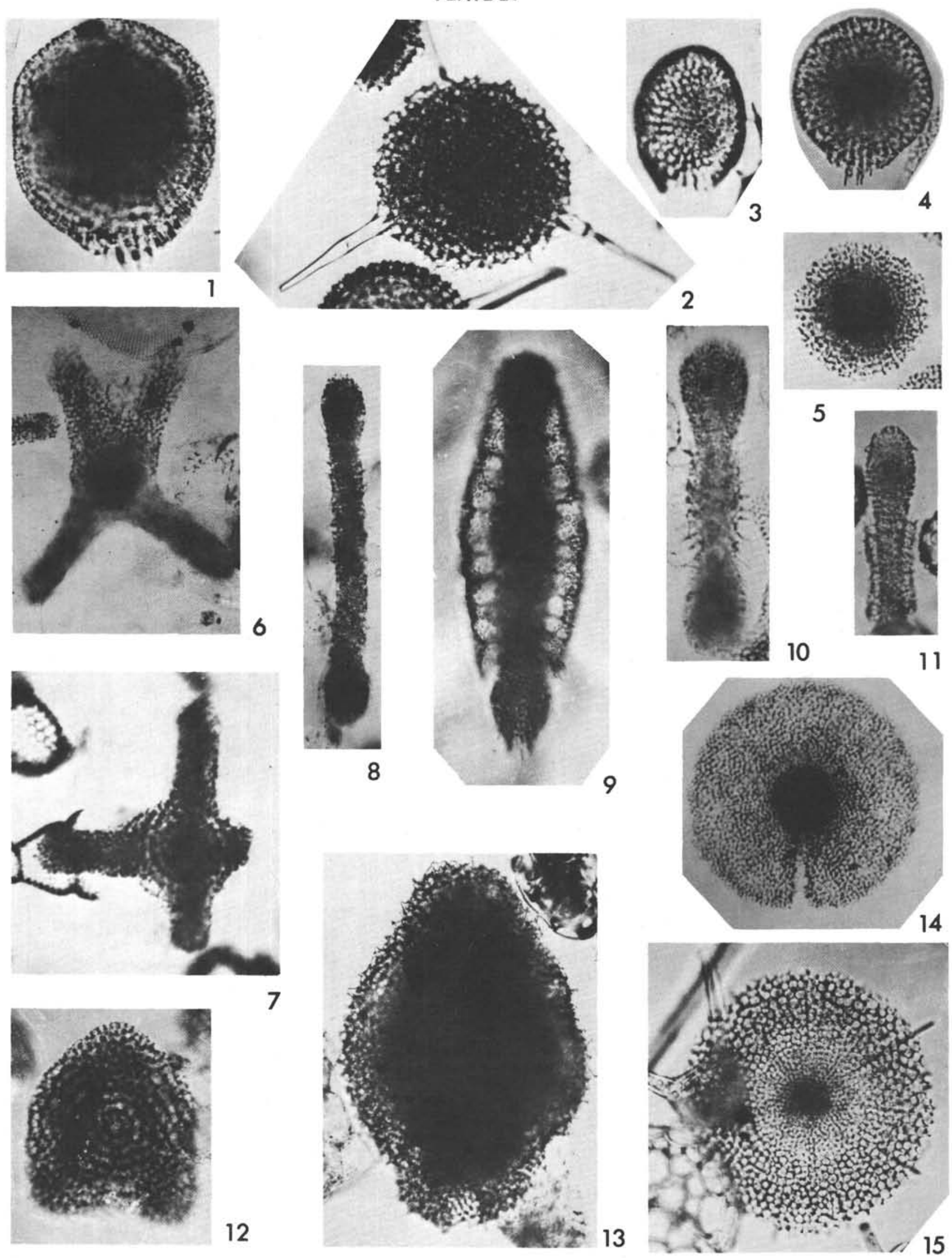
Plate 22

Magnification 200X

Figure 1

Theocapsomma ornata 144-1-CC.

Theocapsomma sp. aff. $T$. ornata 140-2-CC*.

Figure 2

Figure 3

Theocapsomma sp. F group 140-2-CC*.

Figure 4

Diacanthocapsa sp. A group 140-2-CC*.

Theocapsomma? sp. 140-2-CC*

Figure 5

Figure 6

Diacanthocapsa sp. A group 144B-2-5, Top.

Figure 7

Figures 8,

Phormocyrtis embolum group $140-3-3,5-7 \mathrm{~cm}$.

Figure 10 Eucyrtidiidae gen. sp. aff. Pterocyrtidius barbadense 144B-2-6, Top.

Figures 11, 12 Eucyrtidiidae gen.sp. aff. Lithomitra elizabethae Clark et Campbell

11: Western Ural, Ladvinka, Core 28

12: 144B-2-6, Top.

Figures 13, 14 Myllocercion sp. C

13: 139-7-CC.

14: $140-2-2,83-84 \mathrm{~cm}$.

Figure 15

Carpocanopsis? bramlettei 139-7-CC.

Figure 16 Carpocanistrum sp. aff. Sethocorys odysseus $142-9-1,98-100 \mathrm{~cm}$. p. 535

p. 535

p. 535

p. 536

p. 535

Figures 17, 22 Carpocanistrum sp.

17: $139-7-6,80-82 \mathrm{~cm}$.

22: 139-5-CC.

Figure 18 Carpocanopsis sp. aff. C. favosum 142-9-1, 98-100 cm.

Figures 19, 20 Carpocanistrum sp. aff. $C$. p. 536 pulchrum 19: $140-2-1,80-84 \mathrm{~cm}$. 20: $140-2-1,5-7 \mathrm{~cm}$.

Figures 21,23 Carpocanistrum sp. C 139-4-CC.

p. 536

Figure 24

Carpocanopsis favosum group p. 535 $140-2-1,5-7 \mathrm{~cm}$.

p. $537 \quad$ Figures 25, 26

Carpocanium sp. aff. C. coro-

p. 536 natum

25: 144B-2-6, Top.

26: $138-2-3,5-7 \mathrm{~cm}$.

Figures 27, 28 Carpocanobium sp. aff. C. setosa

p. 536

27: $138-2-4,5-7 \mathrm{~cm}$.

28: 144B-2-5, Top.

Figures 29, 30 Carpocanistrum sp. 0 29: $140-2-3,84-85 \mathrm{~cm}$. 30: $140-2-1,5-7 \mathrm{~cm}$.

Figure 31

Tricolocapsa papillosa group 139-1-1, 80-82 cm.

Figure 32

Dicolocapsa microcephala 139-5-CC.

p. 542

p. 535

Figures 33, 34

Tricolocapsa? sp. 33: 140-2-CC* 34: 140A-2-6, 80-82 cm.

Figure 35

Carpocanopsis sp. indet. $138-2-2,80-81 \mathrm{~cm}$.

Figure 36
Carpocanobium sp. indet. 144B-2-5, Top. 
PLATE 22

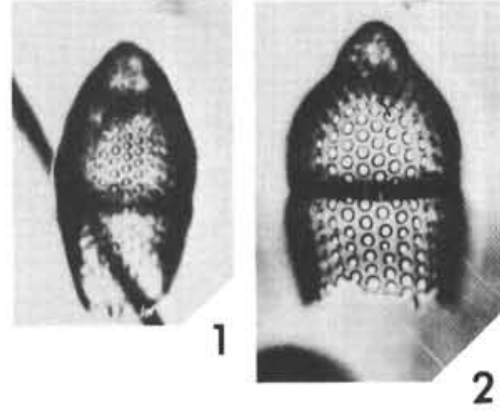

2
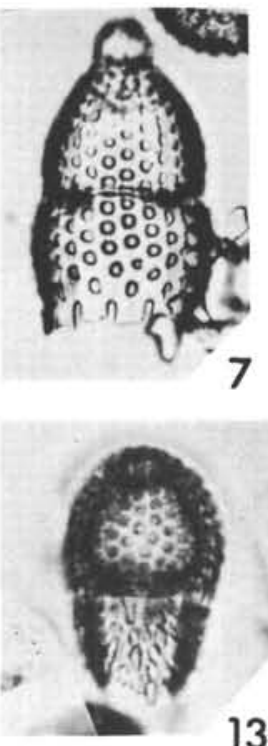

13

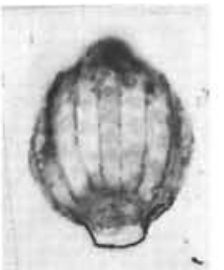

19

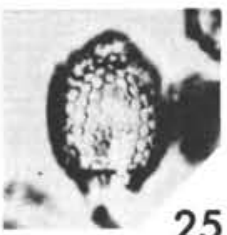

25
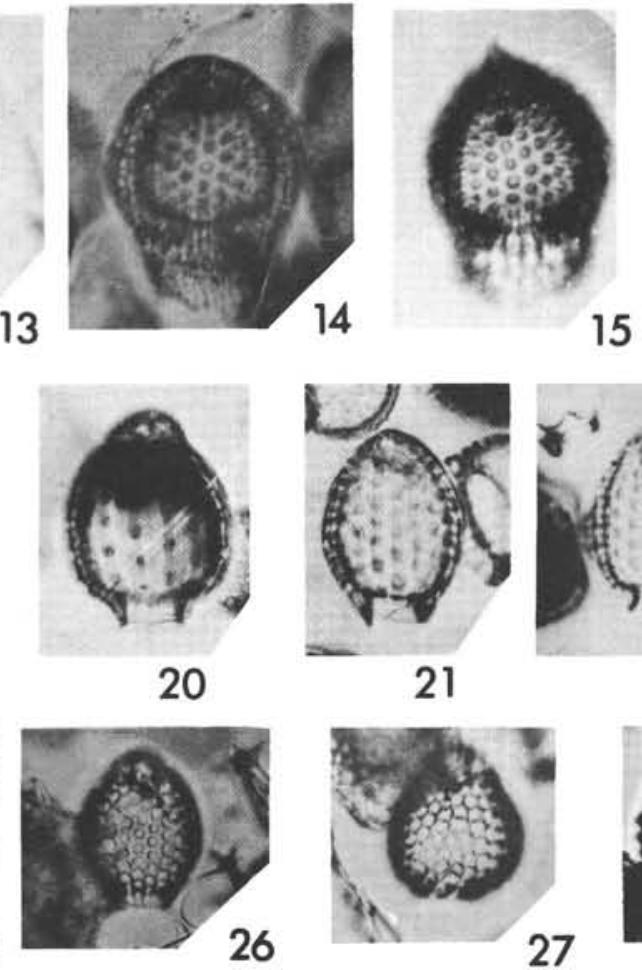

15
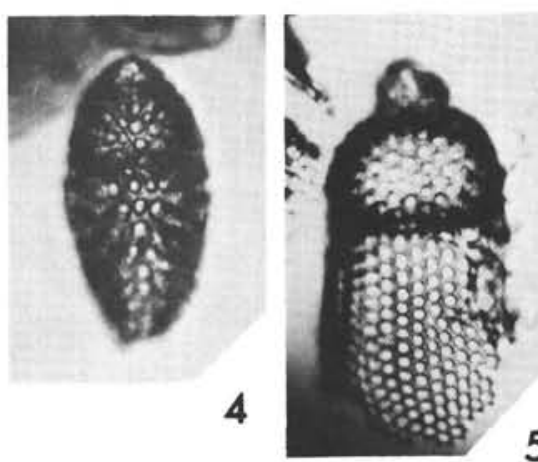

5

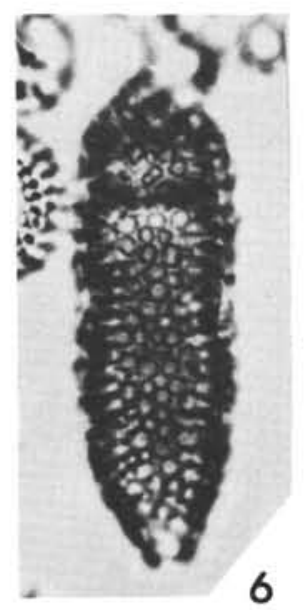

12

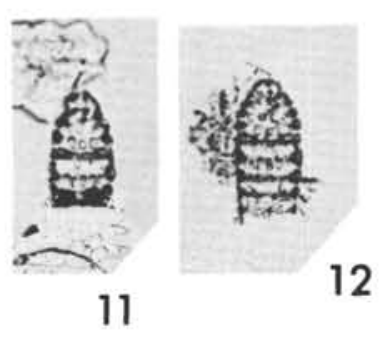

6
18

16
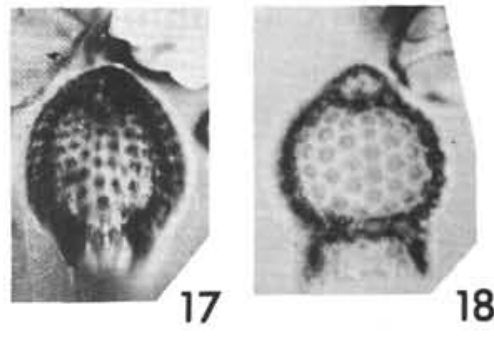
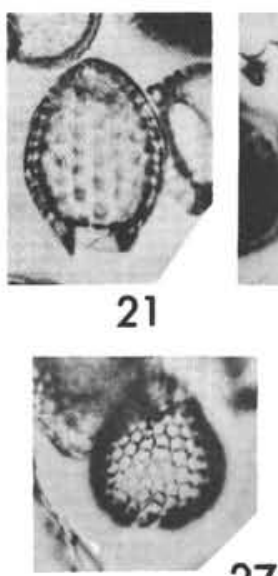

27

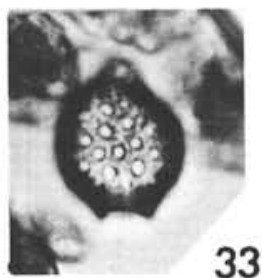

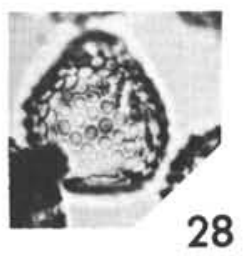

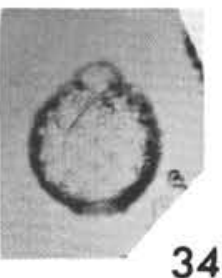

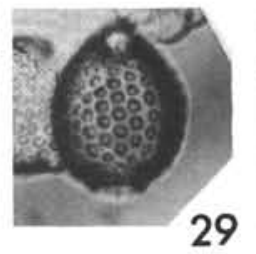

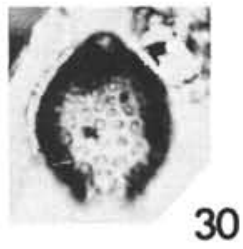

30
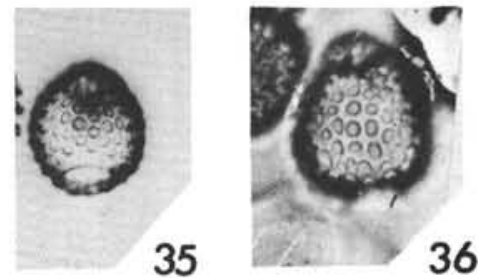
Plate 23

Magnification 200X

Figures 1, 2 Theocampe aff. mongolfieri

p. 538 140-2-CC*.

Figures 3-5 Theocampe mongolfieri

p. 538 $140-3-3,5-7 \mathrm{~cm}$.

Figure 6

Theocampe sp.

p. 537 144B-2-6, Top.

Figure 7

Theocampe excellens 140-2-CC*.

p. 538

Figure 8

Theocampe calimorphos

p. 538 $140-3-3,5-7 \mathrm{~cm}$.

Figure 9

Theocampe eos

p. 538

Figure 10

Theocampe sp. aff.gemmata

p. 538

Figure 11

Theocampe pirum

p. 537 $138-2-3,5-7 \mathrm{~cm}$

Figure 12

Theocampe sp. 140-2-CC*.

p. 537

Figures 13, 14 Theocamptra spp.

13: $140-2-1,5-7 \mathrm{~cm}$.

14: JYN V-16P, 235-237 cm.

Figures 15, 16 Theocamptra sp. aff. ovata

p. 538 144B-2-6, Top

Figures 17-19 Theocamptra ovata

p. 538 17, 18: $140-2-1,5-7 \mathrm{~cm}$. 19: 139-7-CC

Figures 20, 21 Theocamptra marylandica 20: $140-2-3,84-85 \mathrm{~cm}$. 21: $140-2-1,80-82 \mathrm{~cm}$.

Figures 22, 23 Theocamptra sp. aff. marylandica

p. 538 22: $140-2-1,5-7 \mathrm{~cm}$, lateral view. 23: $140-2-1,5-7 \mathrm{~cm}$, frontal view.

Figures 24, 25 Theocamptra corona group $140-2-1,5-7 \mathrm{~cm}$, one and the same specimen.

Figures 26, 27 Theocamptra formaster 26: 144B-2-6, Top, holotype. 27: 144B-2-6, Top.

Figures 28-30 Theocamptra sp. rocyrtis

28: $140-2-4,80-82 \mathrm{~cm}$, holotype, lateral view.

29: $140-2-1,5-7 \mathrm{~cm}$, frontal view.

30: $140-2-1,80-82 \mathrm{~cm}$. 
PLATE 23
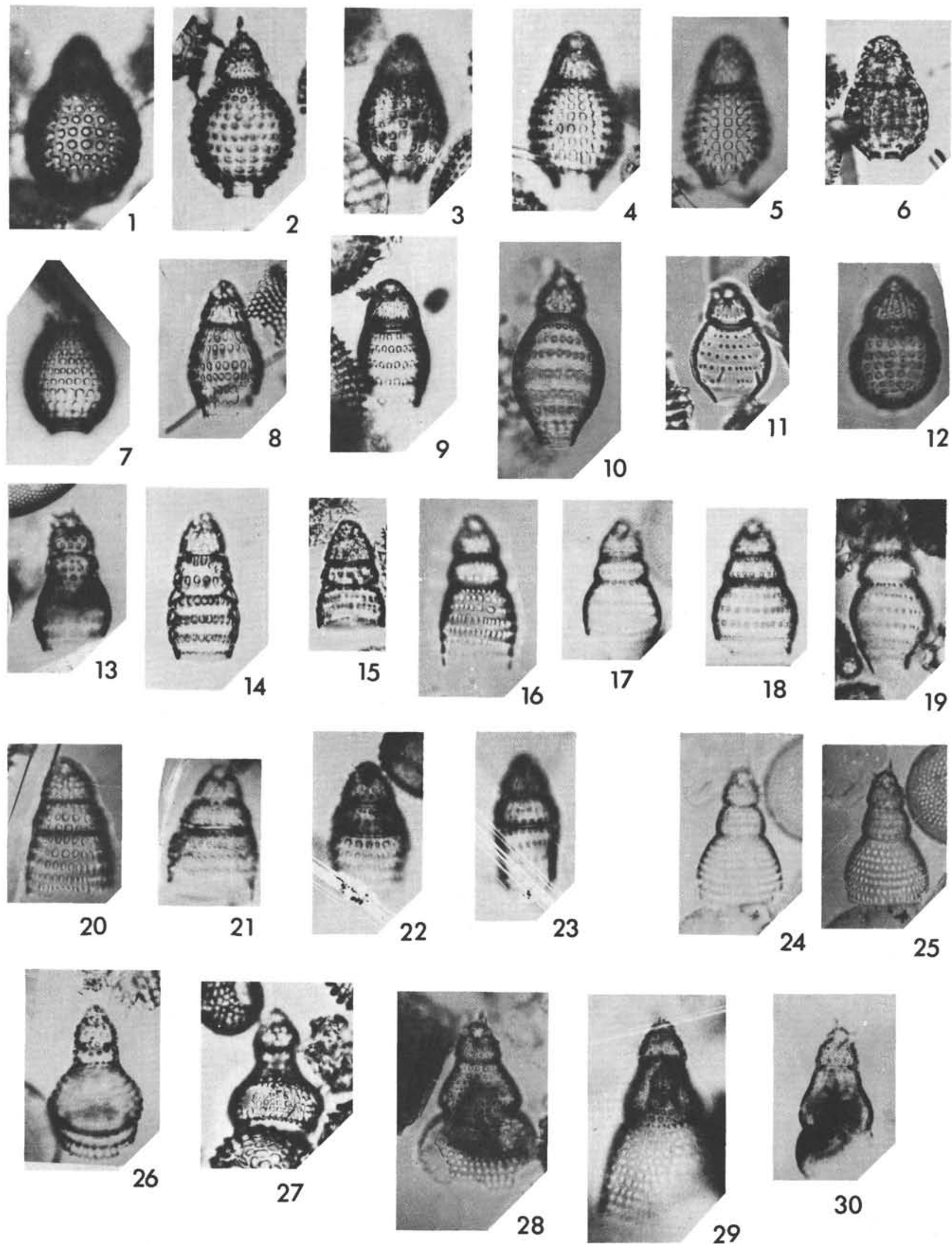
Plate 24

Magnification 200X

Figure $1 \quad$ Lithomitra ? sp. aff. L. lineata $138-2-3,5-7 \mathrm{~cm}$.

Figures 2-5 Lithomitra imbricata group 2, 5: $138-2-2,80-81 \mathrm{~cm}$.

3: $139-5-\mathrm{CC}$

4: 139-7-CC.

Figure 6

Theocamptra sp. aff. ovata 144B-2-5, Top.

Figure 7

\section{Lithamphora? sp.} 140-2-CC*.

Figures 8-11 Botryostrobus sp. P 8, 9: $138-2-6,5-7 \mathrm{~cm}$

10: $138-2-3,5-7 \mathrm{~cm}$.

11: $140-2-6,82-84 \mathrm{~cm}$.

Figures 12-14 Botryostrobus australis group

p. 539

12: $139-1-2,5-7 \mathrm{~cm}$.

13, 14: 139-1-1, 80-82 cm.

Figures 15-18 Botryostrobus auritus group

p. 539

15, 16, 18: $139-1-2,5-7 \mathrm{~cm}$.

17: $139-1-1,80-82 \mathrm{~cm}$.

Figure 19 Botryostrobus lithobotrys

p. 539 139-1-CC.

Figures 20, $21 \quad$ Botryostrobus tumidulus

p. 539 139-1-CC.

Figures 22-24 Spirocyrtis subtilis

p. 540

22: 139-5-CC, holotype.

23: Malaga Mudstone, California.

24: 139-5-CC.

Figure 25

Spirocyrtis sp. aff. S. cornutella $139-1-2,5-7 \mathrm{~cm}$.

p. 540

Figure 26

Spirocyrtis cornutella

p. 541 139-1-1, 80-82 cm.

Figures 27, $28 \quad$ Spirocyrtis sp.

p. 540 27: $139-1-1,5-7 \mathrm{~cm}$.

28: $139-1-1,80-82 \mathrm{~cm}$.

Figures 29, $30 \quad$ Lithomitra nodosaria group

p. 539 29: 139-7-CC.

30: 140-2-CC.

Figure 31 Botryostrobus miralestense

p. 539 139-3-CC.

Figures 32, 33 Lithomitra eruca group

p. 539 32: 139-5-CC.

33: $138-2-4,5-7 \mathrm{~cm}$. 
PLATE 24
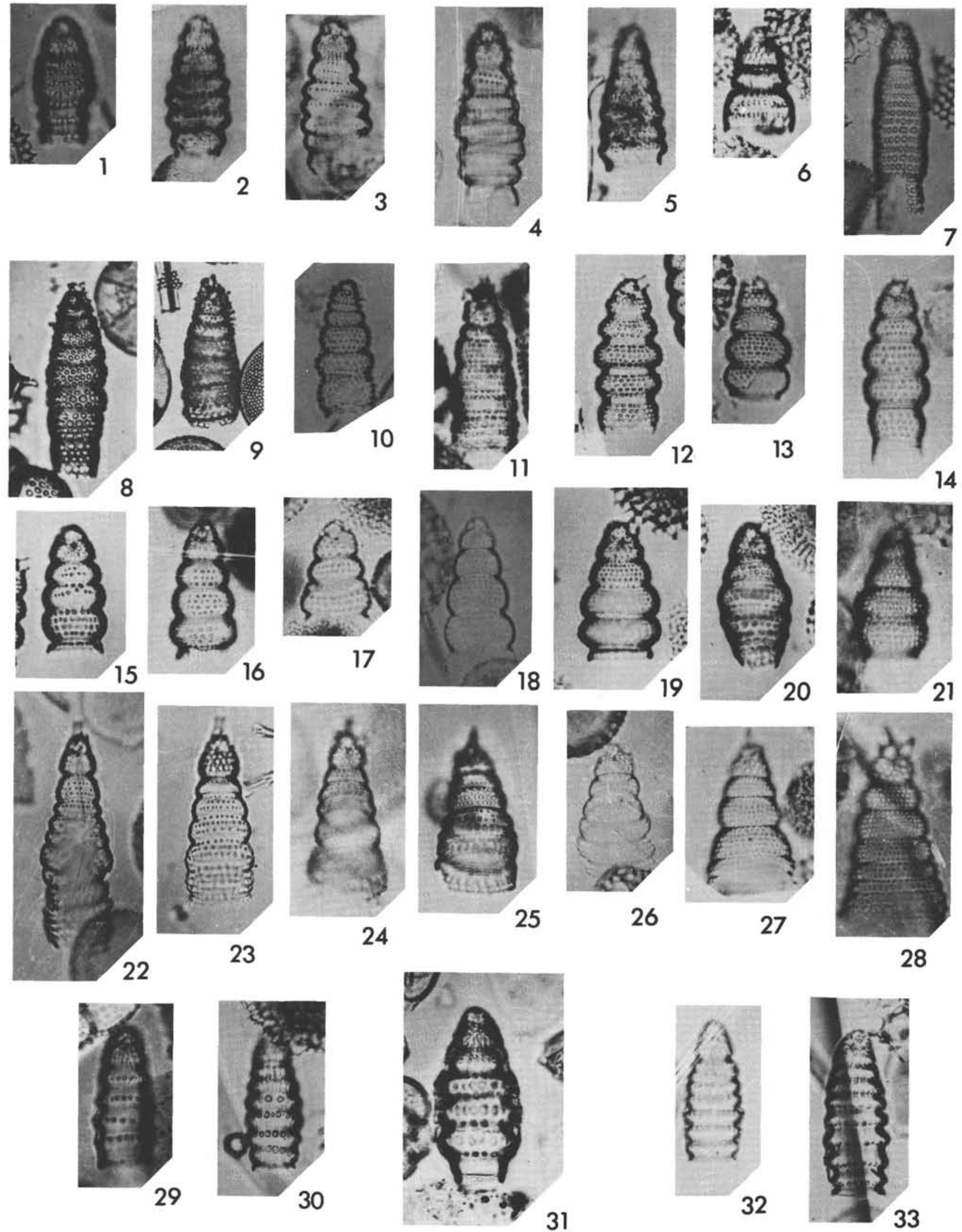
Plate 25

Magnification 200X

Figure 1 Stichocapsa hexagonalis

p. 546 139-1-CC.

Figure 2

Lithostrobus sp.

p. 546 $138-2-6,5-7 \mathrm{~cm}$.

Figure 3 Eucyrtidioidea gen. sp.

p. 547 $140-2-1,5-7 \mathrm{~cm}$.

Figures 4-6 Stichopodium ? microproum

p. 548 4, 6: 140-2-CC*.

5: $138-2-4,5-7 \mathrm{~cm}$.

Figures 7-10 Lithocampe subligata group

p. 546 7, 8: 139-7-CC.

9: 144B-2-6, Top. 10: 144B-2-5, Top.

Figures 11, 12 Stichocorys delmontense

p. 546 11: $140-2-1,5-7 \mathrm{~cm}$.

12: Delmont. Miocene California.

Figure 13

Lithocampe sp. 139-7-CC.

Figure $14 \quad$ Lithocampe tetrapera

p. 546 $139-7-6,80-82 \mathrm{~cm}$.

Figures 15, 16 Lithocampe cornuta 15: $142-\mathrm{CB}$.

15: $142-9-1,98-100 \mathrm{~cm}$.

Figure 17

Lithocampe compacta

p. 546 139-5-CC.

Figure 18

Lithocampe japonica

p. 546 139-4-CC.

Figures 19, 20 Cyrtophormis armata

p. 547

19: 140A-2-5, $5-7 \mathrm{~cm}$.

20: 139-5-CC.

Figure $21 \quad$ Cyrtophormis sp.

p. 547 $140-2-1,5-7 \mathrm{~cm}$.

Figure 22

Stichocorys wolfii

p. 546 $140-2-1,5-7 \mathrm{~cm}$.

Figures 23, 24 Stichocorys coronatus

p. 547 139-5-CC.

Figure 25

Stichocorys peregrinus

p. 547 139-4-CC. 
Plate 25
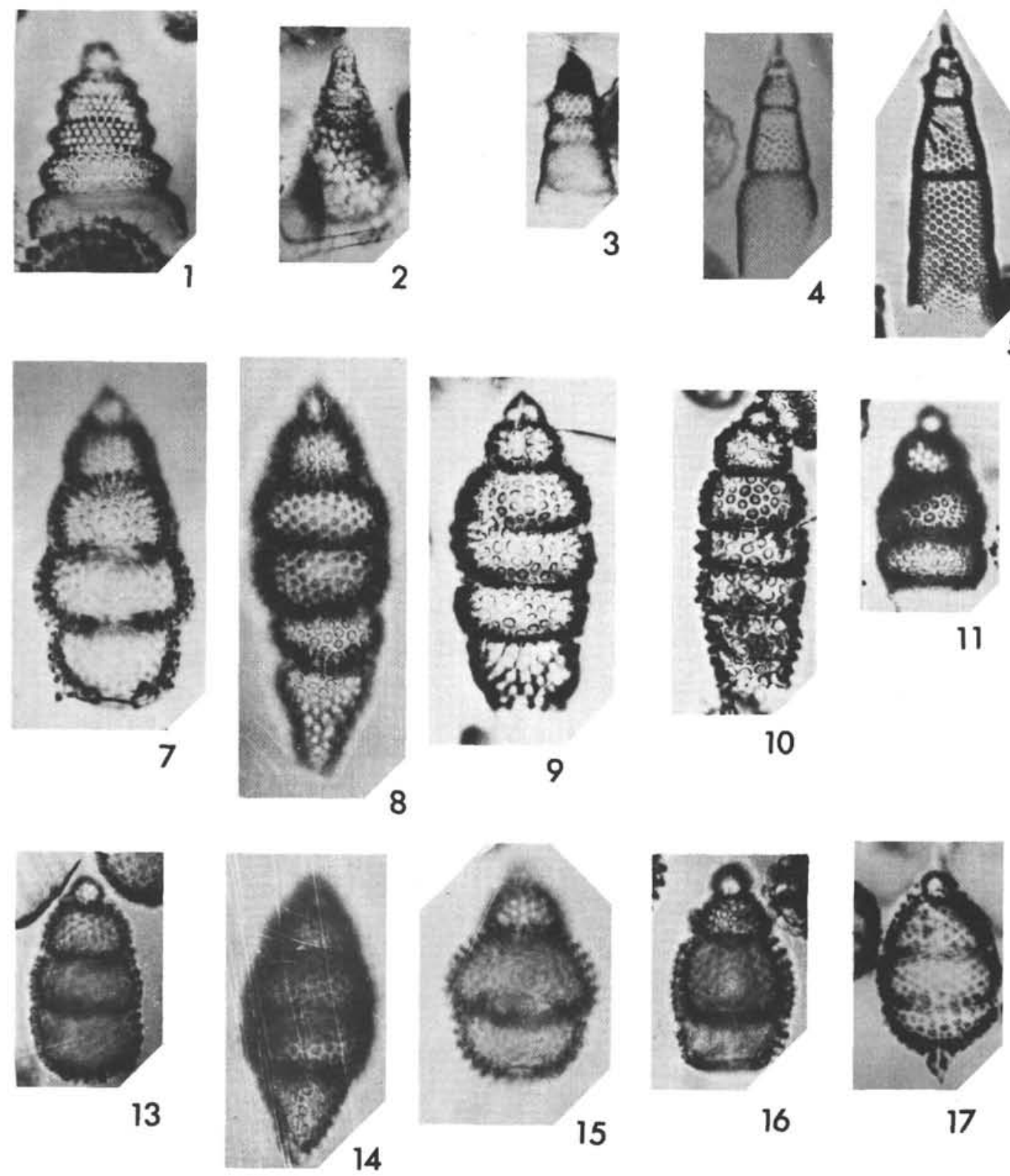

\section{(}
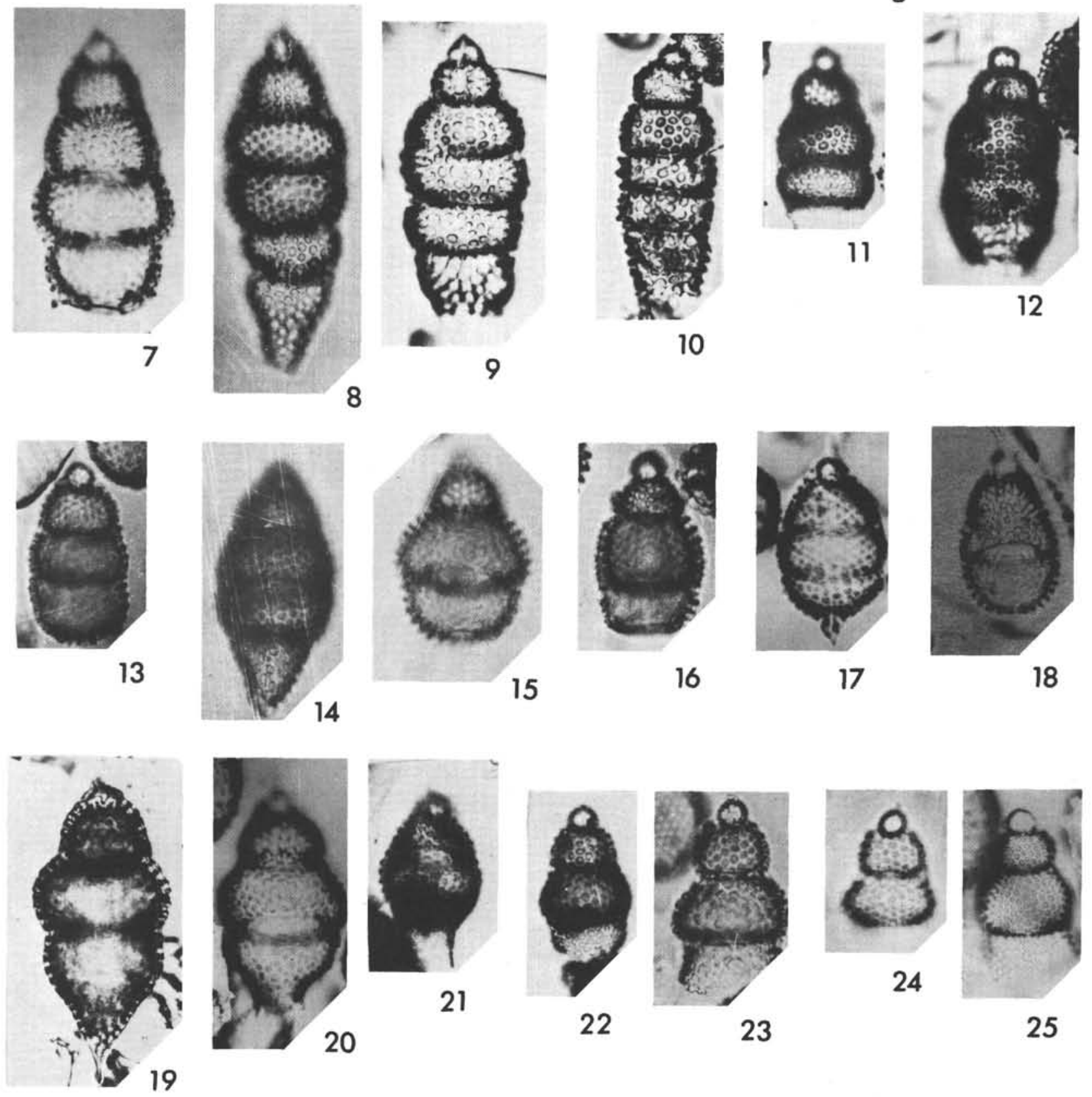

21
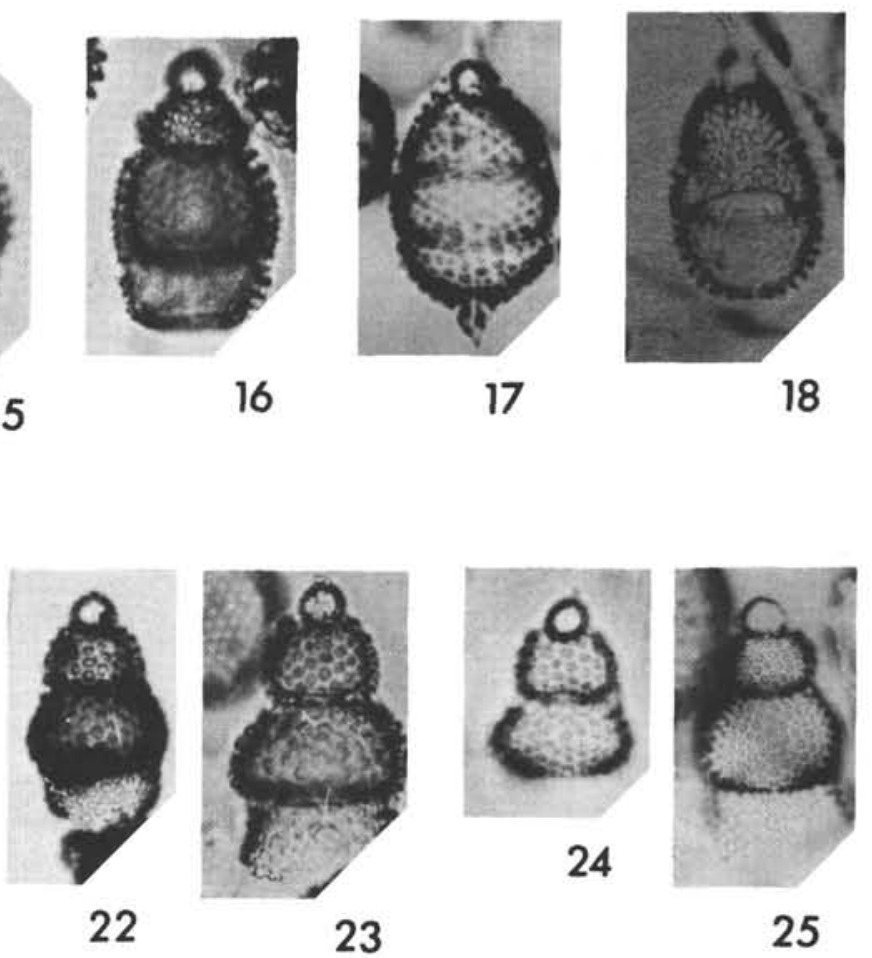

18 
Plate 26

Magnification 200X

Figure 1

Cyrtophormis sp. Ch

p. 547

144B-2-6, Top.

Figures 2-4 Eucyrtidium sp. aff. E. montiparum p. 548 2, 3: $144-1-5,80-85 \mathrm{~cm}$.

4: $140-3-3,5-7 \mathrm{~cm}$.

Figures 5, $6 \quad$ Stichopodium (?) sp. group aff. Eucyrtidium p. 549 matuyamai

5: $139-1-1,80-82 \mathrm{~cm}$.

6: $139-1-2,5-7 \mathrm{~cm}$.

Figure 7

Lithocampium sp. aff. L. diploconus JYN V-20P, $457-459 \mathrm{~cm}$.

Figure $8 \quad$ Lithocampium ? sp. 139-7-CC.

Figures 9,10 Stichopodium martellii

9: JYN V-16P, 235-237 cm.

10: 139-7-CC.

Figure 11 Artocyrtis sp.

p. 549 $139-1-2,5-7 \mathrm{~cm}$

Figure 12 Lithocampium diploconus 140-2-2, 83-84 cm.

Figure $13 \quad$ Stichopodium calvertense

p. 549 $139-1-2,5-7 \mathrm{~cm}$

Figure 14 Stichopodium ? sp. T.

p. 549 139-1-CC.

Figures 15, 16 Stichopodium sp. aff. S. matujamai

15: $139-1-1,80-82 \mathrm{~cm}$.

16: $139-1-2,5-7 \mathrm{~cm}$.

Figure 17

Eucyrtidium acuminatum

p. 548 139-4-CC.

Figures 18, 19 Stichopodium cienkowskii

p. 548

18: $140-2-1,80-84 \mathrm{~cm}$.

19: $139-5-\mathrm{CC}$.

Figure 20

Stichopodium martellii conicum, holotype

p. 548 $140-2-3,84-85 \mathrm{~cm}$.

Figures 21, 22 Stichopodium ? spp.

p. 549 139-1-1, 80-82 cm. 
PLATE 26

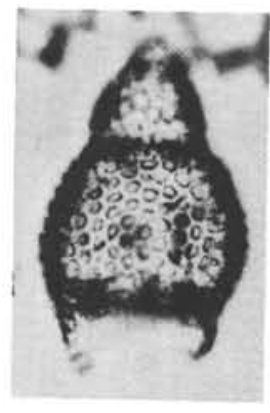

1
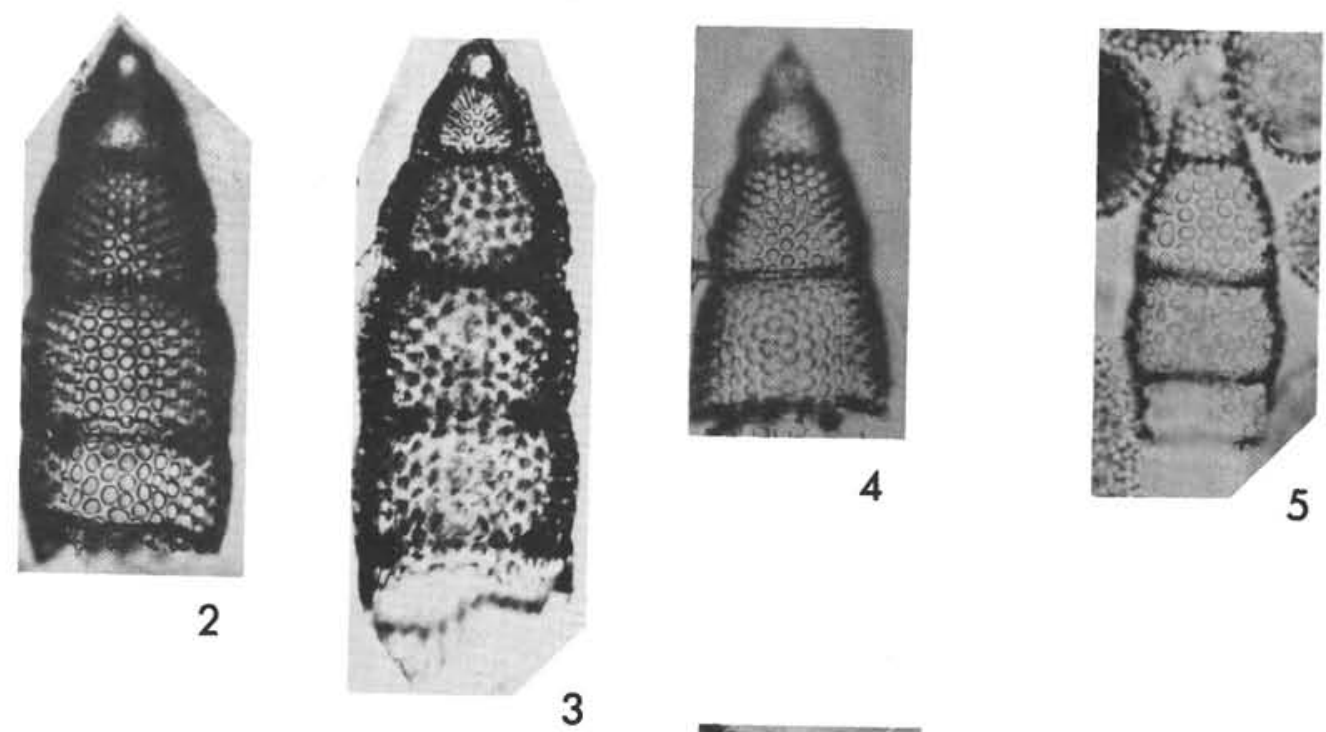

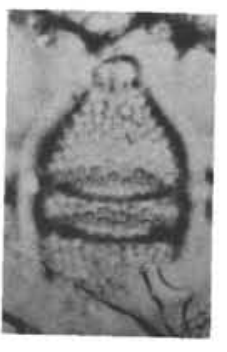

7

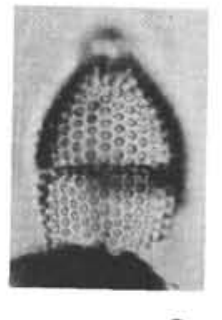

8

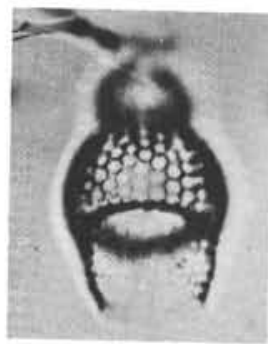

9

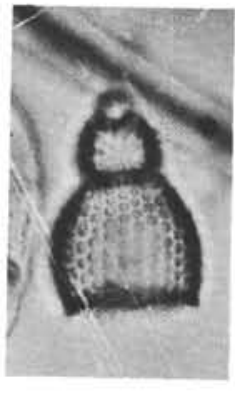

10

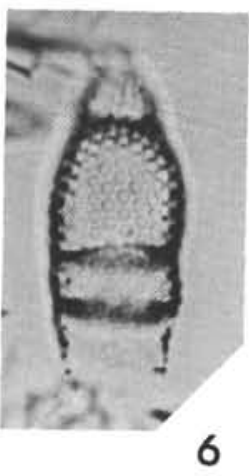

6

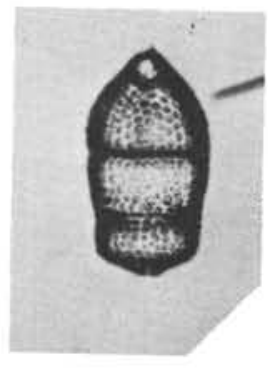

11

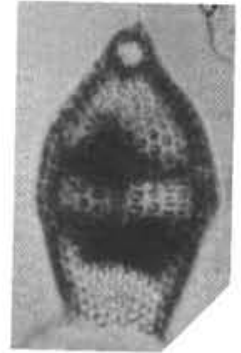

12

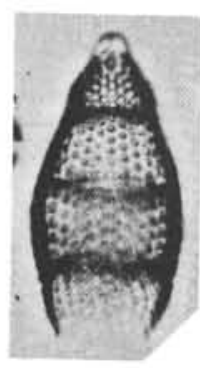

13

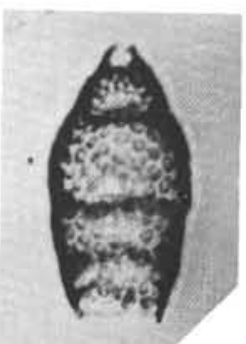

14

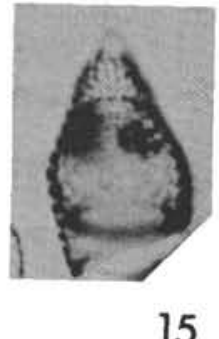

15

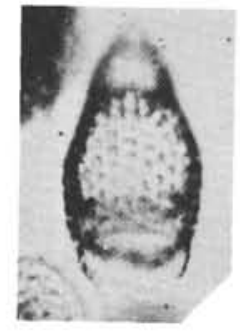

16
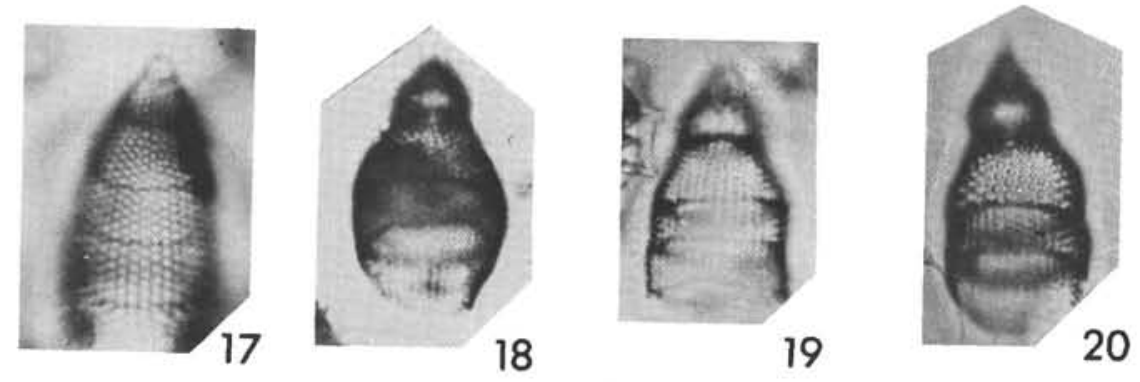

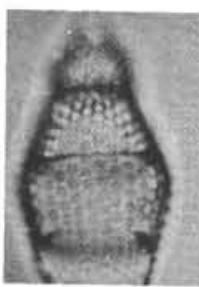

21

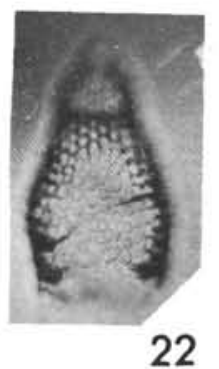


Plate 27

Magnification 200X

Figure $1 \quad$ Stichopilidium sphinx

p. 552 144-1-5, 80-85 cm.

Figure 2 Lithochytris sp. A

p. 552 144-2-3.

Figures 3, $4 \quad$ Lithochytris sp. aff. L. ventricosa

p. 552 144B-2-6, Top.

Figure $5 \quad$ Lithochytris sp. aff. L. tripodium

p. 552 144B-2-6, Top.

Figure $6 \quad$ Lithochytris sp. T.

p. 552 144-1-5, 80-85 cm.

Figure $7 \quad$ Lithochytris sp. 0

p. 552 140-2-CC*.

Figures 8,9 Lithochytris turgidulum

p. 552

Figures 10.11 Pterocanium (?) sp. aff. P. prismatium

p. 553 10: $140 \mathrm{~A}-2-6,80-82 \mathrm{~cm}$.

11: JYN V-20P, $455-457 \mathrm{~cm}$.

Figure 12 Lithochytris sp.

p. 552 $138-2-4,5-7 \mathrm{~cm}$.

Figures 13, 14 Rhopalocanium ornatum

p. 552

13: $144-1-6,80-85 \mathrm{~cm}$.

14: 140A-2-6, broken specimen.

$\begin{array}{lll}\text { Figure } 15 & \text { Pterocyritidium sp. } & \text { p. } 552\end{array}$ 140-2-CC*.

Figures 16,17 Dictyophimus sp. aff. D. hirundo p. 553 16: 139-1-1, 80-82 cm. 17: $139-1-2,5-7 \mathrm{~cm}$.

Figures 18, 19 Pterocyritidium barbadense group p. 552 140-2-CC*. 
PLATE 27
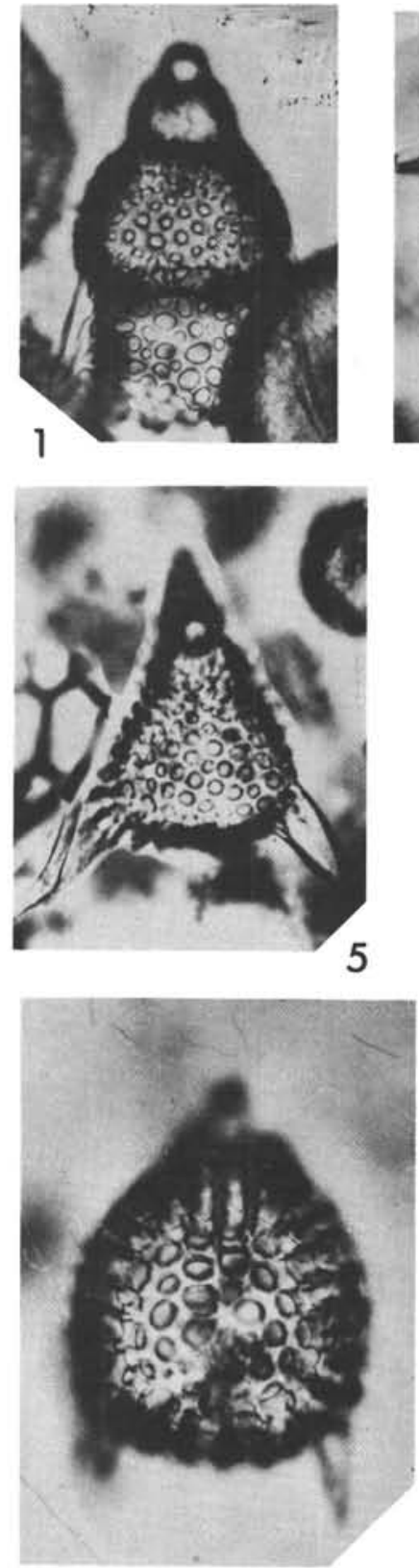

8

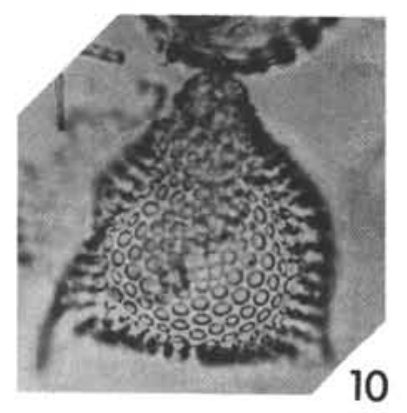

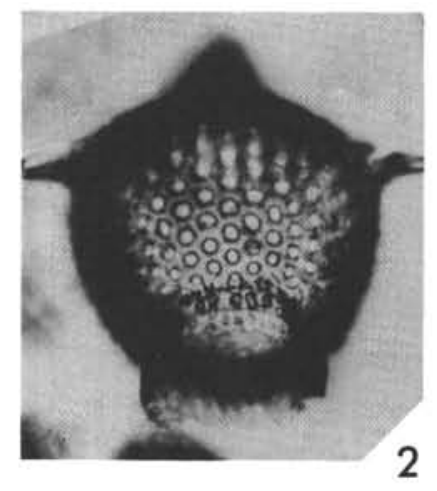
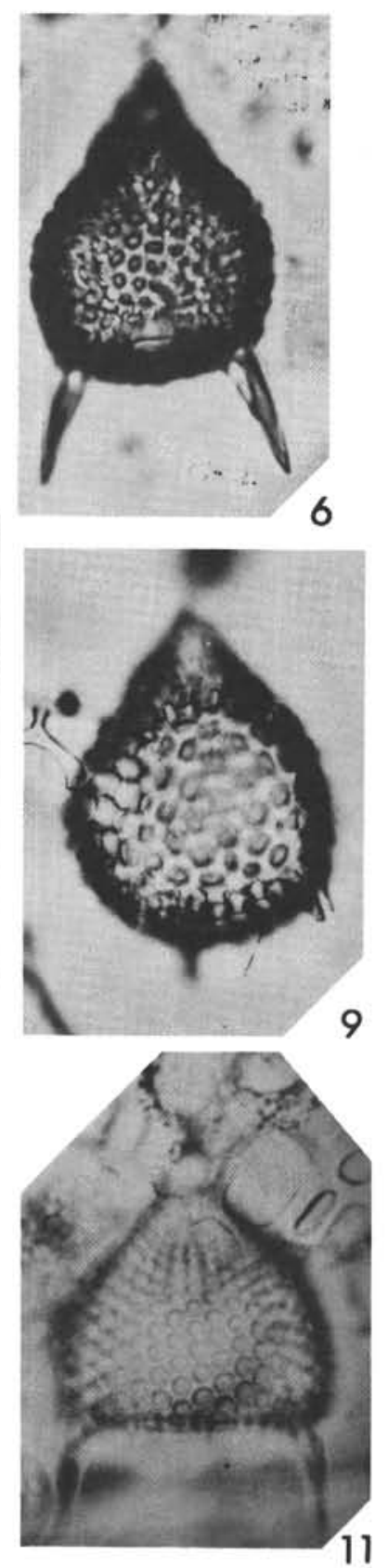
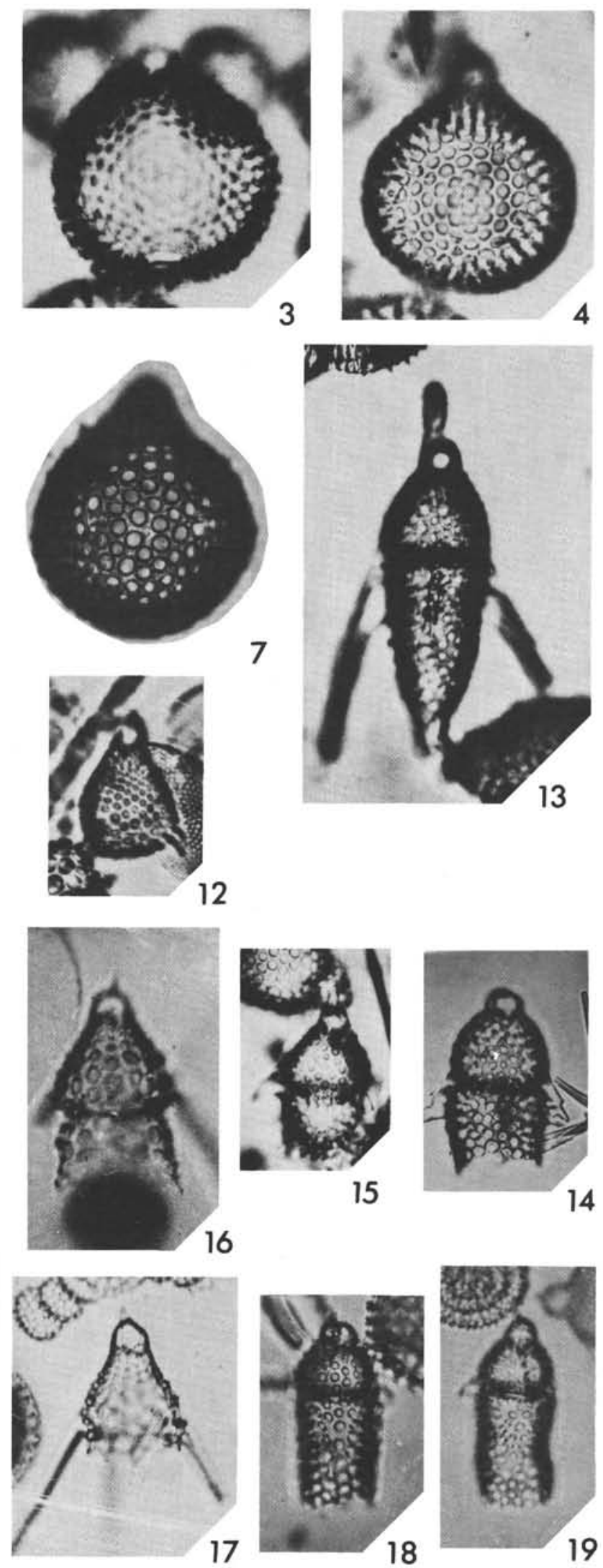
Plate 28

Magnification 200X

Figure $1 \quad$ Cyrtophormis (?) sp. 139-5-CC.

Figures 2, 3 Eucyrtidiidae gen. sp. "rocket"

2: $138-2-3,5-7 \mathrm{~cm}$.

3: 144B-2-6, Top.

Figures 4, 5 Species, similar to Eucyrtidiidae gen. sp.

p. 547 "rocket"
4: 144B-2-5, Top.
5: $138-2-6,5-7 \mathrm{~cm}$.

Figures 6, 7 Eucyrtidiidae gen. sp. W.

6: $140-2-1,5-7 \mathrm{~cm}$.

7: $140-1-2,5-7 \mathrm{~cm}$.

Figure $8 \quad$ Eucyrtidiidae gen. sp. indet $138-2-6,5-7 \mathrm{~cm}$.

Figures 9, 10 Theocorys? spp. indet

9: $140-2-1,5-7 \mathrm{~cm}$.

10: JYN V-16, $235-237 \mathrm{~cm}$.

Figure 11

Cyrtophormis dominasinensis

p. 547 $138-2-4,5-7 \mathrm{~cm}$.

Figure $12 \quad$ Cyrtophormis barbadensis $144-1-4,80-85 \mathrm{~cm}$.

Figures 13-15 Cyrtophormis gracilis

13: $144 \mathrm{~A}-2-6,2-4 \mathrm{~cm}$.

14: 144B-2-5, Top.

15: JYN V-16P, $235-237 \mathrm{~cm}$.

Figures 16-18 Calocyclas asperum

16: $138-2-2,80-81 \mathrm{~cm}$.

17: $140 \mathrm{~A}-2-5,5-7 \mathrm{~cm}$.

18: 144B-2-6, Top.

Figure 19

Clistophaena sp. aff. C. armata $138-2-6,5-7 \mathrm{~cm}$.

Figure 20

Clistophaena sp. $140 \mathrm{~A}-2-4,80-82 \mathrm{~cm}$.

Figure 21 140A-2-6. 
PLATE 28
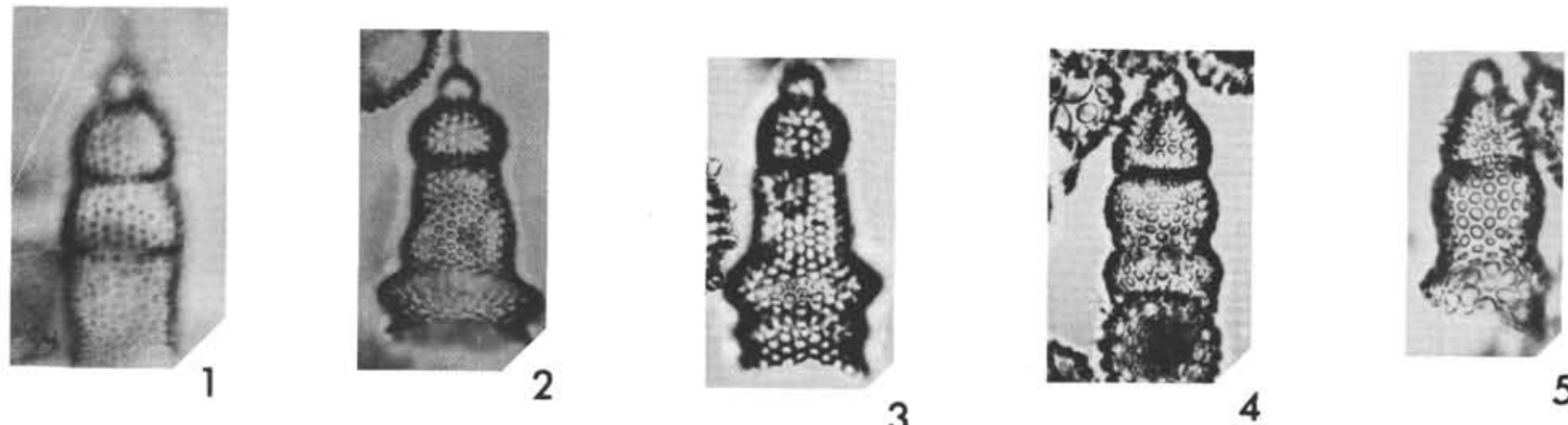

3
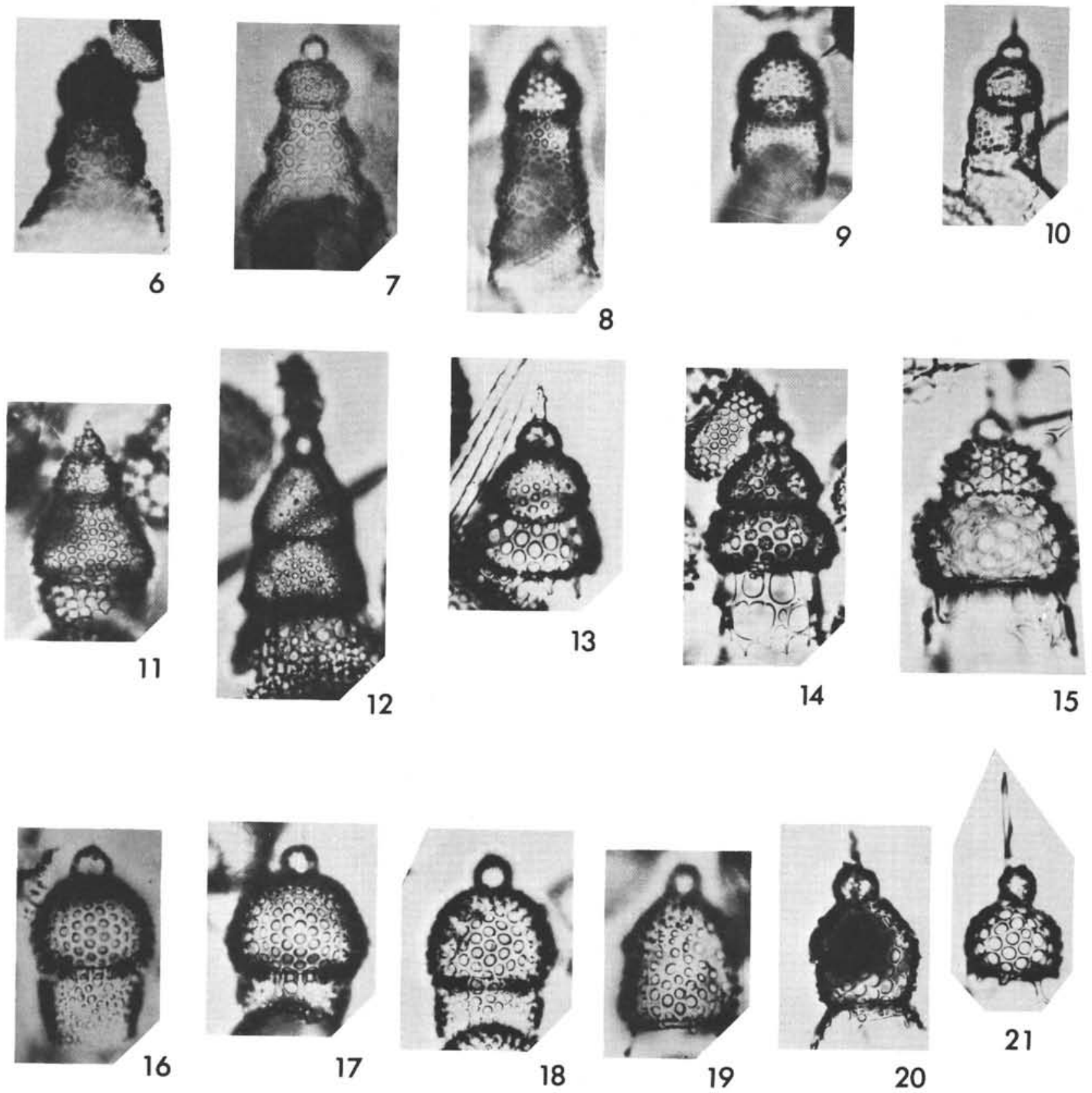
Plate 29

Magnification 200X

Figure 1

Figure 2

Figure 3

Figure 4

Figure 5

Figure 6

Figure 7

Figures 8-10

Figure 11

Figure 12

Figures 13, 14

Figure 15

Figure 16
Lychnocanium bellum 140-2-CC*.

Lychnocanium tripodium 144-1-CC.

Lychnocanium hirundo 144A-2-6, $2-4 \mathrm{~cm}$.

Pteropilium (?) sp. $144-1-6,80-85 \mathrm{~cm}$.

Dictyophimus pocillum $140 \mathrm{~A}-2-6,80-82 \mathrm{~cm}$.

Lychnocanium grande $138-2-2,80-82 \mathrm{~cm}$.

Lychnocanium sp. 144B-2-6, Top.

p. 553

p. 553

p. 553

p. 553

p. 553

p. 553

p. 553

Pteropilium ? sp. aff. Pterocanium contiguum p. 553 group

8: $138-2-6,5-7 \mathrm{~cm}$.

9. $138-2-2,80-81 \mathrm{~cm}$.

10: 140 A $-2-6,80-82 \mathrm{~cm}$.

Pterocanium ? contiguum

p. 553 $138-2-6,5-7 \mathrm{~cm}$.

Pteropilium sp. B.

p. 553 $140-2-3,84-85 \mathrm{~cm}$.

Archipilium spp. aff. A. macropus

p. 553

13: $138-2-2,80-81 \mathrm{~cm}$.

14: $139-1-1,80-82 \mathrm{~cm}$.

Lamprotripus mawsoni

p. 534 $139-1-1,80-82 \mathrm{~cm}$.

Lychnocanium korotnevi

p. 553 
PLATE 29
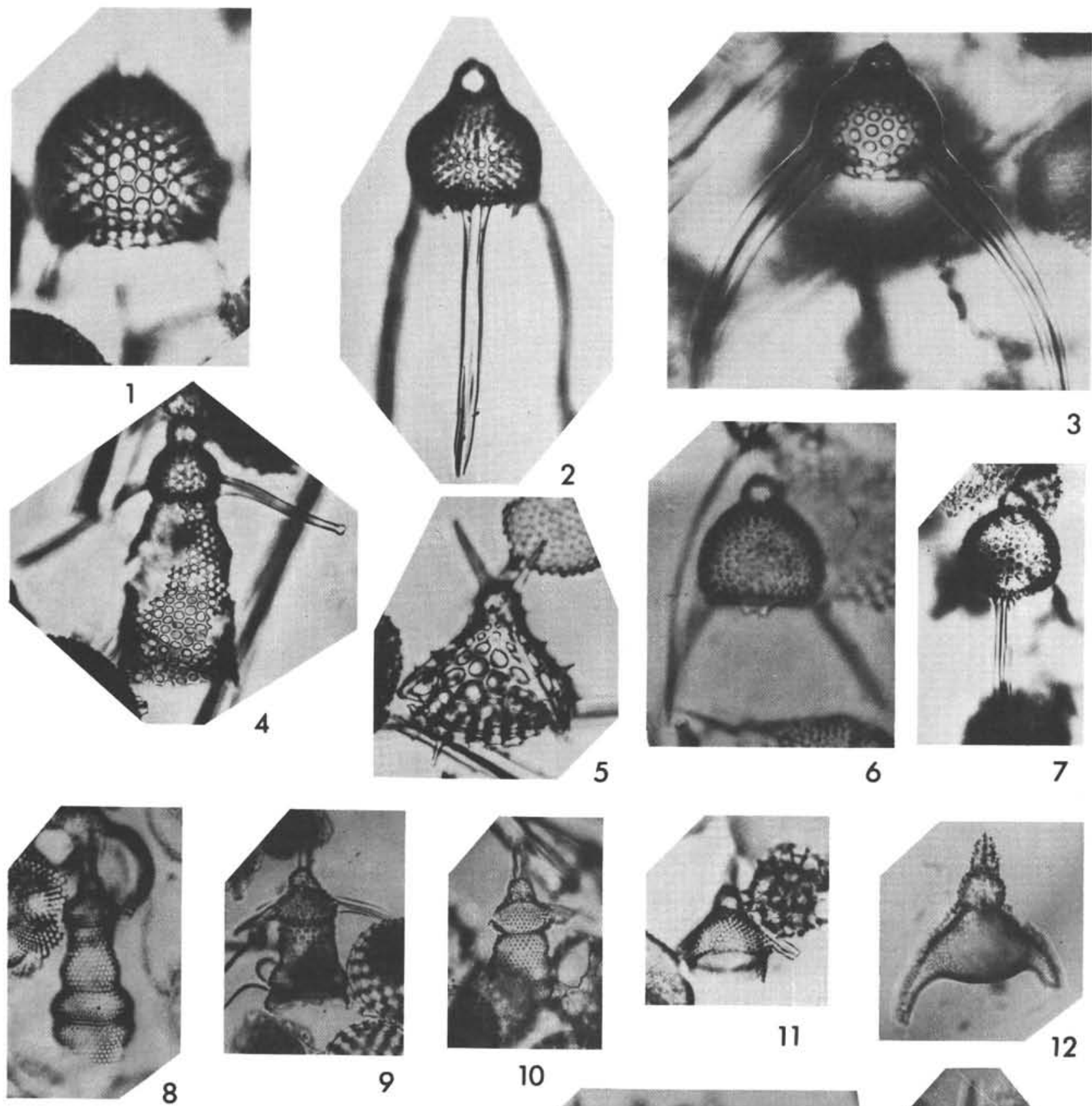

11
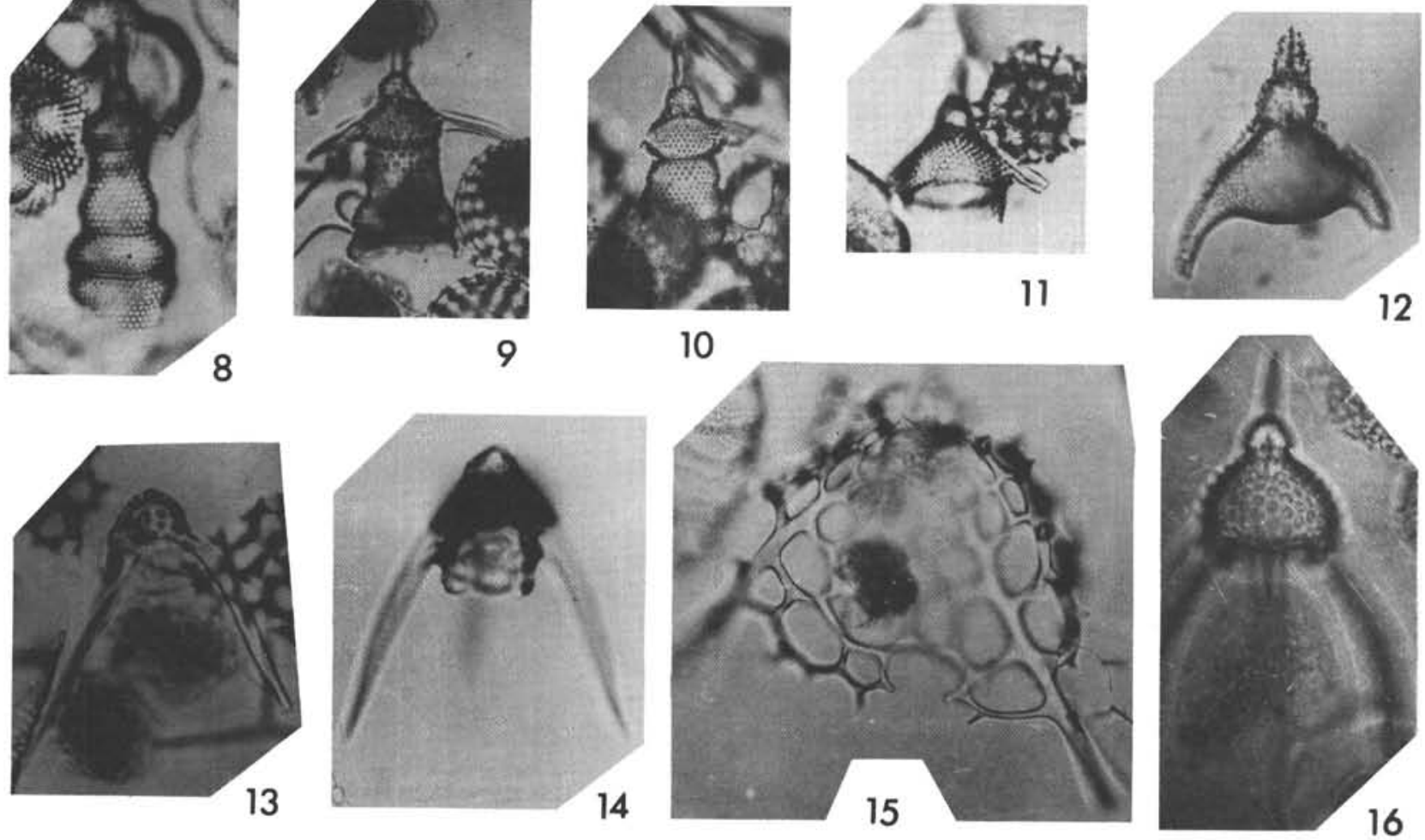
Plate 30

Magnification 200X

$\begin{array}{lll}\text { Figure } 1 & \text { Lithamphora ? sp. } 539\end{array}$ 144B-2-6, Top.

$\begin{array}{lll}\text { Figure } 2 \text { Lithamphora } \text { sp. } 539 & \text { p. }\end{array}$ 140-2-CC*.

$\begin{array}{lll}\text { Figure } 3 & \text { Lithamphora sacculifera } 539\end{array}$ Eocene, California, No. 1795

Figures 4-6 Lithamphora sacculifera quadrata p. 539 140-2-CC* (4: holotype).

$\begin{array}{lll}\text { Figure } 7 & \text { Lithamphora } \text { sp. aff. L. corbula } & \text { p. } 539\end{array}$ 139-5-CC.

Figures 8,9 Cornutella longiseta group p. 551 8: $139-1-2,5-7 \mathrm{~cm}$. 9; $138-2-4,5-7 \mathrm{~cm}$.

$\begin{array}{lll}\text { Figure } 10 \quad \text { Cornutella } \text { sp. aff. } \text { C. californica } & \text { p. } 551\end{array}$ $138-2-6,5-7 \mathrm{~cm}$.

Figures 11, 12 Cornutella clava

p. 551 11: 139-5-CC, holotype. 12: $140 \mathrm{~A}-2-6,80-82 \mathrm{~cm}$.

Figure 13 Cornutella bimarginata group

p. 551 139-1-CC.

Figures 14, 15 Cornutella stiligera group

p. 551 14: $138-2-6,5-7 \mathrm{~cm}$. 15: $140 \mathrm{~A}-2-4,80-82 \mathrm{~cm}$.

Figures 16, 17 Cornutella clathrata p. 551 139-5-CC.

Figures 18-20 Cornutella $\beta$ profunda group p. 551 18: $138-2-4,5-7 \mathrm{~cm}$. 19, 20: $139-1-2,5-7 \mathrm{~cm}$. 

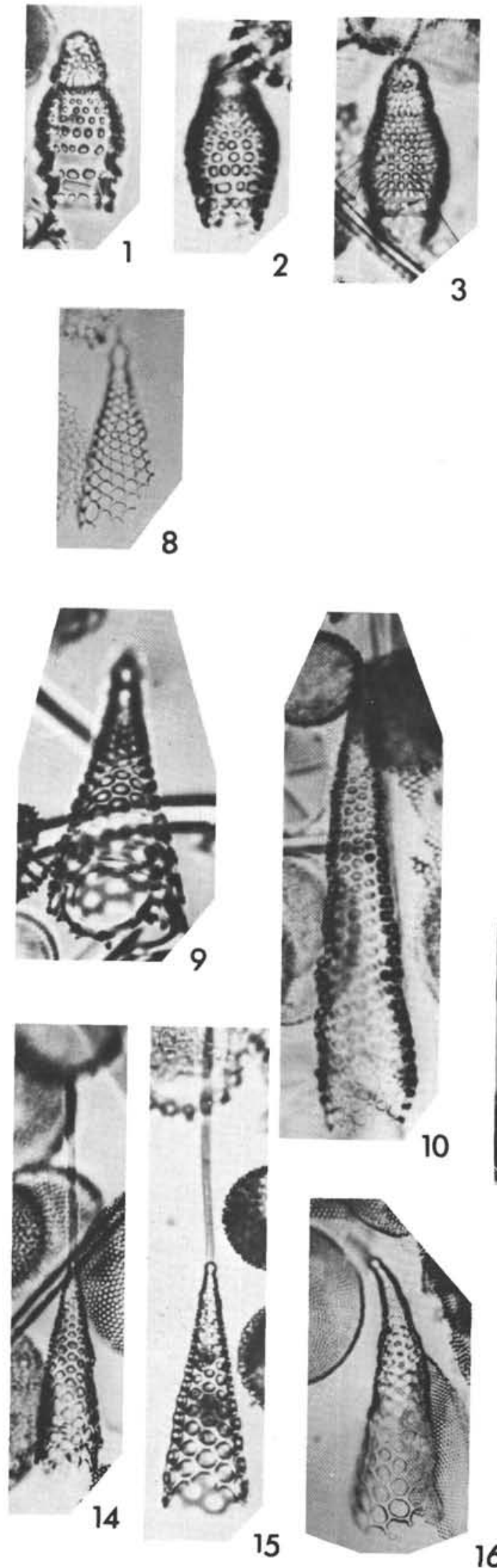

PLATE 30
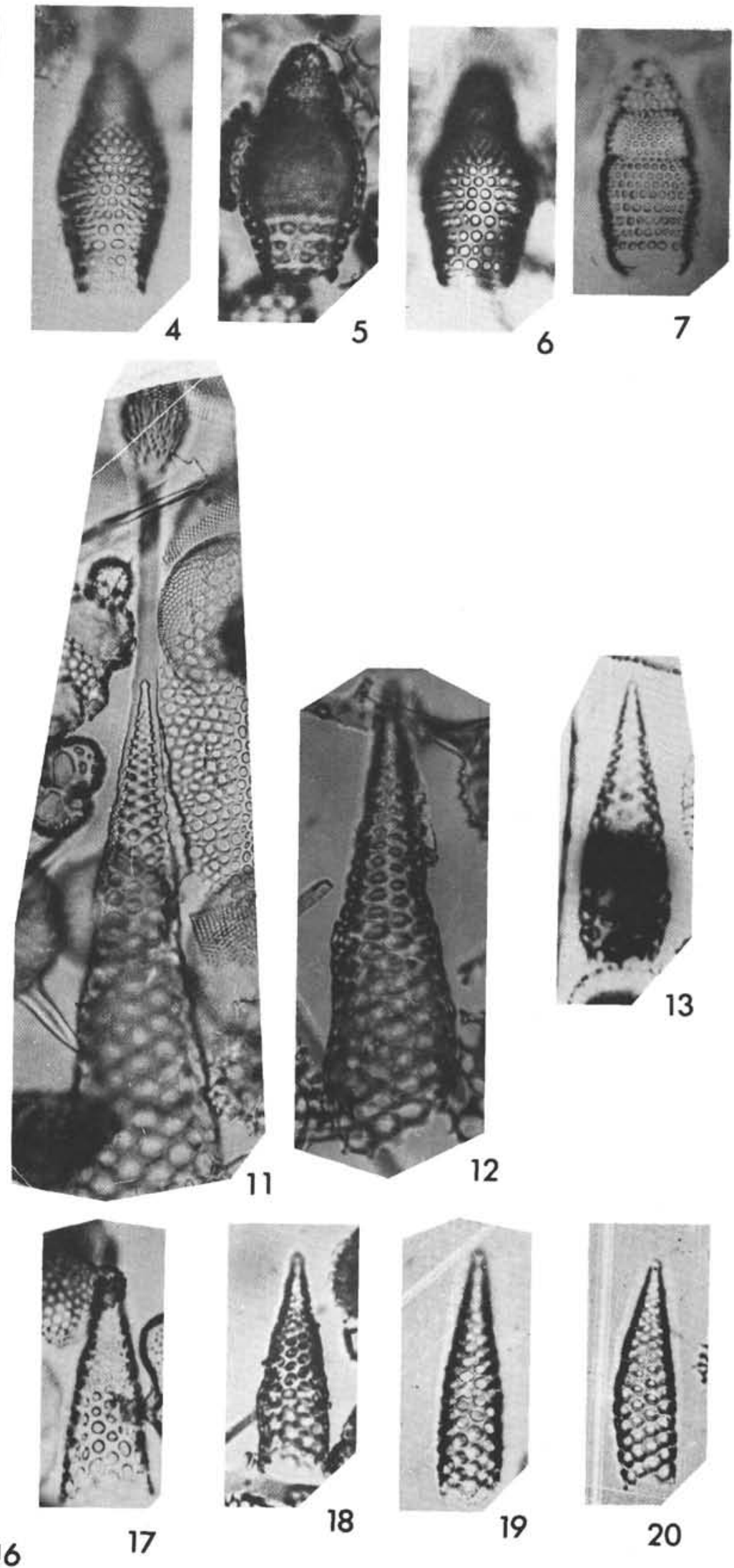
Plate 31

Magnification 200X

Figures 1,2 Bathropyramis aeshna

p. 552

1: $138-2-4,5-7 \mathrm{~cm}$, holotype.

2: $138-2-2,80-81 \mathrm{~cm}$.

Figure 3

Peripyramis magnifica 140A-2-4, 80-82 cm.

p. 551

Figure 4

Peripyramis circumtexta 140-2-CC*.

p. 551

Figure 5

Peripyramis sp. A. 139-5-CC.

Figure 6

$$
\text { Bathropyramis scalaris }
$$
$140 \mathrm{~A}-2-6,80-82 \mathrm{~cm}$.

p. 551

Figure 7

Bathropyramis sp.

$139-1-1,80-82 \mathrm{~cm}$.

Figure 8

Bathropyramis sp. aff. B. spongiosa 139-1-CC.

p. 551

Figure 9

\section{Peripyramis sp. B.} 140A-2-6, $80-82 \mathrm{~cm}$.

Figure $10 \quad$ Peripyramis woodringii

p. 551 $140-2-1,5-7 \mathrm{~cm}$. 
PLATE 31
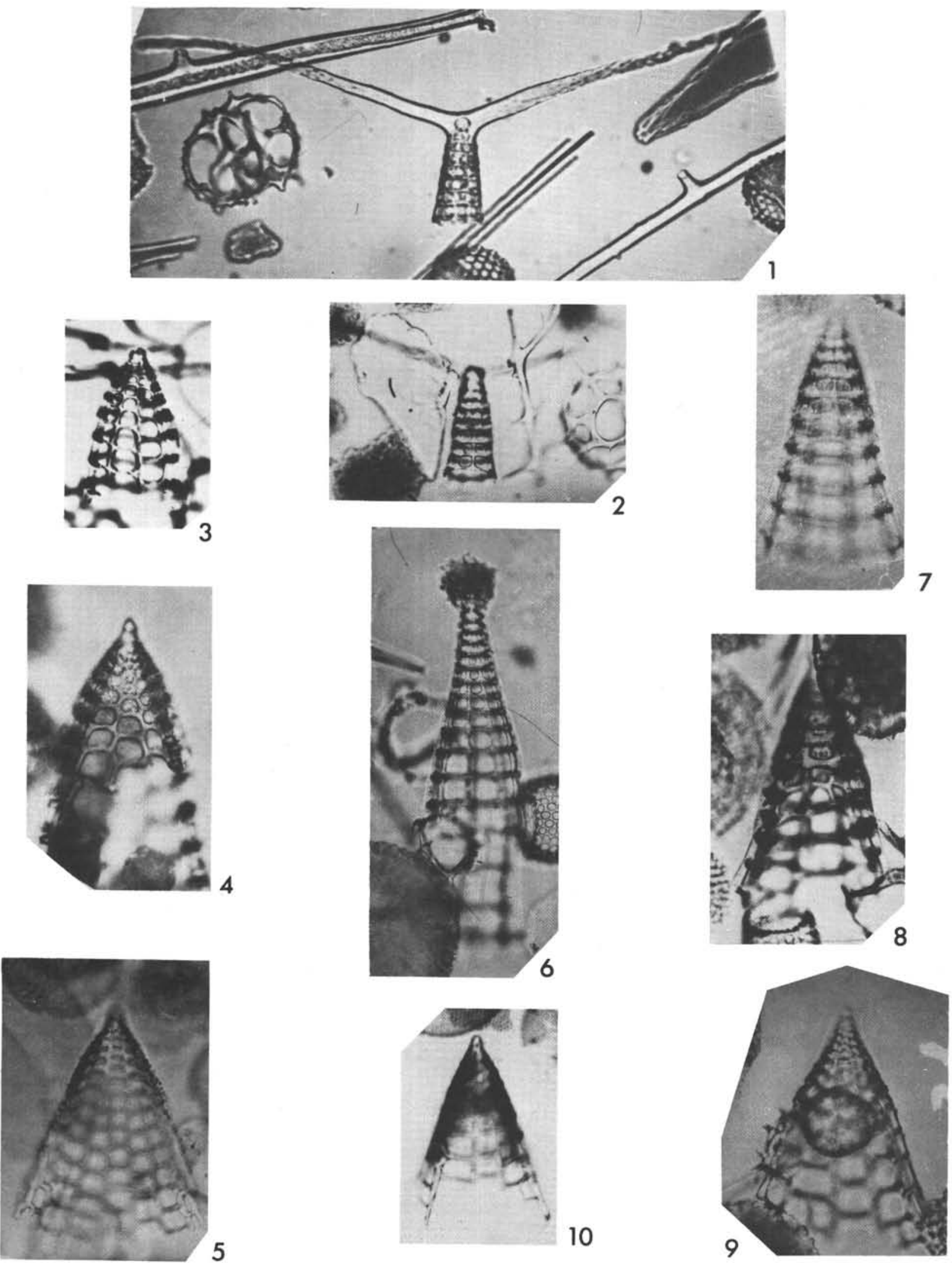
Plate 32

Magnification 200X

Figures 1, 2 Eusyringium striata

p. 549

1. 144B-2-5, Top.

2: Western Siberia, Eocene.

Figure 3 Eusyringium fistuligerum

p. 549 $144-1-5,80-85 \mathrm{~cm}$.

Figures 4, 5 Eusyringium tubulus

p. 549

4: $144-1-5,80-85 \mathrm{~cm}$

5: $138-2-1,5-7 \mathrm{~cm}$.

Figures 6,7 Lithocamnium ? sp. B

p. 550

6: 139-5-CC.

7: $140-2-6,80-82 \mathrm{~cm}$.

Figure $8 \quad$ Thyrsocyrtis argulus

p. 542 $144-1-5,80-85 \mathrm{~cm}$.

Figure 9 Thyrsocyrtis triacantha

p. 542 $144-1-5,80-85 \mathrm{~cm}$.

Figure $10 \quad$ Lampterium sp. G $140-3-3,5-7 \mathrm{~cm}$.

Figure $11 \quad$ Thyrsocyrtis sp. E

p. 542 144B-2-6, Top.

Figure 12 Lampterium chalara

p. 543 $144-1-5,80-85 \mathrm{~cm}$.

Figures 13, 14 Lampterium sp. aff. L. goetheana

p. 543 13: 144-1-CC.

14: $144-1-4,80-85 \mathrm{~cm}$.

Figure $15 \quad$ Lampterium sp. $140-3-3,5-7 \mathrm{~cm}$. 
PLATE 32
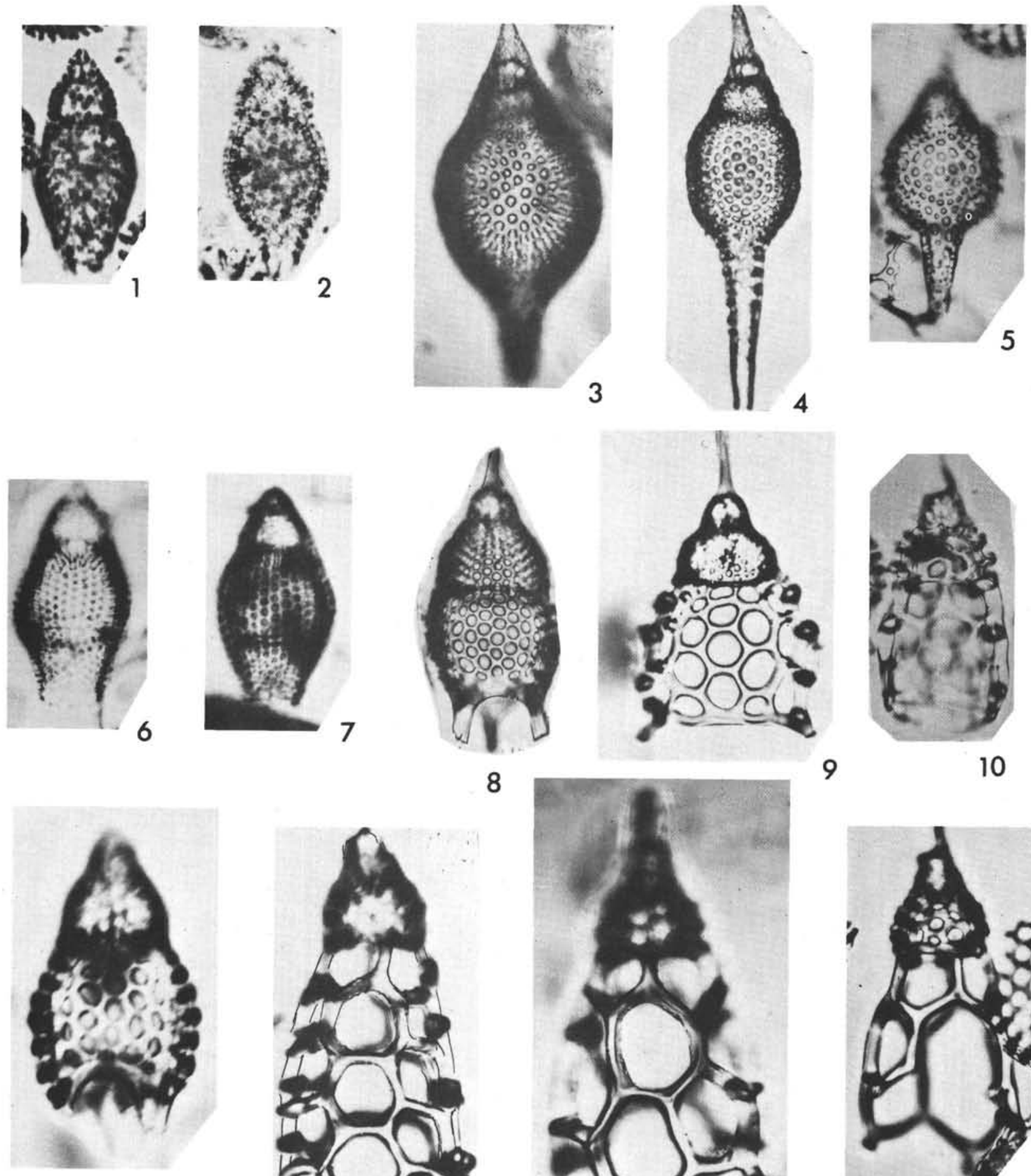

11

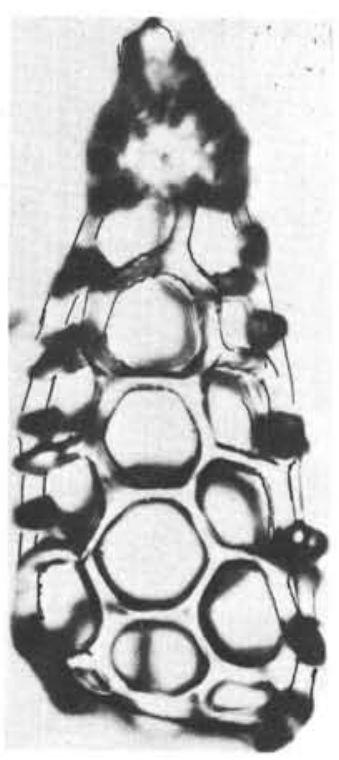

12
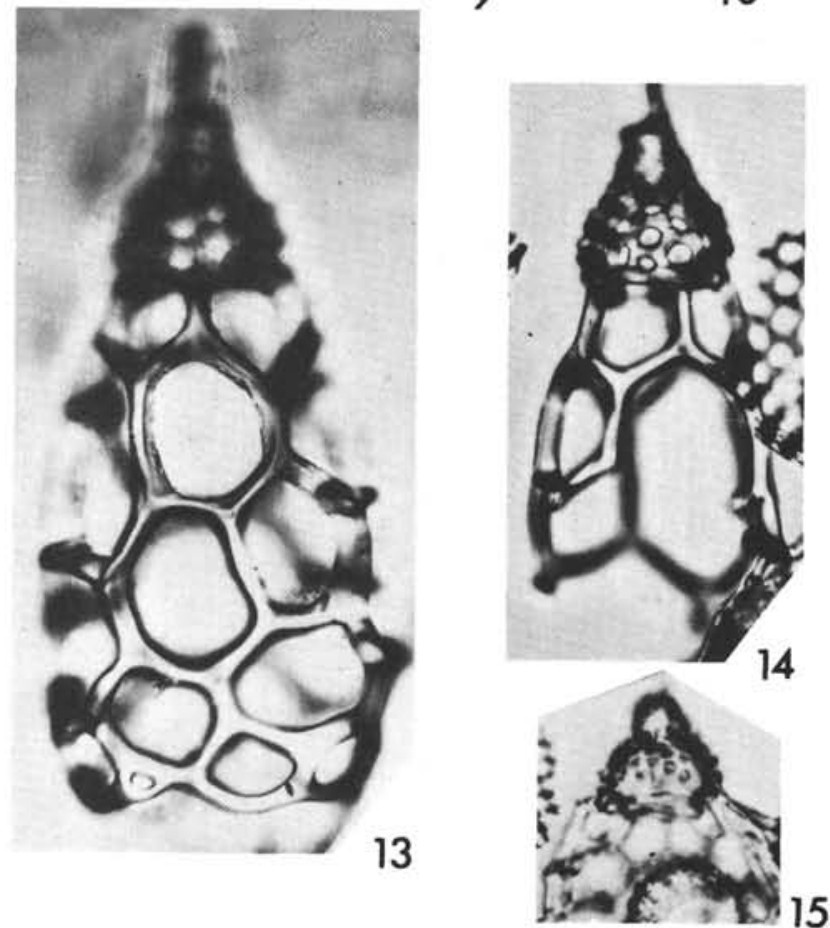
Plate 33

Magnification 200X

Figures 1-3 Anthocyrtella spatiosa group

p. 541 1, 2: $144-1-5,80-85 \mathrm{~cm}$. 3: 144-1-CC.

Figures 4, $5 \quad$ Anthocyrtella sp. M 4: $140-3-3,5-7 \mathrm{~cm}$.

5: Western Siberia Eocene.

Figures 6-8 Eucecryphalus sp.

p. 540 6, 8: 139-1-CC

7: $139-1-2,5-7 \mathrm{~cm}$.

Figure 9

Clathrocyclas universa undella (?) group California, Malaga Mudstone.

Figure 10

Anthocyrtella sp. $140-3-3,5-7 \mathrm{~cm}$.

Figures 11, 12 Clathrocyclas bicornis

11: $139-1-1,80-82 \mathrm{~cm}$ 12: $139-1-2,5-7 \mathrm{~cm}$.

Figure 13

Eucyrtidioidea gen. sp. (=Anthocyrtella hispida Ehrenberg) 140-2-CC*

Figures 14-16 Diplocyclas sp. A group

14: $140-2-C^{*}$.

15: $138-2-6,5-7 \mathrm{~cm}$.

16: $140 \mathrm{~A}-2-4,80-82 \mathrm{~cm}$.

Figures 17, 18 Diplocyclas sp. aff. D. bicorona

p. 540 $139-1-2,5-7 \mathrm{~cm}$.

Figure 19

Diplocyclas ionis group

p. 541

Figures 20-23 $140-2-1,5-7 \mathrm{~cm}$.

p. 535 20, 23: 144B-2-6, Top.

21: $140-2-C^{*}$.

22: $140 \mathrm{~A}-2-6,80-82 \mathrm{~cm}$. 
Plate 33
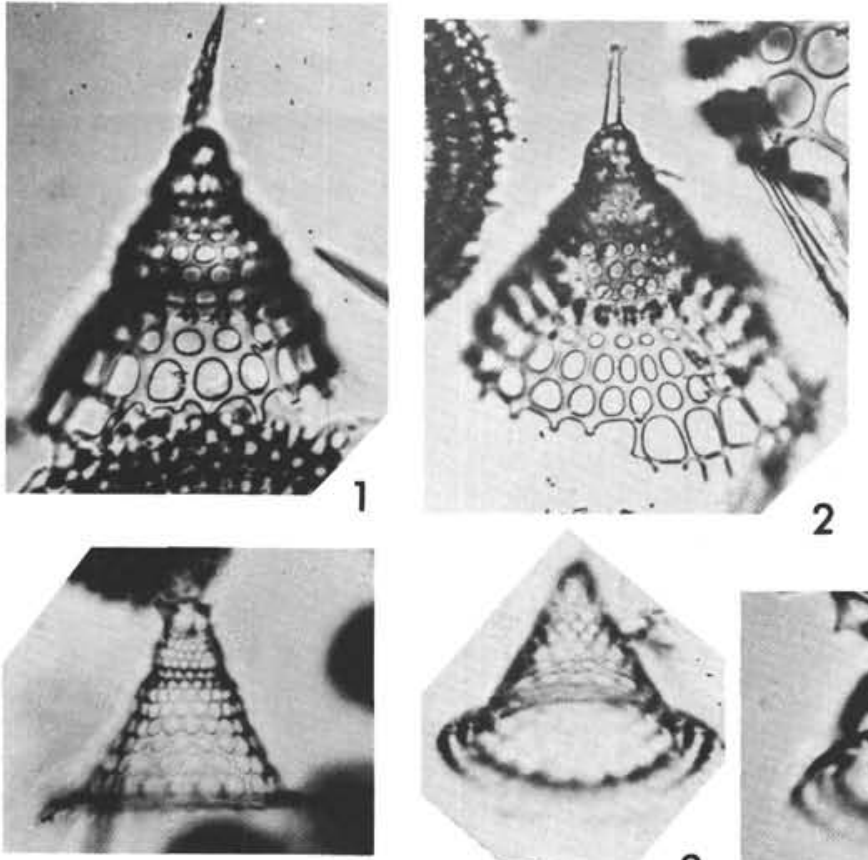

6

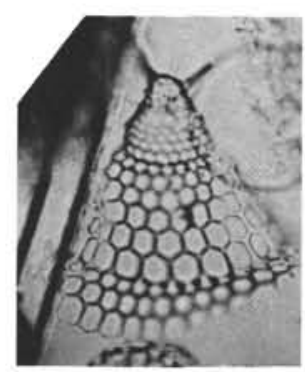

7
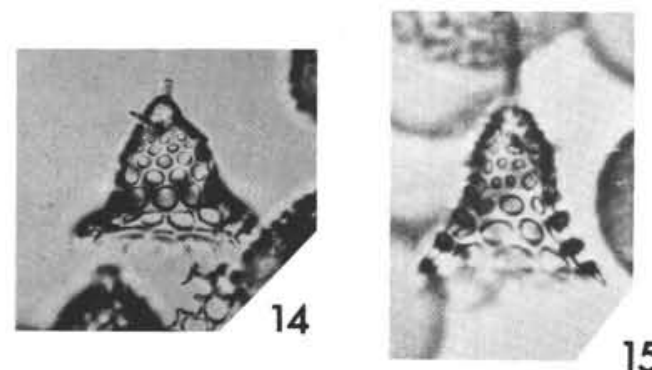

15
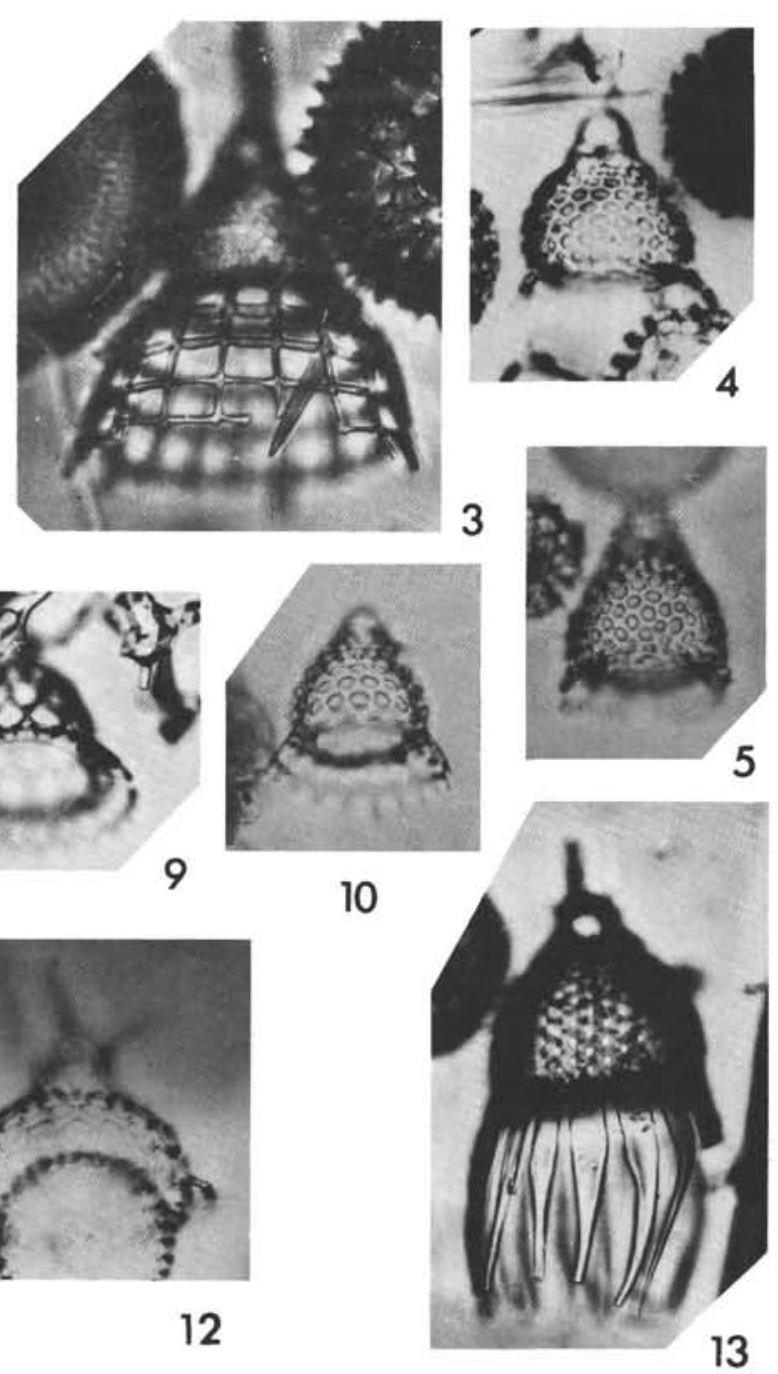

10

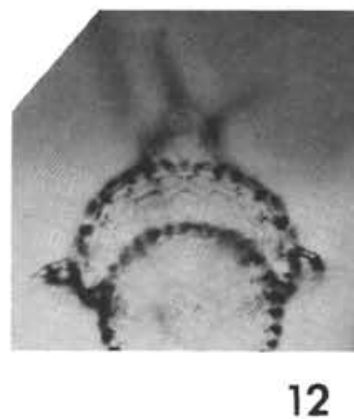

12
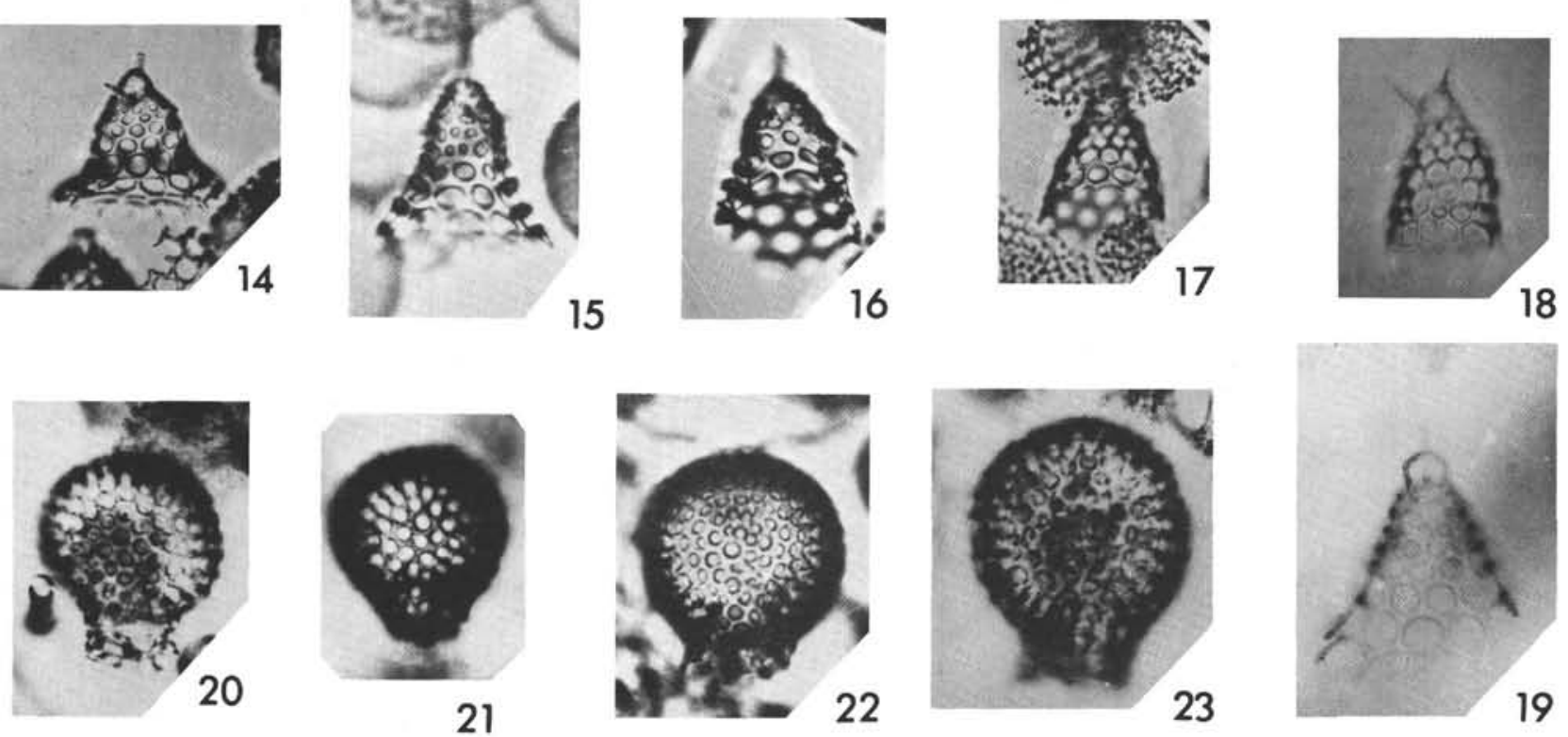
Plate 34

Magnification 200X

Figures 1, 2 Anthocyrtoma sp. Riedel and Sandfillipo or Cycladophora? erinaceus, Ehrenberg same specimen.

144-1-CC.

Figure $3 \quad$ Lithapium ? mitia (?) $140 \mathrm{~A}-2-3,80-82 \mathrm{~cm}$.

p. 551

Figure 4

Calocycloma ampulla 144-1-5, 80-85 cm.

p. 543

Figure 5

Thyrsocyrtis sp. $144-1-6,80-85 \mathrm{~cm}$.

Figure 6

Thyrsocyrtis triacantha

p. 542

Figure 7

Cyclampterium pegetrum, forma I 144B-2-5, Top.

p. 548

Figure 8

Cyclampterium pegetrum, forma II

p. 548 139-5-CC. 
PLATE 34
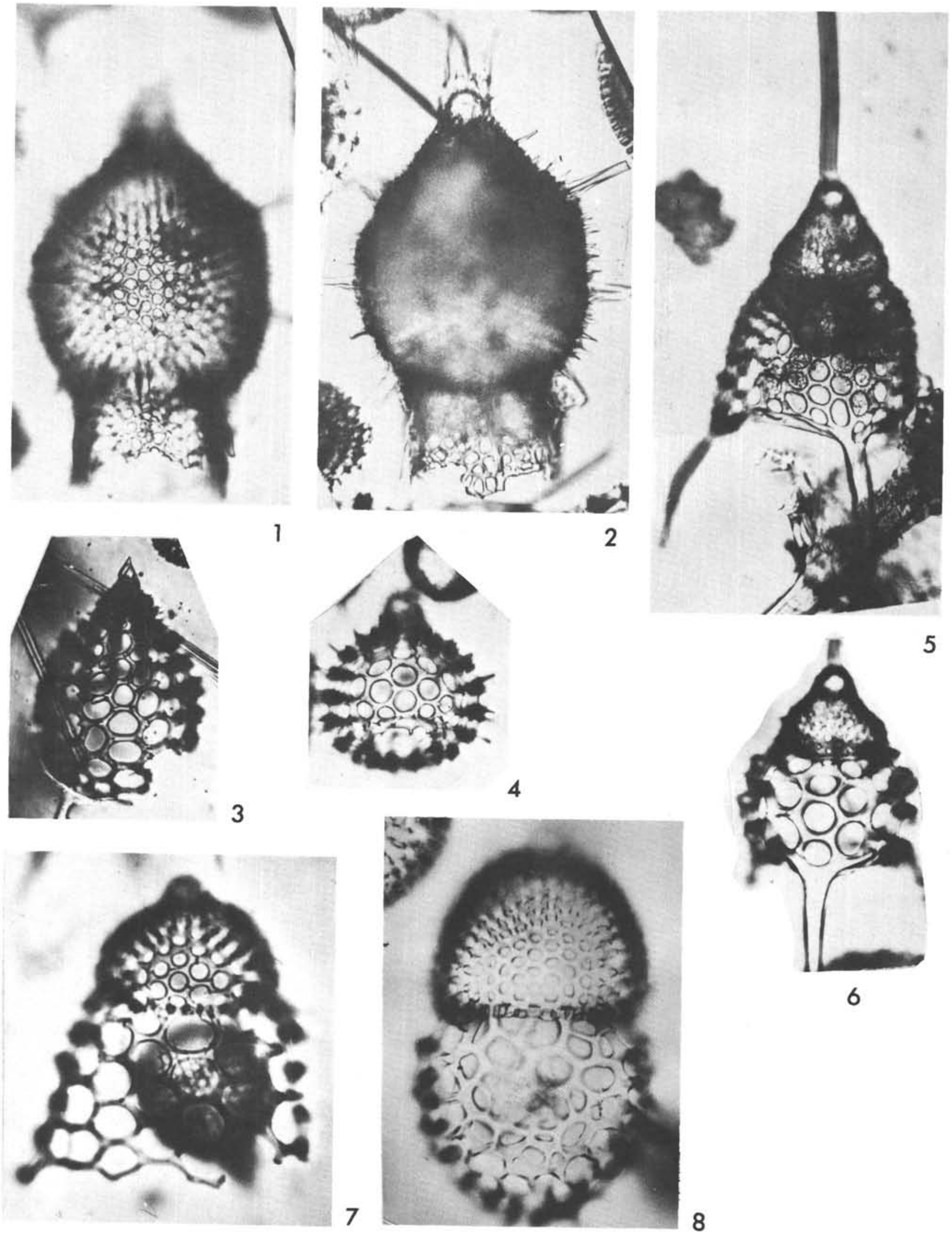
Plate 35

Magnification 200X

Figure 1

Podocyrtis papalis

p. 544 $144-1-5,80-85 \mathrm{~cm}$.

Figure 2

Podocyrtis sp. $140-3-3,5-7 \mathrm{~cm}$.

p. 543

Figure 3 Podocyrtis coronatus

p. 543 140-2-CC*.

Figure $4 \quad$ Podocyrtis sp. aff. P. coronatus 140-2-CC*.

Figures 5-7 Calocycletta acanthocephala 5, 6: same specimen, $138-2-4,5-7 \mathrm{~cm}$. 7: 140-2-CC*.

Figures 8-10 Calocycletta virginis 140-2-CC*.

Figures 11, 12 Calocycletta tuberosa forma A

p. 544 $138-2-1,5-7 \mathrm{~cm}$.

Figures 13, 14 Calocycletta tuberosa forma B

p. 544 13: $140 \mathrm{~A}-2-6,80-82 \mathrm{~cm}$. 14: 144B-2-6, Top.

Figure 15

Calocycletta sp. aff. C. virginis

p. 544 139-7-CC.

Figure $16 \quad$ Calocycletta veneris

p. 544 $142-9-2,58-60 \mathrm{~cm}$.

Figure 17

Calocycletta costata

p. 544 $140-2-2,5-7 \mathrm{~cm}$. 
PLATE 35
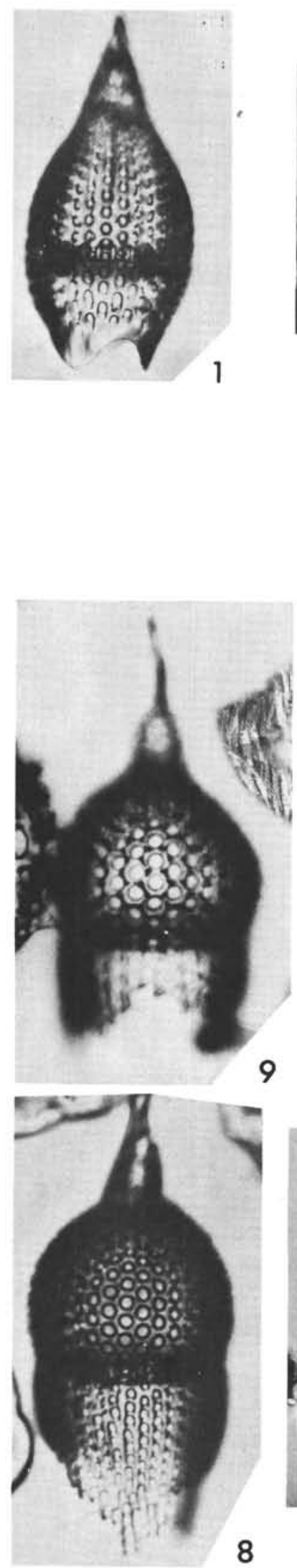
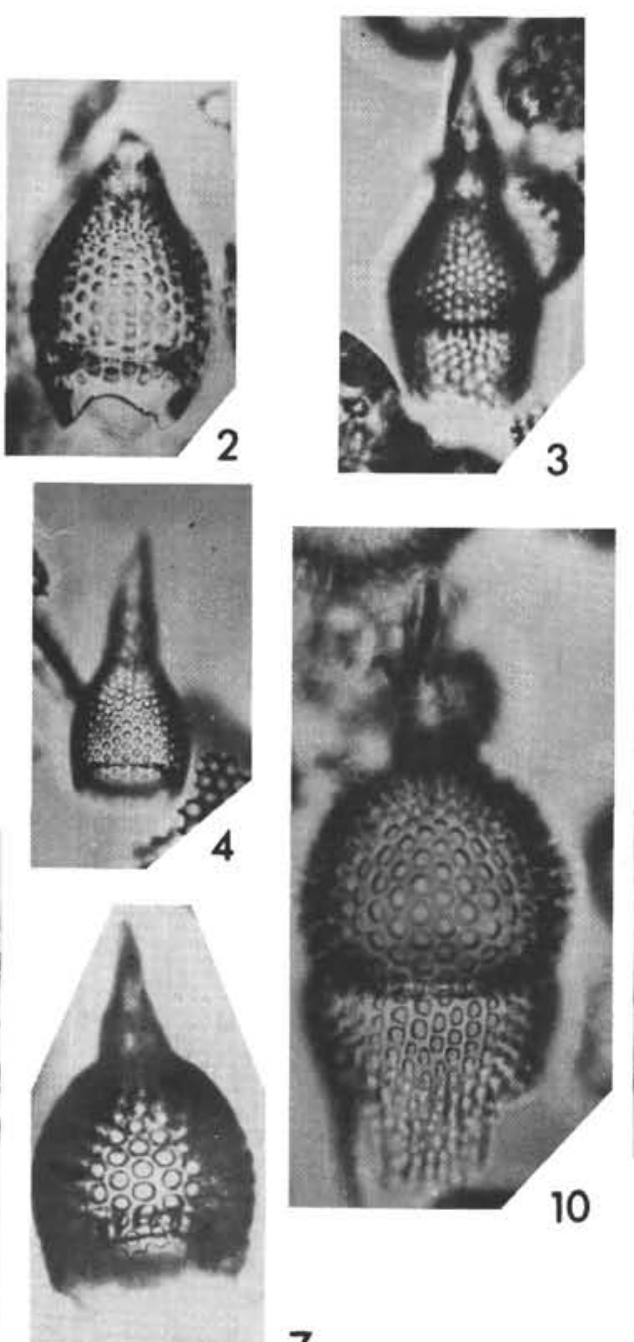

12
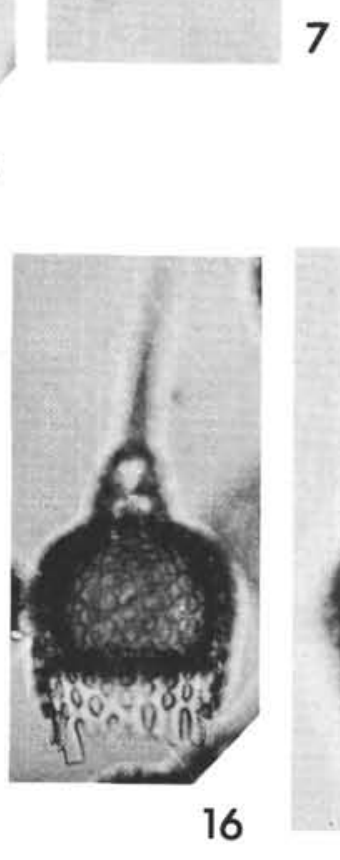
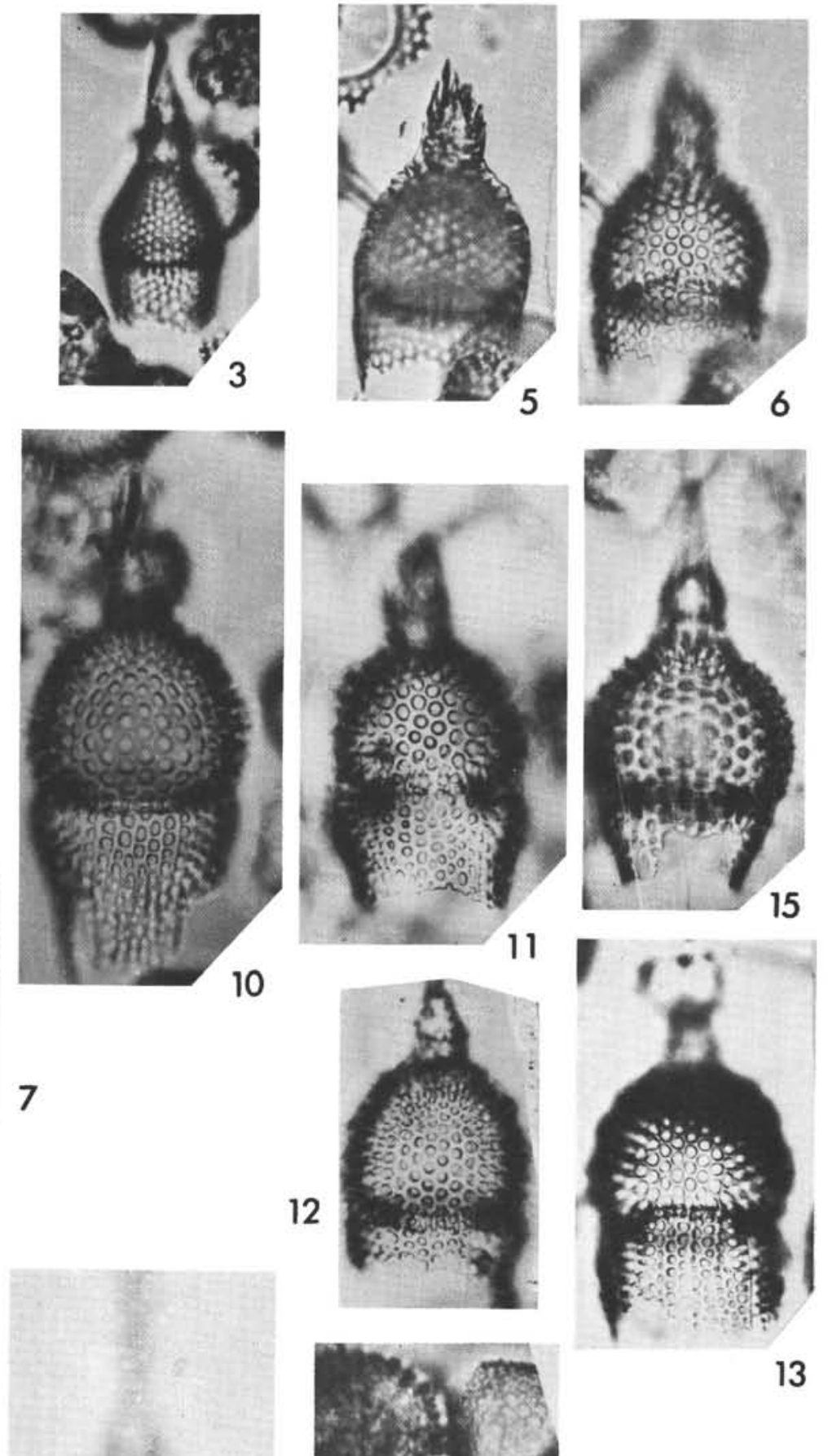

13 
Plate 36

Magnification 200X

Figures 1-3 Lamprocyclas rhinoceros

p. 544

1: 144B-2-6, Top.

2, 3: $138-2 \cdot 1,5-7 \mathrm{~cm}$.

Figure 4

Lamprocyclas $\mathrm{sp}$. A

p. 544 139-4-CC

Figure 5 Lamprocyclas sp. indet.

p. 545 $138-2-2,80-81 \mathrm{~cm}$.

Figures 6, 7 Lamprocyclas heteroporus

p. 545 6: 139-1.CC.

7: $139-1-2,5-7 \mathrm{~cm}$.

Figure 8

Lamprocyclas junonis group

p. 545

Figure 9

Lamprocyclas sp. $139-1-2,5-7 \mathrm{~cm}$.

Figure 10 Anthocyrtidium ovata

p. 545 $139-1-2,5-7 \mathrm{~cm}$.

Figure 11

Anthocyrtidium ophirense

p. 545 $139-1-2,5-7 \mathrm{~cm}$.

Figure 12 Lamprocyclas aff. L. heteroporus $139-1-2,5-7 \mathrm{~cm}$.

Figure $13 \quad$ Lamprocyclas aegles group

p. 544 $139-2-1,5-7 \mathrm{~cm}$.

Figure 14

Lamprocyclas maritalis group

p. 545 139-1-CC.

Figure 15 Theocorythium sp.

p. 544 $139-1-1,80-82 \mathrm{~cm}$.

p. 545

Figures 16-18 Pterocorys clausus group 16, 18: $139-1-2,5-7 \mathrm{~cm}$. 17: 139-1-CC.

Figure 19 Pterocorys sabae

p. 545 $139-1-1,80-82 \mathrm{~cm}$. 
PLATE 36
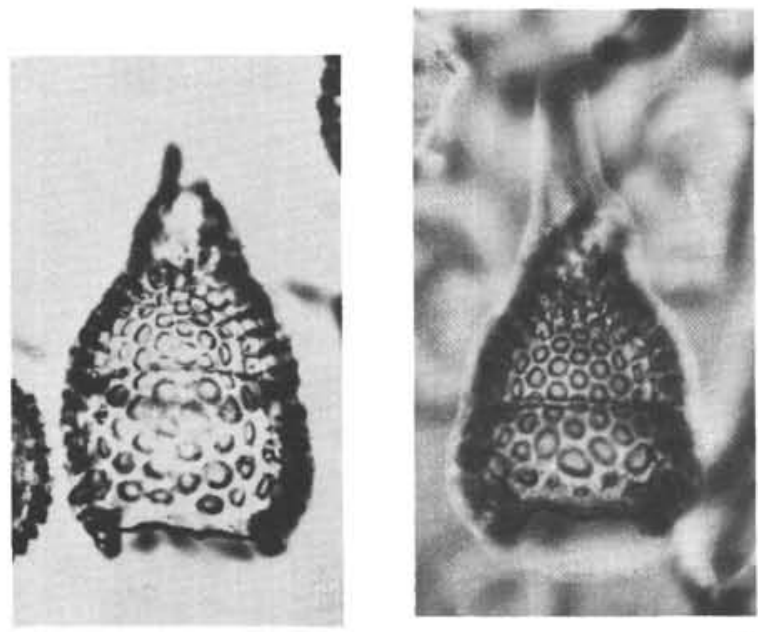

1
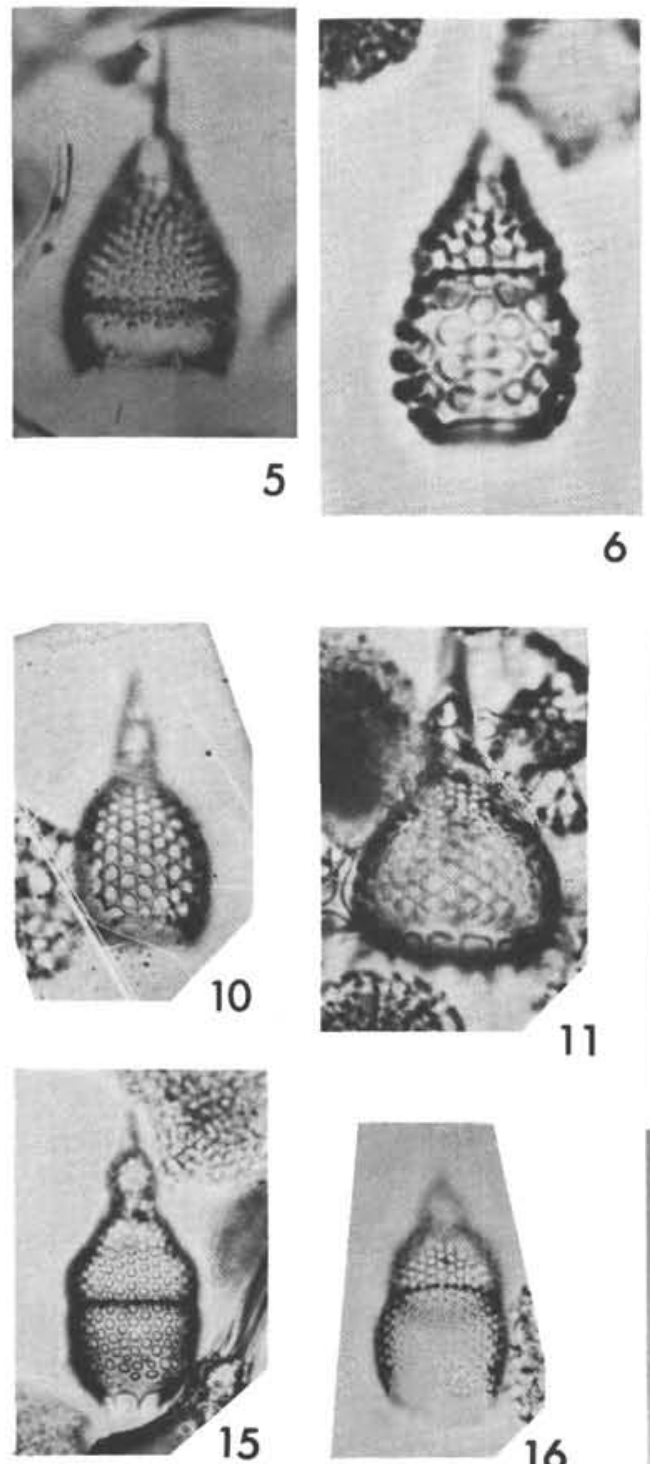

15

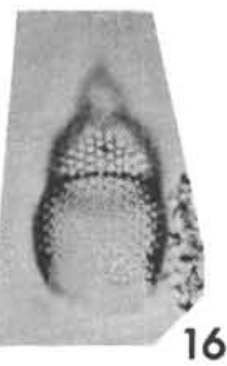

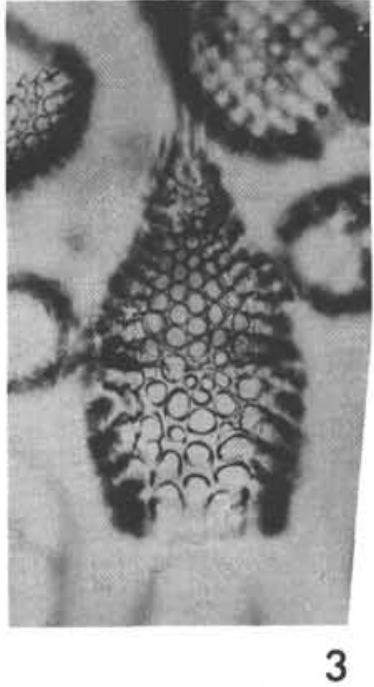
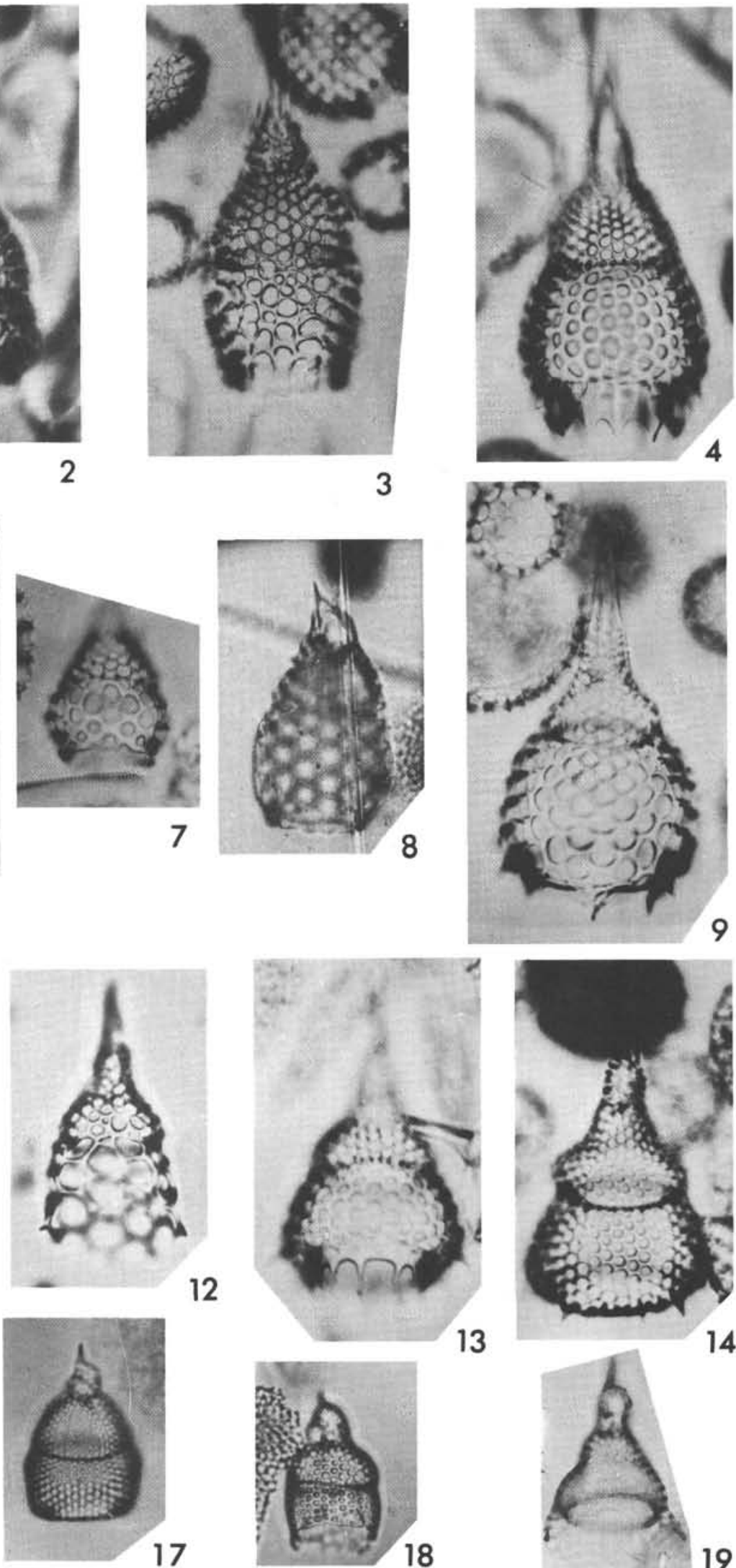

14

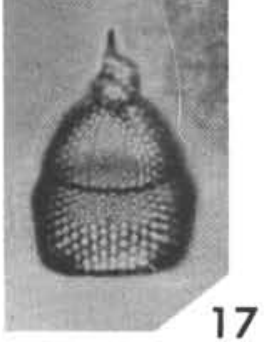

18 
Plate 37

Magnification 200X

Figure $1 \quad$ Lipmanella ? sp. aff. Lithomelissa amazon p. 542 $138-2-6,5-7 \mathrm{~cm}$

Figures 2, 3

Lipmanella (?) sp. M

p. 542

2: 139-5-CC.

3: $140-2-1,5-7 \mathrm{~cm}$.

Figures 4, $5 \quad$ Lipmanella sp. 0 group

p. 542 $140-2-1,5-7 \mathrm{~cm}$.

Figure 6

Ceratocyrtis sp. $140-2-1,80-82 \mathrm{~cm}$.

Figures 7-9 Lipmanella sp. C group 7, 8: 139-5-CC.

9: 139-SW1.

Figure 10

Lipmanella ? dogieli $\mathrm{Ob} 29$ Same specimen as on Figure 53, I in Petrushevskaya 1967.

Figure 11

Lithomelissa (?) campanulaeformis 139-1-CC

Figure 12

Ceratocyrtis sp. aff. C. cucullaris 139-5-CC.

p. 542

p. 542

p. 542

p. 534

Figures 13, 14

Lipmanella sp. aff. L. xiphephorum 13: 139-5-CC.

14: 139-1-CC.

Figure 15

Lipmanella xiphephorum

p. 542 139-1-2, 5-7 cm.

Figure 16

Tripodiscium sp. $138-2-3,5-7 \mathrm{~cm}$.

p. 534

Figure 17

Tripodiscium sp. A $138-2-6,5-7 \mathrm{~cm}$.

p. 534

Figure 18

Pseudodictyophimus sp.

p. 534 139-4-CC.

Figures 19, 20 Pseudodictyophimus sp. A

p. 534 $140-2-1,5-7 \mathrm{~cm}$.

Figure 21

Pseudodictyophimus gracilipes 139-1-CC.

p. 534

Figure 22

Pseudodictyophimus? sp. indet. 139-1-CC.

Figure 23

Ceratocyrtis sp. indet. 139-5-CC.

Figure 24

Pseudodictyophimus sp. B 140-2-CC*

Figures 25, 26 Clathrocorona ? sp.

p. 535 142-9-1, 98-100 cm.

Figures 27-30 Clathrocorona sphaerocephala group 27: $142-9-1,98-100 \mathrm{~cm}$.

28: $140-2-1,80-84 \mathrm{~cm}$. 29: $140-2-1,5-7 \mathrm{~cm}$. 30: 139-5-CC.

Figure 31

Clathrocanium ? sp. $138-2-3,5-7 \mathrm{~cm}$. 
PLATE 37
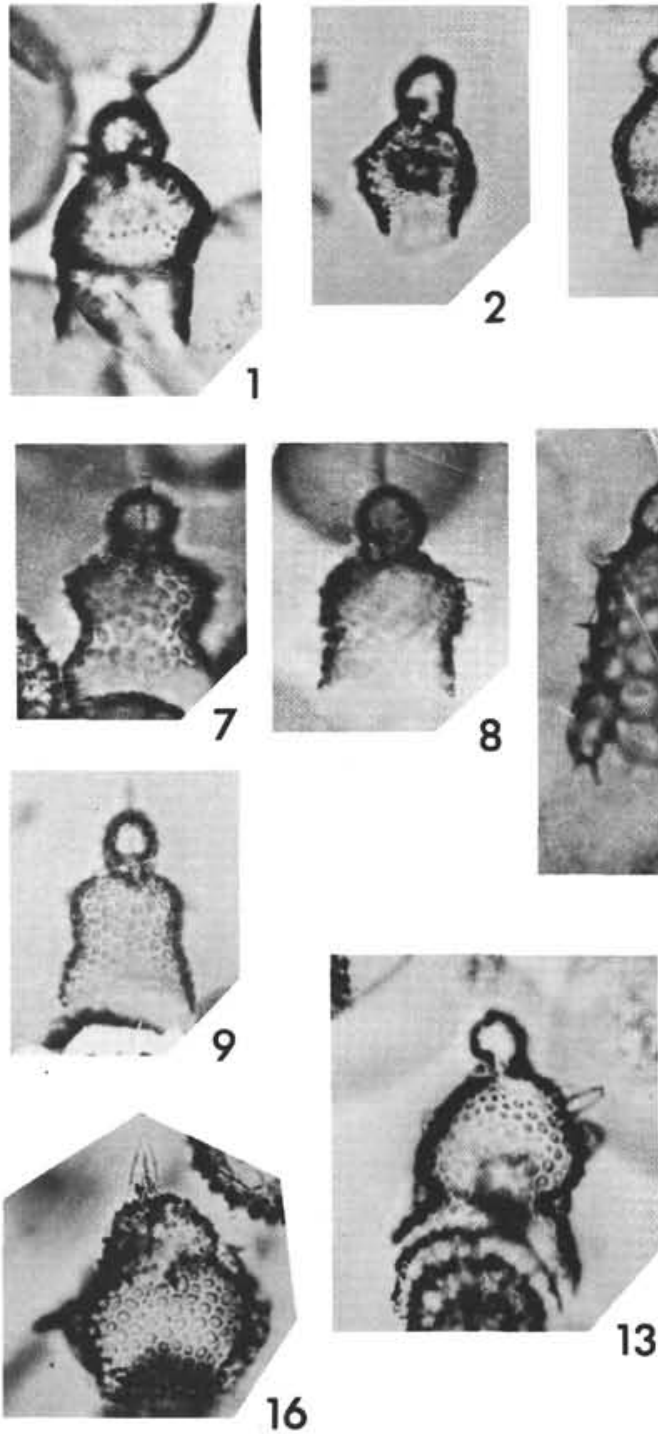

16

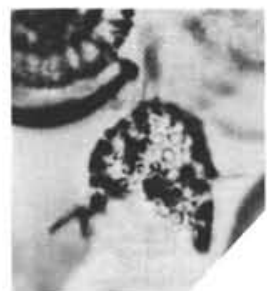

17
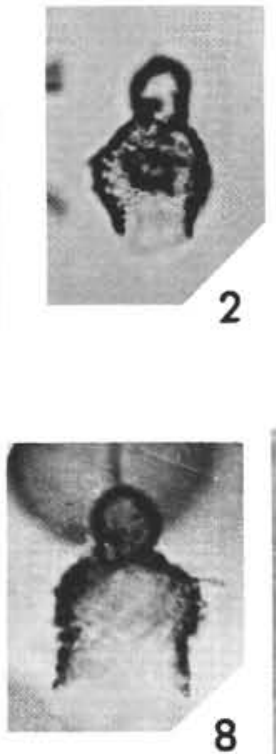

8

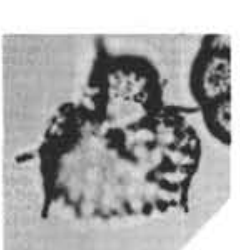

18

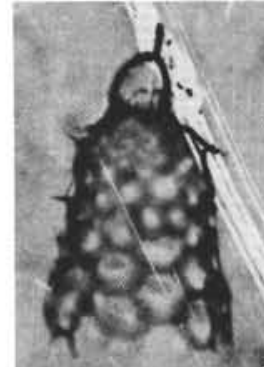

10

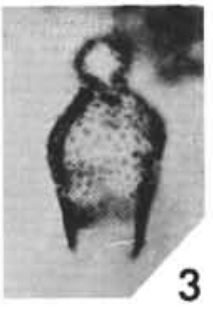

3
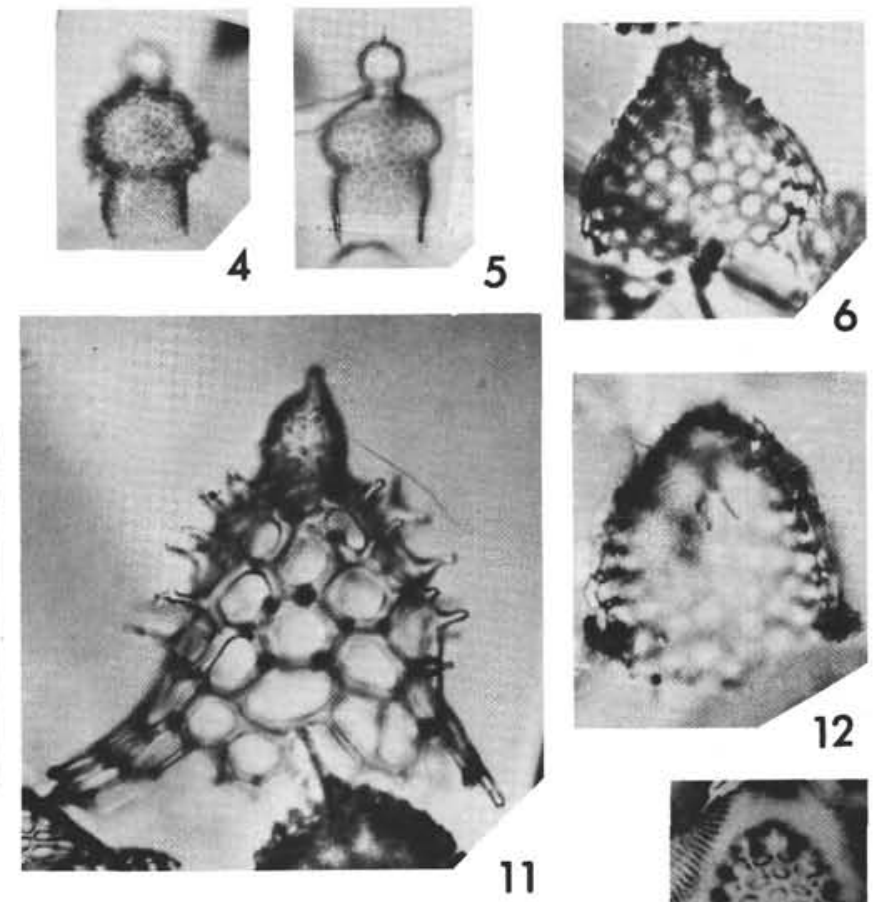

12
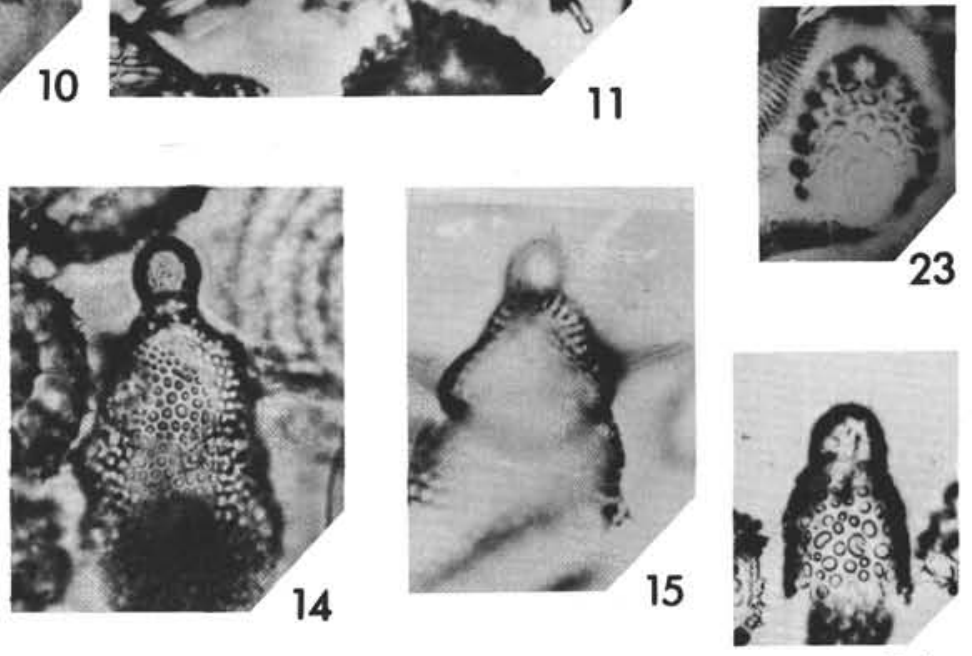

24

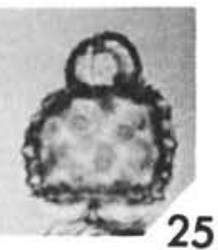

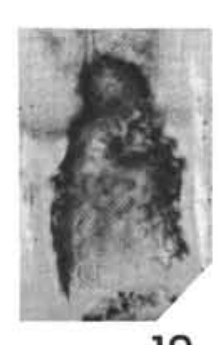

19

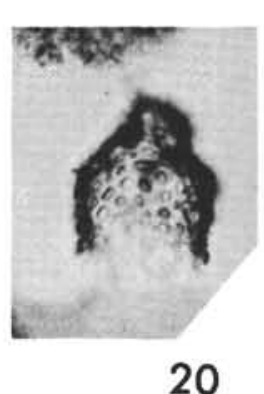

20
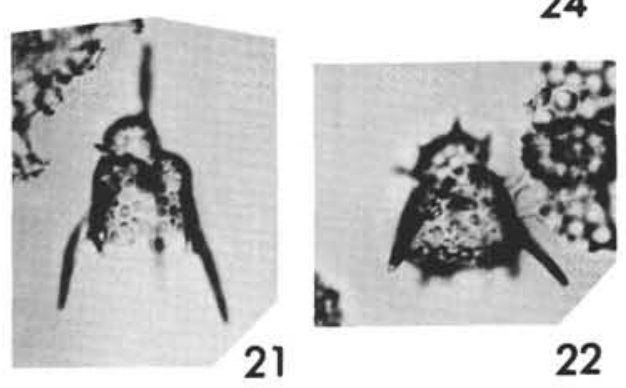

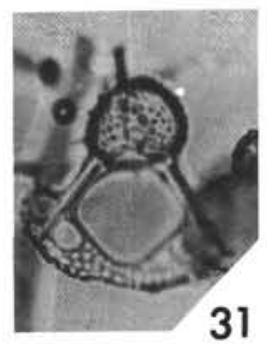


Plate 38

Magnification 200X

Figure 1

Figure 2

Figure 3

Figures 4, 5

Figure 6

Figures 7-10

Figure 11

Figure 12, 13

Figure 14

Figures 15, 16

Figure 17

Figures 18, 19

Figures 20, 21

Figures 22-24

Figure 25

Figures 26, 29

Figures 27, 28

Figure 30
Desmospyris sp. aff. D. lata 140A-2-3.

Thamnospyris schizopodia $140-2-3,5-7 \mathrm{~cm}$.

Thamnospyris sp. aff. T. schizopodia $140-2-3,5-7 \mathrm{~cm}$.

p. 532

p. 531

p. 531

Thamnospyris spp. 140-2-1, 80-84 cm.

Desmospyris sp. aff. D. mamillata $140-3-3,5-7 \mathrm{~cm}$.

p. 531

Rhodospyris sp. aff. $R$. tricornis

p. 531 7, 8: $142-9-1,98-100 \mathrm{~cm}$.

9: $140-2-1,5-7 \mathrm{~cm}$.

10: 139-7-CC.

Rhodospyris sp. A 139-7-CC.

p. 531

p. 532

12: $140-2-1,5-7 \mathrm{~cm}$.

13: $140-2-3,80-85 \mathrm{~cm}$.

Rhodospyris sp. aff. $R$. anthocyrtis

p. 531 $140-2-1,5-7 \mathrm{~cm}$.

p. 531

incomplete.

15: JYN V-16P, $235-237 \mathrm{~cm}$.

16: 139-7-CC.

Desmospyris (?) pannosa

JYN V-16P, 235-237 cm.

Rhodospyris spp. indet

18: $140 \mathrm{~A}-2-6,80-82 \mathrm{~cm}$.

19: 144B-2-5, Top.

p. 531

Spyrida gen. et spp. indet

20: 139-5-CC.

21: 139-7-CC.

Lithotympanium tuberosum $142-9-1,98-100 \mathrm{~cm}$.

p. 533

Desmospyris sp. 140-2-1, 5-7 cm.

Tricolospyris leibnitziana group 26: $140-2-3,84-85 \mathrm{~cm}$.

29: 139-5-CC.

p. 533

Tricolospyris spp. aff. T. leibnitziana 27: 139-5-CC.

28: $140-2-1,5-7 \mathrm{~cm}$.

Spyrida gen. et sp. indet. $140-2-1,5-7 \mathrm{~cm}$. 
PLATE 38
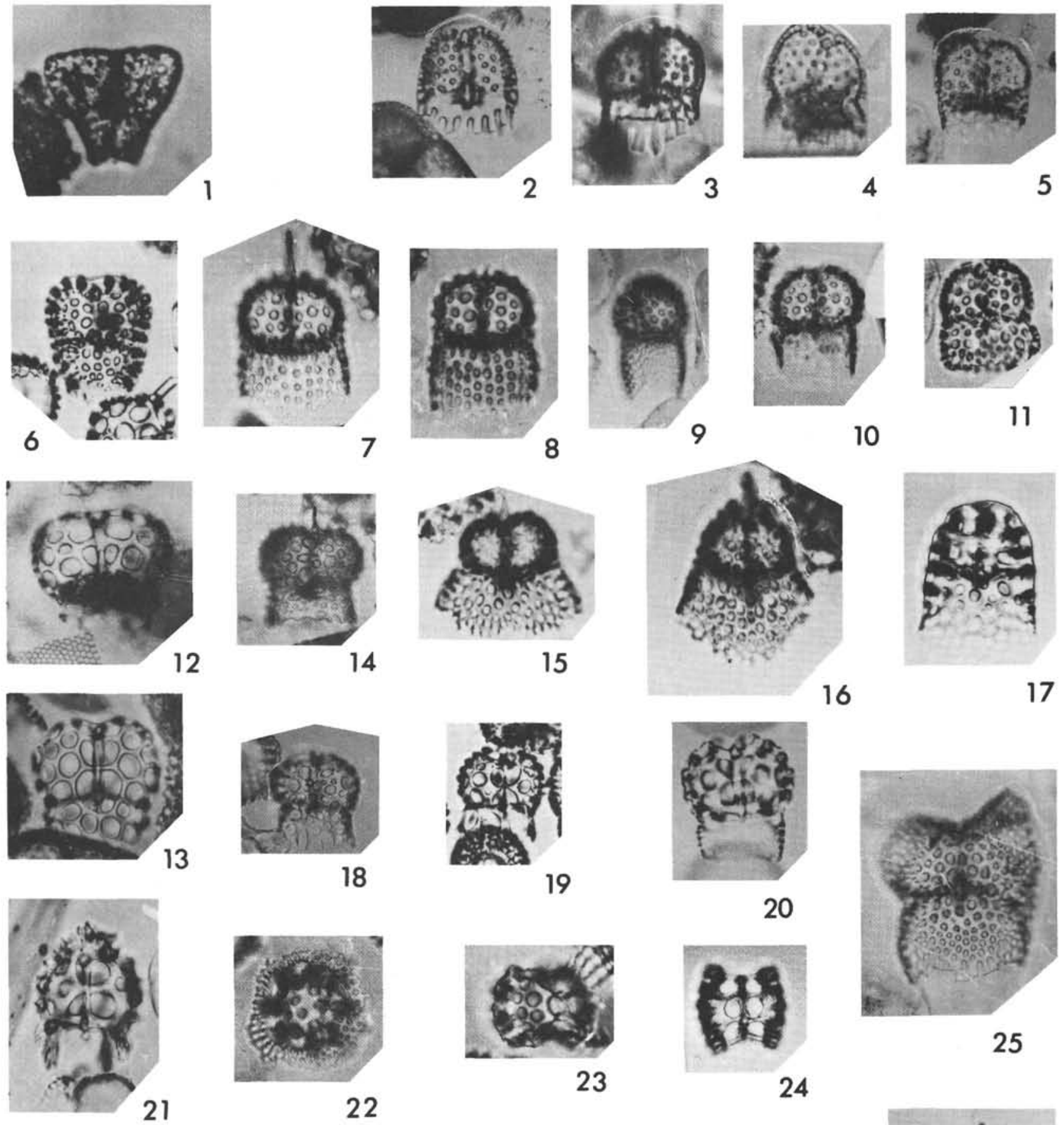

20
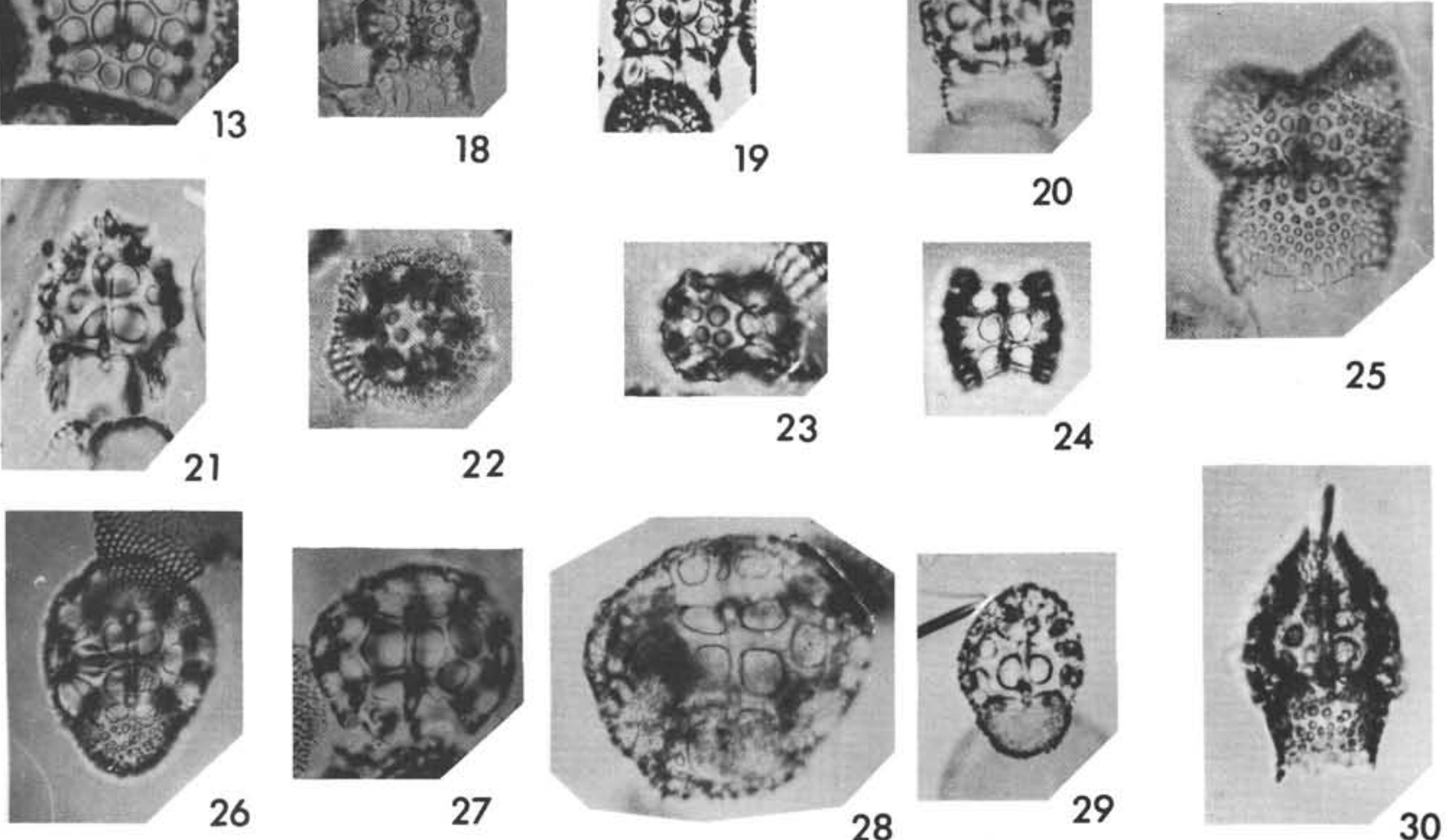
Plate 39

Magnification 200X

Figures 1, 2 Acrobotrys sp. aff. A. sphaerothorax

p. 554

1: 139-7-CC, $\mathrm{Ph}$.

2: $139-5-\mathrm{CC}, \mathrm{Ph} 2$.

Figure 3

Acrobotrys sp. aff. A. disolenia

p. 554

139-5-CC, $\mathrm{Ph} 2$.

Figures 4-6

Botryocella spp. aff. B. cribrosa group

p. 554

4: $138-2-3,5-7 \mathrm{~cm}, \mathrm{Ph}$.

5: $138-2-1,5-7 \mathrm{~cm}$ SLI.

6: 144B-2-6, TOP, SLI.

Figure 7

Botryocyrtis quinaria group

p. 554 140-2-1, 80-84 cm.

Figures 8, 10

Botryocella multicellaris

8: $138-2-3,5-7 \mathrm{~cm}$.

10: 139-7-CC.

Figure 9

Acrobotrys sp. aff. A. disolenia group 139-7-CC.

p. 554

Figure 11

Centrobotrys sp. 144B-2-5, Top.

p. 554

Botryocella sp. 140-2-1, 5-7 cm, Ph1.

Figure 13 Hexaspyris sp.

p. 529 139-5-CC.

Figure 14

Dictyospyris ? clathrata

p. 531 144-1-5, 80-82 cm.

Figure 15

Liriospyris sp. aff. D. clathrata

p. 531 140-3-CC, SL2.

Figure 16 Liriospyris sp..A 140A-2-6, 80-82 cm, SL1.

Figures 17-20 Liriospyris sp. B group

p. 531

$17,18,20:$ 144B-2-5, Top. 19: $138-2-3,5-7 \mathrm{~cm}$.

Figure 21

Liriospyris sp. aff. L. hexapoda 139-7-CC.

Figure 22

Dendrospyris sp. aff. Theospyris felis 139-7-CC.

Figures 23, 24 Tympanomma binoctonum 142-9-3, 90-92 cm.

Figure 25

Trissocyclus elevata 140-2-1, 80-82 cm.

Figures 26-28 Dendrospyris pododendros group 26, 27: 139-7-CC.

28: 139-5-CC.

Figures 29-31 Trissocyclus stauropora

p. 533

29: From the median bar, 142 Bumper.

30: 142 Bumper.

31: From the apex, 142-9-1, 98-100 cm.

Figures 32, 33 Patagospyris pentas

p. 531

p. 532

p. 533

p. 533

p. 532 140-3-CC. 
PLATE 39

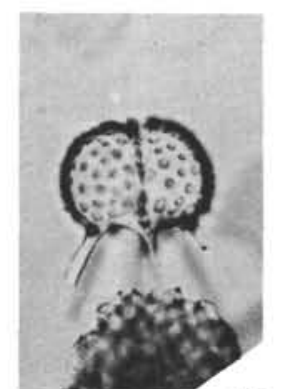

13
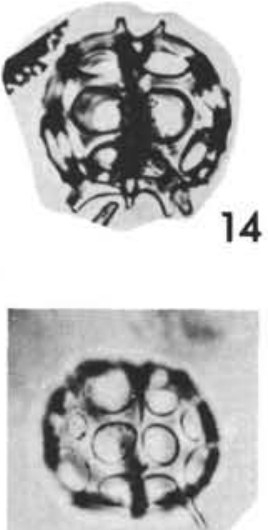

15
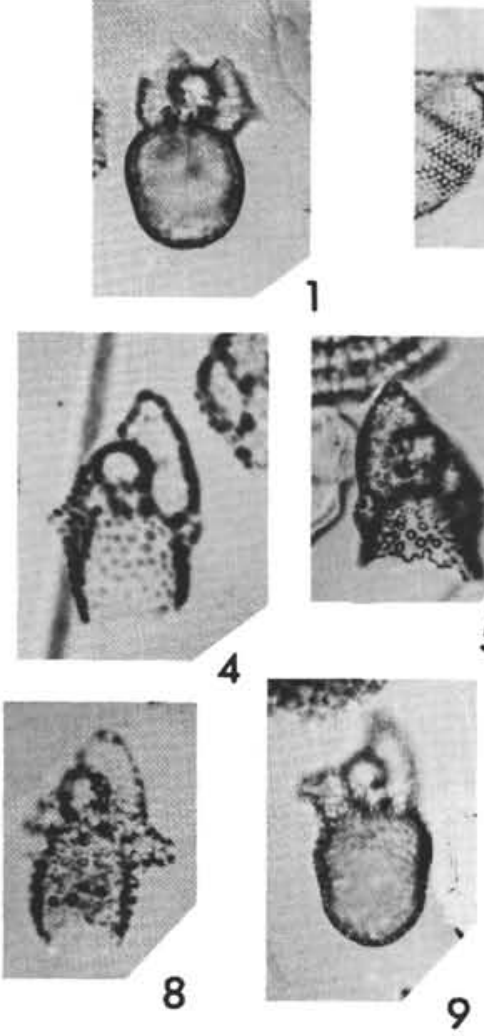
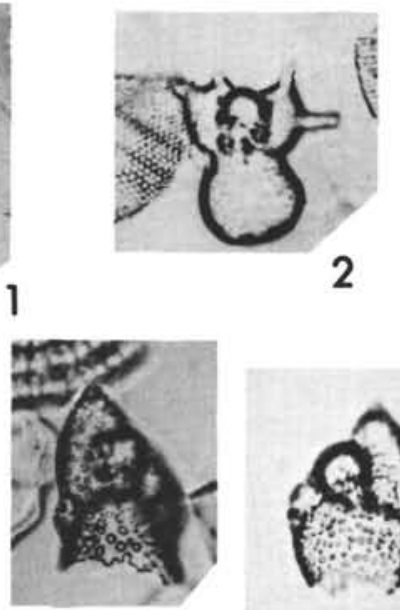

5

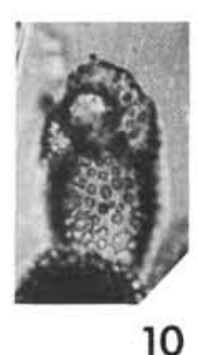

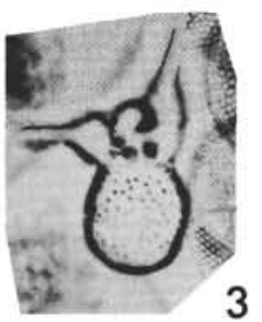
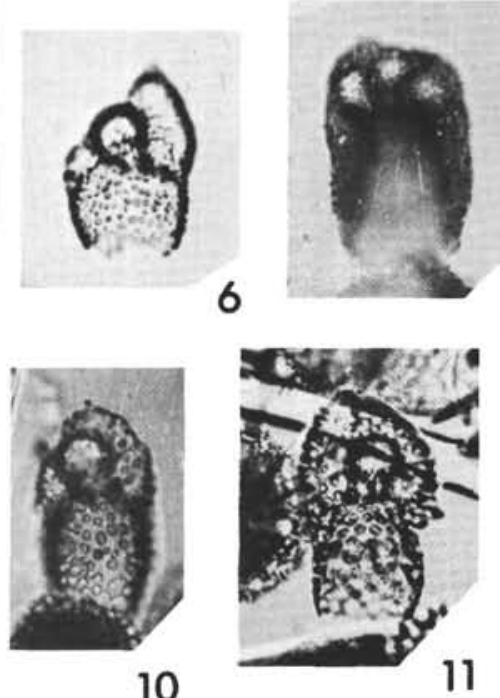

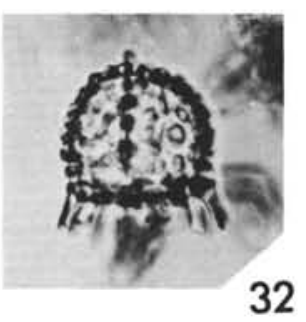

32
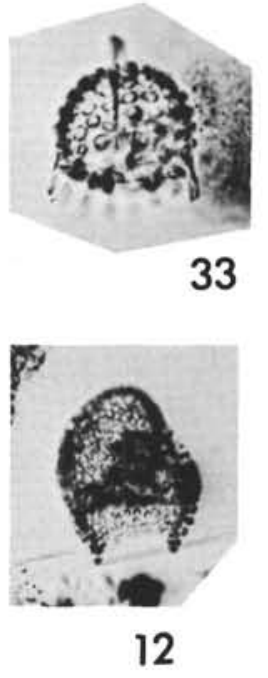
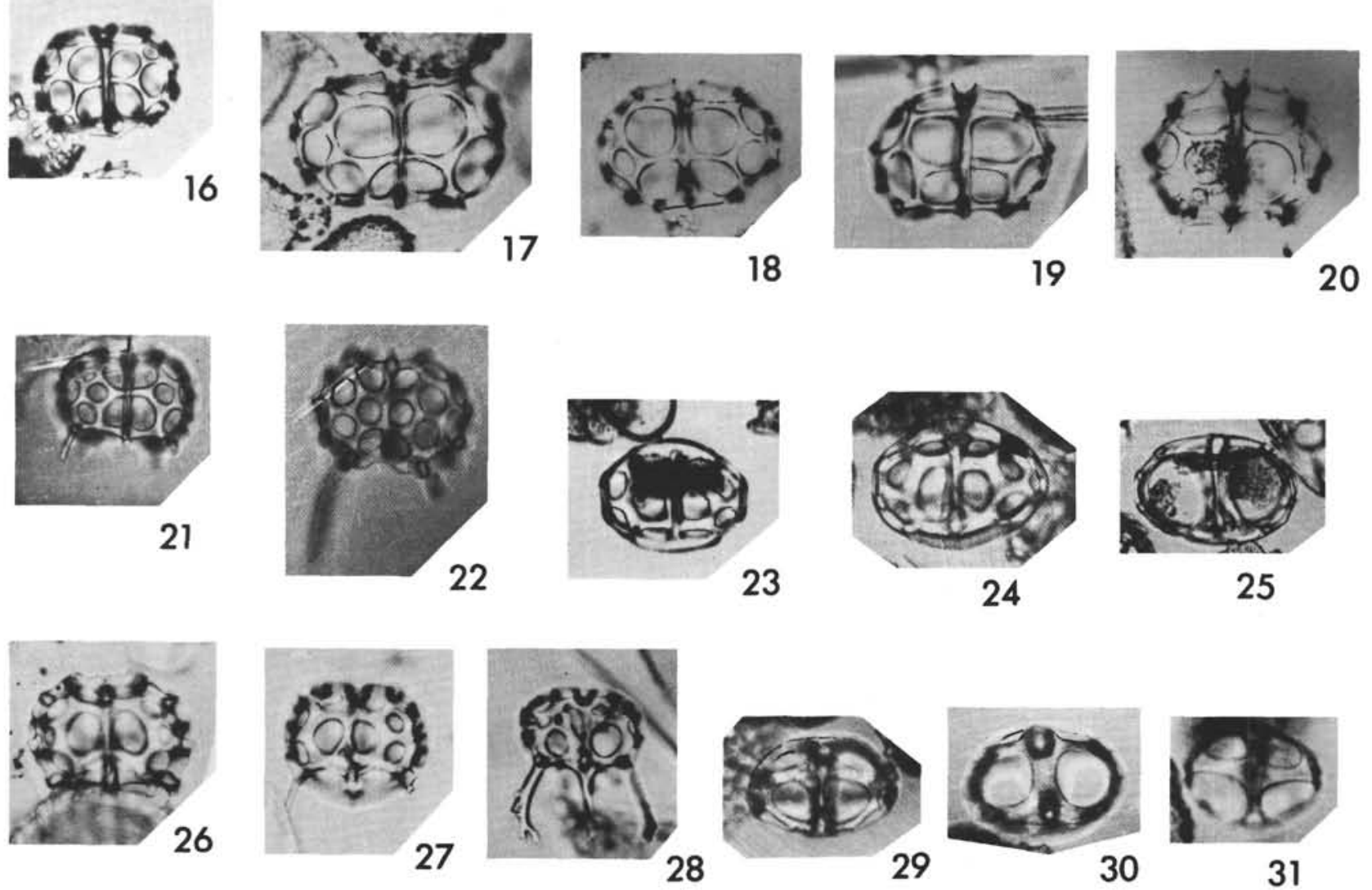
Plate 40

Magnification 200X

Figure $1 \quad$ Petalospyris sp. E

p. 532 140A-2-4.

Figure 2

Figure 3

Figure 4

Figure 5

Figure 6

Figure 7

Figure 8

Figures 9, 10

Figure 11

Figure 12

Figure 13
Desmospyris sp. aff. D. anthocyrtoides 140A-2-5.

Desmospyris sp. aff. D. anthocyrtoides forma 2 144B-2-6, Top, SL 1.

Desmospyris anthocyrtoides 144B-2-6, Top, SL 1.

Dorcadospyris sp. K

p. 532 144B-2-6, Top, CSE 1.

Hexaspyris sp. 140-2-CC*.

p. 529

Dorcadospyris sp. 138-2-6, 5-7 cm Ph.

Patagospyris argisca 144-1-6.

p. 532

Petalospyris triceros group 144B-2-5, Top, SL 1.

Dorcadospyris simplex

p. 532 139-7-CC.

Dendrospyris didiceros group 140-3-3, 5-7 cm, SL 2.

p. 532

Dorcadospyris sp. aff. D. alata $140-2-1,5-7 \mathrm{~cm}$. p. 532 
PLATE 40
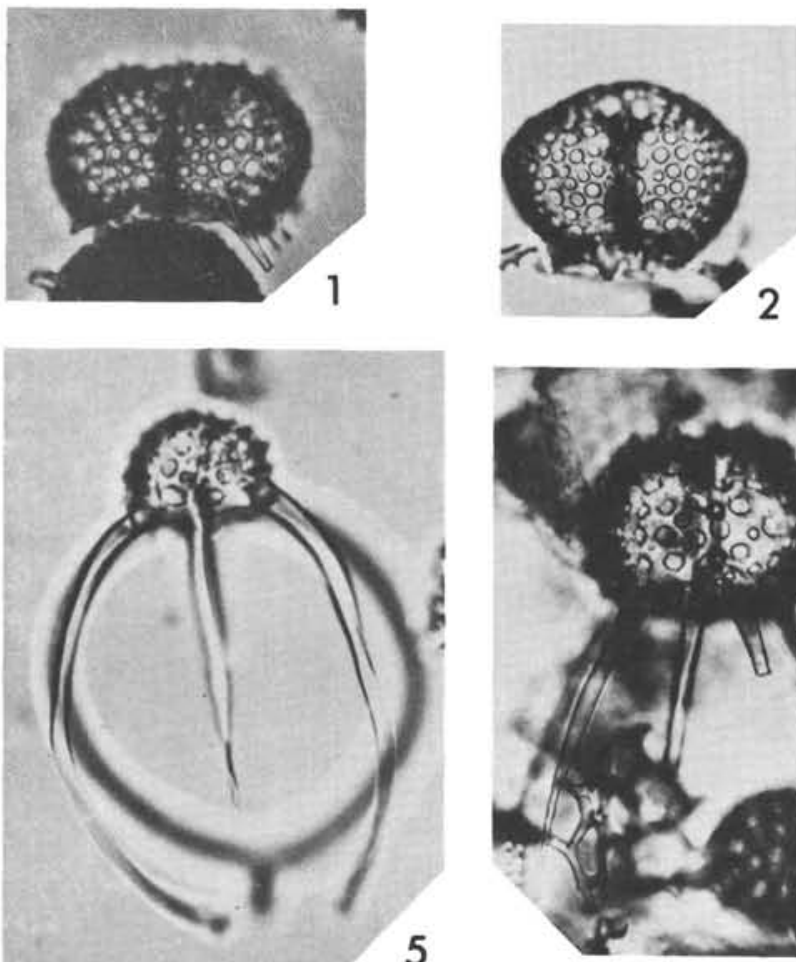

5
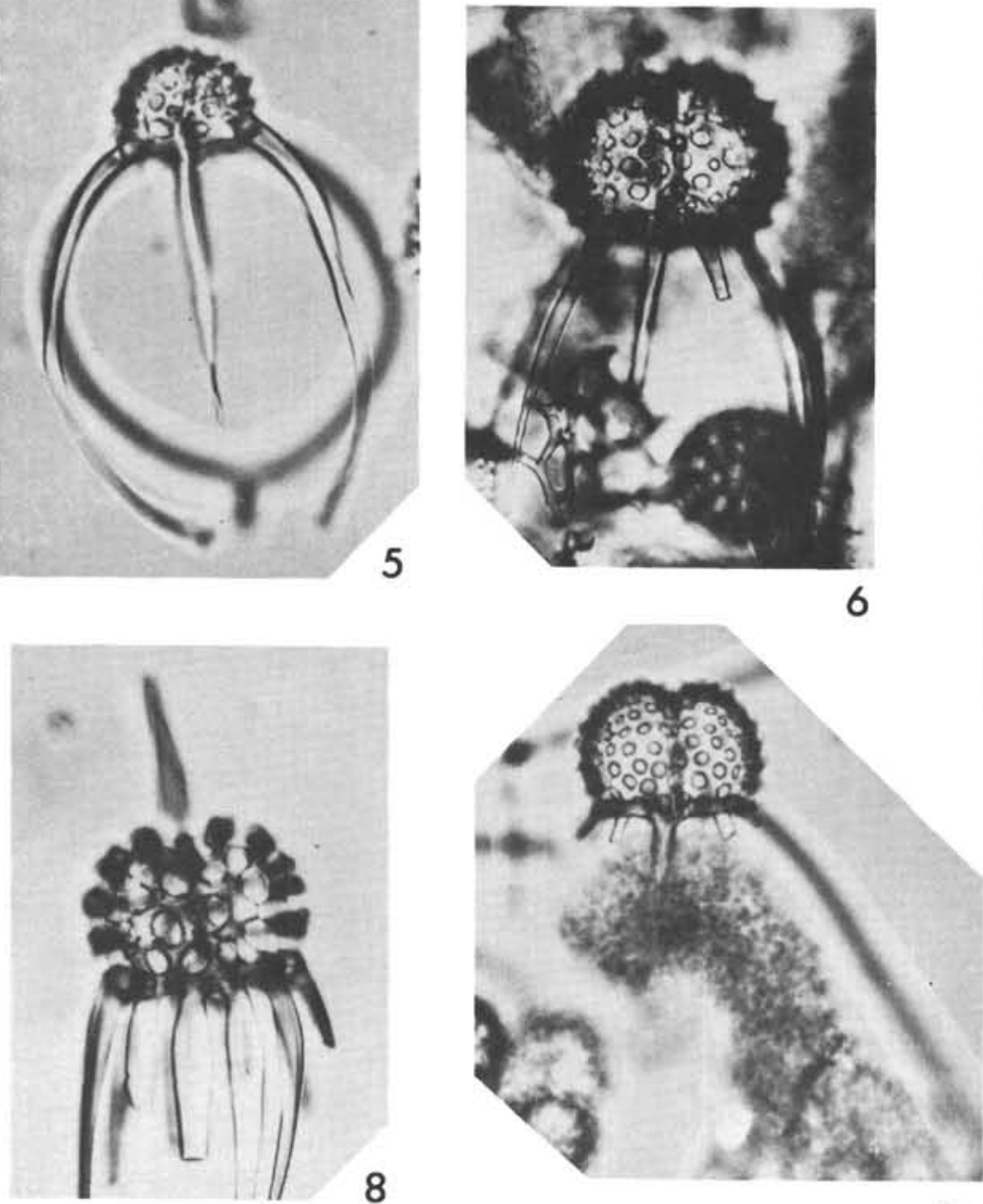
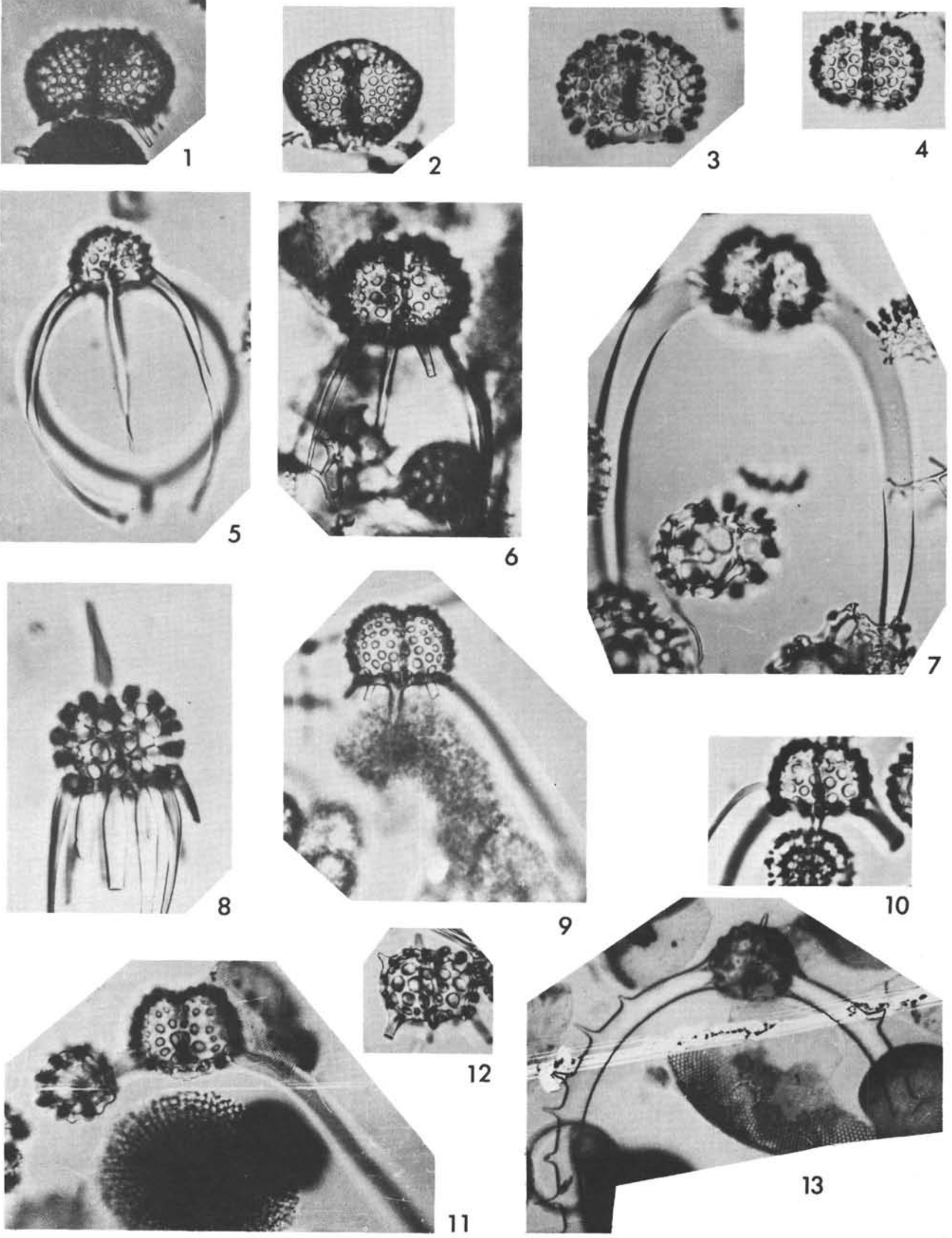
Plate 41

Magnification 200X

Figures 1, $2 \quad$ Eucoronis sp. A

1: $142-9-1,98-100 \mathrm{~cm}$.

2: $139-4-C C$.

Figure 3 Podocoronis toxarium $142-9-2,58-60 \mathrm{~cm}$.

Figure 4

Zygocircus productus 139-1-2, $5-7 \mathrm{~cm}$.

Figures 5, $6 \quad$ Zygocircus cimelium

p. 534

5: Holotype, 140-3-3, 5-7, Y45/0.

6: $140-3-3,5-7 \mathrm{~cm}, \mathrm{M} 45 / 0$.

Figure 7

Zygocircus sp.

p. 534 140-3-CC.

Figures 8-11 Zygocircus butschli
8: $140-3-3,5-7 \mathrm{~cm}$.
9: 144B-2-6, Top.
10, 11: 144B-2-5, Top.

Figure $12 \quad$ Zygocircus (?) sp. indet 140-2-6.

Figures 13, 14 Eucoronis sp. B.

13: $142-9-1,98-100 \mathrm{~cm}$.

p. 533

14: $142-9-3,90-92 \mathrm{~cm}$.

p. 533

Figures 15-17 Eucoronis hertwigii group

15: 144B-2-6, Top.

16: $140-3-3,5-7 \mathrm{~cm}$

17: 144B-2-5, Top. 
PLATE 41
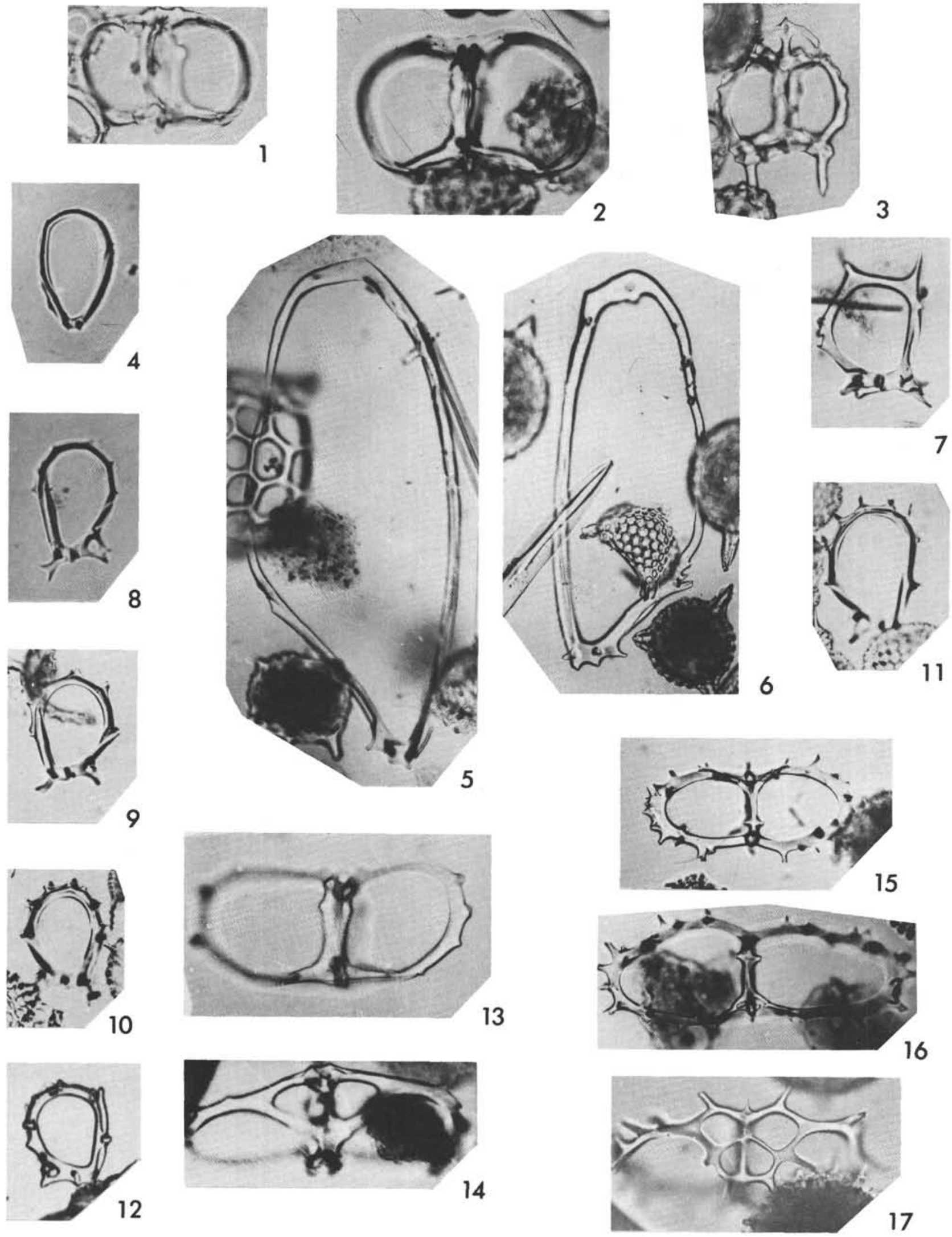


\section{INDEX OF RADIOLARIAN NAMES}

Acanthobotrys, 554

multispina, 554

Acanthodesmia hertwigi, 533

Acanthosphaera setosa, 519 sp., 516

Acrobotrys, 554

disolenia, 544

sp. aff. $A$. disolenia, 504, 508, 554, P1. 39, Figs. 3, 9

sp. aff. A. sphaerothorax, 554, Pl. 39, Figs. 1, 2

Acrocoronis, 533

Acrocubus, 533

amphithectus, 533

arcuatus, 533

cortina, 533

octopylus, 533

Acropyramis, 551

Actinomma, 515

capillaceum, 519

sp. gr. aff. Hexaconthium arachnoidale, 500, 505, 509, 517, P1. 9, Figs. 4-7

Actinommetta, 515

Actinommura, 519

sp. A. 519, Pl. 9, Fig. 13

sp. B 519, Pl. 9, Fig. 14

sp. aff. Thecosphaera californica, 519, P1. 9, Fig. 15

Aegospyris, 532

aegoceras, 532

Amphibrachium robustum, 528

Amphipyndax, 545

enessefi, 496, 500, 545, P1. 8, Fig. 15

sp., 500, 545, P1. 8, Fig. 18

sp. aff. A. enessefi, 545, Pl. 8, Fig. 14

stocki, 496, 500, 545, PI. 8, Figs. 16, 17

plousiousus, 496, 499, 500

Amphisphaera cronos, 520

spinosa, 520

Amphistylus neptunus, 519

Amphymenium, 526

amphistylium, 526, 527

sygartus, 526

Androcyclas gamphonychos, 545

Anthrocyrtella, 541, 543

spatiosa, 543, Pl. 33, Figs. 1-3

Anthocyrtidium, 545

cineraria, 545

ophirense, 496, 506, 510, 545, Pl. 36, Fig. 11

ovata, 506, 510, 545

zanguebaricum, 545, P1. 36, Fig. 10

Anthocyrtis, 541

mespilis, 541

ophirensis, 545, Pl. 36, Fig. 11

ovata, 546, P1. 36, Fig. 10

ventricosa, 552

Anthocyrtissa, 545

Anthocyrtium campanula, 543

flosculus, 544

Anthocyrtoma, Pl. 34, Fig. 1

Anthocyrtonium, 543

Apocubus, 533

Archidiscus, 525

Archiphaena, 531

gorgospyris, 531

Archipilium, 553

macropus, 505, 510

orthopterum, 531

sp. aff. A. macropus, 500, 531, PI. 29, Figs. 13, 14

Artiscium, 522

Artiscus, 522

paniscus, 522

Artocyrtis, 549, P1. 26, Fig. 11

Artophormis dominansiensis, 547

barbadensis, 513, 547

gracilis, 547
Artostrobium, 539

auritum, 539, 540

miralestensis, 539

sp. aff. A. doliolum, 538

sp. B, 540

A secta, 536

prunoides, 536

Asteriscus echiniscus, 523

Astractinium, 524

aristotelis grp., 502, 507, 512, 517, 518, 524, Pl. 16, Figs. 1-5

sp. C, 499, 503, 507, 516, 518, 524, P1. 16, Fig. 10

sp. aff. Lithocyclia crux, 503, 507, 516, 518, 524, P1. 16, Figs. 8,9

Astromma, 522

aristotelis, 524

enthomocora, 522, P1. 12, Fig. 6

hughesi, 500, 505, 509, 522, Pl. 12, Fig. 4

pentactis, 524

petterssoni, 505, 509, 522, Pl. 12, Fig. 5

pythagore, 524

Astrocyclia, 524

solaster, 524

sp., 524, P1. 15, Fig. 7

Astrophacus duplus, 523

Axoprunum, 521 carduum, 521, P1. 10, Fig. 1

liostylum, 521, Pl. 10, Fig. 3

polycentrum, 521, Pl. 10, Figs. 11, 12

stauraxonium, 505, 510, 521, P1. 10, Fig. 10

Baculogypsina gallowayi, 527

sphaerica, 541

Bathrocalpis, 534

campanula, 534

Batropyramis, 551, 552

acephala, 551

aeshna, 552, P1. 31, Figs. 1, 2

quadrata, 551

ramosa, 551

reticulata, 551

sanjoaquinensis, 500, 551, P1. 7, Fig. 20

scalaris, 551, P1. 31, Fig. 6

sp. aff. B. spongiosa, 551, P1. 31, Fig. 8

woodringii, 551

Bekoma, 554

bidarfensis, 502, 516, 554

Botryocella, 554

multicellaris, 499, 503, 507, 508, 517, 518, 554, Pl. 39, Figs. 8-10

sp. $\mathrm{O}, 554$

spp. aff. B. cribrosa, 554, Pl. 39, Figs. 4-6

Botryocyrtis, 554

caputserpentis, 554

microporus, 554

quinaria, 504, 507, 508, 511, 554, Pl. 39, Fig. 7

spp. 554

Botryopyle dictyocephalus, 554

sp. A., 554

Botryostrobus, 539

auritus, 539, P1. 24, Figs. 15-18

australis, 539, Pl. 24, Figs. 12-14

botryocyrtis, 539

lithobotrys, 539, PL. 29, Fig. 19

miralestensis, 539, PL. 29, Fig. 31

tumidulus, 500, 505, 509, 539, Pl. 27, Figs. 20, 21

Brachiospyris, 532

Calocyclas, 547

asperum, 500, 503, 507, 516, 518, 547, Pl. 28, Figs. 16-18

barbadensis, 549

casta, 543

coronata, 547

hannai, 544 
parthenia, 544

turris, 547

veneris, 543

Calocycletta, 543

acanthocephala, 499, 503, 507, 516, 518, 544, Pl. 35, Figs. 5-7 annosa, 499, 503, 507, 508

costata, Table 7, Table 9, Table 10, Table 11, 544, PI. 35,

Fig. 17

tuberosa, 499, 500, Table 7, Table 8, Table 10, Table 13, 543,

544, P1. 35, Figs. 11-14

veneris, Table 7 , Table 8 , Table 9 , Table 10 , Table $11,544, \mathrm{Pl}$.

35 , Fig. 16

virginis, 499, Table 7, Table 10, Table 13, 544, Pl. 35, Figs. 8-10 Calocycloma, 543

ampulla, Table 7, Table 10, Table 12, 543, Pl. 34, Fig. 4

Cannartidium mammiferum, 521

Cannartus, 521

haeckelianus, 522

mammiferus, 500, Table 7, Table 9, Table 10, Table 11, 521, Pl. 12, Fig. 3

petterssoni, 522

prismaticus, Table 7, Table 8, Table 9, 521

sp. A, 522, P1. 12, Figs. 11-14

sp., 522

tubarius, Table 7, Table 8, Table 9, Table 10, Table 11, 521

violina, 499, 500, Table 7, Table 9, Table 10, Table 11, 522, Pl.

12, Figs. 9,10

Carpocanadium, 536

Carpocanarium, 537

Carpocanistrum, 535

cristatum, Table 7, Table 9, Table 10, Table 11, 536

evacuatum, 535

sp., 535, 536, Pl. 22, Figs. 17-22

sp. aff. C. pulchrum, 536, P1. 22, Figs. 19, 20

sp. aff. Setnolorys odysseus, PI. 22, Fig. 16

sp. C, P1. 22, Figs. 21,23

sp. O, 536, P1. 22, Figs. 29, 30

Carpocanium, 536

calocyclothes, 537

coronatum, 536

hexagonale, 536

sp. aff. C. coronatum, 536, Pl. 22, Figs. 25, 26

trepanium, 536

Carpocanobium, 536

sp. aff. C. setosa, 536, Pl. 22, Figs. 27, 28

Carpocanopsis, 535

bramletti, Pl. 22, Fig. 15

cingulatum, 535

cristatum, 536

folvosum, Table 7, Table 9, Table 10, 535

sp. aff. $C$. favosum, Table 7, Table 9, Table 10, 535, PL. 22, Fig. 24

Carposphaera melitomma, 519

Cassideus yoloensis, 540

Cenosphaera sp. aff. C. eugenea, 496, Table 5, 521, Pl. 1, Fig. 10, Pl. 4, Fig. 1

eugenea, 521

Centrobotyrs, 554

sp. A, 554

sp., P1. 39, Fig. 11

termopyla, 500

Cephalopyramis, 551

enneactis, 551

Ceratocyrtis, 534

cucullaris, 534

sp. aff. C. cucullaris, 534, Pl. 37, Fig. 12

Ceratospyris ateuchus, 532

didiceros, 532

furcata, 532

heppaceros, 532

logibarba, 532

ocellata, 532

Ceratospyris setigera, 529

stylophora, 532

triceros, 532
Chitonastrum, 527

lyra, 527

triglochin, 527

Cinclopyramis infundibulum, 551

Circodiscus, 526

microporus, 526, Pl. 19, Figs. 1-7

sp., 526, Pl. 19, Fig. 8

Clathrocanium diodena, 535 sphaerocephalum, 535

Clathrocorona 535

sphaerocephala, Table 7, Table 8, Table 9, Table 10,535, Pl. 37, Figs. 27-30

Clathrocyclas, 540,541

anetbicornis, 540

bicornis, 540, Pl. 33, Figs. 11, 12

ionis, 541

principessa, 540

universa grandis, 541

universa undella, Pl. 33, Fig. 9

Clistophaena armata, Pl. 38, Fig. 19

fossilis, 541

Conarachnium, 545

Conosphaera fossilis, 496, Table 1, Table 2, 521, P1. 1, Fig. 8 sphaeroconus, 496, Table 2, Table 5, 521, Pl. 4, Fig. 2

Cornutana, 550 ortoconus, 550

Cornutella, 550

B. profunda, Table 7, Table 9, Table 10, 551, Pl. 30, Figs. 18-20 bimarginata, 551, PI. 30, Fig. 13

Cornutella californica, 551

clathrata, 550, 551, Pl. 30, Figs. 16, 17

clava, Table 7, Table 9, 551, P1. 30, Figs. 11, 12

cucullaris, 534

hexagona, 550

longisetta, 551, P1. 30, Figs. 8, 9

scalaris, 551,552

sp. aff. C. californica, 551, P1. 30, Fig. 10

stiligera, 551, Pl. 30, Figs. 14-15

trochus, 550

verrucosa, 551

Cornutellium, 550

Cornutissa, 550

Cornutosa, 550

Cornutura, 550

spiralis, 550

Coronidium, 533

dyostephanus, 533

Coronophaena, 531

Coronophatha, 531

Craterocyclas, 544

robustissima, 544

Cromyechinus, 519

antarctica, 519

birealis, 519

icosacanthus, 519

langii, Table 7, Table 9, 519, PL. 9, Fig. 12

sp. 519

tetrapyla, 497, Table 7, Table 9, Table 11, 519, Pl. 9, Fig. 11

Cromyodruppa, sp. 529

Crytamphorella, 541

conara, 541

macropora, Table 2

sp. aff. conara, Table 2, Table 3, Table 5, 541, Pl. 2, Fig. 17

sp. 495, Table 1, Table 3, Pl. 1, Fig. 1

sphaerica, 496, Table 1, Table 2, Table 3, 541, Pl. 2, Fig. 15, 16

Cryptoprora ornata, 535

Cycladophora erinaceus, Pl. 34, Figs. 1, 2, Favosa, 535

goethana, 542, 543

hexapleura, 543

panteon, 548

spatiosa, 541

turris, 497

Cyclampterium, 548

milowi, 499, Table 7, Table 8, Table 10, Table 12, Table 13,548 pegetrum, Table 7 , Table 13,548 , Pl. 34 , Fig. 7,8 
Cypassis, 522 palliata, 522

Cyphantus probus, 529

Cyphonium ceratospyris, 522

Cyrtocalpis, 536 amphora, 536

Cyrtocapsa, 546 chrisalinium, 546 compacta, 546 cornuta, 546 inequispina, 546 ovalis, 546 tetrapera, 546

Cyrtocapsella, 546 cornuta, 546 japonica, 546 tetrapera, 546

Cyrtopera laguncula, 546

Cyrtophormidium, 547

Cyrtophormis, 543, 547

armata, 499, Table 7, Table 9, Table 10, Table 11, 546, 547, Pl. 25 , Figs. 19,20

barbadensis, Table 7, 547, Pl. 28, Fig. 12

cingulata, 547

corona, 538

dominansiensis, 547, Pl. 28, Fig. 11

gracilis, 499, Table 7, Table 8 , Table 10 , Table 12 , Table 13 , 547, Pl. 28, Figs. 13-15

sp. Table 7, Table 9, Table 10, 547, Pl. 25, Fig. 21

sp. Ch., 547, P1. 26, Fig. 1

Cyrtophormiscus, 547

Cyrtostrobus, 546

Cystophormis, 535

pyla, 535

Dactyliosphaera, 527

silvae, 527

sp. aff. Lithocyclia justa, 496, Table 2, Table 3, 527, Pl. 3, Fig. 16

Dactylodiscus cayeuxi, 527

Dendrospyris, 532

acutis, 532

anthocyrtoides, 531

didiceros, Table 7, Table 10, Table 12, 532, Pl. 40, Fig. 12

pododendros, Table 7 , Table 9 , Table 10 , Table 11, 532, Pl. 39 , Figs. 26-28

sp. I, 531

sp. aff. Theospyris feloz, P1. 39, Fig. 22

Desmospyris, 531

anthocyrtoides, 531, Pl. 40, Fig. 4

memillata, 531

pannosa, Pl. 38, Fig. 17

sp. A, Table 7, Table 9, Table 10, 531, Pl. 38, Figs. 12, 13

spp. aff. D. anthocyrtoides, 499, Table 7, Table 8, Table 12, Table 13, 531, Pl. 40, Figs. 2, 3

sp. aff. D. lata, Table 7, Table 12,532, P1. 38 , Fig. 1

sp. aff. D. mamillata, 531, P1. 38, Fig. 6

Diablocampe, 546

Diacanthocapsa, 536

comys, 536

euganea, 536

minima, 535

ovoidea, 496, Table 5

sp. A, Table 5, Table 7, Table 10, Table 12, Table 13, 536, Pl. 7, Fig. 11, Pl. 22, Figs 4, 6

sp. aff. Ancus, Table 4, Table 5

sp. B, Table 5, 536, P1. 7, Figs. 4, 5

Dicolocapsa, 541

microcephala, Table 7, Table 9, Table 10, 541, Pl. 22, Fig. 32

verbeeki, 541

Dictyastrella, 528

Dictyastrum, 528

angulatum, 528, 529

Dictyocephalus bergontianus, 537 callimorphos, 538

eos. 538

miralestensis, 539

obtusus, 531

papillosus, 537

pulcherrimus, 538

Dictyoceras, 542

acanticum, 542

insectum, 542

xiphephorum, 542

Dictyocoryne, 529

pentagona, 529

profunda, 529

Dictyocephalus papillosus, 537

Dictyomitra, 550, 551

albiensis, Table 2

carpatica, 550

clivosa, 546

costata, 496, Table 2, 550, P1. 2, Fig. 3

crassispina, 496, Table 550, P1. 2, Fig. 4

crebrisulcata, 550

disparlita, 550

drigalskii, 540

duodecimcostata, 496, Table 2, Table 3, 550, P1. 2, Figs. 10, 11

ferosia, 545

lamellicostata, 550

multicostata, 496, Table 2, Table 3, Table 4, Table 5, 550, PI. 8 ,

Figs. 9,10

ordinaria, 550

ornata, 496, Table 5, 550, PL. 8, Fig. 8

producta, 546

pseudomacrocephala, Table 2, Table 3, 550, Pl. 2, Fig. 5

regina, 496,550

sagitafera, 550

Sp. A, 550, Pl. 2, Fig. 12

sp. aff. $D$. regina, Table 2, Table 3 , Table 5,550 , P1. 8, Fig. 11

sp. aff. Stichocapsa tecta, 496, Table 3, 550, Pl. 2, Fig. 14

striata, Table 5, 550, Pl. 8, Figs. 12, 13

tiara, 496, Table 2, Table 5, 550, P1. 2, Fig. 8

uralica, 545

veneta, 496, Table 2, 550, Pl. 2, Fig. 2

Dictyophimium, 553

Dictyophimus, 534,553

arabicus, 553

babylonis, 552

crisae, 553

gracilipes, 534

pocillum, 553, Pl. 29, Fig. 5

sp. aff. D. hirundo, 500, 553, Pl. 27, Figs. 16, 17

trisseratus, 553

Dictyospyris clatrata, 531, P1. 39, Fig. 14

Didymocyrtis, 522

ceratospyris, 522

Diplocyclas, 540

bicorona, 500,540

ionis, Table 7, Table 9, 541, Pl. 33, Fig. 19

sp. A, 541, Pl. 33, Figs. 14-16

sp. aff. D. bicorona, 500, 540, Pl. 33, Figs. 17, 18

Discospira, 526

Diplostrobus, 550

crassispina, 550

Dipocubus, 533

Dipodocoronis, 533

Dorcadospyris, 532

alata, 500, Table 7, Table 9, Table 10, 532, Pl. 40, Fig. 13 argisca, 533

ateuchus, 499, Table 7, Table 8, Table 9, Table 10, Table 12, Table 13, 532

dentata, 499, 500, Table 7, Table 9, Table 10, Table 11, 532

simplex, 532, Pl. 40, Fig. 11

sp. K, Table 7, Table 8, Table 13, 532, Pl. 40, Fig. 5

spinosa, 532

Doryconthidium maximum, 520

Druppatractus ostracion, 520

polycentrus, 521 
Echinomma leptodermum, 516 popofskii, 518 quadrisphaera, 518

Ectonocorys, 543

Eribotrys, 537, 540

Eucecriphalium, 540

Eucecriphalus, 540 gegenbauri, 540 sp., Table 7, 540, P1. 33, Figs. 6-8

Euchitonia, 529

elegans, 527

furcata, 527, 529

mulleri, 527

Eucoronis, 533

hertwigi, 533, Pl. 44, Figs. 15-17

perspicillum, 533

sp. A, Table 7, Table 9, Table 11, 533, Pl. 41, Figs. 1, 2

sp. B, Pl. 41, Figs. 13, 14

Eucyrtidiidae gen. sp. "rocket", 499, Table 7, Table 8, Table 9, Table 12, 547, P1. 28, Figs. 2, 3

Eucyrtidiidae gen. sp. W., Table 7, Table 9, Table 10, 547, Pl. 28, Figs. 6, 7

Eucyrtidium, 548

acanthocephalum, 543

acuminatum, 548

ampulla, 543

argus, 546

asperum, 548

auritum, 539

australe, 540

Eucyrtidium cienkowskii, 549

coronatum, 544

cubense, 548

elongatum peregrinum, 546

euporum, 540

exellens, 538

fistuligerum, 549

gemmatum, 538

lagena, 549

lagenoides, 546

matuyamai, 549, Pl. 26, Figs. 5, 6

microporum, 548

mongolfieri, 538

montiparum, 548

pachyderma, 539

papillosum, 537

pirum, 538

profundissimum, 549

sipho, 549

sp. aff. E. montiparum, 499, Table 7, Table 8, Table 10, Table 12 , Table 13,548 , Pl. 26, Figs. $2-4$

E. sp. C, Table 2, Table 3, 548, Pl. 2, Fig. 13

stephanophorum, 542

teusheri, 549

trochus, 545

tubulus, 549

tumidulum, 539

zancleum, 545

Eusyringartus, 550

Eusyringium, 548,549

cannostoma, 549

conosiphon, 549

fistuligerum, Table 7, Table 10, Table 12, Table 13,549, Pl. 32, Fig. 3

japonicum, 546

sp. aff. Theocampe subtilis 496, Table 2, Table 3, 549, Pl. 2,

Fig. 1

sp. cf. vicentense, 547 , Table 7, Table 12

striata, 549, PI. 32, Figs. 1, 2

tubulus, 549, P1. 32, Figs. 4, 5

Eusyringoma, 546

Fenestrantha, 553

Flustrella, 525, 526

concentrica, 525
Gamospyris, 532

circularis, 532

Giraffospyris, 532, 533

didiceros, 532

lata, 532

toxaria, 533

Gongylothorax, 541

sp. aff. G. verbeeki, Table 2, Table 5, 541, Pl. 7, Figs. 18, 19

verbeeki, 496, 541

Gorgospyris schizopodia, 531

Hagiastrum, 527

plenum, 527

sp. aff. Strauralastrum euganea, 527, P1. 6, Figs. 4, 5

Halicalyptra setosa, 536

Haliomma, 517

aequorea, 517

circumtextum, 516, 517

didymocyrtis, 522

inerme, 519

lirianthus, 519

medusa, 519

trinacrium, 515, 516

Haliommetta, 516

miocenica, 500, Table 7, Table 9, 519, 520, Pl. 9, Figs. 8, 9

Heliodiscomma, 523

Heliodiscus, 523

asteriscus, Table 7, Table 10, Table 12, 523, P1. 13, Fig. 3

cingulatum, 523

hexasteriscus, Table 7, Table 10, Table 12, 523, Pl. 13, Fig. 4 pentasteriscus, Table 7, Table 10, Table 12, 523, Pl. 13, Figs. 6,7

saturnalis, 523, Pl. 13, Fig. 8

sp., 523, Pl. 13, Fig. 9

Heliosestilla, 522

spicata, 522, Pl. 13, Fig. 10

Heliosphaera, 519

echinoides, 519

miocenica, 519

Heliosestrum octonum, 522

Helotholus, 534

histricosa, 534

Hemicryptocapsa conara, 541

Hexoconthium arachnoidale, 500, 517

Hexacyclia, 514

Hexzlodus, 544 dendroporus, 544

Hexapyramis sp., 496, Table 2, Table 3

Hexaspyridium, 529

Hexaspyris, 527, Pl. 29, Fig. 13

Histiastrum martinianum, 529

valanginica, 496, Table 3

Holocryptocanium barbui, Table 1, Table 3, Pl. 9, Fig. 3

Holocryptocapsa, 541

fallax, 541

hindei, 541

sp. aff, $H$. hindei, 496, Table 3, 541

Hymeniastrum pythagore, 524

Lamprocyclas, 544

aegles, 500, Table 7, Table 9, 544, PI. 36, Fig. 13

heteroporus, 500, Table 7, Table 9, 545, Pl. 36, Figs. 6, 7

junonis, Table 7, Table 9, 545, Pl. 36, Fig. 8

maritalis, 544, Pl. 36, Fig. 14

nuptialis, 544

rhinoceros, 499, Table 7, Table 8 , Table 9, Table 12, Table 13, 544 , Pl. 36, Figs. 1-3

sp. A, 544, Pl. 36, Fig. 4

Lamprocyclia, 544

Lamprotripus, 534 mawsoni, 500, 534, Pl. 29, Fig. 15

squarrosus, 534

Lampterium, 542,543

chalara, Table 7, Table 10, Table 12, 543, Pl. 32, Fig. 12

goetheana, 499, Table 7, Table 10, Table 12,543 
sp. aff. L. goetheana, 499, Table 10, 542, P1. 32, Figs. 13, 14

Lampitidium, 542

Lanterna chinensis, 543

Lipmanella, 542

cogieli, 499, Table 7, Table 9, 542, Pl. 37, Fig. 10

sp. aff. Lipmanella xiphephorum, 499, Table 7, Table 9, 542, Pl. 37, Figs. 13, 14

sp. aff. Lithomelissa amazon, 542, Pl. 37, Fig. 1

sp. C group, 542

sp. M, Table 7, Table 9, Table 10, 542, Pl. 37, Figs. 2, 3

sp. O, Table 7, Table 9, Table 10, 542, Pl. 37, Figs. 4, 5

xiphephorum, 527, 542, Pl. 37, Fig. 15

Liriospyris, 531, 533

elevata, 533

hexapoda, 531

sp. aff. $L$. clathrata, 531

sp. B, 499, Table 7, Table 8, Table 12, Table 13

sp. 2,496

stauropora, 533

Lithamphora, 539

corbula, 539

furcaspiculata, 539

sacculifera, 539, Pl. 30, Fig. 3

sacculifera quadrata, 499, Table 7, Table 8, Table 10, Table 12, Table 13, 539, Pl. 30, Figs. 4-6

sp., 539, Pl. 30, Fig. 2

sp. aff. L. corbula, Table 7, Table 8, 539, Pl. 30, Fig. 7

Lithapium mitra, Table 10, 550, 551, Pl. 34, Fig. 3

Lithatractus fragilis, 520

santaennae, 520

Lithelidae gen. A., 496, 497, Table 1, Table 4, Table 5, 529, Pl. 5, Figs. 14, 15

Lithelidae gen. B, 496, Table 2, Table 3, 529, Pl. 3, Fig. 17

Lithobotrys cribrosa, 554

nucula, 554

sphaerothorax, 554

Lithocampe, 536, 548

acuminata, 548

aurita, 539

australe, 540

compacta, 546, PI. 25, Fig. 17

compressa, 547

corbula, 539

cornuta, 500, Table 7, Table 9, Table 10, Table 11, 546, Pl. 25, Figs. 15, 16

diploconus, 550

inaequispina, Table 7, Table 9, Table 10, 546

japonica, 546, Pl. 25, Fig. 18

marylandica, 538

radicula, 546

solitaria, 536

subligata, 499, Table 7, Table 8 , Table 9, Table 12, Table 13, 546, Pl. 25, Figs. 7-10

tetrapera, 499, Table 7, Table 9, Table 10, Table 11, 546, PI. 5, Fig. 14

Lithocampium, 548, 549, 550

diploconus, 550, Pl. 26, Fig. 7, 12

sp. A, Table 7, Table 12, 549

sp. B, Table 7, Table 9, Table 10, Pl. 32, Figs. 6, 7

Lithocampula, 546

Lithocircus productus, 533

Lithochytris, 552

pyriformis, 552

sp. A, Table 7, Table 12, 533, 552, Pl. 27, Fig. 2

sp. aff. L. ventricosa, 499 , Table 7 , Table 10, 552, PI. 27, Figs. 3, 4

sp. aff. $L$. tripodium, 499 , Table 7, Table 13, 552, Pl. 27, Fig. 5 sp. O, 499, Table 7, Table 10, Table 12, 552, Pl. 27, Fig. 7

sp. T, 499, Table 7, Table 10, Table 12, 552, Pl. 27, Fig. 6 tripodium, 552

turgidulum, 552, P1. 27, Figs. 8, 9

vesperilio, 552

Lithochytrodes, 552

Lithocyclia, 523

angustum, 524 aristotelis, 524

crux, 524

justa, 496, 527

lenticula, 523

ocellus, Table 7, Table 10, Table 12, 523, 524, Pl. 15, Figs. 1, 2

sp. aff. L. lenticula, 523, Pl. 15, Fig. 3

stella, 523

Lithocyrtidium, 552

Lithomellissa, 534

amazon, 542

campanulaeformis, 542, Pl. 37, Fig. 11

holpites, 534

microptera, 534

sp., 534

Lithomitra, 539

altamiraensis, 539

bramlettei, 540

elizabethae, Pl. 22, Figs. 11, 12

eruca, 539

imbricata, Table 10, 539, Pl. 24, Figs. 2-5

lineata, 539

nodosaria, 539, P1. 24, Figs. 24-30

regina, 550

sacculifera, 539

sp. aff. L. lineata, 538, PI. 24, Fig. 1

Lithomitrella, 539

Lithopilium, 545

macroceras, 545

Lithornithium clausum, 545

dictyoceras, 128,542

Lithostrobus, 546

botryocyrtis, 539

cornutus, 548

duodecimcostatus, 550

elegans, 546

hexagonalis, 500, 546

lithobotrys, 539

pseudoconulus, 546

seriatus, 539

Lithotympanium, 533

tuberosum, Table 7, Table 9, Table 10, Table 11, 533, Pl. 38, Figs. 22-24

Lophoconus rhinoceros, 544

Lophocyrtis, 542

jacchia, 499, Table 7, Table 10, 542, P1. 28, Fig. 21

Lophophaena, 534

apicata, 534

capito, Table 7, Table 8, Table 10, Table 12, Table 13, 535, Pl. 33, Figs. $20-23$

galea orci, 534

radians, 534

Lophophaenoma, 534

sp. G., 534

Lophophaenula, 534

Lychocanissa, 553

Lychnocanium, 554

bellum, Table 7, Table 8, Table 10, PI. 29, Fig. 1

bipes, Table 7, Table 9, 553

falciferum, 553

grande, 553, Pl. 29, Fig. 6

hirundo, 553, Pl. 29, Fig. 3

korotnevi, Table 7, Table 9, 553, Pl. 29, Fig. 16

pyriforme, 552

sp. 553 , PI. 29 , Fig. 7

tridentatum, 553

tripodium, 553, Pl. 29, Fig. 2

turgidulum, 552

Montubus, 554

microporus, 554

Myllocercion, 534, 537

acineton, 534

minima , 496, 535

sp. aff. $M$. minima , 496, Table 3, Table 5, 535, Pl. 5, Figs. 19, 20

sp. C, Table 7, Table 9, Table 10, 535 
Ommatartus, 522

amphicanna, 522

ceratospyris, 522

hughesi, 522

penultimus, 500

spp. aff. O. ceratospyris, 500, Table 7, Table 9, 522, Pl. 12, Figs.

15-17

tetrathalamus, 500,522

Ommatocampe, 522,526

hughesi, 522

polyarthra, 526

spp. aff. Amphimenium amphistylium, 527, P1. 20, Fig. 12

Ommathymenium, 526

Ommatodiscus, 526

Ommatogramma, 528

naviculare, 528

puella, 528

sp. aff. Amphibrachium robustum, 528, Pl. 21, Fig. 10

Otosphaera, 515

annikae, Table 7, Table 9, Table 11, 515, Pl. 9, Fig. 1

auriculata, 515

polymorpha, 515

Panarium tubarium, 522

Panaronium, 522

Panartus tetrathalamus, 522

Patagospyris, 532

anthocyrtis, 531

argisca, 532, Pl. 40, Fig. 8

pentas, Table 7, Table 10, 532, PI. 39, Figs. 32-33

Patellula, 527

planoconvexa, 496, Table 2, Table 3, Plate 3, Fig. 13

verteroensis, 496, Table 2, Table 3, 527, Pl. 3, Figs. 8, 9

Periphaena, 523

decora, Table 7, Table 10, Table 12, 523, Pl. 14, Figs. 1, 2

dupla, 499, Table 7, Table 10, Table 12, Table 13, 523, Pl. 14, Fig. 3

sp., 523, PI. 14, Figs 4, 5

Peripyramis, 551

circumtexta, 551, P1. 31, Fig. 4

magnifica, 551

woodringi, Table 7, Table 9, 551, P1. 31, Fig. 10

Perizona, 523

scutella, 523

Petalospyrella, 532

Petalospyris, 532

anthocyrtoides, 531

argiscus, 532

ateuchus, 532

confluens, 532

foveolata, 532

pentas, 532

sp., 499, Table 7, Table 8, Table 10, Table 12, Table 13, 532, Pl. 40 , Fig. 1

triceros, Table 7, Table 10, Table 12, 532, Pl. 40, Figs. 9, 11

Petassiforma, 540

foremanae, 540

speciosa, 496, Table 5, 540, 540, Pl. 7, Fig. 21

Phacostylus, 522 amphistylus, 522

Phacotriactis, 522 triangula, 522

Phormocampe lamprocyclas, 544

Phormacyrtis, 537

embolum, 537, Pl. 22, Figs. 8, 9

longicornis, 537

proxima, 537

sp. A, 537, Pl. 22, Fig. 7

sp. E, 537

striata, 549

Phormostichoartus corona, 538

sp. aff. P. corona, 538

Pipettaria tubaria, 521

Plectodiscus, 526

bergontianus, 526 circularis, Table 7, Table 12, 526, Pl. 19, Figs. 9-12

Plectopyramis spongiosa, 551

Podocoronis, 533

toxarium, 533, Pl. 41, Fig. 3

Podocyrtarium, 542

Podocyrtidium, 543

Podocyrtis, 543, 549

argulus, 542

chalara, 543

coronatus, 543, Pl. 35, Fig. 3

dominasinensis, 547

fasciata, 543

goetheana, 543

mitra, Table 7, 542

mitrella, 543

papalis, Table 7, Table 10, Table 12, Table 13, 543, Pl. 35, Fig. 1 pedicellaria, 542

sinuosa, Table 10, 542

sp., 543

tetracantha, 542

triacantha, 542

tripodiscus, 542

Podocyrtonium, 542

Porodiscus, 525, 526

bergontianus, 526

circularis, 526

concentricus, Table 12, 525, Pl. 18, Fig. 11

cretaceus, 496, Table 3, Table 4, Table 5, 525, Pl. 5, Figs. 6, 7

delicatulus, 496, 525, Pl. 5, Figs. 8, 9

durus, 526

microponus, 526

orbiculatus, 526

squinaboli, 526

uralicus, 526

Prunopyle tetrapyla, 519

titan, 500

Pseudoaulophacus, 527

florensis, 527

gallowayi, 496, Table 2, 527, Pl. 6, Fig. 1

pargueraensis, 496, 527

sp. aff. P. pargueraensis, Table 3, Table 5, 527, Pl. 3, Figs. 10-12 superbus, 496, Table 2, Table 3, Table 4, Table 5, 527, Pl. 3 ,

Figs. 1-3

Pseudodictyophimus, 534

gracilipes, 534, Pl. 37, Fig. 21

sp. A, 534, Pl. 37, Figs. 19-20

Pteractis, 529

elegans, 529

Pterocanarium, 552

Pterocanium, 552, 553

barbadense, 552

contiguum, 553, P1. 29, Fig. 11

prismatium, 500,553

proserpinae, 552

pyramis, 552

sabae, 545

satelles, Table 7, Table 12, 552

sp. aff. P. prismatium, 553, Pl. 27, Figs. 10, 11

sphinx, 552

Pterocorys, 545

bicornis, 540

campanula, 545

clausus, 545, Pl. 36, Figs. 13-16

columbo, 542

hertwigii, 500

hirundo, 553

korotnevi, 553

minithorax, 500

sabae, Table 7, Table 9, 545, P1. 35, Fig. 19

Pterocyrtidium, 552

barbadense, Table 7, Table 10, Table 12, 542, 552, Plate 22, Fig. 10 , Plate 27, Figs. 18-19

Pteropilium, 553

sp. B, 553, Plate 29, Fig. 12

sp. aff. Pterocanium contiguum, 553, Plate 29, Figs. 8-9

stratiotes, 553 
Rhizosphaeta arcadoporum, 500

Rhodospyris, 531

anthocyrtis, 531

sp. A, 531, Plate 38, Fig. 11

sp. aff. $R$. anthocyrtis, 531, Plate 38, Fig. 14

sp. aff. $R$. tricornis, Table 7, Table 9, Table 11, 531, Plate 38, Figs. 7, 10

sp. Del, Table 7, Table 9, Table 10, 531, Plate 38, Figs. 15, 16 tricornis, 531

Rhopalastrella, 528

Rhopalastrum, 528

angulatum, 529, Plate 17, Figs. 7, 8

lagenosum, 529

profunda, 529, Plate 17, Figs. 4-6, Plate 20, Fig. 8

sp. aff. Dictyocoryne pentagona, 529, Plate 21, Fig. 12

Rhopalocanium, 552 ornatum, 552, Plate 27, Figs. 13, 14

Rhopalodictyum, 529 abissorum, 529

Rhopalosyringium, 537 colpodes, 496,537 magnificum, 537

sp. aff. colpodes, Table 4, Table 5

sp. aff. $R$. magnificum, 537

Schizodiscus, 528

disymmetricus, 528

Semantis triangularis, 534

Sethamphora ampulla, 543 costata, 538

favosa, 536

Sethamphorus, 536

Sethochytris, 552

babylonis, Table 10, 552

triconiscus, 552

Sethoconus bimarginatus, 551

dogieli, 542

speciosus, 540

subtilis, 551

woodfordi, 55

cristata, 536

Sethocorys odysseus, Pl. 22, Fig. 16

Sethopilium macropus, 553

Sethoppyramis, 551

magnifica, 551

pulcherrima, 551

Sethostylus, 522

distylidiscus, 522

sp. 522, Pl. 13, Fig. 1

spicatus, 522

Siphocampe corbula, 539 sp. aff. $S$. corbula, 539

Solenosphaera, 515

Sphaeropyle langii, 519

Spirocyrtidium, 540

Spirocyrtis, 540

cornutella, Table 7, Table 9, 540, Pl. 24, Fig. 26

elegans, 549

scalaris, 540

sp. 540 , Pl. 24, Figs. 27, 28

sp. aff. Sp. cornutella, Pl. 24 , Fig. 25

sp. aff. Sp. scalaris, 540

subtilis, Table 7, Table 9, Table 10, 540, Pl. 24, Figs. 22-24

Spongaster, 528

pentas, 500-528

sp. 528 , Pl. 21, Fig. 13

tetras, 528

Spongasteriscinum, 529

Spongasteriscus, 528, 529

marylandicus, 529

ovatus, 529

sp., Table 8, Table 9, 529, Pl. 20, Fig. 12, Pl. 21, Figs. 6, 7

Spongocore, 528

Spongastractus pachystylus, 521

Spongastrella, 528 puella, 528

velata, 528

Spongocoryne, 528

Spongocyclia cycloides, 529

Spongocysca, 528

Spongosisculus, 528

Spongodiscus, 528

resurgens, Table 7, Table 9, 528, P1. 21, Fig. 5 resurgens osculosa, 500, Table 9, 528, P1. 21, Fig. 4 sp., Table 5

Spongoprunum sp., 496, Table 4, 529, Pl. 4, Figs. 6, 7

Spongopyle insolita, Table 5

osculosa, 528

Spongopyramis, 551

Spongosaturnalis, 521

latuformis, 521

sp., 496, Table 5, 521, Pl. 4, Fig. 5

Spongosphaera, 521

pachystyla, Table 7 , Table 10,521 , Pl. 10, Fig. 5

Spongotripus, 528

morenoensis, 496, Table 4, Table 5, 528, Pl. 6, Figs. 2, 3

regularis, 528

sp., 528, Pl. 21, Fig. 2

Spongotrochiscus, 528

Spongotrochus, 528

brevispinus, 528

longispinus, 528, Pl. 21, Fig. 15

polygonatus, 496, Table 5, 528, Pl. 4, Figs. 9, 10

sp., Table 2, Table 3, Table 4, Table 5, 528, Pl. 3, Fig. 4, Pl. 5 , Figs. 11-12

Spongurus, 528

cylindricus, 528

sp. 528

Squinabollum, 542

fossilis, 496, 541

sp. aff. S. fossilis, 541, Pl. 1, Fig. 4

Stauralastrum euganea, 527

Staurodictya, 525

fresnoensis, 525

ocellata, 525

sp., 525

splendens, 525

targaeformis, 526

Stephanastromma, 527

Stephanastrum, 527, 528

rhombus, 527

rhopaloporum, 527

sp. aff. S. rhopaloporum, 527, PI. 20, Figs. 10, 11

Stephanospyris, 532

cordata, 532

Stichocapsa, 545, 552

asymbatos, 496, Table 2, Table 4, Table 5, 546, Pl. 8, Figs. 1-3 cingulata, 496, Table 5, 546, P1. 8, Fig. 19

dispareita, 496

hexagonalis, 496, Table 9, 546, Pl. 25, Fig. 1

jaspidea, 545

megalocephala, 545

oblongula, 545

producta, 545

sp. Pl. 8, Figs. 6, 7

sp. aff, Lithostrobus elegans, 496, Table 2, 546, Pl. 2, Fig. 7

sp. aff. $S$. producta , 496, Table 5, 546, PP. 8, Figs. 4, 5

sp. aff. $S$. ferosia 496,546, Pl. 2, Fig. 6

stocki, 545

tecta, 550

Stichocorys, 543, 546, 552

armata, 547

baeri, 547

coronatus, 547, Pl. 25, Figs. 23, 24

delmontensis, 500, Table 8, Table 9, Table 10, Table 11, 546, Pl. 25 , Figs. 11,12

diploconus, 547

hushkei, 547

okenii, 547

peregrinus, 500, Table 7, Table 9, 547, P1. 28, Fig. 25 
wolfii, Table 7, Table 9, Table 10, Table 11, 546, Pl. 25, Fig. 22

Stichomitra, 545, 550

asymbatos, 546

cechena, 548

singulata, 546

costata, 550

Stichopilidium, 552, 553

sphinx., Table 10, 552, Pl. 27, Fig. 1

Stichopilium macropterum, 552

Stichopodium, 548

calvertense, Table 7, Table 9, 549, P1. 26, Fig. 13

cienkowskii, Table 7, Table 9, Table 10,549, P1. 26, Figs. 18, 19

dictyopodium, 548, Table 7, Table 9, Table 10, 549, Pl. 26, Figs. 9,10

martelli, Table 7, Table 8, Table 9, 549, P1. 26, Fig. 20

martellii conicum, Table 7, Table 8, Table 9, 549, Pl. 26, Fig. 20

microporum, 548, Pl. 25, Figs. 4-6

sp. aff. Eucyrtidium matuyamai, 549, P1. 26, Figs. 5-6

Stichophormis costata, 550

Stylactys, 528

Stylactractus, 519

coronatus, 497, Table 7, Table 10, Table 12, 520, Pl. 11, Fig. 9

fragilis, Table 7, Table 9, 520, P1. 11, Fig. 12

neptunus, 500, Table 7, Table 9, 520, Pl. 11, Fig. 11

ostracion, 520, Pl. 11, Fig. 1

radiosus, 520

santaennae, Table 11, 520, Pl. 11, Fig. 10

sp., 520

sp. aff. Stylosphaera sulcata, 520, P1. 11, Figs. 13, 14

sp. hays, 520

spinulosus, Table 7, Table 10, Table 12, Table 13, 519, P1. 11,

Figs. 2-4

universus, 520

Stylocyclia, 523

dimidiata, 523, P1. 15, Fig. 4

Stylodictya, 525

aculeata, 526, P1. 18, Fig. 6

clavata, 525

delicatula, 525

gracilis, 525

inaequalispina, 526, Pl. 18, Fig. 8

ocellata, 525

orbiculata, 526, P1. 18, Fig. 7

rosella, Table 7, Table 10, Table 12, 526, Pl. 18, Fig. 7

sp., 526

spendens, 525

targaeformis, 526, Pl. 18, Fig. 10

Stylosphaera, 520

angelina group, Table 7, Table 9, 520, P1. 11, Figs. 15-19

carduus, 521

coronata, 520

hispida, 520

laevis, 520, Pl. 11, Fig. 8

minor, 520, Pl. 10, Fig. 4

radiosa, 520

sp. A, 520 , P1. 10 , Fig. 8

sp. B, 520, Pl, 10, Figs. 7, 30, 32

sp. C, Table 7, Table 9, 520, Pl. 11, Figs. 5-7

spinulosa, 519

sulcata, 520

Stylosphaerella, 520

Stylospongia, 527

hexleyi, 527

planoconvexa, 527

verteroensis, 527

Stylotractura, 519

Stylotrochus helios, 527

Syringium, 546

vinassai, 546

Tessarospyris pododendros, 532

Tetracubus, 533

Tetralocorys, 543

Thamnospyris, 531

schizopodia, 531, P1. 38, Fig. 1

sp. aff. T. Schizopodia, 531, Pl. 38, Fig. 3
Thecosphaera, 519

californica, 519

radians, 519

scabra, 519

sp. A, 519, Pl. 9, Fig. 17

sp. B, 519, PI. 9, Fig. 18

sp. C, 519, Pl. 9, Fig. 19

tripodictyon, 519

Thecosphaerella, 519

Theocalpytra bicornis, 540

davisiana, 540

Theocampe, 537

altamonensis, 538

bassilis, 496, Table 5, 537, Pl. 7, Fig. 7

callimorphos, 538 , Pl. 23, Fig. 8

collaris, 538

dactylica, 538

dadeia, 496, Table 5, 537

eos, 538, P1. 23, Fig. 9

exellens, Table 10, 538, Pl. 23, Fig. 7

lispa, 537

mongolfieri, Table 7, Table 8 , Table 10 , Table 12, Table 13, 538, PI. 23, Figs. 3-5

pirum, Table 7, Table 8, 537, Pl. 23, Fig. 11

sp. aff. $T$. daseia, $537, \mathrm{Pl} .7$, Figs. 8-10

sp. aff. $T$. gemmata, Table 7, Table 10, Table 12, 538, Pl. 23, Fig. 10

sp. aff. T. mongolfieri, 538, Pl. 23, Figs. 1, 2

sp. P, 496, 526, 537, Pl. 7, Fig. 1

stenostoma, 546

subtilis, 549

vanderhofi, 537,538

Theocamptra, 538

collaris, Table 7, Table 9, Table 10, 538

corona, Table 7, Table 8, Table 9, Table 10, Table 11, 539, Pl. 23 , Figs. 24,25

formaster, Table 7, Table 8 , Table 9, Table 10, Table 12, Table 13, 539, P1. 23, Figs. 26, 27

marylandica, Table 7, Table 9, Table 10, 538, Pl. 23, Figs. 20, 21 ovata, Table 7, Table 9, Table 10, 538, Pl. 23, Figs. 17-19

sp. aff. T. marylandica, Table 10, Table 11,538 , P1. 23, Figs. 22, 23

sp. aff. $T$. ovata, 538 , P1. 23, Figs. 15, 16, Pl. 24, Fig. 6

spirocyrtis, Table 7, Table 9, Table 10, 538, Pl. 23, Figs. 28-30

Theocapsa amphora, 536

Theocapsomma, 535

amphora, 536

comys, 497

ornata, 535, P1. 22, Fig.

sp. aff. Th. comys, $496,515,535$, Pl. 7, Fig. 6

sp. aff. Th. ornata, 499, Table 7, Table 12, Table 13, 535, PL. 22, Fig. 2

spp. F, 535, P1. 22, Fig. 3

Theocorbis, 544

Theoconus, 545

jovis, 544

junonis, 545

Theocorys longicornis, 537

ovata, 538

Theocorythium, P1. 36, Fig. 15

Theocotyle, 536, 543

cryptocephala, 543

venezuelensis, Table 7, Table 10,543

Theocyrtis, 544

annosa, 544

tuberosa, 544

Theodiscus superbus, 527

Theospyris felis, PI. 39, Fig. 22

Theopodium, 552

satelles, 552

tricostatum, 553

Tholodiscus, 525

fresnoensis, Table 5, 525, Pl. 5, Fig. 1

ocellatus, Table 7, Table 12, 525, Pl. 18, Figs. 1, 2

sp., Table 4, Table 5, 525, Pl. 5, Fig. 5

splendens, Table 7, Table 12,525 , Pl. 18, Figs. 3-5 
Tholospyris, 533

Thyrsocyrtis, 542, 543, 549

argulus, Table 7, Table 10, Table $13,542,543$, Pl. 32 , Fig. 8

bromia, 499, Table 7, Table 12, 542,545

dionisia, 542

hirsuta hirsuta, 542

jacchia, 542

mitra, 542

rhizodon, 542

sp. E, 542, Pl. 32, Fig. 11

tetracantha, 542

triacantha, Table 7, Table 10, Table 12, 542, Pl. 32, Fig. 9, Pl.

34, Fig. 6

Toxarium cordatum, 533

Toxidium, 533

Trematodiscus, 522

concenticus, 522

microporus, 526

orbiculatus, 526

Triactis, 523

triactis, 523, Pl. 13, Fig. 2

tripyramis tripyramis, 523

Triactiscus, 522

tripyramis, 522

Tricircarium, 533

Tricolocampe, 537,538

amphizona, 539

cylindrica, 537,538

polyzona, 539

Tricolocampium, 537,538

Tricolocapsa, 537

papillosa, 500, Table 7, Table 9, 537, Pl. 22, Fig. 31

sp., 537, Pl. 22, Figs. 33, 34

theophrasti, 537

Tricolocapsula, 537

Tricolospyris, 533

cantiana, 533

leibnitziana, 533, Pl. 39, Figs. 26, 29

Tricyclarium, 533

Trigonactinium, 524

angustum, 499, Table 7, Table 8, Table 10, Table 12 , Table 13 , 522,524 , Pl. 17, Fig. 3 pithagore, Table 7 , Table 8 , Table 10 , Table 12,524 , P1. 17 , Fig. 1

triacantha, 524

Trigonactura angusta, 524

Trigonastrum, 527

regulare, 527

sp. aff. Chitonastrum lyra, 527, Pl. 20, Fig. 3

sp. aff. Euchitonia mulleri, 527, Pl. 20, Fig. 4

Trigonocyclia, 524

prima, 524, Pl. 15 , Fig. 6

sp. A, 524, Pl. 15, Fig. 5

triangularis, 524

Triospyrium, 532

Tripocubus, 533

Tripodiscium, 534

sp. A, 534, Pl. 37, Fig. 17

sp. aff. Lithomelissa hoplites, 496, Table 5, 534, Pl. 7, Fig. 2

tristylospyris, 534

Tripodiscinus, 534

Trissocircus, 533

lentellipsis, 533

Trissocyclus, 533

elevata, 533, P1. 39, Fig. 25

stauropora, 499, Table 7, Table 9, Table 10, Table 11, 533, Pl. 39, Figs. 29-31

Tristylospyris triceros, 532

Tympanidium binoctonum, 533, P1. 39, Figs. 24, 25

Tympanomma, 533

binoctonum, Table 7, Table 8, Table 9, Table 11, 533

Xiphatractus radiosus, 520

trochilus, 519

Xiphostylus plasianus, 520

Zygocircus, 533

butschlii, 534, Pl. 41, Figs. 8-11

cimelium, 534, P1. 41, Figs. 5, 6

productos, Table 7, Table 9, 533, Pl. 41, Fig. 4

sp., 534, P1. 44, Fig. 7

Zygostephanium, 533

dizonium, 533

Zygostephanus dissocircus, 533 